\title{
DIPLOMACIA DA SAÚDE E COVID-19 reflexões a meio caminho
}

Paulo Marchiori Buss Luiz Eduardo Fonseca organizadores

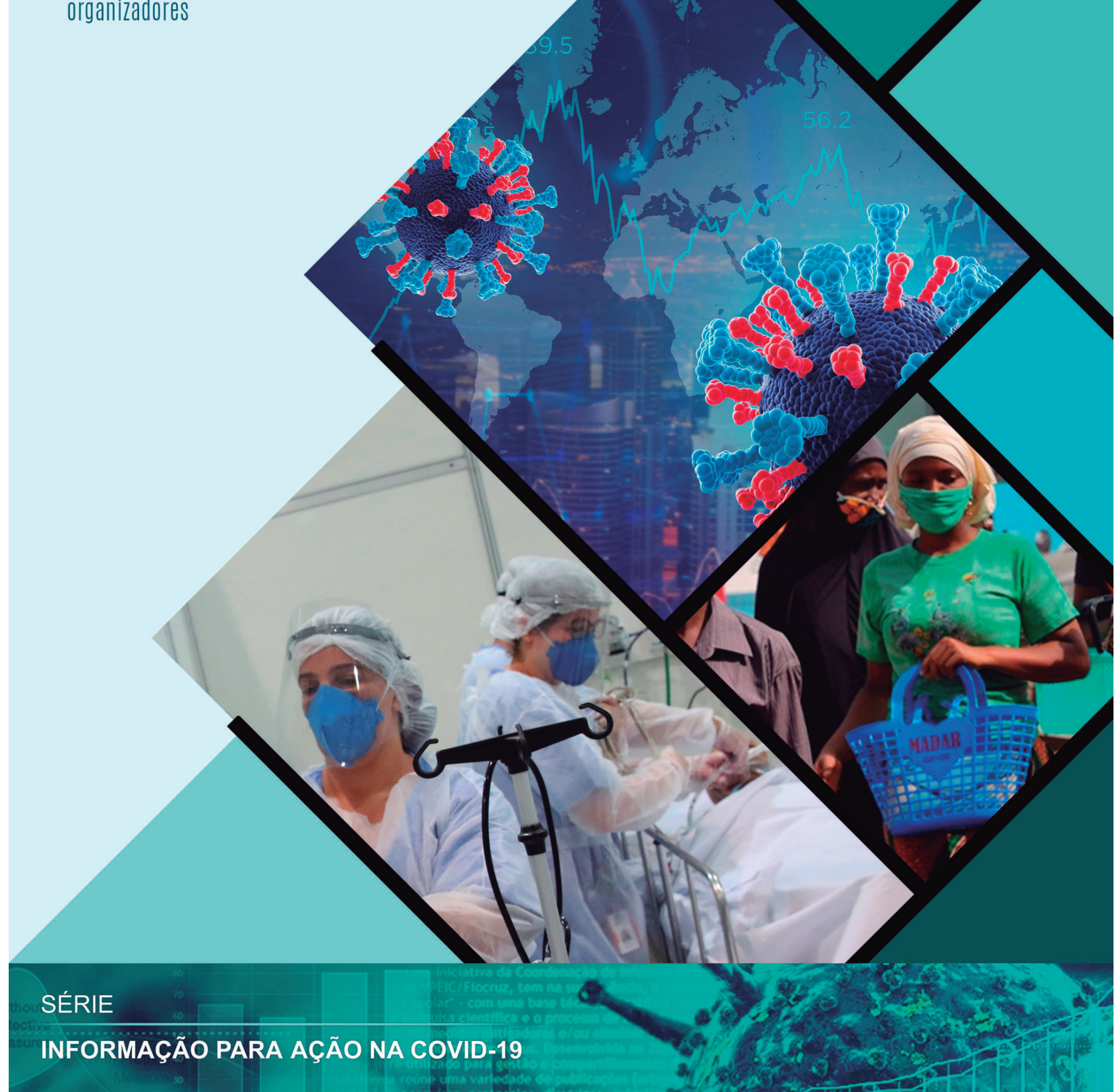



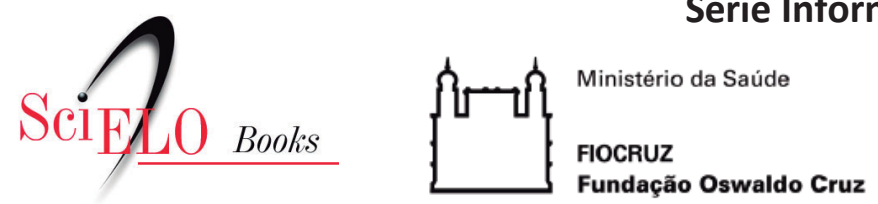

OBSERVATÓRIO COVID-19

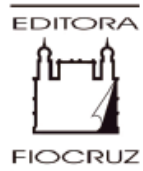

\title{
Diplomacia da saúde e Covid-19 reflexões a meio caminho
}

\author{
Paulo Marchiori Buss \\ Luiz Eduardo Fonseca
}

(Orgs.)

BUSS, P.M., and FONSECA, L.E., eds. Diplomacia da saúde e Covid-19: reflexões a meio caminho [online]. Rio de Janeiro: Observatório Covid 19 Fiocruz; Editora FIOCRUZ, 2020, 360 p. Informação para ação na Covid-19 series. ISBN: 978-65-5708-029-0. https://doi.org/10.7476/9786557080290.

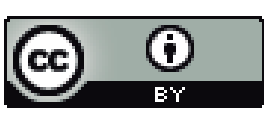

All the contents of this work, except where otherwise noted, is licensed under a Creative Commons Attribution $\underline{4.0 \text { International license. }}$

Todo o conteúdo deste trabalho, exceto quando houver ressalva, é publicado sob a licença $\underline{\text { Creative Commons }}$ Atribição 4.0.

Todo el contenido de esta obra, excepto donde se indique lo contrario, está bajo licencia de la licencia $\underline{\text { Creative }}$ Commons Reconocimento 4.0. 


\section{DIPLOMACIA DA SAÚDE E GOVID-19 reflexões a meio caminho}




\section{FUNDAÇÃO OSWALDO CRUZ}

Presidente

Nísia Trindade Lima

Vice-Presidente de Educação, Informação e Comunicação

Cristiani Vieira Machado

\section{EDITORA FIOCRUZ}

\section{Diretora}

Cristiani Vieira Machado

Editor Executivo

João Carlos Canossa Mendes

Editores Científicos

Carlos Machado de Freitas

Gilberto Hochman

Conselho Editorial

Denise Valle José Roberto Lapa e Silva

Kenneth Rochel de Camargo Jr.

Ligia Maria Vieira da Silva

Marcos Cueto

Maria Cecília de Souza Minayo

Marilia Santini de Oliveira

Moisés Goldbaum

Rafael Linden

Ricardo Ventura Santos
OBSERVATÓRIO COVID- I 9

\section{Comitê Editorial}

Carlos Machado de Freitas (coordenador)

Christovam Barcellos

Daniel Antunes Maciel Villela

Gustavo Corrrea Matta

Lenice Gnocchi da Costa Reis

Margareth Crisóstomo Portela 
Paulo Marchiori Buss

Luiz Eduardo Fonseca

Organizadores

\section{Diplomacia da Saúde e Covid-19 reflexões a meio caminho}

Série Informação para Ação na Covid-19
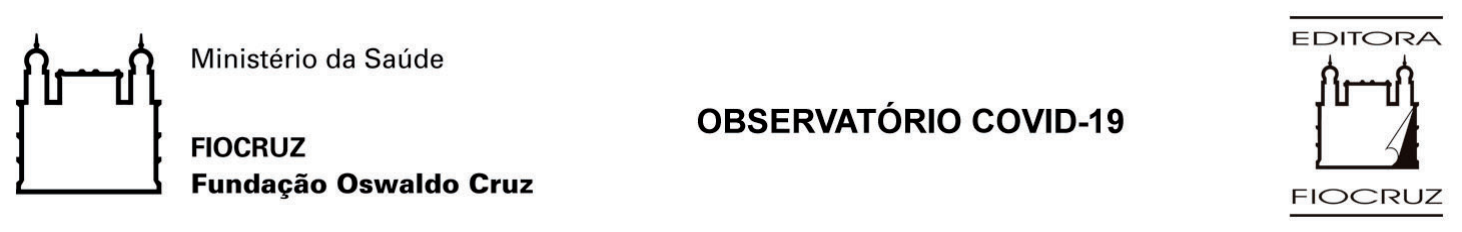
Copyright (C) 2020 dos autores

Todos os direitos desta edição reservados à

FUNDAÇÃO OSWALDO CRUZ / EDITORA

Revisão

Irene Ernest Dias

Normalização de referências

Clarissa Bravo

Capa, projeto gráfico e editoração

Adriana Carvalho e Carlos Fernando Reis

Produção editorial

Phelipe Gasiglia

Imagens da capa

Vírus

Depositphotos, ID391488244 - @ apid

Mulher

(C) Septembre 2020 Timbuktu Institute-Fondation Konrad Adenauer

Policy brief "Les jeunes du Sahel à l'heure de la Covid-19: entre résilience et créativité"

Hospital

Foto: Rovena Rosa, Agência Brasil - São Paulo

Catalogação na fonte

Fundação Oswaldo Cruz

Instituto de Comunicação e Informação Científica e Tecnológica em Saúde

Biblioteca de Saúde Pública

D596d Diplomacia da saúde e COVID- I9: reflexões a meio caminho. / organizado por Paulo Marchiori Buss e Luiz Eduardo Fonseca. - Rio de Janeiro : Observatório Covid- 19

Fiocruz / Editora Fiocruz, 2020.

363 p. : graf. ; mapas (Série Informação para ação na COVID-19)

ISBN: 978-65-5708-029-0

Inclui Bibliografia: 36 I-362.

Site: http://books.scielo.org

I. Infecções por Coronavírus. 2. Diplomacia em Saúde. 3. Tecnologia Biomédica. 4. Saúde Global. 5. Economia. 6. Sindemia. 7. Vulnerabilidade em Saúde. 8. Agências Internacionais. 9. Perfis Sanitários. I. Buss, Paulo Marchiori (Org.). II. Fonseca, Luiz Eduardo (Org.). III. Título. IV. Série.

CDD - 23.ed. -616.2

2020

EDITORA FIOCRUZ

Av. Brasil, 4036, térreo, sala 112 - Manguinhos

$21040-361$ - Rio de Janeiro, RJ

Tels: (2 I) 3882-9039 e 3882-904 I

Telefax: (2I) 3882-9006

e-mail: editora@fiocruz.br

www.fiocruz.br/editora

Editora filiada

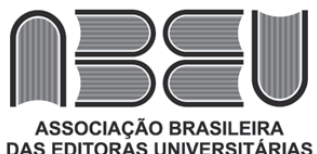




\section{Organizadores}

\section{Paulo Marchiori Buss}

Médico, mestre em medicina social, doutor em ciências. Coordenador do Centro de Relações Internacionais em Saúde (Cris/Fiocruz), membro titular da Academia Nacional de Medicina.

\section{Luiz Eduardo Fonseca}

Médico, mestre e doutor em saúde pública. Coordenador adjunto do Centro de Relações Internacionais em Saúde (Cris/Fiocruz).

\section{Autores}

\section{Aline da Rocha Matos}

Biomédica, mestra em ciências biológicas, doutora em oncologia com pós-doutorado em virologia molecular. Tecnologista do Laboratório de Vírus Respiratórios e do Sarampo do Instituto Oswaldo Cruz (IOC/Fiocruz).

\section{Ana Beatriz de Noronha}

Graduada em engenharia civil e em jornalismo, mestra em comunicação. Jornalista da Coordenação de Cooperação Internacional da Escola Politécnica em Saúde Joaquim Venâncio da Fiocruz (CCl/EPSJV/Fiocruz).

\section{Ana Helena Gigliotti de Luna Freire}

Graduada em relações internacionais, especialista em estratégias de negociações, mestra em relações internacionais. Analista de gestão em saúde no Centro de Relações Internacionais em Saúde (Cris/Fiocruz).

\section{Ana Lúcia Pontes}

Médica, mestra e doutora em saúde pública. Pesquisadora e professora em saúde, epidemiologia e antropologia dos povos indígenas na Escola Nacional de Saúde Pública Sergio Arouca (Ensp/Fiocruz), coordenadora do GT de Saúde Indígena da Associação Brasileira de Saúde Pública (Abrasco).

\section{André Lobato}

Mestre em mídias globais e comunicações, doutorando no Instituto de Economia da Universidade Federal do Rio de Janeiro. Membro das equipes do Centro de Relações Internacionais em Saúde (Cris) e do Centro de Desenvolvimento Tecnológico em Saúde (CDTS), ambos da Fiocruz.

\section{André Luiz da Silva Lima}

Bacharel e licenciado em história, doutor em história das ciências e da saúde. Integrante da Coordenação de Cooperação Social da Presidência da Fiocruz.

\section{André Périssé}

Médico, mestre em doenças infecciosas e parasitárias, doutor em epidemiologia com pós-doutorado em avaliação de impacto à saúde de grandes empreendimentos. Pesquisador em saúde pública do Departamento de Endemias Samuel Pessoa da Escola Nacional de Saúde Pública Sergio Arouca (Ensp/Fiocruz). 


\section{Andrey Cardoso}

Médico, mestre e doutor em saúde pública, com pós-doutorado. Pesquisador titular em saúde pública do Departamento de Endemias Samuel Pessoa da Escola Nacional de Saúde Pública Sergio Arouca (Ensp/Fiocruz).

\section{Augusto Paulo José da Silva}

Biólogo, mestre em biologia. Membro da equipe do Centro de Relações Internacionais em Saúde (Cris/Fiocruz), onde é responsável por Assuntos para o Continente Africano e para a Comunidade dos Países de Língua Portuguesa (CPLP).

\section{Beatriz Nascimento}

Graduada em comunicação social, especialista em relações internacionais, mestra em saúde pública. Membro da Vice-Direção da Escola de Governo em Saúde da Escola Nacional de Saúde Pública Sergio Arouca (Ensp/Fiocruz).

\section{Bianca Leandro}

Bacharel em saúde coletiva e mestra em vigilância em saúde. Tecnologista em saúde pública na Escola Politécnica de Saúde Joaquim Venâncio (EPSJV/Fiocruz) e pesquisadora colaboradora no Laboratório de Monitoramento Epidemiológico de Grandes Empreendimentos da Escola Nacional de Saúde Pública Sergio Arouca (Ensp/Fiocruz).

\section{Carlos Augusto Grabois Gadelha}

Doutor em economia. Professor da Escola Nacional de Saúde Pública Sergio Arouca, líder do Grupo de Pesquisa Desenvolvimento, Complexo Econômico-Industrial e Inovação em Saúde e coordenador das Ações de Prospecção da Presidência da Fiocruz.

\section{Carlos Eduardo Batistella}

Graduado em odontologia, mestre em saúde pública e doutor em educação. Professor do Programa de Pós-Graduação em Educação Profissional em Saúde da Escola Politécnica de Saúde (EPSJV/Fiocruz) e integrante do grupo de pesquisa em Políticas Curriculares do Programa de Pós-Graduação em Educação (ProPEd/Uerj).

\section{Carlos Linger}

Médico pediatra com pós-graduação em saúde pública. Assessor de Cooperação Internacional do Centro de Relações Internacionais em Saúde (Cris/Fiocruz). Foi representante da Organização Pan-Americana da Saúde/Organização Mundial da Saúde na Nicarágua e na Bolívia.

\section{Carlos Machado de Freitas}

Graduado em história, mestre em engenharia de produção, doutor em saúde pública com pósdoutorado em ciências ambientais. Na Fundação Oswaldo Cruz, é pesquisador da Escola Nacional de Saúde Pública Sergio Arouca, onde coordena o Centro de Estudos e Pesquisas em Emergências e Desastres em Saúde (Cepedes/Ensp), é editor científico da Editora Fiocruz e coordena o Observatório Covid- I 9 Fiocruz.

\section{Celso Amorim}

Diplomata, ministro da Defesa (20 I I-20 I 5) e ministro das Relações Exteriores do Brasil (2003-20 I I, 1993-1995). 


\section{Christovam Barcellos}

Graduado em geografia e em engenharia civil, mestre em ciências biológicas e doutor em geociências. Pesquisador titular do Laboratório de Informação em Saúde do Instituto de Comunicação e Informação Científica e Tecnológica em Saúde (Icict/Fiocruz), com ênfase em vigilância em saúde, nos temas geoprocessamento, análise espacial, indicadores de saúde e sistemas de informações geográficas.

\section{Cláudia Hoirisch}

Engenheira química, mestra em gestão e políticas públicas na área da saúde. Membro da equipe do Centro de Relações Internacionais em Saúde (Cris/Fiocruz).

\section{Cristina Schneider}

Médica veterinária e doutora em saúde pública. Foi assessora na interface de saúde animal e humana da Unidade de Gestão de Risco Infeccioso do Departamento de Emergência de Saúde da Organização Pan-Americana da Saúde/Organização Mundial da Saúde. Professora na Washington University.

\section{Daniel Antunes Maciel Villela}

Doutor em engenharia elétrica. Pesquisador da Fundação Oswaldo Cruz, onde é coordenador do Programa de Computação Científica (Procc). Trabalha com modelagem matemática e análise de desempenho, com particular interesse em modelagem matemática e métodos quantitativos em epidemiologia e ecologia de vetores de importância para a saúde pública.

\section{Fábio Araújo}

Graduado em ciências sociais, doutor em sociologia. Integrante da Coordenação de Cooperação Social da Presidência da Fiocruz.

\section{Fabius Vieira Leineweber}

Engenharia químico. Chefe da Divisão de Biotecnologia da Coordenação de Desenvolvimento Tecnológico do Instituto de Tecnologia em Fármacos (Farmanguinhos/Fiocruz).

\section{Felippe Amarante}

Graduado em comunicação social. Atua na área de Cooperação Internacional da Escola Nacional de Saúde Pública Sergio Arouca (Ensp/Fiocruz).

\section{Felix Júlio Rosenberg}

Médico veterinário, mestre em ciências médicas. Diretor do Fórum Itaboraí, Política, Ciência e Cultura na Saúde/Fiocruz, secretário executivo da Rede de Institutos Nacionais de Saúde Pública (Rinsp/CPLP) e coordenador da Rede Latino-Americana e do Caribe de Institutos Nacionais de Saúde Pública da Associação Internacional dos Institutos Nacionais de Saúde Pública (IANPHI).

\section{Gustavo Corrêa Matta}

Graduado em psicologia, mestre e doutor em saúde coletiva. Pesquisador em saúde pública da Escola Nacional de Saúde Pública Sergio Arouca (Ensp/Fiocruz), coordenador da Rede Zika Ciências Sociais da Fiocruz e editor associado da Physis: Revista de Saúde Coletiva.

\section{Helifrancis Condé Groppo Ruela}

Fisioterapeuta com residência multiprofissional em saúde coletiva, mestre em educação profissional em saúde. Coordenador de Cooperação Internacional da Escola Politécnica em Saúde Joaquim Venâncio da Fiocruz (CCl/EPSJV/Fiocruz). 


\section{Ilka Maria Vilardo Montefinese}

Engenheira química, especialista em gestão da qualidade com pós-graduação em engenharia química e processos petroquímicos. Responsável por assuntos relacionados à Europa no Centro de Relações Internacionais em Saúde (Cris/Fiocruz).

\section{Isis Pillar Cazumbá}

Graduada em relações internacionais, pós-graduanda em gestão de projetos. Membro da equipe do Centro de Relações Internacionais em Saúde (Cris/Fiocruz).

\section{João Aprígio}

Graduado em engenharia de alimentos, mestre em microbiologia e doutor em saúde da mulher e da criança. Coordenador da Rede Brasileira de Bancos de Leite Humano, do Centro de Tecnologia e Informação em Bancos de Leite Humano e Aleitamento Materno (Icict/Fiocruz) e do comitê consultivo BVS-Aleitamento Materno do Centro Latino-Americano e do Caribe de Informação em Ciências da Saúde (Bireme); chefe do Centro de Referência Nacional para Bancos de Leite Humano do Brasil; secretário executivo do Programa de Bancos de Leite Humano ibero-americanos (Secretaria Geral Ibero-Americana e Fiocruz); consultor do Ministério da Saúde e professor titular da Fundação Oswaldo Cruz no Instituto Fernandes Figueira (IFF) e no Instituto de Informação Científica e Tecnológica (Icict).

\section{Jorge Antonio Zepeda Bermudez}

Médico, mestre em medicina, doenças infecciosas e parasitárias, doutor em ciências, políticas sociais e saúde. Pesquisador titular da Escola Nacional de Saúde Pública Sergio Arouca (Ensp/Fiocruz).

\section{José Leonídio Madureira de Sousa Santos}

Graduado em gestão ambiental. Integrante da Coordenação de Cooperação Social da Presidência da Fiocruz.

\section{Jussara Ângelo}

Graduada em geografia, mestra em saúde pública e doutora em ciência do sistema terrestre. Pesquisadora em saúde pública no Departamento de Endemias Samuel Pessoa da Escola Nacional de Saúde Pública Sergio Arouca (Ensp/Fiocruz), com atividades relacionadas à análise de impactos socioeconômicos na saúde de grupos populacionais vulneráveis.

\section{Lenice Costa Reis}

Médica, mestra em ciências da saúde e doutora em saúde pública. Pesquisadora da Escola Nacional de Saúde Pública Sergio Arouca (Ensp/Fiocruz), onde atua em atenção ao parto, melhoria da qualidade do cuidado, segurança do paciente e vigilância sanitária.

\section{Letícia Cristina Pereira de Castro}

Bacharel em relações internacionais, mestra em análise e gestão de políticas internacionais. Membro da equipe do Centro de Relações Internacionais em Saúde (Cris/Fiocruz).

\section{Luana Bermudez}

Bacharel em relações internacionais, mestra em saúde pública com MBA em relações internacionais, doutoranda em saúde pública. Assessora da Presidência da Fiocruz.

\section{Lúcia Marques}

Graduada em jornalismo, mestra em saúde pública. Membro da equipe do Centro de Relações Internacionais em Saúde (Cris/Fiocruz), onde atua em assuntos relacionados a Ásia, Oceania e Oriente Médio e no Programa Fiocruz Antártica. 


\section{Luciana Frederico Milagres}

Graduada em relações internacionais, especialista em responsabilidade social e terceiro setor. Atua na Coordenação de Cooperação Internacional da Escola Politécnica em Saúde Joaquim Venâncio (CCl/ EPSJV/Fiocruz).

\section{Luciana Peixoto Affonso}

Bacharel em direito. Analista de Gestão no Centro de Relações Internacionais em Saúde (Cris/Fiocruz), atua na área de cooperação internacional em saúde, com ênfase na efetivação de projetos, em especial no campo da diplomacia em saúde e relações internacionais.

\section{Luiz Augusto Galvão}

Mestre em saúde pública, doutor em saúde coletiva. Professor adjunto na Universidade Georgetown, EUA, e membro do Centro de Relações Internacionais em Saúde (Cris/Fiocruz). Foi diretor da área de desenvolvimento sustentável, saúde ambiental e equidade da Organização Pan-Americana da Saúde (Opas/OMS).

\section{Margareth Crisóstomo Portela}

Graduada em engenharia elétrica, mestra em engenharia biomédica, doutora em política e administração de saúde, com pós-doutorado. Pesquisadora da Escola Nacional de Saúde Pública Sergio Arouca (Ensp/Fiocruz) e coordenadora geral do Proqualis, sediado no Instituto de Comunicação e Informação Científica e Tecnológica em Saúde (Icict/Fiocruz).

\section{Maria Cristina Schneider}

Médica veterinária, mestra em saúde pública, doutora em ciências. Professora adjunta no Departamento de Saúde Internacional da Universidade de Georgetown, EUA, e colaboradora do Instituto de Estudos de Saúde Coletiva da Universidade Federal do Rio de Janeiro (lesc/UFRJ).

\section{Mariane Martins}

Bacharel e licenciada em filosofia, bacharel em desenho industrial. Pesquisadora do Programa de Promoção de Territórios Saudáveis e Sustentáveis em Centros Urbanos (PTSSCU) da Coordenação de Cooperação Social da Presidência da Fiocruz.

\section{Marilda Mendonça Siqueira}

Farmacêutica bioquímica, mestra em biologia parasitária, doutora em microbiologia com pósdoutorado em virologia. Pesquisadora titular e chefe do Laboratório de Vírus Respiratórios, Sarampo e Coronavírus do Instituto Oswaldo Cruz (IOC/Fiocruz).

\section{Marilia Santini de Oliveira}

Médica, mestra em ciências, doutora em ciência. Assessora da Coordenação de Vigilância em Saúde e Laboratórios de Referência/Fiocruz.

\section{Miryam de Souza Minayo}

Graduada em relações internacionais e em nutrição, mestra em direitos humanos e direito internacional humanitário, doutora em direito internacional e relações internacionais. Membro da equipe do Centro de Relações Internacionais em Saúde (Cris/Fiocruz). 


\section{Nísia Trindade Lima}

Mestra em ciências políticas, doutora em sociologia. Presidente da Fundação Oswaldo Cruz (Fiocruz); membro do Comitê Consultivo do Plano de Ação Global para Vidas Saudáveis e Bem-Estar, do Comitê do Fundo de População das Nações Unidas (UNFPA) sobre a Conferência Internacional sobre a População e o Desenvolvimento (ICPD 25) e da Comissão Lancet sobre a Covid-19; copresidente da Rede de Saúde para Todos da Sustainable Development Solutions Network das Nações Unidas (UNSDSN) e do Grupo Diretor de Recuperação Econômica para aconselhar sobre o desenvolvimento de um Roteiro de Pesquisa das Nações Unidas para a Recuperação Covid- 19.

\section{Pedro Burger}

Licenciado em história, especialista em saúde pública, mestre em economia política internacional. Coordenador de Relações Institucionais da Escola Nacional de Saúde Pública Sergio Arouca (Ensp/Fiocruz).

\section{Regina Ungerer}

Médica, especialista em diplomacia da saúde e saúde global, mestra em saúde da criança, doutora em ciências. Membro da equipe do Centro de Relações Internacionais em Saúde (Cris/Fiocruz).

\section{Renata de Saldanha da Gama Gracie Carrijo}

Bacharel em geografia, mestra e doutora em saúde coletiva. Professora e pesquisadora do Instituto de Comunicação e Informação Científica e Tecnológica em Saúde (Icict/Fiocruz).

\section{Ricardo Ventura Santos}

Biólogo, mestre e doutor em antropologia, com pós-doutorado. Professor titular no Departamento de Antropologia do Museu Nacional/UFRJ e pesquisador titular na Escola Nacional de Saúde Pública Sergio Arouca (Ensp/Fiocruz).

\section{Roberta Gondim de Oliveira}

Graduada em psicologia, mestra e doutora em Saúde Pública. Pesquisadora em análise de políticas públicas, ciências sociais e saúde, e planejamento e gestão em saúde.

\section{Rômulo Paes-Sousa}

Especialista em medicina social, doutor em epidemiologia. Pesquisador do Centro de Pesquisa René Rachou (Fiocruz Minas) e do Instituto de Estudo do Desenvolvimento da Universidade de Sussex, Inglaterra.

\section{Rosa Maria Pinheiro Souza}

Mestra e doutora em saúde pública. Vice-diretora da Escola de Governo em Saúde da Escola Nacional de Saúde Pública Sergio Arouca (Ensp/Fiocruz), coordenadora da Secretaria Técnica e Executiva da Rede Brasileira de Escolas de Saúde Pública.

\section{Santiago Alcázar}

Diplomata, bacharel e licenciado em filosofia. Membro da equipe do Centro de Relações Internacionais em Saúde (Cris/Fiocruz).

\section{Sebastián Tobar}

Sociólogo, mestre em ciências, doutorando em saúde pública. Membro da equipe do Centro de Relações Internacionais em Saúde (Cris/Fiocruz). 


\section{Sumário}

Num Mundo em Mudança, Desafios Gigantescos: apresentação

Paulo Marchiori Buss e Luiz Eduardo Fonseca

\section{PARTE I - A DOENÇA E SUAS CIRCUNSTÂNCIAS}

I. Reflexões sobre a Geopolítica depois da Pandemia Celso Amorim

2. A Pandemia da Covid- 19: uma crise sanitária e humanitária Nísia Trindade Lima, Paulo Marchiori Buss e Rômulo Paes-Sousa

3. Desenvolvimento e Pandemia: transformação estrutural para além de um novo normal

Carlos Augusto Grabois Gadelha

4. Tecnologias de Saúde - Medicamentos e Vacinas: bens públicos globais ou disputa de mercado?

Jorge Antonio Zepeda Bermudez e Fabius Vieira Leineweber

5. Conhecendo o Sars-CoV-2 e a Covid- 19

Marilia Santini de Oliveira, Aline da Rocha Matos e Marilda Mendonça Siqueira

6. Saúde Única e a Pandemia de Covid- 19

Cristina Schneider e Marilia Santini de Oliveira

PARTE II - DIPLOMACIA DA SAÚDE E COVID- I 9

7. Prelúdio em Dó Maior: a Covid- 19 nas Nações Unidas Santiago Alcázar

8. Resposta à Pandemia da Covid- I 9 pela OMS e Opas Luiz Augusto Galvão

9. Respostas das Instituições Financeiras Internacionais à Pandemia da Covid- 19

Miryam de Souza Minayo e Isis Pillar Cazumbá

10. O G20 e a Pandemia: entre a economia e a saúde Luiz Eduardo Fonseca

11. Movimento dos Não Alinhados e G77: o Sul Global e a Covid- 19 Regina Ungerer

12. A Resposta da OEA à Pandemia de Covid- 19 em meio ao Desmonte do Multilateralismo 
13. América Latina e Caribe: entre a Covid-19 e a crise econômica e social

Sebastián Tobar e Carlos Linger

14. Brics na Covid- 19: multilateralismo, capacidade tecnológica e colaboração em PDEl

Cláudia Hoirisch

15. A Resposta à Covid- 9 no Continente Africano: a União Africana e a criação do CDC África

Augusto Paulo José da Silva e Felix Júlio Rosenberg

16. A Europa e o Multilateralismo no Enfrentamento da Pandemia da Covid- I 9

Ana Helena Gigliotti de Luna Freire, Letícia Cristina Pereira de Castro e

Ilka Maria Vilardo Montefinese

17. A Covid- 9 na Ásia-Pacífico e no Oriente Médio: fragilidades reveladas,

tensões exacerbadas e reposicionamento de aliados estratégicos

Lúcia Marques

18. O Brasil Seis Meses após a Declaração da Covid- I 9 como Pandemia Global

Carlos Machado de Freitas, Christovam Barcellos, Daniel Antunes Maciel Villela, Margareth Crisóstomo Portela, Lenice Costa Reis, Gustavo Corrêa Matta, André Périssé, Bianca Leandro, Carlos Eduardo Batistella, Fábio Araújo, Jussara Ângelo,

Renata de Saldanha da Gama Gracie Carrijo, Roberta Gondim de Oliveira,

Ana Lúcia Pontes, Andrey Cardoso, Ricardo Ventura Santos, André Luiz da Silva Lima,

José Leonídio Madureira e Mariane Martins

19. China: soberania e descolonização da resposta sanitária

André Lobato

20. Covid- 19: o impossível America first Santiago Alcázar

PARTE III - COVID- 19 E FIOCRUZ

21. Fiocruz como Ator da Saúde Global

Ana Helena Gigliotti de Luna Freire, Ilka Maria Vilardo Montefinese,

Letícia Cristina Pereira de Castro, Luciana Peixoto Affonso, Luiz Eduardo Fonseca e

Paulo Marchiori Buss

22. A Estratégia de Redes Estruturantes na Cooperação Internacional da Fiocruz:

América Latina e CPLP

Sebastián Tobar, Felix Júlio Rosenberg, Augusto Paulo José da Silva,

Rosa Maria Pinheiro Souza, Pedro Burger, Beatriz Nascimento, Felippe Amarante,

Helifrancis Condé Groppo Ruela, Rosa Maria Pinheiro Souza, Ana Beatriz de Noronha,

Luciana Frederico Milagres e João Aprígio 


\section{Num Mundo em Mudança, Desafios Gigantescos}

apresentação

Paulo Marchiori Buss e Luiz Eduardo Fonseca Pela capacidade de ceifar vidas humanas, destruir economias, mexer com as emoções
de milhares de pessoas, produzindo medo e solidão, de expandir-se por todos os países do mundo e deixar imensas dúvidas sobre o futuro, a pandemia da Covid- 9 é um dos maiores acontecimentos de repercussão global dos últimos cem anos da história da humanidade. Na realidade, o transcurso do processo, desde seu início até aqui, mostrou que se trata, mais do que de uma pandemia, de uma sindemia (Horton, 2020a), permeada por uma infodemia (Opas, 2020). Em termos de enfermidade, só é comparável com a vasta e mortal pandemia pelo vírus influenza que, de janeiro de 1918 a dezembro de 1920, infectou cerca de 500 milhões de pessoas, ou aproximadamente um quarto da população mundial à época, deixando um saldo de 17 a 50 milhões de vidas perdidas. A I Guerra Mundial, em cujo contexto social e temporal se insere a gripe "espanhola", teria marcado, para o genial historiador inglês Eric Hobsbawm, o fim do longo século XIX (I789-1914) e o início do que ele denominou o "breve século XX”, epíteto e subtítulo da sua admirável obra Era dos Extremos, que teria durado de 1914 até a queda da União Soviética, em 199I (Hobsbawm, 1994).

Impossível discordar do célebre historiador marxista. Mas nos permitimos arriscar dizer que, embora a revolução tecnológica e a globalização pudessem vir a marcar o início do século XXI, que começou cronologicamente em 2000-200I, tais mudanças não foram suficientes para conduzir a grandes mudanças na ordem global. Contudo, se considerarmos o tempo histórico, ele estaria começando em 2020, com a pandemia pelo Sars-CoV-2 e suas imensas consequências detectadas na forma de viver e conviver, embora ainda não de todo dimensionadas, já que estamos, a nosso ver, apenas a meio caminho nesta pandemia. 
A pandemia está longe de terminar, segundo muitos especialistas, e pode se estender por um a dois anos ou até se transformar numa enfermidade endêmica com surtos epidêmicos, dependendo do tipo de imunidade que deixa, seja por sua infecção natural, seja pela imunidade adquirida por uma vacina - que não temos ainda e não sabemos que capacidade imunogênica terá e que duração de resposta imune deixará.

Por essa razão, denominamos o livro como Diplomacia da Saúde e Covid-1 9: reflexões a meio caminho. A meio caminho por duas razões: porque realmente estamos a dez meses de sua chegada e ela se encontra ainda em expansão no mundo e recrudescendo onde já passou, deixando um triste rastro de mortes e sequelas; e porque, portanto, a resposta que o conjunto de atores da cena política e técnica internacional, que temos a pretensão de examinar, também se encontra a meio caminho.

Desde que eclodiu a pandemia de Covid-19, o Centro de Relações Internacionais em Saúde da Fundação Oswaldo Cruz (Cris/Fiocruz) mobilizou todos seus profissionais para o acompanhamento sistemático do desenvolvimento da enfermidade em todo o mundo. Durante 15 semanas consecutivas, de abril a agosto de 2020, os profissionais do Cris examinaram e produziram informes semanais sobre a resposta à pandemia de Covid- 9 no campo da diplomacia da saúde, nos organismos e iniciativas multilaterais globais e regionais.

Paradoxalmente, um minúsculo RNA que não respeitava fronteiras, que se mantiveram forçosamente abertas à sua propagação, obrigou ao fechamento das fronteiras geopolíticas a seus potenciais portadores, restringindo ao mínimo sua mobilidade. Enquanto se fechavam as fronteiras para conter o vírus, um multilateralismo global ameaçado e multilateralismos regionais se mobilizavam (ou não) para cooperar, visando ao controle do vírus. É desta última questão que tratamos neste volume virtual de 22 capítulos: a resposta do multilateralismo global e regional, por meio da diplomacia da saúde, à pandemia da Covid-19, causada pelo vírus Sars-CoV-2, e suas circunstâncias.

As três partes nas quais se divide a coletânea e seus diversos capítulos são complementares entre si: quando reunidos dão, simultaneamente (no tempo histórico e na geografia), a visão de cada região e a visão mundial, dado o enfoque sobre as institucionalidades multilaterais global e regionais.

Trata-se de um típico instant book,' ou seja, um livro que pretende contribuir com um retrato instantâneo e assumidamente parcial de um fenômeno ou acontecimento

\footnotetext{
' Instant book (livro instantâneo) é um termo usado no mundo editorial para designar um livro produzido e publicado muito rapidamente para atender à demanda da sociedade. Instant books buscam organizar e divulgar o conhecimento (parcial) sobre o fenômeno - de seu início até o momento da publicação.
} 
(Freitag, 1987), neste caso, da resposta à pandemia. Entre os exemplos mais famosos deste tipo de publicação estão os muitos instant books produzidos logo após o afundamento do Titanic, em 1912, que venderam milhares de exemplares de porta em porta e nas esquinas das grandes cidades americanas, europeias e, é claro, do Reino Unido. Estaríamos nós produzindo um instant book não sobre o afundamento físico de um navio, mas sobre o naufrágio de uma forma de viver da nossa humanidade comum, moldada no "breve século XX" e nas últimas décadas?

Em seu artigo de tom quase melancólico, na edição do New York Times de novembro de 1987, Freitag decretava que os tempos dos instant books haviam acabado. Sim, possivelmente, àquela época, terá sido um diagnóstico próximo do correto. Contudo, hoje em dia, com a internet e os e-books, que são de acesso instantâneo, renascem os instant books virtuais, e o volume que o leitor tem em mãos, ou na sua tela, é assumidamente um deles. ${ }^{2}$

Embora intuitivamente possamos reconhecer a necessidade de um "multilateralismo" ativo e generoso para enfrentar uma enfermidade desta natureza e envergadura, por meio de uma ativa "diplomacia da saúde", ou a importância da Covid-I 9 nas discussões no campo da "saúde global”, é decepcionante quando pesquisamos estes termos, isoladamente ou grupados em trio e pares, associados com a enfermidade, no potente site de artigos da Organização Mundial da Saúde (OMS) sobre a enfermidade, que já contém mais de 60 mil artigos. Muitos poucos artigos estão disponíveis, o que justifica mais ainda este apanhado de ensaios sobre a "diplomacia da saúde" em tempos de pandemia.

Para fazê-lo, foram acompanhadas, descritas e analisadas as respostas à pandemia nas diversas instâncias e agências das Nações Unidas, com particular foco na OMS, como não poderia deixar de ser, incluindo a Secretaria-Geral, o Conselho de Segurança, o Conselho Econômico e Social (Ecosoc), o Conselho de Direitos Humanos e outros; nas diversas regiões e alguns países do mundo (América Latina e Caribe, África, Europa, Oriente Médio e Ásia-Pacífico, Brasil, China e Estados Unidos); em organizações ou iniciativas multilaterais, como Brics (Brasil, Rússia, Índia, China e África do Sul), G20, Organização para a Cooperação e Desenvolvimento Econômico (OCDE) e Movimento dos Não Alinhados e G77; e instituições financeiras internacionais - Fundo Monetário Internacional (FMI), Banco Mundial (Banco Mundial) e Banco Interamericano de Desenvolvimento (BID). A descrição e análise

\footnotetext{
2 Um exemplo de instant book tradicional, impresso, e sobre a pandemia, é o livro de Richard Horton (2020), The Covid- 19 Catastrophe, lançado pela Polity Press.
} 
dessas respostas está reunida no conjunto de 14 capítulos que constitui o núcleo duro do livro, a Parte II, denominada "Diplomacia da Saúde e Covid-19".

Como o conjunto de leitores e interessados a que se destina este livro é amplo e variado - de profissionais da saúde a diplomatas, de especialistas em saúde global e diplomacia da saúde a ativistas sociais, entre outros -, introduzimos também conteúdos relativos ao que chamamos "A Doença e suas Circunstâncias" nos seis capítulos reunidos na Parte I deste volume. Para bem fazê-lo, selecionamos alguns temas transversais - geopolítica, crise humanitária, economia, insumos, a doença propriamente dita - e convidamos especialistas de grande envergadura para abordá-los. Ou seja, uma abordagem compatível com a visão hoje dominante de que estamos enfrentando uma pandemia sindêmica (Horton, 2020b).

O embaixador Celso Amorim faz, com a maestria e elegância de sempre, uma reflexão sobre a geopolítica pós-pandemia. Menciona, de partida, a ultrapassagem dos Estados Unidos da América (EUA) pela China como a maior economia do planeta, que terá amplos reflexos também no plano político. ${ }^{3}$ Nesse sentido, aponta para o acréscimo do chamado "poder brando" chinês ou o ativismo diplomático em ações de cooperação em relação à pandemia. Chama a atenção, ademais, para o fato de que não é possível menosprezar o papel e a ambição da Rússia, preferindo, por isso, referir-se a um tripé, em que três superpotências buscariam equilíbrios variáveis. Assinala, ainda, que a União Europeia continuará a ter peso relevante, como ficou demonstrado na poderosa resposta política, fiscal e monetária estruturada para a reconstrução pós-pandemia.

Quanto ao papel da América Latina e Caribe (ALC) na construção da "nova ordem", Amorim entende que há duas opções. A primeira, com cada país atuando isoladamente, correndo o risco de uma subalternidade que os deixará reféns dos interesses de uma das grandes potências. A segunda, atuando de forma tão unida quanto possível, capacitandose para os grandes desafios econômicos e tecnológicos do presente e do futuro. $O$ autor finaliza alertando que questões como clima, pandemia e emprego ocuparão o centro dos debates globais e, visionário, lembra que, como sempre, a história apenas coloca os problemas, cabendo aos seres humanos, devidamente conectados, resolvê-los.

No capítulo seguinte, Trindade, Buss e Paes-Sousa tratam da crise sanitária e humanitária imposta pela pandemia da Covid-19, procurando responder se seria ela um fenômeno inevitável diante da relação que os humanos mantêm com os diversos ecos-

\footnotetext{
3 O que alguns têm denominado "armadilha de Tucídides", parodiando o processo que levou à Guerra do Peloponeso, entre Grécia e Esparta, entre 43 I e 404 a.C.: a ultrapassagem de uma potência dominante por uma emergente.
} 
sistemas e as demais espécies animais e vegetais. Ou, em uma abordagem simplificada, o desfecho episódico - porém recorrente - da forma como se produzem e se consomem bens e serviços no mundo.

Dois temas, entre muitos outros, têm recebido particular atenção nas discussões políticas e técnicas durante a pandemia. As reflexões apresentadas por Gadelha indicam a urgência em apontar caminhos para o futuro, pois a realidade da pandemia, em seu curso natural, tende a agravar a crise e as vulnerabilidades estruturais. Propõe-se, a partir da concepção do Complexo Econômico-Industrial da Saúde (Ceis), uma abordagem passível de ser generalizada para viabilizar um padrão de desenvolvimento norteado pela equidade, pelo bem-estar e pelo dinamismo econômico e tecnológico. Os direitos sociais e à vida são apresentados como parte essencial da solução para a saída da crise, constituindo uma alavanca para sua superação estrutural.

Em vez de um "novo normal" que reproduza nossa desigualdade e as assimetrias globais, podemos construir uma agenda mínima de transformações estruturais que supere as tendências em curso, evidenciadas na pandemia do novo coronavírus, de acirramento da exclusão e da progressiva barbárie social, para que possamos construir um país e uma sociedade melhores, comprometidos com as pessoas que aqui vivem e que são os responsáveis pela riqueza aqui gerada.

A pandemia aumentou a demanda por intervenções que ofereçam resultados na sua contenção ou controle. Embora a ausência de tecnologias levasse à adoção de uma série de medidas não farmacológicas, as desigualdades e iniquidades no acesso a produtos essenciais de saúde já existentes ou em movimento ascendente remetem a décadas de discussão nos mais variados foros mundiais. Bermudez e Leineweber destacam no capítulo 4 deste volume que o histórico recente reflete a coexistência de iniciativas globais e multilaterais, com nítido contraste entre as tecnologias de saúde como bens públicos globais e a disputa acirrada no mercado promovida por interesses econômicos nacionais ou regionais. A competição financeira e as barreiras representadas pela propriedade intelectual ou monopólios decorrentes são obstáculos à cooperação solidária liderada pelas Nações Unidas e pela OMS. A potencialidade de bens públicos globais se revela na perspectiva dos direitos humanos, em uma proposta para o "novo normal” pós-pandemia com acesso universal.

Dado o interesse demonstrado por muitos profissionais em debates dos quais muitos dos autores deste livro participaram, destacamos dois temas de natureza biológica, clínica e epidemiológica, tratados por especialistas de alto nível convidados para desenvolvê-los. Santini de Oliveira, Matos e Siqueira, no capítulo sobre aspectos clínicos e laboratoriais da Covid-19, registram que o Sars-Cov-2, o terceiro coronavírus capaz de causar 
doença humana grave surgido nas últimas duas décadas, disseminou-se rapidamente pelo mundo a partir de Wuhan, na China, onde os primeiros casos de pneumonia intersticial foram relatados em dezembro de 20 I 9. A Covid- 19 foi declarada pandemia pela OMS em março de 2020. O vírus transmite-se pessoa a pessoa por vias direta (gotículas e fômites) e indireta (contato com superfícies contaminadas), causando amplo espectro de manifestações clínicas, desde quadros assintomáticos até quadros respiratórios graves, sepses e óbito. Ainda há muitas lacunas no conhecimento sobre a patogênese e a resposta imune à infecção. O diagnóstico etiológico, importante ferramenta para a vigilância em saúde, é realizado pela detecção de material viral em secreções respiratórias. O tratamento é sintomático e de suporte, e as medidas de prevenção são não farmacológicas, apesar de mais de duas centenas de produtos candidatos vacinais estarem em diferentes fases de desenvolvimento.

Segundo Schneider e Santini de Oliveira, autoras do capítulo sobre a relação entre saúde única e a pandemia, é imprescindível entender que, no planeta compartilhado em que vivemos, o que acontece num local pode afetar a todos e temos que aprender a viver em harmonia entre os seres humanos, respeitando os animais e o meio ambiente. Entender que estamos interligados e a importância da colaboração entre as diferentes disciplinas é a base do conceito de saúde única, que pode fornecer novas ferramentas para pesquisa, serviços eficazes e políticas em benefício da humanidade e dos animais, conservando o ambiente para as gerações atuais e futuras.

Os exemplos da peste, da varíola, da influenza em 1918 e da Covid- 19 demonstram que as epidemias fazem parte da história da humanidade. Para que ocorra uma pandemia é necessária a conjunção de diversos fatores, relacionados ao agente infeccioso, a pessoas, a animais e ao ambiente, considerado não apenas no contexto físico, mas também na forma como o homem ocupa o espaço e como se relaciona socialmente. Para diminuir as probabilidades de que ocorram novos eventos na interface animal-humano-ambiente, a abordagem com enfoque de saúde única pode ser usada tanto na predição como na prevenção e na detecção precoce.

A Parte II do livro trata das questões relativas às respostas multilaterais globais e regionais à pandemia, núcleo duro do que denominamos diplomacia da saúde. Seus diversos capítulos examinam, no mesmo período - as semanas de abril a agosto -, a resposta das diversas organizações multilaterais e internacionais, globais e regionais, e de países-chave no cenário global, propiciando ao leitor um rico panorama, que permite inclusive identificar aquelas mais adequadas e oportunas, e onde foram observadas falhas mais importantes. 
Mais que um exame exaustivo, Alcázar oferece, no capítulo sobre a resposta das Nações Unidas sugestivamente intitulado "Prelúdio em dó maior", um olhar impressionista sobre os diferentes matizes da resposta do sistema das Nações Unidas à Covid- 1 9. Para tanto, faz um sobrevoo, identificando os órgãos principais do sistema, as agências especializadas, os programas e fundos, os comitês e conselhos, que parecem como as complexas partes de um relógio.

A resposta das Nações Unidas aborda a dimensão sanitária, a emergencial e a de retomada, pós-pandemia. Como exemplo das ações desenvolvidas nessas três dimensões, o autor escolheu exibir as ações levadas a cabo pela OMS, a Organização das Nações Unidas para a Alimentação e a Agricultura (FAO) e a Organização Internacional do Trabalho (OIT), três agências especializadas diretamente envolvidas no encaminhamento de soluções para a Covid-19. Como exemplos, escolheu as ações levadas adiante por fundos e programas, especificamente o Programa das Nações Unidas para o Desenvolvimento (Pnud) e a Agência da ONU para Refugiados (Acnur). Finalmente, se deteve a contemplar o coração do sistema, representado pela Assembleia Geral das Nações Unidas (AGNU), o Ecosoc, o Conselho de Direitos Humanos, que depende da AGNU, e o Conselho de Segurança. O capítulo explora, portanto, o que foi, até o final do primeiro semestre de 2020, a resposta desse sistema multilateral à Covid- 19.

As principais atividades de resposta e coordenação global da OMS e de seus escritórios regionais, com destaque para a Organização Pan-Americana da Saúde (Opas), são apresentadas no capítulo em que Galvão faz uma seleção de eventos, iniciativas e documentos que representam áreas temáticas centrais e elementos-chaves da resposta. Esse é o evento de saúde pública de preocupação internacional (PHEIC) mais grave da história da OMS e representa um desafio ao Regulamento Sanitário Internacional e à governança da saúde pública global. Sua magnitude fez com que inúmeras medidas inovadoras fossem tomadas em diversos campos da saúde e de outros setores. O registro dessas atividades permitirá elaborar documentos sobre as lições aprendidas, as lacunas identificadas e, eventualmente, encontrar caminhos para melhor preparação no caso de eventos futuros, que não se restrinjam a mudanças na estrutura burocrática, mas sim envolvam transformações sociais por um mundo mais justo, amigável com a natureza e com melhor segurança humana. Galvão ressalta também as questões relacionadas às iniquidades em saúde, a necessária resposta intersetorial e considerações sobre questões ambientais, desenvolvimento sustentável, equidade, solidariedade e paz.

Minayo e Cazumbá contextualizam e descrevem cronologicamente as principais medidas tomadas pelo Banco Mundial, pelo FMI e pelo BID em resposta à pandemia. Realizam uma revisão dos documentos oficiais lançados por essas instituições e analisam 
criticamente os discursos que, aparentemente, trazem à tona poucas novidades em relação às velhas práticas de concessão de financiamentos. A atual pandemia é um dos maiores desafios que a humanidade enfrentou nos últimos tempos. Calcula-se que levará a grande aumento de pessoas vivendo na extrema pobreza. A extensão desse impacto social e econômico ainda é incerta. Mas não restam dúvidas de que a Covid- 9 provocou um choque mundial, com trágicas consequências para as populações mais vulneráveis. Diante desse panorama, as referidas instituições ampliaram seus mecanismos para mitigar os efeitos da pandemia. No entanto, parecem ter perdido a oportunidade de mudar o paradigma de suas práticas de financiamento aos países mais necessitados.

No capítulo sobre o Grupo dos Vinte (G20) e a OCDE, Fonseca analisa o desempenho dos grupos durante a pandemia da Covid-19. Ao fazê-lo, procura relacionar o G20 com outras instâncias multilaterais e suas relações, principalmente com a OCDE, com a qual tem estreita semelhança e colaboração, no tocante, principalmente, à ajuda internacional. O ensaio trata do paradoxo entre a declaração da cúpula do G20 e a declaração do encontro dos ministros da Saúde do G20: ao passo que a primeira se coloca ao lado do multilateralismo e oferece total apoio ao combate da pandemia e seus reflexos econômicos, a segunda, fruto do dissenso entre EUA e China, não assume posicionamento em relação a seu próprio objeto. O ensaio finaliza com uma reflexão sobre as pautas da economia e da saúde no G20, a partir da pandemia da Covid- 19.

Ungerer descreve brevemente a criação e o contexto histórico do Movimento dos Países não Alinhados (MNA) e do Grupo dos 77 (G77). Analisa os modos como ambos os grupos foram concebidos, como ultrapassaram os anos da Guerra Fria e como enfrentam os desafios de hoje, no cenário mundial. O MNA é a maior coligação de países depois das Nações Unidas e o G77 é a maior organização intergovenamental de países em desenvolvimento das Nações Unidas. Ambos estão mobilizados para enfrentar a pandemia de Covid-19, que a autora apresenta abordando as declarações feitas pelos dois grupos e relacionando as principais ações propostas.

Bermudez afirma que, mesmo em um contexto de questionamento do multilateralismo, a Organização dos Estados Americanos (OEA), com grande apoio dos EUA e do Brasil, tem estado ativa no desenvolvimento de uma resposta à pandemia por intermédio de seus diversos órgãos, como a Secretaria-Geral, o Conselho Permanente, o Conselho Interamericano de Desenvolvimento Integral, a Comissão Interamericana de Direitos Humanos, a Comissão Interamericana de Mulheres, além, é claro, da Organização Pan-Americana da Saúde, que também é o organismo regional especializado em saúde do Sistema Interamericano. 
Desde o início da propagação do Sars-Cov2 nas Américas, esses distintos órgãos da OEA adotaram resoluções, emitiram dezenas de comunicados, diretrizes, publicaram guias, organizaram dezenas de seminários virtuais, criaram repositórios de boas práticas e monitoramento da resposta dos países-membros, entre outras atividades com o objetivo de apoiar os países da região na implementação de respostas e políticas públicas com enfoque nos direitos humanos, inclusivas e acessíveis.

Tobar e Linger analisam a resposta da América Latina e Caribe à Covid- 19, abordando seus aspectos sanitários e econômico-sociais e as medidas implementadas pelos países da região. Para tanto, examinam as declarações, orientações e ações comuns implementadas pela Opas e pelos organismos multilaterais (ou plurilaterais) subregionais, casos da Comunidade de Estados Latino-Americanos e Caribenhos (Celac), do Mercado Comum do Sul (Mercosul), do Organismo Andino de Saúde, do Sistema de Integração Centro-Americano e do Mercado Comum e Comunidade do Caribe (Caricom). E concluem que não será fácil superar a difícil situação que permanecerá no cenário pós-pandêmico se não se fizer uso da diplomacia e da cooperação em saúde e não se aprofundarem os processos de integração regional.

Conforme reporta Hoirisch, o Brics vem, desde o início da pandemia, se reunindo para discutir a Covid-19. O grupo, com $40 \%$ da população e $24 \%$ da riqueza, tem um quinto das mortes no mundo. A autora mostra a resposta de cada país do grupo à Covid-19, destacando o contexto político e os compromissos adotados. Discute a crise China-EUA e a importância do multilateralismo para o grupo. Analisa a cooperação entre os Brics e os extra-Brics. O grupo não representa uma região geográfica específica, constitui uma comunidade de interesses econômicos e políticos comuns, tem uma agenda transnacional com diversas áreas de cooperação e projetos de pesquisa no campo da saúde, com mais iniciativas bilaterais e regionais do que multilaterais. A maioria dos países do Brics tem capacidade tecnológica na área de insumos de saúde e o grupo pode avançar na implementação de um centro de pesquisa em vacinas, estabelecer parcerias entre os fundos que apoiam projetos de pesquisa em cada país e criar um programaquadro do Brics, nos moldes da União Europeia.

Silva e Rosenberg tratam da resposta do continente africano e suas instituições à pandemia de Covid-19. As doenças transmissíveis e as recorrentes epidemias no continente africano levaram a União Africana a criar a sua própria agência especializada em saúde pública, o Centro de Controle e Prevenção de Doenças (CDC África), fruto de cooperação com a OMS e os CDC da China, dos EUA e da União Europeia.

O CDC África, criado oficialmente em 2017, enfrenta a sua primeira pandemia e é chamado a coordenar as ações de resposta à Covid- 19 num continente com 55 países. 
A União Africana é estruturada por oito organizações da integração econômica, das quais seis estão mobilizadas e preparadas para responder à pandemia. A cooperação internacional, reunida em torno da OMS, respondeu ao apelo da União Africana, e o CDC África pode se beneficiar de grandes apoios, no continente e internacionalmente.

Os Países Africanos de Língua Portuguesa (Palop), implicados na implementação da Estratégia Africana de Resposta à Covid-19, podem também contar com a colaboração e solidariedade de todos os Estados-membros da Comunidade dos Países de Língua Portuguesa (CPLP) sob a coordenação da Direção de Cooperação do Secretariado Executivo desta organização, partilhando, através de reuniões virtuais, conhecimento e experiências necessários para o enfrentamento da Covid- 19.

Freire, Castro e Vilardo reúnem as principais medidas do bloco europeu para o combate à Covid- 19 tomadas no período de janeiro a julho de 2020, sob a ótica do multilateralismo. As autoras comentam a evolução da pandemia no continente e, em seguida, os esforços conjuntos nas áreas da saúde, da ciência e tecnologia, da economia e da diplomacia empreendidos por diferentes atores e instâncias regionais europeus, bem como suas articulações e iniciativas para enfrentamento da crise. Por fim, abordam a atuação da Europa no cenário internacional, alguns avanços alcançados e lições aprendidas.

Marques analisa as regiões da Ásia-Pacífico (AP) e do Oriente Médio (OM), que reúnem mais de 65 países e mais de um quarto da população mundial, com grande diversidade cultural, religiosa, socioeconômica e política. Esses países têm similaridades quanto às fragilidades dos sistemas de saúde, mas vivem realidades diferentes ((trabalhadores migrantes na AP e refugiados no OM); diferentes fontes econômicas (petróleo no OM e turismo, tecnologia e insumos estratégicos na AP). Várias fragilidades foram trazidas à tona: megafavelas urbanas, trabalhadores migrantes, refugiados, sistemas de saúde pouco inclusivos, carga de doenças tratáveis ou evitáveis, fome e desnutrição.

As tendências geoestratégicas foram aceleradas e as respostas, inicialmente sanitárias, evoluíram para ações políticas e estratégicas voltadas para a autossuficiência e para um reposicionamento na nova ordem mundial. As fragilidades econômicas e sociais e de governança, as tensões exacerbadas e as novas tensões que afloraram são fatores importantes para a compreensão do cenário de desafios para os países da AP e do OM durante e após a pandemia, inclusive para paz e segurança.

Em seguida, a coletânea trata de três países-chave no contexto global: Brasil, China e Estados Unidos da América. O capítulo "O Brasil seis meses após a declaração da Covid- 19 como pandemia global” foi escrito com base no Boletim Observatório Fiocruz Covid-19 após 6 meses da pandemia no Brasil. Em sua primeira parte, é analisada a evolução de casos e óbitos por Covid- 9 no Brasil e no mundo, e comparada a situação 
singular do país, com lento crescimento e extenso patamar de transmissão desde junho, à de outros países com elevados números de casos e óbitos, como África do Sul, China, Espanha, EUA, Índia, Itália, México, Reino Unido e Rússia. Em seguida é analisada a organização dos serviços de saúde, mediante um balanço, e são delineadas perspectivas, considerando-se tanto a capilaridade de um sistema universal de saúde que propiciou a uma parte expressiva da população brasileira acometida pela Covid- 19 o acesso a serviços de saúde em diferentes níveis de complexidade quanto as fragilidades desse sistema, acumuladas em função do subfinanciamento e de problemas de gestão. Fragilidades e singularidades do sistema que se expressaram tanto na qualidade do cuidado e na segurança dos pacientes quanto na saúde dos trabalhadores da saúde. Por fim, são analisadas as situações de populações como indígenas e moradores de áreas de favelas, que, em razão de diferentes processos sociais, estão vulneráveis à Covid- 19 e apresentam piores indicadores de mortalidade.

A pandemia tornou mais visíveis os avanços no controle e na prevenção de epidemias na China, segundo Lobato. O aumento da capacidade de testagem, o desenvolvimento da ciência nacional e as medidas drásticas de isolamento social fizeram o número total de mortos do país ser inferior ao de vários países desenvolvidos. Sua capacidade de enfrentamento epidêmico foi vista em todas as fases da resposta, do isolamento e sequenciamento do vírus ao desenvolvimento de vacinas. Tal capacidade pode ser atribuída aos sucessivos investimentos do país em ciência e tecnologia, à adesão da população e ao esforço coordenado dos governos central e provinciais. A elevada capacidade instalada do complexo industrial da saúde chinês foi articulada com outras organizações produtivas, garantindo o abastecimento inclusive de mercados estrangeiros. Lobato argumenta que a resposta chinesa foi, do ponto de vista sanitário, soberana e que a cooperação bilateral e multilateral do setor Saúde pode contribuir para o maior engajamento da relação entre Brasil e China.

O mundo do pós-guerra é, em grande medida, produto de um esforço de reconstrução em que os EUA tiveram participação decisiva. Os acordos de Bretton Woods, com a criação do Banco Mundial, do FMI e do Acordo Geral sobre Tarifas e Comércio (Gatt), são apenas alguns exemplos. Mais importante talvez tenha sido a formação e a posterior consolidação do sistema das Nações Unidas como instrumento para o equacionamento de soluções para problemas globais. Com o surgimento da Covid-19, esperava-se do multilateralismo uma resposta à altura. O que se tem visto, contudo, é um desmantelamento institucional, em grande medida levado a efeito pelo presidente dos EUA, Donald Trump. O problema é que para a Covid- 19 não haverá solução que não seja pela via multilateral. Ninguém estará salvo se todos não estiverem 
salvos, segundo Alcázar, no seu capítulo sobre a resposta dos EUA à pandemia, que encerra a Parte II da coletânea.

A Parte III deste volume é dedicada à substantiva contribuição da Fundação Oswaldo Cruz (Fiocruz) e seus institutos à resposta à pandemia, por meio da cooperação internacional bi e multilateral e da atuação de seus dirigentes, líderes e pesquisadores em instituições globais.

No capítulo de Freire e colaboradores apresenta-se a expressiva ação de cooperação internacional da Fiocruz no contexto da pandemia de Covid-19. A presidência da instituição - incluindo suas vice-presidências e coordenações especializadas - e todos os seus institutos têm realizado intenso trabalho de cooperação com o sistema das Nações Unidas, o sistema plurilateral regional e as instituições coirmãs da América Latina e África, além de instituições e laboratórios da Europa e dos EUA. Junto com Câmara Técnica de Cooperação Internacional da Fiocruz, que coordena o trabalho de cooperação em cada um de seus institutos e nas instâncias da presidência, foi feito um levantamento e as informações foram distribuídas segundo as grandes áreas de atuação da instituição, como pesquisa, educação, informação e comunicação, vigilância, assistência e outras. O volume e a qualidade dos resultados apenas reafirmam a importância conferida pela Fiocruz à cooperação internacional, estratégia que beneficia todos os lados envolvidos, sob a consigna "cooperação estruturante em saúde".

Tobar e colaboradores abordam a estratégia de redes estruturantes na cooperação internacional da Fiocruz, nos âmbitos da América Latina e da CPLP. No cenário atual, em que a Covid-19 traspassa as fronteiras dos países, globalizando os riscos sanitários, sociais e econômicos, o trabalho em rede se apresenta como importante estratégia para a cooperação em saúde. O trabalho em rede reúne diferentes atores que se agrupam voluntariamente, permitindo sua articulação e possibilitando a troca e a conjugação de esforços, experiências e conhecimentos para o alcance de objetivos ou soluções comuns. Desde 2009, a Fiocruz tem fomentado a criação de diversas redes estruturantes que se orientam para o desenvolvimento institucional dos sistemas de saúde dos países parceiros, tais como as redes de Institutos Nacionais de Saúde e as de Formação em Saúde Pública e de Educação Técnica em Saúde. Com a pandemia, essas redes mostram como vêm potencializando sua atuação por meio virtual, adaptando seu trabalho à realidade e promovendo um importante movimento de troca e acúmulo de conhecimentos necessários ao combate à Covid- 19.

Segundo Horton (2020), a pandemia de Covid- 19 vai mudar sociedades, governos, pessoas, a medicina e a ciência. Desejaríamos que para muito melhor: que surgisse um mundo menos desigual, mais inclusivo, mais humano, mais cooperativo e com 
maior respeito ao meio ambiente. Tudo isso depende das pessoas, mas também das nações e da política. Estamos todos indelevelmente juntos na grande nave planetária; portanto, as diferenças políticas entre os países precisam ser superadas para que uma nova era surja no multilateralismo, que seja solidário, cooperativo e justo. Para isso trabalhamos na Fiocruz!

A elaboração deste livro foi uma das mais gratificantes produções coletivas de que os autores participaram. Foram 15 semanas de encontros regulares, em que nitidamente se sentia o crescimento de cada um dos integrantes e do coletivo, assim como da qualidade de cada produto.

Como subproduto deste livro virtual, duas outras fontes de informação estão disponibilizadas: os 15 informes semanais, que dão aos interessados um panorama global, regional e institucional de cada semana da pandemia, desde a primeira semana de abril, quando esse processo foi iniciado. O segundo produto é um volume que reúne os relatos dos autores sobre o que se passou nas 15 semanas em cada uma das instituições ou regiões focalizadas.

Portanto, além deste volume virtual, que sintetiza todo o processo, o Cris produziu 15 informes semanais globais e 13 informes institucionais ou regionais. É um notável esforço, feito com grande satisfação e dedicação, pelo serviço que acreditamos estar prestando à instituição a que servimos, bem como à comunidade de saúde e diplomacia nacional e global, com quem temos mantido produtivo diálogo e cooperação.

A publicação deste livro não teria sido possível sem a decisiva contribuição dos membros da Câmara Técnica de Cooperação Internacional em Saúde da Fiocruz, a quem dedicamos reconhecimento por sua contribuição na integração das relações internacionais da Fiocruz, por meio de todas as suas unidades técnicas: Aldo Venâncio (IRR), Analice Braga (Vpeic), Bárbara Trigueiros (ICC), Carlos Eduardo Grault (VPPCB), Carlos Eduardo Rocha (IOC), Claudia Chamas (CDTS), Cristiano Boccolini (lcict), Cristina Guilam (Vpeic), Eleonora Vasconcellos (INCQS), Emmanuelle Batista (Cris), Fabiane Gaspar (COC), Felippe Amarante (Ensp), Flavia Paixão (IGM), Gabriela Lobato (VPAAPS), Guilherme Franco Neto (VPAAPS), Helifrancis Condé (EPSJV), Ivana Barreto (Fiocruz-CE), João Aprígio (IFF), José Paranaguá (Gereb), Julia Rodrigues (CCS), Marcos Targino (Farmanguinhos), Maria da Penha (IAM), Maria Mendes Gomes (IFF), Norma Brandão (IOC), Patrícia Santana (Bio-Manguinhos), Pedro Burger (Ensp), Rafaella Queiroz (IRR), Roberta Freitas (Gereb), Sandra Soares (VPPIS), Tiago Neri (INI), Valber Frutuoso (Presidência), Wilson Savino (Coordenação Regional). 
Este livro também não teria se materializado sem a colaboração da equipe técnica que apoia o trabalho do Cris, solidária em todos os momentos: Cláudia Parente (coordenadora de Gestão), Anderson Nascimento, Barbara Vieira, Ana Paula Apolônio, Mary Fermo, Helena Distelfeld (coordenadora de Convênios e Mobilidade), Emmanuelle Batista, Liliane Botelho, Daniel Ferreira, Milton Lopes, Domingos Esteves, Gabriela Dutra, Luciana Ferreira, Sabrina Lopes, Elen Militão, Marcella Antunes e Guilhermina Duarte.

Agradecemos ainda o importante e constante apoio da Presidência da Fiocruz, na pessoa de sua presidente, Nísia Trindade, e de todas vice-presidências e suas coordenações, assim como os comentários de incentivo dos diversos líderes da Fiocruz que receberam (e continuam recebendo), ao longo das semanas, os informes sobre a resposta global à pandemia para os utilizarem como subsídios em suas decisões. Esse retorno nos incentivou a publicar nesta coletânea o consolidado das semanas por região.

Uma palavra especial de agradecimento à Editora Fiocruz, nas figuras da sua dinâmica diretora, Cristiani Vieira Machado, e do seu competente editor executivo, João Carlos Canossa Mendes, prata da casa e responsável há mais de vinte anos por conduzir a editora pelos caminhos que encarnam o espírito da instituição, que é o de servir com qualidade aos brasileiros, à ciência e ao SuS.

\section{REFERÊNCIAS}

FREITAG, M. On the endangered list: the "instant book". The New York Times, New York, Nov. 15, 1987. Section 3, p. 12.

HOBSBAWM, E. Era dos Extremos: o breve século XX, 1914-199I. São Paulo: Companhia das Letras, 1995. HORTON, R. The Covid-1 9 Catastrophe. Cambridge: Polity Press, 2020a.

HORTON, R. Offline: Covid- 19 is not a pandemic. The Lancet (10255), 2020b. ISSN 0I40-6736. PMID 32979964. doi:10.1016/s0I40-6736(20)32000-6.

OPAS (2020). Entenda a infodemia e a desinformação na luta contra a Covid-19. Página informativa n. 5. Disponível em: < https://iris.paho.org/bitstream/handle/I 0665.2/52054/Factsheet-Infodemic_ por.pdf? sequence $=14>$. Acesso: 16 out. 2020 .

WORLD HEALTH ORGANIZATION (WHO). Covid- I 9, global literature on coronavirus disease. Disponível em: <https://search.bvsalud.org/global-literature-on-novel-coronavirus-20 I9-ncov/>. Acesso em: 18 set. 2020. 



\section{Reflexões sobre a Geopolítica depois da Pandemia'}

Celso Amorim

E mbora seja muito difícil prever como será o mundo pós-Covid-19, parece haver L consenso entre os principais analistas que mudanças profundas ocorrerão no ordenamento vigente depois da II Guerra Mundial, incluídas aí as importantes alterações geopolíticas - menos estáveis do que se supunha - que se seguiram ao fim do "socialismo real" e à dissolução da União Soviética.

Uma das mudanças mais previsíveis, sobre a qual não parece haver grande discordância (independentemente dos juízos de valor sobre ela), é a ultrapassagem dos Estados Unidos da América (EUA) pela China como a maior economia do planeta. Essa ultrapassagem já ocorreu em termos de poder de compra, critério frequentemente usado pelas instituições financeiras internacionais, como o Fundo Monetário e o Banco Mundial, para expurgar flutuações cambiais da medição do peso econômico de cada país. Em mais alguns anos, a superação da economia norte-americana pela chinesa deverá, segundo toda probabilidade, ocorrer também no que se refere ao Produto Interno Bruto (PIB) medido em preços de mercado.

Note-se que a ascensão econômica da China, como costuma ocorrer, reflete-se no plano político e, em menor escala - mas de forma perceptível -, no terreno estratégico militar. Mesmo pensadores ocidentais, notadamente norte-americanos, apontam para o acréscimo do chamado "poder brando" chinês, em contraste com o declínio da capacidade de atração dos EUA. Pesquisas recentes, durante a pandemia, demonstram

\footnotetext{
' Originalmente publicado como artigo na revista Carta Capital, em 15 de junho de 2020. https://www. cartacapital.com.br/opiniao/reflexoes-sobre-a-geopolitica-depois-da-pandemia/ Acesso em: 20 set. 2020.
} 
uma perda de popularidade da autointitulada "terra da liberdade" no imaginário de países europeus, muito especialmente na Alemanha. Nos últimos anos, assistiu-se a uma maior atratividade chinesa, em virtude de programas, como o Um Cinturão, uma Rota, que levaram ao país asiático líderes de diversas nações desenvolvidas. A força de atração da China, apesar de continuadas reticências com relação ao seu regime político, tenderá, a curto e médio prazos, a acentuar-se em virtude da percepção de que, bem ou mal, o país foi capaz de conter o vírus, do ativismo diplomático em ações de cooperação em relação à pandemia, da maior disponibilidade para investimentos em outras áreas do mundo. Ao mesmo tempo, a atitude de indiferença ou mesmo de hostilidade de Donald Trump para com outros países resultará, como apontou, entre outros, Joseph Nye (o criador do conceito), em declínio ainda mais acentuado do poder brando (soft power) norte-americano.

Uma das grandes incógnitas, a ser esclarecida nos próximos meses, é justamente saber para onde vai a política externa dos EUA. Obviamente, os interesses estruturais norte-americanos continuarão a ser os mesmos, a começar pelo capital financeiro, pelas grandes empresas de tecnologia e por considerações de natureza estratégico-militar, ainda que câmbios internos, derivados da pandemia e da crescente revolta da população de origem africana, possam modular substancialmente a forma como esses interesses são apresentados e defendidos mundo afora. Essencialmente, trata-se de saber, por ocasião da escolha entre Joe Biden e Trump, se Washington manterá a atitude de defesa agressiva dos seus interesses econômicos e estratégicos, sem levar em consideração outras posições ou sensibilidades, ou se, como ocorreu em larga medida desde a II Guerra Mundial, buscará modular sua ação de modo a evitar conflitos arriscados e confrontações desnecessárias. A resposta a esta pergunta teremos nos primeiros dias de novembro.

A anteposição EUA-China poderia indicar que o mundo transitará do arremedo de unipolaridade pós-Guerra Fria, que vinha esmaecendo nas duas últimas décadas, em direção a uma nova bipolaridade (alguns analistas falam em "nova Guerra Fria”). Não há que menosprezar o potencial de conflito e rivalidade entre as duas maiores economias do mundo. Um respeitado analista político, que exerceu cargos importantes na administração norte-americana, Graham Allison, cunhou a expressão "armadilha de Tucídides”, a propósito do risco (ou quase certeza) de confrontação ou guerra quando uma potência emergente ultrapassa ou ameaça a supremacia de outra, dominante até então. Foi o que ocorreu entre Atenas e Esparta na Guerra do Peloponeso, cinco séculos antes da nossa era.

Mas não é necessariamente assim. Em primeiro lugar, do ponto de vista estratégicomilitar, não há como descartar a Rússia, cujo potencial em armamentos modernos de 
alto poder destrutivo tem sido constantemente atualizado e aprimorado, de foguetes hipersônicos a torpedos de longuíssimo alcance com capacidade nuclear. Além disso, a Rússia detém um vastíssimo território, que vai do coração da Europa às lonjuras árticas do Extremo Oriente, rico em recursos naturais, a começar por petróleo e gás, cujos papéis na economia mundial dispensam comentários. Sem falar no fato de que, após o período da ressaca yeltsiana, pós-dissolução da URSS, Moscou voltou a demonstrar grande assertividade no terreno internacional, ilustrada, entre outras, pelas ações na Crimeia e na Síria. Assim, do ponto de vista estratégico-militar, mas com óbvio impacto político, seria talvez mais correto, em vez de bipolaridade, falar, como já me referi, de um tripé, em que três superpotências buscariam equilíbrios variáveis.

Hoje, esse equilíbrio tende a se realizar com uma aliança "eurasiana" entre Moscou e Pequim, em face de um governo norte-americano voluntariosamente agressivo e com alto grau de imprevisibilidade, o que ficou demonstrado nos conflitos da Síria e do Afeganistão e, até certo ponto, com relação à Coreia do Norte. Mas a estabilidade dessa aliança está longe de ser um dado permanente. Nada exclui que, como no passado (quem não se lembra do conflito sino-soviético dos anos 60 e 70?), choques de interesse venham a ocorrer entre as duas grandes potências do continente eurasiano e que, eventualmente, Washington possa beneficiar-se. Uma extensíssima fronteira comum pode ensejar importantes ações de cooperação, mas frequentemente é também fonte de atritos. Não é um cenário provável, por ora, dada a grande dependência da Rússia em relação a investimentos e apoio econômico da China, mas não é de se descartar em um cenário de mais longo prazo.

O tripé estratégico não esgota o quadro de atores que conformarão a nova ordem mundial pós-vírus. Em um mundo reconstruído, a União Europeia (UE) continuará a ter peso relevante. Decisões recentes parecem indicar uma renovada disposição de seus mais importantes integrantes, notadamente a Alemanha de Angela Merkel e a França de Emmanuel Macron, em reforçar a União, em particular com uma nova concepção do papel das instituições europeias na política fiscal. Para além de empréstimos, governantes europeus acordaram estímulos diretos de grande vulto, na casa do trilhão de euros, sob a forma de subsídios, para impulsionar a reconstrução pós-pandemia. Obviamente, é necessário aguardar para ver como essas boas intenções anunciadas pela Comissão Europeia se traduzirão em projetos concretos em benefício de economias mais atingidas pela crise. Em um sistema multipolar, em que será necessário contrabalançar o exercício cru do poder com atitudes de autêntica cooperação, a capacidade de iniciativa e de negociação da UE não deve ser subestimada. Paradoxalmente, a médio prazo, o Brexit, sempre apontado como um sintoma de fraqueza, pode ter contribuído para 
um reforço do eixo Paris-Berlim, com ramificações, sobretudo, na Europa Meridional. Claro está que a unidade europeia continuará a enfrentar grandes desafios, entre eles a tendência autocrática de alguns países da antiga órbita soviética, que ameaça tisnar a imagem democrática que o velho continente deseja projetar. Seja como for, nas grandes negociações sobre temas globais, como clima, imigração, comércio e direitos humanos, a Europa tenderá a atuar de forma coordenada. Em um mundo de grandes blocos (EUA, China e Rússia são blocos em si mesmos), a UE fará sentir sua influência.

Isso nos leva, finalmente, à pergunta: qual é o lugar da América Latina e do Caribe e, em particular, do Brasil na construção da nova ordem? Uma opção para os países da região seria a atuação isolada, cada um buscando retirar o máximo de vantagens individuais de alianças preferenciais com algum dos grandes polos estratégicos. Essa opção pela subalternidade, que na verdade tem sido praticada por alguns governos, nos deixará reféns dos interesses de uma das grandes potências responsáveis pelo equilíbrio global. Sempre que o interesse do país ou da região se chocar com a potência hegemônica, este ou esta terá de ceder. No plano dos valores, ideias como solidariedade, cooperação e diálogo pacífico serão postas de lado em deferência ao "destino manifesto" do país líder. Pareceria mais lógico, em uma nova multipolaridade (ainda que com traços de bipolaridade) que se avizinha, que as nações da América Latina e do Caribe atuem de forma tão unida quanto possível, países em desenvolvimento que são e que necessitam ainda se capacitar para os grandes desafios econômicos e tecnológicos do futuro.

Naturalmente, é até difícil imaginar nos dias de hoje, com governos tão díspares e com o maior dos países da região abraçado a uma política de submissão explícita, que um cenário de maior independência possa produzir-se. Mas é essencial que tenhamos clareza a esse respeito para implementar uma verdadeira política de integração e cooperação latino-americana e caribenha (se necessário, no nosso caso, precedida por maior integração sul-americana), quando as condições permitirem.

Essa sonhada unidade sul/latino-americana (e caribenha), para ser eficaz, não poderá dispensar parcerias com outros grupos de países em desenvolvimento. A África, apesar da variedade de situações e de inclinações políticas, tem sabido manter-se unida nas grandes questões globais, das mudanças climáticas ao acesso a vacinas, da oposição às sanções econômicas à defesa do multilateralismo. A cooperação com a África, no caso do Brasil uma obrigação histórica e cultural, é essencial para lograr interesses das nações em desenvolvimento, como se revelou em mais de uma oportunidade, em discussões ambientais, comerciais ou relativas à saúde global. Algo semelhante se dará em relação aos países em desenvolvimento da Ásia (afora a China, que, a rigor, não pode ser considerada em desenvolvimento), a começar pela Índia, cuja economia, 
medida pelo poder de compra, está entre as cinco maiores do mundo. Até que ponto essas nações lograrão um posicionamento independente sem cair na subordinação ou, contrariamente, na hostilidade em relação à China é algo que terá de ser acompanhado e sobre o que não é possível fazer prognósticos claros.

Cabe aqui um parêntese para assinalar que a visão estratégica hoje prevalecente em Washington procura desde já subverter a efetividade desse arranjo multipolar. Em plena pandemia, sob a liderança do secretário de Estado norte-americano, reuniram-se virtualmente os ministros das Relações Exteriores de sete países. Além dos EUA, estavam presentes, segundo noticiário indiano, os titulares das pastas do Exterior de Brasil, Israel, Índia, Austrália, Japão e Coreia do Sul. Esse grupo, aparentemente heterogêneo, tem um traço em comum. Seja por motivos ideológicos, seja por interesses e rivalidades regionais, são vistos como potenciais aliados em uma política de enfrentamento com a China. Curiosamente, nenhum país da Europa, cujos governantes se têm mostrado bastante pragmáticos em relação a Pequim. Embora seja prematuro julgar a estabilidade dessa configuração, ela não deixa de indicar como o atual governo norte-americano vislumbra uma eventual arregimentação antichinesa, totalmente contrária aos nossos interesses, como país e como região. Grupos como o Brics (Brasil, Rússia, Índia, China e África do Sul) e o Ibas (Índia, Brasil, África do Sul), dos quais o Brasil faz parte, podem e devem atuar para diluir essa visão de confronto.

Seria altamente simplificador não considerar, na antevisão do que poderá ser uma nova ordem mundial, as mudanças que ocorrerão nos países ou transversalmente dentro deles. As impressionantes manifestações antirracistas que se estenderam dos EUA para o mundo, com fortes conotações de práticas colonialistas ainda hoje presentes nas políticas migratórias de países europeus, exigirão reformas de fôlego, que virão a se somar a outras demandadas pela pandemia, como melhores serviços de saúde, expansão da esfera pública em questões sociais e culturais. Por outro lado, a fadiga com o neoliberalismo, que havia provocado protestos de massa em países como Chile, Colômbia e Equador, tenderá a alastrar-se por toda a região, na esteira da recessão e do desemprego, na medida em que políticas míopes de austeridade não cedam lugar a investimentos públicos, com maior participação direta do Estado. Não se pode excluir que, em alguns países, de instituições frágeis ou fragilizadas, ocorram grandes convulsões sociais, que tanto podem apontar no sentido de uma verdadeira democratização da sociedade como - há que se admitir - suscitar anseios por segurança e ordem com conotações fascistoides, para além das tendências presentes em países como Brasil e Bolívia. Tais mudanças internas, cuja direção vai depender, em parte, da capacidade de articulação das forças progressistas, não podem ser desconsideradas no desenho que se queira fazer da futura ordem internacional. 
Em suma, nos meses e anos que virão, mudanças internas e no quadro geopolítico mundial vão interagir para que um novo ordenamento substitua o que aí está. Isso deverá, em graus diversos, acontecer em instituições formais, como as Nações Unidas, e nas informais, como os variados "Gs", onde se debatem os temas globais e se elaboram consensos que depois orientarão decisões nacionais e internacionais. Questões como clima, pandemia e emprego ocuparão o centro desses debates. Se eles se realizarão sob uma ótica de solidariedade e cooperação ou do egoísmo e do conflito é algo que vai depender de articulações que possam ser feitas por Estados nacionais e grupos transnacionais, inclusive da sociedade civil. Como sempre, a história apenas coloca os problemas. Cabe aos seres humanos, devidamente conectados, resolvê-los. 


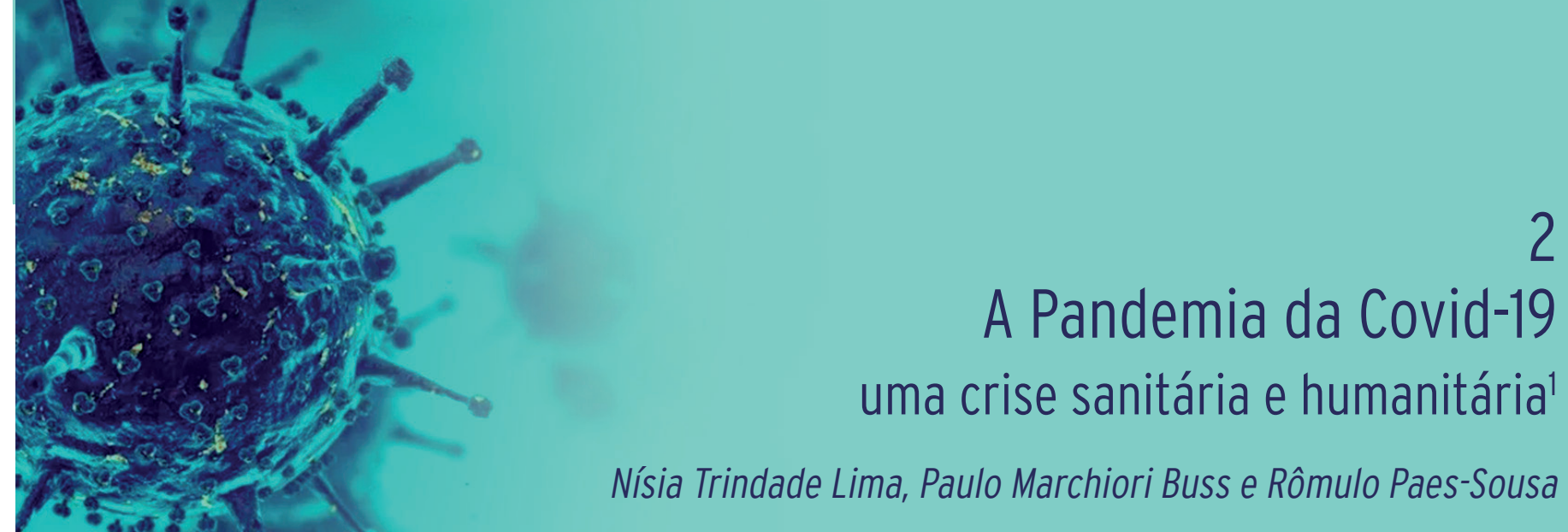

A Pandemia da Covid-19 uma crise sanitária e humanitária'

- m 2020, a pandemia da Covid- 19 tem levado quase todo o planeta a uma crise sa- nitária e humanitária, testando a espécie humana em várias dimensões. A pergunta que se eleva sobre tantas dúvidas é: seria ela um fenômeno inevitável diante da relação que os humanos mantêm com os diversos ecossistemas e as demais espécies animais e vegetais? Ou, em uma abordagem simplificada, o desfecho episódico - porém recorrente - da forma como se produzem e se consomem bens e serviços no mundo?

A pandemia magnifica as tensões dilacerantes da organização social do nosso tempo: globalizada nas trocas econômicas, mas enfraquecida como projeto político global; interconectada digitalmente, porém impregnada de desinformação; à beira de colapso ambiental, mas dominantemente não sustentável; carente de ideais políticos, mas tão avessa à política e a projetos comuns. A pandemia nos coloca diante do espelho, que nos revela um mundo atravessado por muitas crises e carente de mudanças.

Em 1980, Richard Krause constatou a persistência das doenças infecciosas que, em sua visão, representavam uma ameaça permanente a todos os países, independentemente do grau de desenvolvimento econômico e condições sanitárias. Para ele, "as epidemias são tão certas como a morte e os impostos". Pouco antes do impacto da epidemia de Aids, perspectivas como a do citado virologista americano já colocavam em xeque uma das teses dominantes na saúde pública da segunda metade do século XX, caracterizada

\footnotetext{
' Originalmente publicado como: LIMA, N. T.; BUSS, P. M. \& PAES-SOUSA, R. A pandemia da Covid- 19: uma crise sanitária e humanitária Cadernos de Saúde Pública, 36(7), 2020. Ver: <https://doi.org/10.1590/0 I023IIX00177020> Acesso em: 18 set. 2020.
} 
pelo prognóstico da eliminação das doenças decorrentes da afluência e da urbanização. Dessa forma, muitas doenças poderiam ser prevenidas pelos avanços tecnológicos, pela universalização do saneamento básico e, particularmente, pelo desenvolvimento de antibióticos e vacinas. Segundo esse modelo teórico, ocorreria a perda de importância das doenças infeciosas nos países mais ricos, onde as doenças dos períodos de carência cederiam inexoravelmente lugar para as doenças da abundância e do excesso. Contudo, em muitos países permaneceria uma distribuição desigual nos padrões epidemiológicos, indicando que a prevalência de doenças infeciosas, da desnutrição e, mesmo, da baixa expectativa de vida seria inversamente proporcional ao tamanho da economia dos países. No mundo, a desigualdade na distribuição dos padrões epidemiológicos seria função da distribuição desigual das condições socioeconômicas e dos meios de prevenção e tratamento de doenças.

A pandemia do Covid-I 9 evidenciou uma profunda mudança nas relações entre espaço, tempo e doenças infecciosas. Percebeu-se que o mundo estava mais vulnerável à ocorrência e à disseminação global de doenças, tanto conhecidas como novas. A integração das economias em todo o planeta permitiu grande aumento da circulação de pessoas e de mercadorias; promoveu o uso intensivo e não sustentável dos recursos naturais; e acentuou mudanças sociais favoráveis ao contágio das doenças infeciosas, i.e., adensamento populacional urbano, massiva mobilidade de populações nesses espaços, agregação de grandes contingentes de pessoas pobres, que por seu turno acabariam por ocupar habitações precárias com acesso limitado ao saneamento básico. Essas condições permitiram o desenvolvimento da "globalização da doença" Covid-19, tomando aqui de empréstimo a definição de Fidler (2004) relativa à pandemia de síndrome respiratória aguda grave (Sars), que ocorreu em 2002-2003.

\section{NÊMESIS E 0 DESAFIO DAS NOVAS EPIDEMIAS}

Mas, seriam as pandemias fatalidades? Vitórias de Nêmesis, a deusa grega da vingança, tal como nos lembra Philip Roth (20l I) em seu romance sobre as relações entre a epidemia de poliomielite e a II Guerra Mundial nos EUA? Recolocamos aqui a pergunta formulada no início deste artigo. Para respondê-la temos que considerar as epidemias e, sobretudo, pandemias como a que vivemos como um fenômeno multidimensional, a um só tempo biológico, ambiental e social, com fortes implicações econômicas e políticas. Tanto a disseminação acelerada da doença pelo mundo e seus efeitos colaterais como as estratégias de respostas à crise sanitária e humanitária indicam uma sobreposição de tempos e lugares na experiência humana de enfrentar poderosos choques. 
Neste contexto, observa-se o retorno de práticas inadequadas sobejamente registradas em textos científicos e literários: negação da gravidade do quadro, promessas tecnológicas irrealizáveis, cultura do medo, misticismo da imunidade e da cura, mercantilização do cuidado, exortação por um evitável sacrifício alheio, inépcia na gestão dos meios de combate disponíveis, que nos levam todos a um desnecessário sofrimento.

Também, as respostas sociais organizadas contêm aspectos cumulativos do que fomos aprendendo no enfrentamento das doenças. O aparato utilizado para o combate à pandemia tem combinado tecnologias desenvolvidas em diferentes períodos históricos. Medidas quarentenárias foram consolidadas no século XIV, nas cidades portuárias do Mediterrâneo, como estratégia de controle da peste negra. Hospitais modernos e drogas antivirais que são legados do século XX. Essas tecnologias são agregadas a um aparato contemporâneo desenvolvido a partir do final do século passado, como RT-PCR, smartphones, biotecnologia genômica, big data, inteligência artificial, câmeras de monitoramento, geolocalização, drones e telemedicina. Esse conjunto de soluções tem sido utilizado, em alguma medida, pelos cerca de 200 países e territórios atingidos pela doença, de acordo com sua disponibilidade. A cobertura e intensidade do uso dessas tecnologias pelos países indica que a capacidade industrial, o volume de riqueza, a adaptabilidade social e a capacidade de gestão política são os ativos mais importantes a serem mobilizados diante de choques globais de múltiplas dimensões. De certa forma, são sensíveis indicadores de como estão distribuídas as capacidades econômicas e de gestão no nosso planeta.

Como em todas as crises, cada país tende a mobilizar seus melhores ativos para lidar com o problema. Obviamente, nesse percurso, suas fraquezas também são evidenciadas. Portanto, é no confronto dessas forças antagônicas que vidas são ganhas ou inutilmente perdidas.

Os países industrializados da Ásia enfrentaram a pandemia com uma excepcional mobilização de recursos físicos e tecnológicos. Também mobilizaram pessoal capacitado e imobilizaram grandes contingentes populacionais, impondo várias modalidades de isolamento social. Seja por imposição, seja por adesão, China (incluindo Hong Kong), Japão, Taiwan e Coreia do Sul, diversos tipos de restrição da mobilidade foram implementados, em geral com uso intensivo de tecnologias. Contando com recursos mais modestos, Costa Rica, Vietnã e Tailândia também conseguiram conter os avanços da pandemia em seus respectivos países.

Após a Ásia, o epicentro da pandemia se deslocou para a Europa. Em tese, esse seria o melhor território para se combater o vírus: o continente mais homogêneo em termos econômicos e sociais do planeta (ainda que muito diverso em relação à cultura); 
o berço da revolução industrial, dos sistemas nacionais de saúde e dos modelos de proteção social; um espaço densamente povoado por pessoal altamente qualificado e com o melhor sistema rodoferroviário do planeta. Itália, Reino Unido, Espanha e França enfrentaram grandes dificuldades no enfrentamento da doença, com surpreendentes números de mortes. Em seguida, o epicentro da pandemia se deslocou para os EUA, que, embora seja muito mais desigual que os países europeus, tem a maior economia do planeta e grande concentração de recursos para enfrentar choques do porte da Covid-19. A última edição do Global Health Security Index (Cameron, Nuzzo \& Bell, 2019) classificou os EUA e Reino Unido como os países mais preparados entre os pesquisados para enfrentar a emergência de crises sanitárias. Na mesma edição Nova Zelândia e China ocupavam posições mais modestas no ranking - respectivamente $35^{\mathrm{a}} \mathrm{e}$ $5 \mathrm{I}^{\mathrm{a}}$ posições. Contudo, várias nações que acumularam competências diversas, inclusive sanitárias, saíram-se muito pior do que esperado no enfrentamento à pandemia, em função de escolhas inadequadas, ao passo que China e sobretudo Nova Zelândia obtiveram melhores resultados no seu controle. Uma das lições já aprendidas com a pandemia em curso é a necessidade de valorizarmos a gestão pública e o tempo de resposta nos critérios de aferição da capacidade instalada para o enfrentamento de crises sanitárias e humanitárias emergenciais. A resposta rápida, consistente e sustentável de lideranças políticas também se mostrou fundamental nos países que apresentaram melhores resultados no combate à Covid- 19.

A chegada da pandemia à América Latina e Caribe encontra um subcontinente enfraquecido pelo modesto crescimento econômico, quando comparado aos demais continentes; seu setor público (saúde, ciência e educação) debilitado pela redução dos investimentos em políticas públicas, como consequência das políticas de austeridade fiscal; com maior instabilidade política do que na década anterior; e enfraquecido, em seus vínculos regionais, pelo esgarçamento de estruturas como a União de Nações Sul-Americanas (Unasul), o Mercado Comum do Sul (Mercosul), a Organização dos Estados Americanos (OEA) e pela implementação tímida da Comunidade de Estados Latino-Americanos e Caribenhos (Celac). Uma justaposição de debilidades se apresenta em vários países da região, nos quais a escassez de recursos e conflitos nacionais são potencializados pelas fragilidades dos instrumentos de governança regional - que por sua vez já sofriam os efeitos do enfraquecimento dos instrumentos de governança global, incluindo a própria Organização Mundial da Saúde (OMS). 


\section{OPORTUNIDADES PARA REVISÃO DE CAMINHOS}

Mesmo nas grandes catástrofes, o infortúnio nunca é distribuído de forma igual. A prévia, e por vezes secular, acumulação de recursos dota nações e indivíduos de capacidades diferenciadas para o enfrentamento de crises, mesmo quando sobrevêm erros na abordagem inicial dos problemas. Dessa forma, sabemos que a superação da pandemia e reconquista dos padrões sociais e econômicos mais confortáveis se darão de forma desigual.

É preciso que se mobilizem, nos planos global, regional e nacional, os meios para deter o agravamento das desigualdades socioeconômicas - e consequentemente de saúde - que virão em decorrência da contração econômica, estimada em 9 a I0\% para a América Latina, empurrando mais de 30 milhões de habitantes desta região de volta à pobreza (Cepal, 2020).

Políticas econômicas, sobretudo o modelo de alocação de recursos em relação às áreas que se mostraram essenciais para o enfrentamento deste choque (saúde, ciência e tecnologia, educação, e proteção social), devem ser revistas para aumentar a proteção dos países nos choques futuros. A recuperação dos empregos deverá se dar de forma simultânea à busca de mitigação dos efeitos da alteração dos padrões tecnológicos na produção, que já tendia a ter efeitos perversos sobre a empregabilidade. Economistas da saúde têm defendido que a ativação e priorização de um complexo médico-industrial da saúde, adequadamente desenhado e implementado, pode ser parte da solução, trazendo dinamismo econômico e melhorando a capacidade de resposta a problemas sanitários que prejudicam a população e a outras epidemias que possivelmente virão (Gadelha, 2020).

Por fim, é preciso não descuidar da dimensão individual, na qual a vida ao final se realiza, apesar de fortemente influenciada pelos fenômenos mais amplos citados. Para tanto, nos auxilia a perspectiva sociológica proposta por Norbert Elias (1994), na qual a interdependência social configura uma economia dos afetos, articulando as dimensões coletiva e individual. Abordagem que nos ajuda a desenvolver uma visão mais integrada dos fenômenos, nos anos em que convivemos com a Covid- 19.

\section{AGRADECIMENTO}

Os autores agradecem a Guilherme Franco Netto pelo incentivo para publicar este artigo, produto do debate realizado entre os autores no Ciclo de Estudos Saúde e Ambiente, Saúde do Trabalhador e Emergência em Saúde - Covid-19, por ele organizado e mediado. 


\section{REFERÊNCIAS}

CAMERON, E. E.; NUZZO, J. B. E BELL, J. A. Global Health Security Index: building collective action and accountability. Baltimore: Johns Hopkins, Bloomberg School of Public Health, 20I9. Disponível em: <www.ghsindex.org/wp-content/uploads/2019/10/2019-Global-Health-Security-Index.pdf>. Acesso em: 18 set. 2020.

COMISSÃO ECONÔMICA PARA A AMÉRICA LATINA (CEPAL). Informe especial Covid-19, n. 4 , Santiago, 2020. Disponível em: <https://repositorio.cepal.org/bitstream/handle/I1362/45734/4/ S2000438_es.pdf $>$. Acesso em: 18 set. 2020

ELIAS, N. O Processo Civilizador: uma história dos costumes. v. I. Rio de Janeiro: Jorge Zahar, 1994.

FIDLER, D. Sars, Governance and the Globalization of Disease. New York: Springer, 2004.

GADELHA, C. O Complexo Econômico-Industrial da Saúde no Brasil hoje. Nexo, I I maio 2020. Disponível em: < https://www.nexojornal.com.br/ensaio/debate/2020/O-Complexo-Econ\%C3\%B4mico-Industrialda-Sa\%C3\%BAde-no-Brasil-hoje>. Acesso em: 18 set. 2020.

ROTH, P. Nêmesis. São Paulo: Companhia das Letras, 2011. 


\section{3 \\ Desenvolvimento e Pandemia transformação estrutural para além de um novo normal}

Carlos Augusto Grabois Gadelha

D iante da pandemia do novo coronavírus, emerge a percepção sobre os grandes problemas no sistema nacional e global em que vivemos. Muitos economistas entusiastas dos mecanismos autorreguladores do mercado passaram, diante do impasse, a redescobrir Keynes e o papel do Estado. Todavia, como quem espera, à espreita, o perigo e o medo passarem, há, subliminarmente, a perspectiva de que tudo voltará a ser como antes, ainda que sob a marca do romance de Lampedusa de que algo deve mudar para que tudo continue como está e que o mundo do mercado e das finanças permaneça sem freios e sem direcionamento público e continue livre para a predominância da lógica financeira, especulativa e assimétrica do capital, ainda que sob o manto de um "novo normal".

O novo e conservador normal proposto reforçará a natureza da sociedade capitalista em seu momento "livre e turbinado", agravando a desigualdade estrutural em todas suas manifestações, ainda que, para os menos agressivos no exercício dos "plenos poderes”, possa haver medidas paliativas para manter níveis mínimos de controle e calma social, com ações benevolentes e compensatórias que deem estabilidade para que o escorpião da metáfora siga agindo de acordo com sua natureza em todas as esferas da vida. Domesticada pelas novidades remotas, pela ilusão dos empreendedores livres e autônomos e por mínimos assistenciais e ambientais que permitiriam conter a revolta e manter a alienação, perpetua-se uma classe de sub-humanos excluídos inexoravelmente da sociedade do conhecimento em sua fase 4.0.

Em contraposição a um subterfúgio conservador e retrógrado aparentemente predominante nos discursos comumente disponíveis (retrógrado sim, pois mesmo na crise pandêmica o ideal do futuro desta forma sutil de dominação retorna ao período 
anterior a 1945), alerto para o que considero o papel mais nobre do pensamento e de uma ciência social moral como deveria ser a economia. Após a crise de 2008, quando, assim como hoje, muitos iludidos falavam da retomada do pensamento keynesiano, do papel do Estado na regulação do mercado e da importância da esfera coletiva, tudo piorou. Mader, Zwan e Mertens (2020) destacaram que o "novo normal" que surgiu pós-2008 foi um mundo de crescente financeirização, austeridade, precarização de empregos e explosão da desigualdade.

Reforço a urgência da discussão com a sociedade para que não se naturalize a saída da crise pandêmica e para que tudo não volte a ser como antes, em bases piores, pois o mundo e o capital estarão mais concentrados e desiguais. Corroborando com o que Mazucatto (Rodríguez, 2020) afirma, o capitalismo pode ser orientado para um "futuro inovador e sustentável que funcione para todos nós”. É imprescindível que uma grande transformação comece a se plasmar a partir das forças sociais e políticas atuantes no mundo e no Brasil com base em uma visão e ação generosas e cooperativas em âmbito nacional e global para compatibilizar a ordem capitalista com a vida, com a dignidade humana, com o ser coletivo associado aos sistemas universais de proteção social e com o direito à democracia, ao conhecimento científico e tecnológico e ao desenvolvimento.

No campo da saúde, essa percepção passa por fortalecer, simultaneamente, a conquista da construção do Sistema Único de Saúde (SUS) - viabilizando o acesso universal, equânime e integral - e das bases de conhecimento, tecnológicas e produtivas que lhe dão sustentação, como elementos fundamentais para que as iniquidades, assimetrias, a dependência e a vulnerabilidade social e econômica, reveladas pela pandemia, sejam minimizadas. A doença atinge toda a população, mas seus efeitos se mostram extremamente desiguais e socialmente perversos quando analisado o número de óbitos entre diferentes grupos e classes sociais.

A ciência brasileira, mais do que nunca, está mostrando seu valor para a sociedade em um momento crucial como o da pandemia, como revelado pela chance única que tem o Brasil de participar do esforço global de inovação para o acesso universal à vacina para a Covid-19. A densidade científica e tecnológica envolvida no processo de desenvolvimento e absorção de tecnologia para uma vacina é imensa, e estamos no jogo porque nunca saímos dele. O Programa Nacional de Imunizações, criado em 1971, é o exemplo mais avançado da convergência do direito universal à saúde com a construção de bases produtivas e tecnológicas locais, e precisa ser generalizado para todo o sistema de produção e inovação em saúde, o Complexo Econômico-Industrial da Saúde (Ceis).

É essa articulação da dimensão social com a econômica, científica e tecnológica do desenvolvimento que permitirá ao Brasil voltar a ter protagonismo para sair de um 
normal conservador e excludente e entrar em um processo de transformação que torne claro que os direitos sociais e a saúde, ao contrário de fatores impeditivos, são motores para a superação da crise atual, aliando equidade, direitos, desenvolvimento científico e tecnológico e a produção nacional qualificada, de forma a superar os falsos dilemas entre sociedade e economia.

\section{SAÚDE E DESENVOLVIMENTO EM UMA PERSPECTIVA ESTRUTURAL}

A pandemia do novo coronavírus confirmou, de modo contundente, a perspectiva adotada de que as dimensões econômicas e sociais do desenvolvimento são incontornavelmente vinculadas. A visão para o contexto atual foi desenvolvida no texto "O Complexo Econômico-Industrial da Saúde no Brasil hoje" elaborado para a Fundação Friedrich Ebert (FES Brasil), parte integrante do especial "Crise da Covid- I 9: de que políticas públicas o Brasil precisa?", em que foi reforçado o conceito de Complexo Econômico-Industrial da Saúde (Ceis) desenvolvido no início dos anos 2000 (Gadelha, 2020a). Trata-se da relação indissociável entre saúde e desenvolvimento, segundo perspectiva endógena que considera a saúde e o sistema de produção e de inovação relacionado como parte de um padrão de desenvolvimento, e não apenas como um fator acessório, funcional e exógeno à dinâmica do capital.

Nesse artigo, é evidenciada a visão restrita da relação saúde-desenvolvimento, adotada inclusive pela Organização Mundial da Saúde (OMS) há cerca de duas décadas, em forte interação com o Banco Mundial e o Fundo Monetário Internacional (FMI). Essa visão foi consolidada e intensamente difundida no relatório clássico de 2001 sobre a relação entre economia e saúde, Macroeconomics and Health: investing in health for economic development, em que essa concepção, a despeito de, acertadamente, considerar a saúde como um direito humano essencial, acaba, do ponto de vista econômico, reduzindo essa relação ao fornecimento de capital humano. É o que implicitamente aparece na "ajuda" que os países desenvolvidos deveriam oferecer aos países pobres (com grande destaque para a África) para que o enfrentamento e a redução da incidência de doenças como Aids, malária e tuberculose (entre muitas outras doenças transmissíveis) permitissem elevar a produtividade do trabalho e o investimento privado, limitados por uma "infestação" sanitária nos países e regiões pobres.

No artigo, a vertente ortodoxa "esclarecida" do pensamento sobre o elo entre saúde e desenvolvimento é também considerada com base nos trabalhos liderados por importantes pensadores liberais, com destaque para Amartya Sen, que trata a saúde como fator essencial da liberdade de escolha, seguindo o individualismo metodológico que associa o desenvolvimento à liberdade dos indivíduos em sua singularidade. A saúde aparece, mais 
uma vez, como fator exógeno que contribui ou não para o exercício da liberdade individual. A citada concepção leva à conclusão de que "pessoas saudáveis são mais livres para escolher". São reducionismos que não consideram as mazelas sociais e econômicas que estão por trás da geração estrutural de desigualdade em todos os seus níveis.

Em todas essas visões fica omitida a reprodução endógena e dialética da dinâmica capitalista no interior da saúde, que envolve tanto o desenvolvimento das forças produtivas, do investimento, do emprego e da inovação quanto a tendência, inerente ao nosso sistema econômico, de geração de assimetrias e desigualdades nos níveis sociais, territoriais e nacionais, em um processo de clara globalização movida pela inovação em todas suas dimensões (inclusive a financeira) e pela simultânea exclusão.

A realidade concreta da saúde e das necessidades sociais, como revelado de modo devastador na pandemia do novo coronavírus, impõe a necessidade de uma visão integrada. Ficou evidente que as dificuldades na importação de produtos essenciais como ventiladores pulmonares, materiais médicos, insumos dos testes para diagnóstico e as complexas negociações para a transferência de tecnologia em vacinas e outros produtos são questões simultaneamente econômicas e sociais. A separação dessas dimensões é fruto de um olhar analítico fragmentado e reducionista, enraizado na economia, mas também em outras ciências sociais e nas políticas públicas, afastandose dos contextos históricos e temporais específicos nos quais essas dimensões estão articuladas sistemicamente. Temos que conformar um novo padrão de política pública que seja, ao mesmo tempo, sistêmico e comprometido com as demandas de nossa sociedade para garantir o bem-estar.

A abordagem adotada procura olhar a saúde como componente essencial da dinâmica econômica que se reproduz em um espaço específico e de alta importância estratégica. Se a dinâmica global atual gera novas frentes de expansão e de inovação, estas se expressam também no campo da saúde como um dos mais dinâmicos no contexto da quarta revolução tecnológica. Se, ao mesmo tempo, gera assimetrias e exclusão, estas também se reproduzem no campo da saúde. Como desdobramento, e incorporando uma visão de economia política, há necessidade de considerar os espaços de formulação e implementação de políticas públicas pelos Estados nacionais - daí o diálogo analítico e político dessa concepção com as linhas de pesquisa e de políticas públicas que abordam os sistemas nacionais de inovação e os sistemas nacionais de saúde e de bem-estar. Isso envolve, inexoravelmente, a interação desses sistemas com os projetos nacionais de desenvolvimento que, como mencionado, podem, dependendo da escolha política das sociedades, se inserir em processos globais pautados pela solidariedade e pelo direito à vida dos diferentes povos e regiões. 


\section{O COMPLEXO ECONÔMICO-INDUSTRIAL DA SAÚDE (CEIS) E A VULNERABILIDADE DOS SISTEMAS UNIVERSAIS}

Em "Covid-19: a necessidade de retomada de uma agenda estrutural de desenvolvimento", texto original escrito para o Jornal dos Economistas do Conselho Regional de Economia do Rio de Janeiro, defendo, seguindo a aposta teórica da concepção do Ceis, que a pandemia da Covid-19 evidenciou, de modo dramático, que era necessário compreender a base econômica, produtiva e tecnológica da saúde como um sistema interdependente, e não como um conjunto fragmentado de setores (Gadelha, 2020b). E que isso permitirá sair das amarras cognitivas das políticas industriais clássicas do pós-guerra, sempre focadas em segmentos produtivos particulares, facilitando a captura por interesses também particulares.

Tal compreensão envolvia também uma ruptura das barreiras cognitivas e políticas entre as dimensões econômica e social do desenvolvimento. Essas duas dimensões passavam a ser endogeneizadas em certo padrão de desenvolvimento que envolve, a um só tempo e de modo indissociável, os direitos sociais, a equidade e as características da base produtiva e de inovação, sem cair em nenhum reducionismo de determinação de uma instância sobre a outra.

Na perspectiva do Ceis, estamos vulneráveis para enfrentar o coronavírus, como pedintes em um mercado internacional permeado por interesses mercantilistas, em uma abordagem de economia política que articula poder econômico, tecnológico e político. No presente, mais de noventa países já adotam práticas protecionistas com imposição de barreiras e impedimentos ao acesso aos seus produtos, o que é ainda mais grave no âmbito dos países menos desenvolvidos. Nossas importações chegam a quase um orçamento do Ministério da Saúde (podemos estimar em US $\$ 20$ bilhões se contabilizarmos, além das importações em produtos captadas nas estatísticas de comércio exterior, as advindas de bens intermediários e dos pagamentos por tecnologias, reconhecidamente significativos na área da saúde). Apenas em ventiladores pulmonares a dependência do Brasil quintuplicou em termos reais nos últimos vinte anos, atingindo US $\$ 50$ milhões, segundo dados obtidos mediante metodologia utilizada pelo Grupo de Pesquisa Desenvolvimento, Complexo Econômico-Industrial e Inovação em Saúde (GIS), que coordeno na Fiocruz - ver entrevista concedida à revista Radis sob o título "A Covid escancarou problemas estruturais" (Morosini, 2020).

Ainda no texto, cito a imagem mencionada no artigo com o ex-ministro José Gomes Temporão, "Tecnologia em saúde: Brasil não pode ficar de joelhos", no qual argumento que o SUS, como maior sistema universal do mundo, está assentado em "pés de barro" 
no enfrentamento da crise atual. Isso em razão da fragilidade da capacidade produtiva e tecnológica local, tanto para ofertar produtos essenciais no país quanto para se articular de modo soberano com empresas e países mais desenvolvidos, envolvendo acordos de transferência de tecnologia e também relações comerciais virtuosas e complementares para atender às necessidades sociais (Temporão $E$ Gadelha, 2020).

No presente, estamos reféns de uma competição monopólica desleal com práticas que afastam o mundo dos objetivos meritórios de um desenvolvimento global sustentável. As situações econômica e social são dramáticas e completamente indissociáveis.

A pandemia atual do coronavírus revela e confirma a hipótese analítica e metodológica do Ceis. Observamos sequestro de produtos médicos; cancelamento de contratos de ventiladores pulmonares pela existência de "propostas" melhores de países desenvolvidos; falta de acesso a insumos para testes de diagnóstico; extrema fragilidade dos programas de atenção primária em saúde, que foram atingidos por políticas econômicas e sociais restritivas do poder público (seguindo, muitas vezes, a concepção de economistas defensores da austeridade sem limites, em prejuízo da visão moral que marcou a economia política em seu nascimento); unidades de terapia intensiva (UTIs) públicas operando acima do limite de sua capacidade de atendimento, sem garantia de acesso aos excluídos; e diferenças e desigualdades entre pessoas e territórios dentro de nosso país, que geram taxas de letalidade por infecção de coronavírus de mais de dez vezes de diferença entre pessoas que deveriam ter os mesmos direitos. As dimensões econômicas e sociais do desenvolvimento são inevitavelmente vinculadas, de forma que se constitui, ao mesmo tempo, em um erro e em uma falta de visão a oposição nefasta e perversa entre a economia e a saúde.

\section{DE UMA NOVA VISÃO A UM NOVO PROJETO DE TRANSFORMAÇÕES ESTRUTURAIS}

As reflexões apresentadas, seguindo os artigos e entrevistas citados, indicam que para avançar é urgente apontar caminhos para o futuro, pois a realidade em seu curso natural será dramática, não apenas para essa pandemia, mas também para as futuras epidemias e pandemias e para os problemas de saúde que afetam o Brasil, desde o campo das doenças transmissíveis até o das doenças crônicas como câncer e doenças do sistema circulatório, assim como as referentes à saúde mental como a depressão, a tristeza e a solidão, tão marcantes nestes tempos difíceis. A crise e a vulnerabilidade serão agravadas se não pensarmos e agirmos de forma diferente como sociedade nacional e global. 
Ao contrário das políticas industriais e de desenvolvimento produtivo tradicionais, com a marca setorial e muitas vezes capturadas por interesses particulares, temos que aprender um novo padrão de política pública que, ao mesmo tempo, seja sistêmico e comprometido com as demandas de nossa sociedade para garantir o bem-estar. Sistêmico porque o foco nas necessidades, como na saúde, envolve a articulação entre diferentes indústrias (farmacêutica e biotecnológica, de equipamentos e materiais médicos) e destas com os serviços de saúde (o elo final do sistema produtivo da saúde, onde todos os produtos industriais são utilizados, a exemplo do uso dos ventiladores nas UTIs). Comprometidos com as demandas da sociedade porque, contrariamente a um desenvolvimentismo vulgar, não cabe apenas apoiar setores produtivos se estes não estiverem vinculados às necessidades sociais. Não apenas as políticas setoriais, mas também as ditas como orientadas por missões, precisam se inserir em realidades histórico-concretas das necessidades das pessoas que, afinal, financiam o Estado e geram a riqueza de nosso país.

É para a sociedade real brasileira e global que as políticas de desenvolvimento produtivo e de ciência, tecnologia e inovação devem estar voltadas. A perspectiva apresentada propõe uma abordagem passível de ser generalizada para viabilizar um padrão de desenvolvimento norteado pela equidade, pelo bem-estar e pelo dinamismo econômico e tecnológico, se espelhando no Ceis como um dos sistemas produtivos mais importantes e estratégicos do mundo, e pela soberania para implementar políticas sociais para que possamos atender às necessidades de nossa sociedade e não deixar as pessoas vulneráveis para trás pela irracionalidade de uma visão de desenvolvimento míope que opõe os direitos sociais à economia. Os direitos sociais e o direito à vida não apenas cabem no Produto Interno Bruto (PIB), mas são parte essencial da solução, constituindo uma alavanca para a superação estrutural da crise.

A emergência desta pandemia no início do ano evidenciou que seu enfrentamento requeria forte articulação sistêmica, envolvendo: capacidade de inteligência no tratamento e análise dos dados epidemiológicos; disponibilidade em larga escala de produção industrial de testes de diagnóstico moleculares e de seu processamento nos serviços de saúde; produção de equipamentos de proteção individual (EPIs) para o uso por profissionais nos serviços de saúde; existência de máscaras, luvas e materiais de higiene e limpeza no contexto de uma população extremamente vulnerável e sem recursos básicos de água e esgoto; estruturação de uma rede de serviços de atenção básica (decisivos para o cuidado com a saúde e para o diagnóstico rápido e encaminhamento dos pacientes) e de UTIs; capacidade tecnológica e industrial para a produção em escala das futuras vacinas, medicamentos e serviços que utilizem grandes bases de dados e inteligência artificial; 
e enorme aporte das ciências sociais na questão crucial da sociedade que queremos, incluindo a (re)construção de estratégias e meios para viabilizar e atualizar os sistemas de proteção social.

Basta que uma peça do sistema não funcione para fazer ruir toda uma estratégia de saúde e toda capacidade nacional de resposta. A falta de ventiladores, a inexistência de UTIs e de profissionais para sua operação, uma lacuna na organização da atenção básica aberta pela falta de equipes de saúde da família para uma atuação são, todas elas, falhas capazes de desestabilizar o sistema. Os ventiladores apareceram como a ponta de um iceberg que revelou, na fase final da linha do cuidado, a necessidade de articulação sistêmica e as fragilidades dos países como o Brasil em situações de emergência.

A fragilidade e a dependência externa do Complexo Econômico-Industrial da Saúde nacional se impõem como um grande problema de saúde pública. Se faltam EPIs, nossos profissionais da saúde adoecem e morrem de modo triste e desumano. Se faltam ventiladores, a inaceitável segmentação entre ricos e pobres aparece, de modo que uns têm direito à vida ao passo que outros são condenados à morte em uma triste escolha silenciosa de nosso país desigual e excludente. Se não existem sistemas de água e esgoto para todos e se a atenção básica não é estruturada em todo o território, assistimos, por exemplo, a uma das faces mais perversas de nossa desigualdade, na qual a alta letalidade no bairro da Maré, no Rio de Janeiro, chega a ser mais de dez vezes superior à letalidade de bairros da zona sul do mesmo estado.

O direito à vida não tem sido respeitado por falta de capacidade nacional produtiva e tecnológica e por uma visão míope que leva a fragilizar o SUS porque, irresponsavelmente, se advoga que os direitos sociais não cabem no PIB. A saúde é claramente uma frente essencial de desenvolvimento que gera $9 \%$ do produto, 14 milhões de empregos diretos e indiretos e 30\% da capacidade nacional de pesquisa, além de ser a mais promissora porta de entrada na $4^{\text {a }}$ Revolução Industrial. Este setor lidera, no mundo, as novas tecnologias digitais, envolvendo inteligência artificial, o uso e tratamento de grandes bases de dados, as tecnologias de impressão 3D, os conhecimentos em genética (incluindo a edição genética) e sua fusão com o mundo digital, entre muitas outras frentes que respondem pelas profundas transformações em curso.

A perspectiva sistêmica e endógena apresentada não reduz a necessidade de atuação do Estado no desenvolvimento do sistema produtivo e de inovação, mas acentua os requerimentos articulados de intervenção e a necessidade de conexão com a sociedade. Os economistas devem lembrar os ensinamentos de Celso Furtado de que não há desenvolvimento quando as necessidades da população não são atendidas. É necessário 
pensar um novo Estado vinculado às demandas da sociedade, inserido, conectado, transparente e blindado das capturas setoriais.

Este momento dramático do contexto brasileiro impõe a necessidade de diálogo, de generosidade, de respeito mútuo e de ação conjunta para defender as pessoas, a economia nacional e uma sociedade que seja civilizada, na qual a saúde, a equidade, o meio ambiente, a ciência, tecnologia $\xi$ inovação (CTEl) e o dinamismo econômico sejam objetivos compatíveis e favoreçam uma ação global pautada pela solidariedade. Em vez de um "novo normal" que reproduza nossa desigualdade e as assimetrias globais, podemos construir uma agenda mínima de transformações estruturais que supere as tendências em curso de acirramento da exclusão e da progressiva barbárie social para que possamos construir um país e uma sociedade melhores, comprometidos com as pessoas que aqui vivem e que são os responsáveis pela riqueza aqui gerada.

Não se pode tirar da partilha do PIB justamente aqueles que geram a riqueza na qual todos estão assentados. É uma questão ética e humana e, ao mesmo tempo, uma saída para a crise estrutural econômica e civilizatória que enfrentamos ao longo deste século e que precisa ser revertida. Depende de nossas ações e de nossa capacidade de diálogo e de construir, em conjunto, um novo projeto e uma nova utopia transformadora que associe mudança na estrutura social, mudança na estrutura econômica, mudança na participação política e democrática, mudança na esfera da vida, mudança na sociabilidade, mudança na forma de nos relacionarmos com o outro e com a natureza. O futuro é incerto. A trajetória "natural" será o abismo para todos ou a barbárie social. Podemos domar o escorpião na construção de uma sociedade melhor. Já foi possível no passado. Será possível no futuro? Como diria o filósofo, seremos o produto de nossas escolhas!

\section{AGRADECIMENTO}

Agradeço a importante colaboração da equipe da Coordenação das Ações de Prospecção da Fiocruz e, especialmente, de Karla Bernardo Mattoso Montenegro, que, com seu apoio, viabilizou a realização deste trabalho. 


\section{REFERÊNCIAS}

GADELHA, C. G. O Complexo Econômico-Industrial da Saúde no Brasil hoje. FES BR Friedrich-EbertStiftung Brasil - FES BR, São Paulo, 12 maio 2020a, p. I. Disponível em: < https://www.fes-brasil.org/ detalhe/o-complexo-economico-industrial-da-saude-no-brasil-hoje/>. Acesso em: 18 set. 2020.

GADELHA, C. G. Pandemia Covid-19: a necessidade de retomada de uma agenda estrutural de desenvolvimento. Jornal dos Economistas - JE, Rio de Janeiro, 27 jun. 2020b, p. 10-12. Disponível em: $<$ http://www.corecon-rj.org.br/anexos/619CA0C544A7E7BB76C67A9284958182.pdf>. Acesso em: 18 set. $2020>$. Disponível em: 18 set. 2020.

MADER, P.; ZWAN, N. \& MERTENS, D. 9 ways coronavirus could transform capitalism. Tribune, Dagenham, 2 jun. 2020. Disponível em: < https://tribunemag.co.uk/2020/06/9-ways-coronavirus-couldtransform-capitalism>. Acesso em: 18 set. 2020.

MOROSINI, L. A Covid escancarou problemas estruturais. Radis, Rio de Janeiro, 13 jul. 2020. Disponível em: <https://radis.ensp.fiocruz.br/index.php/home/entrevista/a-covid-escancarouproblemas-estruturais >. Acesso em: 18 set. 2020.

RODRíGUEZ, M. A economista que defende uma mudança radical no capitalismo para o mundo pós pandemia. BBC News Brasil, São Paulo, 8 ago. 2020. Disponível em: <www.bbc.com/portuguese/ internacional-5368643 I >. Acesso em: 18 set. 2020.

TEMPORÃO, J. G. \& GADELHA, C. G. Tecnologia em saúde: Brasil não pode ficar de joelhos. Folha de S.Paulo - UOL, São Paulo, 19 abr. 2020, p. A3. Disponível em: <https://wwwl.folha.uol.com.br/ opiniao/2020/04/tecnologia-em-saude-brasil-nao-pode-ficar-de-joelhos.shtml>. Acesso em: 18 set. 2020. 
ção que se mostraram eficazes em alguns países podem ser de difícil implementação na plenitude necessária em outros.

\section{BENS PÚBLICOS E BENS COMUNS, GLOBAIS}

A discussão sobre bens públicos ou bens comuns já estava presente no âmbito internacional no setor da saúde, ainda antes da pandemia. Em 2017, após o surto de ebola de 2014, o Banco Mundial considerou a preparação para pandemias como um "bem público global” (Stein $E$ Sridhar, 20।7), o que justificava a criação de um fundo que permita que o interesse pelo risco de pandemias se mantenha ao longo do tempo, e não apenas diante de ameaças iminentes. Também como resposta ao surto de ebola, a OMS lançou, em setembro de 2019, uma iniciativa de financiamento coletivo para Bens Comuns de Saúde (WHO, 2020d). Mais recentemente, já na pandemia de Covid-19, líderes mundiais pediram que a vacina para Covid- 19 fosse considerada um "bem comum global" (Yunus Centre, 2020). Embora os termos possam parecer intercambiáveis, na economia bens públicos e bens comuns apresentam diferenças significativas para o contexto em questão.

No atual paradigma econômico ortodoxo, bens públicos são definidos como aqueles que ninguém deixa de consumir (não exclusivos) e cujo consumo por um indivíduo não reduz sua disponibilidade para outros (sem rivalidade) (Kaul, Grunberg E Stern, 1999). Exemplos clássicos seriam conhecimento, linguagem, segurança e iluminação de ruas. No contexto da pandemia, ninguém poderia ser excluído da redução de risco de uma doença infecciosa, e uma pessoa que se beneficia disso não previne outra de se beneficiar também.

A classificação como bens comuns, que apresentariam rivalidade mas não seriam exclusivos, é usada com frequência, principalmente em pools. Diferentes daquelas de bens públicos, as características desses produtos dificultam o compartilhamento; isso pode ser observado quando o acesso de alguns subtrai o uso por outros. Exemplos seriam recursos naturais como ar e água, que quando poluídos prejudicam o uso alheio. Há critérios para a inclusão de informação e conhecimento como bens públicos; no entanto, o fato de serem considerados bens privados quando sujeitos a patentes pode prejudicar a inovação (Stiglitz, 20 I4).

Em que pese o adjetivo "global", este traz conotação de rivalidade ou exclusividade aplicada a países, e não a indivíduos ou empresas. Os bens seriam globais não porque são produzidos por vários países, mas por apresentarem benefícios indiretos além das fronteiras nacionais (WHO, 2002). Assim, conforme a política, um sistema de 
saúde nacional pode ser um bem público global, se a vigilância gerar efeitos positivos sobre outros países, por exemplo.

Ademais, alguns aspectos do conhecimento das tecnologias podem ser bens públicos globais, mesmo que o produto em si seja privado. Historicamente, os cenários para o desenvolvimento de novos medicamentos que se iniciaram com investimentos nacionais até meados do século passado passaram por um movimento de internacionalização focado nos países desenvolvidos, e mais recentemente evoluíram para esforços de compartilhamento da carga global (Moon, 2008). As vantagens dessa ampliação, como no conhecimento para o reposicionamento de medicamentos existentes, podem proporcionar benefícios globais.

\section{ACESSO A TECNOLOGIAS COMO DIREITO HUMANO: DESAFIOS E BARREIRAS}

Os direitos humanos são inerentes, inalienáveis, universais, invioláveis, inseparáveis e indivisíveis. A saúde é um componente essencial, não reduzida ao tratamento médico, mas em sua relação com o bem-estar de outras necessidades humanas como alimentação, alojamento e assistência social. A Declaração de Alma-Ata enfatiza essa visão ampliada. No entanto, mais recentemente, as dificuldades se apresentam na forma como uma declaração ministerial (Alcázar \& Buss, 2020) do Fórum Político de Alto Nível do Conselho Econômico e Social da Organização das Nações Unidas (Ecosoc/ONU), baseada na Resolução 70/I da Assembleia Geral das Nações Unidas (Unga, 2020a), não obteve consenso em pautas progressistas.

O debate sobre o acesso a tecnologias, em especial medicamentos, não é novo, pois permeia os debates na OMS há mais de vinte anos. Desde a Estratégia Revisada de Medicamentos na década de 1990, discute-se o confronto entre saúde e comércio e analisam-se os impactos da propriedade intelectual, da globalização e dos tratados de livre-comércio nesse aspecto (Bermudez, 2014, 20 I 7; Bermudez et al., 20 I 8; Bermudez, Luiza E Silva, 2020; Pippo et al., 2020).

Na questão do acesso a medicamentos, o trabalho da OMS para atingir a cobertura universal de saúde se encontra hoje alinhado com as metas da Agenda 2030 e os Objetivos de Desenvolvimento Sustentável (ODS), que incluem o acesso a serviços essenciais de saúde de qualidade e o "acesso a medicamentos essenciais e vacinas seguras, efetivos e de qualidade para todos" (Nações Unidas, 2020). O programa de trabalho da OMS também menciona a Estratégia Global e Plano de Ação em Saúde Pública, Inovação e Propriedade Intelectual (WHO, 20I I) incluindo políticas de acesso a medicamentos genéricos e inovação; regulação para assegurar qualidade; esquemas de cobertura que diminuam o gasto da população; preços adequados; compras e abastecimento e seu uso 
apropriado. No entanto, deve-se considerar que, quando limitada pelo risco financeiro, a proposta de cobertura restringe o acesso universal, como observado na América Latina (Giovanella et al., 2018).

O conceito de acesso, simplificando, deve representar o grau de ajuste entre oferta e demanda (Penchansky $E$ Thomas, 198I), o quanto uma população consegue alcançar o serviço (Thieren, 2005) adequado. Do ponto de vista econômico, a alocação eficiente de recursos, sem benefícios a determinados indivíduos - o que prejudicaria o bemestar de outros - está no conceito de cobertura. E especificamente para medicamentos, formulou-se uma proposta de definição de acesso a medicamentos essenciais como "a relação entre a necessidade de medicamentos e a oferta dos mesmos, na qual essa necessidade é satisfeita no momento e no lugar requeridos pelo paciente (consumidor), e ainda com a garantia da qualidade e a informação suficiente para o uso adequado" (Luiza \& Bermudez, 2004).

Exemplos de pandemias ou epidemias anteriores, entre os quais se destacam a influenza HINI, Sars ou Mers, mostram as dificuldades em implementar políticas que priorizem a igualdade e o enfrentamento a preços inacessíveis de determinados produtos, em especial medicamentos e vacinas. Para o HINI, uma vacina ficou disponível em seis meses, mas países mais ricos compraram toda a produção, e somente após confirmarem sua necessidade doméstica compartilharam 10\% dos estoques (Bollyky $\varepsilon$ Bown, 2020). E no uso de oseltamivir também foram identificados diversos problemas relativos à eficácia (Gupta, Meenu $E$ Mohan, 20 I5) ou mesmo na competição entre países.

Outra das principais barreiras ao acesso desejável são a propriedade intelectual e os monopólios por esta gerados, ocasionando preços elevados, inacessíveis e inaceitáveis. É nesse sentido que se apresenta o enfrentamento entre saúde e comércio, políticas sociais e políticas econômicas, e o falso dilema entre preservar vidas ou preservar a economia. No entanto, apenas com o controle da pandemia seria possível a retomada da economia. Nesta vertente, torna-se necessário reconhecer as tecnologias de saúde (em especial medicamentos e vacinas) para Covid-19 como bens públicos globais (Vilhelmsson E Mulinari, 2018).

\section{SOLIDARIEDADE E INICIATIVAS RECENTES}

Atualmente, a solidariedade mundial se faz presente e acompanhou as iniciativas dos organismos internacionais, em especial das Nações Unidas. Cabe destacar a reunião de ministros da Saúde dos países do Grupo dos Vinte (G20), a Assembleia Geral das Nações Unidas, a Assembleia Mundial da Saúde e outras iniciativas. 
Em 18 de março, o diretor-geral da OMS anunciou uma iniciativa (WHO, 2020e) para gerar evidência de tratamentos ou vacinas efetivas. O objetivo do Solidarity Trial é reduzir em $80 \%$ o tempo (WHO, 2020f) dos estudos clínicos, usando um desenho adaptativo de ensaios (não sendo duplo-cego). Tendo se iniciado com apenas dez países e quatro medicamentos, remdesivir, lopinavir/ritonavir, lopinavir/ritonavir com interferon-beta, e cloroquina (Kupferschimidt $\varepsilon$ Cohen, 2020), em I ${ }^{\circ}$ de de julho esses estudos já contavam com mais de 100 países e cerca de 5.500 pacientes (WHO, 2020f), incluindo o Brasil por intermédio da Fiocruz, atendendo a solicitação do Ministério da Saúde.

No âmbito das Nações Unidas, em 2 de abril de 2020, a Resolução 74/270 da Assembleia Geral, reconhecendo o impacto da pandemia nas sociedades e na economia, especialmente nas populações pobres e mais vulneráveis, reafirmou o compromisso com a solidariedade e pediu cooperação multilateral para a pandemia (Unga, 2020b). Em 20 de abril, a Resolução 74/274 avançou reconhecendo o papel da OMS no fortalecimento dos mecanismos de cooperação para dar suporte ao desenvolvimento, à manufatura e à distribuição de produtos para a Covid, evitando especulação e armazenagem que prejudiquem o acesso (Unga, 2020b).

Nesse contexto se destaca o lançamento (WHO, 2020g) da iniciativa Access to Covid- 19 Tools Accelerator (ACT Accelerator) (WHO, 2020h) em 24 de abril, contando com o apoio de mais de quarenta países e tendo coletado recursos para o desenvolvimento e produção de tecnologias contra a Covid-19. Essa iniciativa, baseada no compromisso dos líderes do $\mathrm{G} 20$ (G20, 2020) estabelecido em 26 de março, começou com 8 bilhões de dólares, estimados pelo Global Preparedness Monitoring Board (GPMB, 2020), para a aceleração do provimento de equipamentos, medicamentos ou vacinas, como preparação de capacidade produtiva e solidariedade multilateral com amplo provimento de acesso, "sem deixar ninguém para trás". Outros países se juntaram a essa iniciativa europeia, para formar a Coronavirus Global Response Initiative em 4 de maio: Canadá, França, Alemanha, Itália, Japão, Arábia Saudita, Noruega, Espanha e Reino Unido (Europe Union, 2020a). Na proposta de um "grupo inclusivo internacional de compradores" (Europe Union, 2020b), em junho o valor dos compromissos levantados totalizava 15,9 bilhões de euros (Europe Union, 2020a).

Na OMS, a Assembleia Mundial da Saúde, realizada pela primeira vez de maneira virtual em maio, aprovou, não sem bastante discussão (Love, 2020), a Resolução WHA73/3 (Resposta à Covid-19) (WHO, 2020i). A proposta previa ampliar o acesso e tratar de um pool de patentes para a Covid-19; mas ao passo que países como o Canadá pediam "licenciamento aberto, universal ou não exclusivo", os EUA pediam 
pelo "uso de mecanismo existentes (...) consistentes com flexibilidades dos tratados internacionais existentes". Ao final, o documento A73/3 apresenta diversas menções às provisões do acordo Trips (Trade-Related Aspects of International Property Rights) com as flexibilidades confirmadas pela Declaração de Doha (WTO, 2020). Ademais, o texto também reconheceu a imunização extensiva como um "bem público global de saúde".

Um mês depois, em 29 de maio, se efetivou o Covid-19 Technology Access Pool (C-TAP), objetivando que todas as vacinas, testes, diagnósticos, tratamentos e outras ferramentas na resposta ao coronavírus sejam disponibilizadas universalmente como bens públicos globais (WHO, 2020j). O C-TAP está baseado na proposta da Costa Rica enviada em 24 de março, que, com a adesão de 57 países-membros, dirigiu atenção ao compartilhamento de conhecimento e cessão voluntária de propriedade intelectual (Costa Rica, 2020). No C-TAP, a Medicines Patent Pool seria responsável pelo pool de patentes, com acesso justo e equitativo como prioridade (Medicines Patent Pool, 2020). Na apresentação do projeto (WHO, 2020k), ao passo que Stiglitz advogava que a propriedade intelectual é um construto social que não tem servido ao propósito, Mazzucato defendia que o compartilhamento seja mandatório, ou que haja condicionantes para o recebimento de financiamentos públicos nas pesquisas. Apesar de nesse evento se ter atribuído às tecnologias a classificação de "bem comum" (por se tratar de um pool), posteriormente, em 12 de junho, outro informe da OMS (WHO, 2020l) reforçou solicitação para que a vacina seja considerada um bem público global.

Em seguimento, no contexto do ACT Accelerator e do C-TAP, a Global Alliance for Vaccines and Immunization (Gavi, 2020a), iniciativa que dissemina acesso a vacinas, lançou uma nova vertente, a Covax e Covax Facility (Gavi, 2020b). Esta vertente se situa no âmbito dos mecanismos financeiros inovadores cujo eixo de atuação, em coordenação com a Coalition for Epidemic Preparedeness Innovations (Cepi, 2020a) e a OMS, é o mecanismo conhecido como Advanced Market Commitment (AMC) para assegurar o financiamento e acelerar o desenvolvimento e produção de vacinas, além do acesso equitativo para todos os países do mundo. A Cepi, mais envolvida no desenvolvimento de vacinas, já investiu US\$ 829 milhões em nove candidatos a vacinas para a Covid- 19. Somente com a Novavax foram 388 milhões de dólares para aumentar a capacidade de produção, além de outras que estão em testes clínicos (Moderna, Oxford/AstraZeneca, Inovio, Clover, University of Queenland). Ademais, também investiu em 2 bilhões de frascos (Cepi, 2020b). Com essa previsão de 2 bilhões de doses de vacinas seguras e de eficácia comprovada até o final de 2021, tal quantitativo seria, de maneira hipotética, disponibilizado igualmente aos países que aderiram, de maneira proporcional à sua população. Na América Latina, Argentina, Brasil e México manifestaram apoio a essa iniciativa. 


\section{O "NOVO NORMAL": BENS PÚBLICOS OU CORRIDA DESENFREADA?}

Pareceria então que, mesmo face à grande conexão do mundo virtual na pandemia, tanto movimentos como iniciativas de solidariedade global estariam direcionando a sociedade para novas bases mais solidárias. Entretanto, o chamado novo normal (Covid-19.., 2020) que deve governar o mundo no pós-pandemia enfrenta uma série de contradições e conflitos característicos de uma sociedade competitiva e excludente por natureza.

As limitações de exportação foram as primeiras iniciativas para a proteção nacional. A partir de alertas sobre possíveis desabastecimentos, a busca por equipamentos como ventiladores, máscaras, ou mesmo medicamentos e outros insumos fez com que diversos países proibissem a exportação desses produtos, com normas que ainda se encontram vigentes em 94 países (ITC, 2020). Sem demora, países como Canadá, Alemanha, Chile, Colômbia e Israel (OMC, 2020) efetivaram medidas de propriedade intelectual como forma de promover o ambiente legal para mecanismos de licenciamento compulsório dos produtos para a Covid-19. No Brasil, o Congresso Nacional tem recebido diversas propostas de alteração legislativa no sentido de agilizar a possibilidade de emissão de licenciamento compulsório no caso de tecnologias associadas à Covid- 19 , alterando a Lei de Propriedade Industrial (Lei 9.279/1996) (Brasil, 1996), coerentes com as recomendações do Painel de Alto Nível em Acesso a Medicamentos do secretáriogeral das Nações Unidas (United Nations Secretary-Generals, 2020).

Recentemente, a África do Sul protocolou Comunicação ao Conselho do Trips (WTO, 2020a), questionando o escopo de uso das flexibilidades do acordo Trips no contexto da pandemia. Com efeito, posteriormente em Reunião do Conselho do Trips (WTO, 2020b), ao passo que países em desenvolvimento expuseram dificuldades no uso das flexibilidades, países desenvolvidos ressaltaram os incentivos aos investimentos do ambiente de propriedade intelectual, assim como o licenciamento voluntário por intermédio do C-TAP. Essa reunião também menciona o estudo trilateral (OMS, OMC, OMPI) de Acesso a Tecnologias Médicas e Inovação (WTO, WHO \& Wipo, 2020), que apresenta a descrição de vários outros aspectos das interações entre saúde pública, comércio e propriedade intelectual, no contexto dos direitos humanos.

No caso de produtos inovadores, os Advanced Market Commitments têm sido instrumento de uma guerra de preços. Exemplificando, os EUA adquiriram o total do quantitativo de remdesivir para os próximos 3 meses (Boseley, 2020) com a Gilead, antes mesmo de o produto figurar na lista dos tratamentos. Ao mesmo tempo, a Gilead busca proteção patentária em cerca de 70 países para o remdesivir e autoriza o licenciamento 
de cinco produtores genéricos (Gilead, 2020a), os quais não podem exportar para os países com proteção, apenas para os de renda mais baixa. Esse comportamento de definir unilateralmente o escopo geográfico, semelhante ao anterior com o sofosbuvir, também produzido pela Gilead, exclui principalmente países de renda média.

A corrida dos países ricos para monopolizar as vacinas que ainda estão em desenvolvimento mostra que as propostas de solidariedade podem não ser efetivas (Gilead, 2020a). O Reino Unido investiu 84 milhões de libras em 100 milhões de doses da vacina da Astra Zeneca/Oxford até o final do ano, e também fechou AMCs com a Pfizer/BioNTech e a Valneva, além de estar em negociação com a GSK/Sanofi (United Kingdom, 2020). O National Health System (NHS) também financia ensaios clínicos no âmbito do programa Recovery Trial, que visa a fornecer evidência científica de melhor qualidade sobre terapias ou reposicionamento de medicamentos, já tendo obtido resultado favorável para a dexametasona. Para vacina, o NHS Covid- 19 Vaccine Research Registry pretende convocar 500.000 voluntários (Recovery, 2020).

A França questionou uma eventual prioridade dos EUA na vacina da Sanofi e a Alemanha comprou 23\% da Curevac por 300 milhões de euros (Curevac, 2020). Também de forma peculiar, Alemanha, França, Itália e Holanda assinaram acordo independente com AstraZeneca para adquirir 300 milhões de doses da vacina até o final de 2020 (Astrazeneca, 2020). Além disso, a Comissão Europeia está prevendo fundos para AMC de vacinas, insumos, testes diagnósticos ou outras medidas de prevenção, com investimentos adicionais em pesquisa e desenvolvimento, infraestrutura e produção. Por sua vez, a Índia, por intermédio do Serum Institute of India, entrou em entendimentos com AstraZeneca para produzir um bilhão de doses de vacinas, das quais 400 milhões antes do final de 2020 (Rajagopal, 2020).

Os EUA, por sua vez, montaram oficialmente uma iniciativa governamental denominada Operation Warp Speed com o objetivo inicial de assegurar 300 milhões de doses de uma vacina segura até janeiro de 202I (United States of America, 2020a). Para essa finalidade, foram identificadas 14 vacinas candidatas, reduzidas a cerca de sete mais promissoras. O financiamento assegurado pelo Congresso dos EUA incluiu mais de 10 bilhões de dólares. Os primeiros acordos com Moderna, Sanofi e Novavax e Johnson $\varepsilon$ Johnson tinham valores que variavam de algumas dezenas a centenas de milhões de dólares (Donald Trump..., 2020), além de outros investimentos em aperfeiçoar capacidades produtivas e insumos como frascos e seringas. Mais recentemente, se observam valores mais elevados nos acordos com a AstraZeneca/Oxford por US\$ 1,2 bilhões (United States of America, 2020b), além de Pfizer/BioNTech e GSK, comprometendo I,95 bilhão (United States of America, 2020c) e 2 bilhões de dólares (United States of America, 2020d), respectivamente. 
Entretanto, essa iniciativa unilateral dos EUA não se soma ao multilateralismo e solidariedade que envolve cerca de 150 países involucrados na iniciativa que estabeleceram a OMS e a Aliança Global para Vacinas e Imunização (Gavi Alliance). Observada mundo afora, entrevistas governamentais e notícias de imprensa evidenciam que a realidade do "novo normal" é uma corrida desenfreada de países ricos com prioridade para suas necessidades ou até para atender a outros interesses de seus governantes.

Ao passo que a vacina da AstraZeneca deve ser oferecida ao preço de custo de cerca de 2,5 dólares ou euros, o governo dos EUA propõe que seja colocado um preço de referência de US\$40 (Kliff, 2020) para as vacinas a serem desenvolvidas, de modo a torná-las inacessíveis para a maioria das populações. Em nítido contraste com os EUA, a Comissão Europeia e diversos países ao redor do mundo apoiam a iniciativa Coronavirus Global Response, que já arrecadou 15,9 bilhões de euros em apoio à ACT Accelerator (Europe Union, 2020c). Ademais, o presidente Xi Jinping anunciou, na abertura da Assembleia Mundial da Saúde, que a vacina chinesa seria um bem público global (China, 2020), afirmação reiterada recentemente pelo ministro da China em reunião dos ministros das Relações Exteriores.

Assim, o contraste entre a visão de um bem público global e a disputa no mercado é realçado pela falta de solidariedade que se esperaria numa emergência de interesse internacional: uma pandemia que atinge o mundo indistintamente, acentuando os desequilíbrios existentes. A governança global do funcionamento do mercado, por meio de mecanismos de transparência, precificação, eliminação das barreiras de propriedade intelectual, seria essencial para o desempenho, pelos Estados nacionais, da missão de criar valor mediante a cooperação.

\section{PERSPECTIVAS E POTENCIALIDADES NA PANDEMIA E NO PÓS-PANDEMIA}

A definição de produtos para a Covid- 19 como bens públicos globais poderia ser um primeiro passo para a superação do problema da propriedade intelectual como barreira ao acesso. Mas ainda existem mais de 2.000 pedidos de patentes (Meds Pal, 2020) para medicamentos para a Covid- 19 no mundo, 16 apenas no Brasil. E, ademais, outros desafios, como a capacidade de produção e o preço ou os próprios critérios que definem a efetividade no controle da pandemia, permaneceriam.

A limitação de licenciamento voluntário do C-TAP é criticada por diversos especialistas e organizações não governamentais. Dado o volume de recursos públicos investidos, o licenciamento poderia ser mandatório ou com mais condicionantes, conforme apontou Mariana Mazzucato no evento de lançamento do C-TAP (WHO, 2020k). A falta desse mecanismo é, possivelmente, uma das causas do acirramento da competição entre países. 
Os investimentos em produção podem ser infrutíferos. As tecnologias de produção de vacinas apresentam plataformas diferentes que não são intercambiáveis. O risco é necessário, mas o que se vê é que antes da pandemia investimentos para o desenvolvimento de vacinas correspondiam a aproximadamente 500 milhões (Gouglas et al., 20 I 8) e que os valores atuais, por mais que se leve em consideração o prazo curto, estão tomando como referência muitas vantagens indiretas à economia, e não a necessidade de garantir os custos mínimos.

Mesmo na cooperação, os critérios para a distribuição das vacinas são incertos. Apesar dos planos de vacinar 20\% da população até final de 2021 (Gavi, 2020b), inicialmente priorizando profissionais da saúde, idosos e portadores de outros fatores de risco, não está claro quais seriam os primeiros países a receber a vacina. Dos 165 países que aderiram à Covax Facility, consórcio mundial que visa a impulsionar o desenvolvimento de vacinas contra a Covid-19, 75 devem financiá-las com recursos próprios (WHO, 2020m) e 95 devem recebê-las gratuitamente, de acordo com critérios de renda média baseados no Produto Interno Bruto (PIB). Com esse critério, países como África do Sul, Paquistão e a maioria da América Latina teriam maiores dificuldades para receber assistência.

O cenário da informação relacionada à Covid- 9 ainda é de grande incerteza. Apesar do elevado número de ensaios clínicos para o reposicionamento de medicamentos, muitos estudos apresentaram menos de cem pacientes, sem grupos controle ou duplo-cego, e um terço deles não apresentava desfechos claros (Mehta et al., 2020). A cloroquina foi o medicamento com o maior número de estudos (Herper $\varepsilon$ Higlin, 2020) registrados para a Covid-19. Embora ainda haja divergência sobre sua eficácia na opinião popular, muitos países que permitiram seu uso já suspenderam essa possibilidade, incluindo a próprio estudo do Solidarity Trial (WHO, 2020f) da OMS. Outros medicamentos, como o Favipiravir, também permanecem controversos, com seu uso autorizado na Índia, China e Rússia.

As recomendações variam entre países e sociedades médicas, muitos estudos com séries de casos ou apenas testes in vitro sugerem resultados promissores para melhor investigação. O próprio remdesivir se mostrou mais promissor na redução de risco ou tempo de internação (Gilead, 2020b), e a dexametasona, apenas em casos internados (The Recovery Collaborative Group, 2020). Além dos medicamentos, algumas terapias como plasma de convalescente (Thomas $\&$ Weiland, 2020), anticorpos monoclonais e soros heterólogos despontam. Nesses casos, observa-se que a resposta pode apenas ajudar o tratamento ou prevenir complicações, sem viabilidade de ampla proteção. 
Essa dúvida também se apresenta na testagem. Embora os testes para Covid-19 apresentem vantagens claras, sendo inclusive defendidos como bens públicos (Johnson, 2020), há polêmica sobre os diferentes tipos, em particular sobre a sensibilidade e especificidade de testes imunológicos (Castro et al., 2020). De forma semelhante, as medidas de distanciamento social e uso de máscaras são questionadas. No caso de vacinas, apenas o FDA apresentou um protocolo claro para sua aprovação: mínimo de 50\% de efetividade em pelo menos diminuir a severidade de sintomas da Covid-19 (United States of America, 2020e). Isso seria mais um auxílio no tratamento, podendo significar que as primeiras vacinas aprovadas não tenham a eficácia necessária para prevenir o contágio.

Subjacente aos problemas supracitados está o nacionalismo exacerbado, como vetor de poder na disputa e eventual criação de bens políticos. Esse acirramento ameaça as necessárias coordenações de respostas à pandemia, prejudicando tanto o financiamento mais eficaz como o compartilhamento de informações, adequados ao maior benefício possível. A ameaça de uma pandemia significa que a capacidade de resposta de qualquer Estado coloca outro em risco.

O termo vaccine nationalism (Kupferschmidt, 2020) se tornou frequente para designar a prioridade doméstica na competição. É possível que as primeiras terapias ou vacinas não apresentem os resultados esperados, e que o volume investido em compromissos precoces não facilite que outros candidatos venham a sobressair. Ademais, nas diversas possibilidades de retaliação entre países, deve-se lembrar do dilema do prisioneiro (Poundstone, 1993), experimento comum da teoria dos jogos em que o maior benefício vem da cooperação. Outro clássico, o experimento do marshmallow em Stanford (Mischel \& Ebbesen, 1970), determina o quanto crianças esperam por dois marshmallows ou comem um imediatamente; talvez Estados ainda estejam se rebelando contra um amadurecimento global.

Conforme salientado pela OMS, o bem público global não seria apenas o produto, mas a imunização (WHO, 2020i). A sutileza dessa afirmação se mostra não apenas na necessidade de cadeias de distribuição e serviços, mas também no grau de cooperação global a ser atingido. É fato que o compromisso com as normativas globais limita a atuação dos Estados nacionais, competindo com esferas de influência de interesses políticos. Mas a maior cooperação regional, mediante uma governança global, possibilitaria que mecanismos específicos em determinadas áreas refletissem melhor o contexto cultural e normas locais.

Por fim, ao mesmo tempo que a pandemia amplifica a iniquidade entre os países e populações negligenciadas e vulneráveis, uma solução individual que perpetue esse 
sistema não se mostra viável. Nesse aspecto, a pandemia oferece riscos diferentes, mas a resposta não pode ser um mérito, visto que os determinantes sociais acometidos não excluem privilégios. Além disso, a solidariedade é uma questão moral, diferente da hipótese de um agente racional ou ideologia de um bem político. Embora a perspectiva da saúde como bem público global apresente evidentes vantagens econômicas, a saúde é, acima de tudo, um direito humano.

A Declaração Universal dos Direitos Humanos foi proclamada pelas Nações Unidas em 1948, como resultante da tragédia da II Guerra Mundial, reconhecendo que a dignidade e direitos iguais e inalienáveis constituem o fundamento da liberdade, da justiça e da paz no mundo, e vedando qualquer discriminação (UN Human Rights, 2020). A humanidade está acima das fronteiras e nos cabe cobrar que o acesso aos bens públicos na vigência da pandemia seja assegurado para todos, sem deixar ninguém para trás. O Sistema Único de Saúde (SUS), como um sistema de acesso universal, tem esse objetivo e representa, portanto, um bem público global.

\section{REFERENNCIAS}

ALCÁZAR, S. E BUSS, P. Conselho de Direitos Humanos da ONU: mais Estado e equidade para enfrentar a pandemia. Centro de Estudos Estratégicos da Fiocruz, 4 ago. 2020. Disponível em: <https://cee. fiocruz.br/?q=Conselho-de-Direitos-Humanos-da-ONU-mais-Estado-e-equidade-para-enfrentara-pandemia >. Acesso em: 18 set. 2020.

ASTRAZENECA. AstraZeneca to supply Europe with up to 400 million doses of Oxford University's vaccine at no profit, 13 June 2020. Disponível em: <https://www.astrazeneca.com/media-centre/ press-releases/2020/astrazeneca-to-supply-europe-with-up-to-400-million-doses-of-oxforduniversitys-vaccine-at-no-profit.html>. Acesso em: 18 set. 2020.

BERMUDEZ, J. Acesso a Medicamentos: direito ou utopia? Rio de Janeiro: E-papers, 2014.

BERMUDEZ, J. Contemporary challenges on access to medicines: beyond the UNSG High-Level Panel. Ciência E Saúde Coletiva, 22(8): 2.435-2.439, 2017.

BERMUDEZ, J. A. Z.; LUIZA, V. L. \& SILVA, R. M. Medicamentos essenciais e medicamentos estratégicos: passado, presente e futuro. In: BERMUDEZ, J. A. Z.; COSTA, J. C. S. E NORONHA, J. C. (Eds.). Desafios do Acesso a Medicamentos no Brasil. Rio de Janeiro: Edições Livres, 2020.

BERMUDEZ, J. A. Z. et al. Assistência farmacêutica nos 30 anos do SUS na perspectiva da integralidade. Ciência E Saúde Coletiva, 23: 1.937-1.949, 2018.

BOLLYKY, T. J. \& BOWN, C. P. The Tragedy of vaccine nationalism: only cooperation can end the pandemic. Foreign Affairs, 2020. Disponível em: <https://www.foreignaffairs.com/articles/unitedstates/2020-07-27/vaccine-nationalism-pandemic >. Acesso em: 18 set. 2020.

BOSELEY, R. US secures world stock of key Covid- 19 drug remdesivir. The Guardian, London, 30 Jun. 2020. Disponível em: <https://www.theguardian.com/us-news/2020/jun/30/us-buys-up-worldstock-of-key-Covid-19-drug >. Acesso em: 18 set. 2020. 
BRASIL. Presidência da República. Casa Civil. Lei n. 9.279, de I 4 maio 1996. Regula direitos e obrigações relativos à propriedade industrial. Brasília, Diário Oficial da União, 14 maio 1996. Disponível em: <http://www.planalto.gov.br/ccivil_03/leis/19279.htm>. Acesso em: 18 set. 2020.

CASTRO, R. et al. Covid- 19: a meta-analysis of diagnostic test accuracy of commercial assays registered in Brazil. The Brazilian Journal of Infectious Diseases, 24(2): 180-187, 2020.

CEPI. Site. Disponível em: <https://cepi.net/>. Acesso em: 18 set. 2020a.

CEPI. Stevanato Group signs an agreement with CEPI to provide pharma glass vials for 2 billion doses of Covid-19 vaccines under development, 25 Jun. 2020b. Disponível em: <https://cepi.net/news_ cepi/stevanato-group-signs-an-agreement-with-cepi-to-provide-pharma-glass-vials-for-2-billiondoses-of-Covid-19-vaccines-under-development/>. Acesso em: 18 set. 2020.

CHINA. National Health Commission of the People's Republic of China. Full text of President Xi's speech at the opening of $73^{\text {rd }}$ World Health Assembly, 19 May 2020. Disponível em: <http://en.nhc. gov.cn/2020-05/19/c_80268.htm>. Acesso em: 18 set. 2020.

COSTA RICA. Costa Rica submits proposal for who to facilitate access to technologies to combat Covid-19, 24 mar. 2020. Disponível: < https://www.presidencia.go.cr/comunicados/2020/03/costarica-submits-proposal-for-who-to-facilitate-access-to-technologies-to-combat-Covid-19/>. Acesso em: 18 set. 2020.

COVID-19 is here to stay. The world is working out how to live with it. The Economist, Johannesburg, Madrid, Paris, Rome, 4 July 2020. Disponível em: <https://www.economist.com/ international/2020/07/04/Covid-19-is-here-to-stay-the-world-is-working-out-how-to-livewith-it>. Acesso em: 18 set. 2020.

CUREVAC. German federal government invests 300 million euros in CureVac, 15 June 2020. Disponível em: <https://www.curevac.com/news/german-federal-government-invests-300-million-euros-incurevac >. Acesso em: 18 set. 2020.

DONALD TRUMP is hoping for a Covid- 19 treatment by November. The Economist, 18 July 2020. Disponível em: <https://www.economist.com/united-states/2020/07/18/donald-trump-is-hopingfor-a-Covid-19-treatment-by-november >. Acesso em: 18 set. 2020.

EUROPE UNION. Coronavirus about response. Disponível em: < https://global-response.europa.eu/ about_en>. Acesso em: 18 set. 2020a.

EUROPE UNION. European Commission. Coronavirus: commission unveils EU vaccines strategy, I7 June 2020b. Disponível em: <https://ec.europa.eu/commission/presscorner/detail/en/ip_20_1103>. Acesso em: 18 set. 2020.

EUROPE UNION. Funds raised. Disponível em: <https://global-response.europa.eu/pledge_en>. Acesso em: 18 set. $2020 \mathrm{c}$.

GILEAD. Gilead presents additional data on investigational antiviral Remdesivir for the treatment of Covid-19, 10 July 2020b. Disponível em: <https://www.gilead.com/news-and-press/press-room/ press-releases/2020/7/gilead-presents-additional-data-on-investigational-antiviral-remdesivir-forthe-treatment-of-Covid-19>. Acesso em: 18 set. 2020.

GILEAD. Voluntary licensing agreements for Remdesivir. Disponível em: < https://www.gilead.com/ purpose/advancing-global-health/Covid-19/voluntary-licensing-agreements-for-remdesivir $>$. Acesso em: 18 set. 2020a. 
GIOVANELLA, L. et al. Sistema universal de saúde e cobertura universal: desvendando pressupostos e estratégias. Ciência E Saúde Coletiva, 23(6): 1.763-1.776, 2018.

GLOBAL PREPAREDNESS MONITORING BOARD (GPMB). Global Preparedness Monitoring Board calls on G7 and G20 leaders to support \$8bn call to scale-up global response to Covid-19, 9 Mar. 2020. Disponível em: <https://apps.who.int/gpmb/assets/pdf/Covid_19_Press_Release_GPMB_9Mar. pdf $>$. Acesso em: 18 set. 2020.

GLOBAL VACCINE ALLIANCE (GAVI). Site. Disponível em: <https://www.gavi.org/>. Acesso em: 18 set. 2020a.

GLOBAL VACCINE ALLIANCE (GAVI). Covax. Disponível em: < https://www.gavi.org/Covid 1 9/covaxfacility $>$. Acesso em: 18 set. 2020b.

GOUGLAS, D. et al. Estimating the cost of vaccine development against epidemic infectious diseases: a cost minimisation study. The Lancet Global Health, 6(I2): el 386-el 396, 2018.

GUPTA, Y. K.; MEENU, M. E MOHAN, P. The Tamiflu fiasco and lessons learnt. Indian Journal of Pharmacology, 47(1): $11-16,2015$.

HERPER, M. \& HIGLIN, E. Data show panic and disorganization dominate the study of Covid- 19 drugs. Stat, Boston, 6 July 2020. Disponível em: <https://www.statnews.com/2020/07/06/data-showpanic-and-disorganization-dominate-the-study-of-Covid-19-drugs/>. Acesso em: 18 set. 2020.

INTERNATIONAL TRADE CENTRE (ITC). Covid- 19 temporary trade measures. Disponível em: < https:// www.macmap.org/Covid 19>. Acesso em: 18 set. 2020.

JOHNSON, S. How to close America'sCovid-19 testing deficit. Project Syndicate, 31 July 2020. Disponível em: <https://www.project-syndicate.org/commentary/blood-spot-serology-Covid I9testing-fast-cheap-reliable-by-simon-johnson-2020-07>. Acesso em: 18 set. 2020.

KAUL, I.; GRUNBERG, I. \& STERN, M. A. (Eds.). Global Public Goods: international cooperation in the 2Ist century. New York: Oxford University Press, 1999.

KLIFF, S. The U.S. Commits to buying millions of vaccine doses: why that's unusual. The New York Times, New York, 22 July 2020. Disponível em: <https://www.nytimes.com/2020/07/22/upshot/ vaccine-coronavirus-government-purchase.html>. Acesso em: 18 set. 2020.

KUPFERSCHMIDT, K. "Vaccine nationalism" threatens global plan to distribute Covid-19 shots fairly. Science, 28 July 2020. Disponível em: <https://www.sciencemag.org/news/2020/07/vaccinenationalism-threatens-global-plan-distribute-Covid-19-shots-fairly>. Acesso em: 18 set. 2020.

KUPFERSCHMIDT, K. \& COHEN, J. WHO launches global megatrial of the four most promising coronavirus treatments. Science, 22 Mar. 2020. Disponível em: <https://www.sciencemag.org/ news/2020/03/who-launches-global-megatrial-four-most-promising-coronavirus-treatments $>$. Acesso em: 18 set. 2020.

LOVE, J. WHO member states poised to adopt weaker than needed Covid- 19 resolution after tortuous negotiations. Knowledge Ecology International, 13 May 2020. Disponível em: < https://www.keionline. org/33044>. Acesso em: 18 set. 2020.

LUIZA, V. L. \& BERMUDEZ, J. A. Z. Acesso a medicamentos: conceitos e polêmicas. In: BERMUDEZ, J. A. Z.; OLIVEIRA, M. A. \& ESHER, A. (Eds.). Acesso a Medicamentos: derecho fundamental, papel del Estado. Rio de Janeiro: Fundação Oswaldo Cruz, 2004. 
MEDICINE PATENT POOL. The Medicines Patent Pool prepared to offer expertise in licensing and patent pooling to address the current Covid-19 crisis, 29 May 2020. Disponível em: <https:// medicinespatentpool.org/news-publications-post/the-medicines-patent-pool-prepared-to-offerexpertise-in-licensing-and-patent-pooling-to-address-the-current-Covid-19-crisis/>. Acesso em: 18 set. 2020.

MEHTA, H. B. et al. Characteristics of registered clinical trials assessing treatments for Covid-19: a cross-sectional analysis. British Medical Journal Open, I0(6): p. e039978, 2020.

MISCHEL, W. \& EBBESEN, E. B. Attention in delay of gratification. Journal of Personality and Social Psychologies, 16(2): 329-337, 1970.

MOON, S. Medicines as global public goods: the governance of technological innovation in the new era of global health. Global Health Governance, 2(2): 1-23, 2008.

NAÇÕES UNIDAS BRASIL (NU). Site. Disponível em: < https://nacoesunidas.org/pos2015/ agenda2030>. Acesso em: 18 set. 2020.

OFFICE OF THE HIGH COMMISSIONER FOR HUMAN RIGHTS (UN HUMAN RIGHTS). Universal Declaration of Human Rights. Disponível em: < https://www.ohchr.org/EN/UDHR/Pages/Language. aspx? LangID = por $>$. Acesso em: 18 set. 2020.

ORGANIZACIÓN MUNDIAL DEL COMÉRCIO (OMC). Covid- I9: medidas relativas a los derechos de propiedad intelectual relacionados con el comercio. Disponível em: < https://www.wto.org/spanish/ tratop_s/Covid19_s/trade_related_ip_measure_s.htm >. Acesso em: 18 set. 2020.

PENCHANSKY, R. \& THOMAS, J. W. The concept of access: definition and relationship to consumer satisfaction. Medical Care, 19(2): 127-140, 1981.

PIPPO, T. et al. Acesso a medicamentos no SUS: avanços e desafios. In: ORGANIZAÇÃO PANAMERICANA DA SAÚDE (Opas). Relatório 30 Anos de SUS. Que SUS para 2030? Brasília: Organização Pan-Americana da Saúde, 2020. p. 218-249.

POUNDSTONE, W. Prisoner's Dilemma. I. ed. New York: Anchor, 1993.

RANDOMISED EVALUATION OF Covid- I 9 THERAPY (RECOVERY). Site. Disponível em: < https://www. recoverytrial.net/>. Acesso em: 18 set. 2020.

RAJAGOPAL, D. AstraZeneca \& Serum Institute of India sign licensing deal for I billion doses of Oxford vaccine. Healthworld.com, 5 June 2020. Disponível em: <https://health.economictimes.indiatimes. $\mathrm{com} /$ news/pharma/astrazeneca-serum-institute-of-india-sign-licensing-deal-for- I-billion-dosesof-oxford-vaccine/76204373 >. Acesso em: 18 set. 2020.

STEIN, F. \& SRIDHAR, D. Health as a "global public good": creating a market for pandemic risk. BMJ, 358: j3397, 2017. Disponível em: <https://www.bmj.com/content/bmj/358/bmj.j3397.full.pdf>. Acesso em: 18 set. 2020.

STIGLITZ, J. Intellectual Property Rights, the Pool of Knowledge, and Innovation. Cambridge: National Bureau of Economic Research, mar. 2014. Disponível em: <http://www.nber.org/papers/w200 I4.pdf>. Acesso em: 6 ago. 2020.

THE GROUP OF TWENTY (G20). G20 Leaders" Statement. Extraordinary G20 Leaders" Summit Statement on Covid-19. Disponível em: <https://g20.org/en/media/Documents/G20_Extraordinary\%20 G20\%20Leaders\%E2\%80\%99\%20Summit_Statement_EN\%20(3).pdf>. Acesso em: I 8 set. 2020. 
THE MEDICINES PATENTS AND LICENCES DATABASE (MEDS PAL). Site. Disponível em: < https://www. medspal.org/?keywords =Covid -19 Epage $=1>$. Acesso em: 18 set. 2020.

THE RECOVERY COLLABORATIVE GROUP. Dexamethasone in hospitalized patients with Covid-19Preliminary report. The New England Journal of Medicine, 2020. Disponível em: <https://www.nejm. org/doi/pdf/1 0.1056/NEJMoa2021436>. Acesso em: 18 set. 2020.

THIEREN, M. Technical Meeting for the Development of a Framework for Universal Access to HIVIAIDS Prevention, Treatment and Care in the Health Sector. Geneva: WHO, 2005. Disponível em: <https:// www.who.int/hiv/universalaccess2010/UA_definitions_Dec05.pdf>. Acesso em: 18 set. 2020.

THOMAS, K. \& WEILAND, N. As Trump praises plasma, researchers struggle to finish critical studies. The New York Times, New York, 4 Aug. 2020. Disponível em: <https://www.nytimes.com/2020/08/04/ health/trump-plasma.html>. Acesso em: 18 set. 2020.

UNITED KINGDOM. Funding and manufacturing boost for UK vaccine programme, I7 May 2020. Disponível em: <https://www.gov.uk/government/news/funding-and-manufacturing-boost-for-ukvaccine-programme>. Acesso em: 18 set. 2020.

UNITED NATIONS GENERAL ASSEMBLY (UNGA). Resolution A/RES/70/I. Transforming our world: the 2030 Agenda for Sustainable Development. Disponível em: <https://undocs.org/en/A/RES/70/I>. Acesso em: 18 set. 2020a.

UNITED NATIONS GENERAL ASSEMBLY (UNGA). A/RES/74/274. International cooperation to ensure global access to medicines, vaccines and medical equipment to face Covid- 19. Disponível em: <https:// undocs.org/A/RES/74/274>. Acesso em: 18 set. 2020b.

UNITED NATIONS SECRETARY-GENERALS. Site. Disponível em: < http://www.unsgaccessmeds.org/>. Acesso em: 18 set. 2020.

UNITED SATES OF AMERICA. U.S. Department of Health and Human Services (HHS). Fact sheet: explaining operation warp speed. Disponível em: <https://www.hhs.gov/about/news/2020/06/16/ fact-sheet-explaining-operation-warp-speed.html>. Acesso em: 18 set. 2020a.

UNITED SATES OF AMERICA. U.S. Department of Health and Human Services (HHS). Trump Administration's operation warp speed accelerates AstraZeneca Covid-19 vaccine to be available beginning in October, 2 I May 2020b. Disponível em: < https://www.hhs.gov/about/news/2020/05/2 I/ trump-administration-accelerates-astrazeneca-Covid- 19 -vaccine-to-be-available-beginning-inoctober.html>. Acesso em: 18 set. 2020.

UNITED SATES OF AMERICA. U.S. Department of Health and Human Services (HHS). U.S. Government engages Pfizer to produce millions of doses of Covid-19 vaccine, 22 July 2020c. Disponível em: $<$ https://www.hhs.gov/about/news/2020/07/22/us-government-engages-pfizer-produce-millionsdoses-Covid-19-vaccine.html>. Acesso em: 18 set. 2020.

UNITED SATES OF AMERICA. U.S. Department of Health and Human Services (HHS). HHS, DOD partner with Sanofi and GSK on commercial-scale manufacturing demonstration project to produce millions of Covid- 19 investigational vaccine doses, 3 I July 2020d. Disponível em: < https://www.hhs.gov/about/ news/2020/07/31/hhs-dod-partner-sanofi-gsk-commercial-scale-manufacturing-demonstrationproject-produce-millions-Covid-19-investigational-vaccine-doses.html>. Acesso em: 18 set. 2020. 
UNITED SATES OF AMERICA. The Food and Drug Administration (FDA). Coronavirus (Covid- 19) update: FDA takes action to help facilitate timely development of safe, effective Covid- 19 vaccines, 30 June 2020e. Disponível em: <https://www.fda.gov/news-events/press-announcements/coronavirusCovid-19-update-fda-takes-action-help-facilitate-timely-development-safe-effective-Covid>. Acesso em: 18 set. 2020.

VILHELMSSON, A. E MULINARI, S. Pharmaceutical lobbying and pandemic stockpiling of Tamiflu: a qualitative study of arguments and tactics. Journal of Public Health (Oxford, England), 40(3): 646$651,2018$.

WORLD HEALTH ORGANIZATION (WHO). Who Commission on Macroeconomics and Health. Working Group 2. Global public goods for health: the report of Working Group 2 of the Commission on Macroeconomics and Health. Geneva: WHO, 2002. Disponível em: < https://apps.who.int/iris/ bitstream/handle/10665/42518/9241590 106.pdf>. Acesso em: 18 set. 2020.

WORLD HEALTH ORGANIZATION (WHO). Global Strategy and Plan of Action on Public Health, Innovation and Intellectual Property. Geneva: WHO, 20I I. Disponível em: < https://www.who.int/phi/ publications/Global_Strategy_Plan_Action.pdf>. Acesso em: 18 set. 2020.

WORLD HEALTH ORGANIZATION (WHO). Covid- 19 Public Health Emergency of International Concern (PHEIC) Global Research and Innovation Forum. Disponível em: < https://www.who.int/ publications/m/item/Covid-19-public-health-emergency-of-international-concern-(pheic)-globalresearch-and-innovation-forum $>$. Acesso em: 18 set. 2020a.

WORLD HEALTH ORGANIZATION (WHO). WHO Director-General'sopening remarks at the media briefing on Covid-19 - II March 2020b. Disponível em: <https://www.who.int/dg/speeches/detail/ who-director-general-s-opening-remarks-at-the-media-briefing-on-Covid-19--- I I-march-2020>. Acesso em: 18 set. 2020.

WORLD HEALTH ORGANIZATION (WHO). Social determinants of health. Disponível em: <https:// www.who.int/social_determinants/thecommission/finalreport/en/>. Acesso em: 18 set. 2020c.

WORLD HEALTH ORGANIZATION (WHO). Common goods for health. Disponível em: <https://www. who.int/health-topics/common-goods-for-health>. Acesso em: 18 set. $2020 \mathrm{~d}$.

WORLD HEALTH ORGANIZATION (WHO). WHO Director-General's opening remarks at the media briefing on Covid-19 - 18 March 2020e. Disponível em: <https://www.who.int/dg/speeches/detail/ who-director-general-s-opening-remarks-at-the-media-briefing-on-Covid-19--- 18-march-2020>. Acesso em: 18 set. 2020.

WORLD HEALTH ORGANIZATION (WHO). "Solidarity" clinical trial for Covid-19 treatments, $2020 f$. Disponível em: <https://www.who.int/emergencies/diseases/novel-coronavirus-2019/global-researchon-novel-coronavirus-20 I9-ncov/solidarity-clinical-trial-for-Covid-19-treatments >. Acesso em: 18 set. 2020.

WORLD HEALTH ORGANIZATION (WHO). Live: Covid- 9 ACT-Accelerator technical update and press briefing, 26 jun. 2020g. Disponível: <https://www.youtube.com/watch?v=5Z9AEI kRDLI>. Acesso em: 18 set. 2020.

WORLD HEALTH ORGANIZATION (WHO). The Access to Covid- I 9 Tools (ACT) Accelerator. Disponível em: <https://www.who.int/initiatives/act-accelerator >. Acesso em: 18 set. 2020 h. 
WORLD HEALTH ORGANIZATION (WHO). Resolution A73/CONF./I Rev.l. Covid-19 response. Disponível em: <https://apps.who.int/gb/ebwha/pdf_files/WHA73/A73_CONFIRevl-en.pdf>. Acesso em: 18 set. 2020i.

WORLD HEALTH ORGANIZATION (WHO). Covid-19 Technology Access Pool. Disponível em: $<$ https://www.who.int/emergencies/diseases/novel-coronavirus-20 I 9/global-research-on-novelcoronavirus-2019-ncov/Covid-19-technology-access-pool>. Acesso em: 18 set. 2020j.

WORLD HEALTH ORGANIZATION (WHO). Live: Launch of the Covid-19 Technology Access Pool, 29 maio 2020k. Disponível em: <https://www.youtube.com/watch?v=RLJRMIU IYY8>. Acesso em: I8 set. 2020.

WORLD HEALTH ORGANIZATION (WHO). Media briefing on Covid-19. Disponível em: < https:// www.youtube.com/watch?v=-iCltxtc8vU>. Acesso em: I 8 set. 20201.

WORLD HEALTH ORGANIZATION (WHO). More than 150 countries engaged in Covid- 19 Vaccine Global Access Facility. Disponível em: <https://www.who.int/news-room/detail/15-07-2020-more-than150-countries-engaged-in-Covid-19-vaccine-global-access-facility>. Acesso em: 18 set. 2020m.

WORLD TRADE ORGANIZATION (WTO). Resolution WT/MIN(OI)/DEC/W/2. Declaration on the Trips Agreement and public health. In: MINISTERIAL CONFERENCE, 4, 9- I 4 Nov. 200 I, Doha. Disponível em: <https://www.who.int/medicines/areas/policy/tripshealth.pdf>. Acesso em: I8 set. 2020.

WORLD TRADE ORGANIZATION (WTO). Resolution IP/C/W/666. Intellectual property and public interest: beyond access to medicines and medical technologies towards a more holistic approach to Trips flexibilities, 17 July 2020a. Disponível em: < https://docs.wto.org/dol2fe/Pages/SS/directdoc. aspx?filename=q:/IP/C/W666.pdf $>$. Acesso em: 18 set. 2020.

WORLD TRADE ORGANIZATION (WTO). Los miembros de la OMC destacan la función del sistema de propiedad intelectual en la lucha contra la Covid- I 9, 30 jul. 2020b. Disponível em: < https://www.wto. org/spanish/news_s/news20_s/trip_30jul20_s.htm>. Acesso em: 18 set. 2020.

WORLD TRADE ORGANIZATION, WORLD HEALTH ORGANIZATION AND WORLD INTELLECTUAL PROPERTY ORGANIZATION (WTO, WHO \& WIPO). Promoting Access to Medical Technologies and Innovation: intersections between public health intellectual property and trade. 2. ed. Geneva: WTO, WHO, WIPO, 2020. Disponível em: <https://www.who.int/publications/i/item/9789240008267>. Acesso em: 18 set. 2020.

yUNUS CENTRE. Covid- 9 Vaccine Global Common Good: appeal from 100 influential global leaders. Disponível em: <https://www.muhammadyunus.org/news/2168/Covid-19-vaccineglobal-common-good-appeal-from-100-influential-global-leaders>. Acesso em: 18 set. 2020. 


\section{5 \\ Conhecendo 0 Sars-CoV-2 e a Covid-19}

Marilia Santini de Oliveira, Aline da Rocha Matos e Marilda Mendonça Siqueira

N este capítulo são descritos de forma resumida os conhecimentos existentes sobre a etiologia, a epidemiologia, a fisiopatogenia, o quadro clínico, o diagnóstico, tratamento e a prevenção da infecção pelo novo coronavírus. As informações aqui contidas devem ser consideradas em um cenário de conhecimento em construção, portanto dependentes da data em que estamos escrevendo.

\section{CORONAVÍRUS}

Os coronavírus (CoVs) pertencem à ordem Nidovirales, família Coronaviridae e subfamília Coronavirinae, e infectam ampla gama de hospedeiros. De acordo com as relações genéticas e filogenéticas entre seus membros, esta subfamília é dividida em quatro gêneros: alfa $(\alpha)$, beta $(\beta)$, gama $(\gamma)$ e delta $(\delta)$. Os membros dos gêneros $\alpha$ e $\beta$ infectam mamíferos, ao passo que os membros dos gêneros $\gamma$ e $\delta$ infectam principalmente pássaros e, adicionalmente, alguns mamíferos (Cui, Li E Shui, 2019). Atualmente, os CoVs que infectam humanos e causam infecções respiratórias leves são dois $\alpha$-CoVs (229E e NL63) e dois $\beta$-CoVs (OC43 e HKUI). Ocasionalmente, essas infecções podem evoluir para casos graves. Adicionalmente, três distintos $\beta$-CoVs, que causam infecções altamente patogênicas em humanos surgiram nas últimas duas décadas, incluindo o primeiramente identificado CoV da síndrome respiratória aguda grave (Sars-CoV), o CoV da síndrome respiratória do Oriente Médio (Mers-CoV) e o mais recentemente descrito Sars-CoV-2, causador da pandemia de Covid- 19.

O Sars-CoV-2 pertence ao subgênero Sarbecovírus, assim como os Sars-CoV e Mers-CoV. O Sars-CoV-2, porém, foi identificado como um vírus distinto com base na baixa identidade genética com esses outros vírus altamente patogênicos. A identidade 
geral de nucleotídeos observada entre o Sars-CoV-2 e o anteriormente descrito SarsCoV é de 80\%, ao passo que a identidade com os Sars-CoVs de morcegos (ZC45 e ZXC2I) é de 89\% (Chan et al., 2020a; Malik et al., 2020; Gralinski \& Menachery, 2020). Além disso, uma identidade de sequência de somente $51 \%$ foi identificada entre 0 Sars-CoV-2 e o Mers-CoV (Ren et al., 2020). Essas análises indicaram, portanto, que o Sars-CoV-2 pode ter se originado de Sars-CoV de morcegos e que outros hospedeiros amplificadores podem ter desempenhado um papel na transmissão de doenças para humanos.

\section{Evolução}

Os CoVs dos gêneros $\alpha$ e $\beta$ evoluem a partir de morcegos, e os $\gamma$ e $\delta$ de pássaros e suínos (Cheng et al., 2007; Woo et al., 2012). Os morcegos também são considerados os hospedeiros naturais para progenitores de CoVs altamente patogênicos em humanos, como Sars-CoV e Mers-CoV (Perlman, 2020) e os reservatórios dos CoVs 229E e NL63 (Graham, Donaldson E Baric, 20I3). Previamente à infecção humana, há o envolvimento de hospedeiros animais intermediários, que então transmitem os CoVs para o hospedeiro humano.

No surto de Sars de 2002 a 2003, identificou-se que o Sars-CoV se originou de morcegos, que foram os hospedeiros reservatórios e, posteriormente, infectaram civetas, mamíferos de pequeno porte, que foram os hospedeiros intermediários. Estes, então, incorporaram mudanças na proteína de superfície viral spike (S), no seu domínio de ligação ao receptor celular da enzima conversora de angiotensina 2 (ACE2), para melhorar sua ligação e este receptor. O vírus adaptado à civeta, durante sua exposição a humanos em mercados de animais vivos, no sul da China, adquiriu subsequentes adaptações que resultaram na cepa epidêmica (Graham, Donaldson E Baric, 20I3), infectando humanos e permitindo, assim, a transmissão entre estes hospedeiros. Esse surto teve mais de 8.000 casos confirmados com mais de 700 mortes, no total, atingindo taxa de mortalidade de quase $10 \%$.

No caso do surto de Mers em 2012, relatado inicialmente na região da Arábia Saudita, foi relatado que os camelos dromedários foram os hospedeiros intermediários. Essa doença teve mortalidade de cerca de $35 \%$.

Relativamente ao Sars-CoV-2, análises do seu genoma identificaram ser este um vírus com sequência recombinante do Sars-CoV oriundo de morcego com outro CoV de origem desconhecida, na região que codifica a proteína $S$ viral que reconhece o receptor ACE2. Algumas hipóteses foram levantadas sobre o provável hospedeiro intermediário 
do Sars-CoV-2, se existente (Ji et al., 2020; Zhang, Wu \& Zhang, 2020), mas ainda não há definição desse possível animal. Uma vez em humanos, a transmissão de pessoa para pessoa ocorre principalmente por meio de contato direto ou indireto e inalação de gotículas respiratórias.

Os CoVs mais recentemente descritos representam grande ameaça à saúde pública global. A atual pandemia de Covid- 19 representa o terceiro surto de CoVs altamente patogênicos em humanos nas últimas duas décadas. Sars-CoV, Mers-CoV e Sars-CoV-2 são exemplos proeminentes de vírus que cruzaram a barreira das espécies, de animais selvagens para humanos.

As experiências prévias com os vários surtos de vírus emergentes conhecidos apontam que a patogenicidade mais alta de um vírus está frequentemente associada a uma transmissibilidade mais baixa. Em comparação com vírus emergentes como ebola, influenza $A(\mathrm{H} 7 \mathrm{~N} 9)$ aviário, Sars-CoV e Mers-CoV, o Sars-CoV-2 tem patogenicidade relativamente menor e transmissibilidade moderada (Chen, 2020).

\section{Características}

Desde o surgimento do Sars-CoV-2, muitos esforços vêm sendo feitos para determinar as características deste novo vírus, por meio de estudos de sequenciamento genômico e avaliação das suas estruturas proteicas. A nomenclatura dos CoVs é oriunda da sua semelhança morfológica com a figura de uma coroa, devido às projeções da proteína S viral a partir de sua estrutura, quando os vírus são observados através de microscopia eletrônica. Suas micrografias eletrônicas revelaram um contorno esférico, diâmetro variando de 60 a $140 \mathrm{~nm}$ e picos distintos de 9 a $12 \mathrm{~nm}$ (Zhu et al., 2020). Esses vírus têm quatro proteínas estruturais, denominadas proteínas $S$, envelope (E), membrana (M) e nucleocapsídeo (N).

Os CoVs têm material genético composto de ácido ribonucleico (RNA) de fita única, com sentido positivo de leitura, não segmentado, com cerca de 30.000 bases nucleotídicas. O genoma viral é envolto pela proteína N. Os dois terços da extremidade inicial $5^{\prime}$ do genoma codificam as poliproteínas pp la e pplab, que são clivadas pelas proteases virais nsp3-PLpro e nsp5-Mpro em 16 proteínas não estruturais, entre elas a RNA polimerase dependente de RNA (RdRP), duas proteases, uma helicase e outras proteínas envolvidas na transcrição e replicação viral (Chan et al., 2020a). As proteínas estruturais $\mathrm{S}, \mathrm{E}, \mathrm{M}$ e $\mathrm{N}$ são codificadas no terço restante da extremidade final $3^{\prime}$ do genoma, assim como as proteínas acessórias ORF-3a, -3b, -6, -7a, -7b, -8, -9a, -9b, e 10 (Chan et al., 2020a). 
Uma característica única do Sars-CoV-2 em relação ao Sars-CoV é a presença de um sítio de clivagem por proteases tipo-furina na sua proteína S (Coutard et al., 2020). A presença desse sítio pode ter alguma relação com o tropismo mais amplo observado por este vírus recente, visto que essas proteases apresentam expressão celular e tecidual generalizada.

\section{A PANDEMIA: EPIDEMIOLOGIA}

Em 31 de dezembro de 2019 as autoridades de saúde chinesas relataram para a Organização Mundial da Saúde (OMS) uma epidemia de casos com infecções respiratórias baixas detectada em Wuhan, a maior área metropolitana da província de Hubei, iniciada no início do mesmo mês. Como não foi possível identificar o agente causal da doença, esses primeiros casos foram classificados como "pneumonia de etiologia desconhecida". O Centro Chinês de Controle e Prevenção de Doenças (CDC) e os CDCs locais organizaram um programa intensivo de investigação de surtos. A etiologia dessa doença é agora atribuída a um novo vírus pertencente à família dos coronavírus (CoV), denominado Sars-Cov-2. Em 1 I de fevereiro de 2020, o diretor-geral da OMS, dr. Tedros Adhanom Ghebreyesus, anunciou que a doença causada por esse novo CoV seria denominada Covid- 19, sigla de “doença por coronavírus 2019” (Cascella et al., 2020).

Esse novo vírus mostrou-se bastante contagioso e se espalhou rapidamente em todo o mundo. Em 30 de janeiro de 2020, de acordo com o Regulamento Sanitário Internacional, o surto foi declarado pela OMS como emergência em saúde pública de interesse internacional (PHEIC), já disseminada para 18 países, com quatro países relatando transmissão local. Em 28 de fevereiro de 2020 a OMS elevou a classificação da situação como nível muito alto de risco de pandemia e em I I de março, quando o número de casos de Covid- 9 fora da China aumentou 13 vezes e o número de países envolvidos triplicou, com mais de I 8.000 casos em I I 4 países e mais de 4.000 mortes, a instituição declarou uma pandemia da nova doença.

Em uma revisão sistemática sobre a epidemiologia da Covid- 19, incluindo 41 artigos identificados nas bases PubMed e de artigos preprint (Park et al., 2020), sugere-se que o número de casos dobra em 3 a 7 dias durante todo o período da curva ascendente da epidemia. Nessa mesma revisão constatou-se que o número de reprodução básico (representado como Ro e referente ao número de novas infecções que uma pessoa infectada pode causar em uma população susceptível) varia de I,9 a 6,5 em um intervalo serial de 4 a 8 dias. 
Informações atualizadas e detalhadas sobre a situação da Covid- 19 no mundo são consolidadas e publicadas por diversas instituições, incluindo a OMS (WHO, 2020a) e a Universidade Johns Hopkins (Johns Hopkins University, 2020). No Brasil, dados detalhados dos diferentes municípios são publicados pelo Ministério da Saúde (Brasil, 2020) e pelas secretarias estaduais de Saúde em seus websites. Informações sobre outras fontes de dados e aspectos epidemiológicos mais amplos da Covid- 9 são compiladas e publicadas pelo Observatório Covid- 19 da Fiocruz (Fiocruz, 2020)

\section{Transmissão}

Os estudos realizados até o momento mostram que o Sars-Cov-2 é transmitido de pessoa a pessoa por via respiratória, através de

- contato direto, por gotículas infectadas e fômites disseminados por um indivíduo doente ao tossir, espirrar ou mesmo falar e respirar a menos de I metro de distância, resultando na inoculação do vírus em boca, nariz e conjuntiva de um indivíduo susceptível (Liu et al., 2020; Li et al., 2020; Burke et al., 2020);

- contato indireto, por contaminação das mãos em superfícies e objetos contaminados com secreções respiratórias de um indivíduo infectado e posterior toque nas portas de entrada.

A transmissão por aerossóis aparentemente ocorre apenas durante a realização de procedimentos geradores deste tipo de partícula, não havendo ainda resultados conclusivos de o que mesmo possa ocorrer em outras situações (CDC, 2020a).

O período de transmissibilidade varia de I a 3 dias antes do início dos sintomas (período pré-sintomático) até cerca de 8 dias após o início destes (CDC, 2020b). Há evidências de que pessoas com infecção assintomática transmitem o vírus, embora com menor efetividade (Kimball et al., 2020; Wan et al., 2020).

\section{PATOGÊNESE E RESPOSTA IMUNE}

Os CoVs humanos associados com as infecções mais leves 229E, NL63, OC43 e HKUI infectam principalmente apenas o trato respiratório superior e causam sintomas relativamente brandos (Fehr \& Perlman, 20I5). No entanto, Sars-CoV, Mers-CoV e SarsCoV-2 também podem se replicar no trato respiratório inferior e causar pneumonia, que pode ser fatal. A destruição das células pulmonares causada pela infecção por SarsCoV-2 desencadeia uma resposta imune local, recrutando macrófagos e monócitos que respondem à infecção, liberando citocinas e iniciando as respostas imunes adaptativas 
dos linfócitos T e B. Na maioria dos casos, esse processo é capaz de resolver a infecção. No entanto, em alguns casos, ocorre uma resposta imune ineficiente, que pode causar uma doença pulmonar grave e até mesmo uma patologia sistêmica.

Após infectar um novo hospedeiro, o vírus replica-se principalmente nas células do trato respiratório superior e inferior, além do gastrointestinal. O Sars-CoV-2 utiliza ACE2, expressa nos pulmões, coração, intestinos, rins, entre outros órgãos (Yan et al., 2020), como seu receptor de entrada celular, e esta ligação tem afinidade de 10 a 20 vezes maior do que a ligação com o Sars-CoV (Wrapp et al., 2020, Walls et al., 2020). Em seguida, ocorre a fusão entre as membranas virais e celulares, com subsequente liberação do genoma viral no citoplasma e as posteriores etapas de replicação até a formação de novas partículas virais prontas para infectar novas células.

Nesse primeiro momento, nas células infectadas, inicia-se a resposta imune inata, correspondente a uma ação antiviral do organismo infectado. Nessa resposta, ocorre ativação da via de interferon do tipo I (IFN-I), fundamental para fornecer proteção eficiente contra infecções virais, que se inicia após o reconhecimento do material genético viral, no citoplasma, pelos sensores celulares do hospedeiro (Streicher $E$ Jouvenet, 20I9). Ao final dessa cascata de ativação de IFN, é feita a indução da expressão de centenas de genes induzidos por IFN (ISGs) (Schoggins, 2019), que, juntamente com outras moléculas controladas por IFN, incluindo citocinas pró-inflamatórias, podem atuar desde inibindo diretamente a replicação viral até recrutando e ativando outras células do sistema imune (Makris, Paulsen $\varepsilon$ Johansson, 20I7). Uma resposta IFN-I robusta, oportuna e localizada é necessária como primeira linha de defesa contra a infecção viral, por promover a eliminação do vírus, induzir reparação tecidual e desencadear a consequente resposta imunológica adaptativa prolongada contra os vírus. Entretanto, as respostas induzidas por IFN-I requerem um ajuste fino, pois sua ativação exacerbada pode ser prejudicial ao hospedeiro, visto que a produção sistêmica, duradoura e não controlada de IFN-I pode levar ao surgimento de doenças inflamatórias.

Geralmente, o Sars-CoV-2 induz a resposta imunológica inata via IFN-I de forma moderada, em comparação com outros vírus respiratórios de RNA (Chu et al., 2020; Blanco-Melo et al., 2020) e com Sars-CoV e Mers-CoV, que já são naturalmente indutores fracos desta resposta, em células humanas (Spiegel et al., 2005; Chan et al., 20I3). Os níveis séricos de IFN-I em pacientes infectados são baixos, apesar de haver detecção da expressão dos ISGs (Chan et al., 2020b; Hadjadj et al., 2020). Uma das explicações para essa baixa indução é que os CoVs, incluindo o SarsCoV-2, desenvolveram várias estratégias para escapar e neutralizar sua detecção 
pelo sistema imune inato e consequente ação antiviral de IFN-I (Chan et al., 2020b; Blanco-Melo et al., 2020; Hadjadj et al.; 2020).

Na maioria dos indivíduos, as células recrutadas eliminam a infecção no pulmão. Em seguida, a resposta imune diminui e os pacientes se recuperam. No entanto, em alguns casos ocorre uma resposta imune ineficiente e replicação elevada do Sars-CoV-2, com liberação excessiva de citocinas e quimiocinas pró-inflamatórias, fenômeno conhecido como "tempestade de citocinas", mediando a inflamação pulmonar generalizada (Tay et al., 2020). Além disso, pode haver infiltração desenfreada de células inflamatórias no sítio de infecção, através do recrutamento pulmonar de células imunes do sangue e da infiltração de linfócitos nas vias aéreas, e associação com linfopenia nos pacientes com Covid-19 (Guan et al., 2020, Qin et al., 2020). Por conseguinte, podem ser gerados imunopatologia pulmonar e dano alveolar difuso, incluindo descamação de células alveolares, formação de membrana hialina e edema pulmonar, além de extravasamento vascular que pode resultar em danos a múltiplos órgãos do hospedeiro.

Indivíduos idosos e com comorbidades têm maior probabilidade de desenvolver essa resposta imunológica ineficiente que causa a patologia grave e deficiência em erradicar o patógeno com sucesso. As razões exatas para esse fenômeno não são claras, embora possam estar relacionadas com o envelhecimento do microambiente pulmonar causando alteração da maturação de células imunes e consequente ativação defeituosa dos linfócitos T (Zhao et al., 20ll).

Na resposta imune adaptativa, na qual são gerados anticorpos que reconhecem o vírus, além da eliminação do vírus e das células infectadas, as respostas séricas de linfócitos T e B contra o Sars-CoV-2 podem ser detectadas a partir de alguns dias após a infecção (Thevarajan et al., 2020). Entretanto, em pacientes com Covid- 9 grave, foi identificada uma relação com a exaustão de células $T$, na qual estas células relevantes para a eliminação do vírus perdem sua capacidade proliferativa e citotóxica, levando eventualmente à sua eliminação (Zheng et al., 2020). Além disso, é provável que os anticorpos gerados sejam eficazes contra o Sars-CoV-2, mas ainda não se sabe se esses pacientes são suscetíveis a reinfecção, das quais há relatos esporádicos. Os estudos para avaliar a eficiência e persistência dos anticorpos sintetizados nos pacientes, de acordo com a gravidade da doença clínica manifestada, ainda estão sendo conduzidos, e informações mais conclusivas serão geradas futuramente. 


\section{MANIFESTAÇÕES CLÍNICAS DA INFECÇÃO PELO SARS-COV-2}

O período de incubação da Covid- 19 é em média de 5 a 6 dias, podendo se prolongar por 14 dias, e o espectro clínico da infecção pelo Sars-Cov-2 é bastante variável, englobando casos assintomáticos, quadros leves sem sintomas respiratórios, doença respiratória leve, moderada e grave, sépsis com disfunção de múltiplos órgão e óbito (WHO, 2020).

Uma revisão sistemática sobre o assunto registra que de 6 a $41 \%$ dos infectados não apresentam sintomas, com uma estimativa média de 16\% (Byambasuren et al., 2020). Entre os pacientes sintomáticos estima-se que 40\% apresentam quadros leves, 40\% moderados, cerca de 15\% doença grave com necessidade de suporte ventilatório e 5\% desenvolvem quadro crítico como sepsis, choque, tromboembolismo e/ou falência de múltiplos órgãos.

Os sintomas mais frequentemente relatados por pacientes com Covid- 9 são febre, tosse, fadiga, anorexia, dispneia, mialgia, dor de garganta, congestão nasal, cefaleia, anosmia e ageusia (WHO, 2020). Outras manifestações são descritas com menor frequência, incluindo neurológicas (encefalopatia, delírio, agitação, meningoencefalite, ansiedade e depressão), embolia pulmonar, síndrome coronariana aguda e acidente vascular cerebral (WHO, 2020).

Há poucos dados sobre o quadro clínico da doença em populações específicas. Em crianças há evidências de que tenham manifestações mais leves que os adultos, embora recentemente tenham sido identificados quadros de uma síndrome hiperinflamatória com falência de múltiplos órgãos e choque nessa população. Mulheres grávidas aparentemente não apresentam quadros diferentes daqueles de adultas não grávidas em idade reprodutiva.

Algumas condições estão associadas a maior risco de doença grave e morte, incluindo idade maior de 60 anos, obesidade, tabagismo, doenças como diabetes, hipertensão arterial, doença pulmonar crônica e neoplasias. Em pacientes com Covid-19 alguns parâmetros clínicos e laboratoriais também parecem associados a pior evolução, como níveis séricos de proteínas inflamatórias e alterações da coagulação.

\section{DIAGNÓSTICO}

Devido à inexistência de sintomas clínicos capazes de diferenciar a doença provocada pelo vírus Sars-CoV-2 daquelas provocadas por outros vírus respiratórios, o diagnóstico laboratorial é a alternativa possível para o diagnóstico conclusivo. O diagnóstico precoce de indivíduos apresentando ou não sinais e/ou sintomas relacionados a infecção pelo 
coronavírus permite rápida intervenção terapêutica e o seguimento de contatos, possibilitando melhor controle da disseminação do vírus.

O ensaio laboratorial recomendado pela OMS e pelo Ministério da Saúde é o ensaio de RT-PCR em tempo real, que detecta a presença do vírus em secreções respiratórias. Esse teste é considerado o padrão-ouro para o diagnóstico da Covid-19. Os testes sorológicos visam a identificar a presença de anticorpos contra o vírus e podem ser em formato de testes rápidos imunocromatográficos ou testes tradicionais como Elisa ou quimioluminescência. Outro ensaio como a detecção de antígenos virais (por Elisa, testes rápidos ou imunofluorescência) ainda não é recomendado para o diagnóstico. A dinâmica da produção e excreção das proteínas virais ainda não está completamente estabelecida e esses testes frequentemente apresentam sensibilidade menor do que os ensaios moleculares.

\section{Detecção de material viral}

Para o diagnóstico por RT- PCR em tempo real, o espécimen clínico preconizado pela OMS e pela Rede de Vigilância do Ministério da Saúde é o swab de naso e/ou orofaringe, visando a obter as células epiteliais do trato respiratório superior infectadas com o vírus.

A detecção viral por RT PCR em tempo real identifica os casos na sua fase inicial, indicando que o indivíduo está com a infecção pelo Sars-CoV-2 sintomática ou assintomática.

No momento, é possível estabelecer que o vírus pode ser detectado pelo menos 48 horas antes do início dos sintomas até 12-14 dias (ao menos 6-7 dias) após. No entanto, a persistência viral foi descrita por períodos mais longos, dependendo da gravidade da doença, com uma mediana de 20 dias em pacientes hospitalizados. Como a metodologia de RT PCR em tempo real detecta parte do genoma viral, essa detecção prolongada não significa necessariamente vírus infectivo.

Recomenda- se a testagem de todos os contatos próximos de um caso positivo. Devido ao potencial de transmissão de pessoas assintomáticas ou pré-sintomáticas, é importante que contatos de indivíduos positivos sejam rapidamente identificados e testados. Embora um resultado negativo nesses indivíduos não exclua a possibilidade de que ele esteja no período de incubação viral, sem que ainda seja possível detectar o vírus.

\section{Testes sorológicos}

Os testes sorológicos detectam anticorpos ( $\lg \mathrm{M}, \lg A$ ou $\lg \mathrm{G})$ gerados como parte da resposta imune individual contra o vírus da Covid-19. Estes testes apresentam grandes diferenças em sensibilidade e especificidade, dependendo do formato do teste (teste 
rápido ou tradicional, como Elisa ou quimioluminescência) e do kit comercial utilizado. Em geral, os anticorpos IgM ou IgG são detectáveis somente após a primeira semana de início dos sintomas clínicos, em aproximadamente 50\% dos casos, aumentando após a segunda semana, e em torno do dia $14,90 \%$ dos pacientes podem apresentar anticorpos detectáveis por Elisa. Essa detecção somente indica que houve um contato prévio com o vírus, mas não permite definir o momento em que tal contato ocorreu.

Os testes sorológicos ainda não são considerados testes de diagnóstico individual e seus resultados devem ser interpretados cuidadosamente de acordo com as informações clínicas, os resultados de outros testes e o contexto epidemiológico. No momento, a implementação destes testes deveria estar direcionada principalmente para pesquisas epidemiológicas e de soroprevalência (Paho, 2020; CDC, 2020b).

\section{TRATAMENTO}

O tratamento da Covid- 19 é basicamente sintomático e de suporte, de acordo com as manifestações clínicas apresentadas. Informações e recomendações detalhadas sobre as linhas de cuidado com os pacientes com Covid- 19 podem ser encontradas no guia de manejo clínico publicado pela Organização Mundial da Saúde (WHO, 2020c)

Centenas de compostos novos e já disponíveis comercialmente foram pesquisados em estudos pré-clínicos para avaliar atividade antiviral, antitrombótica e/ou imunomoduladora; alguns poucos chegaram a ensaios clínicos, muitos dos quais ainda em andamento. Até o momento não há resultados conclusivos provenientes de estudos clínicos.

\section{PREVENÇÃO}

Atualmente estão disponíveis apenas medidas não farmacológicas de prevenção, com as quais se objetiva evitar a transmissão de uma pessoa infectada para outra susceptível. Essas medidas baseiam-se em:

I. Distanciamento físico;

2. Uso de barreiras em frente à boca e ao nariz (como máscaras e protetores faciais);

3. Diagnóstico precoce e isolamento dos infectados, sejam sintomáticos, présintomáticos ou assintomáticos.

Medidas coletivas de isolamento social foram determinadas por diversos países, desde o fechamento de escolas e de locais de vendas de produtos e de serviços não essenciais até o lockdown completo, com interdição de vias de acesso. Essas políticas visam principalmente a achatar a curva de casos a fim de evitar o colapso dos serviços 
de saúde e oferecer proteção especial a indivíduos com maior risco de ter casos graves de Covid- 19, como os mais velhos e os portadores de doenças crônicas. Informações sobre a resposta dos diferentes países à pandemia podem ser vistas em relatórios publicados pela OMS (WHO, 2020d).

Desde a declaração da pandemia, diversos grupos de pesquisadores estão realizando estudos em busca de uma vacina contra o vírus, havendo mais de duas centenas de produtos candidatos até o momento, em diferentes fases de desenvolvimento. Painéis sobre esse assunto são publicados por algumas instituições em websites, como, por exemplo, $<$ https://www.covid- 19 vaccinetracker.org $>$ e $<$ https://www.who.int/publications/m/ item/draft-landscape-of-covid-19-candidate-vaccines $>$.

Como dito na introdução, as informações contidas neste capítulo devem ser consideradas em um cenário de conhecimento em construção, portanto dependentes da data em que estamos escrevendo. O conhecimento sobre as diversas dimensões da enfermidade cresce velozmente no mundo todo e também no Brasil, mostrando o engajamento e o dinamismo da ciência que, praticamente em tempo real, produz conhecimentos fundamentais para um enfrentamento eficaz e equitativo dos grandes desafios impostos ao mundo pela pandemia da Covid- 19.

\section{REFERÊNCIAS}

BLANCO-MELO, D. et al. Imbalanced host response to Sars-CoV-2 drives development of Covid-19. Cell, 181: 1.036, 2020.

BURKE, R. M. et al. Active monitoring of persons exposed to patients with confirmed Covid- 19 - United States, January-February 2020. MMWR Morbidity and Mortality Weekly Report, 69(9): 245-246, 2020.

BYAMBASUREN, O. et al. Estimating the extent of true asymptomatic Covid-1 9 and its potential for community transmission: systematic review and meta- analysis (preprint). MedRxiu, 2020. Disponível em: <https://www.medrxiv.org/content/10.1101/2020.05.10.20097543vl >. Acesso em: 4 jun. 2020.

BRASIL. Ministério da Saúde. Painel Coronavírus. Disponível em: <https://covid.saude.gov.br>. Acesso em: 18 set. 2020.

CASCELLA, M. et al. Features, Evaluation and Treatment Coronavirus (Covid-19). Last update: August 10, 2020. Disponível em: <https://www.ncbi.nlm.nih.gov/books/NBK554776/>. Acesso em: I 8 set. 2020.

CENTERS FOR DISEASE CONTROL AND PREVENTION (CDC). Symptom-Based Strategy to Discontinue Isolation for Persons with Covid-19. Atlanta: Centers for Disease Control and Prevention, 2020a. Disponível em: <https://www.cdc.gov/coronavirus/2019-ncov/community/strategy-discontinueisolation.html>. Acesso em: 4 jun. 2020. 
CENTERS FOR DISEASE CONTROL AND PREVENTION (CDC). Overview of testing for Sars CoV2, 2020b. Disponível em: <https://www.cdc.gov/coronavirus/20 I 9-ncov/hcp/testing-overview.html>. Acesso em: 14 ago. 2020.

CHAN, J. F. W. et al. Genomic characterization of the 2019 novel human-pathogenic coronavirus isolated from a patient with atypical pneumonia after visiting Wuhan. Emerging Microbes and Infections, 9: 221-236, 2020a.

CHAN, J. F. W. et al. A familial cluster of pneumonia associated with the 2019 novel coronavirus indicating person-to-person transmission: a study of a family cluster. The Lancet, 395(10.223): 514-523, 2020b.

CHAN, R. W. Y. et al. Tropism of and innate immune responses to the novel human betacoronavirus lineage $C$ virus in human ex vivo respiratory organ cultures. Journal of Virology, 87: 6.604-6.6I4, 2013.

CHEN, J. Pathogenicity and transmissibility of 2019-nCoV - a quick overview and comparison with other emerging viruses. Microbes and Infection, 22(2): 69-71, 2020.

CHENG, V. C. C. et al. Severe acute respiratory syndrome coronavirus as an agent of emerging and reemerging infection. Clinical Microbiology Reviews, 20: 660-694, 2007.

$\mathrm{CHU}, \mathrm{H}$. et al. Comparative replication and immune activation profiles of Sars-CoV-2 and Sars-CoV in human lungs: an ex vivo study with implications for the pathogenesis of Covid-19. Clinical Infectious Disease, 7 I (6): 1.400-1.409, 2020.

COUTARD, B. et al. The spike glycoprotein of the new coronavirus 2019-nCoV contains a furin-like cleavage site absent in CoV of the same clade. Antiviral Research, 176: 1047.42, 2020.

COVID- I 9 VACCINE TRACKER. Site. Disponível em: <https://www.covid-1 9vaccinetracker.org/>. Acesso em: 18 set. 2020.

CUI, J.; LI, F. E SHI, Z. L. Origin and evolution of pathogenic coronaviruses. Nature Reviews. Microbiology, 17: 181-192, 2019.

FEHR, A. R. \& PERLMAN, S. Coronaviruses: an overview of their replication and pathogenesis. Coronaviruses: methods and protocols, 1.283: 1-23, 2015.

FUNDAÇÃO OSWALDO CRUZ (FIOCRUZ). Observatório Covid- 19: observação para ação. Disponível em: <https://portal.fiocruz.br/observatorio-covid-19>. Acesso em: 18 set. 2020.

GRAHAM, R. L.; DONALDSON, E. F. \& BARIC, R. S. A decade after Sars: strategies for controlling emerging coronaviruses. Nature Reviews. Microbiology, 11:836-848, 2013.

GRALINSKI, L. E. \& MENACHERY, V. D. Return of the Coronavirus: 20I9-nCoV. Viruses, I2: 135, 2020.

GUAN, W. et al. Clinical characteristics of coronavirus disease 2019 in China. The New England Journal of Medicine, 382: 1.708-1.720, 2020.

HADJADJ, J. et al. Impaired type I interferon activity and inflammatory responses in severe Covid-19 patients. Science, 369: 7 18-724, 2020.

JOHNS HOPKINGS UNIVERSITY. Covid- 19 Dashboard by the Center for Systems Science and Engineering (CSSE) at Johns Hopkins University (JHU). Disponível em: < https://coronavirus.jhu.edu/map. html>. Acesso em: 18 set. 2020. 
JI, W. et al. Cross-species transmission of the newly identified coronavirus $2019-n C o V$. Journal of Medical Virology, 92: 433-440, 2020.

KIMBALL, A. et al. Asymptomatic and presymptomatic Sars- CoV-2 infections in residents of a longterm care skilled nursing facility - King County, Washington, March 2020. MMWR Morbidity and Mortality Weekly Report, 69(13): 377-381, 2020.

LI, Q. et al. Early transmission dynamics in Wuhan, China, of novel coronavirus-infected pneumonia. The New England Journal of Medicine, 382(13): 1.199-1.207, 2020.

LIU, J. et al. Community transmission of severe acute respiratory syndrome coronavirus 2, Shenzhen, China, 2020. Emerging Infectious Diseases, 26(6): 1.320-1.323, 2020.

MAKRIS, S.; PAULSEN, M. E JOHANSSON, C. Type I interferons as regulators of lung inflammation. Frontiers in Immunology, 8: I, 2017.

MALIK, Y. S. et al. Emerging novel coronavirus (2019-nCoV): current scenario, evolutionary perspective based on genome analysis and recent developments. The Veterinary Quarterly, 40: 68-76, 2020.

PAN AMERICAN HEALTH ORGANIZATION (PAHO). Laboratory diagnosis for the detection and diagnosis of Covid-19 Infection, 2020. Disponível em: <https://iris.paho.org/bitstream/handle/10665.2/52458/PAHOIMSPHECOVID-19200038_eng.pdf? sequence $=1$ I EisAllowed $=y>$. Acesso em: 18 set. 2020.

PARK, M. et al. A systematic review of Covid- 19 epidemiology based on current evidence. Journal of Clinical Medicine, 9(4): 967, 2020.

PERLMAN, S. Another decade, another coronavirus. The New England Journal of Medicine, 382: 760 762,2020

QIN, C. et al. Dysregulation of immune response in patients with Covid-19 in Wuhan, China. Clinical Infectious Disease, 2020.

REN, L. L. et al. Identification of a novel coronavirus causing severe pneumonia in human: a descriptive study. Chinese Medical Journal, 133: I.0 I 5-1.024. 2020.

SCHOGGINS, J. W. Interferon-stimulated genes: what do they all do? Annual Review of Virology, 6: $567-584,2019$

SPIEGEL, M. et al. Inhibition of Beta interferon induction by severe acute respiratory syndrome coronavirus suggests a two-step model for activation of interferon regulatory factor 3. Journal of Virology, 79(4): 2.079-2.086, 2005

STREICHER, F. \& JOUVENET, N. Stimulation of innate immunity by host and viral RNAs. Trends in Immunology, 40: I.134-1.148, 2019.

TAY, M. Z. et al. The trinity of Covid-19: immunity, inflammation and intervention. Nature Reviews. Microbiology, 20: 363-374, 2020.

THEVARAJAN, I. et al. Breadth of concomitant immune responses prior to patient recovery: a case report of non-severe Covid- 19. Nature Medicine, 26: 453-455, 2020.

WALLS, A. C. et al. Structure, function, and antigenicity of the Sars-CoV-2 Spike glycoprotein. Cell, 181: 281-292.e6, 2020. 
WANG, Y. et al. Characterization of an asymptomatic cohort of Sars-COV- 2 infected individuals outside of Wuhan, China. Clinical Infection Disease, 2020.

WOO, P. C. Y. et al. Discovery of seven novel mammalian and avian coronaviruses in the genus deltacoronavirus supports bat coronaviruses as the gene source of $A$ lphacoronavirus and Betacoronavirus and avian coronaviruses as the gene source of Gammacoronavirus and Deltacoronavirus. Journal of Virology, 86: 3.995-4.008, 2012.

WORLD HEALTH ORGANIZATION (WHO). Clinical management of Covid- 9 interim guidance, 2020a. Disponível em: <https://www.who.int/publications/i/item/clinical-management-of-covid-19>. Acesso em: 18 set. 2020.

WORLD HEALTH ORGANIZATION (WHO). WHO Coronavirus Disease (Covid-19) Dashboard. Disponível em: <https://covid 19.who.int/>. Acesso em: 18 set. 2020b.

WORLD HEALTH ORGANIZATION (WHO). Clinical management of Covid- 19: interim guidance, 27 May 2020c. Disponível em: <https://apps.who.int/iris/handle/10665/332196>. Acesso em: 18 set. 2020.

WORLD HEALTH ORGANIZATION (WHO). Coronavirus disease (Covid-19) pandemic. Disponível em: $<$ https://www.who.int/emergencies/diseases/novel-coronavirus-2019>. Acesso em: 18 set. 2020d.

WORLD HEALTH ORGANIZATION (WHO). Draft landscape of Covid- 9 candidate vaccines. Disponível em: <https://www.who.int/publications/m/item/draft-landscape-of-covid-19-candidate-vaccines>. Acesso em: 18 set. 2020 e.

WRAPP, D. et al. Cryo-EM structure of the 2019-nCoV spike in the prefusion conformation. Science, 367(6.483): 1.260-1.263, 2020.

YAN, R. et al. Structural basis for the recognition of Sars-CoV-2 by full-length human ACE2. Science, 367(6.485): 1.444-1.448, 2020.

ZHANG, T.; WU, Q. \& ZHANG, Z. Probable Pangolin origin of Sars-CoV-2 associated with the Covid- 19 outbreak. Current Biology, 30: 1.346-1.351.e2, 2020.

ZHAO, J. et al. Age-related increases in PGD 2 expression impair respiratory DC migration, resulting in diminished T cell responses upon respiratory virus infection in mice. The Journal of Clinical Investigation, 121: 4.921-4.930, 2011.

ZHENG, H.-Y. et al. Elevated exhaustion levels and reduced functional diversity of T cells in peripheral blood may predict severe progression in Covid- 19 patients. Cellular E Molecular Immunology, I 7: 54 I 543, 2020.

ZHU, N. et al. A novel coronavirus from patients with pneumonia in China, 2019. The New England Journal of Medicine, 382: 727-733, 2020. 


\title{
6 Saúde Única e a Pandemia de Covid-19
}

\author{
Cristina Schneider e Marilia Santini de Oliveira
}

$\mathrm{O}$

s seres humanos, animais e o meio ambiente estão interligados e fazem parte de um sistema complexo e inter-relacionado; o que acontece num local pode afetar todos, e temos que aprender a viver em harmonia com o meio ambiente e os animais. Esse entendimento e a colaboração entre as diferentes disciplinas e setores é a base do conceito de saúde única. Exemplos de epidemias anteriores permitem entender que para que uma pandemia ocorra é necessária a conjunção de diversos fatores. No pós-Covid, será preciso estarmos atentos à interface animal-humano-ambiente, razão pela qual apresentamos sugestões para qualificar essa atenção.

\section{REVISANDO A HISTÓRIA DAS PANDEMIAS}

Para responder aos desafios do mundo atual, que enfrenta uma pandemia, crise humanitária e recessão econômica, com mais de 650.000 óbitos por Covid-19, uma doença zoonótica, nunca foi tão importante a visão de que nós e os animais estamos interligados e compartilhamos um ambiente. Nosso planeta tem mais de 8 bilhões de habitantes, $10 \%$ deles em situação de pobreza extrema e fome, passa por um processo de urbanização acelerada, com pessoas migrando em números como nunca visto antes principalmente devido a conflitos, e frequentes desastres naturais possivelmente por câmbios climáticos. Nesse contexto devemos entender que não estamos sós neste planeta, o que acontece num local pode afetar todos e temos que aprender a viver em harmonia entre os seres humanos, respeitando os animais e o meio ambiente.

As epidemias e pandemias fazem parte da história da humanidade. Em múmias do Egito antigo foi possível demonstrar a presença de vestígios de tuberculose (Rosen, 1993). Em diferentes momentos da Idade Média a peste foi a doença mais temida em diversas partes 
do mundo; estima-se que a pandemia da peste negra em 1348, a mais conhecida, tenha dizimado cerca da metade da população da Europa. Na Idade Moderna a cólera foi um grande desafio; em 1854, John Show demonstrou pela primeira vez a sua transmissão pela água. A introdução da varíola em populações nativas e totalmente susceptíveis na África e nas Américas levou à grande pandemia do século XVI, já que se trata de vírus de transmissão pessoa a pessoa. Ademais, outros vírus da família pox podem estar presentes em várias espécies animais e constituir uma ameaça à saúde pública. Nos últimos 150 anos houve importantes epidemias na interface animal-humano, entre as quais a de febre amarela que assolou o Novo Mundo até o entendimento do ciclo de sua transmissão (que envolve principalmente primatas não humanos e mosquitos) e o desenvolvimento da vacina na década de 1930. A expansão geográfica do vírus da febre amarela, uma das primeiras doenças para as quais foram estabelecidos acordos formais de quarentena, em todo o mundo tem raízes históricas no comércio e na colonização (Najera Hamrick et al., 2017).

Epidemia - A ocorrência em uma comunidade ou região de casos de uma doença, comportamento específico relacionado à saúde ou outros eventos relacionados à saúde claramente acima da expectativa normal. Um único caso de uma doença transmissível ausente por muito tempo de uma população ou primeira invasão por uma doença não reconhecida anteriormente nessa área requer notificação imediata e investigação completa em campo (Porta, 2008).

Pandemia - Epidemia que ocorre em todo o mundo ou em uma área muito ampla, atravessando fronteiras internacionais e geralmente afetando grande número de pessoas (Porta, 2008).

A grande ameaça do século, porém, foi a influenza em 1918 a pandemia mais grave da história recente. Durante a I Guerra Mundial, em março de 1918 um cozinheiro no Kansas, nos Estados Unidos da América (EUA), foi o primeiro caso detectado, e em três semanas mais de mil soldados foram afetados, iniciando a história da chamada gripe espanhola, que se estima tenha matado cerca de 50 milhões de pessoas no mundo $e$ afetado quase um terço da população mundial daquele momento (Taubenberger $\varepsilon$ Morens, 2006; Martini, Bragazzi \& Barberis, 2019). Houve três ondas de pandemia de gripe na ocasião. A primeira apareceu na primavera de 1918, seguida em rápida sucessão por segunda e terceira ondas muito mais fatais, no outono e no inverno de 1918 a 1919, respectivamente. Muitos pesquisadores dedicaram anos de suas carreiras 
a entender o que explicava a gravidade dos casos em certos momentos, se o vírus era o mesmo entre as ondas, qual foi a origem dessa pandemia, que animal estava envolvido e a responder várias outras perguntas, muitas das quais ainda sem resposta cem anos depois (Taubenberger \& Morens, 2006; Martini et al., 20I 9).

A peste, que causou uma epidemia na Idade Média e chegou ao Brasil em 1899, é um excelente exemplo para o enfoque de saúde única. A doença é causada pela bactéria Yersinia pestis, que envolve principalmente roedores selvagens (reservatório) e suas pulgas (vetores), os quais ocasionalmente transmitem a doença a outros animais e humanos, particularmente aqueles que vivem perto de focos naturais de doenças. Determinados fatores ambientes estão associados com a persistência da peste, como tipos de bioma, altitude, temperatura e precipitação (Schneider et al., 20।4).

\section{Componentes da peste}

Humano - Casos/óbitos em pessoas como problema de saúde pública e que podem causar epidemias; pessoas doentes que requerem atenção do sistema de saúde. Casos pulmonares apresentam mortalidade muito alta e rápida.

Animal - Roedores principalmente silvestres e outros animais, como a pulga que transmite a peste.

Ambiental - Focos naturais que mantêm a persistência da bactéria em ciclos silvestres nos quais a peste pode emergir ou reemergir em casos humanos por mais de 30 anos. Áreas com as condições ambientais propícias para a transmissão da doença nos animais.

A primeira pandemia mundial de peste conhecida aconteceu no tempo de Justiniano (542-602 d.C.) e se espalhou pelo mar Mediterrâneo; a segunda pandemia mundial foi registrada entre os séculos XIV e XVI, causou grande mortalidade na Ásia Central e na Europa e foi denominada peste negra; por fim, a terceira e mais recente pandemia se originou na China durante o século XIX. Foi durante esta última que a peste ocorreu pela primeira vez na África e na Região das Américas, começando nas cidades portuárias onde provavelmente foi introduzida pelo tráfego marítimo ou fluvial (Schneider et al., 20I4). Após a introdução da peste nas cidades portuárias, ocorreram grandes surtos humanos em centros urbanos densamente povoados. A infecção propagou-se gradualmente para o interior, geralmente seguindo rotas de transporte. Como ratos domésticos se misturavam com animais silvestres em áreas rurais, a infecção foi transmitida a esses hospedeiros silvestres, que se mantiveram como foco natural do agente infecioso e 
hoje são o principal reservatório em áreas onde a peste continua sendo um problema de saúde pública (Schneider et al., 20|4).

Na América Latina a doença foi identificada pela primeira vez no Paraguai em 1899 e no mesmo ano no Brasil e na Argentina. Durante a primeira metade do século XX a peste foi encontrada durante um ou mais anos em 14 dos 25 países e territórios da América Latina, persistindo em focos em seis países: Argentina, Venezuela, Bolívia, Brasil, Equador e Peru (Schneider et al., 2014).

No Brasil, alguns médicos visionários abriram caminhos na saúde pública e na pesquisa no início do século passado com visão integrada sobre a interface entre animais, pessoas e o ambiente, como Adolfo Lutz e Oswaldo Cruz (Moraes et al., no prelo). Oswaldo Cruz, no seu regresso do Instituto Pasteur de Paris, encontrou o porto de Santos assolado pela peste e logo começou a trabalhar no combate a essa doença. Para tanto, foi fundado, no ano de 1900, o Instituto Soroterápico Federal, na antiga Fazenda de Manguinhos, no Rio de Janeiro. A direção-geral do instituto foi assumida pelo barão de Pedro Affonso e a direção técnica ficou a cargo do jovem cientista Oswaldo Cruz, que em 1902 assumiu sua direção e ampliou suas atividades com a pesquisa básica e aplicada e a formação de recursos humanos. Oswaldo Cruz foi nomeado diretor-geral de Saúde Pública no ano seguinte e usou o instituto como base das suas campanhas de saneamento. Em pouco tempo conseguiu vencer a peste bubônica combatendo os ratos (Leal, 2009). Podemos sugerir que eles foram os precursores em nosso país da noção de saúde única, por terem demostrado a importância dos animais e vetores na transmissão e no controle das doenças epidêmicas.

Atualmente a peste é considerada pela Organização Mundial da Saúde (OMS) endêmica em quatro países da América Latina, que ainda se encontram no período de várias décadas em que a doença pode reemergir de focos naturais nos animais silvestres. O Brasil é um deles; apesar de não apresentar casos desde 2005, há no país focos naturais identificados.

\section{A VISÃO INTEGRADA, CONCEITO DE SAÚdE ÚNICA E DOENÇAS EPIDÊMICAS}

$A$ visão de que a saúde animal e a humana estão relacionadas é conhecida desde o tempo de Hipócrates, mas foi no século XVIII que o cientista alemão Rudolf Virchow descreveu mais claramente esta relação. Na década de 1940, foi fundada a Divisão de Saúde Pública Veterinária no Centro de Doenças Transmissíveis (agora Centros de Controle e Prevenção de Doenças, CDC) nos EUA. Na mesma década, a Organização Pan-Americana da Saúde (Opas) implantou o programa de Saúde Pública Veterinária, trazendo a disciplina da medicina veterinária para atuar conjuntamente com a saúde 
pública, por reconhecer a importância do controle das doenças zoonóticas como a raiva, brucelose, leptospirose e outras (Schneider, Munoz-Zanzi \& Min, 20I9).

A raiva foi a primeira zoonose prioritária no Brasil. Em 1973, mediante um acordo entre os ministérios da Saúde e da Agricultura, foi criado o Programa Nacional de Profilaxia da Raiva, desde o início baseado em um sistema conjunto de vigilância e notificação de casos em humanos e animais domésticos e silvestres (Moraes et al., no prelo).

Na década de 90 registrou-se o início de uma série de novas ameaças à saúde humana e à economia na interface animal-homem, como o surgimento da encefalopatia espongiforme bovina (BSE). Em 2003, a síndrome respiratória aguda grave (Sars) e em seguida surtos de influenza aviária $A(\mathrm{H} 5 \mathrm{NI})$ na Ásia, com potencial risco de pandemia, causaram perdas econômicas globais decorrentes da interrupção do comércio e do declínio do turismo internacional da ordem de bilhões de dólares, além de grande impacto social. Esses eventos fizeram com que o tema da interface animal-homem começasse a chamar a atenção dos tomadores de decisão e cientistas (Schneider, Munoz-Zanzi \& Min, 20I9).

Em 2004, a Wildlife Conservation Society organizou um simpósio na cidade de Nova York com o tema "Construindo pontes interdisciplinares para a saúde em um mundo globalizado" (One World One Health, 2004). A partir de então, a Organização Mundial de Saúde Animal (OIE), a OMS e as Organizações das Nações Unidas para Alimentação e Agricultura (FAO) se uniram para desenvolver estratégias e ações conjuntas balizadas pelo conceito de saúde única (one health), com o objetivo de diminuir os riscos emergenciais e a disseminação de doenças infecciosas resultantes da interface homemanimal-meio ambiente (CNSPV, 2009).

Foi nessa época que a OMS e os países decidiram, levando em consideração que no mundo globalizado as doenças têm o potencial de facilmente transcender fronteiras geopolíticas, revisar o Regulamento Sanitário Internacional (RSI), que passou a conter, além da lista de doenças de sua primeira versão, qualquer evento de potencial ameaça à saúde pública internacional (WHO, 2008). O RSI é um instrumento legal internacional vinculativo para 196 países em todo o mundo, incluindo todos os Estados-membros da OMS. Com esse instrumento, propõe-se prevenir a propagação de doenças através das fronteiras e contê-las em suas comunidades. Como parte da implementação do RSI (2005), os Estados-membros da OMS se comprometem a fortalecer sua vigilância e capacidade de detectar, avaliar e notificar rapidamente possíveis emergências em saúde pública de preocupação internacional (PHEIC).

Um PHEIC é um evento extraordinário que constitui um risco de saúde pública para outros Estados-membros da OMS através da disseminação internacional de doenças 
e potencialmente requer uma resposta internacional coordenada. Quatro critérios de decisão são usados para avaliar eventos de saúde pública:

I. O impacto na saúde pública desse evento é potencialmente grave?

2. Esse evento é incomum ou inesperado?

3. Existe potencial para propagação internacional?

4. Existe potencial para restrições de viagens e comércio?

Se dois dos quatro critérios forem atendidos, os países deverão notificar a OMS dentro de 24 horas. Até o momento, apenas seis eventos foram considerados PHEIC: influenza $A(\mathrm{HINI})$ em 2009; ebolavírus em 20I4; poliovírus selvagem em 20I4; zika vírus em 20 I6; ebolavírus em 2019 e, recentemente, Covid- 19 em 2020. Com exceção da pólio, todos os demais PHEIC relacionam-se à interface animal-humano.

O primeiro estudo importante que chamou a atenção para esse tema foi publicado em 200 I por Taylor e colaboradores, que estimaram que 61\% dos patógenos humanos em todo o mundo eram classificados como zoonoses, assim como $75 \%$ dos patógenos emergentes da última década anterior ao estudo (Taylor, Latham \& Woolhouse, 200I). Outros estudos posteriores realizados com esse enfoque também chegaram a percentuais parecidos, como o de Chomel, Beloto e Meslim (2007) e o de Schneider e colaboradores (201 I), utilizando dados de eventos na Região das Américas.

A detecção de um vírus influenza de potencial pandêmico, o $A(\mathrm{H} 5 \mathrm{NI})$, circulando em aves na Ásia e em outras partes do mundo, resultou na preparação de planos intersetoriais que foram muito úteis para responder ao novo vírus da influenza $A$ (HINI) que, originado em suínos, ocasionou uma pandemia em 2009. Vários outros surtos de influenza $A$ altamente patogênica ocorreram e continuarão ocorrendo, pois o vírus da influenza pode facilmente sofrer drifts (pequenas alterações) e shifts (mudanças bruscas e importantes). Os vírus de influenza $A$ são encontrados em diversos animais, incluindo patos, galinhas, porcos, baleias, cavalos, focas e gatos (CDC, 2020). As aves migratórias são uma constante ameaça de propagação e surgimento de novos vírus em animais domésticos, um risco para a saúde pública e para a economia dos países na qual a produção de carne de aves e suínos é uma de suas maiores commodities, como o Brasil. Uma pandemia de influenza pode ocorrer quando um vírus não humano (novo) da influenza ganha capacidade de transmissão eficiente e sustentada de pessoa a pessoa e consegue se espalhar globalmente (CDC, 2020).

Na última década outros eventos zoonóticos, como os surtos do vírus ebola na África, envolvendo morcegos e primatas não humanos, e a emergência do Mers-CoV 
no Oriente Médio, envolvendo morcegos e camelos no seu ciclo, com alta letalidade em pessoas, ameaçaram grande parte do mundo (CDC, 2020). Até o momento foram identificados sete coronavírus que podem causar infecções em humanos, o primeiro deles o Sars-CoV que ocasionou a epidemia em 2003, envolvendo civetas (felino silvestre) e morcegos (Poland, 2020).

O vírus Sars-CoV-2, causador da doença Covid-19, que rapidamente se expandiu para o mundo todo com alta severidade, também é uma zoonose produzida por um coronavírus. A origem deste novo coronavírus ainda está sendo estudada. Provavelmente envolve também morcegos, reservatórios frequentes de coronavírus, já tendo sido encontrado nessa espécie, em 2017, um sequenciamento genético muito próximo do Sars-CoV-2, mas o hospedeiro intermediário ainda não está elucidado. Houve trabalhos sugerindo que poderia ser o pangolim, um mamífero em vias de extinção muito procurado para a produção de produtos de beleza, para uso na medicina naturalista e como iguaria. Foi encontrado no pangolim um sequenciamento genético semelhante ao Sars-CoV-2, mas não tão próximo como o do morcego (Dias de Sá, Soendergaard $\varepsilon$ Jank, 2020). Como o vírus "pularia" de populações de animais silvestres para pessoas é uma questão bastante complexa e importante a ser respondida. É possível que o mercado de Wuhan, um wet market onde são vendidos animais domésticos, silvestres, vivos e mortos num mesmo lugar, seja um ambiente bastante propício para que isso aconteça. Estão sendo reportados casos de identificação do Sars-CoV-2 em alguns animais, principalmente em felinos e visons. Embora exista alguma evidência indicando provável transmissão de vírus de visons americanos em fazendas de produção para humanos, evidências de avaliações de risco, investigações epidemiológicas e experimentais não sugerem que animais vivos ou produtos animais desempenhem algum papel na infecção por SarsCoV-2 em humanos. A atual pandemia de Covid- 19 é sustentada pela transmissão de humano para humano (OIE, 2020).

Sem dúvida o surgimento da Covid- 19 é uma chamada importante para a utilização do enfoque de saúde única. Existem várias definições de saúde única, como, por exemplo, "uma abordagem colaborativa, multissetorial e transdisciplinar - trabalhando em níveis locais, regionais, nacionais e globais - para alcançar os melhores resultados de saúde e bem-estar, reconhecendo as interconexões entre pessoas, animais, plantas e seu ambiente compartilhado" (King, 2015).

Outra definição de saúde única enfatiza que os animais e os seres humanos compartilham seus ambientes (como ecossistema, solo, clima) e estes são afetados pelo interesse socioeconômico dos seres humanos (como produção de alimentos, comércio, turismo) e sofrem pressões externas (como urbanização, migração, demografia). 
Diferentes disciplinas podem, juntas, fornecer novos métodos e ferramentas para pesquisa e implementação de serviços eficazes para apoiar a formulação de normas, regulamentos e políticas em benefício da humanidade e dos animais, conservando o ambiente para as gerações atuais e futuras. Essa abordagem melhorará a previsão, detecção, prevenção e o controle de riscos infecciosos e outros problemas que afetam a saúde e o bem-estar na interface, contribuindo com os objetivos de desenvolvimento sustentável da Organização das Nações Unidas (ONU) e para a equidade no mundo (Schneider, Munoz-Zanzi \& Min, 2019).

Há também a definição operacional de saúde única:

... é possível integrar esforços em saúde humana, animal e ambiental para prever e controlar certas doenças na interface humano-animal-ecossistema. E (...) abordagens integradas que consideram componentes da saúde humana, animal e ambiental podem melhorar a previsão e o controle de certas doenças. (Rabinowitz et al., 20I3)

Aproveitamos essa definição operacional para dar alguns exemplos de doenças na interface humano-animal-ecossistema, como a raiva humana transmitida por morcego hematófago (Desmodus rotundus). Essa interface é conhecida desde o início dos anos 90. Em 199I, o grupo de trabalho multidisciplinar que assessorava a Coordenação do Programa de Raiva no Ministério da Saúde brasileiro adotou uma abordagem intersetorial e desenvolveu uma metodologia que incluía indicadores de saúde humana, animal e mudanças no ambiente para estabelecer critérios para a definição de risco para a raiva humana transmitida por morcegos, que nesse período começou a ser um problema importante de saúde pública. Foi organizado um curso conjunto saúde e agricultura para repassar a metodologia e capacitar profissionais em controle de populações de morcegos. Trabalhos foram publicados identificando a importância da mudança nos processos produtivos e de alterações no meio ambiente em nível local para o surgimento de casos de raiva humana transmitida por morcegos hematófagos (Schneider et al., 2009). 


\section{Componentes da raiva humana transmitida por morcego (Desmodus rotundus)}

Humano - Mordidas de morcego colocam indivíduos em risco de contrair o vírus e requerem atenção do sistema de saúde. A raiva é uma doença fatal.

Animal - Morcegos infectados transmitem o vírus da raiva entre si e para diferentes espécies, principalmente bovinos e equinos, podendo acarretar perdas econômicas importantes.

Ambiental - Morcegos necessitam de áreas com abrigo e comida abundantes para viver. Quando são estressados ficam doentes e transbordam (spillover) o vírus, infectando também outros animais. Mudanças rápidas no processo produtivo e/ou no meio ambiente, como desmatamento, garimpos e o fim da criação de animais, podem mudar os hábitos alimentares dos morcegos hematófagos, que passam a se alimentar com maior frequência de sangue humano.

Outro exemplo da importância da interface humano-animal-ambiente é o caso da leptospirose, que as pessoas normalmente contraem quando são expostas à urina de animais infectados por meio da lama ou da água, muitas vezes em inundações. Várias publicações demonstram a associação da leptospirose com fatores ambientais e a importância da abordagem da saúde única no entendimento desse problema de saúde pública (Schneider et al., 2011; Schneider et al., 2015; Pereira et al., 2017, Polo et al., 2019).

\section{Componentes da leptospirose}

Humano - Pessoas expostas à urina de animais infectados muitas vezes por meio da água ou da lama ou do contato direta com animais. No Brasil, 10\% dos casos são fatais e requerem atenção do sistema de saúde.

Animal - A leptospira pode ser encontrada em grande parte dos mamíferos, principalmente nos roedores, no gado, em porcos, cavalos, cães e animais selvagens. Acarreta perdas econômicas para criadores de animais domésticos, principalmente em razão de aborto nos bovinos.

Ambiental - Áreas de inundações ou com condições favoráveis para a bactéria sobreviver por mais tempo e com isto aumentar o risco de transmissão a pessoas tipos de solo, determinados tipos de agricultura como plantação de arroz e tabaco, e outros processos produtivos que atraem maior concentração de roedores. 


\section{CONDIÇÕES PARA QUE UMA PANDEMIA DE DOENÇA INFECCIOSA ACONTEÇA}

Pandemia é a ocorrência de um número de casos de determinada doença acima do esperado que atinge o mundo todo ou uma área muito ampla, atravessa fronteiras internacionais e geralmente afeta grande número de pessoas (Porta, 2008). Para que ocorra uma pandemia é necessária a conjunção de diversos fatores, relacionados ao agente infeccioso, aos animais humanos e não humanos envolvidos e ao ambiente, considerado não apenas no contexto físico, mas também na forma como o homem o ocupa e nele se movimenta.

Vários fatores relacionados ao agente infeccioso fazem com que este seja potencialmente causador de pandemias, como por exemplo a forma de sua transmissão, de pessoa a pessoa, por via aérea (como os vírus influenza e os coronavírus) ou por contato (como o ebola e a varíola), e o fato de não depender da existência de vetores (como é o caso da febre amarela), de reservatórios animais ou de hospedeiros intermediários e, portanto, atingir mais facilmente maior número de indivíduos. O potencial pandêmico da peste, por exemplo, que depende da convivência entre ratos, pulgas e humanos, é dado pela existência desses três seres no mundo todo. A capacidade de causar infecção (infectividade) também é um fator importante, assim agentes que utilizam receptores presentes em grande número em células humanas, especialmente aquelas mais próximas das portas de entrada, como no caso das proteínas de superfície das células respiratórias nas quais os vírus influenza e coronavírus se encaixam, são mais eficazes para causar doença mesmo quando presentes em pequena quantidade (Richard E Fouchier, 20I6). Agentes que causam infecção com amplo espectro clínico, com períodos de incubação relativamente longos e menor letalidade também atingem mais facilmente maior número de pessoas, visto que indivíduos infectados ficam bem o suficiente para circular nos ambientes e contaminar outros.

Um importante fator que determina potencial pandêmico é a existência de grande número de pessoas susceptíveis ao agente (sem imunidade) nas diversas regiões do mundo. Por essa razão pandemias geralmente são causadas por agentes novos ou reemergentes. Os vírus, pela sua maior taxa de mutações e capacidade de mudar significativamente, são mais frequentemente causadores de epidemias e pandemias do que outros tipos de microrganismo (Adalga et al., 2018).

O ambiente e a forma como é ocupado pelos humanos são o mais importante fator determinante na dinâmica que resulta em surtos, epidemias e pandemias. Contribuem para a ampla transmissão de agentes infecciosos o estabelecimento de condições propícias ao surgimento de novos agentes (como foi o caso dos coronavírus e do vírus influenza, que causaram a maior parte das pandemias dos séculos XX e XXI); o aumento no número de vetores de determinadas doenças devido à ocupação desordenada e à falta 
de saneamento (como por exemplo o mosquito do gênero Aedes, transmissor da dengue, zika, chigungunha e febre amarela urbana); aglomerações humanas e rápida mobilidade geográfica, relacionadas a guerras e conflitos, pobreza e fome; e formas de produção e de exploração de recursos naturais, entre outras dinâmicas ambientais predatórias.

Os recursos tecnológicos disponíveis atualmente nos permitem pouco controle sobre as características dos agentes infecciosos potencialmente causadores de pandemias e da população susceptível, limitando-nos à busca por tratamento dos doentes e ao desenvolvimento de vacinas e outras formas de prevenção, iniciativas que usualmente ocorrem depois de estabelecida a situação pandêmica. Assim, as ações mais eficientes para predição e prevenção de pandemias dependem, em grande parte, de intervenções no ambiente.

\section{PREDIÇÃO, PREVENÇÃO E DETECÇÃO PRECOCE DE AGENTES INFECCIOSOS POTENCIALMENTE EPIDÊMICOS}

Para diminuir as probabilidades de que ocorram novos eventos na interface animalhumano-ambiente, podemos sugerir diferentes abordagens baseadas no enfoque da saúde única, tanto na predição de novas doenças como em sua prevenção e detecção precoce. Depois que o agente infeccioso passa a ser sustentadamente transmitido de pessoa a pessoa, as ações na interface passam a ter menor importância, a não ser quando se trata de eventos relacionados com produção, comércio ou consumo de alimentos.

O conceito de saúde única e a implementação deste enfoque ainda estão evoluindo. A transdisciplinaridade, que integra as ciências naturais, sociais e da saúde em um contexto de humanidades e transcende suas fronteiras tradicionais, é necessária para realmente se compreender a saúde única e acionar este conceito em ações intersetoriais.

Desde a ameaça de influenza aviária em 2005, a OMS e a Opas têm trabalhado com os países na preparação dos Planos para Emergências, incluindo os instrumentos para avaliar as capacidades básicas dos países para a observância do RSI. Na área técnica de zoonoses, foi solicitada aos países uma lista das zoonoses prioritárias que tenha sido consolidada em parceria entre os setores Saúde e Agricultura. Essa abordagem contempla principalmente as possíveis ameaças de novos vírus de influenza envolvendo aves e/ou suínos. Porém, deixa a desejar na capacidade dos países para detectar novos vírus em animais silvestres, principalmente em morcegos, que são fontes de possíveis transbordamentos para pessoas. Na vigilância de fauna silvestre deveria haver maior participação do setor ambiental, que na maioria dos países não está preparado para esta função. Para fazer vigilância de agente infecciosos em animais silvestres são necessários laboratórios com alta biossegurança e profissionais treinados e equipados com proteção individual, este é um passo ainda a ser dado na predição e deteç̧ão de novas ameaças. 


\section{SUGESTÕES RELACIONADAS À INTERFACE ANIMAL-HUMANO-AMBIENTE NO PÓS-COVID-19}

- Visão integrada (saúde única) - As pessoas e os animais compartilham um ambiente, e a visão transdisciplinar é necessária para que possamos prever, prevenir e detectar novos eventos em sua interface.

- Solidariedade - Estamos todos conectados neste mundo, o que ocorre em um lugar pode afetar não somente aquela comunidade ou país, mas o mundo inteiro, como ocorreu com a Covid- 19; precisamos ser solidários e nos apoiar mutuamente.

- Preservar habitats naturais e evitar spillover de novos vírus - Os animais silvestres, principalmente morcegos, roedores e primatas não humanos, são reservatórios de muitos vírus e outros agentes infecciosos; se estressamos seus ambientes, aumentamos as chances de que desenvolvam a doença, expilam o vírus no ambiente e o transmitam para outros animais e o homem. Devemos preservar seus ambientes naturais.

- Abolir comércio de animais silvestres - A captura e venda de animais silvestres traz o risco da circulação de agentes infecciosos do meio silvestre para grandes áreas urbanas.

- Realizar vigilância animais - Conhecer os agentes capazes de surgir e em que condições isso acontece, assim como a vigilância ativa desses agentes nos ambientes que reúnem as condições para que surjam e se disseminem, porém observando a biossegurança para as pesquisas (principalmente com animais silvestres).

- Observar a biossegurança - Biosecurity na cadeia alimentar como boas práticas de manufatura, práticas de animal welfare, evitar wet markets e outros.

- Observar biosafety dos funcionários, com EPIs, vacina, distanciamento social no momento e outros.

- Definir zoonoses prioritárias - Nas guias de avaliação das capacidades básicas para o cumprimento do RSI, a OMS sugere que os setores Saúde e Agricultura definam conjuntamente uma lista de zoonoses prioritárias e formas de compartiIhar informação entre os setores; para o Brasil, as Equipes de Saúde da Família do Sistema Único de Saúde (SUS), que são multidisciplinares, poderiam, juntamente com os profissionais do Ministério da Agricultura, facilmente atender a essa demanda nos diferentes níveis. 
- Realizar capacitações nos diferentes níveis interdisciplinares e multissetoriais e investigação conjunta de surtos.

- Desenvolver estudos transdisciplinares.

- Desenvolver pesquisas, desenvolvimento tecnológico e inovação na produção de vacinas e diagnóstico rápido, com base na visão de saúde única.

- Políticas e diretrizes intersetoriais.

- Buscar formas de diminuir as desigualdades sociais e de prover melhores condições de vida e acesso aos serviços de saúde e alimentação para todos; só assim teremos um mundo melhor.

\section{REFERÊNCIAS}

ADAlJA, A. A. et al. The Characteristics of Pandemic Pathogens. Baltimore: Johns Hopkins Bloomberg School of Public Health, Center for Health Security, 2018. Disponível em: <https:// www.centerforhealthsecurity.org/our-work/pubs_archive/pubs-pdfs/20 I 8/1805 I 0 -pandemicpathogens-report.pdf >. Acesso em: 18 set. 2020.

CENTERS OF DISEASE CONTROL AND PREVENTION (CDC). Influenza. Disponível em: < https://www. cdc.gov/flu/other/index.html>. Acesso em: 4 ago. 2020.

COMISSÃO NACIONAL DE SAÚDE PÚBLICA VETERINÁRIA (CNSPV). Veterinária. Revista CFMV, 48 : 9-14, 2009.

CHOMEL, B. B.; BELOTTO, A. \& MESLIN, F. X. Wildlife, exotic pets, and emerging zoonoses. Emerging Infectious Diseases, 13(1): 6-11, 2007.

DIAS DE SÁ, C.; SOENDERGAARD, N. E JANK, M. S. Impacto da Covid-1 9 no Agronegócio do Brasil: saúde única, zoonoses e segurança do alimento. São Paulo: Insper, Centro de Agronegócio Global, 2020. Disponível em: <https://www.insper.edu.br/wp-content/uploads/2020/06/impactos-da-covid-19nos-sistemas-agroalimentares-parte2.pdf>. Acesso em: 18 set. 2020.

KING, L. J. One health: communicable diseases at human-animal interface. In: HEYMANN, D. L. (Ed.). Control of Communicable Diseases Manual. 20 ed. Washington: American Public Health Association, 2015. Disponível em: <https://ccdm.aphapublications.org/doi/abs/10.2105/CCDM.2745.012>. Acesso em: 18 set. 2020.

LEAL, L. O. P. A História da Medicina Veterinária. Rio de Janeiro: CRVM-RJ, 2009.

MARTINI, M. et al. The Spanish influenza pandemic: a lesson from history 100 years after 1918. The Journal of Preventive Medicine and Hygiene, 60(1): E64-E67, 20 I 9. Disponível em: <https://www.jpmh. org/index.php/jpmh/article/view/I205>. Acesso em: 18 set. 2020.

MORAES, N. B. et al. A evolução da saúde pública veterinária no Brasil: do controle da raiva à saúde única. Revista do Conselho Federal de Medicina Veterinária, no prelo.

NAJERA HAMRICK, P. et al. Geographic patterns and environmental factors associated with human yellow fever presence in the Americas. PLoS Neglected Tropical Diseases, I I (9): e0005897, 2017. 
ONE WORLD, ONE HEALTH. Building Interdisciplinary Bridges to Health in a Globalized World. Conference summary. Organized by Wildlife Conservation Society and hosted by The Rockefeller University, 2004. Disponível em: <http://www.oneworldonehealth.org/sept2004/owoh_sept04. html>. Acesso em: 18 set. 2020.

PEREIRA, M. M. et al. A road map for leptospirosis research and health policies based on country needs in Latin America. Revista Panamericana de Salud Pública, 41: el31, 2017.

POLAND, G. Another coronavirus, another epidemic, another warning. Vaccine, 38( I 0): v-vi, 2020.

POLO, N. et al. A one health approach to investigating leptospira serogroups and their spatial distributions among humans and animals in Rio Grande do Sul, Brazil, 2013-2015. Tropical Medicine and Infectious Disease, 4(1): 42, 2019.

PORTA, M. A Dictionary of Epidemiology. 5. ed. New York: Oxford University Press, 2008.

RABINOWITZ, P. M. et al. Toward proof of concept of a One Health approach to disease prediction and control. Emerging Infectious Diseases, I9(12): el 30265, 2013.

RICHARD, M. \& FOUCHIER, R. A. M. Influenza A virus transmission via respiratory aerosols or droplets as it relates to pandemic potential. FEMS Microbiology Reviews, 40(I): 68-85, 2016.

ROSEN, G. A History of Public Health. Revised extended edition. Baltimore: Johns Hopkins University Press, 1993.

SCHNEIDER, M. C.; MUNOZ-ZANZI, C. \& MIN, K. "One health" from concept to application in the global world. In: McQUEEN, D. V. \& BUSS, P. (Eds.). Oxford Research Encyclopedia of Global Public Health. New York: Oxford University Press, 2019. Disponível em: <https://wwwnc.cdc.gov/eid/ article/12/1/05-0979_article >. Acesso em: 18 set. 2020.

SCHNEIDER, M. C. et al. Rabies transmitted by vampire bats to humans: an emerging zoonotic disease in Latin America? Revista Panamericana de Salud Pública, 25(3): 260-269, 2009.

SCHNEIDER, M. C. et al. Importance of the animal/human interface in potential public health emergencies of international concern in the Americas. Pan American Journal of Public Health, 29(5): 37 I-379, 201 I.

SCHNEIDER, M. C. et al. Where does human plague still persist in Latin America? PLoS Neglected Tropical Diseases, (8)2: e2680, 2014.

SCHNEIDER, M. C. et al. Leptospirosis in Rio Grande do Sul, Brazil: an ecosystem approach in the animal-human interface PLoS Neglected Tropical Diseases, 9(I I): e0004095, 2015.

TAUBENBERGER, J. K. \& MORENS, D. M. 1918 Influenza: the mother of all pandemics. Emerging Infectious Disease, I2(I): 15-22, 2006. Disponível em: < https://www.ncbi.nlm.nih.gov/pmc/articles/ PMC3291398/>. Acesso em: 18 set. 2020.

TAYLOR, L. H.; LATHAM, S. M. \& WOOLHOUSE, M. E. Risk factors for human disease emergence. Philosophical Transactions of the Royal Society of London B: Biological Sciences, 356 (I.4I I): 983-989, 2001.

WORLD HEALTH ORGANIZATION (WHO). International health regulations, 2005, 2008. Disponível em: <http://www.who.int/topics/international_health_regulations/en/>. Acesso em: 18 set. 2020.

WORLD ORGANIZATION FOR ANIMAL HEALTH (OIE). Covid- I 9 Portal. Questions and answers on Covid-19. Disponível em: <https://www.oie.int/en/scientific-expertise/specific-information-andrecommendations/questions-and-answers-on-2019novel-coronavirus/>. Acesso em: 18 set. 2020. 
PARTE II

\section{Diplomacia da Saúde e Covid-19}

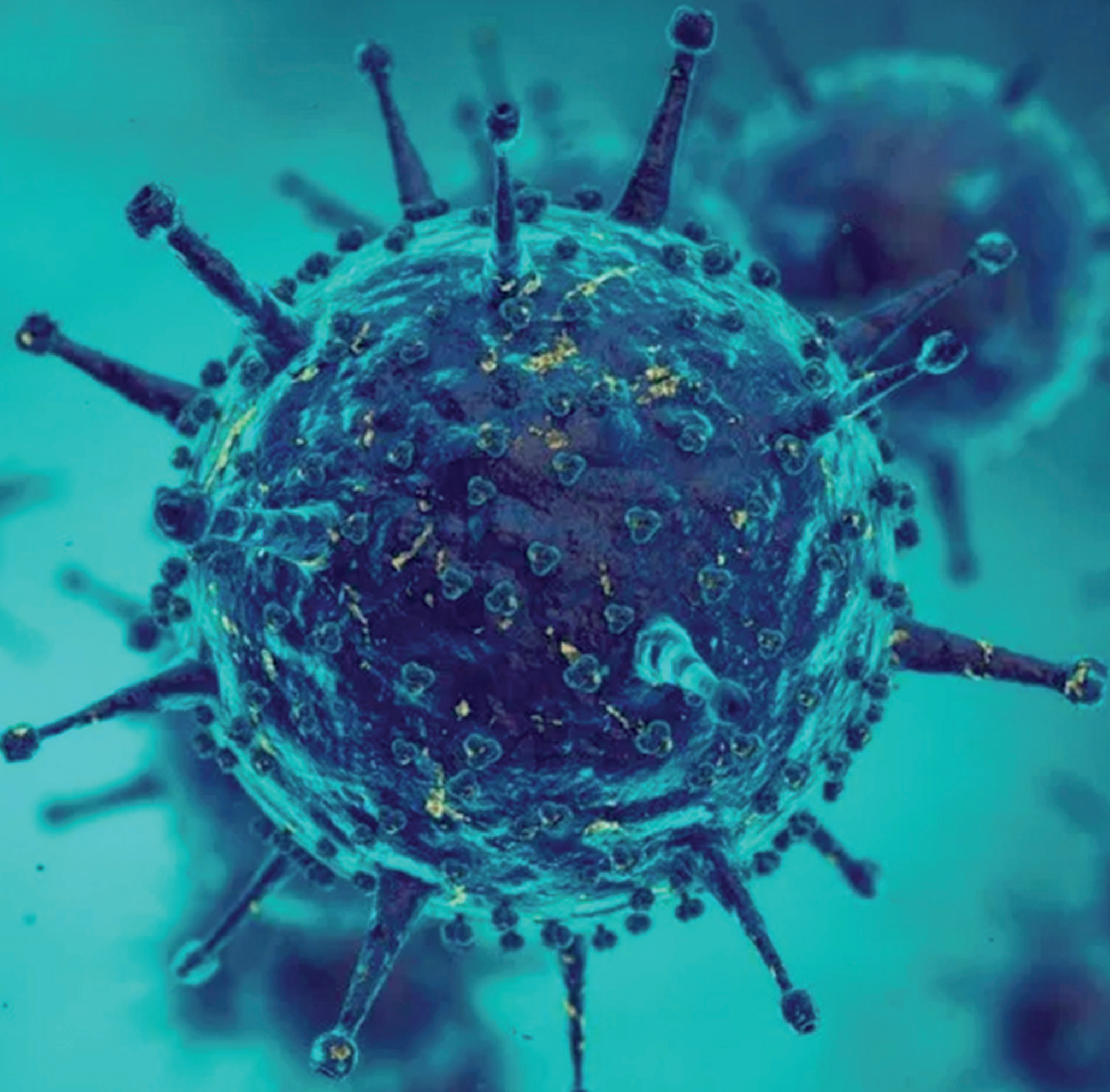





\section{Prelúdio em Dó Maior a Covid-19 nas Nações Unidas \\ Santiago Alcázar}

020 será lembrado como o ano em que um vírus paralisou o mundo. Percebida como

a maior ameaça sanitária de nossa história recente, a pandemia da Sars-Cov-2 vem causando perdas econômicas enormes que alguns comparam às da Grande Depressão de 1929. O mundo todo teve que formular respostas para enfrentar os desafios que foram se amontoando desordenadamente, derrubando, quebrando e enterrando o normal de nossos dias que nos servia de referência.

O sistema das Nações Unidas não poderia ser diferente e também ofereceu respostas à Covid-19. Como as peças de um relógio, os órgãos que compõem o sistema têm, cada um, funções específicas. No presente capítulo procuro mostrar como cada um dos principais órgãos reagiu à multidimensionalidade da pandemia. Assim, a preocupação com os aspectos sanitários e emergenciais e com a retomada pós-pandemia, ainda que distintos, perfazem uma unidade que dá coerência à reação do sistema das Nações Unidas.

\section{A PANDEMIA E A RESPOSTA DAS ESTRUTURAS DAS NAÇÕES UNIDAS}

Em algum momento de janeiro de 2020 o mundo tomou conhecimento da existência de um novo coronavírus. Os coronas eram velhos conhecidos dos virologistas. Anteriormente, estes já os haviam estudado e catalogado, sempre com designações que soavam estranhas. Sars e Mers eram apenas os mais recentes membros daquela família. O homem da rua, no entanto, mal sabia o que era um vírus, quanto mais um coronavírus. Conhecimento irrelevante, sem dúvida, em relação aos inúmeros desafios do dia a dia. Mais ainda porque o tal do vírus encontrava-se relegado possivelmente em um obscuro lugar da China. 
Veio fevereiro. Os casos de infectados começaram a assustar, tanto pelos números em disparada quanto pelo espraiamento da distribuição geográfica. Os óbitos ultrapassariam, em pouco tempo, os da síndrome respiratória aguda grave (Sars) e os da síndrome respiratória do Oriente Médio (Mers) somados. A coisa era séria e teria de ser nomeada para facilitar a comunicação. Em II de fevereiro, o Comitê Internacional sobre Taxonomia de Vírus (ICTV, em sua sigla em inglês), que tem como uma de suas tarefas atribuir nomes a esses segmentos moleculares, reuniu-se para batizar o novo coronavírus com o acrônimo Sars-CoV-2, que causava a enfermidade Covid-19 Coronavirus Disease 19, em referência ao ano de 2019, quando iniciou a sua trajetória (WHO, 2020a).

Sars-CoV-2 passou a designar essa nova arrumação de moléculas de ácido nucleico e proteínas, que literalmente parou o mundo. Todos tomaram conhecimento. Ninguém poderia imaginar que algo assim pudesse acontecer. Ante a falta de resposta terapêutica ou de vacina, as autoridades sanitárias, e o bom senso, recomendaram o óbvio: manter distância, higienizar as mãos, usar máscaras. Em seguida, prescreveram confinamento. O resultado foi o esvaziamento das ruas, cafés e restaurantes, exibido nas fotos reproduzidas nos jornais e nas imagens de desolação transmitidas pela TV. Ao mesmo tempo, mas de maneira menos visível, fecharam-se escritórios, academias, universidades e colégios. Instalou-se o medo. Ninguém queria ser premiado. O resultado foi uma avalanche de inesperados: economia em queda livre; comércio paralisado; perda de postos de trabalho em proporções bíblicas; reversão brutal das expectativas.

Fazia-se necessária uma resposta, ou várias respostas. No primeiro momento não se tinha clareza de que, ante a calamidade que representava a Covid-19, as respostas teriam de ser coordenadas, sob o risco de se tornarem ineficazes.

Neste capítulo trato da resposta das Nações Unidas à Covid-19 e do colossal esforço para manter o mais alto grau de coerência possível. Para se ter uma ideia da complexidade envolvida na formulação desse exercício, é importante conhecer a forma como está estruturado o chamado sistema das Nações Unidas (UN, 2020a). 


\section{A ESTRUTURA DAS NAÇÕES UNIDAS EM BREVE}

A Carta das Nações criou os seis principais da Organização das Nações Unidas (ONU): Assembleia Geral (AGNU), Conselho de Segurança, Conselho Econômico e Social (Ecosoc), Conselho de Tutela (Alcázar E Buss, 2020),' Corte Internacional de Justiça (UN, 2020b) $)^{2}$ e Secretariado.

Existem, ademais, dois grandes grupos dentro do sistema: I) as agências especializadas, com constituições próprias, dirigidas por figuras eleitas pelos seus Estados-partes e financiadas por meio de contribuições mandatórias e contribuições voluntárias, têm como função principal estabelecer quadros normativos internacionais e emitir recomendações; e 2) os programas e fundos, estabelecidos por mandatos da AGNU, dirigidos por funcionários indicados pelo secretário-geral e financiados com contribuições voluntárias somente. Os fundos e programas desenvolvem ações resultantes de seus respectivos mandatos.

Como exemplos das agências especializadas, há a Organização Mundial da Saúde (OMS), a Organização para Alimentação e Agricultura (FAO), a Organização Internacional do Trabalho (OIT), a União Postal Universal (UPU) e a Organização Meteorológica Mundial (OMM).

Como exemplos dos programas e fundos podem-se listar a Conferência das Nações Unidas sobre Comércio e Desenvolvimento (Unctad), o Programa das Nações Unidas para o Desenvolvimento (Pnud), o Programa das Nações Unidas para o Meio Ambiente (Pnuma) e o Alto Comissariado das Nações Unidas para Refugiados (Acnur).

A AGNU é o órgão máximo de deliberação e formulação de políticas dos Estadosmembros. Reúne-se em sessões ordinárias de setembro a dezembro e pode reunir-se em sessões especiais e de emergência, quando necessário. Conta com o apoio de órgãos subsidiários (UN, 2020c). ${ }^{3}$

\footnotetext{
' O Conselho de Tutela suspendeu as suas atividades em $I^{\circ}$ de novembro de 1994, um mês após a declaração de independência de Palau.

${ }^{2}$ Por enquanto a Corte de Haia não tem um papel definido no quadro de respostas do sistema das Nações Unidas. Não se pode descartar, contudo, que venha a tê-lo.

${ }^{3}$ Entre os órgãos subsidiários, caberia mencionar a Comissão de Desarmamento, a Comissão de Direito Internacional e o Conselho de Direitos Humanos, bem como os seis comitês principais, assim denominados: $1^{\circ}$ comitê - assuntos de desarmamento e de segurança internacional; $2^{\circ}$ comitê - assuntos econômicos e financeiros; $3^{\circ}$ comitê - assuntos sociais, humanitários e culturais; $4^{\circ}$ comitê - assuntos especiais de política e descolonização; $5^{\circ}$ comitê - assuntos administrativos e orçamentários; e $6^{\circ}$ comitê - assuntos jurídicos.
} 
O Conselho de Segurança é o órgão para a manutenção da paz e da segurança internacionais. À semelhança da AGNU, o Conselho de Segurança tem o apoio de órgãos subsidiários (UN, 2020d). ${ }^{4}$ É o único órgão das Nações Unidas com poder de sanção.

O Ecosoc é o principal foro do sistema para a promoção do debate sobre desenvolvimento em suas vertentes econômica, social e ambiental. As sessões substantivas do Ecosoc envolvem a totalidade do sistema das Nações Unidas, ademais de amplo espectro de representantes das finanças, organismos intergovernamentais, sociedade civil e grupos da sociedade civil. Apoia-se em suas comissões funcionais, comissões regionais e comitês especializados.

O Secretariado das Nações Unidas inclui departamentos e escritórios entre os quais caberia mencionar, por sua importância neste capítulo, o Escritório da Alta Comissaria para Direitos Humanos (OHCHR), atualmente ocupado por Michelle Bachelet. É importante não confundir o OHCHR com o Escritório do Alto Comissário para Refugiados (UNHCR): o primeiro pertence ao agrupamento "programas e fundos", o segundo é parte do Secretariado. Também é importante esclarecer que o Conselho de Direitos Humanos, sobre o qual escrevemos recentemente um pequeno ensaio ao qual remetemos o leitor (Alcázar E Buss, 2020), é um dos órgãos subsidiários da Assembleia Geral.

A pergunta que tem de ser feita é como essa complexa estrutura respondeu, e responde, à Covid-19. Em grande medida, a resposta, como se verá, é formulada à luz do impacto da pandemia sobre a Agenda 2030 e os Objetivos de Desenvolvimento Sustentável (ODS).

\section{A RESPOSTA DO SISTEMA ONU À PANDEMIA}

Como se recordará, a Assembleia Geral adotou, em 2015, a resolução A/RES/70/I intitulada "Transformando o mundo: Agenda 2030". O documento, de grande ambição, é um reconhecimento explícito da necessidade de ações transformadoras que priorizem as pessoas e o planeta por meio da implementação dos 17 ODS. Com relação às pessoas, pretende-se acabar com a pobreza e a fome em todas as suas formas e dimensões, de maneira a garantir que cada ser humano possa cumprir o seu potencial com dignidade, em ambiente saudável. Com relação ao planeta, trata-se de salvá-lo da degradação, incluindo pela produção e consumo sustentáveis, gerindo de maneira sustentável os seus recursos e tomando medidas vinculadas à mudança climática com vistas a habilitálo para sustentar as necessidades das próximas gerações. O documento trata também

\footnotetext{
${ }^{4}$ Entre os órgãos subsidiários estão as missões para manutenção da paz e os comitês ad hoc de sanções.
} 
da necessidade de garantir que todo ser humano possa ter vida plena e próspera, e que os avanços econômicos, sociais e tecnológicos ocorram em harmonia com a natureza.

Ao passo que a Agenda 2030 pode ser interpretada como o anúncio de uma decisão política, os ODS constituem o mapa para levar adiante tal decisão. Os dois formam uma unidade indivisível. Não tem sentido, por essa razão, pensar que é possível colher aqui e acolá alguns ODS para serem implementados, ignorando os outros. Apoiandose nos resultados do ciclo de conferências das Nações Unidas (UN, 2020b) ${ }^{5}$ e no reconhecimento da validade universal de todos os direitos humanos, os representantes dos Estados-membros das Nações Unidas aceitaram o chamamento para mudar o mundo e apresentaram a conclusão de suas deliberações como uma agenda do povo, pelo povo e para o povo (UN, 2020c).

Ainda que as agências especializadas tenham as suas próprias agendas e que cada uma delas procure o estabelecimento de normas internacionais no âmbito de suas respectivas especificidades, é a Agenda 2030 que consideram quando formulam a resposta à Covid-19. O compromisso alcançado nesse documento continua válido, não obstante a trajetória lenta e errática que se tem observado na implementação dos ODS e o risco real de que os avanços alcançados a duras penas possam ser obliterados pelos inúmeros impactos da pandemia.

A resposta do sistema das Nações Unidas à Covid- 19 atende a três dimensões distintas: a sanitária, a emergencial e a de retomada pós-pandemia. Ainda que distintas, essas três dimensões constituem uma unidade.

A dimensão sanitária, liderada pela Organização Mundial da Saúde (OMS), envolve, entre outros, o apoio para o desenvolvimento de testes de diagnóstico, tratamentos farmacêuticos e vacinas. Esse apoio, por sua vez, relaciona-se à dimensão emergencial, na medida em que tais produtos têm que ser imediata e universalmente acessíveis, uma vez disponíveis, bem como à dimensão de retomada, uma vez que esta terá de incluir entre os seus elementos definidores o acesso universal à saúde.

A questão emergencial, menos específica que a dimensão sanitária, reúne o conjunto das agências especializadas dos programas e fundos em ações com focos distintos: a emergência humanitária; a manutenção da solvência dos negócios; o funcionamento ininterrupto das cadeias de produção e distribuição; a funcionalidade das instituições e dos serviços públicos; a observância dos direitos humanos. De modo semelhante, esta dimensão reflete-se na dimensão sanitária e na dimensão da retomada.

\footnotetext{
${ }^{5}$ Ver a página do Departamento de Assuntos Econômicos e Sociais (Desa) da ONU. Disponível em: < https:// www.un.org/development/desa/en/about/conferences.html>.
} 
Por último, a dimensão de retomada congrega as recomendações para ações transformadoras sob o mote "voltar fazendo melhor" (build back better), para responder com mais eficácia à dimensão sanitária e com mais humanidade à dimensão emergencial (UN, 2020d). ${ }^{6}$

Como exemplos das ações levadas a cabo pelas agências especializadas em resposta à Covid- 19 no quadro de referência acima, mereceriam registro aquelas sob a responsabilidade, respectivamente, da Organização para a Alimentação e Agricultura (FAO) e da Organização Internacional do Trabalho (OIT).

\section{AS RESPOSTAS DA FAO E DA OIT}

A FAO, que tem a custódia de $2 \mathrm{I}$ indicadores dos ODS (FAO, 2020), procura responder à pandemia tanto na dimensão humanitária quanto na dimensão da retomada. Assim, por exemplo, a fome, a insegurança alimentar e a volatilidade dos preços de alimentos, que se encontram entre aqueles indicadores, estão diretamente relacionadas à dimensão humanitária, ao passo que a agricultura sustentável, o uso racional da água e a gestão sustentável das florestas, que também pertencem ao conjunto de indicadores sob sua custódia, se relacionam mais diretamente à dimensão da retomada.

Ainda sobre esse último aspecto, o da dimensão da retomada, a FAO expressouse com clareza no Foro Político de Alto Nível (HLPF, na sigla em inglês). Com efeito, ante as vulnerabilidades expostas pela pandemia nos sistemas agrícolas de todos os países, ricos ou pobres, faz-se urgente uma transformação radical nos modos de produção, distribuição e consumo de alimentos. Esses modos, insustentáveis todos, têm contribuído para a contínua degradação dos solos e dos ecossistemas e sustentado a gênese e a propagação de zoonoses. Por essa razão a FAO defende uma visão holística centrada no conceito "uma saúde" (one health), que aborda a saúde humana, animal e das plantas com um olhar integrador, referente tanto à dimensão emergencial quanto à dimensão de retomada (ver capítulo deste livro sobre o tema).

A OIT, por outro lado, que tem papel crucial no processo de implementação dos ODS, organiza a sua resposta em termos de recomendações dirigidas à dimensão de retomada (ILO, 2020a). Partindo da observação de que a pandemia devastou o mundo do trabalho (estima-se que, ao final do primeiro semestre de 2020, mais de 305 milhões

\footnotetext{
${ }^{6}$ Ver o documento do secretário-geral "United Nations comprehensive response to Covid- 19: saving lifes, protecting societies, recovering better". Disponível em: < https://www.un.org/sites/un2.un.org/files/un_ comprehensive_response_to_covid-19_june_2020.pdf>.
} 
de empregos deixaram de existir), a OIT recomenda a adoção de políticas apoiadas nos seguintes quatro pilares: estimular a economia e o emprego, como for; apoiar as empresas, manter os empregos e os salários; proteger os trabalhadores em seus postos de trabalho, com observância de seus direitos e garantias; e promover o diálogo para a formulação de soluções (ILO, 2020b). ${ }^{7}$

A OIT não ignora as dificuldades envolvidas em suas próprias recomendações, mas diante do quadro desolador representado por aquela assombrosa perda de empregos, a ameaça que recai sobre os 1,6 bilhão que vivem da economia informal e o dramático agravamento da situação dos jovens, não cabe ater-se a velhas fórmulas para novas situações. A economia, é preciso insistir, é contexto-dependente, não um corpo de conhecimentos assentados em evidência científica, cujo modelo por excelência é a física. E o contexto que tem de ser levado em conta é o do desastre humano, não o equilíbrio de contas.

Ainda com relação à dimensão da retomada, a OIT tem um papel crucial na concepção do "novo normal" que surgirá no pós-pandemia. Pode-se fazer conjeturas sobre como será esse novo normal no mundo do trabalho, mas é preciso entender que aquilo não pode resultar em um modelo que ignore o caminho tomado, como se fosse o único possível. O diretor-geral da organização alerta, nesse contexto, para o otimismo acrítico relacionado com um retorno ao estado de coisas anterior. Em escrito de opinião disponível na página web da OIT (ILO, 2020c), o diretor-geral recorda que a crise financeira de 2008-2009 era como uma pandemia. Havia esperança de que, uma vez encontrada e aplicada a vacina contra os excessos do mundo financeiro, a economia global se tornaria mais segura, mais justa e mais sustentável. O que aconteceu foi exatamente o contrário. Os velhos hábitos e costumes das finanças voltaram com grande liberalidade. Se alguma coisa mudou, foi o maior número de brechas no caminho, por onde caem, agora com mais folga, os menos favorecidos.

\section{RESPOSTAS DE PROGRAMAS E FUNDOS}

Exemplos das ações dos programas e fundos em resposta à Covid- 19 podem ser as do Programa das Nações Unidas para o Desenvolvimento (Pnud) e as do Alto Comissariado para Refugiados (Acnur).

O Pnud tem papel central na implementação dos ODS. Ao contrário das agências especializadas, que têm cada uma as suas especificidades próprias, cabe a esse programa

\footnotetext{
${ }^{7}$ Ver a nota conceitual da OIT "Covid-I 9 e o mundo do trabalho". Disponível em: <https://www.ilo.org/ wcmsp5/groups/public/@dgreports/@dcomm/documents/meetingdocument/wcms_747931.pdf>.
} 
coordenar o conjunto de ações do sistema voltadas para a implementação da Agenda 2030 e para os ODS. É preciso recordar que o administrador do programa, o chefe, é o terceiro cargo na hierarquia das Nações Unidas, após o secretário-geral e o vicesecretário-geral. Apoiado na experiência adquirida com os surtos de ebola, HIV/Aids, Sars, Mers, tuberculose e malária, o Pnud coopera com os Estados-membros para que estes respondam à Covid- 19 de maneira rápida e efetiva (UNPD, 2020). ${ }^{8}$

O Acnur opera num universo de mais de 70 milhões de refugiados e deslocados internos, espalhados em 134 países que os acolhem. É do Alto Comissário que, talvez, venha a resposta mais enfática para a busca de soluções: "Se alguma vez houvéssemos precisado recordar que vivemos em um mundo interconectado, a vinda do novo coronavírus trouxe-nos o lembrete". A única forma de tratar a Covid-19, diz o alto comissário, é a comunidade global agir de maneira unida e com solidariedade, porque, como ficou patente com esta pandemia, a saúde de cada pessoa está associada à saúde dos mais vulneráveis e marginalizados, de que fazem parte os refugiados e os deslocados internos (UNHCR, 2020).

Concluída esta parte referente à resposta dos dois grandes grupos do sistema, é de todo pertinente nos concentrarmos no coração do sistema, a começar pela AGNU.

\section{A ASSEMBLEIA GERAL E SUAS RESOLUÇÕES}

A $74^{\text {a }}$ sessão da AGNU adotou duas resoluções relativas à Covid-19. A primeira, $A / R E S / 74 / 270$, intitulada "Global solidarity to fight the coronavirus disease 2019 (Covid-2019)" (Unga, 2020a), foi adotada sem voto, por meio do chamado procedimento de aceitação tácita (silence procedure) (Unga, 2020b), ${ }^{9}$ em 2 de abril. A resolução foi considerada sob o item 123 da agenda, intitulado "Fortalecimento do sistema das Nações Unidas". O texto reconhece que os pobres e os mais vulneráveis são os mais atingidos pela pandemia e que o impacto da crise reverterá os avanços alcançados no quadro dos ODS; que a pandemia reclama uma resposta global, baseada na unidade, na solidariedade e numa cooperação multilateral renovada. Importante é a ênfase conferida ao respeito pleno aos direitos humanos e à afirmação de que não há lugar para discriminação, racismo e xenofobia na resposta ao coronavírus. Ademais, o

\footnotetext{
${ }_{8}^{8}$ Para ter um quadro mais completo, consultar <https://www.undp.org/content/undp/en/home/covid-19pandemic-response.html>.

${ }^{9}$ A decisão 74/544 foi adotada em 27 de março do corrente ano e vem sendo aplicada em todos os órgãos. Disponível em: < https://www.un.org/pga/74/2020/06/I 0/decision-number-74-544-procedure-for-takingdecisions-of-the-general-assembly-during-the-coronavirus-disease-20 I 9-covid- 1 9-pandemic/>.
} 
texto faz um chamamento à intensificação da cooperação, incluindo o intercâmbio de informações, conhecimento científico e boas práticas.

Os elementos do texto destacados acima são importantes porque são os mesmos presentes na resposta das agências especializadas e dos programas e fundos: centralidade das Nações Unidas; preocupação com os mais vulneráveis e marginalizados e com a reversão dos avanços nos ODS; necessidade de união e solidariedade; respeito aos direitos humanos; compartilhamento de conhecimento e de dados. Pode-se dizer que há um consenso não declarado em torno da forma que a resposta deve tomar, mas seria precipitado confiar somente na força das palavras.

A segunda resolução, A/RES/74/274, intitulada "International cooperation to ensure global access to medicines, vacines and medical equipment to face Covid- 19" (Unga, 2020c), foi adotada sem voto, em 20 de abril, sob o mesmo item 123 e por meio do mesmo procedimento de aceitação tácita. O texto contém basicamente os mesmos elementos da resolução anterior, com uma diferença importante. Na parte relativa ao apelo à intensificação da cooperação e ao intercâmbio de conhecimentos, a resolução, de iniciativa do México, oferece um detalhamento mais específico e propõe que os produtos das pesquisas sejam acessíveis a todos os que precisam, de modo particular nos países em desenvolvimento. O texto não diz que o acesso tem que ser universal, para todos, indiscriminadamente. Tímido, limita o escopo do acesso àqueles que mais precisam (making them available to all those in need, in particular in developing countries). Pareceria que nessa resolução a questão do acesso estaria condicionada a um favor especial aos mais necessitados.

Não há menção no texto à arquitetura dos direitos de propriedade intelectual, ou às suas flexibilidades, traindo de certa maneira o que se havia conseguido em 2010 , durante a $65^{a}$ sessão da $A G N U$. Naquela ocasião fora adotada a resolução A/RES/65/95, intitulada "Global health and foreign policy" (Unga, 2020d), que retomava o princípio da Declaração de Oslo com esse mesmo título. Como se recordará, a Declaração de Oslo, concluída por sete ministros de Relações Exteriores, reconhecia que ameaças à saúde comprometem a estabilidade e a segurança de um país (Ministers of Foreign Affairs of Brazil, France, Indonesia, Norway, Senegal, South Africa and Thailand, 2020). A resolução adotada em 2010 reconhecia que, na eventualidade de emergências em saúde, os Estados-membros tinham direito a utilizar plenamente as disposições contidas em Trips (Trade-Related Aspects of International Property Rights), bem como aquelas inseridas na Declaração de Doha sobre Trips e Saúde Pública (WTO, 200 I). Em comparação, a resolução A/RES/74/274 parece uma proposta de calça curta em relação ao texto que resultou da poderosa combinação da saúde global com a 
política exterior; ainda mais quando se percebe que aquela foi elaborada em momento dramático da pandemia, ao passo que esta última se fez em tempos de placidez. Mais ainda estaria por vir.

Pouco antes da adoção da resolução de iniciativa do México, o presidente da Costa Rica endereçara carta ao diretor da OMS, em 23 de março. Na carta, o presidente sugeriu que os direitos sobre tecnologias relevantes para a pandemia fossem depositados em repositórios abertos (open patent pools) (Health Policy Watch, 2020). A ousadia da proposta era, sem dúvida, animadora. A carta transformou-se em texto ambicioso intitulado "A call for action", com a decisiva participação de organizações não governamentais (ONGs). Alguns imaginavam que o texto poderia ser transformado em projeto de resolução para consideração da $73^{\mathrm{a}}$ sessão da Assembleia Mundial da Saúde (AMS), que se reuniria em modo virtual, nos dias 18 e 19 de maio. A trajetória da proposta, ousada em sua origem, foi, no entanto, errática, e ela se transformou em plataforma, apresentada na OMS em $1^{\circ}$ de junho, com ampla fanfarra. É ainda cedo para saber o que resta do sopro de ousadia do presidente da Costa Rica, mas não há como negar a distância entre a proposta original e a da plataforma, nem as legítimas dúvidas sobre o acesso desimpedido aos produtos e tecnologias necessários para esta ou outra pandemia (WHO, 2020b). ${ }^{10}$

Era evidente, então, que a questão do acesso permaneceria encastelada nos direitos de propriedade intelectual, indiferente à devastação provocada pela pandemia. O órgão máximo de deliberação das Nações Unidas, a AGNU, parecia aquém das necessidades do momento. Havia desânimo com a limitada capacidade de reação da organização, em particular, e com o multilateralismo, em geral. Parecia que o consenso alcançado em 2015 quando da adoção da Agenda 2030 e dos 17 ODS, tão necessário agora diante da pandemia, não mais seria possível. A visão transparente do mundo em transformação em decorrência da implementação de uma agenda do povo, pelo povo e para o povo embaçava-se. Parecia que dali em diante a corrida seria para trás, em busca do normal perdido. Como se fosse pouco, o sentimento de desolação receberia a inesperada visita da insensatez, materializada no anúncio nonsense do presidente Donald Trump de que os Estados Unidos da América deixariam a OMS, a entidade responsável pelo estabelecimento de normas sanitárias internacionais, em plena pandemia. Agora, a corrida para trás parecia desenfreada. Não tardaria para chegarmos aos anos 20, se não antes.

\footnotetext{
${ }^{10}$ Ver o texto de $A$ call for action em < https://www.who.int/emergencies/diseases/novel-coronavirus-20 I 9/ global-research-on-novel-coronavirus-20 I 9-ncov/covid- I 9-technology-access-pool/solidarity-callto-action>.
} 
Na mais grave crise vivida pela humanidade desde a II Guerra, a $74^{\mathrm{a}}$ sessão da AGNU produziu apenas duas resoluções de alcance acanhado. É muito pouco para as esperanças depositadas pelos fundadores há 75 anos. O presidente do Azerbaijão, na sua condição de atual presidente do Movimento de Países Não Alinhados (MNA), telefonou ao secretário-geral das Nações Unidas no dia 8 de julho para solicitar, em nome do movimento, seu apoio para a convocação de uma sessão especial da AGNU sobre Covid- 19 (President of the Republic of Azerbaijan Ilham Aliyev, 2020). Em seguida, o presidente da mesma sessão da AGNU submeteu essa proposta à consideração dos Estados-membros, no modo de aceitação tácita. Em carta de 22 de julho, o presidente da AGNU informou em nota que a proposta fora aprovada. A AGNU tem ainda que aprovar a agenda e a data para a sessão especial (Unga, 2020e). Até hoje, quarta-feira, dia 12 de agosto, não há notícia sobre esse evento.

\section{A RESPOSTA DO ECOSOC}

Enquanto isso, seria recomendável examinar a resposta do Conselho Econômico e Social (Ecosoc) à Covid-19. A sessão 2020 desse conselho realizou-se de 7 a 17 de julho, em três segmentos: o segmento de integração, o Foro Político de Alto Nível (HLPF, na sigla em inglês) e o segmento de Alto Nível do Ecosoc. O segmento de integração tem o hercúleo trabalho de reunir e sintetizar o conjunto de recomendações do sistema. $\mathrm{O}$ HLPF, a caixa de ressonância, acolhe a síntese e realiza amplo debate. Suas conclusões são encaminhadas ao segmento de Alto Nível do Ecosoc, que examina o projeto de declaração ministerial previamente preparado, o modifica se necessário, eventualmente o adota e o encaminha para consideração da AGNU. A coisa toda parece convoluta, e isso porque efetivamente ela assim o é. Em sua defesa faz-se necessário considerar a complexidade do sistema das Nações Unidas, bem como o desafio de unificar todas essas vozes em um todo harmônico.

Este ano, como não poderia deixar de ser, a sessão do Ecosoc transcorreu em modo de alerta, por conta dos devastadores impactos da Covid- 19 sobre os logros alcançados até o presente (não muitos, é forçoso reconhecer) no processo de implementação dos ODS. A pandemia pôs a descoberto vulnerabilidades que já existiam. A enfermidade não provocou a crise, é preciso dizê-lo, apenas a acentuou e a tornou patente. Ao pôr a descoberto as iniquidades econômicas e sociais; ao pôr em xeque os dogmas da economia, teimosamente seguidos por quem não sabe que aquela é essencialmente contexto-dependente; ao lançar dúvidas sobre a capacidade dos governos de liderar em tempo de tempestade; ao reduzir a ridículo arrogâncias insustentáveis, a Covid- 9 lança ao ar a pergunta: seremos capazes de forjar consensos? Porque parece evidente que a 
saída para esta crise agravada por um minúsculo vírus terá de vir pela união de todos, com decidido sentimento de empatia, espírito de solidariedade e fortalecimento das instituições multilaterais.

Em um primeiro momento, pareceu que a resposta àquela pergunta seria não, pois o segmento de Alto Nível do Ecosoc deixou de adotar a tão esperada declaração ministerial, que seria a manifestação de consenso com a validade da Agenda 2030 e os ODS na atual conjuntura. A presidente do Ecosoc, a representante permanente da Noruega, tinha, contudo, certeza de que a quase totalidade dos representantes havia reiterado naquelas sessões apoio aos princípios da Agenda 2030 e aos ODS. Com essa confiança inabalável, decidiu pôr o projeto de declaração no modo de aceitação tácita, na segunda-feira dia 20 junho, com prazo de encerramento na quarta-feira, dia 22. Não é preciso fazer suspense. A declaração ministerial foi adotada e será encaminhada à $75^{\mathrm{a}}$ sessão, que terá início em 15 de setembro. Havia esperança, como a tênue luz de uma lâmpada a óleo esticada no meio do desastre humano.

No mesmo dia 17 de junho que encerrou a sessão 2020 do Ecosoc, concluía-se também a $44^{a}$ sessão do Conselho de Direitos Humanos. Recentemente foi publicado pelo Centro de Estudos Estratégicos da Fiocruz artigo sobre essa sessão (CEE/Fiocruz, 2020). Aqui, o que interessa ressaltar é a importância da adoção da resolução relativa ao reconhecimento do papel central do Estado na resposta a emergências de saúde, bem como na resposta aos impactos socioeconômicos provocados por pandemias e emergências sanitárias no desenvolvimento da Agenda 2030 e os ODS. Não parece haver dúvida de que as políticas de mercado têm a sua validade severamente questionada em situações como a que se está vivendo; e que provavelmente não se estaria vivendo a presente situação se tais políticas não tivessem sido abraçadas sem pudor e sem sentido crítico.

A resolução vai além e faz a demanda tão esperada, mas não realizada na $A G N U$. Com efeito, o parágrafo operativo (PO) $5^{\circ}$ da resolução A/HRC/44/L.23/Rev. I (Unga, 2020f) faz um chamamento para o acesso universal e desimpedido a todos os produtos e tecnologias para a Covid-19, bem como para a retirada de todos os obstáculos injustificados para tanto. Esse PO ecoa o parágrafo 16 da declaração ministerial do Ecosoc sobre o mesmo tema (Ecosoc, 2020). Ambos os parágrafos são um reconhecimento de que as disposições de Trips e de outros acordos internacionais devem condicionar-se à presente situação, e não o contrário. Não é menor o que se alcançou na $44^{\mathrm{a}}$ sessão. 


\section{A FALTA DE RESPOSTA DO CONSELHO DE SEGURANÇA}

Caberia agora examinar brevemente a falta de resposta do Conselho de Segurança à Covid-19. Em 23 de março, o secretário-geral fez um apelo em favor da suspensão de todas as hostilidades. O pedido foi endossado por 180 Estados-membros, vinte movimentos armados, organizações regionais, líderes religiosos, ONGs e mais de oitocentas organizações da sociedade civil. As circunstâncias, contudo, não se dobrariam a tão singelo pedido. O conselho, por sua vez, parecia fazer ouvidos moucos.

O Conselho de Segurança tampouco convocaria sessão especial para tratar da questão da Covid-19. É curioso, pois o artigo 24 da Carta das Nações Unidas confere a esse órgão a responsabilidade principal pela manutenção da paz e da segurança internacional. Aparentemente, o conceito de segurança estaria a merecer revisão urgente à luz da devastação causada pela pandemia, que alguns dizem ser o maior desastre humano desde a II Guerra. E não seria descabido fazer tal revisão à luz da resolução acima sobre saúde global e política exterior, que oferece oportunidade para ventilar o conceito de segurança, preso numa lógica caduca, em um momento da história em que a maior ameaça para a espécie é o aparente elogio à loucura de nossa civilização. É preciso entender e aceitar que não foi uma causa estranha a que provocou a pandemia, mas o conjunto de decisões e ações duvidosas, aceitas porque trariam benefícios, diziam os mais conscientes, enquanto a maioria perguntava: acaso somos guardiões?

De maneira semelhante, também estaria a merecer visita o artigo 26, pelo qual se entende que os recursos humanos e econômicos globais devem ser minimamente desviados para atender à necessidade de armamentos para a paz e a segurança (UN, 2020e). Tendo em conta os gastos anuais efetuados com armamentos em todo o mundo, o advérbio dá a sensação de estar um pouco deslocado e não parece adequado para expressar a realidade. Em alguns países há ainda a proposta de aumentar os gastos militares, em plena pandemia, dando razão àquela afirmação de que o maior perigo que temos a enfrentar é o elogio da loucura.

A lógica que motivou a redação dos dois referidos artigos da Carta das Nações Unidas é francamente diferente da que é preciso para abordar a Covid- 19 ou outras pandemias que estão aguardando na fila a hora para serem chamadas, porque é evidente que se o "normal" que nos trouxe até aqui não for rapidamente transformado em um "novo normal", sustentável e enraizado na Agenda 2030 e nos ODS, não haverá mais necessidade de Conselho de Segurança. Nem de sobrancelhas levantadas.

Por último, cabe breve menção à resposta do secretário-geral que, em verdade, é a de todo o sistema; que, por sua vez, é a dos representantes dos Estados-membros presentes 
nas agências especializadas e nos diversos corpos, numa composição convoluta de referências e autorreferências. Por essa razão, a voz do secretário-geral é uma espécie de sintonização que procura captar, sem ruídos, as diferentes frequências de ondas em que são formuladas as respostas do sistema.

O leitor interessado poderá visitar a página do secretário-geral para obter informações sobre as iniciativas e os lançamentos dos chamados policy papers (UN, 2020f).

Momentos antes de entregar este capítulo aos editores, fomos informados do debate que estava ocorrendo no Conselho de Segurança sobre pandemias, na quarta-feira, 12 de agosto. O debate, intitulado "Pandemias e os desafios de manutenção da paz" (Pandemics and the challenges of sustaining peace) e transmitido ao vivo pelo sistema de videoconferência aberto do Conselho de Segurança (Security Council Open VTC), foi presidido pela ministra de Relações Exteriores da Indonésia, com a participação especial do secretário-geral das Nações Unidas, Antonio Guterres, do ex-secretário-geral, Ban Ki-Moon, e da diretora do Centro de Cooperação Internacional da Universidade de Nova York, Sarah Cliffe. As discussões tomaram como marco de referência documento ad hoc preparado (concept note) (United Nations Security Council, 2020) pela delegação da Indonésia, que ocupa atualmente a presidência do Conselho.

O ponto central a ser destacado é o reconhecimento de que as pandemias não podem ser abordadas somente como uma questão de saúde. A Covid- 19 ameaça aprofundar as brechas sociais, econômicas e políticas preexistentes. A pandemia está aumentando os riscos para a intensificação de conflitos, tais como insegurança alimentar, discursos de ódio, migração em massa, instabilidade nas fronteiras e distribuição desigual de bens e serviços. Em alguns casos, esse estado de coisas pode criar novas ameaças à paz e à segurança internacional. Há consenso de que a Covid-19, pelas razões aqui apontadas, pode reverter os acordos de paz alcançados a duras penas.

É curioso que o conselho mencione a possibilidade de reversão de acordos de paz e não faça nenhuma referência à devastação que já se observa na Agenda 2030 e nos ODS, que certamente contribuiriam para a paz com mais eficácia do que supõe. Mais curioso ainda quando o propósito do debate era o intercâmbio de ideias sobre o impacto da Covid- 19 na manutenção da paz e na exploração de possíveis apoios aos países em situação de conflito.

Há um sabor de mauvaise foi num debate que se contenta com as velhas ferramentas para se perguntar como pode ajudar ante o novo fenômeno da Covid-19, como se a responsabilidade estivesse em outro lugar, certamente abstrato. Havia, portanto, uma saída, mas não foi utilizada: retomar o espírito da Declaração de Oslo sobre Saúde Global e Política Externa para forjar um novo normal, que terá de ser melhor ou não será. 
Em cada uma dessas peças de relojoaria que compõem as Nações Unidas, a resposta foi diferente. Em cada uma delas, o impacto será maior ou menor para a solução do problema. Em todas elas há um esforço genuíno de fazer o melhor possível. Há conquistas, como aquelas alcançadas no Ecosoc e no Conselho de Direitos Humanos, e há frustrações, como a pouca atenção da AGNU à maior ameaça à humanidade desde a II Guerra, como dizem alguns, e à mais grave crise econômica desde a Grande Depressão de 1929, como dizem outros. Há também decepções, como a incapacidade do Conselho de Segurança em ater-se a um conceito de segurança que não contempla novas ameaças à vida.

Ainda assim, as Nações Unidas, que representam uma das maiores conquistas da civilização, são imprescindíveis num mundo que reclama soluções globais e não admite aventuras unilaterais, isolacionistas e descoladas da implacável realidade. O tempo que nos toca viver é o de união, solidariedade e responsabilidade com a Casa Comum, o planeta Terra.

\section{REFERÊNCIAS}

ALCÁZAR, S. E BUSS, P. Conselho de Direitos Humanos da ONU: mais Estado e equidade para enfrentar a pandemia. Centro de Estudos Estratégicos da Fiocruz, 4 ago. 2020. Disponível em: <https://cee. fiocruz.br/?q=Conselho-de-Direitos-Humanos-da-ONU-mais-Estado-e-equidade-para-enfrentara-pandemia >. Acesso em: 18 set. 2020.

CENTRO DE ESTUDOS ESTRATÉGICOS DA FIOCRUZ (CEE/FIOCRUZ). Sobre o CEE. Disponível em: $<$ https://cee.fiocruz.br/?q=node/I8>. Acesso em: 18 set. 2020.

FOOD AND AGRICULTURE ORGANIZATION OF THE UNITED NATIONS (FAO). Sustainable Development Goals. Disponível em: <http://www.fao.org/sustainable-development-goals/indicators/ en/>. Acesso em: 18 set. 2020.

HEALTH POLICY WATCH. Carta de Carlos Alvarado Quesada e Daniel Salas Peraza, presidente e ministro da Saúde da Costa Rica, respectivamente, para Tedros Adhanom Ghebreyesus, diretor-geral da Organização Mundial da Saúde. Disponível em: <https://www.healthpolicy-watch.org/wp-content/ uploads/2020/03/Picture.png > . Acesso em: 18 set. 2020.

INTERNATIONAL LABOUR ORGANIZATION (ILO). Decent work and the 2030 Agenda for Sustainable Development. Disponível em: <https://www.ilo.org/global/topics/sdg-2030/lang--en/index.htm>. Acesso em: 18 set. 2020a.

INTERNATIONAL LABOUR ORGANIZATION (ILO). Concept note. Disponível em: < https://www.ilo. org/wcmsp5/groups/public/@dgreports/@dcomm/documents/meetingdocument/wcms_747931. pdf $>$. Acesso em: 18 set. 2020b.

INTERNATIONAL LABOUR ORGANIZATION (ILO). New normal? Better normal! Disponível em: $<$ https://www.ilo.org/global/about-the-ilo/newsroom/news/WCMS_743326/lang--en/index. htm >. Acesso em: 18 set. 2020c. 
MINISTERS OF FOREIGN AFFAIRS OF BRAZIL, FRANCE, INDONESIA, NORWAY, SENEGAL, SOUTH AFRICA AND THAILAND. Oslo Ministerial Declaration - Global Health: a pressing foreign policy issue of our time. The Lancet, 369(9.570): 1.373-1.378, 2007. Disponível em: <https://www.thelancet. com/journals/lancet/article/PIISO I40-6736(07)60498-X/fulltext>. Acesso em: 18 set. 2020.

PRESIDENT OF THE REPUBLIC OF AZERBAIJAN ILHAM ALIYEV. Ilham Aliyev has made a phone call to United Nations Secretary-General Antonio Guterres, 8 July 2020. Disponível em: <https:// en.president.az/articles/39527>. Acesso em: 18 set. 2020.

THE UN REFUGEE AGENCY (UNHCR). Coronavirus outbreak. Disponível em: < https://www.undp.org/ content/undp/en/home/covid-19-pandemic-response.html>. Acesso em: 18 set. 2020.

UNITED NATIONS (UN). The United Nations System. Disponível em: < https://www.un.org/en/pdfs/ un_system_chart.pdf $>$. Acesso em: 18 set. 2020a.

UNITED NATIONS (UN). Department of Economic and Social Affairs. Conferences $\varepsilon$ Summits. Disponível em: <https://www.un.org/development/desa/en/about/conferences.html>. Acesso em: 18 set. $2020 \mathrm{~b}$.

UNITED NATIONS (UN). Department of Economic and Social Affairs. Sustaintable Development. Transforming our world: the 2030 Agenda for Sustainable Development. Disponível em: <https:// sustainabledevelopment.un.org/post20 I5/transformingourworld >. Acesso em: I 8 set. 2020c.

UNITED NATIONS (UN). United Nations comprehensive response to Covid- 19: saving lives, protecting societies, recovering better, Jun. 2020. Disponível em: < https://www.un.org/sites/un2.un.org/files/ un_comprehensive_response_to_covid-19_june_2020.pdf $>$. Acesso em: 18 set. 2020d.

UNITED NATIONS (UN). Charter of the United Nations. CHAPTER V: THE SECURITY COUNCIL. Disponível em: <https://www.un.org/en/sections/un-charter/chapter-v/index.html>. Acesso em: 18 set. $2020 e$.

UNITED NATIONS (UN). Covid- 19 response. From the UN Secretary-General. Disponível em: <https:// www.un.org/en/coronavirus/un-secretary-general>. Acesso em: 18 set. $2020 \mathrm{f}$.

UNITED NATIONS DEVELOPMENT PROGRAMME (UNDP). Covid-I 9 pandemic. Humanity needs leadership and solidarity to defeat the coronavirus. Disponível em: <https://www.undp.org/content/ undp/en/home/covid-19-pandemic-response.html>. Acesso em: 18 set. 2020.

UNITED NATIONS ECONOMIC AND SOCIAL COUNCIL (ECOSOC). Resolution E/2020/L.20-E/ HLPF/2020/L. I. Ministerial declaration of the high-level segment of the 2020 session of the Economic and Social Council and the 2020 high-level political forum on sustainable development, convened under the auspices of the Council, on the theme "Accelerated action and transformative pathways: realizing the decade of action and delivery for sustainable development". Ecosoc, 17 july 2020. Disponível em: $<$ https://sustainabledevelopment.un.org/content/documents/26780md_2020_hlpf_hls.pdf $>$. acesso em: 18 set. 2020.

UNITED NATIONS GENERAL ASSEMBLY (UNGA). Resolution A/RES/74/270. Global solidarity to fight the coronavirus disease 2019 (Covid-19). Unga, 2020a. Disponível em: <https://undocs.org/en/A/ RES/74/270>. Acesso em: 18 set. 2020. 
UNITED NATIONS GENERAL ASSEMBLY (UNGA). Decision 74/544. Procedure for taking decisions of the General Assembly during the coronavirus disease 2019 (Covid-19) pandemic. Unga, 2020b. Disponível em: <https://www.un.org/pga/74/2020/06/10/decision-number-74-544-procedurefor-taking-decisions-of-the-general-assembly-during-the-coronavirus-disease-2019-covid- 19 pandemic/>. Acesso em: 18 set. 2020.

UNITED NATIONS GENERAL ASSEMBLY (UNGA). Resolution A/RES/74/274. International cooperation to ensure global access to medicines, vaccines and medical equipment to face Covid-19. Unga, 2020c. Disponível em: <https://undocs.org/en/A/RES/74/274>. Acesso em: 18 set. 2020.

UNITED NATIONS GENERAL ASSEMBLY (UNGA). Resolution A/RES/65/95. Global health and foreign policy. Unga, 2020d. Disponível em: < https://undocs.org/en/A/RES/65/95>. Acesso em: 18 set. 2020.

UNITED NATIONS GENERAL ASSEMBLY (UNGA). Decisions regarding the Thirty-first special session of the General Assembly. Unga, 22 July 2020e. Disponível em: <https://www.un.org/ pga/74/2020/07/22/decisions-regarding-the-thirty-first-special-session-of-the-generalassembly/>. Acesso em: 18 set. 2020.

UNITED NATIONS GENERAL ASSEMBLY (UNGA). Resolution A/HRC/44/L.23/Rev. I. The central role of the State in responding to pandemics and other health emergencies, and the socioeconomic consequences thereof in advancing sustainable development and the realization of all human rights. Unga, 15 July $2020 f$. Disponível em: <https://undocs.org/A/HRC/44/L.23/Rev. I >. Acesso em: 18 set. 2020.

UNITED NATIONS SECURITY COUNCIL. S/2020/765. Letter dated 30 July 2020 from the Permanent Representative of Indonesia to the United Nations addressed to the Secretary-General. Disponível em: $<$ https://www.undocs.org/en/S/2020/765 > . Acesso em: 18 set. 2020.

WORLD HEALTH ORGANIZATION (WHO). Naming the coronavirus disease (Covid- 19) and the virus that causes it. Disponível em: <https://www.who.int/emergencies/diseases/novel-coronavirus-2019/ technical-guidance/naming-the-coronavirus-disease-(covid-20I9)-and-the-virus-that-causes-it $>$. Acesso em: 18 set. 2020a.

WORLD HEALTH ORGANIZATION (WHO). Solidarity call to action. Disponível em: < https://www. who.int/emergencies/diseases/novel-coronavirus-20 I 9/global-research-on-novel-coronavirus2019-ncov/covid-19-technology-access-pool/solidarity-call-to-action>. Acesso em: 18 set. 2020b.

WORLD TRADE ORGANIZATION (WTO). Declaration on the TRIPS Agreement and public health. WTO, 20 Nov. 200I. Disponível em: <https://www.wto.org/english/thewto_e/minist_e/min0I_e/ mindecl_trips_e.htm>. Acesso em: 18 set. 2020. 



\section{Resposta à Pandemia da Covid-19 pela OMS e Opas}

Luiz Augusto Galvão

$\mathrm{N}$ este capítulo está registrado o acompanhamento descritivo e não exaustivo das ações estratégicas e operacionais da Organização Mundial da Saúde e sua repartição regional para as Américas relacionadas à pandemia da Covid- 19 no período compreendido pela coletânea. Foram incluídos no texto os links que levam diretamente aos documentos e páginas mencionados para facilitar ao leitor encontrar a informação, as quais incluem aspectos técnicos específicos como aqueles relacionados aos trabalhadores da saúde e às iniquidades em saúde, bem como guias técnicas para as atividades de combate à pandemia.

\section{CONTEXTO INSTITUCIONAL}

A resposta mundial à pandemia da Covid-19 contou com um bem público internacional que não existia na pandemia de 1918: a Organização Mundial da Saúde (OMS), que, valendo-se do aprendizado da Oficina Sanitária Pan-Americana (OSP), se estruturou ao longo de mais de setenta anos e às custas de muita dedicação e compromisso dos Estados-membros, da comunidade científica e da sociedade civil. Fruto de um mundo imperfeito, esse bem público conseguiu inspirar-se no melhor da saúde mundial e apresentar soluções compatíveis com os mais elevados padrões, muitas vezes servindo de estímulo para que os países dessem um passo à frente e em conjunto realizassem, ainda que parcialmente, a visão de um futuro mais saudável, justo, seguro e em paz.

Em 31 de dezembro de 2019, a OMS foi alertada para um conjunto de casos de pneumonia que estavam sendo observados pelo governo da República Popular da China e que em 7 de janeiro de 2020 tiveram sua causa confirmada: um novo tipo de 
coronavírus o Sars-CoV-2 estava causando a doença, que passou a ser denominada “doença por coronavírus de 2019” ou Covid- 19.

Após a reunião do Comitê de Emergência do Regulamento Sanitário Internacional (RSI) em 30 de janeiro, o diretor-geral da OMS, dr. Tedros Adhanom Ghebreyesus, declarou que o surto de Covid- I 9 se caracterizava como um "evento de saúde pública de preocupação internacional (PHEIC)", o maior nível possível de alerta de saúde pública mundial. Seguindo o RSI, a comunidade global de saúde pública foi chamada a dar a máxima atenção e desenvolver ações coordenadas de saúde pública de acordo com as recomendações da OMS.

Dia 3 de fevereiro de 2020 marcou o lançamento do Plano Estratégico de Preparação e Resposta (SPRP) da OMS, o qual estabeleceu as medidas de saúde pública que a comunidade internacional deve apoiar em todos os países para se prepararem ou responderem à Covid- 19 (WHO, 2020a).

A OMS não atuou sozinha. Em 4 de fevereiro o secretário-geral da Organização das Nações Unidas (ONU), António Manuel de Oliveira Guterres, ativou a Política de Gestão de Crises da organização, o maior nível possível de alerta de crise no sistema das Nações Unidas, que pela primeira vez foi ativado para responder a uma crise de saúde pública. Em 12 de fevereiro a OMS anunciou as Diretrizes de Planejamento Operacional para Apoiar o Desenvolvimento dos Planos de Ação Nacional (WHO, 2020a) e a Plataforma de Parceiros Covid-19 (WHO, 2020b), que permitem às autoridades nacionais, às equipes da OMS nos países e aos parceiros da ONU planejar as necessidades de recursos, alocar recursos, identificar lacunas de financiamento e monitorar o progresso em relação aos planos de ação nacionais. Também estão disponíveis cursos sobre esses e outros assuntos relacionados à Covid- 19 na plataforma interativa de transferência de conhecimento da OMS OpenWHO (WHO, 2020c)

A Assembleia Geral da ONU, em apoio à OMS, aprovou em 2 de abril a resolução 74/270, "Global solidarity to fight the coronavirus disease 2019 (Covid-19)" (Unga, 2020), na qual reforça a importância da cooperação internacional e do multilateralismo e "Solicita ao sistema das Nações Unidas, sob a liderança do secretário-geral, que trabalhe com todos os agentes relevantes para mobilizar uma resposta global à pandemia e seu impacto adverso de natureza social, econômica e financeira em todas as sociedades".

Para orientar a resposta do sistema, a ONU lançou em março de 2020 um plano estratégico dirigido a todas as agências, incluindo a OMS, intitulado "Shared responsibility, global solidarity: responding to the socio-economic impacts of Covid- I 9" (UN, 2020), o qual localiza a saúde em um contexto de resposta mais amplo e prioriza as ações a serem realizadas por todas as agências, com destaque para a OMS. 
A OMS lançou um plano estratégico, Covid-19 Strategy (WHO, 2020d), o qual é revisado e atualizado periodicamente. Esse plano tem como objetivos centrais:

I. Mobilizar todos os setores e comunidades para participarem da resposta;

2. Controlar casos e clusters para prevenir a transmissão comunitária, isolando e tratando os casos e rastreando e estabelecendo a quarentena a todos os contatos;

3. Suprimir a transmissão comunitária por meio de distanciamento físico e outras medidas apropriadas, como restrições de viagens domésticas e aglomerações;

4. Reduzir a mortalidade por meio da assistência clínica adequada aos afetados pela Covid-19;

5. Desenvolver vacinas e terapêuticas seguras, eficazes e acessíveis.

Os Estados-membros responderam de forma ativa ao chamado do diretor-geral da OMS e seus aconselhamentos, e pediram apoio a vários grupos de Estados-membros, como a União Africana, a União Europeia, o Grupo dos Sete (G7), o Grupo dos Vinte (G20), os doadores do Grupo dos 12 (GI2), bem como outras organizações multilaterais regionais.

De forma especial, a OMS estabeleceu um trabalho colaborativo com o Grupo Banco Mundial, o Fundo Monetário Internacional e outras instituições como a Aliança Global para Vacinas e Imunização (Gavi Alliance), o Fundo Global e a agência internacional de financiamentos em saúde Unitaid. O setor privado também participa ativamente da resposta, por intermédio de companhias do setor Saúde, de outros setores e de organismos como o Fórum Econômico Mundial e a Câmara Internacional de Comércio.

A Organização Pan-Americana da Saúde (Opas), acompanhando as orientações emanadas da sede, tem apoiado intensamente os países na implementação regional e nacional das recomendações da OMS por intermédio de um comando regional. A OMS (WHO, 2020e) e a Opas (Paho, 2020) estabeleceram plataformas para a divulgação ampla e completa de linhas do tempo das ações da OMS, informações epidemiológicas, técnicas e estratégicas para a Região das Américas.

Ainda que os documentos mencionem as populações vulneráveis, não existe um detalhamento suficiente sobre como será garantida a proteção aos trabalhadores dos setores da saúde e de serviços essenciais, comunidades afrodescendentes, populações economicamente fragilizadas e em situação de rua, pessoas com mais de 70 anos, população carcerária e portadores de algumas precondições de saúde (hipertensão, diabetes, obesidade, asma, imunossupressão e renais). 
Os países e as instituições internacionais aprenderam com os erros e acertos do processo, têm corrigido os métodos de controle da pandemia da Covid- 19 e melhorado o sistema de previsão, governança e minimização de efeitos sistêmicos nas sociedades. O retorno à situação anterior "normal" da vida social e econômica parece algo distante e, para muitos, indesejável, já que as falhas nos sistemas preexistentes estão sendo responsabilizadas pelas dificuldades no controle da situação. Apesar desses avanços, ainda há questões a esclarecer sobre a efetividade da resposta e as melhores estratégias para restabelecer as atividades da sociedade de forma gradual e sanitariamente coerente.

\section{MOBILIZAÇÃO DE RECURSOS E AÇÃO CONJUNTA}

Em abril a OMS lançou uma aliança internacional para acelerar a produção e distribuição de tratamentos da Covid- 19. A iniciativa visou a arrecadar fundos, no que teve sucesso. Ainda assim, neste momento a OMS conta com apenas a metade do US $\$ 1.7$ bilhão que ela estima necessário até o final de 2020. Além disso, outras iniciativas têm mobilizado recursos para o desenvolvimento de uma vacina efetiva e que esteja à disposição no mercado em tempo recorde. O dr. Tedros Adhanom Chebreyesus tem enfatizado que, além da vacina, a iniciativa deve contemplar outros insumos, no contexto da cobertura universal da saúde e na busca da equidade em saúde. O diretor-geral da OMS conta com o apoio e a participação ativa dos presidentes da França, Alemanha, Costa Rica e da Fundação Gates, Gavi, Wellcome Trust, Unitaid, União Africana, entre outros.

Um grupo representativo das associações de saúde pública, academias científicas, associações da sociedade civil e autoridades políticas enviou uma carta ao secretáriogeral da ONU sugerindo que se instale na OMS um grupo de trabalho sobre a equidade em saúde para manter o foco da equidade na implementação de medidas de combate à pandemia (Sustentaible Health Equity, 2020).

A OMS também lançou a iniciativa Access to Covid-19 Tools (ACT), com o apoio e ativa participação de chefes de Estado, líderes globais em saúde e parceiros do setor privado. O ACT é uma colaboração global público-privada para acelerar o desenvolvimento, a produção e o acesso equitativo aos novos diagnósticos, tratamentos e vacinas da Covid- 19 (WHO, 2020f).

A Plataforma de Parceiros Covid-19 lançada pela OMS é uma ferramenta de habilitação para que os países, parceiros, doadores e colaboradores possam registrar e obter ajuda na resposta global à pandemia. Até abril, 92 países estavam participando da plataforma, 112 planos de resposta haviam sido incluídos e 329 doadores haviam feito contribuições (WHO, 2020b). 
A ONU desenvolveu um quadro global que fornece uma estratégia para a resposta socioeconômica à Covid-19. Essa estratégia baseia-se em cinco pilares cruciais: proteção dos serviços e sistemas de saúde; proteção social e serviços básicos; proteção de empregos, pequenas e médias empresas e dos atores produtivos mais vulneráveis; resposta macroeconômica e colaboração multilateral; e coesão social e resiliência comunitária (UNPD, 2020).

A Rede Global de Alerta e Resposta (Global Outbreak Alert and Response Network, Goarn) lançou um hub de conhecimentos sobre a Covid- 19. O hub é projetado como um repositório central de informações de saúde pública com orientação, ferramentas e webinars de alta qualidade que podem ser acessados livremente (Goarn, 2020).

A iniciativa de Equipes Médicas de Emergência (EMT) implantou um total de 19 equipes internacionalmente, e outras 36 equipes estão apoiando operações nacionais (WHO, 2020g).

O sistema de parceiros da OMS disponibiliza um mecanismo para acessar a cadeia estratégica de suprimentos cruciais da Covid- 19 de origem global que atualmente estão enfrentando condições de mercado restritas, o Covid Supply Chain System (CSCS) (WHO, 2020h). Esse sistema de fornecimento da ONU Covid- 19 envia suprimentos em várias regiões da OMS, incluindo as Américas, onde a Opas tem a função central de coordenação e implementação.

A resposta da Opas se encontra em grande parte incorporada nas informações referentes à resposta da OMS anteriormente descrita. A Opas tem participado das atividades no nível dos países da Região das Américas. Também tem apoiado a Coordenadoria de Organizações Indígenas da Bacia Hidrográfica do Amazonas (Coica) na proteção das nações indígenas da bacia amazônica (Coica, 2020). O fotógrafo brasileiro Sebastião Salgado também tem liderado um movimento em favor da proteção dos indígenas da Amazônia, o qual tem grande apoio internacional (Globo News, 2020). Outros artistas de renome também têm contribuído com shows em parceria com a ONG Global Citizen (Global Citizen, 2020).

Os parlamentares receberam informações fundamentais sobre a Covid-19 em um webinar) sobre "Lições da pandemia Covid-19: ação parlamentar para reduzir riscos, fortalecer a preparação de emergências e aumentar a resiliência". Essa iniciativa conjunta da OMS, da Estratégia Internacional das Nações Unidas para a Redução de Desastres (UNDRR) e da União Interparlamentar teve a participação de 472 parlamentares de 84 países e incluiu uma discussão sobre medidas preventivas e preparação para uma resposta efetiva às pandemias no futuro (IPU, 2020). 


\section{A ASSEMBLEIA MUNDIAL DA SAÚDE}

Em meio à pandemia da Covid- 19 a OMS preparou e realizou, pela primeira vez na história da organização, uma Assembleia (virtual) Mundial da Saúde (AvMS), a $73^{\text {a }}$ AMS e I ${ }^{\mathrm{a}}$ AvMS, de 17 a 19 de maio de 2020 (WHO, 2020i).

A Assembleia Mundial da Saúde é o corpo decisório máximo da governança da saúde global. Apesar de realizada pela primeira vez de forma virtual, a $73^{\mathrm{a}} \mathrm{AMS}$ cumpriu seu objetivo de tratar do assunto mais urgente do momento: a pandemia da Covid- 19.

A União Europeia liderou a elaboração de uma resolução que detalhou a resposta mundial à pandemia e foi apoiada por mais de 130 países. Essa resolução, aprovada por consenso, também incluiu a realização de uma avaliação da resposta à pandemia e teve observações de um Estado-membro sobre o seu conteúdo referente à saúde sexual e reprodutiva, à questão das patentes e ao início imediato da avaliação da resposta à pandemia. As observações, cumprindo as regras estabelecidas nessa nova modalidade de assembleia, fica registrada por escrito no espaço virtual de trabalho dos Estados-membros.

Outras duas resoluções importantes foram aprovadas. A primeira se refere à suspensão das atividades, o que significa que a assembleia fica em sessão, mas suspensa até que seja restabelecida. A outra diz respeito à regra para a apresentação e a decisão dos novos temas, a chamada regra do silêncio; segundo essa regra, as resoluções serão enviadas pelo diretor-geral aos Estados-membros e se após um período de 14 dias não houver qualquer oposição, será considerada aprovada.

A longa lista de pronunciamentos dos países teve como tônica as ações que estavam realizando e planejando implementar para combater a epidemia da Covid-19. Também trataram da crescente preocupação com a iniquidade em saúde e suas consequências para o acesso aos recursos necessários para atender os menos favorecidos, e das consequências multidimensionais das epidemias nas condições econômicas, sociais e ambientais a curto, médio e longo prazos.

Houve grande número de pronunciamentos de apoio à OMS, incluindo aqueles feitos por chefes de Estado ao início e ao fim do evento. Como foi divulgado na grande imprensa, e não se pode obviar, a pandemia acirra e revela realidades difíceis no plano global: a grande iniquidade mundial; a necessidade de sistemas de saúde universais baseados na atenção primária; a relevância dos determinantes sociais e ambientais da saúde; a divisão política e econômica mundial das grandes potências; as limitações da diplomacia em promover a união e a colaboração adequada à magnitude de um evento como a pandemia. 
A Agenda Abreviada, publicada desde o dia 29 de abril, contou com uma seleção dos itens da agenda original que foram submetidos ao procedimento de silêncio (quem não apresenta objeções ou sugestões até uma data-limite é considerado a favor). Aprovada pelo Conselho Executivo, incluiu a abertura formal, eleições de autoridades da assembleia e do comitê executivo, discurso do diretor-geral, discurso do palestrante convidado, aprovação da resolução com interveniência dos países e sessão de encerramento.

A agenda provisória modificada e abreviada estava organizada sobre os pilares do plano estratégico da OMS. Incluía documentos e sessões plenárias sobre os quatro pilares da meta dos três bilhões (The Triple Billion targets) do plano estratégico de cinco anos da OMS: garantir que mais I bilhão de pessoas se beneficiem da cobertura universal de saúde, mais I bilhão estejam protegidas de emergências em saúde e I bilhão melhorem suas condições gerais de saúde e bem-estar (WHO, 2020j). De forma resumida, os temas adiados são:

- Pilar I - Mais um bilhão de pessoas beneficiadas pela cobertura universal de saúde Atenção primária à saúde, reuniões da ONU sobre cobertura universal de saúde e sobre prevenção e controle de doenças não transmissíveis, plano global de ação de vacinas, tuberculose, epilepsia, doenças tropicais negligenciadas, inovação e propriedade intelectual e recrutamento internacional de pessoal de saúde.

- Pilar 2 - Um bilhão de pessoas mais protegidas contra emergências em saúde Trabalho da OMS em emergências de saúde, preparação para a gripe, cólera, erradicação da poliomielite e em regulamentos internacionais de saúde.

- Pilar 3 - Um bilhão de pessoas a mais desfrutando de melhor saúde e bem-estar Década de envelhecimento saudável, nutrição materna e infantil e esforços em segurança alimentar.

- Pilar 4-OMS mais eficaz e eficiente fornecendo melhor apoio aos países

Revisão e atualização do orçamento do programa 2020-2021, reforma da OMS, avaliação da eleição do diretor-geral e relatórios de progresso de planos e programas sobre: demência, saúde ocular, erradicação da dracunculose, prevenção, diagnóstico e manejo clínico da sepse, destruição dos estoques do vírus da varíola, envenenamento por serpentes, saúde reprodutiva.

Estratégia para acelerar o progresso para o alcance das metas e metas internacionais de desenvolvimento, saúde e meio ambiente: resposta global aos efeitos da poluição do ar, mutilação genital, dimensão da saúde pública do problema mundial das drogas, estratégia da OMS em pesquisa em saúde. 


\section{CONTINUIDADE DAS AÇÕES TÉCNICAS}

O combate à pandemia e a cada vez mais vigilante e robusta atuação da OMS, reforçados na $73^{\mathrm{a}}$ AvMS, continuaram com diversos eventos virtuais, incluindo aqueles de capacitação dos recursos humanos por meio da Academia da OMS, que foi implementada com o apoio substancial do governo da França e deve entrar em plena operação em 2021 (WHO, 2020k).

Uma tarefa fundamental de continuidade são as revisões periódicas dos manuais de orientações da OMS sobre estratégias de vigilância para infecção humana da Covid-19, com uma visão geral das estratégias de vigilância que os Estados-membros têm implementado, incluindo novas orientações sobre o rastreamento de contatos como ferramenta essencial de saúde pública para o controle de surtos de doenças infecciosas (WHO, 2020l).

\section{POOL DE ACESSO À TECNOLOGIA COVID-19 (COVID-19 TECHNOLOGY ACCESS POOL, C-TAP)}

O diretor-geral da OMS e o presidente da Costa Rica lançaram o Pool de Acesso à Tecnologia Covid- 19 (Covid- 19 Technology Access Pool, C-TAP). A iniciativa contou com o apoio de mais de trinta países, incluindo o Brasil, além de parceiros e instituições internacionais. Na cerimônia de lançamento participaram a primeira-ministra de Barbados, o presidente do Equador, o presidente de Palau, o secretário-geral da Cruz Vermelha, embaixadores na ONU sediados em Genebra, líderes de toda a ONU e da academia, da indústria e da sociedade civil.

O C-TAP garantirá que os avanços científicos beneficiem toda a humanidade e sejam disponibilizados como bens públicos globais, de acordo com a resolução da $73^{\mathrm{a}}$ AvMS. Também se constitui em um marco para a solidariedade e a colaboração globais com base na ciência aberta, por ser uma plataforma de compartilhamento de informações com acesso equitativo às tecnologias e outras ferramentas para o combate à Covid- 19.

A participação no pool é voluntária e deve possibilitar que os dados e a propriedade intelectual sejam compartilhados de forma equitativa pela comunidade global, acelerando a descoberta de vacinas, medicamentos e outras tecnologias por meio de pesquisas em ciência aberta.

A iniciativa deve aumentar o acesso e facilitar o desenvolvimento de medicamentos para países de baixa e média rendas e promover modelos de inovação aberta e transferência de tecnologia que aumentam a capacidade local de fabricação e fornecimento, 
inclusive por meio da adesão ao Open Covid Pledge e à Technology Access Partnership (TAP) (Open Covid Pledge, 2020; TAP, 2020).

A C-TAP é uma iniciativa irmã do Acelerador de Acesso a Ferramentas de Combate à Covid- 19 (ACT) e de outras iniciativas semelhantes e também deve apoiar a Agenda 2030 e outras iniciativas de resposta à Covid- 19.

Até o momento, o C-TAP Covid- 19 tem adesão de Argentina, Bangladesh, Barbados, Bélgica, Belize, Butão, Brasil, Chile, República Dominicana, Equador, Egito, El Salvador, Honduras, Indonésia, Líbano, Luxemburgo, Malásia, Maldivas, México, Moçambique, Noruega, Omã, Paquistão, Palau, Panamá, Peru, Portugal, São Vicente e Granadinas, África do Sul, Sri Lanka, Sudão, Países Baixos, Timor Leste, Uruguai e Zimbábue. Aquelas instituições que quiserem se inscrever podem fazê-lo no link $<$ https://www. who.int/emergencies/diseases/novel-coronavirus-20 I 9/global-research-on-novelcoronavirus-2019-ncov/covid-19-technology-access-pool/take-action-now > (WHO, 2020m).

\section{OS EFEITOS DA COVID-19 EM OUTRAS DOENÇAS}

A pandemia tem causado prejuízo e ameaça retrocesso em relação aos avanços alcançados no combate a outras doenças, como as doenças crônicas não transmissíveis (DCNTs), a Aids e a tuberculose, entre outras.

A OMS divulgou os resultados de uma avaliação rápida feita em 155 países sobre os serviços de DCNTs durante a pandemia (WHO, 2020n). Segundo o relatório, os serviços de prevenção e tratamento de DCNTs foramalterados, tendo havido redução em 53\% dos serviços para tratamento de hipertensão, $49 \%$ dos serviços para tratamento de diabetes, $42 \%$ daqueles de tratamento de câncer e $31 \%$ das emergências cardiovasculares.

O grande número de remanejamentos de funcionários que trabalham na área de DCNTs para apoiar a epidemia da Covid- 9 provocou o adiamento e o cancelamento de tratamentos planejados, além da escassez de medicamentos, insumos para diagnósticos e outras tecnologias fundamentais para os serviços.

Os resultados da modelagem sobre o custo da inação no combate à Aids (Figshare, 2020) demonstraram que as interrupções de serviço relacionadas à Covid- 19 podem causar centenas de milhares de mortes extras por HIV. Foi feita análise do potencial impacto das interrupções do tratamento de três meses ou seis meses sobre a mortalidade por Aids e a incidência do HIV na África Subsaariana. No cenário de interrupção de seis meses, as estimativas de mortes relacionadas ao excesso de Aids em um ano variaram 
de 471.000 a 673.000 , tornando inevitável que o mundo perca a meta global de 2020 de menos de 500.000 mortes relacionadas à Aids em todo o mundo.

Esse tipo de preocupação com o impacto da Covid- 19 sobre outras doenças já havia sido tratado em outras ocasiões pelo diretor-geral da OMS, que chamou a atenção para seus efeitos sobre a saúde mental, a vacinação de rotina, os cuidados materno-infantis, para seus impactos na cadeia de produção alimentar e para o uso de substâncias químicas no combate ao Covid- 9 que levam ao aumento das exposições devido à utilização mais frequente e generalizada de desinfetantes para as mãos e produtos de limpeza.

\section{A COVID-19 E 0 MEIO AMBIENTE}

Este ano, o Dia Mundial do Meio Ambiente, 5 de junho, teve como foco a preservação da biodiversidade, com o tema "Hora da natureza" (World Environment Day, 2020). Nessa ocasião, a OMS e outras agências lembraram os impactos que os ambientes naturais têm na saúde e no bem-estar mental. Além de fonte dos alimentos, esses ambientes são essenciais para manter a limpeza e qualidade do ar e da água. Os seres humanos se beneficiam dos serviços da natureza e com ela mantêm uma interação que em alguns casos é também a origem de doenças. Atividades humanas como desmatamento descontrolado, agricultura intensiva, poluição do meio, interação com animais silvestres e com outros recursos naturais causam grandes prejuízos aos ecossistemas e ao equilíbrio planetário, o qual resulta em uma resposta adaptativa que pode resultar em endemias, epidemias e pandemias como aquelas a que assistimos ao longo da história da humanidade.

A interrupção da contaminação ambiental inadvertida, resultante da parada temporária das atividades econômicas e das medidas de distanciamento físico imposto pela pandemia da Covid-19, revelou a imagem de um planeta momentaneamente despoluído, demonstrando o impacto que a geração de energia, as atividades econômicas e o transporte têm na poluição do ar e das águas, na emissão de carbono e no nível de ruído urbano.

Seguindo o chamado do secretário-geral das Nações Unidas, António Guterres, a OMS emitiu um manifesto clamando os países a aproveitarem a oportunidade de "usar a recuperação para reconstruir um mundo melhor", com mais equidade socioeconômica, e agir sobre a crise climática que, apesar de eclipsada pela pandemia, representa um risco de catástrofes imenso que tem sido constantemente relegado ao segundo plano.

O "Manifesto para uma recuperação saudável do Covid-19" (WHO, 2020o) assinala que a Covid- 19 é o maior choque global em décadas, com milhares de vidas 
perdidas, levou a economia mundial a recessão e causou danos e paralisia dos sistemas de saúde. Também chama a atenção para a importância de manter os compromissos com o desenvolvimento sustentável, visto que a redução de despesas gerada com o negligenciamento da proteção ambiental, da preparação de emergências, dos sistemas de saúde e das redes de segurança social provou ser uma falsa economia, que tem custado muito mais ao mundo do que teriam custado os investimentos na Agenda 2030 e seus ODS. O documento pede que nas decisões a serem tomadas para uma recuperação saudável e verde sejam observadas as seguintes prescrições:

I. Proteger e preservar a natureza como fonte da saúde humana;

2. Investir em serviços essenciais (água, saneamento e energia limpa) e nos serviços de saúde;

3. Transição energética para alternativas saudáveis;

4. Promover sistemas alimentares saudáveis e sustentáveis;

5. Construir cidades saudáveis e vivas;

6. Encerrar o financiamento da poluiçã̃o com dinheiro público.

Na mensagem pública da OMS no Dia Mundial do Ambiente, a organização chama atenção para o fato de que o impacto da atividade humana no meio ambiente está aumentando o risco de doenças infecciosas emergentes em humanos, das quais $60 \%$ têm origem em animais, principalmente da vida selvagem. Também faz menção à importância da preservação e recuperação dos ambientes naturais e espaços verdes para o bem-estar humano, da mitigação dos impactos das mudanças climáticas e da redução da poluição no ar, no solo e na água. E lembra que essa atitude pode também diminuir os riscos de desastres causados pela combinação de eventos climáticos extremos e erosão da terra.

O chamado da OMS também lembra que a natureza estimula a recreação ativa e ajuda a aliviar o estresse diário, sendo, portanto, fator de promoção da saúde, em particular da saúde mental, e de prevenção da mortalidade precoce por DCNTs. O Dia Mundial do Ambiente também foi lembrado como uma oportunidade para reforçar as ações para a implementação da Agenda 2030 e dos seus Objetivos de Desenvolvimento Sustentável, em particular os ODS 3, 14 e 15, que são de responsabilidade compartilhada entre vários setores. 


\section{O DESAFIO DA INFORMAÇÃO SOBRE A PANDEMIA EM MEIO ÀS AÇÕES DE CONTROLE}

Durante a resposta à pandemia, a OMS e os países-membros têm destinado grande parte dos recursos e das ações para conhecer e documentar vários aspectos básicos desconhecidos da Covid- 19. Essa ação de "trocar um pneu com o carro andando" não é uma novidade quando se trata de doenças emergentes. A doença pelo vírus zika teve característica semelhantes. Essa situação e a transparência e oportunidade com que a OMS tem comunicado os resultados de pesquisas e estudos têm, muitas vezes, gerado reação negativa dos meios de comunicação e até mesmo de autoridades que não estão acostumadas a tratar com fenômenos biológicos e com decisões baseadas em evidências. Mudanças de orientação em relação a viagens e ao controle de fronteiras, à transmissão por pacientes assintomáticos, ao uso de máscaras e outros são exemplos de decisões características de fenômenos como uma pandemia em curso.

O painel de controle Dashboard da Covid- 19 da OMS apresenta informação estatística e epidemiológica atualizada, incluindo a contagem diária oficial de casos e de óbitos relatados pelos países, territórios e áreas. Esse painel permite visualizar dados e explorar vários aspectos da informação que podem ser úteis aos usuários (WHO, 2020p).

Para contribuir com o controle da infodemia, a OMS estabeleceu a Rede de Informações para Epidemias da OMS (EPI-WIN), que fornece recursos e atualizações regulares, respondendo a perguntas pertinentes à medida que a epidemia se desenrola. O objetivo dessa rede é evitar o aparecimento de mitos que costumam surgir nas mídias sociais e outras fontes e alavancar as redes existentes dentro de setores para disseminar informações de qualidade (WHO, 2020q).

\section{PESQUISA, DESENVOLVIMENTO E INOVAÇÃO}

Desde o princípio, a OMS entendeu a necessidade de produzir conhecimento ao mesmo tempo que se estabeleciam ações para mitigar os efeitos e controlar a epidemia. Em fevereiro a cientista-chefe da organização, Soumya Swaminathan, convocou uma reunião de consulta global a cientistas para avaliar o nível de conhecimento sobre o novo vírus, chegar a um consenso sobre as questões cruciais de pesquisa que precisam ser respondidas com urgência, encontrar maneiras de trabalhar juntos para acelerar a produção do conhecimento e mobilizar o financiamento de pesquisas prioritárias para reduzir esse surto e se preparar para outros no futuro.

O relatório da reunião (WHO, 2020r) confirmou a adoção da estratégia de Pesquisa e Desenvolvimento da OMS (WHO, 2020s), já utilizada para outras doenças, 
como uma estrutura que deve guiar as ações nesta pandemia. A sequência de esforços coordenados pela OMS inclui o Projeto Solidariedade (WHO, 2020t), coordenado no Brasil pela Fiocruz e pelo Pool de Acesso a Tecnologias (PAT).

A OMS e os profissionais da saúde pública têm mantido a transparência e a discussão aberta das informações e descobertas em tempo real. Essa atitude alinhada com a ciência aberta traz vantagens evidentes para a aceleração na produção de conhecimento. Sendo nova nos ambientes acadêmicos, em alguns casos tal atitude deu margem a interpretações equivocadas, precipitadas ou mesmo mal-intencionadas. A transparência em temas especializados é muito boa porque aumenta a possibilidade de averiguar fontes e de realizar testes de reprodutibilidade, mas obviamente deve ser feita por pessoal capacitado para tanto. Quando pessoal não habilitado para o uso do método científico ou de metodologias da saúde pública passa a executar análises e tirar conclusões além das suas credenciais, tende-se a produzir desconhecimento e causar confusão entre a opinião pública. No método tradicional de produção científica também ocorre o uso indevido de ideias ou mesmo o uso espúrio da informação, o qual também produz desinformação, mas naquele ambiente restrito é mais difícil que tal prática seja detectada e confrontada pelo público e entre pares (Roso, 2020).

\section{AVANÇOS NO TRATAMENTO DA COVID-19 E NA PRODUÇÃO DA VACINA}

Salvar vidas e controlar a epidemia são objetivos imediatos nas ações da OMS de resposta à pandemia. Desde o início até o momento, aprendizados importantes sobre o tratamento da doença ocorreram e cada vez mais os protocolos de tratamento clínicos incorporam novas rotinas que têm permitido melhora no prognóstico daqueles que adoecem e necessitam de cuidados clínicos hospitalares. Ensaios clínicos como aquele que demonstrou que a dexametasona, um corticosteroide, pode salvar vidas em pacientes gravemente doentes com Covid-19 é um exemplo desses avanços. Essa descoberta pode reduzir a mortalidade em cerca de um terço de pacientes em ventilação mecânica e em cerca de um quinto em pacientes em tratamento com suprimento de oxigênio sem ventilação mecânica. Como outros protocolos, esse benefício se aplica apenas em pacientes gravemente doentes com Covid- 19 e não foi observado em pacientes com doença mais leve.

Esse resultado está associado com os esforços da OMS para acelerar as tecnologias de saúde para o Covid-19. Os resultados reforçam a importância de grandes ensaios clínicos randomizados que produzam rapidamente evidências que possam ser aplicadas de imediato. 
A OMS publica diversos guias sobre o manejo clínico da Covid-19, os quais são atualizados segundo as novas descobertas e resultados de estudos (WHO, 2020v). A organização e suas representações regionais e escritórios de países trabalham de forma estreita com todos os parceiros para desenvolver ainda mais terapêuticas e vacinas que salvam vidas e possam ser utilizadas no combate à Covid- 19.

Os progressos no campo da vacina também têm sido inovadores. Em uma parceria público-privada há muitas vacinas sendo desenvolvidas e algumas já na fase 3 de provas, o que pode significar a disponibilidade de uma vacina segura e eficaz em tempo recorde. Ao mesmo tempo, ações para viabilizar a produção massiva das vacinas, sua distribuição e aplicação em escala populacional capaz de limitar a transmissão têm sido levadas adiante. A OMS acompanha os avanços nesse campo e publicou um documento com uma visão panorâmica sobre os avanços globais de 2019-2020 em direção à vacina do novo coronavírus (WHO, 2020v). E adverte que a inclusão de qualquer produto ou entidade em qualquer um dos documentos não constitui qualquer aprovação ou endosso pela OMS desse produto ou entidade, e não deve ser considerada ou interpretada como tal. Embora tome medidas para verificar a exatidão das informações, a OMS não pode garantir a exatidão, completude, adequação para um propósito específico, qualidade, segurança, eficácia, comercialização de qualquer um dos produtos mencionados. A OMS também se isenta de qualquer responsabilidade ou responsabilidade por qualquer morte, incapacidade, lesão, sofrimento, perda, dano ou outro tipo de prejuízo que possa surgir em conexão com a aquisição, distribuição ou uso de qualquer produto incluído em qualquer um desses documentos.

\section{ESCRITÓRIO REGIONAL DA OMS PARA AS AMÉRICAS (AMRO/OPAS)}

Como a pandemia é um fenômeno global, toda a ação regional é feita em estreita colaboração com a sede da organização em Genebra e, portanto, seria tedioso repetir as ações específicas regionais da Opas que são parte do relato anterior geral da OMS. No entanto, é importante ressaltar que a Opas mantém uma plataforma de informações dedicada à Região das Américas (Paho, 2020a) na qual vários aspectos da região são detalhados e podem servir para orientações mais específicas aos países e aos organismos regionais.

$\mathrm{Na}$ apreciação dos países a Opas continua fazendo um acompanhamento muito importante, o que inclui um sistema de informações da Região das Américas (Paho, 2020).

Também é importante registrar que a Opas realizou em 22 e 23 junho de 2020, de forma virtual, a $166^{\text {a }}$ sessão do seu comitê executivo. O informe sobre a situação da 
Covid- I 9 na região incluiu a preocupação com o seu quadro socioeconômico, que está bem informado pela Comissão Econômica para a América Latina e o Caribe (Cepal) em seu observatório (Ecla, 2020a) e no informe especial sobre desafios sociais nos tempos da Covid- 19 (Ecla, 2020b).

As resoluções incluíram o estabelecimento de uma mudança na governança institucional, em particular no que diz respeito à implementação de mecanismos de análise de risco sobre projetos extraorçamentários de grande vulto que poderiam causar danos econômicos e de reputação à organização. E a aprovação de uma proposta para a realização da reunião do conselho diretivo de forma virtual nos dias 28 e 29 de setembro de 2020, com uma agenda reduzida aos temas que sejam indispensáveis para a operação da Opas e àqueles relacionados à Covid- 19.

Outra medida que deve seguir seu curso é o Grupo de Trabalho dos Estadosmembros (MSWG), que deverá entregar ao $58^{\circ}$ Conselho Diretor as recomendações sobre as prioridades estratégicas da Opas previamente estabelecidas no orçamento do seu Programa 2020-202 I e em seu Plano Estratégico 2020-2025.

Um feito regional inédito no sistema ONU e muito relevante para a compreensão e o planejamento regional foi a elaboração do relatório intitulado "Saúde e economia: uma convergência necessária para enfrentar a Covid-19 e retomar o caminho para o desenvolvimento sustentável na América Latina e no Caribe" (Ecla, 2020c). Esse relatório conjunto da Cepal e da Opas indica a necessidade de controlar a epidemia de Covid- I 9 para que uma retomada econômica da região seja possível.

Segundo o relatório, a pandemia causou a maior recessão da história, que implicará queda do crescimento regional de 9,1\% em 2020, acompanhada do aumento do desemprego, que deverá atingir uma taxa de cerca de 13,5\%, do aumento da taxa de pobreza para 37,3\% da população e do aumento da desigualdade. Alicia Bárcena, secretária executiva da Cepal, e Carissa F. Etienne, diretora da Opas, enfatizaram a relevância dos altos graus de desigualdade acompanhados por elevados níveis de pobreza, informalidade, desproteção social e limitado acesso à saúde oportuna e de qualidade. O relatório aborda questões fundamentais da dinâmica do contágio e o alto grau de urbanização e metropolização da região, com falta de serviços sanitários e transporte público inadequado.

O relatório chama atenção para certos grupos em situação especial de vulnerabilidade, como os 85 milhões de idosos, os trabalhadores informais (54\% do emprego regional), as mulheres (a maioria em atividades informais, com aumento do trabalho não remunerado e maior exposição à violência doméstica), as nações e povos indígenas (60 milhões 
de pessoas e com comunidades que podem desaparecer), as pessoas afrodescendentes ( 130 milhões de pessoas em 20 I 5), as pessoas com deficiência (70 milhões de pessoas) e os migrantes. Todos esses grupos necessitam de uma atenção especial que atenue suas condições especiais de vulnerabilidade.

O relatório também faz propostas para a retomada e a reconstrução que indicam a necessidade de articular as políticas de saúde com as econômicas, sociais e produtivas. Isso inclui o fortalecimento dos sistemas de saúde, com enfoque na atenção primária à saúde; o cumprimento das funções essenciais de saúde pública; a implementação de políticas de Renda Básica de Emergência (IBE); o reconhecimento da saúde como direito humano e bem público garantido pelo Estado; o fortalecimento da saúde pública; a consolidação de sistemas de proteção social universais e integrais; a implementação de uma política fiscal progressiva e um gasto público suficiente, eficiente, efetivo e equitativo; a aceleração na transformação digital; a redução da dependência regional de produtos médicos importados e mudanças na matriz produtiva, juntamente com um impulso no investimento verde.

\section{Nações e povos indígenas das Américas}

A maioria dos indígenas continua a sofrer discriminação histórica e sistêmica, o que gerou alta carga de pobreza, desemprego e enorme desigualdade em saúde, inclusive no acesso aos serviços de saúde e de saneamento básico. Além disso, eles têm especial vulnerabilidade a doenças transmissíveis, o que os torna mais vulneráveis ao Covid- 19.

Diante da situação urgente na região amazônica, a Opas e a Coordenadoria de Organizações Indígenas da Bacia Hidrográfica do Amazonas (Coica) fizeram um acordo para trabalhar conjuntamente na luta contra o Covid-19 na região. A Coica inclui organizações indígenas da selva peruana, do leste da Bolívia, da Amazônia equatoriana, da Amazônia colombiana e da Amazônia brasileira.

O acordo da Opas visa a fortalecer os serviços de saúde na Amazônia por meio da oferta de recursos humanos, suprimentos e dispositivos médicos, incluindo testes, tratamentos e vacinas. A declaração destaca as populações que vivem em isolamento voluntário. A Opas realizará um fórum regional das organizações internacionais que atuam na área para coordenar a resposta às nações indígenas da Amazônia.

Foi elaborado um documento de orientação denominado "Considerações sobre povos indígenas, afrodescendentes e outros grupos étnicos durante a pandemia Covid- 19" (Paho, 2020b). Nesse documento são identificados desafios, preocupações e lacunas na resposta à Covid- 19 entre os povos indígenas e as populações afrodescendentes 
da região e oferecidas recomendações para mitigar as lacunas nessa resposta entre os povos indígenas:

- Garantir que as informações e a comunicação em saúde pública sejam acessíveis por meio de campanhas de comunicação culturalmente adequadas e de qualidade;

- Tomar decisões de forma participativa com os povos indígenas e organizar diálogos interculturais para informar os membros da comunidade sobre as medidas a serem adotadas em relação ao Covid- 19;

- Incluir a variável etnia nos registros de saúde para gerar informações sobre as necessidades de intervenção em diferentes populações;

- Promover ações intersetoriais para enfrentar os determinantes sociais da saúde que afetam a resposta ao Covid- 19 e sua prevenção.

\section{Trabalhadores do setor Saúde e de setores básicos de serviços}

Durante todo o transcurso da pandemia, têm sido destacados o valor e a importância de proteger e reconhecer os trabalhadores que atuam nos serviços de saúde e em outros serviços essenciais como transporte e comércio. A Organização Internacional do Trabalho (OIT) publicou o manual Garantir a Segurança e Saúde no Trabalho durante a Pandemia (OIT, 2020), e no Dia Mundial da Segurança e da Saúde no Trabalho a OMS convocou todos a tomarem medidas urgentes para fortalecer as capacidades dos países de proteger a saúde e a segurança dos trabalhadores da saúde (WHO, 2020x).

Os profissionais da saúde estão na linha de frente da resposta ao surto de Covid- I 9 e, como tal, expostos a riscos de infecção. Os perigos incluem exposição a patógenos, longas horas de trabalho, sofrimento psíquico, fadiga, burnout ocupacional, estigma e violência física e psicológica. Para enfrentar esses problemas é necessário estabelecer medidas para a prevenção e controle de infecções, segurança e saúde ocupacional, saúde mental e apoio psicossocial aos trabalhadores

Já foram infectados com Covid- 19 mais de 35 mil profissionais da saúde, os quais muitas vezes estão submetidos à falta de medidas adequadas de prevenção e controle de infecções, à falta de equipamentos de proteção individual e à falta de controles ambientais e administrativos. Muitos profissionais têm que trabalhar horas extras por causa da crescente demanda e da escassez de profissionais da saúde. Esses profissionais também enfrentam riscos psicossociais durante as emergências pelo aumento da demanda e por testemunharem sofrimento e mortalidade. Esses riscos psicossociais podem levar a fadiga, burnout ocupacional, aumento do sofrimento psíquico ou diminuição da saúde mental. 
A OMS estabelece a necessidade de níveis adequados de pessoal e rotação clínica nas unidades de saúde, de medidas para minimizar os riscos psicossociais e do acesso dos profissionais da saúde a apoio psicossocial.

Os profissionais têm sofrido também violência e estigma em todo o mundo. Entre $8 \%$ e $38 \%$ dos profissionais da saúde sofrem violência física em algum momento de suas carreiras. Muitos mais são ameaçados ou expostos à agressão verbal e ao estigma social por causa de seu trabalho.

A OMS convocou os governos, empregadores e organizações de trabalhadores a instituir medidas de tolerância zero à violência contra os trabalhadores da saúde no local de trabalho e em seus deslocamentos, e para intensificar o apoio social e o respeito a esses trabalhadores e suas famílias.

\section{Saúde mental e Covid-19}

O medo, a preocupação e o estresse são respostas normais a ameaças percebidas ou reais, como quando nos deparamos com a incerteza ou o desconhecido. No caso da pandemia da Covid-19, esses sentimentos, somados às mudanças significativas no dia a dia, no trabalho em casa, no eventual desemprego temporário, na educação domiciliar de crianças e à falta de contato físico com outros familiares, amigos e colegas têm gerado aumento da demanda por cuidados com a saúde mental. A OMS preparou materiais para profissionais da saúde, gestores de unidades de saúde, pessoas que estão cuidando de crianças, idosos, pessoas isoladas e membros do público de forma mais geral, para ajudar a cuidar da saúde mental (WHO, 2020w).

A Opas do Brasil desenvolve em colaboração com parceiros uma campanha para promover a saúde mental no contexto da Covid-19, divulgando uma série de vídeos dirigidos a profissionais da saúde, cuidadores de pessoas idosas e de crianças e à população em geral (Opas, 2020).

\section{APRECIAÇÃO DA OMS AOS SEIS MESES DA PANDEMIA}

Em sua fala no dia em que a pandemia completou seis meses, o diretor-geral voltou a expressar a sua preocupação com a aceleração que levou à marca de dez milhões de casos e meio milhão de mortos, e afirmou que o "pior está por vir". Ele enumerou as medidas que a OMS tomou e ressaltou a necessidade de que os países, as cidades e os indivíduos cumpram a sua parte. Tomando como exemplo Coreia do Sul, Japão e outros países, ele voltou a enumerar as áreas e as medidas necessárias para controlar a pandemia: empoderar as comunidades, suprimir a transmissão, salvar vidas, acelerar a pesquisa 
e manter a liderança política e moral. E condenou, mais uma vez, a politização da pandemia, pedindo, como sempre, a união e a solidariedade de todos neste momento e no período que está por vir. Esse pronunciamento está disponível em: < https://youtu.be/

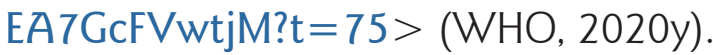

Alguns pontos de destaque da fala do diretor-geral da OMS no balanço em 27 de julho de 2020:

- Em 31 de julho completam-se seis meses desde que a OMS declarou o Covid-19 uma emergência de saúde pública de interesse internacional.

- Esta é a mais grave situação que a OMS declarou como emergência de saúde global.

- A pandemia continua acelerando e já conta com 16 milhões de casos notificados e 640 mil mortes, sendo que número total de casos praticamente dobrou nas últimas seis semanas.

- A Covid-I9 mudou o nosso mundo: uniu e separou pessoas, comunidades e nações, mostrando a capacidade positiva e negativa dos seres humanos.

- Aprendemos muito, e ainda estamos aprendendo, mas os pilares fundamentais da resposta não mudaram: liderança política, informação e engajamento e escuta das comunidades.

- Também as medidas básicas necessárias para suprimir a transmissão e salvar vidas não mudaram: encontrar os casos, isolá-los, testar e cuidar dos casos e dos contatos, e colocar em quarentena os contatos.

- As medidas não farmacêuticas também são as mesmas: manter distância física, limpar as mãos, evitar aglomerados de gente e ambientes fechadas e usar máscara como recomendado.

- Nos últimos seis meses, a OMS tem trabalhado incansavelmente para apoiar os países em sua preparação para responderem a esse vírus: publicou orientações sobre como encontrar, testar e tratar casos e proteger os profissionais da saúde, um protocolo para testes para o vírus, convocou centenas de cientistas para desenvolver um roteiro para pesquisa. Nunca antes a OMS produziu um volume tão grande de conselhos técnicos em um período tão curto.

- Mais de 4 milhões de pessoas se inscreveram nos cursos de treinamento através da plataforma de aprendizagem on-line OpenWHO.org

- A OMS lançou o Estudo Solidário para encontrar respostas rápidas sobre quais terapêuticas são as mais eficazes e voos solidários para enviar milhões de kits de teste e toneladas de equipamentos de proteção em todo o mundo. 
- A OMS atua em conjunto com organizações comunitárias, grupos religiosos, setores público e privado, empresas de tecnologia e muitos outros grupos no combate à infodemia.

- Foi conformado o ACT Accelerator, para acelerar o desenvolvimento, a produção e a distribuição equitativa de vacinas, diagnósticos e terapêuticas.

- Apesar disso, ainda há um longo e difícil caminho pela frente. Os impactos da pandemia são sentidos muito além do sofrimento causado pelo próprio vírus. Muitos serviços essenciais de saúde foram interrompidos, os serviços de prevenção, testes e tratamento foram interrompidos, as cadeias de suprimentos estão sendo interrompidas, recursos financeiros e humanos já anteriormente limitados estão sendo desviados e o foco político mudou para conter a pandemia e recuperar a economia.

- Existe um risco real de perdermos os ganhos de saúde global, desenvolvimento e estabilidade social, econômica e política. Mas não somos prisioneiros da pandemia, cada um de nós pode fazer a diferença: o futuro está em nossas mãos.

- A OMS continua totalmente comprometida a servir todas as pessoas e todos os países com ciência, soluções e solidariedade.

\section{Conclusões da quarta reunião do Comitê de Emergência, em 1 de agosto de 2020}

\section{Em relação à Secretaria da OMS}

I. Comunicar rapidamente lições aprendidas e melhores práticas.

2. Coordenar e mobilizar organizações, parceiros e redes multilaterais globais e regionais para um compromisso político na resposta à pandemia Covid-19, inclusive para o desenvolvimento de vacinas e terapêuticas.

3. Fornecer orientação pragmática para reduzir o risco de fadiga de resposta no contexto de pressões socioeconômicas.

4. Apoiar os Estados-membros e parceiros na condução da vigilância da Covid- 19 incluindo as ferramentas e treinamentos sobre definições e identificação de casos, rastreamento de contatos e certificações de óbito; e incentivar o uso das plataformas como o Sistema Global de Vigilância e Resposta à Influenza. 
5. Acelerar a pesquisa sobre as incógnitas cruciais remanescentes do Sars-CoV-2, como a origem animal e potenciais reservatórios animais, melhorar a compreensão da epidemiologia da Covid- 19 e a eficácia das medidas de saúde pública.

6. Combater a desinformação e a infodemia desenvolvendo e disseminando mensagens claras e personalizadas sobre a pandemia Covid- 19 e seus efeitos.

7. Apoiar diagnósticos, terapêuticas seguras e eficazes e desenvolvimento rápido e transparente de vacinas (inclusive em países em desenvolvimento) e acesso equitativo por meio do Acelerador de Acesso a Ferramentas de Combate à Covid- 19 (ACT); apoiar todos os países na implementação dos ensaios clínicos necessários e preparar-se para a implantação de terapêuticas e vacinas.

8. Revisar as orientações da OMS relacionadas à saúde em viagens, para reforçar medidas informadas de evidências consistentes com as disposições do IHR (2005) para evitar interferências desnecessárias em viagens internacionais.

9. Apoiar os Estados-membros, particularmente os países vulneráveis, no fortalecimento de seus serviços essenciais de saúde e nas cadeias de suprimentos.

\section{Recomendações aos Estados-membros}

I. Compartilhar as melhores práticas, inclusive a partir de revisões com a OMS e as lições aprendidas com países que estão reabrindo com sucesso suas sociedades (incluindo empresas, escolas e outros serviços) e mitigando a possibilidade de ressurgimento do Covid- 19.

2. Apoiar organizações regionais e globais multilaterais e incentivar a solidariedade global na resposta ao Covid- 19.

3. Aprimorar e sustentar o compromisso político e a liderança para estratégias nacionais e atividades de resposta localizadas impulsionadas pela ciência.

4. Continuar aumentando a capacidade de vigilância em saúde pública, testes e rastreamento de contatos.

5. Compartilhar informações e dados oportunos com a OMS por meio de plataformas como o Sistema Global de Vigilância e Resposta à Influenza.

6. Fortalecer o engajamento da comunidade, capacitar os indivíduos e abordar a desinformação, fornecendo orientações, razões e recursos claros para que a saúde pública e as medidas sociais sejam aceitas e implementadas. 
7. Participar do Acelerador de Acesso a Ferramentas de Combate à Covid- I 9 (ACT), participar de ensaios relevantes e se preparar para a introdução terapêutica e vacinal segura e eficaz.

8. Implementar, atualizar regularmente e compartilhar com a OMS informações sobre medidas e orientações sobre viagens adequadas e proporcionais, com base em avaliações de risco, inclusive sobre medidas para mitigar os riscos potenciais de transmissão internacional do Covid- 19 e facilitar o rastreamento de contato internacional.

9. Manter serviços essenciais de saúde com financiamento, suprimentos e recursos humanos suficientes e preparar sistemas de saúde para lidar com a gripe sazonal, com outros surtos simultâneos da doença e com desastres naturais.

\section{DESAFIOS}

As dúvidas levantadas por países-membros sobre a efetiva atuação da OMS no combate à pandemia e a decisão de alguns de cortar o pagamento das cotas e de outras contribuições voluntárias à organização causaram muitas distrações. Essas decisões também apressaram o anúncio de várias instituições e países de que aumentariam a contribuição à OMS, a ponto de, no show promovido por artistas em 18 de abril, já não ser mais necessária a doação de recursos porque o teto do fundo solicitado pela OMS já havia sido atingido.

A pandemia aumentou em volume e em extensão e tem causado extrema preocupação entre as autoridades de saúde, que se confrontam com novos desafios como a fadiga popular, as medidas de isolamento social e distanciamento físico, o limite da sobrevivência para aqueles que dependem de trabalho diário e a falta de perspectiva de um tratamento eficaz ou de um método de prevenção efetivo a curto ou até mesmo médio prazo.

Neste período da pandemia da Covid-19, a OMS tem demonstrado uma capacidade única e efetiva de gerar os guias técnicos necessários, assim como de implementar várias atividades estratégicas para aumentar a transparência e combater a desinformação gerada pela infodemia. Não faltaram desafios técnicos e de outra ordem para combater a pandemia e evitar grande número de mortes e enfermos. O compromisso dos trabalhadores da saúde que souberam aproveitar esse bem público internacional foi o esteio das vitórias obtidas até o momento. 


\section{REFERÊNCIAS}

COORDINADORA DE LAS ORGANIZACIONES INDÍGENAS DE LA CUENCA AMAZÓNICA (COICA). Site. Disponível em: <https://coica.org.ec>. Acesso em: 18 set. 2020.

ECONOMIC COMMISSION FOR LATIN AMERICA (ECLA). Covid-19 Observatory in Latin America and the Caribbean: economic and social impact. Disponível em: <https://www.cepal.org/en/topics/ covid-19>. Acesso em: 18 set. 2020a.

ECONOMIC COMMISSION FOR LATIN AMERICA (ECLA). The social challenge in times of Covid- 19. Disponível em: <https://www.cepal.org/en/publications/45544-social-challenge-times-covid-19>. Acesso em: 18 set. 2020 b.

ECONOMIC COMMISSION FOR LATIN AMERICA (ECLA). ECLAC and PAHO Present Joint Report on Health and the Economy in the Context of Covid-19, 27 July 2020c. Disponível em: <https://www. cepal.org/en/news/eclac-and-paho-present-joint-report-health-and-economy-context-covid-19>. Acesso em: 18 set. 2020.

FIGSHARE. Estimation of the potential effects of disruption to HIV programs in sub-Saharan Africa caused by Covid- I 9: results from multiple models. APPENDIX, 6 May 2020. Disponível em: < https://figshare. com/articles/Estimation_of_the_potential_effects_of_disruption_to_HIV_programs_in_subSaharan_Africa_caused_by_Covid-19_results_from_multiple_models_APPENDIX/I 2279932/I >. Acesso em: 18 set. 2020.

GLOBAL CITIZEN. Where you live shouldn't decide whether you live: everyone deserves access to good healthcare. Disponível em: < https://www.globalcitizen.org/en/issue/health/>. Acesso em: I8 set. 2020.

GLOBAL OUTBREAK ALERT AND RESPONSE NETWORK (GOARN). Covid-I9 knowledge hub. Disponível em: < https://extranet.who.int/goarn/COVIDI9Hub>. Acesso em: 18 set. 2020.

GLOBO NEWS. Sebastião Salgado organiza manifesto para cobrar proteção dos indígenas contra a Covid- 19. Disponível em: < http://g I.globo.com/globo-news/videos/v/sebastiao-salgado-organiza-manifesto-paracobrar-protecao-dos-indigenas-contra-a-covid-19/8527956/>. Acesso em: 18 set. 2020.

INTER-PARLIAMIENTARY UNION (IPU). Lessons from the Covid- 9 pandemic: a webinar with WHO, UNDRR and WHO, 4 maio 2020. Disponível em: < https://www.youtube.com/watch?v=cosS0CjУxy oEfeature =youtu.be $>$. Acesso em: 18 set. 2020.

OPEN COVID PLEDGE. Site. Disponível em: <https://opencovidpledge.org > . Acesso em: 18 set. 2020.

ORGANIZAÇÃO INTERNACIONAL DO TRABALHO (OIT). Garantir a Segurança e Saúde no Trabalho Durante a Pandemia. Geneva: OIT, 2020. Disponível em: <https:/www.ilo.org/wcmsp5/groups/ public/---europe/---ro-geneva/---ilo-lisbon/documents/publication/wcms_744845.pdf > . Acesso em: 18 set. 2020.

ORGANIZAÇÃO PAN-AMERICANA DA SAÚDE (OPAS). Ministério da Saúde e Opas iniciam campanha para promover a saúde mental no contexto da Covid-19. Disponível em: <https://www.paho.org/bra/ index.php?option =com_contentEview $=$ articleEid $=61$ 148:ministerio-da-saude-e-opas-iniciamcampanha-sobre-saude-mental-no-contexto-da-covid- 19 Eltemid=839>. Acesso em: 18 set. 2020.

PAN AMERICAN HEALTH ORGANIZATION (PAHO). Covid- I 9 Information System for the Region of the Americas. Disponível em: <https://paho-covid I9-response-who.hub.arcgis.com>. Acesso em: 18 set. 2020a. 
PAN AMERICAN HEALTH ORGANIZATION (PAHO). Considerations on indigenous peoples, afrodescendants, and other ethnic groups during the Covid-19 pandemic. Disponível em: <https:// iris.paho.org/bitstream/handle/10665.2/5225 I/PAHOIMSPHECOVID-19200030_eng. pdf? sequence $=1$ EisAllowed $=y>$. Acesso em: 18 set. $2020 \mathrm{~b}$.

ROSO, L. Declaração da OMS sobre pacientes assintomáticos causa estranheza entre médicos. GZH, Porto Alegre, 9 3jun. 2020. Disponível em: <https://gauchazh.clicrbs.com.br/coronavirus-servico/ noticia/2020/06/declaracao-da-oms-sobre-pacientes-assintomaticos-causa-estranheza-entremedicos-ckb8 I I zfg003r0 I 5nicknh6ki.html>. Acesso em: 18 set. 2020.

SUSTENTAIBLE HEALTH EQUITY. Site. Disponível em: < https://www.sustainablehealthequity.org>. Acesso em: 18 set. 2020.

TECH ACCESS PARTNERSHIP (TAP). Site. Disponível em: < https://techaccesspartnership.net>. Acesso em: 18 set. 2020.

UNITED NATIONS (UN). Shared Responsibility, Global Solidarity: responding to the socio-economic impacts of Covid-19, Mar. 2020. Disponível em: <https://unsdg.un.org/sites/default/files/2020-03/ SG-Report-Socio-Economic-Impact-of-Covid 19.pdf>. Acesso em: 18 set. 2020.

UNITED NATIONS DEVELOPMENT PROGRAMME (UNPD). UN sets out Covid-19 social and economic recovery plan. Disponível em: <https://www.undp.org/content/undp/en/home/newscentre/news/2020/UN_sets_out_Covid_social_and_economic_recovery_plan.html > . Acesso em: 18 set. 2020.

UNITED NATIONS GENERAL ASSEMBLY (UNGA). Resolution A/RES/74/270. Global solidarity to fight the coronavirus disease 2019 (Covid-19), 2020a. Disponível em: <https://undocs.org/en/A/ RES/74/270>. Acesso em: 18 set. 2020.

WORLD ENVIRONMENT DAY. Time for nature. Disponível em: < https://www.worldenvironmentday. global/pt-br>. Acesso em: 18 set. 2020.

WORLD HEALTH ORGANIZATION (WHO). Covid-19 Strategic Preparedness and Response Plan. Operational planning guidelines to support country preparedness and response. Geneva: WHO, 2020a. Disponível em: <https://www.who.int/docs/default-source/coronaviruse/covid-19-sprp-unctguidelines.pdf>. Acesso em: 20 set. 2020.

WORLD HEALTH ORGANIZATION (WHO). Covid-I 9 partner's platform. Disponível em: <https:// covid 19 partnersplatform.who.int/>. Acesso em: 18 set. 2020b.

WORLD HEALTH ORGANIZATION (WHO). Open WHO. Diretrizes de planejamento operacional e plataforma de parceiros para apoiar a preparação e a resposta do país à Covid- 19. Disponível em: < https:// openwho.org/courses/UNCT-COVIDI 9-preparacao-e-resposta-PT>. Acesso em: 18 set. 2020c.

WORLD HEALTH ORGANIZATION (WHO). Covid- 19 strategy update - 14 Apr. 2020d. Disponível em: $<$ https://www.who.int/publications/i/item/covid-19-strategy-update---14-april-2020>. Acesso em: 18 set. 2020.

WORLD HEALTH ORGANIZATION (WHO). Timeline: WHO'sCovid-19 response. Disponível em: $<$ https://www.who.int/emergencies/diseases/novel-coronavirus-2019/interactive-timeline>. Acesso em: 18 set. 2020 e. 
WORLD HEALTH ORGANIZATION (WHO). Global leaders unite to ensure everyone everywhere can access new vaccines, tests and treatments for Covid- 19, 24 Apr. 2020f. Disponível em: <https://www. who.int/news-room/detail/24-04-2020-global-leaders-unite-to-ensure-everyone-everywhere-canaccess-new-vaccines-tests-and-treatments-for-covid-19>. Acesso em: 18 set. 2020.

WORLD HEALTH ORGANIZATION (WHO). Global Medical Teams - EMT. Disponível em: <https:// extranet.who.int/emt/>. Acesso em: 18 set. $2020 \mathrm{~g}$.

WORLD HEALTH ORGANIZATION (WHO). Covid- I 9 Supply Chain System: requesting and receiving supplies. Disponível em: <https://www.who.int/publications/m/item/covid-19-supply-chainsystem-requesting-and-receiving-supplies $>$. Acesso em: 18 set. $2020 \mathrm{~h}$.

WORLD HEALTH ORGANIZATION (WHO). Seventy-third World Health Assembly, May I8- 19 2020i. Disponível em: <https://www.who.int/about/governance/world-health-assembly/seventy-thirdworld-health-assembly>. Acesso em: 18 set. 2020.

WORLD HEALTH ORGANIZATION (WHO). The Triple Billion targets, 18 Apr. 2020j. Disponível em: $<$ https://www.who.int/news-room/q-a-detail/the-triple-billion-targets >. Acesso em: 18 set. 2020.

WORLD HEALTH ORGANIZATION (WHO). Launch of the WHO Academy and the WHO Info mobile applications. Disponível em: <https://www.who.int/news/item/13-05-2020-launch-of-the-whoacademy-and-the-who-info-mobile-applications\#.XsUODmYDepg.link>. Acesso em: 18 set. 2020k.

WORLD HEALTH ORGANIZATION (WHO). Public health surveillance for Covid-19: interim guidance. Disponível em: <https://www.who.int/publications/i/item/who-2019-nCoVsurveillanceguidance-2020.7>. Acesso em: 18 set. 20201.

WORLD HEALTH ORGANIZATION (WHO). Take action now. Disponível em: < https://www.who.int/ emergencies/diseases/novel-coronavirus-20 I 9/global-research-on-novel-coronavirus-20 I 9-ncov/ covid-19-technology-access-pool/take-action-now>. Acesso em: 18 set. 2020m.

WORLD HEALTH ORGANIZATION (WHO). Rapid assessment of service delivery for NCDs during the Covid-19 pandemic, 29 May 2020. Disponível em: < https://www.who.int/publications/m/item/ rapid-assessment-of-service-delivery-for-ncds-during-the-covid-19-pandemic $>$. Acesso em: 18 set. 2020n.

WORLD HEALTH ORGANIZATION (WHO). WHO Manifesto for a healthy recovery from Covid- I9, 26 May 2020o. Disponível em: <https://www.who.int/news-room/feature-stories/detail/whomanifesto-for-a-healthy-recovery-from-covid-19>. Acesso em: 18 set. 2020.

WORLD HEALTH ORGANIZATION (WHO). WHO Coronavirus Disease (Covid-19) Dashboard. Disponível em: <https://covid I9. who.int/>. Acesso em: 18 set. 2020p.

WORLD HEALTH ORGANIZATION (WHO). About EPI-WIN. Disponível em: < https://www.who.int/ teams/risk-communication/about-epi-win >. Acesso em: 18 set. 2020q.

WORLD HEALTH ORGANIZATION (WHO). A Coordinated Global Research Roadmap: 2019 novel coronavirus. Geneva: WHO, 2020r. Disponível em: <https://www.who.int/blueprint/prioritydiseases/key-action/Coronavirus_Roadmap_V9.pdf?ua=1 >. Acesso em: 18 set. 2020.

WORLD HEALTH ORGANIZATION (WHO). Global Observatory on Health RED. Disponível em: < https:// www.who.int/research-observatory/analyses/rd_blueprint/en/>. Acesso em: 18 set. 2020s. 
WORLD HEALTH ORGANIZATION (WHO). "Solidarity" clinical trial for Covid-I 9 treatments. Disponível em: <https://www.who.int/emergencies/diseases/novel-coronavirus-2019/globalresearch-on-novel-coronavirus-20 I 9-ncov/solidarity-clinical-trial-for-covid-19-treatments $>$. Acesso em: 18 set. 2020 t.

WORLD HEALTH ORGANIZATION (WHO). Clinical management of Covid- 19, 27 May 2020u. WHO Coronavirus Disease (Covid-19) Dashboard. Disponível em: <https://www.who.int/publications/i/ item/clinical-management-of-covid-19>. Acesso em: 18 set. 2020.

WORLD HEALTH ORGANIZATION (WHO). Draft landscape of Covid- 9 candidate vaccines. Disponível em: <https://www.who.int/publications/m/item/draft-landscape-of-covid-19-candidate-vaccines $>$. Acesso em: 18 set. $2020 \mathrm{v}$.

WORLD HEALTH ORGANIZATION (WHO). WHO calls for healthy, safe and decent working conditions for all health workers, amidst Covid- 19 pandemic, 28 Apr. 2020x. Disponível em: <https://www.who. int/news-room/detail/28-04-2020-who-calls-for-healthy-safe-and-decent-working-conditionsfor-all-health-workers-amidst-covid-19-pandemic >. Acesso em: 18 set. 2020.

WORLD HEALTH ORGANIZATION (WHO). Mental health $\varepsilon$ Covid- 19. Disponível em: < https://www. who.int/teams/mental-health-and-substance-use/covid-19>. Acesso em: 18 set. 2020w.

WORLD HEALTH ORGANIZATION (WHO). Live from WHO Headquarters - Covid-I 9 daily press briefing 29 June 2020. Disponível em: <https://www.youtube.com/watch?v=EA7GcFVwtjMEfeatur $\mathrm{e}=$ youtu.beEt $=75>$. Acesso em: 18 set. 2020y. 


\section{Respostas das Instituições Financeiras Internacionais à Pandemia da Covid-19}

Miryam de Souza Minayo e Isis Pillar Cazumbá

A

pandemia gerada pelo novo coronavírus é um dos desafios mais sérios que a humanidade enfrentou nos últimos tempos e gerou (e ainda está gerando) uma crise sanitária e humanitária sem precedentes. O custo total em perdas da vida humana já está próximo de 600 mil pessoas e se encontra em plena ascensão. Concomitantemente à extensa perda de vidas e à profunda crise sanitária, o mundo está vivenciando um colapso econômico que supera a Grande Depressão de 1929 e afetará severa e desigualmente o bem-estar de grande parte da população mundial. Mais ainda, assim como a Covid- 19 afeta mais gravemente pessoas com problemas de saúde preexistentes, a atual crise econômica também revela sua pior face dentro dos países e nas populações mais vulneráveis.

Segundo relatório do Banco Mundial (World Bank, 2020a), as previsões mais otimistas calculam que a atual crise econômica e sanitária levará a grande aumento das pessoas vivendo em extrema pobreza e, na pior das hipóteses, na persistência prolongada da pandemia. Diante desse cenário, muitos países buscaram suporte nas instituições financeiras internacionais (IFIs) para apoiar seus esforços internos na luta contra a pandemia. A maior parte das IFIs destinou linhas de crédito rápidas para mitigar os efeitos da pandemia, criando mecanismos disponíveis para seus países-membros, inclusive oferecendo-lhes assistência técnica.

Medidas como suspensão dos pagamentos do serviço da dívida dos países mais pobres foram tomadas para ajudá-los a gerenciar o grave impacto da crise. O Grupo dos Vinte (G20) respondeu, em um primeiro momento, a esse apelo endossando a suspensão do serviço da dívida no crédito bilateral oficial no valor de cerca de I I bilhões de dólares. Além disso, foi feito um chamamento aos credores do setor privado para que participassem dessa iniciativa em termos comparáveis. 
Em maio de 2020, mais de cem países em desenvolvimento haviam recorrido a diferentes modalidades de financiamento das IFIs. Essa assistência foi a maior e mais rápida resposta de tais instituições às crises econômicas. Somada a isso, a Corporação Financeira Internacional (CFI) - braço do setor privado parte do Banco Mundial disponibilizou 8 bilhões de dólares em financiamento pelo mecanismo de via rápida, para cerca de trezentas empresas que solicitaram suporte (World Bank, 2020b). Esse financiamento é importante para micro, pequenas e médias empresas, especialmente vulneráveis a choques globais, e ajudará na preservação de empregos.

Do ponto de vista regional, o Banco Interamericando de Desenvolvimento (BID) informou que seu apoio financeiro à crise estará concentrado em quatro áreas: resposta imediata à saúde pública; redes de proteção para populações vulneráveis; produtividade econômica e emprego; e políticas fiscais para aliviar impactos econômicos. Essa instituição colocou à disposição dos países até 12 bilhões de dólares, que podem ser usados para mitigar os efeitos danosos da pandemia (BID, 2020a).

Neste capítulo são contextualizadas e descritas cronologicamente as principais medidas financeiras tomadas em resposta à pandemia. Foi realizada uma revisão dos documentos oficiais lançados por essas instituições desde o início da pandemia e analisados criticamente os discursos que, possivelmente, trazem à tona pouca novidade com relação às velhas práticas de concessão de financiamento para os países de baixa e média rendas - num momento em que urgem medidas para desacelerar o aprofundamento da desigualdade.

\section{INSTITUIÇÕES FINANCEIRAS INTERNACIONAIS: BREVE CONTEXTUALIZAÇÃO}

Ao longo da história houve dois grandes esforços para a concertação de um sistema financeiro interacional: o padrão-ouro (1890-1914) e o Sistema de Bretton Woods (1944-197I). As principais instituições do sistema financeiro internacional atual tiveram as suas bases estabelecidas no contexto do fim da II Guerra Mundial. O receio de uma nova crise internacional como a da década de 1930 impulsionou os Estados a acordarem medidas de regulamentação para um novo sistema monetário que pudesse favorecer a reconstrução das economias no pós-guerra e o crescimento econômico, além de orientar o comportamento financeiro entre os Estados. Em 1944, representantes de 44 países se encontraram na cidade de Bretton Woods, nos Estados Unidos da América (EUA), para a Conferência Financeira e Monetária das Nações Unidas com o intuito de deliberar e assinar a chamada Carta de Breton Woods, que deu origem ao Fundo Monetário Internacional (FMI) e ao Banco Internacional de Reconstrução e Desenvolvimento (Bird, hoje o núcleo do Grupo Banco Mundial), que começaram a funcionar em 1947. 


\section{Banco Mundial}

O Bird (de agora em diante Banco Mundial) foi idealizado para apoiar a reconstrução e recuperação econômica da Europa no pós-II Guerra. Em 1960, foi instituída a Associação Internacional de Desenvolvimento (AID), com o objetivo de reduzir a pobreza, fornecendo empréstimos (chamados créditos) e doações para programas que estimulassem o crescimento econômico, reduzissem as desigualdades e melhorassem as condições de vida das pessoas. Após a década de 1960, a instituição foi assumindo um papel mais destacado não apenas no apoio ao desenvolvimento de infraestruturas dos países pobres, mas também em projetos nas áreas da educação, da saúde, da agricultura e de gestão de recursos ambientais e naturais, da administração pública, do desenvolvimento financeiro e do setor privado. Hoje o Banco Mundial é uma fonte importante de assistência financeira e técnica para os países em vias de desenvolvimento em todo o mundo e conta com 187 países-membros.

O Grupo Banco Mundial é uma instância multilateral composta por cinco instituições: o Bird, a Agência Multilateral de Garantia de Investimento (AMGI), a CFI, o Centro Internacional para Arbitragem de Disputas sobre Investimentos (Ciadi) e a AID.

No processo decisório do Banco Mundial não se aplica o princípio da igualdade soberana; não há, portanto, um voto por país. Em seu lugar, é utilizado um sistema de cotas, ou seja, o montante de recursos depositado pelo país equivale a um percentual do capital - ações - do banco. Os cinco maiores acionistas são EUA, Japão, Alemanha, França e China. A cota também é levada em consideração para estabelecer os valores máximos de empréstimos que os países podem pedir ao banco, os quais, de maneira geral, não podem ultrapassar o valor da cota-parte.

\section{Fundo Monetário Internacional}

Em 1944, os líderes dos 44 países reunidos em Bretton Woods tinham como objetivo evitar a repetição de políticas destrutivas que pudessem desencadear outro conflito mundial. Nesse sentido, o Fundo Monetário Internacional (FMI) foi criado para promover a cooperação monetária. Seu principal objetivo é garantir a estabilidade do sistema monetário internacional - sistema de taxas de câmbio e pagamentos internacionais -, o que permite que os países (e seus cidadãos) negociem entre si. Em 2012, o mandato do fundo foi atualizado para incluir todas as questões macroeconômicas e do setor financeiro, relacionadas à estabilidade global (IMF, 2020a).

Com o objetivo de manter a estabilidade e evitar crises no sistema monetário internacional, o FMI monitora as políticas de seus 189 países-membros, bem como os 
processos de desenvolvimento econômico-financeiro nacionais, regionais e globais por meio de um sistema formal conhecido como surveillance (vigilância). O fundo concede empréstimos a países-membros que estão enfrentando problemas reais ou potenciais de balanço de pagamentos. Para isso, estabelece programas de ajustes junto ao país e condiciona o apoio financeiro contínuo à implementação efetiva desses ajustes. Em resposta à crise econômica global de 2008, em abril de 2009 o FMI fortaleceu sua capacidade de empréstimo e aprovou uma grande revisão de seus mecanismos de apoio financeiro, com reformas adicionais adotadas nos anos subsequentes. Essas mudanças aprimoraram o seu kit de ferramentas de prevenção de crises.

Assim como o do Banco Mundial, o processo decisório do FMI funciona como uma sociedade por cotas. Os EUA têm 16,5 I \% do total das cotas (IMF, 2020b), portanto têm, sozinhos, o poder de inviabilizar uma decisão, uma vez que para a aprovação de uma medida pelo órgão decisório são necessários 85\% das cotas.

\section{Banco Interamericano de Desenvolvimento}

O Banco Interamericano de Desenvolvimento (BID) foi criado em I959, como instituição de apoio ao desenvolvimento da região, com mandato e ferramentas considerados inovadores para a época. Inicialmente, 19 países foram signatários do seu Convênio Constitutivo. Seus programas de empréstimos e cooperação técnica para projetos de desenvolvimento econômico e social iam além do mero financiamento, como era o habitual naquele momento.

Ao longo dos anos, novos países da Região das Américas foram formalizando sua associação ao banco. Igualmente, países não pertencentes à região também demonstraram interesse e reuniram as condições para se tornarem membros. Atualmente, o BID possui 48 países-membros, assim divididos: 26 são mutuários da América Latina e Caribe; dois não mutuários da região (EUA e Canadá); 16 são países europeus (Suíça, Suécia, Reino Unido, Portugal, Países Baixos, Noruega, Itália, França, Finlândia, Eslovênia, Espanha, Dinamarca, Croácia, Bélgica, Áustria e Alemanha) e quatro são países asiáticos (Japão, Israel, China e Coreia do Sul).

Para fazer parte do BID, a regra (BID, 2020b) é que o país solicitante seja membro da Organização dos Estados Americanos (OEA). Caso um país não regional queira se afiliar, deve fazer parte do FMI. A outra regra, que rege as duas situações, é uma subscrição de ações do capital ordinário e uma colaboração para o Fundo para Operações Especiais do Banco. 
No BID, assim como no Banco Mundial e no FMI, o voto não (IDB, 2020b) atende ao princípio da soberania e, portanto, não corresponde a um voto por país. Em seu lugar, cada Estado-membro tem seu poder de voto determinado por sua subscrição de recursos ao capital ordinário da instituição.

\section{Observação}

As três instituições financeiras lançam relatórios periódicos situacionais em suas diversas áreas de atuação e fazem análises ou apontam problemas e possíveis direcionamentos ou orientações resolutivas. Desde o início da pandemia foram publicadas centenas de relatórios.

\section{CRONOLOGIA DA RESPOSTA DAS IFIS À PANDEMIA DA COVID-19}

Medidas de distanciamento social, confinamento e quarentena impuseram e estão impondo um altíssimo custo econômico e social em todo o mundo. A combinação dessas políticas resultou na redução, se não na parada completa, de atividades de produção, consumo, circulação de mercadorias e pessoas por um período incerto, desafiando a sobrevivência de empresas (micro, pequenas e grandes) e, consequentemente, levando milhões de trabalhadores ao desemprego. Em diversos países, que ainda se encontram em quarentena, a atividade produtiva de alguns setores permanece parada. As cadeias globais de suprimentos foram cortadas e ainda não foram retomadas em sua totalidade.

As economias do mundo, portanto, sofrem com os efeitos debilitantes da pandemia. Diante desse panorama, o FMI, o Banco Mundial e os bancos de desenvolvimento regionais enfrentam o desafio de ajudar a manter os motores da economia global funcionando. Muitos países, particularmente os de economia em desenvolvimento, têm procurado assistência dessas organizações.

Para informar como está se dando a resposta à crise sanitária do ponto de vista financeiro, serão descritos a seguir a cronologia e os principais elementos das iniciativas realizadas pelo FMI, Banco Mundial e BID desde o anúncio da pandemia pela Organização Mundial da Saúde (OMS).

\section{Fundo Monetário Internacional}

Desde a declaração de pandemia pela OMS, em II de março de 2020, até o dia 31 de julho de 2020, o FMI recebeu 102 pedidos de financiamento de emergência. No dia 16 de março, cinco dias após o anúncio da OMS, o FMI publicou um documento contendo orientações para a tomada de medidas políticas, sobretudo econômicas, para enfrentar a 
crise da Covid- 19 (IMF, 2020c). Anunciou também que estava preparado para mobilizar sua capacidade de crédito de um trilhão de dólares para ajudar os países-membros a combaterem a pandemia e seus custos humanos, econômicos e financeiros.

No dia 25 de março, em uma declaração conjunta, o FMl e o Banco Mundial exortaram os credores bilaterais oficiais a suspender os pagamentos do serviço da dívida dos países mais pobres (IMF, 2020d). A iniciativa foi considerada poderosa e de ação rápida, capaz de liberar recursos que pudessem ser usados para salvaguardar vidas e meios de subsistência. O G20 respondeu ao apelo concordando com a suspensão do serviço da dívida dos países mais pobres no crédito bilateral oficial no valor de cerca de II bilhões de dólares. O FMI, o Banco Mundial e o G20 também solicitaram aos credores do setor privado que participassem dessa iniciativa em termos comparáveis, o que poderia adicionar mais 7 bilhões de dólares em alívio.

Dois dias depois, o Conselho Executivo do Fundo aprovou algumas modificações (IMF, 2020e) imediatas em seu Fundo Fiduciário de Assistência a Desastres e Contenção (FFACC), para oferecer alívio ao serviço da dívida dos países-membros mais pobres e vulneráveis. Graças ao FFACC, o FMI pode conceder subsídios para o alívio da dívida a países de baixa renda habilitados, após desastres naturais e emergências de saúde graves que se espalham rapidamente. Para o contexto atual, as modificações no FFACC expandiram os critérios que possibilitaram abranger melhor as circunstâncias criadas por uma pandemia global e se concentraram em fornecer suporte para as necessidades mais imediatas.

Em 15 de abril, o Conselho Executivo aprovou o estabelecimento de uma Linha de Liquidez de Curto Prazo (LLCP) para contribuir com o fortalecimento da rede de segurança financeira global, como parte da resposta à pandemia (IMF, 2020f). Essa modalidade é um mecanismo de apoio rotativo e renovável para os países-membros que têm políticas econômicas fortes e precisam de apoio moderado à balança de pagamentos no curto prazo. Nesses casos, a LLCP fornece acesso rotativo de até 145\% da cota.

No dia 20 de maio, o número países que pediram financiamento de emergência aumentou fortemente, ultrapassando 100 . Com o intuito de dar conta da ampla demanda, o FMI dobrou o acesso a suas instalações de emergência (IMF, 2020g) - Rapid Credit Facility (IMF, 2020h) e Rapid Financing Instrument (IMF, 2020i) -, para possibilitar o desembolso de cerca 100 bilhões em financiamento. Essas medidas permitiram que o fundo fornecesse assistência de emergência rapidamente, sem necessidade de apresentação de um programa completo e sem as condicionalidades mais tradicionais previstas pela instituição. Desse modo, até o final de maio seu Conselho Executivo havia 
aprovado financiamentos a mais de 60 países, um recorde na história do fundo. Esse número aumentou para mais de 70 até o fim do mês de julho.

Além dos empréstimos, financiamentos e alívios oferecidos pelo FMI no contexto da pandemia, o FMI está fornecendo consultoria em tempo real sobre políticas de apoio ao desenvolvimento de capacidades a cerca 160 países. A consultoria abrange temas e questões urgentes, como gerenciamento de caixa, supervisão financeira, segurança cibernética e governança econômica. Os especialistas técnicos também estão trabalhando com os países para revisar e atualizar suas estratégias de gestão da dívida.

\section{Banco Mundial}

Com o intuito de amortecer os impactos econômicos e sociais nos países em desenvolvimento, menos de uma semana após o anúncio da pandemia da Covid-19, em 17 de março, o Conselho Executivo do Banco Mundial e o Conselho de Administração da $\mathrm{CFI}$ aprovaram um pacote de financiamento de desembolso acelerado de 14 bilhões de dólares para ajudar empresas e países em seus esforços de prevenção, detecção e resposta à disseminação do novo coronavírus (BM, 2020a). A medida conta com empréstimos a empresas privadas do setor da saúde.

Em 2 de abril de 2020, o Banco Mundial anunciou que estava preparado para desembolsar até 160 bilhões de dólares nos 15 meses subsequentes. Isso inclui 50 bilhões de dólares em novos recursos da AID por meio de doações e empréstimos altamente concessionais. Esse desembolso total, segundo o banco, tem como objetivo reduzir o tempo de recuperação, criar condições de crescimento, apoiar pequenas e médias empresas e ajudar a proteger os pobres e vulneráveis. O Banco Mundial anunciou que para essas operações está focalizando fortemente a pobreza, com ênfase no financiamento baseado em políticas de proteção das famílias mais necessitadas e do meio ambiente.

Nesse mesmo dia foi lançado o primeiro grupo de projetos utilizando o mecanismo de via rápida dedicado à Covid-19, no valor de 1,9 bilhão de dólares em assistência financeira a 25 países. Também em 2 de abril o Banco Mundial lançou o primeiro lote de projetos específicos para a América Latina e o Caribe. As iniciativas faziam parte da resposta global do banco à Covid-19, sendo que na primeira fase estava previsto apoio num total de 14 bilhões de dólares.

No dia $1{ }^{\circ}$ de maio, entrou em vigor a Iniciativa de Suspensão de Pagamentos do Serviço da Dívida (DSSI) (Word Bank, 2020c). A instituição trabalhou com o FMI para instar os credores bilaterais oficiais a conceder alívio da dívida aos países mais pobres 
do mundo, ou seja, àqueles que se qualificam para receber financiamento da AID. O G20 concordou em aplicar uma abordagem coordenada, e os credores privados foram incentivados a contribuir com esse esforço também. A iniciativa permite que os países mais pobres liberem recursos para responder à pandemia do Covid- 19 e promove a transparência e a sustentabilidade da dívida.

Sobre a iniciativa, David Malpass, presidente do Banco Mundial, observou que ela abre caminho para medidas há muito esperadas para aumentar a transparência e a sustentabilidade da dívida e do investimento (BM, 2020b). Essa decisão teve apoio do G20, que propôs a criação de um site que mostre a composição dos pagamentos anuais esperados do serviço da dívida dos 73 países que podem receber alívio. A transparência de todos os investimentos e compromissos financeiros é um passo fundamental para a criação de um clima de investimento atraente que permitirá, segundo David Malpass, alcançar melhores resultados para os habitantes dos países em desenvolvimento.

Em 19 de maio, o Banco Mundial anunciou que suas operações de emergência para combater a Covid- I 9 haviam alcançado 100 países em desenvolvimento, representando $70 \%$ da população mundial. Essa assistência é a maior e mais rápida resposta a crises na história do Grupo Banco Mundial.

Em princípios de julho, o Banco Mundial comunicou que para apoiar os programas de emergência desde o início da pandemia, o financiamento concedido pela entidade foi aumentado significativamente durante o exercício fiscal de 2020 (EF2020), encerrado no dia $1^{\circ}$ de julho (BM, 2020b). O valor total dos compromissos que o banco assumiu foi de 74 bilhões de dólares - um incremento de 14,6 bilhões.

Num balanço geral, o apoio prestado pelo Bird a países de renda média atingiu 28,5 bilhões de dólares no ano fiscal de 2020, o que representa um aumento de 23,2 bilhões em relação ao ano anterior (World Bank, 2020d). Os empréstimos e doações da AID para os países mais pobres atingiram 30,4 bilhões. Uma proporção significativa do financiamento do Banco Mundial (Bird e AID) durante o EF2020 foi para ajudar os países a combaterem a pandemia do Covid-19. Como parte desse financiamento, entre março e o final de junho o banco aprovou um montante de 6,3 bilhões de dólares destinados a fornecer apoio emergencial à saúde em 108 países, incluindo 33 Estados frágeis e afetados por conflitos e 22 pequenos Estados. Esse montante inclui um desembolso significativo da CFI em apoio a empresas privadas - inclusive as do setor Saúde.

Com os financiamentos concedidos, juntamente com assistência técnica, aconselhamento político e apoio analítico, pretende-se ajudar os países a lidar com os profundos impactos econômicos, sociais e sanitários da pandemia. 


\section{Banco Interamericano de Desenvolvimento}

Quando o surto da Covid- 19 ainda era caracterizado pela OMS como Emergência em Saúde Pública de Interesse Internacional, em janeiro de 2020, o Grupo BID aumentou a disponibilidade de recursos e ajustou seus instrumentos de empréstimo, a fim de acelerar seu apoio aos países afetados pelo vírus.

Em 26 de março de 2020, após extenso diálogo com os governos de seus paísesmembros e análise técnica de seus especialistas, o Grupo BID anunciou (BID, 2020a) que seu apoio ao enfrentamento da pandemia na região se concentraria em quatro áreas: resposta imediata à saúde pública; redes de proteção para populações vulneráveis; produtividade econômica e emprego e políticas fiscais para aliviar impactos econômicos. Ademais, comunicou que além de reprogramar a carteira existente de projetos para a área da saúde enfrentar a crise, o banco poderia direcionar 3,2 bilhões de dólares adicionais ao programa de empréstimos inicialmente estipulado para 2020. Esses fundos, somados aos recursos disponíveis já programados para 2020, colocariam à disposição dos países até 12 bilhões de dólares para enfrentarem a crise e suas sequelas. Também está disponível um orçamento de 5 bilhões de dólares do BID Invest para o setor privado. Desse total, 4,5 bilhões vêm de seu programa de investimentos, com foco nas empresas impactadas pela crise. Além disso, o BID Invest está trabalhando em um novo mecanismo de mitigação de crises, no valor de 500 milhões de dólares, visando a apoiar investimentos que proporcionem uma resposta direta à pandemia pelo setor da saúde e pelos setores a este relacionados. Além de facilitar acesso a empréstimos de curto prazo para pequenas e médias empresas por meio de instituições financeiras e financiamento da cadeia de suprimentos.

Em 9 de junho, o BID anunciou a expansão dos riscos cobertos pela Linha de Crédito Contingente para Emergências de Desastres Naturais (LCCEDN) para incluir os riscos relacionados à saúde pública e à Covid- 19 (IDB, 2020a). O instrumento expandido inclui uma cobertura temporária única da Covid-19, dada a magnitude sem precedentes do atual surto, e uma cobertura ex ante de longo prazo para futuras pandemias e epidemias. Desse modo, o banco pretende melhorar a gestão de passivos públicos contingentes dos países. Para a atual pandemia, os países podem solicitar até 90 milhões de dólares ou 0,6\% do Produto Interno Bruto (PIB) - o que for menor. Para o futuro, poderão demandar cobertura para emergências de saúde pública de até 100 milhões de dólares ou até I\% do PIB - o que for menor.

No caso do Brasil, no dia 13 de agosto, o BID anunciou um empréstimo no valor de I bilhão de dólares destinado ao fortalecimento da capacidade de resposta emergencial 
do país às necessidades das populações vulneráveis e dos trabalhadores (BID, 2020c). O empréstimo vai apoiar a execução de programas criados no período de emergência, como o Auxílio Emergencial e o Programa Emergencial de Manutenção do Emprego e Renda, além das transferências do Bolsa Família. Os recursos serão distribuídos em dois grupos de programas emergenciais do governo: o primeiro é destinado a programas para populações em vulnerabilidade; o segundo, à preservação de empregos e renda formal. O país terá 25 anos para pagar a dívida, com um período de carência de cinco anos e meio.

O banco também estabeleceu plataformas de intercâmbio e aprendizado para disponibilizar todo o conhecimento técnico para a região e facilitar o diálogo com organizações internacionais e governos que estão colaborando para combater a pandemia.

Finalmente, o BID publicou um número expressivo de relatórios com o objetivo de analisar, monitorar e avaliar a crise que a Covid-19 impôs à região. Até o dia 31 de julho de 2020, foram lançados 54 documentos relacionados aos impactos da pandemia. Destaca-se aqui uma série de três relatórios focados em políticas públicas para ajudar a América Latina e o Caribe a lidarem com o os efeitos negativos da crise sanitária: 1) "La política pública frente al Covid-19: Recomendaciones para América Latina y el Caribe” (Blackman et al., 2020), publicado em abril. Neste informe se discutem políticas públicas para a região que havia começado a ser afetada pela pandemia; 2) Del Confinamiento a la Reapertura: consideraciones estratégicas para el reinicio de las actividades en América Latina y el Caribe en el marco de la Covid-I 9 (Pagés et al., 2020), lançado em maio. No documento se propõe uma série de medidas que orientam os tomadores de decisões sobre como e quando deveriam reabrir os países social e economicamente; e 3) Salir del Túnel Pandémico con Crecimiento y Equidad: una estrategia para un nuevo compacto social en América Latina y el Caribe (Izquierdo et al., 2020), lançado em julho. Neste último relatório são descritas as opções políticas dos países para expandir suas possibilidades de enfrentar os desafios econômicos da crise, com ênfase no crescimento e na equidade.

\section{PERSPECTIVAS ECONÔMICAS E SOCIAIS PÓS-PANDEMIA NOS ÂMBITOS REGIONAL E GLOBAL}

O FMI publicou em junho de 2020 a revisão de seu relatório World Economic Outlook (WEO), de abril (IMF, 2020j) do mesmo ano, intitulado "A Crisis like no other, an uncertain recovery” (IMF, 2020k). O crescimento global foi projetado em 4,9\% em 2020, o que significa I,9 ponto percentual abaixo da previsão anterior. Segundo o documento, 
no primeiro semestre de 2020 a pandemia da Covid-19 teve impacto na atividade econômica mais negativo do que o previsto, e também se projeta que a recuperação deverá ser ainda mais gradual do que o prognosticado anteriormente.

No relatório o FMI projetou o crescimento global em 202 I para 5,4\%. Isso resultaria num PIB global para o próximo ano de cerca de 6,5 pontos percentuais menor do que as projeções de janeiro de 2020, anteriores à Covid- 19.

Assim como nas projeções do WEO de abril de 2020, há um grau de incerteza acima do normal em torno dessa previsão. A projeção baseia-se em suposições importantes sobre as consequências da pandemia. Pela primeira vez, estimava-se um crescimento negativo para todas as regiões em 2020. Mas, ainda assim, observam-se importantes diferenças entre as economias em escala individual, em função da evolução da pandemia e da eficácia das estratégias de contenção.

Nos países com taxas de infecção em declínio, o FMI observa que a desaceleração na trajetória de recuperação econômica contemplada nas previsões atualizadas se baseia num distanciamento social persistente entrando pelo segundo semestre de 2020. Isso pode deixar grandes cicatrizes, devido ao fato de as atividades de suprimento sofrerem mais do que o esperado num confinamento no primeiro e segundo semestres de 2020 com um possível golpe na produtividade. Nas sociedades com dificuldades em controlar as taxas de infecção, um confinamento mais longo causaria ainda mais danos às atividades econômicas. $\mathrm{O}$ impacto adverso sobre as famílias de baixa renda é particularmente agudo, ressalta o relatório, colocando em risco o progresso significativo feito com o investimento na redução da pobreza extrema no mundo desde década de 1990.

No documento o FMI faz um apelo a que todos os países, incluindo aqueles que parecem haver superado os picos de infecção, garantam recursos adequados aos seus sistemas de saúde. A comunidade internacional deve oferecer um apoio muito maior às iniciativas nacionais de países com capacidade limitada em seus sistemas de saúde, principalmente sob a forma de apoio e assistência financeiros, canalizando recursos para garantir acesso das populações a custo acessível a vacinas à medida que os ensaios clínicos progridam.

Ademais, no WEO de junho se enfatiza que, nos casos que requerem confinamento, a política econômica deve continuar atenuando as perdas de renda das famílias por meio de medidas substanciais e bem direcionadas, além de oferecer apoio às empresas que sofrem as consequências de restrições obrigatórias à atividade. Em países com altas taxas de emprego informal, o confinamento obrigatório levou a desemprego e perdas abruptas de renda de muitos desses trabalhadores (entre esses, a situação pior é a dos imigrantes, geralmente separados de suas redes de apoio). 
Nos casos das economias que estão reabrindo, o apoio direcionado deve ser interrompido à medida que a recuperação se inicie. E devem ser adotadas políticas que estimulem e promovam a demanda e facilitem e incentivem a realocação de recursos para setores que provavelmente estarão menores após a pandemia.

Por fim, no documento o FMI faz um apelo à necessidade da cooperação multilateral em várias áreas. E relembra que a liquidez de reserva é urgentemente necessária para os países que enfrentam crises na saúde, por meio, por exemplo, do alívio da dívida e do financiamento através da rede global de segurança financeira. Além disso, aproveitando a redução sem precedentes nas emissões de gases de efeito estufa durante a pandemia, incita as autoridades a l) implementarem seus compromissos com a mitigação das mudanças climáticas; 2) expandirem a aplicação dos impostos utilizando critérios de equidade; 3) tributarem as emissões de carbono ou sistemas equivalentes. Por fim, convoca a comunidade internacional a agir sem demora para impedir a reincidência dessa catástrofe, organizando reservas internacionais de suprimentos e equipamentos de proteção essenciais, financiando pesquisa, sustentando os sistemas de saúde pública e estabelecendo estratégias eficazes para ajudar as pessoas mais necessitadas.

O Banco Mundial, por sua vez, também lançou, em junho, um relatório sobre as perspectivas econômicas regionais e sobre o profundo impacto da crise sanitária na desigualdade (World Bank, 2020a). Em abril, o banco havia calculado que a Covid- 19 havia mergulhado entre 40 e 60 milhões de pessoas na extrema pobreza. No entanto, com a mudança do epicentro da epidemia da Europa e da América do Norte para o hemisfério sul, as estimativas do impacto do vírus na pobreza global também mudaram.

Diante da atualização das previsões de crescimento de junho realizadas pelo FMI, o Banco Mundial poderá atualizar suas estimativas. As novas previsões de crescimento contêm duas hipóteses - referência e tendência de queda - que permitem explorar duas situações diferentes na forma como a pandemia pode afetar a pobreza.

No cenário de referência, segundo o relatório, supõe-se que os surtos permaneçam nos níveis atualmente esperados de redução e que a atividade se recupere durante este ano. No cenário de tendência de queda, por sua vez, presume-se que os surtos persistam por mais tempo do que o esperado, forçando a manter ou reintroduzir medidas de contenção. Se o cenário de tendência de queda se concretizar, no relatório se prognostica que empresas vulneráveis podem desaparecer dos mercados, famílias vulneráveis reduziriam drasticamente seu consumo e países de baixa e média renda sofreriam imenso estresse financeiro. No cenário de referência, o crescimento mundial se contrai em torno de $5 \%$ em 2020, e no cenário de tendência de queda prevê-se uma contração de crescimento de 8\% em 2020. 
No cenário de referência, o Banco Mundial estima que 7I milhões de pessoas entrariam para a pobreza extrema, medida de acordo com a linha de pobreza internacional de 1,90 dólar por dia. No cenário de tendência de queda, esse número aumentaria para 100 milhões. Mas fica claro que as projeções do que acontecerá em 2021 e além são acompanhadas ainda de muita incerteza.

Do ponto de vista regional, no mesmo relatório de julho o Banco Mundial avaliou que a América Latina e o Caribe sofrerão uma queda de 7,2\% na atividade econômica em 2020. O FMl, também em sua edição de julho do WEO, vaticinou que na América Latina, onde a maioria dos países ainda luta para conter infecções, as duas maiores economias, Brasil e México, devem se contrair 9, I e 10,5\%, respectivamente, em 2020.

Como é possível observar nos relatórios das instituições financeiras internacionais analisadas, a pandemia não apenas levou (e continua levando) os sistemas de saúde a seus limites, mas se tornou rapidamente uma ameaça para toda a economia global, em uma escala muito maior que a crise financeira de 2007-2008. Os países mais ricos responderam de forma rápida e, de modo geral, comprometeram-se com medidas econômicas de apoio consistente a seus cidadãos e ao setor privado. No entanto, a realidade foi bem diferente para os países de baixa e média rendas. Seus governos não foram capazes de oferecer tais medidas e suas populações estão fadadas a enfrentar as profundas mazelas impostas ou escancaradas pela Covid- 19.

Somado-se a isso, a quarentena atingiu de maneira muito desigual a mão de obra de diferentes áreas em todo o mundo. Trabalhadores informais e de serviços como restaurantes e hotelaria padeceram com um impacto negativo particularmente agudo da pandemia - que poderá aumentar significativamente a desigualdade. Segundo o FMI, a fração da população mundial que vive em extrema pobreza (com menos de 1,90 dólar por dia), que havia caído para menos de 10\% nos últimos anos (era de mais de $35 \%$, em 1990), pode voltar a crescer devido à atual crise da Covid- 19 em mais de $90 \%$ dos mercados emergentes. As economias em desenvolvimento estão projetadas para registrar crescimento negativo da renda per capita em 2020. Em países com altas taxas de emprego informal e de trabalhadores imigrantes, as quarentenas levaram a desemprego e perdas abruptas de renda para muitas pessoas. Soma-se a isso a inquietante constatação feita pela Organização das Nações Unidas para a Educação, a Ciência e a Cultura (Unesco, 2020) de que o fechamento generalizado de escolas, em cerca de 150 países até o final de maio, afetou aproximadamente 1,2 bilhão de crianças em idade escolar (cerca de 60\% do total global) em todo o mundo (Unesco). Esse fato 
terá efeitos desproporcionalmente negativos sobre as perspectivas principalmente nos países de baixa renda, afetando significativamente a aprendizagem dessas crianças e o seu futuro, entre outros fatores.

Diante desse panorama pouco alentador, as instituições financeiras multilaterais procuraram exercer um papel central no apoio aos países mais afetados pelo ônus social, financeiro e sanitário da Covid-19, e agiram de forma rápida com recursos financeiros e um conjunto de ferramentas para lidar com o impacto da pandemia.

No entanto, o discurso do presidente do Banco Mundial na Conferência virtual de Ministros da Economia do G20, em 23 de março, parece indicar que as tradicionais condicionalidades do FMI e do Banco Mundial, ainda que tenham sido flexibilizadas diante da emergência atual, continuam presentes nas negociações bilaterais (BM, 2020c). Malpass destacou que os países precisam implementar reformas estruturais para reduzir o tempo de recuperação e criar confiança de que os níveis de retomada de crescimento podem ser altos. E ressaltou que o Banco Mundial trabalhará para promover mercado e perspectivas de crescimento naqueles países que são impedidos por contarem com muitos regulamentos, subsídios, regimes de licenciamento, proteção comercial ou litígio.

Outro fato que relativiza a extensão das medidas apresentadas é o pronunciamento da diretora do FMI, Kristina Giorgieva, poucos dias depois do discurso de Malpass. Ela anunciou que o fundo estava revisando seus instrumentos de empréstimo para examinar o que poderia ser readequado para o contexto da pandemia (IMF, 2020l). E exemplificou sugerindo que expandir o uso de linhas de crédito preventivas ou antecipar provisões de liquidez de curto prazo nos instrumentos já existentes poderia ser uma alternativa para que os países acessem os recursos do FMI. Em outras palavras, o FMI conclamava os países a continuarem requerendo seus empréstimos através dos mecanismos tradicionais.

Com relação à fundamental iniciativa de alívio do pagamento do serviço da dívida para os países mais pobres, liderada pelo FMl e Banco Mundial, o G20, em sua reunião de julho, adiou para outubro qualquer possível extensão. Essa iniciativa poderia desafogar as economias mais pobres e permitir que esses recursos fossem investidos no enfrentamento das demandas ligadas à pandemia. Segundo o comunicado, foram beneficiados 42 dos 73 países elegíveis e o G20 continuará trabalhando para uma ampliação no segundo semestre (G20, 2020). Mas não sem antes considerar o desenvolvimento da situação da pandemia Covid- 19 e as conclusões de um relatório do FMI e do Banco Mundial sobre as necessidades de liquidez dos países elegíveis - que serão submetidas ao G20 antes da reunião de outubro de 2020. 
Essa mudança de tom é um desalento para as populações mais vulneráveis. Em sentido conexo, a priorização de políticas fiscais e soluções orientadas para o mercado têm efeitos adversos nos sistemas públicos de saúde dos países que recebem empréstimos das instituições financeiras internacionais. Tanto as reformas estruturais como as condicionalidades contidas nos mecanismos de empréstimos convencionais implicam medidas de austeridade que têm efeitos nocivos nos sistemas e nos resultados dos sistemas de saúde. Durante décadas, esses dispositivos comprometeram particularmente os sistemas públicos de saúde dos países de menor renda. As condicionalidades restritivas dos empréstimos podem limitar a capacidade de um país de aumentar o investimento público para fornecer serviços de saúde essenciais necessários para garantir esse direito fundamental e o desenvolvimento inclusivo.

Ainda que o resultado final do impacto social e econômico da pandemia seja incerto, não restam dúvidas de que a Covid- 19 provocou enorme choque mundial, acarretando recessões acentuadas em numerosos países e com trágicas consequências para as populações mais vulneráveis. Portanto, no cenário atual urgem políticas consistentes para proteger os seres humanos mais afetados e melhorar a capacidade dos países para enfrentar eventos semelhantes no futuro.

Nesse sentido, as IFls têm a chance de desempenhar um papel fundamental, mobilizando as economias desenvolvidas e chamando-as a que exerçam o espírito do multilateralismo e da solidariedade - como foi o caso da iniciativa de alívio dos serviços da dívida (World Bank, 2020e). A pandemia, diferentemente de outras crises, leva para a arena internacional a noção de que não há como superá-la de forma unilateral. Somente se todos os países do globo - ricos e pobres - puderem responder de maneira adequada à doença (em todos os sentidos) é que as sociedades alcançarão o momento pós-pandemia proximamente.

O FMI, ao menos em seus escritos, se expressa no mesmo sentido:

Todos os países - incluindo aqueles que aparentemente superaram os picos de infecções - devem garantir que seus sistemas de saúde tenham os recursos adequados. A comunidade internacional deve intensificar amplamente seu apoio às iniciativas nacionais, inclusive por meio de assistência financeira a países com capacidade limitada de cuidados em saúde. Além de canalização de fundos para a produção de vacinas à medida que os testes avançam, de modo que doses adequadas e acessíveis estejam rapidamente disponíveis para todos os países. Onde os bloqueios são necessários, a política econômica deve continuar a amortecer as perdas de renda familiar com medidas consideráveis e bem direcionadas, bem como fornecer apoio às empresas que sofrem as consequências das restrições impostas à atividade (...). Uma cooperação multilateral forte continua sendo essencial em várias frentes. (IMF, 2020m, tradução nossa) 
Apesar do recrudescimento do conservadorismo em nível mundial, a crise gerada pela pandemia do novo coronavírus deveria ser uma oportunidade para a mudança de paradigma das práticas das IFIs, más allá de la retórica.

\section{REFERÊNCIAS}

BANCO INTERAMERICANO DE DESENVOLVIMENTO (BID). Grupo BID anuncia áreas prioritárias de apoio aos países afetados pelo Covid-19, 26 mar. 2020a. Disponível em: <https://www.iadb.org/ pt/noticias/grupo-bid-anuncia-areas-prioritarias-de-apoio-aos-paises-afetados-pelo-covid-19>. Acesso em: 18 set. 2020.

BANCO INTERAMERICANO DE DESENVOLVIMENTO (BID). Site. Disponível em: < https://www.iadb. org/pt/sobre-o-bid/how-are-we-organized>. Acesso em: 18 set. 2020b.

BANCO INTERAMERICANO DE DESENVOLVIMENTO (BID). BID destina US\$ I bi para apoio a populações vulneráveis e trabalhadores no Brasil, 13 ago. 2020c. Disponível em: <https://www. iadb.org/pt/noticias/bid-destina-us- I-bi-para-apoio-populacoes-vulneraveis-e-trabalhadores-nobrasil>. Acesso em: 18 set. 2020.

BANCO MUNDIAL (BM). La respuesta del Grupo Banco Mundial a la Covid- 19 aumenta a USD 14000 millones para ayudar a sostener las economías y proteger el empleo, 17 mar. 2020a. Disponível em: <https:// www.bancomundial.org/es/news/press-release/2020/03/1 7/world-bank-group-increases-covid-19response-to-14-billion-to-help-sustain-economies-protect-jobs>. Acesso em: 18 set. 2020.

BANCO MUNDIAL (BM). En medio de múltiples crisis, el Grupo Banco Mundial reorienta programas e incrementa el financiamiento a USD 74000 millones en el ejercicio de 2020, 10 jul. 2020b. Disponível em: < https://www.bancomundial.org/es/news/press-release/2020/07/10/amid-multiplecrises-world-bank-group-refocuses-programs-and-increases-financing-to-74-billion-in-fiscalyear-2020>. Acesso em: 18 set. 2020.

BANCO MUNDIAL (BM). Palabras del presidente del Grupo Banco Mundial, David Malpass, en la teleconferencia de Ministros de Finanzas del G-20 sobre la Covid- 19, 23 mar. 2020c. Disponível em: $<$ https://www.bancomundial.org/es/news/speech/2020/03/23/remarks-by-world-bank-grouppresident-david-malpass-on-g20-finance-ministers-conference-call-on-covid-19>. Acesso em: 18 set. 2020 .

BLACKMAN, A. et al. La Política Pública frente al Covid-19: recomendaciones para América Latina y el Caribe. Washington: IDB, 2020. Disponível em: < https://publications.iadb.org/es/la-politica-publicafrente-al-covid-19-recomendaciones-para--america-latina-y-el-caribe>. Acesso em: 18 set. 2020.

INTER-AMERICAN DEVELOPMENT BANK (IDB). IDB expands coverage for Covid- 19 and public health risks in contingent loans, 9 Jun. 2020. Disponível em: < https://www.iadb.org/en/news/idb-expandscoverage-covid-19-and-public-health-risks-contingent-loans>. Acesso em: 18 set. 2020a.

INTER-AMERICAN DEVELOPMENT BANK (IDB). Capital stock and voting power. Disponível em: $<$ https://www.iadb.org/en/about-us/capital-stock-and-voting-power >. Acesso em: 18 set. 2020b.

INTERNATIONAL MONETARY FUND (IMF). Articles of Agreement. Washington: International Monetary Fund, 2020a. Disponível em: <https://www.imf.org/external/pubs/ft/aa/index.htm>. Acesso em: 18 set. 2020. 
INTERNATIONAL MONETARY FUND (IMF). Members' quotas and voting power, and IMF board of governos. Disponível em: <https://www.imf.org/external/np/sec/memdir/members.aspx>. Acesso em: 18 set. $2020 b$.

INTERNATIONAL MONETARY FUND (IMF). Medidas de política para enfrentar a crise do coronavírus, 16 mar. 2020c. Disponível em: < https://www.imf.org/pt/Publications/Policy-Papers/Issues/2020/03/I 6/ Policy-Steps-to-Address-the-Corona-Crisis-49262>. Acesso em: 18 set. 2020c.

INTERNATIONAL MONETARY FUND (IMF). Joint Statement World Bank Group and IMF call to action on debt of IDA countries, 25 Mar. 2020d. Disponível em: <https:/www.imf.org/en/News/ Articles/2020/03/25/pr20 I 03 -joint-statement-world-bank-group-and-imf-call-to-action-ondebt-of-ida-countries >. Acesso em: 18 set. 2020.

INTERNATIONAL MONETARY FUND (IMF). IMF enhances debt relief trust to enable support for eligible low-income countries in the wake of the Covid-19 pandemic, 27 Mar. 2020e. Disponível em: <https:// www.imf.org/en/News/Articles/2020/03/27/pr20I I 6-imf-enhances-debt-relief-trust-to-enablesupport-for-eligible-lic-in-wake-of-covid-19>. Acesso em: 18 set. 2020.

INTERNATIONAL MONETARY FUND (IMF). IMF adds liquidity line to strengthen Covid- 19 response, 15 Apr. 2020f. Disponível em: < https://www.imf.org/en/News/Articles/2020/04/15/pr20 I63-imf-addsliquidity-line-to-strengthen-covid-19-response>. Acesso em: 18 set. 2020.

INTERNATIONAL MONETARY FUND (IMF). Transcript of IMF Press Briefing, 2 I May 2020g. Disponível em: < https://www.imf.org/en/News/Articles/2020/05/21/tr052 I 20-transcript-of-imf-press-briefing > . Acesso em: 18 set. 2020

INTERNATIONAL MONETARY FUND (IMF). IMF Rapid Credit Facility (RCF), 9 Apr. 2020 h. Disponível em: <https://www.imf.org/en/About/Factsheets/Sheets/2016/08/02/21/08/Rapid-CreditFacility\#: : :text $=$ The $\% 20$ Rapid\%20Credit\%20Facility\%20(RCF,urgent\%20balance $\% 20$ of $\% 20$ payments\%20need>. Acesso em: 18 set. 2020.

INTERNATIONAL MONETARY FUND (IMF). The IMF's Rapid Financing Instrument (RFI), 9 Apr. 2020i. Disponível em: <https://www.imf.org/en/About/Factsheets/Sheets/2016/08/02/19/55/ Rapid-Financing-Instrument\#: : text $=$ The\%20Rapid\%20Financing\%20Instrument $\% 20$ (RFI,diverse\%20needs\%20of\%20member\%20countries>. Acesso em: 18 set. 2020.

INTERNATIONAL MONETARY FUND (IMF). World economic outlook, April 2020: the great lockdown, Apr. 2020j. Disponível em: <https://www.imf.org/en/Publications/WEO/Issues/2020/04/14/weoapril-2020>. Acesso em: 18 set. 2020.

INTERNATIONAL MONETARY FUND (IMF). World economic outlook update, June 2020k. Disponível em: <https://www.imf.org/en/Publications/WEO/Issues/2020/06/24/WEOUpdateJune2020>. Acesso em: 18 set. 2020.

INTERNATIONAL MONETARY FUND (IMF). Transcript of press briefing by Kristalina Georgieva following a Conference Call of the International Monetary and Financial Committee, 27 Mar. 2020l. Disponível em: $<$ https://www.imf.org/en/News/Articles/2020/03/27/tr032720-transcript-press-briefing-kristalinageorgieva-following-imfc-conference-call>. Acesso em: 18 set. 2020.

INTERNATIONAL MONETARY FUND (IMF). World economic outlook update, June 2020m. Disponível em: <https://www.imf.org/en/Publications/WEO/Issues/2020/06/24/WEOUpdateJune2020>. Acesso em: 18 set. 2020. 
INTERNATIONAL MONETARY FUND (IMF). World Economic Outlook Update, June 2020n. Disponível em: <https://www.imf.org/en/Publications/WEO/Issues/2020/06/24/WEOUpdateJune2020>. Acesso em: 18 set. 2020.

IZQUIERDO, A. et al. Salir del Túnel Pandémico con Crecimiento y Equidad: una estrategia para un nuevo compacto social en América Latina y el Caribe. Washington: IDB, 2020. Disponível em: <https:// publications.iadb.org/es/salir-del-tunel-pandemico-con-crecimiento-y-equidad-una-estrategiapara-un-nuevo-compacto-social-en-america-latina-y-el-caribe>. Acesso em: 18 set. 2020.

PAGÉS, C. et al. Del Confinamiento a la Reapertura: consideraciones estratégicas para el reinicio de las actividades en América Latina y el Caribe en el marco de la Covid- 19. Washington: IDB, 2020. Disponível em: $<$ https://publications.iadb.org/es/del-confinamiento-a-la-reapertura-consideraciones-estrategicaspara-el-reinicio-de-las-actividades-en-america-latina-y-el-caribe-en-el-marco-de-la-covid-19>. Acesso em: 18 set. 2020.

THE GROUP OF TWENTY (G20). Communiqué. G20 Finance ministers \& Central Bank governs, meeting 18 July 2020. Disponível em: <https://g20.org/en/media/Documents/Final\%20G20\%20FMCBG\%20 Communiqu\%C3\%A9\%20-\%20July\%202020.pdf>. Acesso em: 18 set. 2020.

UNITED NATIONS EDUCATIONAL, SCIENTIFIC AND CULTURAL ORGANIZATION (UNESCO). Education: from disruption to recovery. Disponível em: <https://en.unesco.org/covidI9/educationresponse>. Acesso em: 18 set. 2020.

WORLD BANK. Global Economics Prospects. Washington: World Bank, 2020a. Disponível em: <https:// www.worldbank.org/en/publication/global-economic-prospects>. Acesso em: 18 set. 2020.

WORLD BANK. How the World Bank Group is helping countries with Covid- 19 (coronavirus), 2020b. Disponível em: < https://www.worldbank.org/en/news/factsheet/2020/02/I I/how-the-world-bankgroup-is-helping-countries-with-covid-19-coronavirus>. Acesso em: 18 set. 2020.

WORLD BANK. Debt service suspension and Covid-19, I I May 2020c. Disponível em: < https://www. worldbank.org/en/news/factsheet/2020/05/1 1/debt-relief-and-covid-19-coronavirus >. Acesso em: 18 set. 2020.

WORLD BANK. Amid multiple crises, World Bank Group refocuses Programs and Increases financing to $\$ 74$ billion in fiscal year 2020, 10 July. 2020d. Disponível em: < https://www.worldbank.org/en/ news/press-release/2020/07/I0/amid-multiple-crises-world-bank-group-refocuses-programs-andincreases-financing-to-74-billion-in-fiscal-year-2020>. Acesso em: 18 set. 2020.

WORLD BANK. Covid-1 9: debt service suspension initiative, I 9 June 2020e. Disponível em: <https:// www.worldbank.org/en/topic/debt/brief/covid-19-debt-service-suspension-initiative >. Acesso em: 18 set. 2020. 


\section{0 \\ 0 G20 e a Pandemia entre a economia e a saúde}

Luiz Eduardo Fonseca

Grupo dos Vinte (G20) foi criado em 1999 para responder às crises financeiras do final do século XX (México em 1994, Ásia em 1997 e Rússia em 1998). Não constitui uma organização internacional, e sim um fórum formado, inicialmente, por ministros de finanças e chefes dos bancos centrais das 19 maiores economias do mundo, com presidência rotativa a cada ano, sem secretariado permanente nem recursos próprios. O G20 pode ser lido como um arranjo moldado num sistema-mundo (Wallerstein, 1986) capitalista neoliberal no qual a economia está sempre na frente e, portanto, no centro da sua agenda, organizada e estruturada pelo país na sua presidência pro tempore.

Essa característica ficou marcada na crise financeira global de 2008, quando o fórum assumiu seu papel de ator importante na esfera multilateral e realizou sua primeira Cúpula de Chefes de Estado do G20, em Washington, para buscar uma solução multilateral para a crise junto com o Banco Mundial e o Fundo Monetário Internacional (FMI). Esse encontro, realizado em novembro de 2008, durante o governo Bush, sob pressão da França e da Inglaterra, foi denominado Cúpula sobre os Mercados Financeiros e a Economia Global.

A declaração da Cúpula de Washington do G20 cita como uma das bases da crise financeira as políticas macroeconômicas inconsistentes e insuficientemente coordenadas, e aponta a necessidade de reformas estruturais, refletindo a pressão de outros atores para o reconhecimento da importância das políticas sociais em fóruns de governança global $(G 20,2008)$. Foi em 2010, na Cúpula de Seul do G20, que se fez a primeira menção à combinação entre políticas sociais e socioeconômicas. Desde então o G20 tem aprimorado constantemente sua governança em políticas sociais, procurando tornar mais efetivas suas recomendações, com repercussões nas políticas nacionais e 
na prática de seus membros. Entretanto, a extensão do foco das políticas sociais nas atenções do G20 depende muito do desempenho do país que está na presidência pro tempore do grupo.

Em 2014, durante a epidemia de ebola na África, que matou mais de 4.000 pessoas, o posicionamento do G20, na sua Cúpula de Brisbane (Japan, 2014), foi muito pobre. No penúltimo parágrafo da declaração, os países do G20 se mostraram "preocupados" e apoiaram uma resposta internacional urgente e coordenada, se comprometendo a fazer "tudo que fosse possível" para conter a crise e a ela responder, instando instituições financeiras internacionais a ajudar os países afetados.

Totalmente diferente foi o posicionamento do G20 diante pandemia Covid-19, que afetou todos os países do mundo se colocando como a maior ameaça na memória viva à saúde, ao bem-estar e à economia global. Em 26 de março, os líderes do G20 realizaram uma cúpula extraordinária virtual com foco no Covid-19 e, diante do severo impacto econômico dessa pandemia, assumiram a defesa da saúde de forma surpreendente, inclusive ampliando o acesso ao crédito e flexibilizando regras financeiras consideradas sacrossantas.

Neste ensaio procuro analisar o papel, as interlocuções e a abrangência das ações do G20 como fórum de países que busca soluções, mediante o fortalecimento das organizações multilaterais, para enfrentar crises financeiras e de outros setores, como o caso da saúde com a Covid-19. Procuro analisar também as expectativas quanto ao arranjo do G20 como modelo de estrutura para uma instância multilateral e sua efetividade em relação às suas deliberações, tomadas de decisão, entregas e gestão política interna, ajustadas às políticas nacionais e à prática de seus membros (Kirton, Kulik \& Bracht, 2015).

\section{O G20 NO SISTEMA MULTILATERAL DE COMBATE À COVID-19}

A criação das Nações Unidas (ONU), há 75 anos, reforçou o multilateralismo como pilar importante na manutenção da paz mundial e da cooperação para a prosperidade global. Nesse período, segundo arranjos geopolíticos, outros grupamentos multilaterais se formaram, como a Organização do Tratado do Atlântico Norte (Otan, 1949), a Comunidade Europeia (1950), o Movimento dos Não Alinhados (1955) e a União Africana (1963), assim como outras instâncias segundo arranjos econômicos, como a Organização para a Cooperação e Desenvolvimento Econômico (OCDE, 196I), o G77 (1964), o G7 (1975) e o G20 (1 999). Todos esses grupos formam, portanto, um sistema multilateral (mais tarde acrescido de grupamentos regionais e sub-regionais) consolidado com total respeito às Nações Unidas e suas agências e em consonância com estas. 
Contudo, recentemente alguns países têm questionado a globalização econômica como limitante da soberania nacional e influenciadora nas suas decisões, além das formas atuais de governança global multilateral, que estariam tomando decisões antidemocráticas. O modelo de globalização imposto pelo Ocidente, após a II Guerra Mundial, colocando a "democracia" a trabalhar para a economia global, em vez do contrário, teria sido uma das argumentações para o crescimento de um certo populismo de direita (Rodrik, 2016). Nos anos recentes, alguns países têm assumindo posições protecionistas e nacionalistas, com pouco compromisso multilateral, baseadas em uma narrativa neoliberal com abordagens peculiares de políticas públicas de proteção social.

Diferentemente da crise financeira de 2008, quando o foco era salvar bancos, a crise provocada pela pandemia da Covid-19 propiciou inúmeras declarações políticas e programas econômicos buscando proteger também as pessoas, principalmente os mais vulneráveis, e revelou discordâncias quanto à coordenação global da crise. Recomendações sanitárias e programas socioeconômicos preconizados por organizações e instâncias multilaterais acabaram sendo implementados nacionalmente, de acordo com os governos locais e seus posicionamentos políticos.

Esta pandemia não tem sido apenas uma emergência sanitária com efeitos socioeconômicos globais. Tem sido um momento decisivo para o atual sistema global de cooperação política e socioeconômica. A competição estratégica entre Estados Unidos da América (EUA), China e Rússia, escancarada pela Covid- I 9, ameaçando a malha das organizações multilaterais e, inclusive, o papel coordenador da Organização Mundial da Saúde (OMS), trouxe à tona problemas há muito escamoteados no concerto de nações, como a desigualdade em todas suas manifestações (econômica e social, racial, religiosa, de gênero, entre outras), além de questões ambientais, de infraestrutura urbana, de tecnologias digitais, de deslocamentos de populações, entre muitas outras.

O G20 teve papel relevante na resposta à crise de 2008, coordenando a estabilização do sistema financeiro global; desde então, os acordos desse grupo não têm sido tão dramáticos ou abrangentes (Atkinson, 2020). Contudo, a atuação do G20 tem sido importante para resolver diferenças em múltiplas questões globais e, diante de uma crise global como da Covid-19, a rede G20 foi logo chamada a se manifestar e participar em diversas iniciativas e instâncias multilaterais.

No mesmo dia em que a OMS declarou estado de pandemia para a Covid- 19, a Global Solution Summit fez um pronunciamento exortando o G20 a assumir um papel relevante na estabilização da economia mundial e na ajuda aos países em desenvolvimento na gestão e na orientação da crise (Global Solutions, 2020). No dia seguinte, em 12 de março de 2020, a Câmara de Comércio Internacional, preocupada com as restrições 
de viagem e comércio, se posicionou em favor de uma tomada de decisão do G20 para garantir o acesso a suprimentos médicos essenciais e o financiamento necessário no combate à Covid- 19 (ICC, 2020). No dia seguinte, a OMS lançou o Fundo Solidário de Resposta à Covid-19 para receber doações privadas de indivíduos, corporações e instituições para o enfrentamento global da pandemia (WHO, 2020a).

Ainda em março, o Grupo dos Sete (G7) conclamou o G20 para uma resposta relacionada à saúde pública, aos empregos e ao crescimento econômico e, em seguida, a OMS lançou o programa Solidarity Trial, para ampliar as pesquisas clínicas e biológicas para novos tratamentos e vacinas para a Covid- 19 (WHO, 2020b). Na mesma semana, o Conselho da OCDE se reuniu e fez um apelo ao G20 para apoiar um novo Plano Marshall.

A Cúpula Virtual do G20 ocorreu no dia 26 de março de 2020. Numa declaração conjunta os membros se comprometeram com o reforço do multilateralismo, junto à OMS, ONU, FMI e Banco Mundial, para sanar futuros danos na economia global, em especial nos países de baixa e média rendas, com foco na capacitação e ajuda ao continente africano na consolidação de sua defesa sanitária (G20, 2020a). O G20 prometeu injetar 5 trilhões de dólares na economia global por meio de um Plano de Ação elaborado por seus bancos centrais e ministérios da Economia.

Durante a reunião do G20, o diretor-geral da OMS, Tedros Adhanom, lembrou que a humanidade somos todos, compartilhamos o mesmo planeta, as mesmas esperanças, os mesmos sonhos e o mesmo destino, e fez três pedidos ao grupo: I) combater a pandemia com determinação, com a ciência e suas evidências; 2) dar resposta global à Covid-19, apoiando o Plano Estratégico de Preparação e Resposta e os países africanos com pacotes de estímulo e alívio da dívida; 3) trabalhar em conjunto na produção e distribuição equitativa dos insumos essenciais e eliminar barreiras comerciais que colocam os trabalhadores da saúde e seus pacientes em risco (WHO, 2020c).

O pronunciamento de diferentes agências pedindo que o G20 se posicionasse demonstra a importância do grupo como novo ator no arranjo global da questão multilateral.

A relação das Nações Unidas, do G7 e da União Europeia (UE) com o G20 se faz através de uma rede informal de formuladores de políticas, tais como a OCDE, o Global Solutions Summit, além dos diferentes grupos de trabalho no âmbito do próprio G20 (T20, C20, W20, entre outros) que aconselham e preparam propostas para cúpulas de alto nível, proclamando reconhecimento da liderança da ONU em suas diversas instâncias técnicas setoriais. A ligação direta entre esses conselheiros e os líderes do G20 funciona como impulsionador da cooperação e da garantia de pré-acordos rápidos quando uma reunião se aproxima. 
Manifestando a necessidade de reforçar o multilateralismo, a Assembleia Geral virtual da ONU, de 2 de abril, aprovou na sua resolução 74/270 o Global Solidarity to Fight the Coronavirus Disease 2019, apoiado enfaticamente pela mobilização de fundos coordenada pela OCDE, com apoio de diversos grupos corporativos e grupos regionais multilaterais (Unga, 2020). Dias depois, ministros das Finanças e governadores dos bancos centrais do G20, reunidos virtualmente, discutiram ações para atacar a pandemia e lançaram um Plano de Apoio à Economia Global na Covid-19, cujos principais objetivos eram proteger vidas, salvaguardar os empregos e rendas das pessoas, restaurar a confiança, preservar a estabilidade financeira, reavivar e recuperar mais fortemente o crescimento, minimizar interrupções nas cadeias globais de suprimentos e fornecer ajuda a todos os países que precisam de assistência, alocando mais de US $\$ 200$ bilhões para o financiamento de países emergentes e de baixa renda (Japan, 2020).

\section{REUNIÃO DE MINISTROS DA SAÚDE DO G20 DURANTE A PANDEMIA DA COVID-19 E A CRISE DO MULTILATERALISMO}

Em plena pandemia, a saúde tem sido usada como palco para os antagonismos no cenário político global e questionamentos nas bases do multilateralismo.

No dia 14 de abril de 2020, os EUA suspenderam o pagamento de sua contribuição à OMS até que se apurassem os "erros" da organização na condução da resposta à pandemia da Covid-19, principalmente em relação à China. A saída dos EUA da OMS foi oficializada em 4 de julho. Essa postura norte-americana, apoiada por alguns países, exprimindo interesses nacionais e questionando o atual modelo gerencial e de atuação das instâncias multilaterais, acabou se expressando também na reunião de ministros da Saúde do G20.

Um dia antes da reunião dos ministros da Saúde do G20, em 18 de abril de 2020, o Grupo de Trabalho da Saúde (grupo técnico de assessoramento dos ministros) redigiu e aprovou uma proposta de texto de I I páginas a ser submetida aos ministros participantes como base da declaração oficial. Esse rascunho, com 52 parágrafos, reconhecia os sistemas de saúde resilientes, fortes, responsivos, inclusivos e sustentáveis como fundamentais, assim como o mandato da OMS na coordenação da luta internacional contra a pandemia. O Grupo de Trabalho em Saúde do G20 também preparou um documento chamado "G20: ações urgentes de combate ao Covid-19", com três partes: I) Princípios (colaboração internacional, cooperação e resposta multissetorial e os mais vulneráveis em primeiro lugar); 2) Respostas imediatas (a. financiamento, b. diagnósticos, terapêuticos e vacinas, c. estratégias de apoio e d. comunicar-se de 
forma transparente); 3) Resposta a longo prazo (preparação e resposta do sistema de saúde, incluindo sua resiliência e capacidade) (Wintour, Harvey \& Beaumont, 2020).

Contudo, no dia seguinte, durante a reunião virtual, a equipe dos EUA, numa atitude hostil, questionou a atuação da OMS diante da conduta da China no manejo da epidemia. Em vez de uma declaração detalhada, os ministros da Saúde do G20 emitiram uma breve declaração dizendo que havia lacunas na maneira como o mundo lidava com pandemias. Essa breve declaração de uma página, chamada "Os ministros da Saúde do G20 coordenam os esforços para combater a Covid- 19" (Wintour, Harvey $\varepsilon$ Beaumont, 2020), simplesmente enfatizou que "a saúde e o bem-estar das pessoas estão no centro de todas as decisões tomadas para proteger vidas, combater doenças, fortalecer a segurança global em saúde e aliviar os impactos socioeconômicos resultantes da Covid-19" e reconheceu que a pandemia tem mostrado fraquezas sistêmicas nos sistemas de saúde. O documento também reconheceu: I) vulnerabilidades na capacidade de prevenir e responder à pandemia e à segurança global; 2) necessidade de ações para melhorar a preparação para o enfrentamento de pandemias; 3) a importância da utilização de soluções digitais; 4) a ênfase na segurança do paciente; e 5) a importância da melhoria dos sistemas de saúde com base em valor de resultados e combate à resistência antimicrobiana.

O clima da reunião ficou abalado pela atitude inesperada dos EUA, que repercutiu na mídia mundial. O jornal The Guardian, por exemplo, afirmou que os EUA armaram uma arapuca para a declaração do G20 que fortalecia a OMS:

A hostilidade dos EUA em relação à OMS anulou a publicação de um comunicado dos ministros da Saúde do G20 que se comprometia a fortalecer o mandato da OMS na coordenação de uma resposta à pandemia global de coronavírus. Em vez de uma longa declaração com parágrafos detalhados, os líderes emitiram uma breve declaração dizendo que havia lacunas na maneira como o mundo lidava com as pandemias. O fracasso em concordar com uma declaração sublinha até que ponto a pandemia se tornou um palco que reproduz um desacordo global mais amplo entre os EUA e a China, no qual outros países se veem cada vez mais forçados a tomar partido.

A declaração final, sem fazer nenhuma menção de reconhecimento à coordenação multilateral da OMS, exortou os ministros da Saúde do G20 a trocar experiências nacionais e adotar medidas preventivas para conter a pandemia, compartilhando conhecimento e fechando lacunas em suas capacidades de resposta e prontidão. Ou seja, um claro retrocesso na abordagem multilateral e, ao contrário, o fortalecimento de uma postura voltada para trocas bilaterais calcadas em "experiências nacionais". Por fim, a declaração se exime de qualquer monitoramento de suas próprias decisões ao acordar que "os 
ministros tomarão quaisquer outras medidas que possam ser necessárias para conter a pandemia e se reunirão novamente quando necessário”.

Nesse sentido, criou-se um paradoxo dentro do próprio G20. Ao passo que a reunião de cúpula do grupo se comprometeu junto à OMS, ONU, FMI e Banco Mundial com o reforço do multilateralismo, principalmente para sanar futuros danos na economia global, prometendo injetar 5 trilhões de dólares na economia global através de um Plano de Ação elaborado por seus bancos centrais e ministérios da Economia e apoiar as iniciativas carreadas pela OCDE e UE para a pesquisa de medicamentos e vacinas no combate à Covid-19, os próprios ministros da Saúde do G20 se eximiram de se manifestar em favor de medidas que afetam diretamente suas áreas de atuação.

Pela primeira vez neste século, economia e saúde dividem a atenção de todos os países do globo. O risco de uma recessão econômica, a necessidade de novos comportamentos individuais e coletivos e o apelo à solidariedade global clamam por um futuro em que os três pilares do desenvolvimento sustentável (econômico, social e ambiental) deverão ser levados mais a sério. A economia deverá se repensar e, portanto, nos últimos anos o tema do financiamento do desenvolvimento e da cooperação entre os povos vem tomando espaço nas agendas tanto da OCDE quanto do G20.

\section{O G20, A OCDE E A AJUDA OFICIAL AO DESENVOLVIMENTO}

A Organização para a Cooperação e Desenvolvimento Econômico (OCDE), fundada em I 96 I para estimular o progresso econômico e o comércio mundial, é uma organização econômica intergovernamental que conta com 38 países-membros. Alberga mais de trezentos comitês e grupos de trabalho que abrangem quase todas as áreas de formulação de políticas. Esses comitês propõem soluções, avaliam dados e políticas e revisam as ações políticas entre os países-membros (OCDE, 2020c).

A OCDE tem sido uma das principais instituições econômicas do mundo desde a sua criação, contudo, na entrada do século XXI, outras organizações internacionais surgiram para ampliar a arquitetura econômica global, principalmente o G20. No entanto, a OCDE converteu o que poderia ser uma concorrência em parceria e oportunidade. Criou um fórum e um centro de conhecimento exclusivo para dados e análises, troca de experiências, compartilhamento de práticas e conselhos sobre políticas públicas que tem realizado cada vez mais tarefas operacionais, de implementação e de monitoramento para o G20, que por si tem suas capacidades limitadas a grupos de trabalho.

As duas entidades cooperam cada vez mais para resolver suas respectivas deficiências. O aumento da cooperação permitiu que a OCDE recuperasse sua relevância 
dentro da arquitetura de governança econômica global, ao mesmo tempo que o funcionamento do G20 é reforçado graças às contribuições da OCDE sobre um número crescente de questões.

A crescente sinergia entre ambas as organizações, que congregam praticamente os mesmos membros, levanta algumas preocupações sobre o papel e o funcionamento dessas entidades na arquitetura da ajuda e assistência ao desenvolvimento. Ambas atuam junto a governos, formuladores de políticas e cidadãos, trabalhando no estabelecimento de padrões internacionais baseados em evidências e na busca de soluções para uma série de desafios sociais, econômicos e ambientais.

Contudo, desde 1969 o Comitê de Assistência ao Desenvolvimento da OCDE (CAD) define e promove o que é conhecido como Ajuda Oficial ao Desenvolvimento (AOD), que visa especificamente ao desenvolvimento econômico e ao bem-estar dos países em desenvolvimento. A AOD continua a ser a principal fonte de financiamento para a ajuda ao desenvolvimento, que tem um componente de doação de pelo menos $25 \%$ (OECD, 2020a). Os membros do CAD/OCDE justificam anualmente as solicitações de assistência oficial ao desenvolvimento a seus respectivos parlamentos.

Foi por intermédio do CAD que a OCDE promoveu os fóruns de Alto Nível sobre a Eficácia da AOD que produziram as famosas declarações de Roma (2003), Paris (2005), Accra (2008) e Busan (20ll), nas quais se discutiu e se preconizou a formulação de princípios para uma ajuda internacional efetiva aos países em desenvolvimento. Segundo a OCDE, a formulação desses princípios surgiu da necessidade de entender por que a AOD não estava "produzindo" resultados palpáveis de desenvolvimento, e se deveria também intensificar os esforços para o cumprimento das metas ambiciosas estabelecidas pelos Objetivos de Desenvolvimento do Milênio (ODM) (OECD, 2020b). Esses eventos de alto nível acabaram endossados por diversas organizações e entidades internacionais, entre as quais o G20 e mais de cem países, como o modelo para maximizar o impacto da ajuda.

Acontece que "produtos eficazes" de desenvolvimento são, como dito acima, baseados em evidências e na busca de soluções, muitos deles preconizados em policy briefs da própria OCDE e do G20, geralmente fundamentados em valores básicos das sociedades e na visão de mundo dos países doadores. Seriam uma versão light do que antes foi muito criticado como "condicionalidades" da ajuda e do financiamento internacional?

Como procedimentos "baseados em evidências" são expandidos na estrutura da "ajuda" aos países? Um pequeno exemplo foi a adoção da chamada Avaliação de Impacto Regulatório (AIR), geralmente considerada como "avaliação de impacto 
da inflação". Primeiramente, em 1978, essa avaliação passou a ser exigida pela administração Carter nos EUA e foi ampliada durante o governo Reagan, com a análise de custo-benefício tornando-se uma abordagem metodológica necessária. A AIR foi logo adotada pela Austrália (1985). Em meados dos anos 1990, aproximadamente 12 países da OCDE já haviam implementado requisitos de AIR de alguma forma. Até 2000, vinte dos 28 países da OCDE tinham implementado os requisitos da AIR e, atualmente, praticamente todos os países da OCDE usam AIR, cuja exigência também começou a ser fortemente promovida pelo Banco Mundial aos seus países clientes. Como resultado, um número crescente de países em desenvolvimento adota agora os requisitos da AIR (Jakupec \& Kelly, 20 I6).

Desde 2019, a OCDE vem reportando e medindo os empréstimos da AOD com mais precisão e credibilidade, garantindo a comparabilidade de dados entre os provedores, incentivando cada vez mais a alocação de recursos concessionários para a implementação dos ODS e promovendo maior transparência e maior responsabilização, de forma a garantir que a AOD vá aonde é mais necessário e tenha o maior impacto no desenvolvimento. Não se nega a importância dessas medidas, mas a questão é a quem elas beneficiam mais, aos países doadores ou aos países beneficiários, aos quais cabe o aperfeiçoamento de seus quadros técnicos para robustecer o diálogo e poder de argumentação entre os parceiros.

Esse será um ponto crucial nas negociações e aplicações dos empréstimos e doações das organizações financeiras, como o Banco Mundial e o FMI, assim como das instâncias multilaterais como a OCDE, a UE e o G20 no enfrentamento da pandemia da Covid-19. Como tal, deverá ser tratado com base nos padrões de equidade e solidariedade que vêm pautando os discursos dessas agências no durante e com projeções para um futuro pós-pandemia.

A Covid-19 põe em jogo o papel do G20 no multilateralismo tanto do ponto de vista epidemiológico (EUA, Brasil, África do Sul e Índia, membros do grupo, estão entre os países com maior índice de contaminação) quanto do ponto de vista político e empresarial, uma vez que a pandemia exige coordenação e priorização de políticas e de investimentos. Por um lado, o G20 incorpora as mesmas tensões que persistem nas organizações multilaterais do sistema ONU; por outro, experimenta inovação por não ter uma sede e estrutura administrativa fixa, o que diminui custos, e por incorporar novos atores e grupos de trabalho nas suas discussões e na construção de suas recomendações. 
Nestes cinco meses de enfrentamento da pandemia, o G20 já realizou e emitiu declarações em diferentes frentes como educação, agricultura e gênero, entre outras. Contudo, sua postura mais contundente ainda é no campo da economia, cuja vertente mais comprometida se faz passar pelo que chama de "investimento em infraestrutura", que resvala no acesso a eletricidade, água limpa, serviços de saúde, educação, saneamento e transporte público para melhorar a vida das pessoas. Assim, na análise de diversos documentos percebe-se que a questão da saúde, com foco na Covid-19, preenche os primeiros parágrafos de todas as declarações de grandes atores globais (ONU, OIT, OMC, G7, G20, OCDE, EU, entre outros), com subsequente agregação de suas necessidades específicas, mas com prioridade para planos de ajuste econômico.

O recente Encontro Virtual de Dirigentes de Ministérios das Finanças e Bancos Centrais do G20, realizado em julho de 2020, previu forte contração da economia global e pediu que sejam tomadas medidas imediatas e excepcionais para enfrentar a pandemia e seus "impactos entrelaçados na saúde e nas áreas sociais e econômicas". Para isso, preconiza a implementação de ações de estabilidade fiscal, monetária e financeira sem precedentes, para que as instituições financeiras internacionais e organizações internacionais relevantes possam fornecer apoio crítico aos países emergentes, em desenvolvimento e de baixa renda, reiterando o compromisso de garantir uma rede de segurança financeira global, com um FMI mais forte (G20, 2020b).

Paralelamente, durante a pandemia, o Banco Mundial anunciou até US\$ 12 bilhões de apoio imediato às respostas dos países à pandemia e o FMI declarou, tardiamente, que poderia relaxar as medidas de ajuste estrutural para permitir que os países invistam na prevenção e tratamento do coronavírus. Com apoio da OCDE e da UE, espera-se uma iniciativa mais urgente e decisiva do Banco Mundial e do FMl, como a amortização da dívida, seguindo a declaração do G20, que exige um plano de ação para salvaguardar a economia global em resposta à Covid- 19.

Ao examinar o caminho tomado pelos comunicados tanto das suas cúpulas de líderes quanto de suas reuniões setoriais, percebe-se que a agenda política e econômica preconizada pelo G20 não vai muito além das iniciativas multilaterais preexistentes, desenvolvidas por organismos internacionais mais tecnocráticos. Isso destaca a força e influência duradoura desses organismos na política da regulação financeira internacional, mesmo diante de uma crise importante que politizou a política financeira em um grau incomum.

Paradoxalmente, assombrando a bandeira do "novo normal" e lembrando que a coisa mais velha no mundo é o novo, a UE está lutando por um instrumento comum de enfrentamento da dívida na Zona do Euro chamado "laços corona" para reforçar suas próprias economias. 
Na verdade, o Norte Global já mobilizou centenas de bilhões de dólares, que estão disponíveis para financiar medidas de resgate, como cortes de impostos, benefícios de desemprego prolongados, feriados hipotecários e liquidez para pequenas e médias empresas (Kickbusch et al., 2020). A utilização desses recursos e suas condicionalidades será um grande teste para o que vem sendo chamado de "novo normal". Resta ainda saber como serão utilizados todos esses dólares, como sairá o campo da saúde depois deste furacão: fortalecido ou enfraquecido?

Para os cidadãos comuns é bastante desconcertante vivenciar experiências de confinamento e austeridade e ver enormes somas de dinheiro serem subitamente disponibilizadas para fortalecer a economia e a infraestrutura nacional e os serviços públicos famintos de investimentos. Políticos que chegaram ao poder com planos para enfraquecer o governo, desmantelar o Estado e privatizar funções governamentais estão agora discutindo como fortalecer grandes setores estratégicos. Talvez devamos apostar no multilateralismo apoiado na volta do Estado forte pós-pandemia; contudo, não há como prever futuras agendas políticas ou lideranças ao final desta travessia.

\section{REFERÊNCIAS}

ATKINSON, C. G20 leaders must answer to Covid- 19. Science, 368(6.487): I 1 1, 2020.

GLOBAL SOLUTIONS. Site. Disponível em: <https://www.global-solutions-initiative.org/>. Acesso em: 18 set. 2020.

INTERNATIONAL CHAMBER OF COMMERCE (ICC). Site. Disponível em: < https://iccwbo.org/>. Acesso em: 18 set. 2020.

JAKUPEC, V. \& KELLY, M. Development aid: regulatory impact assessment and conditionality. Journal Impact Assessment and Project Appraisal, 34(4): 319-329, 2016.

JAPAN. Ministry of Foreign Affairs of Japan. G20 Leaders' Communiqué. In: BRISBANE SUMMIT: G20 LEADERS COMMUNIQUÉ, 15-16 Nov. 2014, Brisbane. Disponível em: <https://www.mofa.go.jp/ files/000059841.pdf >. Acesso em: 18 set. 2020.

JAPAN. Ministry of Finances. G20 Finance Ministers and Central Bank Governors Meeting, Communiqué, 15 Apr. 2020. Disponível em: <https://www.mof.go.jp/english/international_policy/convention/ g20/g20_20200415_01.htm >. Acesso em: 18 set. 2020.

KICKBUSCH, I. et al. Covid- 19: how a virus is turning the world upside down. BMJ, 369: m I 336, 2020. Disponível em: <https://doi.org/10.1136/bmj.mI336>. Acesso em: 18 set. 2020.

KIRTON, J.; KULIK, J. \& BRACHT, C. Slowly succeeding: G20 social policy governance. In: KAASCH, A. E MARTENS, K. Actors and Agency in Global Social Governance. Oxford Scholarship Online, Nov. 2015.

ORGANISATION FOR ECONOMIC CO-OPERATION AND DEVELOPMENT (OECD). Official Development Assistance (ODA). Disponível em: < https://www.oecd.org/dac/financing-sustainable-development/ development-finance-standards/official-development-assistance.htm>. Acesso em: 18 set. 2020a. 
ORGANISATION FOR ECONOMIC CO-OPERATION AND DEVELOPMENT (OECD). The High Level Fora on Aid Effectiveness: a history. Disponível em: <https://www.oecd.org/dac/effectiveness/ thehighlevelforaonaideffectivenessahistory.htm >. Acesso em: 18 set. $2020 \mathrm{~b}$.

ORGANISATION FOR ECONOMIC CO-OPERATION AND DEVELOPMENT (OECD). Organisational structure. Disponível em: <https://www.oecd.org/about/structure/>. Acesso em: I8 set. 2020c.

RODRIK, D. Put globalization to work for democracies. The New York Times, New York, 17 Sept. 2016.

THE GROUP OF TWENTY (G20). Declaration Summit on Financial Markets and the World Economy, 15 Nov. 2008. Disponível em: <https://g20.org/en/g20/Documents/2008-Washington-Declaration\%20 of $\% 20$ the $\% 20$ Summit $\% 20$ on $\% 20$ Financial\%20Markets $\% 20$ and\%20the $\% 20$ World\%20Economy. pdf $>$. Acesso em: 18 set. 2020.

THE GROUP OF TWENTY (G20). Extraordinary G20 Leaders' Summit Statement on Covid- 1 9. Disponível em: $<$ https://g20.org/en/media/Documents/G20_Extraordinary\%20G20\%20Leaders\%E2\%80\%99\%20 Summit_Statement_EN\%20(3).pdf > . Acesso em: 18 set. 2020a.

THE GROUP OF TWENTY (G20). Communiqué. G20 Finance Ministers \& Central Bank Governs, Meeting 18 July 2020. Disponível em: <https://www.mof.go.jp/english/international_policy/convention/g20/ g20_200718.pdf>. Acesso em: 18 set. 2020b.

UNITED NATIONS GENERAL ASSEMBLY (UNGA). Resolution A/RES/74/270. Global solidarity to fight the coronavirus disease 2019 (Covid-19), 3 Apr. 2020. Disponível em: <https://undocs.org/en/A/ RES/74/270>. Acesso em: 18 set. 2020.

WALLERSTEIN, I. Societal development, or development of the World- System? In: WALLERSTEIN, I. The Essential Wallerstein. International Sociology, I( I): I-17, 1986.

WINTOUR, P.; HARVEY, F. \& BEAUMONT, P. US scuppers G20 coronavirus statement on strengthening WHO. The Guardian, London, 20 Apr. 2020. Disponível em: <https://www.theguardian.com/ world/2020/apr/20/us-scuppers-g20-coronavirus-statement-on-strengthening-who>. Acesso em: 18 set. 2020.

WORLD HEALTH ORGANIZATION (WHO). WHO, UN Foundation and partners launch first-of-itskind Covid- 19 Solidarity Response Fund, 13 Mar. 2020a. Disponível em: <https://www.who.int/ news-room/detail/13-03-2020-who-un-foundation-and-partners-launch-first-of-its-kind-covid19-solidarity-response-fund >. Acesso em: 18 set. 2020.

WORLD HEALTH ORGANIZATION (WHO). "Solidarity" clinical trial for Covid- 19 treatments, 2020b. Disponível em: <https://www.who.int/emergencies/diseases/novel-coronavirus-2019/globalresearch-on-novel-coronavirus-20 I 9-ncov/solidarity-clinical-trial-for-Covid-19-treatments $>$. Acesso em: 18 set. 2020.

WORLD HEALTH ORGANIZATION (WHO). G20 Health Ministers virtual Meeting Saudi Arabia, I 9 Apr. 2020c. Disponível em: <https://www.who.int/dg/speeches/detail/g20-health-ministers-virtualmeeting-saudi-arabia >. Acesso em: 18 set. 2020. 


\section{1 Movimento dos Não Alinhados e G77 o Sul Global e a Covid-19}

Regina Ungerer

$\mathrm{N}$ este capítulo é brevemente descrita a criação e o contexto histórico do movimento dos países não alinhados (MNA) e do Grupo dos 77 (G77) e feita uma pequena análise do modo como ambos os grupos foram concebidos, como ultrapassaram os anos da Guerra Fria e como enfrentam os desafios de hoje, no cenário mundial. O MNA é a maior coligação de países depois das Nações Unidas e o G77, a maior organização intergovenamental de países em desenvolvimento das Nações Unidas. Ambos os grupos estão mobilizados para enfrentar a pandemia de Covid- 19.

\section{MOVIMENTO DOS NÃO ALINHADOS}

O Movimento dos Não Alinhados (MNA) é um fórum político formado por um grupo de países que não se alinham oficialmente com nenhum grande bloco de poder ou grupo de países (Azerbaijani Chairmanship to the Non-Aligned Movement, 2020a). A maior coligação de países depois das Nações Unidas, é composto por 120 Estados-membros de todas as partes do mundo e dele também participam 17 estados e dez organizações internacionais com status de observador.

O MNA foi concebido em I 96 I no contexto da polarização das relações internacionais resultantes de blocos e alianças militares da Guerra Fria. Foi o resultado inevitável da luta contra o colonialismo e da necessidade dos países recém-independentes em todas as partes do mundo de proteger e fortalecer sua independência nacional e exercer sua plena soberania em questões políticas e econômicas. Em outras palavras, o MNA foi formado como uma organização de Estados que não desejavam se alinhar formalmente com os Estados Unidos da América (EUA) ou a União Soviética, as duas maiores potências à época, e buscavam permanecer independentes ou neutros. 
A criação do MNA baseou-se nos princípios da Conferência de Bandung realizada em 1955, em que 29 países asiáticos e africanos, que não eram mais colônias europeias, e sim países independentes, se comprometeram a promover a cooperação econômica e cultural entre si e a resistir ao colonialismo ou neocolonialismo por qualquer país. A Conferência de Bandung foi o primeiro grande movimento de resistência coletiva dos países que haviam deixado de ser colônias europeias e se opunham à forma tradicional de ajuda internacional entre os países considerados desenvolvidos do Norte e os países considerados subdesenvolvidos do Sul (Acharya, 2016).

Em 1960, à luz dos resultados alcançados com a Conferência de Bandung, a criação

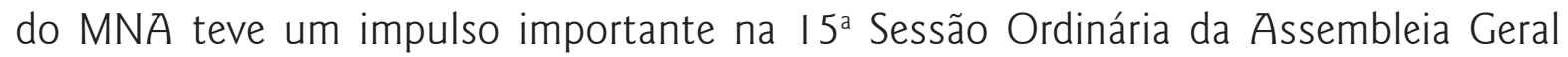
das Nações Unidas (AGNU), durante a qual 17 novos países africanos e asiáticos independentes foram admitidos como membros. Era o início de uma mudança importante no cenário e no balanço de forças dentro da Organização das Nações Unidas (ONU) em favor dos países menos desenvolvidos. Importante destacar o papel desempenhado pelos então chefes de Estado e de governo do Egito, Gamal Abdel Nasser; de Gana, Kwame Nkrumah; da Indonésia, Ahmed Sukarno; da lugoslávia, Josip Broz Tito, e pelo primeiroministro da Índia, Shri Jawaharlal Nehru, que mais tarde se tornariam os fundadores do movimento e seus líderes emblemáticos.

Com uma base geográfica ampla de países, o MNA foi fundado e realizou sua primeira conferência, a Conferência de Belgrado, entre I e 6 de setembro de 1961, sob a liderança dos fundadores e com a participação de 26 países: Afeganistão, Argélia, lêmen, Mianmar, Camboja, Sri Lanka, Congo, Cuba, Chipre, Egito, Etiópia, Gana, Guiné, Índia, Indonésia, Iraque, Líbano, Mali, Marrocos, Nepal, Arábia Saudita, Somália, Sudão, Síria, Tunísia e lugoslávia. O grupo preferiu declarar-se como um movimento, e não como uma organização, a fim de evitar as implicações burocráticas desta última.

Em um contexto mais amplo, o principal fator que contribuiu para a organização da conferência foi o impacto da descolonização e o nascimento de grande número de países africanos recém-independentes no cenário mundial na década de 1960.

O que uniu esse grupo diversificado de países foi seu compromisso coletivo de resistir às pressões das duas grandes potências para que se aliassem a uma ou outra e às ameaças nucleares. Isso significava não se envolver com alianças militares e a elas se vincular, principalmente a Organização do Tratado do Atlântico Norte (Otan), vinculada aos EUA, e o Pacto de Varsóvia, vinculado à União Soviética (Espósito, 20।9).

No entanto, a Conferência de Belgrado preocupava os EUA. Apesar de o objetivo principal da conferência ter sido dar voz a um grupo de países não comprometidos com o Ocidente (EUA) ou com o Leste (União Soviética) e chamar a atenção para os 
desequilíbrios econômicos e financeiros entre os países ricos e pobres, os EUA temiam que a conferência tivesse um cunho "comunista", especialmente por ser organizada e realizada na lugoslávia com a participação de Cuba.

Como o movimento era dominado desde o início por países africanos e asiáticos, houve uma tentativa de incluir países da América Latina na conferência. As tentativas de incluir países latino-americanos desafiavam a hegemonia americana no continente. Chamava a atenção também o relacionamento ambíguo de Cuba com o movimento dos não alinhados. Se por um lado o país era claramente visto como um sólido aliado ao bloco soviético, por outro era um exemplo heroico de um pequeno país nacionalista desafiando um vizinho gigante. Havia uma ambivalência americana entre incentivar ou desencorajar seus aliados menores de participar de um movimento que alguns viam com indiferença, mas outros com preocupação.

Porém, o domínio e a influência americana sobre a América Latina foram suficientes para impedir a participação dos países deste continente na reunião. O Brasil, numa tentativa de influenciar outros países da região, liderou uma campanha inútil para convencê-los a enviar, pelo menos, observadores. Foi uma manobra para diminuir o descontentamento americano por ver seus aliados participando de uma reunião de nações declaradamente não comprometidas com nenhuma das duas partes, quando o que se buscava era exatamente o comprometimento e aliança com um dos lados. Ao final, Bolívia, Brasil e Equador foram os únicos países da América do Sul a enviarem observadores e Cuba foi o único país da América Latina a participar dessa conferência. Brasil continua sendo um membro observador do MNA.

Na conferência foram proclamados os “Dez princípios de Bandung” que nortearam as relações entre as nações, grandes ou pequenas:

1. Respeitar os fundamentos dos direitos humanos e os objetivos e princípios das Nações Unidas.

2. Respeitar a soberania e integridade territorial de todas as nações.

3. Reconhecer a igualdade entre todas as raças e a igualdade entre todas as nações, grandes e pequenas.

4. Não interferir nos assuntos internos de outro país.

5. Respeitar o direito de toda nação de se defender, individual ou coletivamente, em conformidade com a Carta das Nações Unidas.

6. Não usar pactos de defesa coletiva para beneficiar os interesses específicos de qualquer uma das grandes potências. 
7. Abster-se de atos ou ameaças de agressão e uso da força contra a integridade territorial ou a independência política de qualquer país.

8. Resolver todas as disputas internacionais por meios pacíficos, como negociação, conciliação, arbitragem ou acordo judicial, bem como por outros meios pacíficos de escolha das partes, em conformidade com a Carta das Nações Unidas.

9. Promover interesses e cooperação mútuos.

10. Respeitar a justiça e as obrigações internacionais.

Tais princípios foram adotados posteriormente como as principais metas e objetivos da política de não alinhamento e foram essenciais até o início dos anos 90, quanto terminou a Guerra Fria. Seu cumprimento se tornou o critério essencial para a participação de qualquer país no MNA. Esses critérios deixavam claro que o movimento dos não alinhados não havia sido concebido para desempenhar um papel passivo na política internacional, mas para formular suas próprias posições de maneira independente, de modo a refletir os interesses de seus membros.

O MNA continuou crescendo e, com 47 países-membros e dez observadores, organizou sua segunda conferência, realizada entre 5 e 10 de outubro de 1964 no Cairo, Egito. Essa reunião foi marcada pela discussão sobre uma nova ordem econômica que fosse mais justa.

Apesar de toda a sua doutrina antimilitar, o fato é que os países do MNA estiveram envolvidos em várias disputas na década de 1960, como a crise na Indochina, a Guerra do Vietnã, o golpe de Estado no Irã, as guerras árabe-israelenses e os conflitos na América Latina. De fato, essas tensões fizeram com que se passassem seis anos até a realização da terceira conferência do MNA. Foi a partir dessa conferência, realizada em Lusaka, Zâmbia, entre 8 e 10 de setembro de 1970, que o movimento começou realmente a tomar forma. Com 54 membros, a conferência de Lusaka ressaltava o não alinhamento e o progresso econômico. Desde então, os debates do MNA sempre tiveram um foco político e outro econômico.

A quarta conferência do MNA foi realizada em Argel, Argélia, entre 5 e 9 de setembro de 1973, e até hoje é considerada uma das mais importantes. Não só porque o movimento já havia garantido a participação de 75 países-membros plenos, inclusive Argentina e Peru, que participavam pela primeira vez, mas porque estavam presentes oito países observadores e três convidados europeus, Áustria, Finlândia e Suécia. Estavam presentes também o Movimento Popular de Libertação de Angola (MPLA), o Partido Africano pela Libertação da Guiné e Cabo Verde (PAIGC), a Frente de Libertação 
de Moçambique (Frelimo), a Organização Popular da África Sul Ocidental (Swapo, da Namíbia) e a Organização pela Libertação da Palestina (OLP) (Bissio, 20l5).

Desde o início, as ações do MNA foram fatores importantes no processo de descolonização da Ásia e África, e o movimento sempre manteve sua oposição ao apartheid e a não adesão a pactos militares multilaterais. Ao longo de sua história, o MNA desempenhou papel fundamental na preservação da paz e segurança mundiais, diante da complexa situação internacional que exigia lealdade a uma ou outra superpotência. Embora muitos membros do MNA estivessem, de fato, mais bem alinhados com os EUA ou a União Soviética e apesar de alguns conflitos entre seus membros, o movimento manteve uma coesão durante a Guerra Fria.

Com o fim da Guerra Fria, o MNA concentrou-se no desenvolvimento de relações multilaterais e na união entre os países de média e baixa rendas. Até hoje tenta exercer sua influência para evitar rivalidades entre nações, mantendo sua luta contra todas as suas formas e manifestações de colonialismo, neocolonialismo, racismo, ocupação e dominação estrangeira. Apesar de muitos obstáculos, continua combatendo o desarmamento e o uso da força nas relações internacionais. Busca permanentemente aderir às normas e princípios do direito internacional e tem persistido nos avanços para melhorias econômicas, justiça social e sustentabilidade ambiental.

Durante seus quase 60 anos de existência, o MNA reuniu um número crescente de países que, apesar de sua diversidade ideológica, política, econômica, social e cultural, aceitaram seus princípios fundamentais e os objetivos principais do movimento, demonstrando prontidão para realizá-los. Historicamente, os países não alinhados demonstraram a capacidade de superar suas diferenças e encontraram um terreno comum para a ação que leva à cooperação mútua e à defesa de valores compartilhados.

Hoje, os países do Movimento dos Não Alinhados são quase dois terços dos Estadosmembros das Nações Unidas e representam mais da metade da população mundial. Estão particularmente concentrados nos países considerados de média e baixa rendas, embora o MNA também tenha certo número de países de alta renda.

O MNA criou um estilo administrativo único, não hierárquico, proporcionando a todos os seus membros, independentemente do seu tamanho e importância, a oportunidade de participar na tomada de decisões. Sua presidência é rotativa e seu secretariado é mantido no país que detém a presidência. Ao assumir a presidência, o país designa uma seção de seu Ministério de Relações Exteriores para lidar com as questões relacionadas ao MNA. Como os países deste fórum reúnem-se regularmente na ONU, os embaixadores das missões dos países funcionam como ministros do MNA e, em geral, assumem 
uma posição comum e falam em uníssono nas reuniões e negociações. O MNA não possui uma sede oficial e não mantém um website.

Desde seu início, o MNA já foi presidido por 3 I chefes de Estado e já realizou 18 cúpulas de chefes de Estado. A última foi realizada em outubro de 2019 em Baku, capital do Azerbaijão, com o tema "Defendendo os princípios de Bandung para garantir uma resposta adequada aos desafios do mundo contemporâneo". De 2019 a 2022, o secretariado estará a cargo do governo do Azerbaijão (Azerbaijani Chairmanship to the Non-Aligned Movement, 2020b).

Com o crescimento da pandemia do Covid- 19 em todas as partes do mundo, os países do MNA se reuniram no dia 25 de março de 2020 para abordar a luta global para combatê-la e discutir o papel que poderiam assumir no tratamento e na mitigação dos resultados causados por esta doença, tanto em seus países como em outros. O informe sobre essa reunião encontra-se em <https://namazerbaijan.org/pdf/acdoc4.pdf> (Azerbaijani Chairmanship to the Non-Aligned Movement, 2020c).

Em 4 de maio de 2020, os chefes de Estado e de governo membros do MNA realizaram uma segunda reunião virtual sobre a Covid-19, intitulada "Unidos contra a pandemia de Covid- 19", com o objetivo de contribuir efetivamente para os esforços globais de combate aos efeitos da pandemia. Nessa reunião decidiram estabelecer uma força-tarefa dos países do MNA para elaborar um banco de dados contendo as necessidades e requisitos médicos e humanitários de seus Estados-membros para serem submetidos pela presidência do MNA a todos os países doadores, organizações humanitárias internacionais, instituições financeiras internacionais, entidades privadas transnacionais que executam projetos de responsabilidade social e outras, para possível apoio e assistência. O informe dessa reunião encontra-se em <https://namazerbaijan.org/pdf/acdoc9.pdf> (Azerbaijani Chairmanship to the Non-Aligned Movement, 2020d).

\section{GRUPO DOS 77}

Na década de 1960, grande número de novos países recém-ingressados nas Nações Unidas passou a expressar seu descontentamento com o sistema econômico internacional vigente. Um marco importante desse período foi a declaração feita pelos países em desenvolvimento na $18^{a}$ Sessão da AGNU, em Nova York, em novembro de 1963. Nessa declaração esses países ressaltaram a necessidade de uma nova política internacional de comércio e desenvolvimento, com condições para expandir o comércio entre nações com graus de desenvolvimento semelhantes, redução de barreiras que impediam as exportações de suas matérias-primas para os países industrializados e estabilização dos preços em níveis mais justos. 
A declaração destacava ainda que os países em desenvolvimento buscavam relações econômicas internacionais mais estáveis para que pudessem encontrar seus próprios recursos necessários ao crescimento autossustentável.

Nesse novo quadro mundial, e com as tensões da Guerra Fria, a década entre 1960 e 1970 foi declarada a Década das Nações Unidas para o Desenvolvimento. Previa-se um crescimento econômico de $5 \%$ ao ano para os países em desenvolvimento, o que não se concretizou.

Havia uma grande lista de questões que apontavam para a necessidade de fomentar ampla cooperação internacional para que os países menos desenvolvidos pudessem alcançar segurança econômica coletiva em relação aos países desenvolvidos. Este seria um dos instrumentos necessários para a manutenção da paz mundial.

Nesse cenário aconteceu a primeira Conferência das Nações Unidas sobre Comércio e Desenvolvimento (Unctad). Realizada de 23 de março a 16 de junho de 1964 em Genebra, Suíça, essa conferência seria o fórum no qual os países em desenvolvimento poderiam discutir os problemas relacionados ao seu desenvolvimento econômico.

Algumas semanas antes da primeira reunião da Unctad, o secretariado da conferência se reuniu em Nova York, sob a liderança do economista argentino Raul Prebisch, seu secretário-geral. Prebisch era de opinião que, embora o mercado fosse útil como alocador de recursos, não ajudava os países menos desenvolvidos que precisavam de benefícios e tratamento especial para poderem funcionar de maneira eficaz. Referindo-se aos países latino-americanos, ele aconselhou o grupo a se juntar aos países africanos e asiáticos em um único bloco.

Nesse contexto, surgiu uma ampla coalizão conhecida como Grupo dos 77 (G77) (The Group of 77 at the United Nations, 2020a), criado em 15 de junho de 1964 por 77 países do movimento dos não alinhados que assinaram a "Declaração conjunta dos setenta e sete países em desenvolvimento", emitida ao final da primeira sessão da Unctad. Originalmente, o grupo reunia 75 países. No entanto, o Japão, que se encontrava a meio caminho entre os países desenvolvidos e os países em desenvolvimento, e a Nova Zelândia assinaram a declaração conjunta que deu origem ao G77.

De 10 a 25 de outubro de 1967 realizou-se em Argel, Argélia, a primeira reunião do G77, que adotou a "Carta de Argel" e uma estrutura institucional permanente, que foi gradualmente desenvolvida e levou à criação de capítulos do Grupo dos $77 \mathrm{com}$ escritórios de ligação em: 
I. Genebra (Unctad, Conferência das Nações Unidas sobre Comércio e Desenvolvimento);

2. Nairóbi (Pnuma, Programa das Nações Unidas para o Meio Ambiente);

3. Paris (Unesco, Organização das Nações Unidas para a Educação, Ciência e Cultura);

4. Roma (FAO/Ifad, Organização das Nações Unidas para Agricultura e Alimentação/ Fundo Internacional para o Desenvolvimento da Agricultura);

5. Viena (Unido, Organização das Nações Unidas para o Desenvolvimento Industrial);

6. Grupo dos 24 (G-24) em Washington, DC (FMI e Banco Mundial).

Atualmente o G77 é composto de 134 países, mas manteve o nome original devido ao seu significado histórico. A missão do G77 é permitir que os países do Sul se articulem e promovam seus interesses econômicos coletivos e assim aumentem sua capacidade de negociação conjunta internacional dentro do sistema das Nações Unidas. Em outras palavras, o G77 busca uma nova ordem econômica internacional (New International Economic Order, Nied). Um sistema que Ihes permita ter controle real sobre seus recursos naturais, fora do neocolonialismo.

O G77 é composto por todos os membros das Nações Unidas, com exceção dos membros do Conselho da Europa (exceto a Bósnia e Herzegovina), todos os membros da Organização para Cooperação e Desenvolvimento Econômico (exceto o Chile) e todos os membros da Commonwealth de Estados independentes.

O G77 se tornou o interlocutor do Sul em todos os fóruns relevantes da ONU e seus associados. É importante ressaltar que a China normalmente endossa as posições do grupo, de modo que as decisões geralmente são emitidas em nome do G77 + China.

O G77 tem uma presidência que atua como o mais alto órgão político dentro de sua estrutura organizacional. O presidente atua como seu porta-voz e coordena a ação do grupo em cada capítulo. Seu mandato é alternado anual e regionalmente entre África, Ásia-Pacífico e América Latina e Caribe. A República Cooperativa da Guiana ocupa a presidência do Grupo dos 77, em Nova York, no ano de 2020.

A Cúpula do Sul é o órgão supremo de tomada de decisões do G77. A $1^{\mathrm{a}}$ e a $2^{\mathrm{a}}$ cúpulas do Sul foram realizadas em Havana, Cuba, de 10 a 14 de abril de 2000, e em Doha, Catar, de 12 a 16 de junho de 2005, respectivamente (The Group of 77 at the United Nations, 2020b).

Com a pandemia do Covid-19, o G77 + China manifestaram sua preocupação com a propagação do vírus e com o modo como a pandemia afetou as vidas e os meios de 
subsistência de muitas pessoas, além de ter enfraquecido economias e desafiado os sistemas de saúde de muitos países.

Em declaração às Nações Unidas em julho de 2020, o G77 e a China estimaram que a maioria dos países em desenvolvimento deverá perder ao redor de 800 bilhões de dólares devido à contração das exportações. E que a diminuição do setor de turismo deverá ser em torno de $20 \%$ a 30\%, resultando em uma queda no Produto Interno Bruto (PIB) dos países de até 16\%. Projeta-se também que o montante total dos pagamentos da dívida dos países com vencimento em 2020 será de US\$ 1,62 trilhão e US\$ 1,08 trilhão em 2021, dos quais US $\$ 562$ bilhões são devidos por governos de países de baixa e média renda (The Group of 77 at the United Nations, 2020c). A recessão econômica que o mundo está enfrentando tem o potencial de reverter os ganhos de desenvolvimento alcançados nas últimas décadas e exacerbar as desigualdades e vulnerabilidades existentes.

Acreditando em um consenso global para resolver os problemas da dívida externa dos países em desenvolvimento, o G77 elogiou a iniciativa do Fundo Monetário Internacional (FMI) e do Banco Mundial de suspender os pagamentos da dívida dos países de renda mais baixa, para 2020, dentro da Associação Internacional para o Desenvolvimento (IDA). O impacto da dívida enfrentada por muitos países de média e baixa rendas, pelos países mais vulneráveis e por aqueles que enfrentam desafios específicos compromete severamente sua capacidade de suportar o impacto da Covid- 19 e investir na implementação da Agenda 2030.

Portanto, o G77 espera que o FMI possa dispor de ferramentas de empréstimo de emergência, acelerar o suporte técnico e aumentar sua capacidade total de empréstimo para responder aos países que solicitarem fundos de emergência a fim de salvar vidas, sustentar a atividade econômica, proteger empregos e aliviar as restrições de liquidez. Insta o Banco Mundial, o FMI, os bancos multilaterais e regionais de desenvolvimento, os credores bilaterais e outros credores comerciais e privados a oferecer alívio imediato e substancial da dívida, bem a como providenciar outras medidas de apoio aos países em desenvolvimento, para ajudá-los a gerenciar a crise provocada pela pandemia da Covid-19. O G77 também solicitou aos países doadores que cumpram seus compromissos com a agenda para o desenvolvimento e aumentem seus esforços para alcançar o que foi acordado na Agenda de Ação de Adis Abeba sobre Financiamento para o Desenvolvimento. 


\section{DIFERENÇAS ENTRE 0 MNA E 0 G77}

Alguns analistas do dito Norte Global consideram o MNA e o G77 como organizações controversas, cujas razões de ser, atualmente, poderiam ser postas em dúvida, pois trazem à tona as marcadas divisões Norte-Sul das décadas de 1960 e 1970.

Pode-se entender que as mudanças globais de hoje geram uma estrutura mundial mais complexa, caracterizada pelo regionalismo e pela ascensão de algumas nações ou bloco de nações em desenvolvimento que poderiam se sobrepor os objetivos dessas organizações. Da mesma forma, instituições como o Banco do Sul e o Banco de Desenvolvimento do Brics esperam ser alternativas mais reais ao FMI.

Braveboy-Wagner (2014) ressalta que apenas a menção de G77 e MNA tende a provocar uma reação negativa de alguns estudiosos que não fazem parte do Sul Global e, certamente, alguns analistas do Norte gostariam de ver a desintegração desses grupos. Os países do Norte sempre foram arredios a essas instituições. A União Europeia assumiu a estratégia de colaborar com os países do Sul em uma base regional, mais gerenciável, ao passo que os EUA são mais adeptos dos acordos bilaterais.

O chanceler brasileiro Celso Amorim, em seu livro Breves Narrativas Diplomáticas, considera que, hoje em dia, o MNA tem menor relevância. Outros organismos, fóruns e grupos internacionais de cunho econômico tais como o Grupo dos Vinte (G20), o Ibas (Índia, Brasil, África do Sul) e o Brics (Brasil, Rússia, Índia, China e África do Sul) teriam mais visibilidade no cenário mundial (Amorim, 2013).

No entanto, o MNA e o G77 existem e ainda são relevantes devido a sua identidade coletiva comum. É preciso, no entanto, reforçar seus objetivos e aperfeiçoar sua inserção em meio às mudanças mundiais que vêm proporcionando estruturas mais estratificadas entre os próprios países em desenvolvimento.

Em termos de estrutura global, o G77, mais do que o MNA, teve que se adaptar ao contexto de Sul Global mais estratificado. Os programas da Unctad há muito tempo têm prestado atenção especial aos países menos desenvolvidos, aos pequenos Estados insulares em desenvolvimento e aos Estados sem acesso ao mar, todos com problemas de desenvolvimento específicos e únicos. Hoje, países do Sul Global incluem membros que adquiriram alto desenvolvimento econômico e humano e foram incorporados aos grupos de países desenvolvidos, mas cuja vulnerabilidade ainda os torna membros valiosos do G77 (Braveboy-Wagner, 20I4).

Dessa forma, a existência e a persistência do G77 e do MNA estão de acordo com a visão de que as organizações tendem a se adaptar e encontrar novos papéis, em vez de 
morrer de obsolescência. E não se deve esquecer que o MNA e o G77 são plataformas para os países em desenvolvimento manifestarem suas preocupações e cooperarem em questões de interesse mútuo.

Em um momento de incerteza global devida à pandemia de Covid-19, os países não alinhados e o Grupo dos 77 vêm expressando sua preocupação com os impactos imediatos e de longo prazo nos países de média e baixa rendas, esperando que as instituições e parceiros doadores não meçam esforços para ajudar os governos de tais países a implementaram medidas de combate à propagação da doença.

\section{REFERÊNCIAS}

ACHARYA, A. Studying the Bandung conference from a Global IR perspective. Australian Journal of International Affairs, 70(4): 342-357, 2016. Disponível em: < https://www.tandfonline.com/doi/full/I 0.1080/10357718.2016.1168359>. Acesso em: 23 ago. 2017.

AMORIM, C. Breves Narrativas Diplomáticas. São Paulo: Benvirá, 2013.

AZERBAIJANI CHAIRMANSHIP TO THE NON-ALIGNED MOVEMENT. History of NAM. Disponível em: $<$ https://www.namazerbaijan.org/news/3 >. Acesso em: 18 set. 2020a.

AZERBAIJANI CHAIRMANSHIPTO THE NON-ALIGNED MOVEMENT. NAM member countries. Disponível em: <https://namazerbaijan.org/pdf/Members-and-observers.pdf>. Acesso em: 18 set. 2020b.

AZERBAIJANI CHAIRMANSHIP TO THE NON-ALIGNED MOVEMENT. Communique of the Coordinating Bureau of the Nonaligned Movement (NAM) on the Covid-19 Pandemic. Disponível em: <https:// namazerbaijan.org/pdf/acdoc4.pdf>. Acesso em: 18 set. 2020c.

AZERBAIJANI CHAIRMANSHIP TO THE NON-ALIGNED MOVEMENT. Online Summit-level Meeting of the Non-Aligned Movement Contact Group in response to Covid-19. Disponível em: <https:// namazerbaijan.org/pdf/acdoc9.pdf>. Acesso em: 18 set. 2020d.

BISSIO, B. Bandung, não alinhados e mídia: o papel da revista Cadernos do Terceiro Mundo no diálogo Sul-Sul. Austral: Brazilian Journal of Strategy E International Relations, 4(8): 21 -42, 2015. Disponível em: <https://seer.ufrgs.br/austral/article/view/59957>. Acesso em: 5 ago. 2020.

BRAVEBOY-WAGNER, J. A. The NAM and the G77: the unexpected persistence of tricontinental multilateralism. In: UACES, Sept. I-3, 20I4, Cork. Disponível em: <https://www.researchgate. net/publication/329440464_The_NAM_and_the_G77_The_Unexpected_Persistence_of_ Tricontinental_Multilateralism>. Acesso em: 9 jul. 2020.

ESPÓSITO, F. A. "Não Comprometidos": o movimento dos países não alinhados nas páginas do jornal O Estado de São Paulo em 1961, 2019. Dissertação de Mestrado, São Paulo: Pontifícia Universidade Católica de São Paulo. Disponível em: < https://tede2.pucsp.br/handle/handle/22208>. Acesso em: 5 ago. 2020. 
OfFICE OF THE HISTORIAN. Bandung Conference (Asian-African Conference), 1955. Disponível em: <https://history.state.gov/milestones/1 953-1960/bandung-conf>. Acesso em: I 8 set. 2020.

THE GROUP OF 77 AT THE UNITED NATIONS. G77 executive secretariat mourns passing of staff member. Disponível em: <https://www.g77.org/> . Acesso em: 18 set. 2020a.

THE GROUP OF 77 AT THE UNITED NATIONS. The member states of the Group of G77. Disponível em: $<$ https://www.g77.org/doc/members.html>. Acesso em: 18 set. $2020 \mathrm{~b}$.

THE GROUP OF 77 AT THE UNITED NATIONS. Statement by the Group of 77 and China on Covid- 19 pandemic and debt (New York, 22 July 2020). Disponível em: < https://www.g77.org/statement/ getstatement. php?id=200722>. Acesso em: 18 set. 2020c.

UNITED NATIONS CONFERENCE ON TRADE AND DEVELOPMENT (UNCTAD). Site. Disponível em: $<$ https://unctad.org/en/Pages/Home.aspx>. Acesso em: 18 set. 2020. 


\section{2 A Resposta da OEA à Pandemia de Covid-19 em meio ao Desmonte do Multilateralismo}

Luana Bermudez

esde o início da propagação do Sars-Cov2 nas Américas, a Organização dos

Estados Americanos (OEA) tem estado ativa no desenvolvimento de uma resposta à pandemia por intermédio de seus diversos órgãos, como a Secretaria-Geral, o Conselho Permanente, o Conselho Interamericano de Desenvolvimento integral, a Comissão Interamericana de Direitos Humanos, a Comissão Interamericana de Mulheres, além, é claro, da Organização Pan-Americana da Saúde, que também é o organismo regional especializado em saúde do Sistema Interamericano.

\section{SOBRE A OEA}

A OEA (OEA, 2020-I) foi criada em 1948 com a assinatura da Carta da OEA (OEA, 2020-2) em Bogotá, Colômbia. A carta entrou em vigor em 195I e já foi emendada algumas vezes desde então. Porém, pode-se remeter a origem do organismo à Primeira Conferência Internacional Americana, realizada entre outubro de 1889 e abril de 1890, que resultou na criação da União Internacional das Repúblicas Americanas e foi o que deu início ao sistema interamericano.

A organização tem como pilares a democracia, os direitos humanos, a segurança e o desenvolvimento, e de acordo com o artigo $1^{\circ} \mathrm{da}$ Carta da OEA, como objetivo estabelecer "uma ordem de paz e de justiça, para promover sua solidariedade, intensificar sua colaboração e defender sua soberania, sua integridade territorial e sua independência”.

A OEA tem como Estados-membros todos os 35 países independentes do continente americano, além de 69 Estados e a União Europeia como observadores permanentes. Sendo assim, a organização trabalha em apoio aos países-membros em seus esforços para a redução da pobreza, o aumento do desenvolvimento econômico, a consolidação 
da democracia, o fortalecimento da governança, o enfrentamento de ameaças à segurança e a defesa dos direitos humanos das populações da região.

Os quatro pilares mencionados se conectam transversalmente à estrutura do organismo com o objetivo de gerar diálogo político, cooperação, instrumentos jurídicos e mecanismos de acompanhamento.

I. A organização é composta pelos seguintes órgãos:

2. Assembleia Geral

3. Reunião de Consulta dos Ministros das Relações Exteriores

4. Conselhos (Conselho Permanente e Conselho Interamericano de Desenvolvimento Integral)

5. Comissão Jurídica Interamericana

6. Comissão Interamericana de Direitos Humanos

7. Secretaria-Geral

8. Conferências Especializadas

9. Organismos Especializados

- Organização Pan-Americana da Saúde

- Instituto Interamericano da Criança

- Comissão Interamericana de Mulheres

- Instituto Pan-Americano de Geografia e História

- Instituto Interamericano de Cooperação para a Agricultura (OEA, 2020-3).

Além disso, a Assembleia Geral pode estabelecer órgãos subsidiários e outras entidades também, conforme previsto na Carta da OEA e de acordo com a necessidade dos países-membros. Esses organismos têm funções relacionadas com assuntos técnicos e determinadas de acordo com o interesse dos países. Entre as entidades que se demonstraram ativas na resposta à pandemia estão a Fundação Pan-Americana de Desenvolvimento (Padaf, 2020), a Comissão Interamericana para o Controle do Abuso de Drogas (Cicad) e o Comitê Interamericano contra o Terrorismo (CICTE). 


\section{RESPOSTA À PANDEMIA}

\section{Conselhos}

O Conselho Permanente (CP) (OEA, 2020-4) decidiu em sessão extraordinária virtual (OEA, 2020-5) no dia 16 de abril que realizaria reuniões virtuais até que haja condições para que o órgão realize sessões presenciais (CP/RES. II 50 (2280/20). Além disso, aprovou também resolução CP/RES. II5I (2280/20) intitulada "Resposta da OEA à pandemia da Covid-19", que destaca a necessidade de união diante desta crise sem precedentes, de fortalecimento da cooperação e solidariedade entre os Estadosmembros (intercâmbio de informações, conhecimentos científicos, lições aprendidas e melhores práticas), de priorização da prevenção da violência de gênero e de toda forma de discriminação (racismo e xenofobia) e da promoção da ação regional (OAS, 2020a).

Uma semana depois da resolução do CP para a realização de reuniões virtuais, no dia 28 de abril o Conselho Interamericano de Desenvolvimento Integral (Cidi) (OEA, 2020-6) adotou a mesma resolução (OEA, 2020-7). Além disso, também aprovou um programa de trabalho (OEA, 2020-7) da Secretaria Executiva de Desenvolvimento Integral (Sedi) em resposta à Covid-19, considerando os desafios, oportunidades e compromissos dos Estados-membros.

No dia 17 de junho, o CP e o Cidi realizaram uma reunião conjunta (OEA, 2020-8) com o tema "Construção de resiliência após a pandemia de Covid-19". A reunião contou com a participação de 24 países-membros, incluindo o Brasil, e começou com um painel de discussão de expertos dos campos da saúde, agricultura, economia, alimentação e desastres.

Os expertos levantaram diversos temas que acreditam ser relevantes para a construção de resiliência no contexto da pandemia, como a abordagem regional; a segurança alimentar; a inclusão de grupos em situação vulnerável, como os migrantes e refugiados, nos programas de proteção social dos Estados-membros; uma estratégia integral de gestão de desastres; a melhoria de oportunidades econômicas; a proteção ambiental e a proteção de infraestrutura, entre outros. Entre os diversos temas mencionados, cabe destacar a menção à garantia de sistemas de saúde resilientes, ou seja, sistemas de saúde com capacidade de absorver mudanças e manter o serviço de qualidade para a população mesmo durante crises e depois delas. Esse tema já é discutido há anos e sempre volta à pauta depois de surtos de doenças infecciosas, como no caso das epidemias de $\mathrm{HIN} \mathrm{I,} \mathrm{ebola,} \mathrm{chicungunha,} \mathrm{zika,} \mathrm{e/ou} \mathrm{depois} \mathrm{desastres} \mathrm{naturais} \mathrm{que} \mathrm{afetam}$ o bem-estar da população, como furacões, terremotos, enchentes, deslizamentos de terra etc. Essas emergências acabam destacando deficiências estruturais importantes 
nos nossos sistemas de saúde, e não poderia ser diferente no caso da atual pandemia de Covid-19, principalmente da região latino-americana, conhecida como a mais desigual do mundo. Uma importante diferença entre a emergência atual e as anteriores é que essa afetou também sistemas de saúde considerados robustos de países de alta renda, como no caso da Europa. O que nos leva a perceber a real importância de uma reflexão e discussão sobre o fortalecimento dos sistemas de saúde e a soberania nacional para o desenvolvimento tecnológico.

O tema também já foi levantado diversas vezes pela diretora da Organização PanAmericana de Saúde (Opas), dra. Carissa Etienne, em diversos de seus discursos em eventos internacionais. Em 2016, um documento intitulado "Sistemas de saúde resilientes" foi aprovado pelo $55^{\circ}$ Conselho Diretor da Opas, que se reúne anualmente (Paho, 2016). Esse documento delineia uma série de esforços necessários para garantir que os sistemas de saúde estejam preparados para futuras emergências de saúde pública com foco na cooperação técnica nas áreas de preparação para desastres, redução de riscos e resposta; vigilância de doenças e gestão de surtos; e saúde universal.

Além disso, o CP também realizou diversas reuniões (OEA, 2020-9), ordinárias e extraordinárias, para dar seguimento aos temas administrativos e de acompanhamento, e discutir as atividades da OEA de resposta à pandemia (Bermudez, 2020)

\section{Secretaria-Geral}

A Secretaria-Geral é considerada o órgão central e permanente da OEA, tendo a função crucial de assessoria aos demais órgãos do organismo (OEA, 2020-10). Cabe destacar a proatividade desse órgão na resposta à pandemia, com a emissão de comunicados, organização de seminários virtuais, publicação de guias e levantamento de boas práticas. No início de abril, a Secretaria-Geral fez um comunicado sobre a situação das populações indígenas durante a pandemia, instando os Estados-membros a dedicarem atenção especial a este grupo com o objetivo de mitigar o impacto social e econômico nesta população considerando sua situação duplamente vulnerável, decorrente de marginalização histórica e da vida em territórios isolados geograficamente (OEA, 2020-I I). O avanço da pandemia na população indígena é muito dramático e tem sido acompanhado por uma série de desafios. Especialistas apontam que vírus respiratórios foram vetores do genocídio indígena em vários momentos da história e que a pandemia aumenta o risco de mais um extermínio.

Uma das principais atividades da Secretaria-Geral foi a publicação, no início de junho, de um Portal de Consultas, Fóruns e Repositório durante e após a pandemia, que tem como objetivo ser um fórum para propor ideias e iniciativas, ouvir opiniões, debates 
e reflexões através de seminários e mesas-redondas virtuais, além de um repositório de boas práticas na luta contra a Covid-19 (OEA, 2020-12). A sociedade em geral, incluindo cidadãos, servidores públicos e sociedade civil, pode participar no portal.

Como parte dos esforços para reduzir o impacto econômico e social da pandemia, a OEA assinou um acordo de cooperação com diversos governos da região para implementar um plano de digitalização de micro, pequenas e médias empresas (OEA, 2020-13). O plano foi feito em parceria da OEA com a Kolau, empresa de marketing digital parceira do Google. Ele está disponível para empresas de todos os setores e permite que estas construam sites dinâmicos articulados com as plataformas do Google. Até o momento, o plano foi implementado em I I países da região (Bolívia, Chile, Colômbia, El Salvador, Equador, Paraguai, Jamaica, Honduras, Costa Rica, Guatemala e México) e beneficiou mais de 65 mil empreendedores.

Entre as dezenas de fóruns virtuais (OEA, 2020-14) realizados, destaca-se o Fórum de Jovens das Américas sobre o papel e as perspectivas da juventude em relação à Covid-19, que aconteceu no dia $1^{\circ}$ de julho (OAS, 2020b). Esse foi o $41^{\circ}$ fórum entre o secretário-geral e milhares de jovens, representados por alguns jovens líderes, representantes de organizações e redes juvenis como porta-vozes, e teve como objetivo unir as observações e recomendações de jovens relacionadas com o tema. Os temas discutidos no evento foram a recuperação econômica e o empreendimento; os sistemas de saúde e o acesso a informação de qualidade; grupos vulneráveis e igualdade de gênero; o papel da juventude e educação; os efeitos da mudança climática no Caribe; desenvolvimento econômico, social e emprego digno; juventude e Objetivos de Desenvolvimento Sustentável (ODS); participação de jovens e inclusão cidadã; e resposta e postura dos jovens nas Américas.

No tema de sistemas de saúde e acesso a informação, foi destacada necessidade de desenvolvimento de políticas de saúde através de plataformas abertas e colaborativas para ajudar a lidar com situações de ansiedade, incerteza e convívio familiar, além de estratégias de comunicação inclusivas sobre saúde mental para populações indígenas, com o objetivo de evitar o estigma.

Cabe destacar também a discussão sobre grupos em situação vulnerável e gênero, na qual se ressaltou que a Covid- 19 afeta majoritariamente e de maneira diferenciada as juventudes afrodescendentes, indígenas, com deficiências, mulheres, LGBTQI+, em situação de mobilidade e em situação de detenção, resultando no aumento da pobreza nestes grupos. Além disso, foi mencionado o aumento da violência baseada em gênero durante o isolamento social e a insuficiência da resposta das instituições dos Estadosmembros no marco da pandemia para atender às necessidades da juventude. 


\section{Guias publicados}

Conforme mencionado, a Secretaria-Geral publicou alguns guias desde o início da pandemia, com o objetivo de orientar os países-membros em relação a temas considerados prioritários. Em abril foi publicado um Guia Prático de Respostas Inclusivas e com Enfoque de Direitos perante a Covid-I 9 nas Américas (OEA, 2020- 1 5), elaborado com o fim de apoiar os Estados-membros na implementação de respostas com enfoque nos direitos humanos, inclusivas e acessíveis.

Em junho, a OEA publicou a Carta Democrática Interamericana: guia para a ação política de enfrentamento à pandemia sob princípios democráticos (OEA, 2020-16), desenvolvido com o objetivo de promover os princípios democráticos como elementos essenciais para a restauração econômica e social e a resposta às demais consequências da pandemia. O documento aborda a necessidade de proteção de grupos vulneráveis, como trabalhadores informais, de adoção de medidas transversais e de transparência nas atividades governamentais.

Em julho, foi publicado o Guia para organizar eleições em tempos de pandemia (OEA, 2020-17) elaborado com o apoio da Opas, com o objetivo de fornecer aos países-membros recomendações de medidas para a realização de eleições seguras e a redução do risco de transmissão de Covid- 19 a todos os participantes, visto que muitos dos países da região têm eleições previstas para 2020. O documento está organizado em três partes: um resumo das medidas sanitárias recomendadas pelos organismos internacionais competentes para a mitigação e controle do Sars-CoV-2; diretrizes gerais para a realização de eleições no contexto da pandemia; e propostas de medidas específicas. Além disso, identifica quatro fatores imprescindíveis para a avaliação e a tomada de decisão em relação às eleições do país:

- Condição de saúde

A decisão deve ser tomada com base em uma avaliação de risco rigorosa, levando em consideração estudos, relatórios, projeções e recomendações dos órgãos de saúde competentes e atores envolvidos na resposta do país à pandemia.

- Marco jurídico

A eventual decisão pelo adiamento das eleições deve ser tomada com base nos procedimentos legislativos formais, garantindo a segurança jurídica e os direitos políticos dos cidadãos.

- Acordos políticos

É importante que a decisão seja tomada com base em uma ampla consulta com os setores políticos do país, com o objetivo de evitar desconfianças políticas. 
- Data

É crucial definir um novo cronograma eleitoral.

Cabe destacar que o guia reconhece a impossibilidade de prever a evolução da pandemia a longo prazo, em razão da possibilidade de haver ondas epidêmicas intercaladas com períodos de baixo nível de transmissão. Sendo assim, o documento destaca a necessidade de observar as recomendações de saúde pública em todas as medidas e atividades propostas no guia.

Finalmente, no fim do mês de julho a OEA publicou também um documento (OEA, 2020-18) com propostas para melhorar a situação de migrantes e refugiados da Venezuela durante a pandemia, no qual se ressalta a necessidade de que os Estadosmembros criem políticas de assistência adequadas que permitam à população de migrantes e refugiados venezuelanos se integrar de maneira estável e segura à dinâmica social e econômica dos países. No documento são apresentadas nove recomendações na área da saúde, cinco relacionadas à educação, nove ao emprego ou outros meios de subsistência, seis à segurança alimentar, outras seis relacionadas à necessidade de proteção e quatro na área de habitação.

Entre as recomendações de saúde destaca-se a adoção de medidas para facilitar o acesso dessas populações aos serviços de atenção primária, a elaboração de programas específicos para a população migrante e refugiada, a realização de campanhas de conscientização e prevenção e a criação de centros de saúde em lugares de maior concentração de migrantes, entre outros.

\section{Comissão Interamericana de Mulheres (CIM)}

A CIM foi criada pela Assembleia Geral da OEA com o objetivo de garantir o reconhecimento dos direitos das mulheres nas políticas públicas dos países-membros (OEA, 2020-19). A comissão tem trabalhado durante a pandemia destacando o impacto diferenciado da crise sobre as mulheres.

Com esse foco, já foram publicados dois documentos informativos. O primeiro é sobre os impactos da pandemia nas vidas das mulheres, com o objetivo de gerar insumos para que os Estados-membros possam desenvolver políticas inclusivas com foco nas necessidades delas, fortalecer os espaços de defesa dos seus direitos e garantir sua participação igualitária nos comitês de resposta à crise (OEA, 2020-20). O documento tem como temas centrais a tomada de decisão, a violência contra mulheres, os direitos econômicos das mulheres e a saúde, com ênfase na saúde sexual e reprodutiva. 
O segundo documento publicado tem como foco a violência contra as mulheres em relação às medidas destinadas a reduzir a propagação da Covid- 19 (OEA, 2020-21). Seu objetivo é o fortalecimento das capacidades dos Estados-membros e o fornecimento de informações inovadoras para a elaboração de planos, programas e políticas públicas para o combate e prevenção da violência contra meninas e mulheres. Ele é o resultado de uma série de reuniões promovidas pela CIM tanto com a sociedade civil quanto com expertos e altas autoridades dos Estados-membros, além de análise de notícias da mídia e alertas de entidades públicas e privadas sobre o aumento da violência contra mulheres durante a pandemia. Nele são identificados novos padrões de violência que surgiram com as medidas de confinamento e distanciamento social implementadas para controlar a propagação do Sars-CoV-2, como no caso de mulheres vítimas de violência doméstica que de repente se viram confinadas com seus agressores. Por fim, são estabelecidas recomendações para a prevenção e o combate à violência.

Cabe destacar também a publicação de um artigo de posicionamento sobre muIheres da área rural, a agricultura e o desenvolvimento sustentável nas Américas em tempos de pandemia (OEA, 2020-22). No artigo são destacados os desafios enfrentados pelas mulheres da zona rural, como camponesas, agricultoras e indígenas, com a chegada da pandemia, porém o foco é dirigido para a contribuição que este grupo provê à economia e para a oportunidade de possíveis mudanças de paradigma no consumo, com a criação de novos pactos para fortalecer a segurança e a soberania alimentar na perspectiva de gênero.

Outro importante recurso elaborado pela CIM foi o Repositório: Covid- 19 na vida das mulheres, onde é possível encontrar iniciativas inovadoras e boas práticas de resposta à pandemia com um enfoque de gênero, tanto dos países-membros como de outras organizações e atores relevantes (OEA, 2020-23).

\section{Comissão Interamericana de Direitos Humanos (CIDH)}

A CIDH (OEA, 2020-24) foi criada em 1959 pela OEA e faz parte do Sistema Interamericano de Proteção dos Direitos Humanos (SIDH), junto com a corte que foi criada em 1979. Desde a chegada da pandemia na região, a comissão tem se mostrado bastante ativa, com a publicação de diretrizes, dezenas de comunicados, resoluções e boletins, entre outros (OEA, 2020-25).

Em março a CIDH publicou diretrizes (OEA, 2020-26) para a proteção abrangente da saúde e dos direitos humanos contra a pandemia na região, com base na Relatoria Especial sobre Direitos Econômicos, Sociais, Culturais e Ambientais (Redesca) e em outros mecanismos de monitoramento vigentes. Essas diretrizes estão voltadas para 
a necessidade de tomar medidas especiais para a garantia dos direitos dos cidadãos afetados pelas medidas de controle; de assegurar que as empresas garantam os direitos humanos de seus trabalhadores; e de dar atenção especial aos grupos em situação de vulnerabilidade, incluindo povos indígenas, camponeses, migrantes, pessoas privadas de liberdade, grupos sociais nas periferias das cidades e grupos econômicos negligenciados pelas redes de segurança social, pessoas com deficiência, pessoas com certas patologias e doenças, os idosos e as crianças e adolescentes.

Logo depois, a CIDH elaborou também um documento com recomendações para a garantia e fortalecimento da livre circulação de informação durante a pandemia (OEA, 2020-27). No documento são preconizadas a transparência das informações em relação à ameaça do vírus, a garantia de acesso à internet pela população, a proteção dos jornalistas, o combate às fake news e a proteção dos direitos individuais na utilização de ferramentas de tecnologia para a vigilância.

No fim do mês de março, a CIDH deu um passo importante na resposta à pandemia e instalou uma Sala de Coordenação e Resposta Oportuna e Integrada (Sacroi) à crise relacionada com a pandemia de Covid- I9 (OEA, 2020-28). A sala foi criada com o objetivo de dar continuidade e fortalecer a estratégia da CIDH de monitoramento dos impactos sobre os direitos humanos de populações e grupos vulneráveis no contexto da pandemia. Tal monitoramento permite trabalhar de maneira preventiva em situações que possam gerar impactos relacionados aos direitos humanos na região.

Uma das primeiras iniciativas e principais resultados da Sacroi foi a elaboração da Resolução n. $01 / 2020$, intitulada "Pandemia e direitos humanos nas Américas", adotada pela $\mathrm{CIDH}$ no dia 10 de abril (OEA, 2020-29). A resolução contém 85 recomendações aos Estados-membros voltadas para que estes adotem um enfoque de direitos humanos em suas estratégias, políticas e medidas dirigidas ao enfrentamento da pandemia, incluindo os planejamentos de retomada de atividades e de restauração econômica e social. Essa resolução é vista como um marco no direito à saúde na Região das Américas. Entre as diversas contribuições da resolução, cabe destacar a menção ao direito à saúde como um direito independente, e não apenas parte do direito à vida, e como bem público de responsabilidade dos Estados, os quais têm o dever de prover informação ampla e baseada em evidências.

No fim de julho, a CIDH adotou uma segunda resolução (n. 4/2020) intitulada "Direitos humanos das pessoas com Covid- I 9" (OEA, 2020-30). Dessa vez, o objetivo da resolução é fornecer um conjunto de diretrizes para apoiar os Estados-membros na implementação de ações de proteção do direito à saúde de pessoas com Covid- 19. Das 52 diretrizes, 17 são sobre a proteção do direito à saúde. Nessa resolução destaca- 
se o dever do Estado na garantia do acesso de suas populações a medicamentos, vacinas, bens e tecnologias médicas essenciais para prevenir e tratar a Covid-19. Além disso, enfatiza-se o direito de populações indígenas e tribais a receber atenção com enfoque intercultural, levando em consideração os cuidados, as práticas curativas e as medicinas tradicionais desses povos. E reitera-se a importância do enfoque intersetorial e multidisciplinar na abordagem da crise, sempre na perspectiva da indivisibilidade dos direitos humanos.

Além da elaboração de resoluções, a Sacroi elaborou também um site para facilitar o acesso à informação sobre o monitoramento pela CIDH de respostas adotadas pelos Estados-membros e seus impactos sobre os direitos humanos. O site (OEA, 2020-28) contém informação estratégica, boletins informativos diários sobre a situação regional, seminários virtuais e estatísticas sobre os casos de Covid- I 9 na região e no mundo.

Por fim, outra iniciativa importante da CIDH foi o lançamento do Sistema Interamericano de Monitoramento de Recomendações (Simore Interamericano), mecanismo de prestação de contas, transparência e participação na supervisão das recomendações na região (OEA, 2020-3I). Suas principais funções são permitir que os cidadãos façam buscas especializadas sobre as recomendações de resoluções, relatórios temáticos e medidas cautelares concedidas, e que os usuários façam contribuições mediante o envio de informações sobre a observância de recomendações por parte dos Estados-membros.

O multilateralismo, não apenas no nível regional mas também no nível mundial, vem sofrendo desgaste ao longo dos anos, o que pode ser exemplificado com a dissolução da União de Nações Sul-Americanas (Unasul) e, mais recentemente, com a saída dos Estados Unidos da América (EUA) da Organização Mundial da Saúde (OMS) durante uma pandemia com forte impacto sanitário e socioeconômico. Esse processo de desgaste parece ter se acelerado com a chegada da pandemia.

Ao mesmo tempo que a OMS, com o questionamento sobre a gestão da pandemia, e a Opas, com o questionamento do Programa Mais Médicos, viram alvo dos EUA, e consequentemente do Brasil, os dois países participam ativamente na OEA, o que ressalta a importância da organização na promoção de uma ação regional. Além disso, a apresentação de um candidato dos EUA a presidente do Banco Interamericano de Desenvolvimento (BID) pela primeira vez desde a criação da instituição, rompendo um acordo tácito entre os governos da região, evidencia também o interesse do país na dominação geopolítica em um momento de crescimento da influência da China sobre 
os países da região. A região latino-americana parece estar presa em uma disputa de interesses entre os EUA e a China, que depende em grande parte das eleições presidenciais dos EUA no fim de 2020.

Alguns acontecimentos importantes na OEA durante a pandemia foram a recondução de Luis Almagro, diplomata uruguaio, como secretário-geral e a transferência da presidência da Cúpula das Américas para os EUA.

Em maio, Almagro iniciou seu segundo mandato (OEA, 2020-32) como secretáriogeral da OEA. Ele concorreu ao cargo com María Fernanda Espinosa, ex-ministra de Relações Exteriores e de Defesa do Equador, e foi reeleito no dia 20 de março com 23 dos 34 possíveis votos dos membros ativos da organização. O diplomata teve grande apoio dos EUA e demonstrou forte oposição aos governos de Cuba, Nicarágua e Venezuela em seu primeiro mandato. Em seu discurso de posse, Almagro reiterou o grande desafio de apoiar os países no combate à pandemia de Covid- I9, seu compromisso com a luta contra a desigualdade na região e ressaltou que seu foco no segundo mandato seria a normalização da democracia na região.

Também é importante ressaltar que os EUA assumiram a presidência do processo da Cúpula das Américas, encontro que reúne chefes de Estado dos países do continente americano. A primeira Cúpula das Américas teve lugar em 1994, também sob a presidência dos EUA, que na ocasião propuseram a Área de Livre-Comércio das Américas (Alca). Durante a cerimônia de transferência da presidência do Peru para os EUA, Michael Kozak, secretário assistente interino para Assuntos do Hemisfério Ocidental do Departamento de Estado dos EUA, destacou a agenda do país para restaurar a economia global pós-pandemia e mencionou que a defesa da democracia será a prioridade, falando especificamente de esforços relacionados aos regimes da Venezuela, da Nicarágua e de Cuba (OEA, 2020-33). Vê-se, então que o secretário-geral da OEA está completamente alinhado com a agenda norte-americana, o que justifica o apoio do país ao bloco regional, mesmo em um momento de extrema contestação do multilateralismo.

\section{REFERÊNCIAS}

BERMUDEZ, L. Resposta da OEA à Covid-19. Informes de 16 de jun. a 19 jul. 2020. Disponível em: < https://www.arca.fiocruz.br/bitstream/icict/43296/2/OEA.pdf>. Acesso em: 18 set. 2020.

ORGANIZAÇÃO DOS ESTADOS AMERICANOS (OEA). Quem somos. Disponível em: < http://www. oas.org/pt/sobre/quem_somos.asp >. Acesso em: 18 set. 2020-1.

ORGANIZAÇÃO DOS ESTADOS AMERICANOS (OEA). Tratados multilaterais. Disponível em: < http:// www.oas.org/dil/port/tratados_A-4I_Carta_da_Organiza\%C3\%A7\%C3\%A3o_dos_Estados_ Americanos.pdf>. Acesso em: 18 set. 2020-2. 
ORGANIZAÇÃO DOS ESTADOS AMERICANOS (OEA). Organograma. Disponível em: < http://www. oas.org/legal/spanish/organigramaOEAesp.pdf>. Acesso em: 18 set. 2020-3.

ORGANIZAÇÃO dOS ESTAdOS AmERICANOS (OEA). Sobre o Conselho Permanente. Disponível em: $<$ http://www.oas.org/pt/council/about.asp >. Acesso em: 18 set. 2020-4.

ORGANIZAÇÃO DOS ESTADOS AMERICANOS (OEA). Conselho Permanente aprovou sessões virtuais e a resposta da OEA à Covid-19, 17 abr. 2020-5. Disponível em: <https://www.oas.org/pt/centro_ midia/fotonoticia.asp?sCodigo=FNP-98952>. Acesso em: 18 set. 2020.

ORGANIZAÇÃO DOS ESTADOS AMERICANOS (OEA). Acerca del Consejo Interamericano para el Desarrollo Integral - CIDI. Disponível em: <http://www.oas.org/es/cidi/acerca.asp >. Acesso em: 18 set. 2020-6.

ORGANIZAÇÃO DOS ESTADOS AMERICANOS (OEA). Resoluciones del CIDI - 2020. CIDI/ RES.340/20: Reuniones Virtuales del Consejo Interamericano para el Consejo Integral a causa de la Pandemia Covid-19. Disponível em: <http://www.oas.org/es/cidi/cidi_documentos_Res_20.asp>. Acesso em: 18 set. 2020-7.

ORGANIZAÇÃO DOS ESTAdOS AMERICANOS (OEA). O Conselho Permanente e o Conselho Interamericano de Desenvolvimento Integral da OEA analisam a resiliência após a pandemia do Covid-19, 15 jun. 2020-8. Disponível em: < https://www.oas.org/pt/centro_midia/nota_imprensa. asp?sCodigo $=$ AVI-07 I/20>. Acesso em: 18 set. 2020.

ORGANIZAÇÃO DOS ESTADOS AMERICANOS (OEA). Sessões. Disponível em: < http://www.oas.org/ pt/council/CP/Past/>. Acesso em: 18 set. 2020-9.

ORGANIZAÇÃO DOS ESTAdOS AMERICANOS (OEA). Secretraría General. Disponível em: < http:// www.oas.org/es/acerca/secretaria_general.asp>. Acesso em: 18 set. 2020- 10.

ORGANIZAÇÃO DOS ESTADOS AMERICANOS (OEA). Comunicado de la Secretaría General de la OEA sobre situación de la población indígena durante la crisis del Covid-19, 3 abr. 2020-11. Disponível em: $<$ https://www.oas.org/es/centro_noticias/comunicado_prensa.asp?sCodigo=C-029/20>. Acesso em: 18 set. 2020.

ORGANIZAÇÃO DOS ESTAdOS AMERICANOS (OEA). Post Covid-19: portal OEA para consultas, foros y repositorio. Disponível em: <https://www.oas.org/ext/es/principal/covid-19/Inicio>. Acesso em: 18 set. 2020-12.

ORGANIZAÇÃO DOS ESTADOS AMERICANOS (OEA). OEA y Bolivia se unen para impulsar digitalización de las MIPYMES, 3 ago. 2020-13. Disponível em: <https://www.oas.org/es/centro_ noticias/fotonoticia.asp?sCodigo =FNC-99558>. Acesso em: 18 set. 2020.

ORGANIZAÇÃO DOS ESTADOS AMERICANOS (OEA). Fóruns virtuais. Disponível em: < https://www. oas.org/ext/en/main/covid-19/Virtual-Forums>. Acesso em: 18 set. 2020-14.

ORGANIZACIÓN DE LOS ESTADOS AMERICANOS (OEA). Guía Práctica de Respuestas Inclusivas y con Enfoque de Derechos ante el Covid- 19 en las Américas. Washington: OEA, 2020 - 15. Disponível em: <http://www.oas.org/es/sadye/publicaciones/GUIA_SPA.pdf>. Acesso em: 18 set. 2020.

ORGANIZACIÓN DE LOS ESTADOS AMERICANOS (OEA). La Carta Democratica Interamericana. Guía de Acción Política para Enfrentar la Pandemia del Covid-19. Washington: OEA, 2020-16. Disponível em: $<$ http://www.oas.org/documents/spa/press/La-CDI-Guia-de-accion-politica-para-la-pandemia-5.28. pdf >. Acesso em: 18 set. 2020. 
ORGANIZACIÓN DE LOS ESTADOS AMERICANOS (OEA). Guía para Organizar Elecciones en Tiempos de Pandemia. Washington: OEA, 2020-17. Disponível em: <http://www.oas.org/documents/spa/ press/OEA-guia-para-organizar-elecciones-en-tiempos-de-pandemia.pdf?fbclid=IwAR0iBODVtGP TyWpIEej6RnmV6UqQYvcM_Zq_nIGYTnIPISiLasV4noW5qPc>. Acesso em: 18 set. 2020.

ORGANIZACIÓN DE LOS ESTAdOS AMERICANOS (OEA). Propuestas Para Mejorar la situación de los migrantes y refugiados venezolanos en el marco del Covid-19, jun. 2020-18. Disponível em: $<$ http://www.oas.org/documents/spa/press/Propuestas-OEA-y-Coalicion-por-Venezuela_esp. pdf?fbclid=IwAR0juRaPsTXwbOXy I PM9- I BKCPN_U--chqCSf9ikydEFTOVYoaLOKBg3dbw > . Acesso em: 18 set. 2020.

ORGANIZACIÓN DE LOS ESTADOS AMERICANOS (OEA). Comisión Interamericana de Mujeres. Misión y mandatos. Disponível em: <http://www.oas.org/es/cim/nosotros.asp>. Acesso em: 18 set. 2020-19.

ORGANIZACIÓN DE LOS ESTADOS AMERICANOS (OEA). Comisión Interamericana de Mujeres. Covid-I 9 en la Vida de las Mujeres: razones para reconocer los impactos diferenciados. Washington: OEA, 2020-20. Disponível em: < http://www.oas.org/es/cim/docs/ArgumentarioCOVIDI 9-ES.pdf>. Acesso em: 18 set. 2020.

ORGANIZACIÓN DE LOS ESTADOS AMERICANOS (OEA). La Violencia contra las Mujeres frente a las Medidas Dirigidas a Disminuir el Contagio del Covid-19. Washington: OEA, 2020-21. Disponível em: $<$ http://www.oas.org/es/cim/docs/Covid-1 9-RespuestasViolencia-ES.pdf>. Acesso em: 18 set. 2020.

ORGANIZACIÓN DE LOS ESTADOS AMERICANOS (OEA). Las mujeres rurales, la agricultura y el desarrollo sostenible en las Américas en tiempos de Covid- 19. Disponível em: < http://www.oas.org/ es/cim/docs/DocumentoPosicion-MujeresRurales-FINAL-ES.pdf>. Acesso em: 18 set. 2020-22.

ORGANIZACIÓN DE LOS ESTADOS AMERICANOS (OEA). Repositorio: Covid-19 en la vida de las mujeres. Disponível em: <http://www.oas.org/es/cim/RepositorioCOVID-19.asp>. Acesso em: I8 set. 2020-23.

ORGANIZAÇÃO DOS ESTADOS AMERICANOS (OEA). Comissão Interamericana de Direitos Humanos. Disponível em: < http://www.oas.org/pt/cidh/>. Acesso em: 18 set. 2020-24.

ORGANIZAÇÃO DOS ESTADOS AMERICANOS (OEA). Comunicados de Imprensa. Disponível em: $<$ http://www.oas.org/pt/cidh/prensa/comunicados.asp >. Acesso em: 18 set. 2020-25.

ORGANIZACIÓN DE LOS ESTADOS AMERICANOS (OEA). La CIDH y su REDESCA instan a asegurar las perspectivas de protección integral de los derechos humanos y de la salud pública frente a la pandemia del Covid-19, 20 mar. 2020-26. Disponível em: <http://www.oas.org/es/cidh/prensa/ comunicados/2020/060.asp>. Acesso em: 18 set. 2020.

ORGANIZACIÓN DE LOS ESTADOS AMERICANOS (OEA). Covid- 19: Los gobiernos deben promover y proteger el acceso y la libre circulación de la información durante la pandemia - Expertos internacionales. Disponível em: <http://www.oas.org/es/cidh/expresion/showarticle.asp?artID=1 170EIID=2>. Acesso em: 18 set. 2020-27.

ORGANIZACIÓN DE LOS ESTADOS AMERICANOS (OEA). Sacroi Covid-19. Disponível em: < http:// www.oas.org/es/cidh/SACROI_COVIDI9/>. Acesso em: 18 set. 2020-28.

ORGANIZACIÓN DE LOS ESTADOS AMERICANOS (OEA). Resolución 1/2020. Pandemia y Derechos Humanos en las Américas. Disponível em: < http://www.oas.org/es/cidh/decisiones/pdf/ResolucionI-20-es.pdf >. Acesso em: 18 set. 2020-29. 
ORGANIZACIÓN DE LOS ESTADOS AMERICANOS (OEA). Resolución 4/2020. Derechos Humanos de las Personas con Covid- 19. Disponível em: < http://www.oas.org/es/cidh/decisiones/pdf/Resolucion4-20-es.pdf $>$. Acesso em: 18 set. 2020-30.

ORGANIZACIÓN DE LOS ESTADOS AMERICANOS (OEA). Simore Interamericano. Disponível em: $<$ https://www.oas.org/ext/es/derechos-humanos/simore/>. Acesso em: 18 set. 2020-31.

ORGANIZAÇÃO DOS ESTADOS AMERICANOS (OEA). Luis Almagro toma posse de seu segundo mandato como Secretário-geral da OEA, 26 maio 2020. Disponível em: <https://www.oas.org/pt/ centro_midia/nota_imprensa.asp?sCodigo $=$ AVI-062/20 >. Acesso em: 18 set. 2020-32.

ORGANIZACIÓN DE LOS ESTADOS AMERICANOS (OEA). Ceremonia de traspaso de la presidencia del proceso de cumbres del gobierno de la República del Peru. In: CUMBRE DE LAS AMÉRICAS, AL GOBIERNO DE LOS ESTADOS UNIDOS DE AMÉRICA, ANFITRIÓN DE LA CUMBRE DE LAS AMÉRICAS, VIII, IX, 2020, on-line no Facebook. Disponível em: <https://www.facebook.com/events/276494506909659>. Acesso em: 18 set. 2020-33.

ORGANIZATION OF AMERICAN STATES (OAS). The OAS Response to the Covid-19 Pandemic, 17 Apr. 2020a. Disponível em: <http://www.oas.org/en/cim/docs/CP42233S06-EN.pdf>. Acesso em: 18 set. 2020.

ORGANIZATION OF AMERICAN STATES (OAS). Young Americas Dialogue 2020 Role and Perspectives of Youth Responding to Covid-19, I July 2020b. Disponível em: <https:/www.oas.org/ext/en/main/ covid- 1 9/Virtual-Forums/ArtMID/3425/ArticleID/3274/Young-Americas-Dialogue-2020-Role-andPerspectives-of-Youth-Responding-to-Covid-19>. Acesso em: 18 set. 2020.

PAN-AMERICAN HEALTH ORGANIZATION (PAHO). 55th Directing Council, 68th Session of the Regional Committee of WHO for The Americas Washington, D.C., USA, 26-30 September 2016. Disponível em: <https://www.paho.org/hq/dmdocuments/2016/CD55-9-e.pdf>. Acesso em: 18 set. 2020.

PAN AMERICAN DEVELOPMENT FOUNDATION (PADF). PADF reponse to Covid-19. Disponível em: $<$ https://padf.org/covid-19/>. Acesso em: 18 set. 2020. 


\section{3 América Latina e Caribe entre a Covid-19 e a crise econômica e social}

Sebastián Tobar e Carlos Linger

Tran

ranscorridos pouco mais de seis meses após o primeiro caso na Região das Américas, identificado nos Estados Unidos da América (EUA) em 20 de janeiro deste ano, e cinco meses após o primeiro caso na América Latina $(\mathrm{AL})$, diagnosticado em São Paulo em 26 de fevereiro, a região se tornou o epicentro mundial da pandemia da Covid - 19.

Até o momento, registram-se, globalmente, cerca de 20 milhões de casos e mais de 800 mil mortes por Covid-19, dos quais mais de 10 milhões de casos e 400 mil óbitos nas Américas; dos dez países com mais casos no mundo, cinco se encontram na região: Brasil, México, Peru, Chile e Colômbia (JHU, 2020). Também em países da AL se encontram as taxas de letalidade mais elevadas do mundo.

Os países da América Latina e Caribe (ALC) compartilham algumas semelhanças nos campos econômico, político, social e cultural, mas ao mesmo tempo são muito heterogêneos.

A partir das medidas implementadas pela China e países europeus, os países da América Latina tiveram a possibilidade de organizar a resposta à Covid-19, com base nas lições aprendidas, mas o fizeram de forma incompleta, e o impacto da epidemia foi intenso na região. Contudo, algumas propostas de resposta à pandemia tinham consistência.

O Sistema Econômico Latino-Americano e do Caribe (Sela) preparou o "Resumo das principais medidas, ações e políticas implementadas pelos Estados-membros do Sela”, que comentamos a seguir (Sela, 2020).

Mais de 25 países da ALC adotaram medidas de quarentena preventiva/confinamentos por áreas, impulsionando regimes de exceção ou toque de recolher, ou declararam emergência nacional. O fechamento de escolas e a suspensão de atividades edu- 
cativas foi outra medida adotada pela quase totalidade dos países latino-americanos. Vinte e quatro deles implementaram planos de fortalecimento do setor Saúde para responder à pandemia da Covid-19 e impulsionaram atividades como aquisição de equipamentos hospitalares, aumento do número de leitos comuns e de unidades de terapia intensiva (UTIs) e fornecimento de insumos. Pelo menos 22 países implementaram planos para mitigar o impacto da Covid- 9 sobre as famílias, como ajustes no custo de alguns serviços básicos como eletricidade e gás, incluindo o pagamento do custo às empresas fornecedoras.

A suspensão dos voos e o fechamento dos aeroportos, evitando o deslocamento de viajantes, foi outra medida impulsionada na maioria dos países da região.

Ruiz Caro (2020) destaca que

as estratégias utilizadas pelos governos latino-americanos para enfrentar a pandemia foram diferentes e também seus resultados, mesmo nos casos em que medidas semelhantes foram implementadas. Sem dúvida, as características demográficas desempenham um papel fundamental, embora não menos importante sejam a força dos sistemas de saúde preexistentes, os níveis de informalidade no emprego, a capacidade da liderança política de transmitir claramente um discurso único sobre o tratamento da pandemia, os níveis de inclusão financeira e os indicadores de desenvolvimento social.

A referida autora afirma que é possível agrupá-los basicamente em três tipos: o negacionista do Brasil, México e Nicarágua;' as quarentenas rigorosas e obrigatórias adotadas pela maioria dos países: ${ }^{2}$ e aqueles que combinavam elementos de obrigação e liberdade, como Uruguai e Costa Rica e, inicialmente, as quarentenas focadas no Chile.

As ferramentas acordadas globalmente, como o Regulamento Sanitário Internacional (RSI), mostraram-se impotentes diante da pandemia e os países fecharam deliberadamente

\footnotetext{
' Brasil, México e Nicarágua são os países que subestimaram a pandemia, priorizando a economia em detrimento da saúde. O caso mais visível é o do Brasil, onde o presidente decidiu explicitamente não liderar a luta contra o Covid- 19 e foram os governadores dos estados que promoveram medidas de confinamento não obrigatório e cessação de atividades, exceto as essenciais. O presidente do México também subestimou a pandemia e transferiu a decisão sobre o cumprimento das medidas aos cidadãos. Embora as escolas e as atividades educacionais tenham fechado cedo (em 30 de março), diferentemente de outros países da região que favoreciam um conjunto de medidas integrais entre as quais estava o confinamento, o presidente mexicano incentivava reuniões sociais. Somente em 2 I de abril as empresas não essenciais foram suspensas e os estados foram autorizados a tomar suas decisões, e muitos destes implementaram medidas mais drásticas.

${ }^{2}$ A natureza compulsória das medidas exigia a promoção de políticas para mitigar os efeitos da pandemia na economia, como subsídios sociais, supressão de demissões e dívidas, além de outras medidas econômicas e fiscais. Argentina, Colômbia, e Peru são exemplos.
} 
suas fronteiras como principal estratégia para proteger seus territórios, além de promover medidas de isolamento para impedir a propagação da doença.

As medidas adotadas pelos países representam um revés em um processo de construção conjunta de uma comunidade nos territórios de fronteira. Em vez de integração, identificando possíveis caminhos comuns para a ação coletiva conjunta em saúde mediante a cooperação, foram levantadas barreiras nas fronteiras, havendo casos inclusive do uso de forças militares para impedir o fluxo transfronteiriço de pessoas.

Todos os países da AL fecharam fronteiras. A disparidade no crescimento do número de casos no Brasil, que ocupa quase metade da América do Sul e faz limites com quase todos os países, reforçou a decisão política de fechar fronteiras e implantar medidas sanitárias. Isso gerou a passagem clandestina de grupos populacionais, aumentando os possíveis riscos de disseminação do vírus.

A região, pelo fato de ser a mais desigual do mundo, é especialmente vulnerável à Covid-19, em razão de seus altos níveis de informalidade do trabalho e da fragilidade e subfinanciamento da urbanização e dos sistemas de saúde e proteção social. Soma-se a esses elementos a coexistência da Covid- 19 com outras epidemias, como sarampo e dengue, que têm alto impacto na morbimortalidade.

A Covid-19 chegou aos países da ALC através de aeroportos e passageiros de viagens internacionais, migrando pouco a pouco das áreas urbanizadas das capitais para as favelas e periferias das grandes e médias cidades, e agora invade o interior dos países. Se inicialmente afetou indivíduos e famílias de classe média e alta, a disseminação progressiva do vírus está ocorrendo com maior intensidade entre os trabalhadores mais pobres e de menor renda, desempregados e informais, que vivem em casas com acesso difícil a água, tratamento de esgoto e coleta de lixo e, ademais, precisam sair de casa para buscar os recursos mínimos necessários para viver, usando transportes coletivos totalmente cheios e, portanto, fonte de contágio.

Como afirma Klicksberg (2020), "o mito de que a pandemia afeta a todos igualmente não tem apoio em bases empíricas, mas é funcional porque permite ocultar relações múltiplas e silenciosas entre pandemia e desigualdade". Na AL, a população real deve seguir as recomendações de lavagem das mãos com sabão, distanciamento social, uso de máscara, ausência de contaminação. A população corre o risco de contrair o vírus, mas o grau de vulnerabilidade varia de acordo com os determinantes sociais da saúde.

Além disso, quando se examina a situação de renda, cor e raça ou etnia, verifica-se que a epidemia está afetando desproporcionalmente pessoas de baixa renda, pobres e extremamente pobres, afrodescendentes, indígenas e migrantes. 


\section{CONTEXTO ECONÔMICO E SOCIAL DA REGIÃO}

A região tem sido caracterizada por altos níveis de desigualdade e por uma estrutura de produção pouco diversificada e altamente heterogênea, na qual os setores de baixa produtividade geram aproximadamente $50 \%$ dos empregos. Esse padrão contribui para gerar grande desigualdade na renda familiar, que pode ser atribuída à distribuição estratificada de ganhos, níveis de produtividade, geração de empregos de qualidade e proteção social dos trabalhadores e de seus grupos familiares.

Esse processo já está sendo chamado de Grande Bloqueio e é a pior crise econômica mundial desde o colapso da Bolsa de Nova York em 1929 e o período da Grande Depressão que se seguiu. Também é certo que a crise econômica afetará mais profundamente os países periféricos, que dependem da exportação de produtos básicos primários e do turismo para garantir o equilíbrio de sua balança comercial. Neste caso estão todos os países da região.

O Fundo Monetário Internacional (FMI) prevê uma contração econômica global ao redor de 4,9\% em 2020 (FMl, 2020). A pandemia teve um impacto econômico mais negativo do que o esperado em seus primórdios e a recuperação será mais lenta do que o previsto anteriormente.

A pandemia causou a recessão mais profunda da história da ALC, que, segundo projeções da Comissão Econômica para a América Latina e o Caribe (Cepal), implicará uma queda no crescimento regional de 9, I\% em 2020.

O impacto da pandemia na economia da região terá como implicações:

- O desemprego aumentará de 8,1\%, em 2019, para 13,5\%, em 2020 (44 milhões de desempregados, 18 milhões a mais que em 2019).

- Haverá aumento de 7,0 pontos percentuais na taxa de pobreza, que atingirá $37,3 \%$ da população (231 milhões no total, com 45 milhões de novos pobres).

- A pobreza extrema tende a aumentar 4,5 pontos percentuais, para 15,5\%, o que representa um aumento de 28 milhões de pessoas ( 96 milhões de pessoas no total).

- A desigualdade se acentuará, com um aumento médio no índice de Gini de 4,9 pontos percentuais de 2019 a 2020.

- A queda na atividade econômica levará o Produto Interno Bruto (PIB) per capita na ALC, no final de 2020, ao observado em 2010, um retrocesso de dez anos.

- Estima-se que 2,7 milhões de empresas poderão fechar devido à crise e necessitarão de apoio. 
- As medidas físicas de distanciamento necessárias para controlar a transmissão têm consequências em termos de perdas de emprego e renda; um grupo particularmente vulnerável são os trabalhadores informais (principalmente mulheres), que representam $54 \%$ do emprego total na região.

Os impactos econômicos serão maiores em famílias de baixa renda. A Cepal desenvolveu um relatório especial denominado "Covid- 19: enfrentar os efeitos cada vez maiores do Covid- I 9 para uma reativação com igualdade - novas projeções”, no qual reavaliou o impacto no PIB dos países da região, projetando queda de 9,1\%, em média, em 2020, com reduções de 9,4\% na América do Sul, 8,4\% no México e América Central e de $7,9 \%$ no Caribe, excluída a Guiana (Cepal, 2020a).

Segundo a Cepal, alguns efeitos podem ser esperados:

- Diminuição da atividade econômica dos principais parceiros comerciais: a excessiva dependência da região de suas exportações será afetada em volume e valor pela recessão global.

- Queda nos preços dos produtos primários e deterioração nos termos de troca: a contração da demanda mundial (principalmente na China) terá papel de destaque na retração dos preços; e crise no mercado de petróleo (redução de $24 \%$ no preço em março de 2020).

- Rompimento das cadeias globais de suprimentos, começando pelos fornecedores chineses e, depois, envolvendo a produção europeia e dos EUA, com possíveis impactos no México e no Brasil.

- Menor demanda por serviços de turismo: proibições e restrições de viagens.

- Intensificação da aversão ao risco e agravamento das condições financeiras globais: maior demanda por ativos seguros, menor demanda por ativos financeiros na região e depreciação da moeda nos países da ALC.

As medidas de distanciamento e isolamento preventivo aplicadas nos países afetaram o setor de serviços, com uma contração no comércio, no transporte e nos serviços sociais, responsáveis por $64 \%$ do emprego formal na região.

A Covid- 19 terá um impacto no comércio internacional, contraindo o comércio internacional para a região em termos de valor e volume. No nível sub-regional, o maior impacto é esperado na América do Sul, devido à ênfase na exportação de bens primários, tornando-a mais vulnerável com os preços mais baixos. Também os países exportadores de petróleo sofrerão perdas, casos do México, Venezuela, Equador e Colômbia, que podem ser muito afetados. 
As exportações regionais para a China seriam as que mais cairiam e poderiam afetar as cadeias de valor, sendo Argentina, Brasil, Chile e Peru as principais vítimas.

\section{RESPOSTAS DOS SISTEMAS DE SAÚDE À COVID-19}

Os sistemas de saúde da ALC não estavam preparados para enfrentar a pandemia e, em muitos casos, já subfinanciados, mostraram-se extremamente frágeis (Telesur TV, 2020). Eles se caracterizam pela fragmentação de responsabilidades por cobertura e benefícios (falta de sistemas universais e abrangentes) e pela segmentação e falta de continuidade da assistência à saúde: o sistema só consegue detectar os pacientes quando apresentam sintomas mais graves, não conseguindo realizar detecção precoce ou trabalhar em rede (OPS, 2020a). Trabalhar em rede significaria identificar precocemente os indivíduos e buscar contactantes e sintomáticos.

A pandemia teve fortes impactos nos sistemas de saúde de todos os países da região, devido à escassez de mão de obra qualificada e de suprimentos médicos, ou devido ao aumento significativo dos custos. A maioria dos países já não vinha investindo o suficiente em saúde: os gastos públicos em saúde do governo central, que em 2018 representavam 2,2\% do PIB regional, estão longe dos $6 \%$ do PIB recomendados pela Organização Pan-Americana da Saúde (Opas) para reduzir as desigualdades e aumentar a proteção financeira, dentro da estrutura de acesso e cobertura universal.

Muitos dos sistemas de saúde da região estão organizados de maneira inadequada para as respectivas realidades sociais e de saúde, e isso vem influenciando a resposta à epidemia. Eles geralmente são estruturados com serviços do setor público para pessoas de baixa renda, serviços de seguridade social para trabalhadores formais e serviços privados para aqueles que podem pagar por eles. Talvez o Brasil, e certamente Cuba, sejam as exceções; este último é uma exceção absolutamente positiva, com um sistema público, universal, gratuito, abrangente, equitativo e de qualidade.

A maioria dos sistemas é segregada e claramente desigual, oferecendo serviços de qualidade diferente para diferentes grupos populacionais. Embora tenham sido empreendidas reformas para reduzir essa fragmentação e expandir o acesso ao sistema de saúde, até agora estas foram absolutamente insuficientes.

Os sistemas de saúde da região tendem a ser geograficamente centralizados, com profissionais da saúde e serviços médicos especializados concentrados em poucos centros urbanos. As instalações são insuficientes para o nível esperado de demanda e dependem, em grande parte, das importações de equipamentos e suprimentos. Esse é um grande problema porque, em II de março de 2020, por exemplo, 24 países no mundo restringiram as exportações de equipamentos médicos, medicamentos ou seus componentes. 
Há grandes lacunas no acesso aos sistemas de saúde, no setor público ou nos planos de saúde privados. Além disso, as dificuldades no acesso aos centros de saúde são agudas nas áreas rurais e remotas.

Como autoridades governamentais de saúde nos países, os ministérios da Saúde assumiram o papel de liderar o enfrentamento da pandemia, associado a medidas extrassetoriais, implementadas necessariamente por outros setores do governo. Em quase todos os países, o chefe da nação assumiu grande parte da coordenação e contatos frequentes com a imprensa, articulando todos os setores nas respostas.

Em geral, os ministérios da Saúde tiveram um desempenho razoável. Mas a insuficiência histórica de financiamento adequado, a falta de preparação prévia para emergências em saúde, a fragilidade da vigilância epidemiológica e sanitária, a falta de testes de diagnóstico, a oferta reduzida de leitos de terapia intensiva, a falta de recursos humanos adequadamente preparados, a oferta inadequada de medicamentos e equipamentos para o atendimento de pacientes críticos, tudo isso afetou a qualidade da resposta, e estamos pagando um preço alto.

Infelizmente, também ocorreram processos de corrupção em alguns países, com preços superfaturados, num conluio abominável entre governantes depravados e provedores privados sem escrúpulos.

\section{DIPLOMACIA E COOPERAÇÃO EM SAÚDE EM TEMPOS DE PANDEMIA}

A pandemia encontrou a ALC em um momento de sensível enfraquecimento de alguns de seus processos de integração regional. Com a inaceitável extinção da União de Nações Sul-Americanas (Unasul), patrocinada pelos governos do Brasil, Chile, Argentina (então sob o governo Macri), Colômbia e outros, um importante espaço político e de saúde regional na América do Sul se perdeu, em um momento de extrema necessidade. Quem seria capaz de substituí-lo na coordenação de esforços e implementação da cooperação? A seguir se examinam as respostas de algumas das estruturas regionais existentes.

A Opas mostrou intensificação de suas atividades, alertando as autoridades sobre futuras tendências epidemiológicas, apoiando tecnicamente o fortalecimento dos sistemas de saúde e enfatizando aspectos de grande relevância na região, como as enormes desigualdades e iniquidades, a importância do estabelecimento de critérios científicos na constituição de protocolos de atenção, no monitoramento do problema de saúde mental e no monitoramento da saúde do trabalhador da saúde, entre outros. No site da Opas estão disponíveis para consulta os 145 relatórios de resposta à pandemia da Covid- 19 nos quais se apresenta o desempenho da organização semana a semana (OPS, 2020b). Ver também o capítulo 8 deste volume, escrito por Galvão. 
Embora tenha tido um desempenho importante vinculado à Covid-19, a Opas foi influenciada por fortes riscos associados aos recursos provenientes das contribuições de seus Estados-membros (OPS, 2020c). Em 31 de maio deste ano, a organização registrava US\$162,2 milhões em dívidas de contribuições regulares, das quais 67\% eram dos EUA, $15 \%$ do Brasil e 5\% da Argentina. Os governos do Brasil e da Argentina (da época) se alinharam com a decisão do governo Trump de não contribuir para a Opas, o que gerou uma das maiores crises econômicas nos 118 anos de sua existência.

Por outro lado, uma organização regional que tem um desempenho importante no âmbito da pandemia é a Cepal. Em resposta à solicitação da Comunidade dos Estados da América Latina e do Caribe (Celac), a Cepal desenvolveu um observatório (Cepal, 2020b) que compila as políticas públicas que os 33 países da região da ALC estão promovendo, medidas para mitigar os impactos econômicos e sociais da região. Recentemente, a Cepal e a Opas prepararam relatório conjunto sobre saúde e economia no contexto da Covid-19, destacando que somente após o achatamento da curva de contágio e morte seria possível reativar as economias da região. Nesse sentido, propõem uma abordagem trifásica que inclui a adoção de políticas de saúde, econômicas, sociais e produtivas destinadas a controlar e mitigar os efeitos da pandemia, reativando as economias com proteção e reconstrução de maneira sustentável e inclusiva (OPS \& Cepal, 2020).

A Organização dos Estados Americanos (OEA) tem atuado ativamente no desenvolvimento de uma resposta à pandemia por intermédio de seus diversos órgãos, como a Secretaria-Geral, o Conselho Permanente, o Conselho Interamericano de Desenvolvimento Integral, a Comissão Interamericana de Direitos Humanos, a Comissão Interamericana de Mulheres, a Fundação Pan-Americana de Desenvolvimento, além, é claro, da Opas, que é a organização regional de saúde especializada no Sistema Interamericano. No capítulo 12 deste livro, Bermudez apresenta de forma mais completa a ação da OEA no enfrentamento da pandemia.

A Celac realizou duas reuniões de especialistas para monitorar a Covid- 19 (30 de janeiro e 13 de fevereiro) e, posteriormente, uma Reunião Ministerial sobre Assuntos de Saúde (26 de março), com a participação da Cepal, da Secretaria-Geral Ibero-Americana (Segib), do Mercado Comum e Comunidade do Caribe (Caricom) e da Opas. A 7 de agosto, em reunião ancorada pelo Paraguai, a Celac discute o acesso à vacina antiCovid I9, sob a liderança de Argentina e México, que prometem atuar com firmeza na promoção do acesso equitativo nos países da região: a Argentina produziria o ingrediente farmacêutico ativo (IFA) da vacina da AstraZeneca e o México a envasaria.

No entanto, essas diversas instituições e/ou mecanismo multilaterais regionais não conseguiram estruturar uma agenda regional conjunta, com ações comuns específicas 
contra a pandemia. Apenas recentemente, em 23 de julho, foi realizada uma reunião virtual entre os ministros das Relações Exteriores da Celac com a China para discutir a cooperação internacional em tempos de pandemia. Como resultado, a China anunciou que teria um crédito no valor de I bilhão de dólares para o acesso a vacinas e medicamentos dos países da Celac (Agencia Telam, 2020; El régimen..., 2020).

O Escritório das Nações Unidades de Serviço para Projetos (Unops) lançou o Observatório Regional de Preços de Medicamentos, com o propósito de promover a transparência e a inclusão, a publicidade proativa, aberta e acessível a informações sobre a pandemia da Covid-I 9 e as respetivas políticas básicas, incluindo as que se relacionam com as compras públicas de insumos médicos e medicamentos. Trata-se de uma plataforma digital que apresenta os preços dos medicamentos adquiridos em compras públicas de 18 países da região com 22 referências, como também as compras realizadas pelo Unops.

Da mesma forma, o Fórum para o Progresso da América do Sul (Prosur), substituto da Unasul, apesar de ter conduzido reuniões virtuais nas quais se discutiu a ideia de compra conjunta de drogas ou harmonização das regulamentações de fronteiras, ainda não demonstrou ser um mecanismo eficaz para ação coletiva e cooperação regional pela falta de experiência conjunta na área da saúde. A partir de duas declarações presidenciais relacionadas com iniciativas de trabalho conjunto em torno da Covid- 19, o Prosur criou cinco grupos de trabalho ad hoc para discutir os temas contemplados nas declarações: 1) Migração e fronteira; 1) Compras conjuntas; 3) Acesso a créditos internacionais; 4) Epidemiologia e disponibilidade de dados; 5) Trânsito de mercadorias.

Recentemente, em 12 de agosto de 2020, foi realizada reunião com o objetivo de constituir o grupo de trabalho de compras conjuntas, preparar proposta da presidência pro tempore para uma mesa com este objetivo e definir os passos a seguir. Na reunião, chamou a atenção a participação de representantes de chancelarias e a reduzida presença dos ministérios de Saúde. Por outro lado, as grandes diferenças nos regimes de compras dos países indicam dificuldades para avançar no processo de compras consolidadas, mas que poderiam ser facilitadas com a participação da Opas e do Banco Interamericano de Desenvolvimento (BID), pela experiência que têm neste tema.

O Sistema de Integração Regional da América Central (Sica) e o Caricom são duas iniciativas multilaterais sub-regionais que têm ampla experiência em trabalhar de maneira coesa entre seus membros para enfrentar contingências comuns, como furacões ou outras ameaças climáticas, agora exploradas no caso da pandemia.

O Sica (2020) desenvolveu várias iniciativas, por meio de sua Comissão de Ministros da Saúde (Comisca), como o Plano Regional de Contingência para a América Central e 
a República Dominicana contra a Covid-19, o Observatório Regional da Covid-19 com seus relatórios semanais e outras estratégias regionais, mobilizando recursos.

A Agência de Saúde Pública do Caribe, ${ }^{3}$ uma organização de saúde do Caricom, realizou ações importantes para fortalecer a capacidade de diagnóstico laboratorial, o acesso a insumos estratégicos e o desenvolvimento de padrões para responder à pandemia nesses países (Carpha, 2020).

Na Comunidade Andina de Nações (CAN), após algumas turbulências entre seus Estados-membros com a Venezuela e os esforços para devolvê-la ao bloco, a Organização Andina da Saúde (Organismo Andino de Salud, 2020) conseguiu uma importante articulação entre os países andinos, por meio de um intercâmbio substancial de informações epidemiológicas e lições aprendidas sobre manejo de pandemia, diagnóstico laboratorial, impacto socioeconômico, saúde mental e outros aspectos relacionados à Covid- 19.

O Mercado Comum do Sul (Mercosul) vive período de tensões políticas entre seus dois principais parceiros, Argentina e Brasil. Diante da pandemia, e considerando a necessidade de uma coordenação regional eficiente e permanente, apoiada em boas práticas, o Paraguai convocou uma reunião virtual extraordinária, na qual os presidentes do organismo firmaram, em 19 de março de 2020, uma "Declaração sobre coordenação regional para a contenção e mitigação do coronavírus e seu impacto” (Mercosur, 2020). O principal resultado da declaração foi que, no âmbito de um projeto já existente de Pesquisa, Educação e Biotecnologias Aplicadas à Saúde, o Fundo para a Convergência Estrutural do Mercosul (Focem) aprovou contribuição de US\$16 milhões adicionais, destinados inteiramente ao combate coordenado à Covid-19. A iniciativa visa a impulsionar a coordenação das autoridades nacionais dos quatro Estados-partes (Argentina, Brasil, Paraguai e Uruguai), em particular para melhorar as capacidades nacionais para a realização de testes de detecção do vírus. A execução desse projeto não ficou livre de alguns obstáculos burocráticos, que a deixaram sem a velocidade necessária para os tempos da pandemia.

\footnotetext{
${ }^{3}$ A Agência Caribenha de Saúde Pública (Carpha) é o instituto regional de saúde pública criado em 2010 por decisão dos chefes de Estado do Caricom, com a função de preparar respostas a emergências de saúde, exercer liderança no campo da saúde pública e atuar nas áreas de informação, educação e comunicação, investigação, formulação de políticas e treinamento, serviços de laboratório, análise da vigilância em saúde, desenvolvimento e capacitação de recursos humanos e planejamento estratégico e mobilização de recursos (Carpha, 2020).
} 
Diante do avanço da epidemia e do impacto significativo nas populações indígenas, a Organização do Tratado de Cooperação Amazônica (OTCA) $(2020)^{4}$ e a Opas elaboraram o Plano de Contingência para a Proteção da População Indígena Altamente Vulnerável, que abrange a Bolívia, Brasil, Colômbia, Equador, Guiana, Peru e Suriname, tendo aprovado um fundo de quase I milhão de dólares pela iniciativa de Bens Públicos Regionais do BID, que abre uma janela de oportunidades para o trabalho nas áreas de fronteira.

A Covid-19 encontrou os países da América Latina com um panorama diferente daquele da Europa ou da Ásia. Trata-se de uma região de renda média, mas com grande heterogeneidade e marcantes desigualdades entre os países e no interior destes. Apresenta grandes diferenças na renda e no acesso à saúde dos diferentes grupos, como povos indígenas, afrodescendentes, migrantes. Além disso, mais de $77 \%$ da sua população vivem em cidades grandes e médias, de alta densidade demográfica, com dificuldades de acesso a água e saneamento, em comunidades, favelas e bairros com grande vulnerabilidade, o que agrega maiores desafios para o cumprimento de medidas básicas para conter a epidemia.

Embora os países tenham tido tempo para aprender com as experiências da China e da Europa em relação à pandemia, a iniquidade e os determinantes da saúde de cada país têm afetado negativamente os resultados, com excesso de perdas de vidas.

Os países com estratégia de atenção primária em saúde bem desenvolvida, casos de Cuba e Costa Rica, tiveram melhor desempenho diante da pandemia. Também indicadores como a percentagem do gasto público em saúde, o PBI, número de leitos por 1.000 pessoas, número de médicos por 10.000 pessoas, número de médicos intensivistas, ventiladores e leitos de UTI permitem explicar o desempenho quanto à capacidade de lidar com a pandemia.

\footnotetext{
${ }^{4}$ A OTCA reconhece como pano de fundo o Tratado de Cooperação Amazônica (TCA), celebrado em julho de 1978. O TCA, assinado pela Bolívia, Brasil, Colômbia, Equador, Guiana, Peru, Suriname e Venezuela, é o instrumento jurídico que reconhece a natureza transfronteiriça da Amazônia. Seus principais objetivos são a promoção do desenvolvimento da região e a incorporação desses territórios nas respectivas economias nacionais, fundamentais para manter o equilíbrio entre o crescimento econômico e a preservação do meio ambiente. Em novembro de 20II, foi adotado o Compromisso de Manaus, que estabelece um conjunto de medidas para promover o novo papel da OTCA no enfrentamento dos desafios internacionais e o desenvolvimento sustentável da Amazônia, o que gerou melhores condições de vida para todas as populações da região (OTCA, 2020).
} 
Políticas negacionistas ou de subestimação da pandemia, aliadas à falta de políticas nacionais e baixa capacidade de reitoria, e de priorização da economia em detrimento da saúde têm gerado perdas de vidas e não têm conseguido evitar a queda da atividade econômica - Brasil e México com -9, I \% e - 10, I \%, respectivamente, segundo o Fundo Monetário Internacional (FMI).

Países com sistemas de saúde frágeis, populações sem proteção social, sem acesso a água e saneamento, baixos níveis de educação e altos níveis de iniquidade têm mais dificuldade de ter bom desempenho quanto à morbimortalidade pela Covid- 19.

O multilateralismo tem falhado. A superposição de iniciativas das várias multilaterais sub-regionais, sem coordenação entre si, prenuncia reduzida efetividade das iniciativas multilaterais na região, o que já se está verificando na prática concreta da cooperação.

A pandemia tem gerado alto impacto sanitário, social e econômico, indicando que para superar a situação de crise são necessárias instituições multilaterais fortes de cooperação, assim como o estabelecimento de cadeias produtivas que integrem as economias da região.

\section{REFERENNCIAS}

AGENCIA TELAM. China ofrece un multimillonario crédito a Latinoamérica para acceder a la vacuna contra el coronavirus. Disponível em: <https://www.telam.com.ar/notas/202007/493371-chinacredito-latinoamerica-vacuna-coronavirus.html>. Acesso em: 18 set. 2020.

CARIBBEAN PUBLIC HEALTH AGENCY (CARPHA). Site. Disponível em: <https://carpha.org >. Acesso em: 7 ago. 2020.

CARO, RUIZ A. Las estrategias para enfrentar el Covid- 19 en América Latina, 2020. America Latina en Movimiento, 3 ago. 2020. (Boletín n. 9 - Integración Regional, una Mirada Crítica, del GT Integración Regional y Unidad Latinoamericana de Clacso). Disponível em: <https://www.alainet.org/es/ articulo/208235>. Acesso em: 8 out. 2020.

COMISIÓN ECONÓMICA PARA AMÉRICA LATINA (CEPAL). Enfrentar los efectos cada vez mayores del Covid- 9 para una reactivación con igualdad: nuevas proyecciones, jul. 2020a. Disponível em: $<$ https://www.cepal.org/es/publicaciones/45782-enfrentar-efectos-cada-vez-mayores-covid-19reactivacion-igualdad-nuevas $>$. Acesso em: 3 ago. 2020.

COMISIÓN ECONÓMICA PARA AMÉRICA LATINA (CEPAL). Observatório Covid- 19 em América Latina y el Caribe: impacto económico y social. Disponível em: <https://www.cepal.org/pt-br/taxonomy/ term/8342>. Acesso em: 30 jul. 2020b.

EL RÉGIMEN chino ofreció prestar mil millones de dólares a América Latina para que compre sus vacunas contra el Covid-19. Infobae, 23 jul. 2020. Disponível em: <https://www.infobae.com/america/ mexico/2020/07/23/china-prestara-usd-1000-millones-a-mexico-america-latina-y-el-caribe-parala-compra-de-vacunas-contra-el-covid-19/>. Acesso em: 30 jul. 2020. 
FONDO MONETARIO INTERNATIONAL (FMI). Actualización de las perspectivas de la economía mundial, jun. 2020. Disponível em: < https://www.imf.org/es/Publications/WEO/Issues/2020/06/24/ WEOUpdateJune2020>. Acesso em: 3 ago. 2020.

JOHNS HOPKINS UNIVERSITY (JHU). Covid-I 9 Dashboard by the Center for Systems Science and Engineering (CSSE) at Johns Hopkins University (JHU). Disponível em: < https://coronavirus.jhu.edu/ map.html>. Acesso em: 7 ago. 2020.

KLIKSBERG, B. Los impactos desiguales de la pandemia. Le Monde Diplomatique, n. 254, ago. 2020. Disponível em: < https://www.eldiplo.org/254-como-curar-la-desigualdad/los-impactos-desigualesde-la-pandemia/>. Acesso em: 3 ago. 2020.

MERCOSUR. Declaración de los presidentes del Mercosur sobre la coordinación regional para la contención y mitigación del coronavirus y su impacto, 18 mar. 2020. Disponível em: <https://www. mercosur.int/documento/declaracion-de-los-presidentes-del-mercosur-covid I 9/>. Acesso em: 30 jul. 2020.

ORGANISMO ANDINO DE SALUD. Covid-19. Disponível em: <http://orasconhu.org/portal/ node/596 >. Acesso em: 30 jul. 2020.

ORGANIZACIÓN DEL TRATADO DE COOPERACIÓN AMAZÓNICA (OTCA). Site. Disponível em: $<$ www.otca-oficial.info >. Acesso em: 8 ago. 2020.

ORGANIZACIÓN PANAMERICANA DE LA SALUD (OPS) \& COMISIÓN ECONÓMICA PARA AMÉRICA LATINA (CEPAL). Salud y economía: una convergencia necesaria para enfrentar el Covid- 19 y retormar la senda hacia el desarrollo sostenible en América Latina y el Caribe. Disponível em: <https://www. cepal.org/sites/default/files/pr/files/hoja_informativa_-OPS-cepal._final._spa.pdf $>$. Acesso em: 3 ago. 2020.

ORGANIZACIÓN PANAMERICANA DE LA SALUD (OPS). Acceso a servicios de salud integrales, equitativos y de calidad. Disponível em: < https://www.paho.org/salud-en-las-americas-20 I 7/?post_ type $=$ post_t_esEp $=3 \mathrm{I}$ I Elang $=\mathrm{es}>$. Acesso em: 3 ago. 2020a.

ORGANIZACIÓN PANAMERICANA DE LA SALUD (OPS). Informes de situación de la Covid- 19. Disponível em: < https://www.paho.org/es/tag/informes-situacion-covid-19>. Acesso em: 18 set. 2020b.

ORGANIZACIÓN PANAMERICANA DE LA SALUD (OPS). Informe sobre la recaudación de las contribuciones señaladas. In: SESIÓN DEL COMITÉ EJECUTIVO, 166, del 22-23 jun. 2020c, sesión virtual. Disponível em: <https://www.paho.org/hq/index.php?option=com_ docmanEview=downloadEalias $=52024$-cel66-7-s-informe-contribucionesEcategory_ slug $=$ cel 66 -esEltemid=270Elang=es $>$. Acesso em: 30 jul. 2020.

SISTEMA DE LA INTEGRACIÓN CENTROAMERICA (SICA). Informes Centroamérica y República Dominicana unidos contra el coronavirus (Covid- 19). Disponível em: < https://www.sica.int/consulta/ documentos_1615_12_l.html>. Acesso em: 30 jul. 2020.

SISTEMA ECONÓMICO LATINOAMERICANO Y DEL CARIBE (SELA). Covid- 1 9: resumen de las principales medidas, acciones y políticas. Disponível em: <http://www.sela.org/es/centro-de-documentacion/ base-de-datos-documental/bdd/62873/covid- I 9-resumen-de-las-principales-medidas-estadosmiembros-sela $>$. Acesso 8 de outubro de 2020.

TELESUR TV. Armando de Negri analiza carencias en los sistemas de salud, 31 jul. 2020. Disponível em: <https://youtu.be/hFO0OMGqWEk>. Acesso em: 3 ago. 2020. 



\section{4 \\ Brics na Covid-19 multilateralismo, capacidade tecnológica e colaboração em PD\&l}

Cláudia Hoirisch

Em dezembro de 2019, a Organização Mundial da Saúde (OMS) foi alertada sobre diversos casos de uma pneumonia que se instalou na cidade de Wuhan, na China. Em um mês, haviam sido confirmados 2.798 casos da Covid- 19 no mundo. Desses, 98,7\% foram notificados pela China, um dos países integrantes do Brics, além de Brasil, Rússia, Índia e África do Sul. Em II de março de 2020, a OMS classificou a Covid- 19 como uma pandemia.

Em 2 I de julho, a China parecia ter controlado a epidemia, ao passo que os outros quatro países do Brics - Brasil, Índia, Rússia e África do Sul - figuravam entre os cinco países com o maior número de casos (Worldmeters, 2020), atrás apenas dos Estados Unidos da América (EUA).

Desde que a pandemia se instalou, o Brics, grupo inicialmente formado em 2009 e acrescido da África do Sul em 201 I, já vinha realizando reuniões virtuais para tratar da questão do novo coronavírus, já que seus sistemas de saúde têm enfrentado desafios sociais, políticos e econômicos para lidar com a infecção.

No quadro atual de crise do arranjo multilateral e de crescente polaridade entre EUA e China, alguns países têm alimentado ceticismo quanto à relevância do Brics. A pandemia do novo coronavírus escancarou problemas antigos e trouxe à tona aspectos relevantes para a construção de um novo futuro nas vertentes política, diplomática e sanitária.

Neste capítulo é apresentada uma rápida contextualização do Brics e, em seguida, uma visão geral da resposta de cada país do grupo em relação ao novo coronavírus, na qual é destacada a vertente diplomática, ou seja, os compromissos que o grupo adotou durante a pandemia numa ação coletiva e de ajuda mútua; o contexto político no qual 
os países estavam inseridos; a crise China-EUA e a importância do multilateralismo para o grupo. O capítulo se encerra com uma apreciação da cooperação entre os Brics e os ruídos internos, assim como da cooperação extra-Brics.

\section{ANTECEDENTES}

Na ordem mundial, os países do Brics apresentam-se como um novo modelo de bloco de países. São uma alternativa ao que existe, dominado pelo Ocidente. O grupo baseia-se nos princípios da cooperação, do respeito mútuo e do equilíbrio de interesses.

O Brics não representa uma região geográfica típica, geralmente constituída por um conjunto de Estados próximos uns aos outros. É uma comunidade de interesses econômicos e políticos comuns na governança global. Durante sua existência, o Brics conseguiu formar uma agenda transnacional. Entre as áreas mais importantes da cooperação, estão, entre outros, a coordenação das atividades desses países em organizações internacionais, incluindo a Organização das Nações Unidas (ONU) e suas agências especializadas (p. ex., a OMS) e a melhoria do sistema financeiro global; projetos conjuntos de pesquisa; cooperação nos campos da saúde, das mudanças climáticas e da proteção ambiental. Nos últimos anos, o Brics criou sua própria instituição financeira, na forma do Novo Banco de Desenvolvimento (NBD) (New Development Bank, 2020) com um capital de US $\$ 100$ bilhões e um Arranjo Contingencial de Reserva de mais US\$ 100 bilhões.

Com raras exceções, a maioria dos laços cooperativos dentro do Brics são bilaterais, não multilaterais. O grupo busca a resolução de vários problemas comuns e a consolidação de interesses materiais mais pragmáticos, como a colaboração em pesquisa e o contrabalanço do expansionismo ocidental no jogo da geopolítica.

Os países do Brics estão ativamente usando o fórum para avançar agendas que possivelmente encontrariam mais resistências nos arranjos multilaterais clássicos. Um exemplo: em 2013, a China lançou a Iniciativa Nova Rota da Seda (ou Cinturão e Rota) (BRI, 2020). Inicialmente, tal iniciativa visava ao desenvolvimento de um corredor de transporte terrestre através do território da Eurásia; no final, o projeto adquiriu uma dimensão verdadeiramente global, incorporando as regiões Ásia-Pacífico, África e fazendo acordos com alguns países da América Latina.

\section{RESPOSTAS POLÍTICAS, SANITÁRIAS E ECONÔMICAS DOS PAÍSES DO BRICS}

Na Rússia, desde que a Covid-19 se instalou, os pesquisadores ficaram intrigados com o baixo número de casos confirmados em um país com um sistema de saúde 
subfinanciado. As explicações variavam de fatores geográficos (o tamanho do país e o isolamento da maioria de suas áreas urbanas dificultariam o percurso do vírus); número limitado de testes de alta qualidade; diagnóstico incorreto (pneumonia); forma de relatar os casos forçando a subnotificação (existe uma convenção que exclui aqueles que têm o vírus, mas não morreram diretamente dele), até suspeitas de manipulação das estatísticas de morbidade (Roth, 2020; Foy \& Burn-Murdoch, 2020). A crise chegou ao país no momento em que o Kremlin procurava concentrar suas energias políticas na pressão por emendas constitucionais que permitissem que Putin permanecesse no poder até 2036.

A pandemia expôs muitas das falhas do sistema de saúde russo. O presidente e o primeiro-ministro Mikhail Mishustin transferiram o problema para os líderes regionais. País com reputação de administração descendente, os aspectos positivos da resposta da Rússia vieram em grande parte de iniciativas locais. Redes de pequenos centros antiepidêmicos construídos na antiga União Soviética após um surto de peste bubônica na década de 1920, que haviam adquirido experiência também com surtos anteriores de tuberculose - outra doença infecciosa que ataca o sistema respiratório -, se mobilizaram contra o coronavírus (Galeotti, 2020).

O presidente Putin não quis enfrentar a crise para não levantar questões sobre seu desempenho de liderança e sua competência geral para a tomada de decisões. A resposta da Rússia a essa crise de saúde revelou a natureza do regime político, seu contrato social com a população e a tomada de decisões estratégicas (Herd, 2020).

Entre as ações para combater a doença, houve o incentivo ao uso de transfusões de plasma sanguíneo de pacientes recuperados para ajudar na recuperação da infecção viral.

Várias agências estatais, como Rospotrebnadzor, o Serviço Federal de Supervisão da Proteção dos Direitos do Consumidor e Bem-Estar Humano, além de empresas farmacêuticas privadas, estão trabalhando no desenvolvimento de uma vacina contra o coronavírus. A Universidade de Sechenov está desenvolvendo uma vacina (Coronavirus..., 2020) que se enquadra na categoria de uso antecipado (testes clínicos sendo feitos pelo Instituto Gamalei). Outra vacina, a EpiVacCorona, está na fase 2 de desenvolvimento. Além disso, medicamentos estão em uso (mefloquina), outros estão sendo modificados para combater o vírus (Russia..., 2020), como é o caso do antiviral avifavir (favipiravir/avigan) ou foram desenvolvidos (levilimab).

Na Índia, é provável que a extensão real do surto seja muito maior que a reportada, devido ao baixo número de testes e ao acesso limitado aos cuidados de saúde em algumas áreas. O país gasta apenas 3,53\% do Produto Interno Bruto (PIB) em saúde, quando a média mundial é 9,9\%. A Índia tem a vantagem de ser o maior produtor 
mundial de medicamentos genéricos; no entanto, importa da China 70-85\% dos insumos farmacêuticos ativos (IFAs) para a produção de medicamentos. Enquanto não é descoberta a vacina, o Ministério Ayush (Ayurveda, Yoga \& Naturopatia, Unani, Siddha e Homeopatia) está buscando validação científica para medicamentos tradicionais indianos (ayurveda) que podem agir no fortalecimento da imunidade. Após identificar problemas de confiabilidade com os kits de diagnóstico fabricados pela China (Sharma, 2020), a Índia está produzindo seus próprios testes.

O país abriga o maior fabricante privado de imunizantes em unidades produzidas. Empresas indianas de vacinas, algumas vezes em parceria com universidades (Oxford e Wisconsin Madison) e biofarmacêuticas estrangeiras (FluGen e Codagenix), estão realizando a etapa de desenvolvimento e avaliação clínica das vacinas candidatas para Covid- 1 9. Em setembro, duas empresas indianas, Bharat Biotech e Zydus Cadila (Kumar, 2020), estavam desenvolvendo vacinas contra a Covid- 19 em fase 2, respectivamente Covaxin e ZyCov-D. Para a Covaxin, a Bharat Biotech se juntou ao Instituto Nacional de Virologia, que faz parte do Conselho Indiano de Pesquisa Médica (ICMR).

Índia e China têm grandes populações, e o desenvolvimento de uma vacina pode ser a única chance para o fim do confinamento.

Quando a Covid- I 9 surgiu em dezembro de 2019 na China, os cientistas chineses conseguiram identificar rapidamente o vírus e em I I de janeiro de 2020 compartilharam internacionalmente dados de sequenciamento genômico. Até o fim de janeiro, médicos chineses haviam identificado as características clínicas de pacientes com a doença, a transmissão pessoa a pessoa, características genômicas e epidemiologia, alertando o mundo sobre a ameaça da Covid- 19.

A Comissão Nacional de Saúde da China enviou, em parceria com a OMS, grupos de infectologistas a Wuhan no início do surto para investigar os riscos e a transmissão da Covid-19; suas recomendações levaram à decisão de isolar Wuhan em 23 de janeiro e incluíram a necessidade de construir abrigos.

A China decidiu apurar a veracidade das alegações dos EUA (Verificação..., 2020) contra o seu país em relação às origens da Covid-19. O embaixador chinês nos EUA pediu aos políticos americanos que acabassem com o jogo de responsabilizar a China, para não correrem o risco de desacoplar a China dos EUA, prejudicando os esforços chineses no combate à doença e na coordenação chinesa para reascender a economia global. O conflito diplomático não prejudicou a colaboração científica. Especialistas em saúde da China e dos EUA concordaram em agir conjuntamente na troca de informações científicas contra a Covid-19, por julgarem que os cuidados com a saúde podem ser 
locais, mas a pesquisa é global e o mundo deve confiar em métodos científicos para lidar com a pandemia. Para fortalecer ainda mais seu soft power, a China enviou enorme quantidade de suprimentos médicos e assistência médica a mais de cinquenta países africanos e à União Africana.

Em setembro, a China estava realizando testes clínicos (Corum, Wee $\&$ Zimmer, 2020) fase 3 em quatro vacinas com uso limitado que estavam sendo desenvolvidas pela Sinovac; pela CanSino Biological Inc e Beijing Institute of Biotechnology; e pela Sinopharm e Wuhan Institute. A Sinovac estabeleceu um acordo de transferência de tecnologia com o Instituto Butantan (SP). Naquele mesmo mês, a China estava desenvolvendo duas vacinas na fase 2 e quatro na fase 1 .

$\mathrm{Na}$ África do Sul, o presidente Cyril Ramaphosa foi amplamente elogiado por ter tomado medidas decisivas ao introduzir, no fim de março, um dos bloqueios mais rápidos e rigorosos do mundo. Três semanas após o primeiro caso ser identificado no país, todos os residentes receberam ordens de ficar em casa por cinco semanas e, durante algum tempo, pareceu que o país escaparia do pior da pandemia. Porém, quatro meses depois, a África do Sul tinha o quinto maior número de casos de Covid- 19 do mundo, depois dos EUA, Brasil, Índia e Rússia. É responsável por mais da metade de todos os casos africanos, e o custo econômico do bloqueio parece ter sido em vão, pois o país está enquadrado no pior cenário esboçado pelos epidemiologistas.

O governo sul-africano parece não ter antecipado uma catástrofe econômica tão dramática e foi forçado a relaxar os regulamentos de isolamento em $1^{\circ}$ de maio e permitir que a maioria dos setores da economia fosse aberta a partir de $1^{\circ}$ de junho, quando o número de casos estava em alta.

À medida que o governo buscava equilibrar saúde e economia, sua resposta à pandemia degenerava em uma série de regulamentos contraditórios que parecem ter sido mais influenciados por grupos de pressão mais poderosos do que pela ciência ou pela economia. Igrejas, cassinos e restaurantes têm permissão para operar por algum tempo com certas restrições, mas parques públicos e praias permanecem fechados. Em julho, táxis micro-ônibus, o principal meio de transporte para a maioria dos sul-africanos, também foram autorizados a operar com 100\% da capacidade; ao mesmo tempo, as viagens domésticas de lazer são proibidas, mesmo para as pessoas que queiram dirigir seus próprios carros.

A África do Sul está testando a vacina BCG para o combate aos sintomas do coronavírus. E o país, assim como o Brasil, aderiu ao Ensaio Clínico Solidariedade da OMS. 
No Brasil, o poder central desrespeita abertamente e desencoraja medidas de distanciamento social e de isolamento introduzidas por governadores estaduais e prefeitos, cuja autonomia para legislar medidas contra a pandemia foi autorizada pelo Supremo Tribunal Federal. Populações mais vulneráveis, em especial do Norte e Nordeste, dependem exclusivamente do Sistema Único de Saúde (SUS). A probabilidade de a doença se espalhar e causar condições mais graves e mais mortes é significativamente maior entre os mais pobres e não brancos.

Tem havido cortes no orçamento da Saúde e da pesquisa desde dezembro de 2016. A formação de grupos de pesquisa competentes custou décadas de esforço nacional, e são eles que permitem enfrentar epidemias e aumentar a expectativa de vida da população. Se as restrições orçamentárias não forem corrigidas a tempo, serão necessárias muitas outras décadas para reconstruir a capacidade científica e de inovação do país.

Na crise do coronavírus, o Brasil se viu dependente de importação de diversos produtos. O SUS, universal, não pode conviver com fragilidade tecnológica, pois depende de insumos, kits de diagnósticos, fármacos, medicamentos e equipamentos de saúde. É preciso inseri-los no centro da política nacional de desenvolvimento.

O país tem feito diversos esforços para conter a pandemia. Pelo trabalho realizado na Fundação Oswaldo Cruz (Fiocruz), o país foi reconhecido pela OMS como referência laboratorial em coronavírus nas Américas para realização de testes confirmatórios da doença, além de integrar a rede de especialistas em laboratório da entidade para a Covid- 19.

Para fomentar a investigação, foram abertas chamadas públicas de $\mathrm{R} \$ 100$ milhões nas áreas de diagnóstico, desenvolvimento de vacinas e testes clínicos; sequenciamento em larga escala do código genético de vírus; ensaios clínicos de medicamentos para combater a Covid-19; uso de biologia computacional para seleção de moléculas para inibir a replicação viral; ensaio clínico usando uma seleção de moléculas feitas por inteligência artificial.

Em setembro, estavam em andamento no Brasil centenas de pesquisas científicas (370 pesquisas..., 2020) voltadas para o tratamento e combate da Covid-19. Os temas abordados nas pesquisas abrangem plasma convalescente como alternativa terapêutica, soros produzidos por cavalos (IVB, 2020), estudos sobre o desenvolvimento de testes sorológicos e evolução da prevalência da infecção no país, entre outros.

O Brasil tem atuado em algumas iniciativas (Braga, 2020) na busca por um imunizante, como as que vêm sendo desenvolvidas pelo InCor/FMUSP; pelos institutos René Rachou/Fiocruz MG e Butantan; por Bio-Manguinhos/Fiocruz; por Bio-Manguinhos e Emergex; pelo Instituto de Ciências Biomédicas da USP (vacina sob a forma de spray nasal) e pela PDS Biotech e Farmacore. 
Medicamentos existentes estão sendo redirecionados para tratar a Covid-19. O Brasil participa do Estudo Clínico Solidariedade, em parceria com a OMS, que vem sendo implementado em hospitais de diferentes estados, inclusive no Instituto Nacional de Infectologia (INI/Fiocruz). Na esperança de encontrar uma vacina, o país estabeleceu acordos de cooperação técnica para produção de vacinas (encomenda tecnológica) com o Reino Unido (Universidade de Oxford e AstraZeneca) com desenvolvimento por Bio-Manguinhos e, por intermédio do governo de São Paulo, com a China (Sinovac Biotech), para a produção da CoronaVac, que contará com o codesenvolvimento do Instituto Butantan, proprietário do estudo clínico.

\section{DIPLOMACIA, CONTEXTO POLÍTICO E MULTILATERALISMO EM MEIO À PANDEMIA: RESPOSTAS DIPLOMÁTICAS DO BRICS}

Antes mesmo de a OMS classificar a Covid-I 9 como uma pandemia, os países Brics decidiram realizar um encontro na tentativa de afastar a ameaça comum. Em uma reunião dos Sherpas e Sous-Sherpas do Brics em II de fevereiro de 2020, foi emitida uma "Declaração da presidência russa do Brics sobre o novo surto epidêmico por coronavírus" (Russian Federation, 2020), na qual o grupo expressou simpatia, apoio e solidariedade à China; se disponibilizou a cooperar com aquele país e sublinhou "a importância de evitar a discriminação, estigma e reação exagerada ao responder ao surto". A declaração clamava pelo fortalecimento da colaboração científica em doenças infecciosas. Por fim, pedia esforços conjuntos para detectar, prevenir e controlar infecções por pandemia usando tecnologias modernas desenvolvidas nos países do Brics.

À medida que a pandemia se espalhava pelos países, mais reuniões foram se sucedendo (Ranepa, 2020). Os chanceleres do Brics se reuniram por videoconferência em 28 de abril, quando defenderam a importância da cooperação multilateral e seu compromisso com o multilateralismo. Concordaram em intensificar o compartilhamento de informações e experiências, promover a colaboração na pesquisa de drogas e vacinas. Na ocasião, chegaram ao entendimento que o Novo Banco de Desenvolvimento do Brics (NBD ou Banco Brics), primeira instituição multilateral não regional pós-Bretton Woods, iria estabelecer um fundo de US\$ 15 bilhões para financiar a recuperação econômica dos países do grupo.

Em março, o NDB já havia aprovado um Empréstimo Emergencial de 7 bilhões de yuans para ajudar a China no combate à Covid-19, em especial para ajudar as três províncias mais atingidas, Hubei, Guangdong e Henan. Esses empréstimos podem ser usados para financiar gastos diretos relacionados com a luta contra o coronavírus ou contribuir para a recuperação econômica dos países-membros. Após China, Índia e 
África do Sul receberem empréstimos para enfrentar o coronavírus, foi a vez de o Brasil obter um empréstimo de US\$ I bilhão (Banco..., 2020), o que fez o apoio financeiro do NDB contra o vírus subir para US\$ 4 bilhões. O banco emitiu títulos de referência Covid (US $\$ 1,5$ bilhão em três anos no mercado internacional de capitais) e os recursos líquidos provenientes da emissão desses títulos serão utilizados para financiar atividades de desenvolvimento sustentável nos seus países-membros, incluindo empréstimos de assistência emergencial.

Em 7 de maio, os altos funcionários da saúde do Brics fizeram uma reunião virtual. Entre os tópicos centrais da discussão estavam a melhoria de métodos de testagem da nova infecção por coronavírus e a busca de métodos de tratamento de pacientes com diagnóstico confirmado. Houve troca de experiências sobre as medidas adotadas pelos membros do grupo no combate à Covid-19 e acordo sobre compartilhá-las posteriormente com especialistas de outros países; debate sobre a interação entre seus sistemas de saúde; concordância em continuar fornecendo apoio mútuo em atividades para prevenir e tratar o coronavírus, bem como em criar condições favoráveis para o fornecimento de medicamentos e insumos de diagnóstico, preparações imunobiológicas e equipamentos médicos.

Para estimular a cooperação multilateral e colocar em prática os compromissos discutidos durante a pandemia, decidiram abrir uma chamada para selecionar projetos conjuntos de pesquisa científica, tecnológica e de inovação na temática da Covid- I 9 que envolvessem pelo menos três dos cinco países do bloco, em cinco linhas de pesquisa: PED de novas tecnologias para diagnósticos da Covid- 19; PED de vacinas e medicamentos para Covid-19 (incluindo o reposicionamento dos existentes); sequenciamento genético do novo coronavírus e estudos sobre epidemiologia e modelagem matemática; inteligência artificial e computação de alto desempenho orientadas para a pesquisa de novos medicamentos, o desenvolvimento de vacinas, tratamentos, testes clínicos e sistemas e infraestruturas de saúde relacionados à Covid- 19; e estudos epidemiológicos e testes clínicos para avaliar a sobreposição de Sars-CoV-2 e outras comorbidades, em especial a tuberculose.

A cúpula do Brics deste ano está prevista para começar em 13 de novembro, em São Petersburgo, na Rússia, depois que o Covid- 19 levou Moscou a desistir de realizá-la em julho, como planejado originalmente.

Todas essas mobilizações podem ser interpretadas como indicações de que os integrantes do Brics pretendem combater o coronavírus com a ajuda do grupo. A demora do grupo em operacionalizar algumas decisões acordadas em suas declarações pode ser 
mais bem entendida quando se analisam o contexto político nos quais esses países estão inseridos, os motivos que levaram à crise do multilateralismo e quais são os países que representam ameaças externas aos interesses americanos.

\section{RÚSSIA E CHINA COMO AS PRINCIPAIS AMEAÇAS AOS INTERESSES DOS EUA: EXISTE CLIMA PARA $O$ BRICS?}

No fim de abril de 2020, os chanceleres do Brics apoiaram a salvaguarda do multilateralismo. Entretanto, cabe levantar algumas questões que, ao contrário da declaração dos chanceleres, põem em xeque o próprio multilateralismo. Dois processos estavam em curso antes e durante a pandemia, e se cruzam: a tensão bilateral EUAChina e o fato de as instituições multilaterais estarem sob estresse. A Covid- 19 apenas contribuiu para exacerbá-los.

A explicação subjacente ao comportamento norte-americano de culpar a China pela disseminação da epidemia e os motivos pelos quais os EUA deixaram de apoiar o multilateralismo podem ser mais bem entendidos mediante a análise da Estratégia de Segurança Nacional dos EUA de 2017. No documento, "a promoção da prosperidade econômica e a liderança tecnológica americana" e "o avanço da influência global dos EUA" são estabelecidos como interesses e objetivos estratégicos dos EUA, e a Rússia e a China são identificadas como as principais "ameaças externas" aos interesses nacionais do país, por quererem "alterar a hierarquia do poder mundial, deslocando ou reduzindo a influência global dos EUA".

No período de 75 anos desde a implantação de um sistema multilateral, os EUA alcançaram uma centralidade mundial e um nível de poder global sem precedentes na história da humanidade, influenciando regras de convivência internacional. Ao mesmo tempo, essa mesma expansão do poder americano contribuiu decisivamente para o "ressurgimento" da Rússia (como potência militar), para o salto econômico da China e para a ascensão de várias outras potências regionais, que passaram a se utilizar das regras do sistema interestatal e de suas mesmas normas, regimes e instituições para contestar o novo mundo liberal e unipolar americano. China, Rússia e vários outros países que se utilizam hoje da "diplomacia de Westfália" e da "geopolítica das nações" (inventada pelos europeus) vêm questionando a própria hierarquia desse sistema liderado pelos EUA.

Além de considerar as potências regionais do Brics (China e Rússia) como ameaças externas, os EUA também passaram a combater o multilateralismo, afastando-se da Organização das Nações Unidas para a Educação, a Ciência e a Cultura (Unesco) e 
do Conselho de Direitos Humanos das Nações Unidas, e vêm ameaçando deixar organizações internacionais como Organização Mundial do Comércio (OMC) e a OMS em razão de opção pelo exercício unilateral de seu poder, por meio da força e da promoção ativa da divisão e da dispersão de seus concorrentes, assim como do boicote a todo tipo de bloco político e econômico regional, seja a União Europeia (UE), a União de Nações Sul-Americanas (Unasul) ou o próprio Brics. A reação norte-americana de afastamento e ataques aos organismos multilaterais está ocorrendo porque outras potências estão questionando esse arranjo a fim de consolidar suas posições e obter benefícios resultantes. Para Fiori, como no mito da Torre de Babel, os EUA atacam países, organismos e blocos para evitar que as potências questionadoras cheguem ao céu (Gabinete PR4, 2020).

Portanto, em um momento em que as organizações internacionais como as Nações Unidas, sua agência especializada de saúde, a OMS, a UE e o Grupo dos Vinte (G20) foram criticados por não conseguirem responder coletivamente à pandemia, os chanceleres do Brics enfatizaram a importância de salvaguardar o multilateralismo.

\section{A IMPORTÂNCIA DO MULTILATERALISMO PARA 0 BRICS E 0 PAPEL DA OMS}

Entre os objetivos do Brics estão o fortalecimento das instituições de Bretton Woods, evidenciado na declaração da Cúpula de Brasília em 20 I 9, e o aumento do poder regional de cada um. De fato, os Estados não hegemônicos contam com instituições multilaterais para atingir seus objetivos, e os países do grupo, por si sós, não conseguem empreender esforços para lidar com crises de larga escala. Uma paralisia no nível de outras instituições multilaterais afetaria negativamente a formação de agendas no Brics.

Durante a pandemia, os países do Brics e a OMS têm trabalhado em sinergia para enfrentar as deficiências de seus sistemas de saúde e as sérias consequências sociais e econômicas de uma inevitável depressão econômica global. O papel de liderança da OMS contribuiu para colocar a narrativa científico-humanitária sobre o novo coronavírus em um lugar inédito, tanto para a definição de políticas de saúde quanto para as expectativas mundiais em relação aos processos de contágio, à vigilância de processos epidêmicos, ao escopo de sua propagação e a opções de contenção. Sob o manto da Iniciativa Rota da Seda Saudável e para apoiar o multilateralismo, a China forneceu, além de US $\$ 50$ milhões à OMS, mais US $\$ 2$ bilhões, durante a abertura da $73^{\mathrm{a}}$ Assembleia Mundial de Saúde, e a Rússia se comprometeu a doar US\$ I milhão. 


\section{COOPERAÇÃO ENTRE OS PAÍSES DO BRICS: RESPOSTAS BILATERAIS E RUIIDOS}

Nesta seção, serão analisadas as relações bilaterais com a China, o membro mais poderoso do Brics. Em meio à cooperação entre os pares do Brics, a engrenagem mais suave parece ser a que articula China e Rússia. Em uma conferência de imprensa após a reunião dos chanceleres do Brics, o chanceler russo, Sergei Lavrov, declarou: "Quando falamos de cooperação com a China, citamos fatos. Estes incluem entrega de suprimentos humanitários, kits de medicamentos e testes, envio de médicos especialistas, consultas mútuas e outros". Governos, instituições de pesquisa e empresas da China e da Rússia estão envolvidos na cooperação antiepidêmica e veem a saúde pública e a biotecnologia como pontos-chave na colaboração bilateral em CTEI. Em junho do ano passado, os presidentes Putin e $X i$ Jinping haviam designado os anos de 20202021 como o de cooperação em C,TEl russo-chinesa (Russian-Chinese..., 2020) quando enfatizaram que as relações entre os dois países haviam evoluído para uma ampla parceria estratégica de coordenação para uma nova era. Nesse novo ambiente, os dois países estão promovendo pesquisas científicas conjuntas, realizando estudos sobre a origem do vírus, suas fontes e sua estratégia de mutação. Em maio de 2020, havia mais de dez projetos de cooperação científica e técnica entre os dois países, incluindo o desenvolvimento de dispositivos de proteção médica, a melhoria da eficácia de testes de diagnóstico, medicamentos e pesquisas na área de vacinas. O Centro Estadual de Pesquisa em Virologia e Biotecnologia da Rússia (Vector) e os centros de Biotecnologia do Ministério da Ciência e Tecnologia da China, por exemplo, estavam trabalhando em testes de diagnósticos e desenvolvimento de vacinas.

Mas, mesmo nessa estreita relação, houve atrito durante a pandemia. A Rússia foi um dos primeiros países a fechar suas fronteiras com a China e os condutores de transportes públicos na Rússia foram instruídos a monitorar passageiros chineses e acionar a polícia no caso de identificarem "pessoas de nacionalidade chinesa" em seus veículos. Apesar dessas tensões, os interesses comuns da China e da Rússia superam suas diferenças. As relações pessoais entre os presidentes $X i$ Jinping e Putin parecem não ter sido afetadas e o contato oficial e diplomático funciona sem problemas, tanto é que a China retribuiu enviando suprimentos de proteção para a Rússia. Pode-se prever que os laços bilaterais se desenvolverão em uma direção favorável.

Se os ruídos gerados pela Rússia não afetaram as relações diplomáticas com a China, o mesmo não aconteceu com o Brasil. O primeiro episódio ocorreu quando o Brasil responsabilizou o governo chinês pela pandemia do novo coronavírus; o segundo ocorreu com o ex-ministro da Educação, que insinuou que o país asiático sairia fortalecido da crise mundial causada pela Covid- 19 (Weintraub..., 2020). Em resposta, a Embaixada 
da China afirmou que as declarações eram influências negativas ao desenvolvimento saudável das relações bilaterais China-Brasil (China..., 2020). Em ataque recente, o chanceler brasileiro publicou um texto em que alertava que um plano comunista estaria sendo desenhado para usar a pandemia com o intuito de fortalecer as entidades internacionais, entre as quais a OMS, e por meio delas influenciar o mundo. As autoridades de saúde brasileiras já estavam lutando para obter suprimentos para enfrentar a epidemia antes da intervenção desastrosa do ex-ministro da Educação, e o imbróglio só agravou o quadro. A China é a maior produtora de máscaras e equipamentos de saúde, e a pandemia ocasionou aumento na demanda mundial por esses suprimentos. Apesar de equipamentos chineses estarem sendo esperados no Brasil, contratos de compra não são garantia de recebimento. O chefe da Câmara de Comércio e Indústria Brasil-China, Charles Andrew Tang, se disse preocupado com a sucessão de atritos na relação entre os dois países e afirmou que o Brasil depende de uma boa relação com os chineses (China ameaça..., 2020) para combater o coronavírus. As autoridades chinesas disseram que um dos critérios para fornecer assistência (Tan, 2020) é o modo como os possíveis beneficiários trataram a China no passado. Prova disso é que a província de Sichuan doou material médico endereçado para Pernambuco, estado com que mantém relações de irmandade há 28 anos (Província..., 2020).

Em maio, o presidente chinês $X i$ Jinping manteve conversas telefônicas com o presidente sul-africano Cyril Ramaphosa. Em declarações a Ramaphosa, Xi disse que a China e a África do Sul são "bons irmãos" e o país continuaria apoiando a África do Sul contra a pandemia e prestaria assistência dentro de sua capacidade (President..., 2020). Expressando gratidão pela ajuda da China no combate à doença, Ramaphosa retribuiu dizendo que a China é um "verdadeiro amigo" e "parceiro confiável" da África do Sul e dos países africanos. O governo chinês prometeu que "uma vez concluído o desenvolvimento e implantação da vacina Covid- 19 na China, os países africanos seriam os primeiros a se beneficiar".

Talvez o conjunto mais crítico de diferenças esteja na díade China-Índia. Reações da Índia indicam agora como a pandemia afetou esse relacionamento já difícil, à parte o conflito sino-indiano. Primeiro, para combater possíveis aquisições oportunistas de empresas indianas (Natarajan, 2020), a Índia alterou as regras para proibir que empresas chinesas assumissem o controle de empresas quebradas devido às perdas causadas pela pandemia. Segundo, a Índia cancelou a importação de testes de diagnóstico chineses para o coronavírus, alegando que não eram confiáveis por terem baixa taxa de precisão (Índia..., 2020). O porta-voz chinês descreveu o comportamento da Índia como "injusto e irresponsável”. Recentemente, os dois países entraram em choque na chamada Linha de Controle Real (LAC, na sigla em inglês), na fronteira que separa esses dois países no 
vale de Galwan, em Ladakh, onde compartilham mais de $3.440 \mathrm{~km}$ e ao longo da qual tem havido reivindicações territoriais. A Rússia foi acionada para apaziguar os ânimos.

Se o equilíbrio entre Índia e EUA e os vínculos Rússia-China e Rússia-Índia permanecerem mas a rivalidade EUA-China se intensificar; se o conflito da China e Índia escalar na disputa para ver quem abocanha o território no alto do Himalaia; se os laços Brasil-EUA e as tensões Rússia-EUA se intensificarem, com certeza se ampliarão as perspectivas de uma fratura interna no Brics.

Os integrantes do Brics são membros de várias associações regionais. Diante dos conflitos externos e internos e do enfraquecimento das instituições multilaterais, em especial do sistema das Nações Unidas, num momento em que cada país está lutando para conter a epidemia, a cooperação bilateral e de curto prazo regional mostra a liderança dos países Brics nas respectivas regiões e pode trazer benefícios de longo prazo para os países do grupo.

\section{RESPOSTAS EXTRA-BRICS}

Cada país do Brics tem interesse em se projetar regionalmente, seja por meio de cooperação bilateral regional ou via blocos regionais. As crises fornecem oportunidade para esses países se lançarem e reiteram as razões pelas quais certas estruturas foram criadas. A liderança regional de cada país do Brics ajuda a discernir as potencialidades de cada um no grupamento.

Por intermédio da Opas, o Brasil respondeu de forma regionalizada (Dominguez, 2020), capacitando em fevereiro, na Fiocruz, especialistas da Argentina, Bolívia, Chile, Colômbia, Equador, Panamá, Paraguai, Peru e Uruguai em vigilância laboratorial, fornecendo o protocolo para o diagnóstico da Covid-19, recomendações sobre biossegurança e transporte de amostras (Diagnóstico..., 2020). Quando estabeleceu um acordo com a Universidade de Oxford para receber a vacina, o Brasil tinha intenções de negociar o abastecimento para toda a América Latina (Jansen, 2020).

A Rússia forneceu I milhão de kits de testes Covid- 19 aos países da Comunidade de Estados Independentes (CEI) (Russia to..., 2020).

No âmbito bilateral, a Índia enviou médicos para o Kuwait e para as Maldivas, equipamentos médicos para Bangladesh e alimentos para o Afeganistão. Como a maior fornecedora de medicamentos genéricos do mundo, o país está recorrendo à sua indústria farmacêutica proeminente e fornecendo medicamentos (Solanki, 2020) para 85 países. Com relação aos países vizinhos do sul da Ásia, a Índia disponibilizou sua capacidade e experiência em medicina e saúde pública para toda a região. Por sua iniciativa, os líderes 
dos países da Associação Sul-Asiática para a Cooperação Regional (Saarc) realizaram uma videoconferência em 15 de março para coordenar uma abordagem em relação à Covid-19. Vários projetos foram lançados, incluindo um Fundo de Emergência Covid-19, para o qual a Índia contribuiu com US\$ 10 milhões e o conjunto dos demais países do grupo, com quase US $\$ 9$ milhões. Em 26 de março foi realizada uma videoconferência de profissionais da saúde representando os países da Saarc, ocasião em que foi criado um grupo para médicos dos países participantes, sobre gestão de pacientes, testes e vigilância de doenças. A Índia desenvolveu ainda a plataforma digital COARX da Saarc Covid- 19 para facilitar o intercâmbio de informações e ferramentas especializadas sobre a doença entre os profissionais da saúde designados na região, além de recursos de treinamento on-line e módulos de e-learning, cobrindo diversos tópicos relacionados ao tratamento da pandemia do novo coronavírus.

Um mês após o surto ter sido registrado em Wuhan, a China lançou ações bilaterais de cooperação internacional, motivadas pela necessidade de reverter a crescente desconfiança dos países vizinhos, que o identificaram como um país "irresponsável" devido à demora em anunciar o vírus. A chamada "diplomacia das máscaras" - que faz parte da Rota da Seda Saudável (HSR), braço da Iniciativa Cinturão e Rota - teve seu batismo com o envio de máscaras e kits de diagnóstico para a Coreia do Sul e o Irã, inicialmente os países mais afetados. A China também enviou equipes de especialistas em saúde para o Iraque e o Irã. Procurou reativar em abril o acordo ampliado da Associação dos Estados-Membros do Sudeste Asiático (Asean+3, com China, Japão e Coreia do Sul), que mais tarde enfrentou esforços de obstrução dos EUA.

Durante a pandemia, os Brics empreenderam mais cooperações bilaterais e regionais do que multilaterais.

A pandemia pode acelerar a criação de um Centro de Pesquisa e Desenvolvimento de Vacinas Brics, que conta com o forte apoio da Índia, Rússia e África do Sul e contaria com o suporte do NBD. Muitos países do grupo têm competências tecnológicas, e a colaboração em pesquisa poderia ajudar a catalisar o processo. A China está na vanguarda da pesquisa de vacinas contra a Covid-19. Sua experiência mostra a importância de investir em sistemas nacionais de saúde e pesquisa para aumentar a capacidade laboratorial e a força de trabalho, fundamentais para uma resposta nacional rápida e eficaz às emergências de saúde. A demora em obter consenso sobre a implementação desse centro de vacinas pode ser devida ao impacto que a pandemia teve nas economias 
desses países,' à Guerra Fria vivenciada pela China ou ao fato de a China já ter vacinas em estágios avançados.

Enquanto o referido centro não é operacionalizado, os países do Brics poderiam estabelecer uma aliança inclusiva de vacinas, por meio da qual negociariam em conjunto a compra de grandes quantidades de imunizante para a Covid- 19 com os desenvolvedores e produtores a fim de obterem melhores preços e torná-las acessíveis.

O país do grupo que mais aderiu às recomendações da Organização para a Cooperação e Desenvolvimento Econômico (OCDE) para a saída da pandemia e apresentou melhor desempenho até agora foi a China. Para o Brasil e a Rússia, a pandemia serviu de alerta sobre a necessidade de que haja melhor interface de cooperação entre ciência, política e sociedade. A prestação de proteção social e serviços essenciais a todos, especialmente aos pobres e vulneráveis, deveria estar no cerne da relação de governança Estadopessoas. Governos - como o do Brasil (atraso e desvios do pagamento emergencial), da Índia (ajuda insuficiente) e da África do Sul - deveriam se esforçar em manter o país unificado, investir nos sistemas de saúde e implementar políticas de proteção para evitar crises alimentares e desintegração social.

Para países como o Brasil, que está tentando garantir seus próprios acordos com fabricantes de vacinas, o mecanismo da Aliança Global para Vacinas e Imunização (Gavi Alliance) representa, com seu portfólio de candidatas a vacinas, um meio de reduzir os riscos associados a candidatas individuais que não demonstrem eficácia ou obtenham licença. Com mais essa opção (Moreira, 2020), o país terá que desembolsar cerca de US\$ 2 bilhões para adquirir vacinas para imunizar pelo menos 20\% de sua população (duas doses) por meio do mecanismo Covid-19 Global Access Facility (Covax Facility), ${ }^{2}$ destinado aos países de rendas média e alta. A China anunciou que iria aderir à Covax; espera-se que honre seu compromisso de transformar as vacinas

\footnotetext{
' Segundo projeções do FMI, as expectativas de declínio no PIB em 2020 são de 5,3\% no Brasil, 5,5\% na Rússia e 5,8\% na África do Sul. China e Índia parecem ser os países menos afetados, com variação percentual anual positiva de, respectivamente, 1,2 e 1,9\%.

2 Pool financeiro que ajuda empresas a desenvolver vacinas mais rapidamente e garantir acesso justo e equitativo a todos os países do mundo. É coliderada pela Gavi, pela Coalizão de Inovações em Preparação para Epidemias (Cepi) e pela OMS, trabalhando em parceria com fabricantes de vacinas de países desenvolvidos e em desenvolvimento. Os 75 países que financiariam as vacinas com seus próprios orçamentos firmam parceria com até noventa países de baixa renda que poderiam ser apoiados por meio de doações voluntárias ao Compromisso Antecipado de Mercado (AMC) da Gavi. Juntos, esse grupo de cerca de 165 países representa mais de $60 \%$ da população mundial. O primeiro AMC firmado foi um acordo de US\$750 milhões entre a Gavi e a farmacêutica britânica AstraZeneca para fabricar 300 milhões de doses da vacina que está sendo desenvolvida em parceria com a Universidade de Oxford.
} 
Covid- 19 em um bem público global (China..., 2020). O compartilhamento de vacinas será um teste de cooperação multilateral na área internacional.

O acesso a tecnologias pode se dar de modo voluntário ou compulsório, caso haja proteção patentária. Nem sempre é possível chegar a um acordo voluntário, e no caso de vacinas a Licença Compulsória (LC) não faz muito sentido, uma vez que são muito mais complicadas de produzir do que medicamentos de pequenas moléculas. Portanto, não é realista pensar que alguns países irão produzir suas próprias versões de vacinas. Para contornar as patentes e propriedade intelectual e garantir o acesso equitativo e preços acessíveis, é preciso participar de iniciativas multilaterais.

Os ministérios de Ciência e Tecnologia dos países que compõem o Brics devem continuar apoiando projetos conjuntos realizados por pesquisadores e instituições de pelo menos três destes países.

\section{REFERENNCIAS}

370 PESQUISAS científicas para tratar e combater a Covid- 19 estão em andamento no Brasil. Pfarma. com.br, 2 jun. 2020. Disponível em: <https://pfarma.com.br/coronavirus/5695-pesquisas-cientificascovid 19.html >. Acesso em: 18 set. 2020.

BANCO do Brics aprova empréstimo de US\$ I bilhão ao Brasil. Valor Econômico, Rio de Janeiro, 20 jul. 2020. Disponível em: <https://g l globo.com/economia/noticia/2020/07/20/banco-do-brics-aprovaemprestimo-de-us-1-bilhao-ao-brasil.ghtml>. Acesso em: 18 set. 2020.

BELT AND ROAD INITIATIVE (BRI). Site. Disponível em: < https://www.beltroad-initiative.com/beltand-road $>$. Acesso em: 18 set. 2020.

BRAGA, M. Veja como está a participação do Brasil na corrida pela vacina contra a Covid-19. Portal GI, Rio de Janeiro, 20 jun. 2020. Disponível em: < https://gl.globo.com/bemestar/coronavirus/ noticia/2020/06/20/veja-como-esta-a-participacao-do-brasil-na-corrida-pela-vacina-contra-acovid-19.ghtml>. Acesso em: 18 set. 2020.

CHINA officially joins Covax: spokesperson. Xinhuanet, 9 set. 2020.

CHINA AMEAÇA corte no comércio se bolsonaristas insistirem em hostilidades. Uol, São Paulo, 06 abr. 2020. Disponível em: < https://noticias.uol.com.br/politica/ultimas-noticias/2020/04/06/china-ameacacorte-no-comercio-se-bolsonaristas-insistirem-em-hostilidades.htm>. Acesso em: 18 set. 2020.

CHINA chama comentário de Weintraub de "fortemente racista" e aponta "influência negativa" em relação com Brasil. O Globo, Rio de Janeiro, 6 abr. 2020. Disponível em: <https://oglobo.globo. $\mathrm{com} / \mathrm{mundo} / \mathrm{china}$-chama-comentario-de-weintraub-de-fortemente-racista-aponta-influencianegativa-em-relacao-com-brasil- I-24353469>. Acesso em: 18 set. 2020.

CORONAVIRUS vaccine update: Russia's Sechenov University claims to be the first to complete human trials; here's what we know so far. Times of India, Mumbai, 13 Jul. 2020. Disponível em: <https:// timesofindia.indiatimes.com/life-style/health-fitness/health-news/coronavirus-vaccine-updaterussias-sechenov-university-claims-to-be-the-first-to-complete-human-trials-heres-what-weknow-so-far/photostory/76935427.cms >. Acesso em: 18 set. 2020. 
CORUM, J.; WEE, S-L. \& ZIMMER, C. Coronavirus Vaccine Tracker. The New York Times, New York, 2020. Disponível em: <https://www.nytimes.com/interactive/2020/science/coronavirus-vaccine-tracker. html>. Acesso em: 18 set. 2020.

DIAGNÓSTICO em rede. Radis, 21 , Rio de Janeiro, mar. 2020, p. 21 . Disponível em: <https://radis. ensp.fiocruz.br/phocadownload/revista/Radis210_web.pdfs.

DOMINGUEZ, B. Global: novo coronavírus é a sexta emergência em saúde pública de importância internacional declarada pela OMS. Radis, 2 I , Rio de Janeiro, mar. 2020, p. 14-20. Disponível em: < https:// radis.ensp.fiocruz.br/phocadownload/revista/Radis210_web.pdf>. Acesso em: 18 set. 2020.

FOY, H. E BURN-MURDOCH, J. Russia's Covid death toll could be 70 per cent higher than official figure. Financial Times, Moscow, London, II May 2020. Disponível em: <https://www.ft.com/ content/77cd2cba-b0e2-4022-a265-e0a9a7930bda >. Acesso em: 18 set. 2020.

GABINETE PR4. Ciclo de debates | Política e Covid-19, I jun. 2020. Disponível em: <https://www. youtube.com/watch?v=Sybil A2R_qM>. Acesso em: 18 set. 2020.

GALEOTTI, M. Russia is weathering Covid-19, no thanks to Putin. Word Politics Review, 10 June 2020. Disponível em: < https://www.worldpoliticsreview.com/articles/28826/russia-s-putin-is-failing-todeal-with-covid-19-and-russians-know-it>. Acesso em: 18 set. 2020.

HERD, G. P. Covid-19, Russian responses, and President Putin's operational code. George C. Marshall European Center for Security Studies, n. 50, Apr. 2020. Disponível em: < https://www.marshallcenter.org/ en/publications/security-insights/covid-19-russian-responses-and-president-putins-operationalcode >. Acesso em: 18 set. 2020.

ÍNDIA cancela pedidos de testes para coronavírus da China por "problemas de performance". Valor Econômico, Rio de Janeiro, 27 abr. 2020. Disponível em: < https://valor.globo.com/mundo/ noticia/2020/04/27/india-cancela-pedidos-de-testes-para-coronavirus-da-china-por-problemasde-performance.ghtml>. Acesso em: 18 set. 2020.

INSTITUTO VITAL BRAZIL (IVB). Instituto Vital Brazil anuncia patente de soro contra a Covid-I9. Disponível em: <http://www.vitalbrazil.rj.gov.br/noticias/Instituto-Vital-Brazil-anuncia-patentede-soro-contra-a-Covid-19.html>. Acesso em: 18 set. 2020.

JANSEN, R. Brasil negocia possibilidade de fazer vacina contra o coronavírus. Estadão, São Paulo, 5 jun. 2020. Disponível em: <https://saude.estadao.com.br/noticias/geral,brasil-negocia-possibilidadede-fazer-vacina-contra-o-coronavirus,70003325364>. Acesso em: 18 set. 2020.

KUMAR, S. Scientists scoff at Indian agency's plan to have Covid- 19 vaccine ready for use next month. Science, Washington, 6. Jul. 2020. Disponível em: < https://www.sciencemag.org/news/2020/07/scientists-scoffindian-agencys-plan-have-covid-19-vaccine-ready-use-next-month>. Acesso em: 18 set. 2020.

MOREIRA, A. Brasil precisará pagar US\$ 2 bi para comprar vacinas contra Covid- 19 e imunizar 20\% da população. Valor Econômico, Rio de Janeiro, 15 jul. 2020. Disponível em: <https://valor.globo.com/ brasil/noticia/2020/07/1 5/brasil-precisara-pagar-us-2-bi-para-comprar-vacinas-contra-covid- 19 e-imunizar-20percent-da-populacao.ghtml>. Acesso em: 18 set. 2020.

NATARAJAN, S. China e Índia: o que há por trás da escalada de tensão que deixou 20 soldados mortos em choque na fronteira. BBC News Brasil, 16 jun. 2020. Disponível em: <https://www.bbc.com/ portuguese/internacional-53073587>. Acesso em: 18 set. 2020. 
NEW DEVELOPMENT BANK. Site. Disponível em: <https://www.ndb.int/>. Acesso em: 18 set. 2020.

PRESIDENT Xi says China will continue to support South Africa, Hungary over Covid- 19. CGTN, I 5 May 2020. Disponível em: <https://news.cgtn.com/news/2020-05-15/Xi-<Jinping-says-China-supportsSouth-Africa-Hungary-over-Covid-19-QwjlfCbkSQ/index.html>. Acesso em: 18 set. 2020.

PROVÍNCIA chinesa de Sichuan doa materiais médicos para Pernambuco. Xinhua Português, 9 maio 2020. Disponível em: <http://portuguese.xinhuanet.com/2020-05/09/c_139042743.htm>. Acesso em: 18 set. 2020.

ROTH, A. Russia defends its "exceptionally precise" Covid- 19 death data. The Guardian, Moscow, 14 May. 2020. Disponível em: <https://www.theguardian.com/world/2020/may//4/coronavirus-russiadefends-its-exceptionally-precise-covid-19-death-data >. Acesso em: 18 set. 2020.

RUSSIA registers new drug to contain complications caused by Covid-19. CGTN, 8 Jun. 2020. Disponível em: <https://news.cgtn.com/news/2020-06-08/Russia-registers-new-drug-to-containcomplications-caused-by-Covid-19-R9vpZzmRs4/index.html>. Acesso em: 18 set. 2020.

RUSSIA to supply I mln Covid- 19 test kits to foreign partners: PM. Xinhua Net, 29 May 2020. Disponível em: < http://www.xinhuanet.com/english/2020-05/29/c_139099191.htm>. Acesso em: 18 set. 2020.

RUSSIAN FEDERATION. Russian Brics Chairmanship Statement on the novel coronavirus pneumonia epidemic outbreak in China, issued on February 11, 2020 at the Ist Meeting of Brics Sherpas/SousSherpas in St. Petersburg, II Feb. 2020. Disponível em: < https://www.mid.ru/en/foreign_policy/ news/-/asset_publisher/cKNonkJE02Bw/content/id/403515I >. Acesso em: 18 set. 2020.

RUSSIAN PRESIDENTIAL ACADEMY OF NATIONAL ECONOMY AND PUBLIC ADMINISTRATION (RANEPA). Brics. Russian presidency 2020. Disponível em: < https://www.ranepa.ru/eng/ciir-ranepa/ brics-russian-presidency-2020/>. Acesso em: 18 set. 2020.

RUSSIAN-CHINESE fight against Covid- 19 to encourage bilateral cooperation - Xi Jinping. Tass, Russia News Agency, Beijing, 26 ago. 2020. Disponível em: <https://tass.com/world/1 $193957>$. Acesso em: 18 set. 2020.

SHARMA, K. India opts for own Covid- 19 tests kits, rejecting those from China. Nikkei Asia, I May 2020. Disponível em: <https://asia.nikkei.com/Politics/India-opts-for-own-Covid-19-tests-kitsrejecting-those-from-China >. Acesso em: 18 set. 2020.

SOLANKI, V. Why India's response to Covid-1 9 matters to us all. International Institute for Strategic Studies (IISS), 29 Apr. 2020. Disponível em: < https://www.iiss.org/blogs/analysis/2020/04/sasiawhy-indias-response-to-Covid-19-matters-to-us-all>. Acesso em: 18 set. 2020.

TAN, H. As China's cases dwindle, Beijing strives to take the lead in the coronavirus crisis. CNBC, New Jersey, 3 Apr. 2020. Disponível em: <https://www.cnbc.com/2020/04/03/china-pursues-globalleadership-ambitions-in-coronavirus-response.html>. Acesso em: 18 set. 2020.

VERIFICAÇÃO da realidade das alegações dos EUA contra a China em relação à Covid-19. Xinhua Português, 10 maio 2020. Disponível em: <http://portuguese.xinhuanet.com/202005/10/c_139045375.htm >. Acesso em: 18 set. 2020.

WEINTRAUB usa Cebolinha da Turma da Mônica para fazer chacota de chineses. Portal Uol, São Paulo, 4. abr. 2020. Disponível em: <https://wwwl.folha.uol.com.br/mundo/2020/04/weintraub-usacebolinha-da-turma-da-monica-para-fazer-chacota-de-chineses.shtml>. Acesso em: 18 set. 2020.

WORLDOMETERS.COM. Site. Disponível em: <http://www.worldometers.com/> . Acesso em: 18 set. 2020. 


\section{5 \\ A Resposta à Covid-19 no Continente Africano a União Africana e a criação do CDC África}

Augusto Paulo José da Silva e Felix Júlio Rosenberg

R eunimos e apresentamos aqui a informação disponível sobre o enfrentamento coletivo da Covid- 9 na África por parte das principais organizações regionais do continente africano: a União Africana (UA) e a sua agência especializada, o Centro de Controle e Prevenção de Doenças (CDC África), os seis blocos econômicos regionais e as diversas agências de cooperação bilateral e multilateral, a sociedade civil e o setor privado.

\section{A UNIÃO AFRICANA}

A União Africana (UA), constituída por 55 Estados-membros, foi formalmente fundada em julho de 2002 em Durban, África do Sul, após uma decisão tomada em setembro de 1999 por sua antecessora, a Organização de Unidade Africana (OUA, 1963-1999), no sentido de criar uma nova organização continental para continuar o seu trabalho.

Para não recuarmos tanto no tempo e nos atermos mais ao que interessa à resposta do continente africano à atual pandemia, alguns momentos-chave nos parecem relevantes para perscrutarmos, entre 2019 e 2020, o papel de liderança da UA nos domínios político-diplomático, econômico, social e sanitário, tendo em conta a inflexão de rumo que a pandemia certamente já causou na Agenda 2063 da União Africana.

Em primeiro lugar, na passagem da presidência pro tempore do Egito para a África do Sul, entre fevereiro 2019 e fevereiro 2020, assinalamos a entrada em vigor do Acordo sobre Zona de Comércio Livre. Em segundo lugar, o realce conferido à a realização da primeira reunião de coordenação entre a União Africana e as Comunidades Econômicas Regionais (CERs). Em terceiro lugar e para 2020, a adoção pelos chefes de Estado e de governo da Agenda de Paz e Segurança da União Africana sob o lema "Silenciar as armas: criar as condições para o desenvolvimento da África". 
Como quarto marco, a criação e operacionalização do Centro de Controle e Prevenção de Doenças da União Africana (CDC África), aprendidas que foram as lições da terrível epidemia do ebola no período de 2014 a 2016.

\section{CDC ÁFRICA}

Alguns eventos importantes rodearam a criação do CDC África, que merece um especial destaque porque tem uma participação inicial da Fundação Oswaldo Cruz (Fiocruz) e tudo indicava que o Brasil estaria envolvido em etapas subsequentes até a concretização desse processo. Tudo começou com a Cúpula de Chefes de Estado e de Governo da União Africana, realizada na Nigéria entre 15 e 16 de julho de 20 I3, quando se resolveu: a necessidade de prestar uma atenção muito especial ao trabalho sobre a Agenda de Desenvolvimento pós-2015; e a necessidade de criar um Centro Africano para o Controle e Prevenção de Doenças (o CDC África) para enfrentar problemas de saúde prioritários na África e servir de plataforma para partilhar conhecimentos e fortalecer capacidades para responder a situações de emergência e ameaças de saúde pública (Declaração de Abuja, UA, 2013).

Tendo tomado parte nessa cúpula de julho de 2013, a Organização Mundial da Saúde (OMS) imediatamente organizou, em setembro de 2013 e à margem da $63^{\mathrm{a}}$ Sessão do Comitê Regional, um painel intitulado Rede de Instituições de Pesquisa em Saúde Pública na Região Africana com o objetivo geral de promover a integração das instituições de saúde pública como parte da estratégia regional para fortalecer a vigilância, a prevenção e a luta contra as doenças. A Fiocruz foi convidada e o dr. Felix Rosenberg integrou esse painel juntamente com os drs. Abdulsalami Nasidi, do Centro de Luta contra as Doenças da Nigéria (atual CDC), e Odile Ouwe Missi Oukem, do Centre de Recherche Médicale et Sanitaire du Niger (Cermes). O painel teve também dois oradores: os drs. Janusz Paweska, do Instituto Nacional para as Doenças Transmissíveis da África do Sul, e Ron Ballard, do CDC dos EUA. Note-se que, no Relatório Final da OMS dos temas apresentados pelos painelistas, o do representante da Fiocruz é referido como "Experiência no desenvolvimento de uma rede integrada de laboratórios de saúde pública nos países lusófonos da África” (WHO, 2013).

Em janeiro de 20 I4, a Cúpula de Chefes de Estado e de Governo instou a OMS e as outras partes interessadas, principalmente a China (CDC) e os Estados Unidos (CDC), a apoiarem a criação do CDC África. A OMS/Afro ajudou na finalização do documento de síntese e na sua apresentação em Luanda. Angola, à Primeira Reunião de Ministros Africanos da Saúde, convocada conjuntamente pela União Africana e a OMS em abril de 2014. Em junho, a Comissão da União Africana criou o Grupo de Trabalho Multinacional 
(GTM) com o intuito de definir as modalidades e o roteiro para a estruturação do CDC África. No GTM participaram 16 Estados-membros, selecionados com base em representação geográfica entre aqueles que manifestaram interesse, mas com a ausência dos Países Africanos de Língua Portuguesa (Palop).

Ficou acordado que a OMS, a Comissão da União Africana e o futuro CDC África criariam mecanismos de colaboração mediante um Memorando de Entendimento que garantisse sinergias e evitasse a duplicação de funções atualmente exercidas pela OMS. A OMS deveria continuar desempenhando plenamente o seu papel de liderança técnica na área da saúde para apoiar a implementação e a operacionalização do CDC África.

E, finalmente, a 31 de janeiro de 2017, os chefes de Estado e de governo da União Africana lançaram oficialmente o CDC África como instituição técnica especializada da União Africana.

O Brasil não participou no GTM, ou melhor, não foi convidado, mesmo tendo o seu grande instituto de saúde pública, a Fiocruz, no mapa de cooperação internacional com incidência no continente africano, um escritório e um projeto de fábrica de medicamentos em Maputo, capital de Moçambique.

A ausência no GTM, criada pela União Africana, de uma instituição como a Fiocruz com todo o seu lastro de prestígio em ciência, tecnologia e inovação, para além de estranha, pode ser considerada uma grande falha da própria União Africana, que, pelo visto, nem sequer levou em consideração o Acordo de Cooperação Técnica que então vigorava (e aparentemente vigora) entre a República Federativa do Brasil e a União Africana, assinado em 2007 pelo então Ministro das Relações Exteriores, Celso Amorim, e pelo ex-presidente da Comissão da União Africana, Alpha Oumar Konaré.

E entramos tranquilamente no ano de 2020 com grande expectativa sobre a primeira visita da diretora regional da OMS para África, acordada com a presidente da Fiocruz para acontecer na segunda semana de março. Só que os acontecimentos galopantes que vinham sendo noticiados a partir de Wuhan, levando a que a OMS declarasse, em 30 de janeiro, a Covid-19 como uma Emergência de Saúde Pública de Importância Internacional - o mais alto nível de alerta desta organização - e, em II de março, 2020, como uma pandemia (Paho, 2020), obrigaram a alterar tudo e a concentrar esforços de todos os países na preparação e resposta ao novo coronavírus. 


\section{CDC África e as principais ações de resposta à Covid-19}

Em fevereiro de 2020 realizou-se a primeira reunião de emergência de ministros da Saúde com o objetivo de fortalecer a cooperação e a coordenação em toda a África para responder à Covid- 9 (African Union, 2020a).

Para além dos ministros da Saúde e seus representantes, também estiveram presentes a OMS (Genebra, Brazzaville e Cairo), as organizações da integração econômica regional, a República Popular da China, a Grã-Bretanha, os Estados Unidos da América, Janssen Vaccine e a Fundação Gates, entre outras organizações internacionais.

A diretora regional da OMS para África fez as suas observações, sublinhando que a OMS está empenhada em apoiar a África na resposta à Covid-19, tendo para isso sido implementadas múltiplas iniciativas em torno da prontidão, gestão de casos, prevenção de infecções (IPC).

O diretor-geral da OMS interveio para dizer que a maior preocupação da organização continua sendo o potencial de propagação da Covid-19 em países com sistemas de saúde mais fracos. O diretor do CDC África traçou uma visão geral sobre a situação da Covid-19, salientando que mesmo com medidas de contenção drásticas e restritivas, o surto não mostra sinais de abrandamento e que a África está especialmente em risco devido às suas fortes ligações com a China e à fragilidade dos sistemas de saúde. Seria necessária uma estratégia continental alargada com base numa coordenação e comunicação eficazes para assegurar a detecção rápida e contenção da Covid-2019. Ele apresentou a estratégia continental fundamentada no estabelecimento de uma força-tarefa denominada Africa Taskforce for Coronavirus (AFTCOR). Essa força-tarefa é constituída por grupos de trabalho conjunto entre o CDC África, a OMS e os especialistas dos Estados-membros para trabalharem em torno de cinco eixos: vigilância, mediante rastreio de pontos de entrada; prevenção e controle de infecções; manejo clínico de formas graves; diagnóstico laboratorial e subtipagem; e a comunicação de risco.

A sessão foi encerrada com os ministros da Saúde e seus representantes adotando a Estratégia Conjunta Continental (Africa Joint Continental Strategy for Covid-19), que passa a ser liderada pela AFTCOR a fim de abordar a pandemia da Covid- 19 no continente, vinculando todos os seus Estados-membros (African Union, 2020g).

Vale assinalar a presença do único representante dos Palop, na pessoa do dr. Eduardo Samo Gudo, diretor-geral adjunto do Instituto Nacional de Saúde (INS) do Ministério da Saúde de Moçambique. 
A partir desse momento, o instrumento de cooperação entre os Estados-membros da União Africana para a resposta à Covid- 19 passou a ser a Africa Joint Continental Strategy for Covid-19, sob a liderança da força-tarefa (AFTCOR) coordenada pelo CDC África.

O fim do mês de maio ficou marcado pelo anúncio de uma nova iniciativa da União Africana: a criação do Programa de Liderança em Saúde Global Koffi Annan, do CDC África (African Union, 2020b), em memória do $7^{\circ}$ secretário-geral das Nações Unidas e Prêmio Nobel da Paz, Kofi Annan, originário de Gana, terra natal de Kwame N’Krumah (1909-1972), o primeiro presidente de Gana e um dos fundadores do pan-africanismo e da União Africana.

O Programa de Liderança em Saúde Global Kofi Annan do CDC África foi construído sobre três componentes: o Programa de Liderança em Saúde Pública, o Programa Acadêmico de Saúde Pública e a Academia de Liderança Virtual em Saúde Pública.

Para apoio logístico, o CDC África pode, a partir do mês de maio, utilizar os meios militares aéreos dos Estados-membros para responder às necessidades dos países no âmbito da resposta à Covid- 19 (African Union, 2020c).

Foi concluída uma nova parceria com o Comitê Internacional da Cruz Vermelha (CICV), tendo ambos realizado um webinar visando a desenvolver ações de resposta focadas nas prisões.

Das inúmeras ações de capacitação por webinars, constatou-se a falta de ações de formação dos profissionais da saúde em língua portuguesa para os oriundos de Estadosmembros dos Palop. Até agora, apenas duas ações de formação em língua portuguesa foram administradas, mas no âmbito da iniciativa da Organização Oeste Africana da Saúde da Comunidade Econômica dos Estados da África Ocidental (OOAS/Cedeao). Podemos considerar que se abre o fosso no acesso à informação e ao conhecimento entre os Estados-membros da União Africana, determinado pela preferência hegemônica dos idiomas inglês e francês, relegando eventualmente para as calendas gregas o português e o espanhol. Tendo em consideração que a maioria dos profissionais dos Palop não é fluente em inglês nem em francês, é de esperar que o CDC África venha a tomar medidas atinentes à redução da exclusão linguística do grupo dos Palop.

\section{Parceria com a Fundação Mastercard}

Na primeira semana de junho, foi concluído um acordo de parceria no valor de 40 milhões de dólares americanos entre o CDC África e a Fundação Mastercard. Este acordo está enquadrado no programa da Fundação Mastercard Covids- 19 Recovery and 
Resilience Program. A verba é destinada a financiar a iniciativa do CDC's Partnership to Accelerate Covid- 19 Testing (PACT), do CDC África (Mastercard Foundation, 2020).

Recorde-se que a iniciativa Parceria para Acelerar os Testes da Covid- 19 (PACT) tem, essencialmente, quatro objetivos:

I. aumentar os testes da Covid- 19;

2. continuar a capacitação dos trabalhadores da saúde;

3. criar uma plataforma para compras agrupadas no CDC África e

4. destacar I milhão de agentes de saúde comunitários que ajudarão a localizar os contatos de casos confirmados (African Union, 2020c).

\section{Parceria com a União Europeia}

O chefe da Delegação da União Europeia (UE) na União Africana, o embaixador Ranieri Sabatucci, e o diretor do CDC África anunciaram, numa conferência de imprensa, um pacote de apoio à Covid- 19.

O embaixador afirmou que "a solidariedade global é a chave para combater a Covid-19. Por isso, nestes tempos difíceis a parceria entre a Team Europe e a União Africana é tão forte e fiável como sempre". E que "a experiência europeia está ensinando que uma abordagem continental é essencial para combater a Covid- 19 e o CDC África está numa posição privilegiada para coordenar uma resposta continental, graças à experiência que vem adquirindo em lidar com epidemias".

O diretor do CDC África, agradecendo a UE, afirmou que esta pandemia é um desafio global que exige que todos trabalhem em conjunto com um nível único de cooperação. Os países precisam aumentar rapidamente os testes e o rastreio de contatos, destacar mais profissionais da saúde e continuar a alimentar a componente da cadeia de fornecimento. Tudo isso exige parcerias fortes. A contribuição da União Europeia é profundamente adequada para o propósito de fazer o continente alcançar os objetivos do PACT.

A subvenção de 10 milhões de euros será seguida, nos próximos tempos, por um fundo adicional (pelo menos 15 milhões de euros) e/ou apoio material para reforçar a resposta da África à pandemia.

É preciso realçar que a UE está na vanguarda da luta contra a crise da Covid- 19 não só na Europa como também no mundo. A resposta específica da UE segue uma abordagem conhecida por Team Europe, que combina recursos da UE, dos seus Estados-membros e das instituições financeiras, particularmente o Banco Europeu de Investimento e o 
Banco Europeu para a Reconstrução e Desenvolvimento. Os montantes prometidos para apoiar os países parceiros na luta contra a Covid- 19 ascendem a 20 bilhões de euros, dos quais cerca de 5 bilhões estão previstos para o continente africano.

\section{Lançamento do Consórcio para Ensaios Clínicos de Vacinas Covid-19}

O CDC África lançou uma nova iniciativa denominada Africa CDC Consortium for Covid- 9 Vaccine Clinical Trial (CONCVACT), o consórcio para o ensaio clínico de vacinas da Covid- 9 (African Union, 2020e). Trata-se do resultado de uma conferência virtual de dois dias (24 e 25 de junho) denominada Africa's Leadership Role in Covid- 19 Vaccine Development and Access, organizada pelo CDC África e presidida pelo presidente pro tempore da União Africana, Cyril Ramaphosa, presidente da África do Sul.

O CONCVACT visa a assegurar mais de dez ensaios clínicos de vacinas em fase tardia o mais cedo possível no continente africano, reunindo desenvolvedores e financiadores globais de vacinas, bem como organizações africanas que facilitem os ensaios clínicos. Seu objetivo é garantir que sejam gerados dados suficientes sobre a segurança e a eficácia de vacinas candidatas mais promissoras para a população africana, para que, uma vez aprovadas, possam ser distribuídas com segurança na África.

Até o fim de junho, a organização vem continuando ações de resposta focadas mais essencialmente no apoio ao fortalecimento da vigilância, do laboratório, na comunicação de risco e na formação e capacitação de recursos humanos por meio da realização de webinars regulares, exclusivamente em inglês e francês, o que limita ainda mais a participação dos Palop.

\section{A participação no desenvolvimento e acesso a potenciais vacinas}

Como parte da implementação da Estratégia Continental Conjunta da África para combater a Covid-19, a Comissão da União Africana e o CDC África realizaram uma conferência virtual para discutir o papel de liderança da África no sentido de permitir o desenvolvimento, acesso e equidade para uma futura vacina Covid- 19 (African Union, 2020f).

\section{PAPEL DO ESCRITÓRIO DA OMS PARA ÁFRICA (OMS/AFRO)}

Desde a importação do primeiro caso na Região Africana da OMS, a pandemia propagou-se em 46 dos 47 países dessa região e causou perturbações sociais e econômicas sem precedentes. 
E apesar da criação do CDC África, a OMS/Afro vem trabalhando, desde março, em estreita colaboração com os 47 Estados-membros da África e outros parceiros com base no seu Covid- 9 Strategic Response Plan for the WHO African Region (WHO, 2020a)

Logo no começo da pandemia, a diretora regional da OMS para a África chamou a atenção para a existência de uma grave penúria de infraestrutura para o tratamento de casos críticos da Covid-19. Por essa situação dramática, a Covid-19 não poupou a classe dirigente africana mundializada e viajante, uma clientela esbanjadora nos prestigiados hospitais da Europa, da Arábia Saudita, de Israel e da Ásia (WHO, 2020c). E por causa de cancelamento de voos, fechadas as fronteiras e não podendo viajar para o estrangeiro, muitos desses dirigentes estão agora confinados em seus respectivos países, enfrentando as consequências concretas das suas políticas sobre um continente que se contenta em consagrar menos de $5 \%$ (em vez dos exigidos 15\%) do seu Produto Interno Bruto (PIB) à saúde pública, debatendo-se com uma média de 2 médicos por 10.000 habitantes e 1,8 leito por 1.000 pessoas (Tilouine, 2020).

E apesar da chegada tardia da pandemia à Região Africana da OMS, que cobre apenas seus 47 Estados-membros, o vírus propagou-se rapidamente pelo continente. A partir de abril, os casos confirmados e de óbitos pela Covid- 19 começaram a aumentar de forma preocupante.

Em termos econômicos e sociais, a pandemia começou por afetar as grandes economias da região com ligações internacionais mais fortes (Egito, África do Sul, Marrocos, Argélia, Costa do Marfim, Nigéria, Senegal, Angola), por causa de um declínio acentuado nos preços de matérias-primas. Por exemplo, os preços de petróleo bruto e de metais industriais tiveram forte queda (de $50 \%$ e $11 \%$, respetivamente, entre dezembro 2019 e março 2020). Também podemos incluir os países que vivem do turismo, como Cabo Verde, Marrocos, Egito, Tunísia e muitos países da África Oriental, como Tanzânia, Quênia ou Ilhas Maurícias, onde o turismo ficou reduzido a zero. Em pouco tempo, os investidores estrangeiros retiraram mais de 83 bilhões de dólares americanos do continente (Chatin, 2020).

Na Região Africana da OMS e até o período em análise, Gana era o país que mais testes fazia, com a média de 30 testes por 10.000 mil pessoas.

No dia 28 de maio, o Escritório Regional da OMS para a África fez um balanço sobre os três meses (março a maio) da pandemia nos seus 47 Estados-membros. Na resposta, a OMS ajudou os países a fortalecer medidas tais como o rastreio e tratamento dos casos e capacitação do pessoal da saúde. Mais de 10 mil profissionais da saúde foram capacitados nos domínios de prevenção e controle, tratamento, logística, diagnóstico laboratorial e 
comunicação. Por outro lado, o Escritório Regional realocou mais de 900 profissionais em nível regional e nacional para apoiar a resposta à Covid- 19. Em colaboração com o Programa Alimentar Mundial (PAM), a Fundação Ma Jack da China e o CDC África, a OMS ajudou no envio de lotes de material e equipamentos médicos. Em vários países da região, os testes laboratoriais foram a partir de então descentralizados das cidades capitais. Gana, Quênia, Etiópia, África do Sul e Nigéria dispõem, todos, de vários laboratórios para efetuar os testes. A Etiópia, por exemplo, reorientou as capacidades analíticas do Laboratório Nacional de Saúde Animal para o diagnóstico da Covid- 19.

A OMS/Afro colabora estreitamente com os governos, o CDC África, as agências das Nações Unidas e outros parceiros para apoiar a intensificação da resposta por meio de coordenação, recursos humanos especializados, fornecimento de material médico indispensável e ajuda à coleta e análise de dados.

Entretanto, foi declarado o fim do surto de ebola no nordeste da República Democrática do Congo (RDC), quase dois anos após o primeiro caso ter sido confirmado. O Ministério da Saúde da RDC fez o anúncio após não terem sido notificados novos casos 42 dias desde que o último paciente testou negativo para o vírus. O surto teve início em agosto de 2018 , com 3.470 casos, 2.287 vidas perdidas e 1.17 I sobreviventes, o que o torna o segundo mais letal após o da África Ocidental, que durou de 2014 a 2016.

E num esforço conjunto para melhorar a pesquisa e desenvolvimento (PED) de medicamentos tradicionais para a Covid- 9 na África e, em colaboração com o CDC África, a OMS/Afro criou um comitê/painel consultivo especializado para fornecer aconselhamento científico independente e apoio aos países sobre a segurança, eficácia e qualidade das terapias de medicina tradicional. O designado Comitê Regional de Peritos em Medicina Tradicional da Covid-19, composto de 25 membros, irá apoiar os Estados-membros da OMS na realização de ensaios clínicos de medicamentos tradicionais em conformidade com as normas internacionais. Os integrantes do Comitê Regional de Peritos são principalmente de instituições de pesquisa, autoridades reguladoras nacionais, programas de medicina tradicional, departamentos de saúde pública, academias, farmacêuticos e organizações da sociedade civil dos Estados-membros do continente africano.

\section{AS COMUNIDADES ECONÔMICAS REGIONAIS (REC, REGIONAL ECONOMIC COMMUNITIES)}

Uma vez que os casos da Covid- 9 não estão repartidos equitativamente, representando ainda o norte e o sul da África mais de metade dos casos confirmados, seria impensável não recorrer a organizações da integração econômica regional a quem compete a adoção e adaptação de iniciativas e estratégias global e continental. 
Das oito organizações da integração econômica regional, reconhecidas como pilares da União Africana, estão mais diretamente envolvidas na resposta à Covid- 19 estas seis:

- Mercado Comum da África Oriental e Austral (Comesa, Common Market for Eastern and Southern Africa);

- Comunidade da África Oriental (EAC, East African Community);

- Comunidade Econômica dos Estados da África Central (Eccas, Economic Community of Central African States);

- Comunidade Econômica dos Estados da África Ocidental (Ecowas, Economic Comunity of West Africa);

- Autoridade Intergovernamental para o Desenvolvimento (Igad, Intergovernmental Authority on Development);

- Comunidade de Desenvolvimento da África Austral (SADC, Southern African Development Community).

\section{Mercado Comum da África Oriental e Austral (Comesa, Common Market for Eastern and Southern Africa)}

É o maior bloco regional africano, com 21 Estados-membros e 492,5 milhões de habitantes. Inclui muitos dos países que pertencem à OMS do Mediterrâneo oriental. Embora não tendo uma área específica da saúde, é o seu secretariado que vem organizando e coordenando as ações de cooperação para a resposta à pandemia. Publica regularmente um detalhado boletim sob o título Measures in Comesa Member States in Response to Covid (Comesa, 2020).

Essa publicação mensal inclui uma lista de medidas e ações conjuntas que os seus Estados-membros implementam para conter a propagação do vírus.

\section{Comunidade da África Oriental (EAC, East African Community)}

Uma comunidade de seis Estados e 168,5 milhões de habitantes. Em maio, foi realizada uma Cúpula virtual de Chefes de Estado e de Governo que tomou decisões importantes sobre abordagens regionais a implementar como resposta à Covid- 19.

É interessante assinalar que essa comunidade já dispunha de um Plano de Contingência Regional para as Epidemias (2018-2023), que é o principal instrumento de cooperação e coordenação das emergências sanitárias nessa região (Customs Union, 2020). 


\section{Comunidade Econômica dos Estados da África Central (Eccas, Economic Community of Central African States)}

Com II Estados-membros e 158,3 milhões de habitantes, integra 3 Palop (Angola, Guiné Equatorial e São Tomé e Príncipe). O secretário-geral da Eccas apresentou por videoconferência, perante a Comissão de Consolidação da Paz das Nações Unidas, a situação em que se encontravam os seus Estados-membros em relação à Covid- 19 e estratégias de resposta regional contra a pandemia.

Com a particularidade de ter uma espécie de sub-bloco econômico, a Comunidade Econômica e Monetária da África Central (Cemac), a Eccas partilha uma moeda, o franco CFA da África Central, e uma agência especializada de saúde, a Organização de Coordenação e Cooperação contra as Grandes Endemias na África Central (Oceac). A Oceac coordena a resposta à Covid- 19 no âmbito do Plano Sub-Regional de Prevenção, Preparação e Resposta à Pandemia nos Estados-membros da Cemac aprovado pelos ministros da Saúde deste sub-bloco da Eccas, tendo sido mobilizados 152 milhões de dólares americanos para financiar projetos de combate à Covid- 19.

\section{Comunidade Econômica dos Estados da África Ocidental (Ecowas, Economic Comunity of West Africa)}

Com 15 Estados-membros, a Comunidade Econômica dos Estados da África Ocidental (Cedeao) é uma comunidade de 339,8 milhões de habitantes e dois Palop (Cabo Verde e Guiné-Bissau). O presidente da República Federal da Nigéria foi escolhido por seus pares para coordenar as ações da Cedeao de resposta à Covid-19. A escolha aconteceu na última Cúpula Extraordinária de Chefes de Estado e de Governo da Cedeao. Para a resposta à Covid-19, destacam-se os três comitês de Coordenação Ministerial: Saúde; Finanças e Transportes; Logística e Comércio. Esses três comitês preparam os informes regulares para que o presidente da Nigéria mantenha informados os seus homólogos sobre as atividades de resposta em curso no âmbito da comunidade (Ecowas, 2020).

\section{Autoridade Intergovernamental para o Desenvolvimento (Igad, Intergovernmental Authority on Development)}

São os países do Chifre da África (Djibuti, Etiópia, Eritreia, Quênia, Somália, Sudão do Norte, Sudão do Sul e Uganda) que desenvolvem iniciativas transfronteiriças não só para o enfrentamento da degradação ambiental e prolongadas secas, mas também para o grande número de campos de refugiados nas diferentes fronteiras comuns. 
Os ministros das Finanças da Igad comprometem-se a contribuir para o Fundo de Emergência contra a Covid-19, e a União Europeia anunciou a criação de um pacote financeiro que incluirá assistência humanitária imediata e apoio ao reforço dos sistemas de saúde e à atenuação da crise econômica (Igad, 2020).

\section{Comunidade de Desenvolvimento da África Austral (SADC, Southern African Development Community)}

A SADC é composta de 16 países e 312,7 milhões de habitantes e 2 Palop (Angola e Moçambique).

O impacto da Covid- 19 sobre as cadeias de valor, com destaque para a cadeia de valor das pescas e da aquicultura, é a matéria objeto de deliberação durante a reunião virtual dos ministros de Tutela da Agricultura e Segurança Alimentar e das Pescas e Aquicultura. A SADC analisa o estado atual da implementação das suas Diretrizes sobre a Harmonização e Facilitação das Operações de Transporte Transfronteiriço na Região e sobre os esforços de mobilização de recursos empreendidos por seu secretariado para o combate à Covid-19, dando ênfase à adoção de protocolos de testes harmonizados, incluindo o reconhecimento mútuo dos resultados e a obtenção de um acordo sobre o período de validade destes.

A SADC promoveu uma mesa-redonda virtual com a Organização das Nações Unidas (ONU), a Conferência Internacional sobre a Região dos Grandes Lagos, a SADC, a União Africana, a Comissão Econômica das Nações Unidas para a África e parceiros regionais e internacionais (Banco Mundial, Banco Africano de Desenvolvimento, Fundo Monetário Internacional, entre outros) em apoio aos países da região dos Grandes Lagos nas ações coletivas de mobilização de recursos e apoio para enfrentar a pandemia da Covid- 19 (SADC, 2020).

\section{Comissão Econômica da ONU para a África (ECA, UN Economic Commission for Africa)}

Criada pelo Conselho Econômico e Social das Nações Unidas (Ecosoc/ONU) em 1958 como uma das cinco comissões regionais da ONU, seu mandato é promover o desenvolvimento econômico e social dos seus Estados-membros, fomentar a integração intrarregional e promover a cooperação internacional para o desenvolvimento da África. Desempenhando um duplo papel como braço regional da ONU e como componentechave do panorama institucional africano, a ECA está bem posicionada para dar contribuições únicas no enfrentamento dos desafios de desenvolvimento do continente, como está a acontecer na resposta à pandemia da Covid- 19. 


\section{CONSEQUÊNCIAS DA COVID-19: UM DIÁLOGO POLIITICO COM A JUVENTUDE AFRICANA}

Para um continente com mais de 1,2 bilhão de pessoas, as taxas de infecção e mortalidade por coronavírus são comparativamente baixas, mas a pandemia da Covid- 19 está causando impactos econômicos negativos maciços que serão sentidos por muitos anos. O continente será, provavelmente, ainda mais afetado pelas consequências humanas, sociais e econômicas da pandemia, tendo as pessoas vulneráveis e marginalizadas, especialmente mulheres e jovens, mais afetadas, visto que a pandemia ameaça reverter ganhos econômicos e sociais duramente conquistados. Os países africanos estão a implementar uma resposta com duas vertentes, centrada em medidas imediatas de saúde e sociais e na recuperação econômica, à medida que prosseguem as discussões entre os decisores políticos sobre a reconstrução de economias africanas mais fortes e de tecidos sociais.

Num esforço para trazer os jovens africanos para a conversa, a Comissão Econômica para África (ECA), em parceria com a Comissão da União Africana (CUA) e o Unicef-GenU (Generation Unlimited), organizou um diálogo virtual sobre política de juventude sobre o tema "Reconstruir melhor com a juventude africana" (Generation Unlimited, 2020).

O encontro destacou os desafios específicos que a juventude africana enfrenta em face da pandemia e das medidas de sua mitigação; apresentou os esforços da juventude para responder aos diferentes aspectos da realidade atual da pandemia e abordou os temas da educação, inovação, emprego, saúde e envolvimento cívico e comunitário significativo, entre outros.

\section{DIÁLOGO ENTRE A ONU E OS EMBAIXADORES AFRICANOS EM PEQUIM}

Com foco no Marco das Nações Unidas para a Resposta Socioeconômica Imediata à Covid- I 9, foi organizado um encontro entre a Missão da União Africana na China e a Comissão Econômica das Nações Unidas para África (ECA). O diálogo teve como pano de fundo estas consequências devastadoras da pandemia da Covid-19: as dezenas de milhares de vidas perdidas; famílias desfeitas; hospitais sobrecarregados; trabalhadores essenciais com excesso de trabalho e uma taxa de desemprego galopante. Em todo o mundo, a pandemia aprofundou as desigualdades entre países e dentro de cada um deles, exacerbou a pobreza e reverteu o progresso de sua redução.

Na reunião ressaltou-se que a China, por ter sido primeiro país a sofrer o impacto da Covid- 19 e um dos primeiros a emergir do pior período de choque socioeconômico, está bem posicionada para partilhar conhecimento necessário à recuperação por meio 
de ações que incluem rígido controle e contenção de epidemias, afrouxamento gradual das medidas de controle e retorno escalonado à produção e ao trabalho. Essas medidas, observaram os participantes, poderiam oferecer lições para os países africanos, a serem adaptadas aos contextos e capacidades locais. Salientou-se igualmente que a recuperação da China não foi completa e que os desafios de saúde e socioeconômicos que subsistem, particularmente no que diz respeito aos grupos populacionais vulneráveis, serão de grande relevância para os países parceiros.

O diálogo também proporcionou uma oportunidade única aos funcionários da ONU e africanos de trocar opiniões sobre: 1) como a experiência da China no período pandêmico poderia ser apreciada e adaptada pelos países africanos; 2) que papel a China poderia desempenhar para cooperar com a África no combate à Covid-19, para além do fornecimento de suprimentos médicos; e 3) como a China, a ONU e a África poderiam trabalhar juntas no âmbito do Quadro Socioeconômico da ONU, amplamente adotado, para priorizar e sequenciar as respostas políticas à Covid- 19 e à recuperação pós-pandêmica.

A secretária executiva da ECA, Vera Songwe, reconheceu as contribuições da China para a África por meio da doação de suprimentos médicos essenciais e da iniciativa de suspensão do serviço da dívida (DSSI). Ela declarou em seus comentários que a família da ONU continuará suas contribuições para apoiar "a reconstrução melhor" e observou que a ECA já iniciou importantes caminhos de colaboração entre a ONU e as entidades chinesas no continente africano.

Rahamtalla M. Osman, representante da União Africana, destacou a necessidade de um conjunto abrangente de intervenções multissetoriais a médio e longo prazos, incorporando o envolvimento e a experiência dos setores privado e público, para equalizar oportunidades e garantir a segurança humana. "Há uma necessidade real de resposta global coordenada, especialmente em relação à sustentabilidade da dívida dos países de baixa e média rendas", enfatizou Babatunde Ahonsi, coordenador residente da ONU na China, acrescentando: "Vamos manter os compromissos que assumimos e acompanhar o compartilhamento das melhores práticas e ideias para o engajamento na adaptação do plano de ação do Fórum sobre Cooperação China-África (Focac), indo até os impactos em nível de país".

As embaixadas participantes e as agências da ONU partilharam resultados recentes de estudos de impacto nas respectivas áreas especializadas e discutiram as áreas prioritárias para que China, ONU e África trabalhem em conjunto em resposta à Covid- 19 e após a pandemia. 
Mais de quarenta embaixadores e altos funcionários de países africanos e da equipe de países da ONU juntaram-se à reunião on-line e pessoalmente no edifício da ONU.

À luz dessa relação entre a União Africana e a República Popular da China, mediada pela ONU, vêm aí a Hwawei e o 5G, no momento de acirrada guerra comercial em que a atual administração dos Estados Unidos da América (EUA) começa a intimidar muitos países para que escolham com quem cooperar para a aquisição e instalação dessa nova tecnologia. Vai ser interessante o posicionamento dos Estados-membros da União Africana sobre essa questão num futuro que já começou!

\section{COMUNIDADE DOS PAÍSES DE LÍNGUA PORTUGUESA (CPLP)}

A CPLP foi criada no dia 17 de julho de 1996 como foro multilateral privilegiado para o aprofundamento da amizade mútua entre os seus nove Estados-membros.

A maioria dos Estados-membros desta comunidade integra outros blocos continentais na África, América Latina, Ásia e Europa. Por isso, resposta conjunta formal, mais estruturada e coordenada em nível ministerial se revelaria uma missão quase impossível.

A CPLP dispõe de um Plano Estratégico de Cooperação em Saúde (Pecs-CPLP, 20 I 9-2022) aprovado pelos ministros da Saúde, cuja implementação está interrompida justamente por causa da Covid- 19.

Entretanto, a partir de junho e com o apoio da Direção de Cooperação do Secretariado Executivo, houve iniciativas, acordadas em reuniões virtuais com os Estados-membros, sobre vários temas relacionados com a resposta à Covid-19, dos quais merecem destaque:

- Impacto da Covid-I9 na igualdade de gênero: no âmbito dos Pontos Focais de Gênero da CPLP, foi debatido o desenvolvimento de abordagens articuladas no sentido de encontrar respostas partilhadas e solidárias para as medidas que se impõem na resposta à pandemia e sua mitigação. $A$ reunião foi convocada por Cabo Verde, na condição de presidente pro tempore da CPLP, em articulação com o Instituto Cabo-Verdiano para a Igualdade e Equidade de Gênero (Icieg) e o Secretariado Executivo da CPLP. Participaram representantes do Brasil, Cabo Verde, Moçambique, Portugal e Timor Leste e da Direção de Cooperação do Secretariado Executivo da CPLP (CPLP, 2020a).

- Covid-19 e estado de direito em coletânea de legislação dos Países Africanos de Língua Portuguesa (Palop) e Timor Leste (TL): no âmbito do Projeto de Apoio à Consolidação do Estado de Direito (Paced), foi elaborada, em parceria com o 
Legis-Palop+TL, a Coletânea de Legislação Palop e Timor Leste: Covid- 19 e estado de direito ( $2^{\mathrm{a}}$ edição) para "responder ao momento de emergência que vivenciam os Estados-membros” (CPLP, 2020b).

- As Redes Estruturantes do Pecs-CPLP: as Redes de Institutos Nacionais de Saúde Pública (Rinsp-CPLP), de Escolas Técnicas de Saúde (Rets-CPLP) e de Escolas Nacionais de Saúde Pública (Rensp-CPLP), em colaboração com a Direção de Cooperação do Secretariado Executivo da CPLP, realizaram reuniões virtuais com boa participação de seus membros, permitindo trocas de informação sobre as principais ações de enfrentamento da Covid- 19 nos Estados-membros. Dada a diversidade e complementaridade dessas redes, elas têm um capítulo próprio no qual serão pormenorizadas as atividades específicas que contribuem para a resposta à Covid- 19.

Abordar o modo como diferentes organizações do continente africano vêm enfrentando a pandemia do novo coronavírus pode contribuir para melhorar a percepção da sociedade sobre a importância das instâncias de cooperação multilateral para a solução dos problemas globais. E para a região africana, reconhecidas as fragilidades dos sistemas nacionais de saúde, a maior compensação às suas fragilidades só pode ser conseguida com a existência e atuação firme e coordenada da União Africana e dos seus seis blocos econômicos em torno de uma estratégia continental conjunta, a Africa Joint Continental Strategy for Covid- 19 Outbreak.

\section{REFERÊNCIAS}

AFRICAN UNION. African Union mobilizes continent-wide response to Covid- 19 outbreak. Disponível em: < https://africacdc.org/news-item/african-union-mobilizes-continent-wide-response-to-covid19-outbreak/>. Acesso em: 18 set. 2020a.

AFRICAN UNION. African Union Commission announces the Africa CDC Kofi Annan Global Health Leadership Programme, 25 May 2020b. Disponível em: <https://au.int/en/ pressreleases/20200525/african-union-commission-announces-africa-cdc-kofi-annan-globalhealth>. Acesso em: 18 set. 2020.

AfRICAN UNION. Africa CDC deploys 28 frontline responders to Burkina Faso, Cameroon, Mali and Niger using African Union strategic lift capability, 3I May 2020c. Disponível em: <https://au.int/en/ pressreleases/2020053 I/africa-cdc-deploys-28-frontline-responders-burkina-faso-cameroon-maliand >. Acesso em: 18 set. 2020.

AFRICAN UNION. African Union rolls out partnership to accelerate Covid-19 testing, 4 Jun. 2020d. Disponível em: <https://africacdc.org/news-item/african-union-rolls-out-partnership-toaccelerate-covid-19-testing/>. Acesso em: 18 set. 2020. 
AFRICAN UNION. African Union Commission launches consortium for Covid- 19 vaccine clinical trial. Disponível em: < https://africacdc.org/news-item/african-union-commission-launches-consortiumfor-covid-19-vaccine-clinical-trial >. Acesso em: 18 set. 2020 e.

AFRICAN UNION. Virtual Conference on Africa's leadership role in the development and access to potential Covid-19 vaccines. Disponível em: <https://au.int/en/newsevents/20200624/virtualconference-africa-leadership-role-development-and-access-covid-19>. Acesso em: 18 set. $2020 \mathrm{f}$.

AfRICAN UNION. Report of an Emergency Meeting of Africa Ministers of Health on the Covid-19 Outbreak, 22 Fev. 2020g. Disponível em: <https://africacdc.org/download/report-of-an-emergencymeeting-of-africa-ministers-of-health-on-the-covid-19-outbreak>. Acesso em: 18 set. 2020.

CHATIN, M.-F. L'Afrique et le coronavirus: un solide défi pour la coopération internationale. RFI, 03 Apr. 2020. Disponível em: < http://www.rfi.fr/fr/podcasts/20200404-afrique-et-coronavirus-solided\%C3\%A9fi-coop\%C3\%A9ration-internationale>. Acesso em: 18 set. 2020.

COMMON MARKET FOR EASTERN AND SOUTHERN AFRICA (COMESA). Measures in Comesa Member States in Response to Covid-19. II. ed. LusaKa: Comesa, 2020. Disponível em: <https://www.comesa. int/wp-content/uploads/2020/06/Measures-in-COMESA-MS-in-Response-to-Covid-19-Vol- II pdf>. Acesso em: 18 set. 2020.

COMUNIDADE DOS PAÍSES DE LÍNGUA PORTUGUESA (CPLP). Covid-19 e estado de direito em coletânea de legislação dos Palop e Timor Leste, 10 jul. 2020. Disponível em: <https://www.cplp.org/ id-46 | 6.aspx?Action $=1$ ENewsId =8858EM =NewsV2EPID = 1 | 402>. Acesso em: 18 set. 2020.

COMUNIDADE DOS PAÍSES DE LÍNGUA PORTUGUESA (CPLP). Estados-membros da CPLP debatem impacto da Covid-19 na igualdade de género, 29 jun. 2020. Disponível em: <https://www.cplp.org/ id-46 I 6.aspx?Action = I ENewsId=884 I EM=NewsV2EPID= I I 402>. Acesso em: 18 set. 2020.

CUSTOMS UNION. EAC Covid-19 updates. Disponível em: <https://www.eac.int/coronavirus>. Acesso em: 18 set. 2020.

ECONOMIC COMMUNITY OF WEST AFRICAN STATES (ECOWAS). President Brou briefs Ecowas Champion on the Fight against Covid-19, 12 Jun. 2020. Disponível em: <https://www.ecowas.int/ president-brou-briefs-ecowas-champion-on-the-fight-against-covid-19/>. Acesso em: 18 set. 2020.

GENERATION UNLIMITED. Site. Disponível em: <https://www.generationunlimited.org/>. Acesso em: 18 set. 2020.

INTERGOVERNMENTAL AUTHORITY ON DEVELOPMENT (IGAD). IGAD Finance Ministers commit to contribute to Emergency Fund against Covid-19. Disponível em: <https://www.igad.int/2406igad-finance-ministers-commit-to-contribute-to-emergency-fund-against-covid-19>. Acesso em: 18 set. 2020.

MASTERCARD FOUNDATION. Africa CDC and Mastercard Foundation Partner to deliver I million test kits, deploy 10,000 community health workers for Covid- 19 response. Disponível em: <https:// mastercardfdn.org/africa-cdc-and-mastercard-foundation-partner-to-deliver- 1-million-test-kitsdeploy-10000-community-health-workers-for-covid-19-response/>. Acesso em: 18 set. 2020.

ORGANIZAÇÃO PAN-AMERICANA DA SAÚDE (OPAS). Folha informativa Covid-19 - Escritório da Opas e da OMS no Brasil. Disponível em: <https://www.paho.org/bra/index.php?option=com_conte ntEview $=$ articleEid $=6101$ : covid I 9 gltemid $=875>$. Acesso em: 18 set. 2020. 
SOUTHERN AFRICAN DEVELOPMENT COMMUNITY (SADC). Office of the Special Envoy of the Secretary-General for the Great Lakes in Africa. Press release. Disponível em: <https://www.sadc. int/files/4815/9258/7257/PRESS_RELEASE_-_UN_and_partners_discuss_collective_actions_for_ Covid-19_in_the_Great_Lakes_region_00000003.pdf>. Acesso em: 18 set. 2020.

TILOUINE, J. En Afrique, le coronavirus met en danger les élites dirigeantes. Le Monde, Paris, 3 abr. 2020. Afrique. Disponível em: < https://www.lemonde.fr/afrique/article/2020/04/03/en-afrique-lecovid-19-met-en-danger-les-elites-dirigeantes_6035384_3212.html >. Acesso em: 18 set. 2020.

WORLD HEALTH ORGANIZATION (WHO). Final Report. Sixty-third section of the WHO Regional Committee for Africa, 2-6 sept. 2013, Brazzaville. Disponível em: <https://www.afro.who.int/sites/ default/files/sessions/final-reports/nv-afr-rc63-16-Report-of-the-Regional-Committee.pdf>. Acesso em: 18 set. 2020.

WORLD HEALTH ORGANIZATION (WHO). Regional Office for Africa. The Corona Virus Disease 2019 (Covid- 19): strategic response plan for the WHO African Region. Washington: WHO, 2020a. Disponível em: <https://www.afro.who.int/sites/default/files/2020-06/SPRP\%20BUDGET\%200520_01.pdf>. Acesso em: 18 set. 2020.

WORLD HEALTH ORGANIZATION (WHO). Regional for Africa. La pandemie de Covid-I9 s'étend en Afrique. Disponível em: <http://whotogo-whoafroccmaster.newsweaver.com/ JournalfrenchNewsletter/ae5 bl0ms2z2qwjwzfkm7 hf?lang =enEa $=2 \varepsilon p=5681453 \mathrm{I}$ $\varepsilon t=31103707>$. Acesso em: 18 set. 2020. 


\section{A Europa e o Multilateralismo no Enfrentamento da Pandemia da Covid-19}

Ana Helena Gigliotti de Luna Freire, Letícia Cristina Pereira de Castro e Ilka Maria Vilardo Montefinese

O velho continente vivenciou diversas epidemias e pandemias ao longo da história. A peste negra, pandemia de peste bubônica, assolou a região no século XIV, tendo resultado na morte de mais de um terço da população e provocado grandes impactos sociais e econômicos nos países da antiga Eurásia. A praga retornou várias vezes como surtos até o início do século XX. Outras epidemias de relevância e com diferentes impactos na região foram varíola, cólera, gripe espanhola (influenza de 1918), tifo epidêmico, HIV e, mais recentemente, a influenza HINI (gripe suína), a primeira do século XXI. O ano de 2020 deu lugar à pandemia de Covid- 19, causada pelo novo coronavírus (Sars-CoV-2), de repercussões globais sem precedentes, das mais variadas ordens, na história recente das epidemias.

Neste capítulo vamos tratar da evolução da pandemia na Europa em diversas dimensões complementares: sanitária, econômico-social e, também, da diplomacia da saúde. Trata-se de abordagens coletivas multilaterais do processo epidêmico, como aquelas propiciadas pela Comissão Europeia (CE) e por agências como o Centro Europeu de Prevenção e Controle das Doenças (ECDC) e a Agência Europeia de Medicamentos (EMA), além da OMS Europa.

\section{O DESENVOLVIMENTO DA PANDEMIA E SUAS CIRCUNSTÂNCIAS}

A pandemia de Covid- 19 na Europa teve seus primeiros casos registrados na França em 24 de janeiro de 2020, nas cidades de Bordeaux e Paris. Os três primeiros pacientes haviam retornado de viagem à China, onde a epidemia começou. A França foi o décimo país do mundo a confirmar casos. A Itália registrou seus primeiros casos em 3 I de janeiro e então declarou o país em estado de emergência sanitária nacional; em março fizeram 
a mesma declaração a Espanha e, logo depois, a França. Em 13 de março, a Organização Mundial da Saúde (OMS) declarou que a Europa era o novo (então segundo) epicentro do Sars-CoV-2, com mais casos sendo registrados todos os dias do que a China no auge da epidemia. Sendo o destino mais procurado do mundo, não é difícil entender por que, rapidamente, o continente se tornou o principal disseminador da doença.

No início da pandemia no continente europeu, os sistemas de saúde de países como Itália, Espanha e Reino Unido lutaram para dar conta do surto de Covid-19, após profundas medidas de austeridade na última década. Nesse período, o serviço nacional de saúde italiano, por exemplo, registrou cortes da ordem de bilhões de euros, com redução significativa dos leitos de unidade de terapia intensiva (UTI) no país, juntamente com a privatização progressiva dos cuidados em saúde. O país recebeu ajuda internacional da China, que ofereceu máscaras, ventiladores e consultoria especializada. O Ministério da Saúde italiano priorizou a distribuição adicional de equipamentos de proteção para a equipe médica.

A doença avançou em velocidade muito superior à capacidade de resposta dos sistemas de saúde e à capacidade de articulação dos governos. Menos de dois meses separam o registro do primeiro caso da doença da condição da região de epicentro da epidemia. A resposta inicial da Europa à Covid- 19 foi lenta, isolacionista e desarticulada: Estados se concentravam em esforços nacionais, e cenas de fechamento de fronteiras, protecionismo e disputa por equipamentos não foram raras. Com a chegada do verão europeu, a reabertura antes programada na Europa preocupou muitos países. A OMS alertou sobre a possibilidade de os sistemas de saúde europeus serem ainda mais afetados por uma segunda onda de contaminação no continente. Em julho, o número de novos casos e novas mortes registradas pela Europa foi muito superior ao dos meses anteriores e em muitas cidades houve transmissão acelerada do vírus. Até o fim de julho foram reportados mais de 3,2 milhões de casos na região e mais de 211 mil mortes pela doença.

Em abril, os primeiros esforços de coordenação começaram a apresentar resultados concretos em áreas como saúde pública, economia e ciência, tecnologia $\varepsilon$ inovação (CTEl). Há que se registrar que a União Europeia (UE) não tem mandato para atuar na área da saúde, competência não delegada por seus membros. Mesmo em cenário pandêmico, cada sistema de saúde nacional atua de maneira autônoma, recebendo apoio da UE por intermédio da Comissão Europeia (CE), de agências como o Centro Europeu de Prevenção e Controle das Doenças (ECDC) e a Agência Europeia de Medicamentos(EMA) e de ações coordenadas como compras conjuntas de material médico e investimentos em vacinas.'

\footnotetext{
I A UE conta com agências que são entidades jurídicas independentes das instituições do bloco, criadas para conduzir tarefas específicas. Existem agências descentralizadas, executivas, de política comum de segurança e defesa, e outros organismos.
} 
No primeiro semestre de 2020, o continente foi marcado por uma série de acontecimentos em função da qual já se fala sobre o nascimento de uma "nova Europa":

- Janeiro - primeiros casos de Covid- 19 na Europa;

- Fevereiro - coronavírus chega a II países da Europa: Itália, França, Espanha, Suíça, Áustria, Croácia, Alemanha, Reino Unido, Finlândia, Suécia, Bélgica. Itália é o terceiro país com mais casos no mundo;

- Março - OMS decreta pandemia; países europeus declaram emergência sanitária nacional; Europa é o centro ativo da pandemia;

- Abril - Eurogrupo aprova pacote de ajuda financeira de 500 bilhões de euros; criação do Access to Covid- 19 Tools Accelerator; lançamento do First ERA vs Corona Action Plan;

- Maio - apoio à Conferência Coronavirus Global Response; Comissão Europeia destina um bilhão de euros para o programa de pesquisa Horizon 2020;

- Julho - reabertura de fronteiras; aprovação do fundo de recuperação da UE; petição Right to Cure, pedindo a renúncia ao direito de patente em favor do acesso livre e universal à vacina contra a Covid- 19.

\section{RESPOSTA DA INSTITUCIONALIDADE EUROPEIA}

Após o sobressalto inicial, a UE se organizou em suas diversas instâncias e agências e vem conseguindo oferecer respostas coordenadas tanto internamente quanto no cenário internacional. Sua sofisticada teia institucional de governança regional compreende Conselho, Comissão, Parlamento e diferentes agências específicas para a área da saúde, como o ECDC, que atua em parceria técnica com o braço regional da OMS, a OMS Europa. Neste espectro, é interessante notar que o ECDC está vinculado à UE, que tem 27 membros mas acompanha e monitora um conjunto de trinta países, por englobar a Noruega, a Islândia e Lichtenstein. A cobertura de ação da OMS Europa, por sua vez, alcança 53 países do continente europeu, de maneira que o cruzamento de dados entre as diferentes instâncias se torna prejudicado.

$\mathrm{Na}$ área da saúde pública, as competências do bloco se limitam ao apoio, coordenação e complementação de ações nacionais, distribuindo-se por entre suas diferentes instâncias. É notória a diferença de coordenação nos âmbitos econômico, social e diplomático, áreas nas quais o mandato da UE é mais concreto e que serão abordadas adiante. Assim, no campo da saúde, entram em cena de forma mais presente, além da Comissão Europeia, o ECDC e a OMS Europa, uma das seis regionais da OMS, colaborando na publicação de diretrizes e coordenando ações. 
A OMS Europa disponibilizou website para acompanhamento da situação, que fornece informações sobre como os sistemas de saúde vêm respondendo à crise (Covid- 19 Health System Response Monitor, 2020), além de divulgar e concentrar publicações (como guias e diretrizes), webinários e coletivas de imprensa virtuais (WHO, 2020a). A organização também vem realizando treinamentos e segue prestando sua tradicional assistência, presencial e virtualmente, avaliando situações e oferecendo conselhos sobre estratégias de enfrentamento. O ECDC também tem seu portal específico para albergar informações e notícias sobre a Covid- 19, onde publica orientações, boletins epidemiológicos e seu monitoramento (ECDPC, 2020).

A recomendação pela OMS de que todas as pessoas usem máscaras, que aconteceu no final de julho, reverberou de forma intensa e diversa no seio da UE e seus países. Os noticiários repercutiram a recomendação abordando as diferenças de abordagem no tocante à obrigatoriedade de uso em diferentes localidades. A OMS Europa também orientou os países-membros a incluírem a imunização contra doenças evitáveis por vacinas (vaccine predictable disease, VPD) como um serviço de saúde essencial, determinando que a imunização seja um direito e uma responsabilidade de todos, mesmo durante o surto da pandemia, principalmente para evitar surtos de outras doenças.

Reconhecendo que os desafios e as circunstâncias variam de país para país, que não existe uma abordagem única e que é importante estabelecer uma comunicação clara com o público para construir a confiança e garantir que os cidadãos observem restrições específicas à situação, a OMS se coloca como importante mediadora entre ciência e sociedade. Interessante notar que organizações internacionais da área da saúde, como a OMS e suas regionais e algumas instâncias europeias, oferecem informações científicas claras e acessíveis a toda a sociedade, atuando como divulgadoras da ciência ao manterem o mundo informado sobre recomendações científicas, avanços e desafios no enfrentamento da pandemia.

Tanto a UE (e seus Estados-membros) quanto a OMS foram criticadas por tardarem em articular e coordenar respostas à crise. Contudo, doações, esforços por parte dos sistemas de saúde e ações inovadoras de alguns governos ajudaram os Estados a diminuir o número de infectados e avançar no tratamento da doença. Por outro lado, a articulação e a coordenação tardias, de fato, revelaram a carência de instrumentos comuns e políticas públicas na área da saúde.

No tocante à sua competência, a Comissão Europeia, presidida por Ursula von der Leyen, se concentrou em reforçar os setores de saúde pública e mitigar impactos socioeconômicos, estabelecendo uma equipe de resposta e mobilizando meios para ajudar os Estados-membros a coordenar respostas nacionais em áreas como pesquisa 
para tratamento, diagnóstico e vacina; fronteiras e mobilidade; medidas econômicas; combate à desinformação; e saúde pública. Neste último campo, entre as ações coordenadas pela CE destaca-se o apoio direto aos sistemas de saúde, com o reforço de mais 2 bilhões de euros do orçamento da UE para financiar o instrumento de apoio de emergência RescEU (parte do Mecanismo de Proteção Civil da UE), que passa a incluir emergência sanitária entre os desastres naturais (REScEU, 2020). A iniciativa tem a finalidade de criar uma reserva de equipamentos médicos estratégicos e vitais (ventiladores, equipamentos de proteção individual, vacinas e materiais de laboratório, entre outros) e também mobilizar equipes para assistência aos países mais vulneráveis do continente ou aqueles onde emergencialmente o material é mais necessário. Esse instrumento permite à comissão adquirir diretamente em nome dos Estados-membros, financiando e coordenando o transporte de equipamentos médicos e de pacientes em regiões transfronteiriças. Outra ação conduzida pela comissão que se destacou no enfrentamento do caos gerado pela pandemia foi o apoio às operações de repatriamento de europeus retidos no exterior, com financiamento de $75 \%$ dos custos associados, a cargo do Mecanismo de Proteção Civil da UE.

Em relação à pesquisa em colaboração, a CE destinou I bilhão de euros para o programa Horizon 2020, para financiar projetos de Pesquisa, Desenvolvimento e Inovação (PDEl) em Covid-19, abordando a epidemiologia, a preparação e a resposta a surtos e o desenvolvimento de diagnósticos, tratamentos, vacinas e infraestruturas de pesquisa. Os fundos suplementares incluem: 450 milhões de euros para pesquisa em tratamentos, diagnósticos e prevenção; 400 milhões de euros em investimentos na pesquisa e no desenvolvimento, incluindo a ampliação das instalações de produção; e 150 milhões de euros para inovações contra o coronavírus.

O First "ERAvsCORONA" Action Plan (Europe Union, 2020), apoiado pelos ministros responsáveis pela pesquisa e inovação, estabelece dez ações prioritárias para coordenar as atividades em pesquisa e inovação, medidas-chave a serem observadas pelos serviços da comissão e pelos ministérios nacionais, registradas a seguir.

I. Coordenar o financiamento à PDEl em Covid- 19.

2. Estender e apoiar ensaios clínicos multicêntricos em larga escala por toda a UE para o gerenciamento clínico de pacientes.

3. Abrir novos financiamentos para abordagens rápidas e inovadoras relacionadas à resposta ao coronavírus, com foco em: impactos sociais e econômicos da resposta ao surto; tecnologias médicas e aplicações de tecnologias de informação e comunicação (TICs); e preparação dos sistemas de saúde. 
4. Apoiar empresas inovadoras, aumentando o apoio ao programa Acelerador Piloto do Conselho Europeu de Inovação, ${ }^{2}$ no âmbito do Horizon 2020 e estabelecendo plataforma para encontros com grupos dedicados e espaços de troca e conexão entre pequenas e médias empresas (PMEs), investidores, compradores públicos, corporações e outros.

5. Criar oportunidades para que outras fontes de financiamento contribuam para PDEI em coronavírus, concedendo selos de excelência a PMEs/startups avaliadas como excelentes, mas não selecionadas para financiamento do Conselho Europeu de Inovação.

6. Estabelecer um balcão único para ofertas de financiamento de PDEI, a Plataforma Era Corona, que reúne todas as iniciativas de financiamento em vigor (European Commission, 2020a).

7. Estabelecer uma força-tarefa ad hoc de alto nível em PED, para aconselhar sobre possíveis ações relevantes em pesquisa, identificar prioridades de médio e longo prazos e se comunicar com o público em geral.

8. Garantir acesso às infraestruturas de pesquisa, buscando a disponibilidade dos serviços fornecidos bem como dos dados gerados, considerados vitais para o avanço da ciência; lançamento de novos serviços como, por exemplo, computação de alto desempenho e inteligência artificial.

9. Compartilhar dados de pesquisa, mediante o estabelecimento da plataforma europeia de intercâmbio de dados para o Sars-CoV-2 e o intercâmbio de informações, conectada à European Open Science Cloud (2020), permitindo o compartilhamento rápido de dados e resultados de pesquisa para acelerar descobertas. Os pesquisadores devem ser requisitados a fornecer acesso aberto imediato e completo e a compartilhar os resultados da pesquisa em tempo real.

10. Mobilizar investidores europeus e sociedade civil, por meio do Hackathon pan-EU (EUvsVirus, 2020), realizado no âmbito do Horizon 2020, quando foram selecionadas 117 soluções inovadoras. Espera-se que esse hackathon reduza o tempo de implantação de soluções inovadoras desenvolvidas, uma vez que permite o aproveitamento de trabalhos já realizados, e forneça informações aos hospitais e administrações públicas sobre as soluções inovadoras existentes em outros Estados-membros.

\footnotetext{
2 Em 2017, foi lançada a fase piloto do Conselho Europeu de Inovação (EIC) para transformar as descobertas científicas da Europa em empresas capazes de proceder a uma transposição mais rápida para uma escala maior. A previsão é que o Conselho Europeu de Inovação esteja funcionando plenamente a partir de 202 I, no âmbito do próximo Programa de Investigação e Inovação Horizonte Europa (Comissão Europeia, 2020).
} 
Destaque-se, no âmbito da ciência aberta, o lançamento em abril do Portal de Dados Covid-19, pela Comissão Europeia e pelo Instituto Europeu de Bioinformática (EMBLEBI) da UE e seus parceiros de pesquisa (objeto do item 9 acima), importante iniciativa multilateral no campo (Covid- 9 Portal Data, 2020). O portal permite a coleta rápida e o compartilhamento abrangente de dados de pesquisa disponíveis, de diferentes fontes, para as comunidades de pesquisa globais. A ferramenta possibilita carregar, acessar e analisar dados de referência relacionados à Covid-19. O movimento da ciência aberta, em particular o da abertura de dados de pesquisa, vem sendo reconhecido como fundamental para o avanço democrático das descobertas e para o desenvolvimento de bens públicos globais, principalmente ao garantir amplo acesso a informações no momento em que são obtidas.

A UE está atenta à ressurgência de casos da Covid-19, tendo a comissão lançado o comunicado "Preparação para a saúde em curto prazo na UE" (European Commission, 2020b)", a fim de preparar o bloco para novos focos. A CE busca apoiar medidas que assegurem a interoperabilidade no rastreamento de casos entre os Estados-membros, operando por infraestrutura segura de Tecnologia de Informação (TI). Esse plano integra as novas orientações sobre medidas de saúde pública e assistência médica, como testes, vigilância e preparação entre os países da UE.

O Parlamento Europeu, única instância cujos representantes são eleitos pelos cidadãos para representar seus interesses, traz proposta de Regulamento do Parlamento Europeu e do conselho relativo à criação de um programa de ação no domínio da saúde para o período 2021 -2027 (Comissão Europeia, 2020), no âmbito do programa EU4Health (2020), abordando questões como desigualdade e Objetivos de Desenvolvimento Sustentável (ODS) e se pautando nos princípios de "Saúde única" (One health) e "Saúde em todas as políticas". Entre os pontos relevantes estão a proposta de meIhoria dos sistemas nacionais de saúde, medidas contra doenças transmissíveis e não transmissíveis, a disponibilidade e acessibilidade dos preços de medicamentos e outros produtos relevantes em situação de crise. Outra iniciativa do Parlamento é a petição "Direito à cura" (Right2Cure, 2020), publicada nas redes, pedindo à Comissão Europeia que renuncie aos seus diretos de patente, a fim de garantir o acesso universal à vacina.

Sim, a Comissão Europeia também está financiando suas vacinas, antecipando compras e compartilhando riscos com a indústria farmacêutica, a exemplo do que vem acontecendo no mundo. O financiamento funcionará como um contrato de compra antecipado. Mesmo ciente dos riscos envolvidos, a CE antecipa o pagamento e, uma vez pronta a vacina, os países da UE terão direito a certo número de doses (Sánchez, 2020). A compra será feita de forma centralizada pela comissão. Os projetos que receberão os aportes foram avaliados por técnicos, que levaram em conta critérios como rigor 
científico da pesquisa, tecnologia empregada, capacidade de produção em grande escala e custo. A vacina tem sido vista como único elemento capaz de garantir a retomada das economias e da normalidade possível.

No tocante à temática, cumpre destacar a parceria estabelecida entre a Fundação Oswaldo Cruz (Fiocruz) e o Universidade de Oxford para a produção da vacina desenvolvida nessa universidade. A partir de uma carta-compromisso, o governo britânico, o Ministério da Saúde e a Casa Civil da Presidência da República do Brasil firmaram compromisso com a AstraZeneca, que detém o licenciamento da vacina desenvolvida por Oxford. Como resultado, a Fiocruz firmou acordo com a biofarmacêutica para a compra dos primeiros lotes e início do processo de transferência de tecnologia da vacina. Nos termos da legislação brasileira, trata-se de uma encomenda tecnológica, modalidade de compra pública que é um estímulo à inovação, na qual a instituição adquire o produto antes do término dos ensaios clínicos, compartilhando o risco tecnológico. O investimento inclui a transferência de tecnologia para que a produção seja completamente internalizada e nacional, quando o IFA (ingrediente farmacêutico ativo) será produzido no Brasil. O modelo de incorporação tecnológica permite investimento no parque tecnológico da fundação, aumentando a capacidade de reação à novas epidemias parecidas e conferindo autonomia de produção. O acordo permite que a Fiocruz seja responsável pelo fornecimento da vacina para a América Latina, caso esta se mostre eficaz e segura.

Bem diferente da área da saúde pública, a economia encontra na UE um avançado estágio de integração econômica e monetária, com possiblidade de avançar para uma (inédita) união fiscal. Novamente o velho continente viu a necessidade de se reconstruir economicamente e avançou um passo inédito em seu processo de regionalização, com a contração de uma dívida comum para a reconstrução de economias individuais. As negociações e a coordenação de ações entre nações não foram fáceis e expuseram diversas dificuldades do multilateralismo, como o compartilhamento de soberania, o encaminhamento de diferenças de padrões de alinhamento, conflito de interesses e tradições e, finalmente, a estratificação de poder. No caso do contexto atual específico da UE, foram observados desafios em relação à fragmentação por blocos de países afins ${ }^{3}$ e à unanimidade como critério no processo decisório.

\footnotetext{
${ }^{3}$ Países frugais (Áustria, Dinamarca, Suécia e Países Baixos), liderados pelo primeiro-ministro holandês, que ganharam a companhia da Finlândia, pressionaram para que o fundo fosse voltado para reformas econômicas e buscavam a diminuição do subsídio proposto originalmente pela comissão, de 500 bilhões de euros, e a possibilidade de fiscalizar a aplicação dos recursos liberados. Países do sul (Espanha, Itália, Grécia e Portugal) não queriam cláusulas ligadas às suas economias. Países de Visegrado (Hungria, Polônia, República Tcheca e Eslováquia): Polônia não aceita cláusulas ambientais; Hungria e Polônia se opõem ao condicionamento da distribuição de fundos ao respeito pelo princípio do estado de direito, regra proposta pela Comissão Europeia para evitar que governos violem princípios como a liberdade de expressão ou a independência do sistema judicial.
} 
O Banco Central Europeu liberou um empréstimo de 750 bilhões de euros e foram tomadas outras medidas de apoio orçamentário. Um plano bilionário, histórico e disruptivo de mutualização de dívida e subvencionamento de economias foi idealizado pelo eixo Berlim-Paris, proposto pela Comissão Europeia, aprovado pelo Conselho e encaminhado para o Parlamento Europeu, a quem compete aprová-lo. A reunião de negociação, que durou cinco dias, se encerrou com um acordo de condições mais exigentes que as inicialmente previstas. O montante destinado a ser distribuído como doação foi de 390 bilhões de euros, em detrimento dos 500 bilhões previstos inicialmente, e o montante a ser concedido como empréstimo subiu de 250 bilhões de euros para 360 bilhões.

Antes disso, outros movimentos pavimentaram o caminho. A Comissão Europeia criou o instrumento Support to mitigate Unemployment Risks in an Emergency (Sure) (Eur-Lex.Europa, 2020) de 100 bilhões de euros, para apoiar a manutenção dos postos de trabalho e remuneração dos trabalhadores. O programa é uma reação ao aumento do desemprego e ajuda os países da UE a cobrirem os custos dos regimes nacionais de redução do tempo de trabalho e de medidas similares que permitam às empresas europeias salvaguardar postos de trabalho.

Politicamente, ao mesmo tempo que lida com as negociações de cunho econômico dos seus membros, a UE enfrenta os impactos e os acordos ligados ao Brexit, saída do Reino Unido do bloco. Além da grave recessão causada pela pandemia, a UE perdeu essas importantes contribuições financeiras. A intenção do bloco é alcançar acordos de parceria com o Reino Unido em todos os campos, inclusive, mais tarde, no campo da segurança e defesas externas.

A pandemia da Covid- 19 está acelerando e transformando a história e os processos que conformam a nova ordem mundial, anunciada por mudanças no equilíbrio de poder global, nas estruturas econômicas, no papel das agências multilaterais, nos padrões de interação social e nas formas de trabalho. A UE se coloca em uma interessante posição na iminência de uma "repaginada Guerra Fria" protagonizada por Estados Unidos da América (EUA) e China, em busca de hegemonia política e econômica. O vácuo de uma liderança historicamente conduzida pelos EUA abre oportunidades para UE e Ásia se colocarem nas relações internacionais com uma abordagem cooperativa e multilateral, apesar de suas diferenças no tocante a valores como liberdade e direitos humanos.

Na presidência rotativa da UE desde julho, a chanceler alemã Ângela Merkel coloca a pandemia como sua prioridade interna e no cenário externo, reconhece os EUA como parceiro mais importante da Europa (apesar das dificuldades em áreas como clima, comércio e papel das organizações internacionais na luta contra a pandemia), ao mesmo 
tempo que deixa claro seu interesse em estreitar os diálogos com a China e a Rússia. O presidente francês Emmanuel Macron, por sua vez, defende a construção de um novo e mais forte modelo econômico europeu, clamando por uma Europa forte, unida e soberana, mais independente dos EUA e da China.

Ao mesmo tempo que se coloca como o maior caso de sucesso dos movimentos de integração regional, a UE também se apresenta como importante ator e bastião do multilateralismo no cenário pandêmico, com destaque para o seu apoio à OMS e sua liderança no programa The Access to Covid- 19 Tools (ACT Accelerator) (WHO, 2020b), lançado em abril pela organização para acelerar o desenvolvimento de testes, vacinas e medicamentos seguros e eficazes para diagnosticar, prevenir e tratar a Covid-19. Em maio os principais líderes europeus deram apoio à Conferência Mundial de Doadores, que até julho já tinha arrecadado mais de 15 bilhões de euros para investir na plataforma Access to Covid- 19 Tools (ACT), movimento que visa a ajudar não só a Europa, mas também países de outras regiões, em especial os mais pobres. Ainda em julho, a plataforma se uniu a parceiros para expandir o acesso à dexametasona para países de baixa e média renda (Unitaid, 2020) como parte da garantia de acesso equitativo à terapêutica na resposta à Covid- 19.

É notório o esforço europeu de atuação no âmbito multilateral, manifestado por discursos de autoridades de vários países sobre a importância da concertação internacional para o enfrentamento à pandemia. Se por um lado vimos os EUA retirando seu financiamento à OMS, por outro assistimos à Comissão Europeia e ao alto representante da UE para política externa, Josep Borrell, emitir uma declaração instando os EUA a recuarem de sua decisão de deixar a OMS e afirmando que a UE segue apoiando a organização, inclusive disponibilizando financiamento adicional.

A Europa também está articulada para uma resposta global humanitária, que visa a prestar assistência a seus parceiros, combinando contribuições recolhidas de instituições da UE, incluindo as financeiras, com os recursos mobilizados pelos Estados-membros, para fazer face às consequências humanitárias, sanitárias e outras da pandemia de Covid-19. O documento que manifesta a "Resposta global da UE ao coronavírus: apoio aos nossos países parceiros" atesta que "A UE liderará os esforços no âmbito do G7 e do G20, em coordenação com as Nações Unidas, o Banco Mundial, o FMl e outras instituições multilaterais, para promover uma resposta multilateral forte e coordenada a esta pandemia mundial" (UE, 2020). A assistência aos parceiros no exterior objetiva responder às necessidades imediatas, tanto no setor humanitário como no setor dos cuidados na saúde; reforçar os sistemas de saúde, saneamento e abastecimento de água dos países parceiros; e fazer face às consequências econômicas e sociais. 
Nesse âmbito, a Comissão Europeia criou uma ponte aérea humanitária da UE, para assegurar o transporte de trabalhadores humanitários e de equipamento de emergência para algumas das zonas mais críticas no mundo. A prioridade é dada a países africanos, onde a pandemia agrava ainda mais as muitas crises humanitárias já existentes. O primeiro voo saiu em maio, transportando trabalhadores humanitários de várias organizações não governamentais (ONGs) e 13 toneladas de material humanitário. $\mathrm{Na}$ viagem de volta, os voos trazem cidadãos da UE e outros passageiros amparados por operação de repatriamento. A iniciativa, pensada inicialmente como temporária, pode durar até seis meses e é um esforço conjunto da comissão e dos Estados-membros. Ela é disponível para uso do pessoal humanitário das administrações nacionais, das ONGs e das agências da Organização das Nações Unidas (ONU), complementando os serviços logísticos do Plano Global de Resposta Humanitária das Nações Unidas (ONU, 2020). A comissão financia 100\% dos custos de transporte e cada parceiro é responsável pela aquisição do material humanitário.

A UE demonstrou capacidade de coordenação de esforços na área da saúde, ainda que tardiamente, mesmo com falta de um mandato supranacional e de políticas comuns para o setor: foram muitas as iniciativas de cunho humanitário, monitoramento epidemiológico e pesquisas em colaboração (Conselho Europeu, 2020). O esforço empreendido para encontrar uma vacina é inédito, assim como aquele voltado para a recuperação econômica do bloco. À medida que as implicações econômicas se tornavam mais evidentes, a UE começou a se afirmar. O Banco Central Europeu divulgou um empréstimo de 750 bilhões de euros, e outras medidas de apoio orçamentário e do Mecanismo Europeu de Estabilidade foram tomadas. Apesar das assimetrias e divergências internas, o bloco conseguiu avançar no processo de integração regional, aprofundando seus compromissos em nome da solidariedade entre os Estados-membros. No plano internacional, a UE atua e discursa de forma a reforçar o multilateralismo e valores como liberdade, proteção aos direitos humanos e ao meio ambiente, demostrando disposição para disputar seu espaço em um mundo que vem se desenhando com contornos de multipolaridade.

Para a saúde global, a pandemia traz enormes desafios, mas também oportunidades. O momento abre espaço para se promover sistemas de saúde públicos fortes e para que os temas ligados à saúde sejam absorvidos por agendas políticas e econômicas, nacionais e internacionais. Os debates sobre equidade, acesso e solidariedade ganham espaço e relevância. Hans Kluge, diretor regional da OMS Europa, elencou lições 
aprendidas com a pandemia em torno da necessidade de que haja sistemas de saúde fortalecidos que possam conter possíveis novas ondas e ao mesmo tempo manter a capacidade dos serviços de atenção básica à população; da centralidade que a saúde deve ocupar em agenda política interconectada; e da solidariedade internacional como resposta efetiva à crise.

\section{REFERÊNCIAS}

COMISSÃO EUROPEIA. Regulamento do Parlamento Europeu e do Conselho relativo à criação de um programa de ação da União no domínio da saúde para o período 202 I -2027 e que revoga o Regulamento (UE) n. 282/20 I 4 (Programa UE pela Saúde). Disponível em: < https://eur-lex.europa.eu/legal-content/ PT/TXT/HTML/?uri=CELEX:52020PC0405Eamp;from=EN>. Acesso em: 18 set. 2020.

COMISSÃO EUROPEIA. Representação em Portugal. Criação do Conselho Europeu de Inovação. Disponível em: <https://ec.europa.eu/portugal/news/creation-european-innovation-council_pt>. Acesso em: 18 set. 2020.

CONSELHO EUROPEU. Infografia: a resposta de emergência da UE à pandemia de Covid- 19. Disponível em: <https://www.consilium.europa.eu/pt/infographics/covid-19-eu-emergency-response>. Acesso em: 18 set. 2020.

COVID- 19 DATA PORTAL. Site. Disponível em: <https://www.covid I 9dataportal.org/>. Acesso em: 18 set. 2020.

COVID-19 HEALTH SYSTEM RESPONSE MONITOR. Site. Disponível em: <https://www. covid I 9healthsystem.org/mainpage.aspx>. Acesso em: 18 set. 2020.

EU4HEALTH. Site. Disponível em: <https://eu4health.eu/>. Acesso em: 18 set. 2020.

EUR-LEX.EUROPA. Regulamento (UE) 2020/672 do Conselho de 19 de maio de 2020 relativo à criação de um instrumento europeu de apoio temporário para atenuar os riscos de desemprego numa situação de emergência (SURE) na sequência do surto de Covid-19. Jornal Oficial da União Europeia, 20 maio 2020. Disponível em: <https://eur-lex.europa.eu/legal-content/PT/TXT/PDF/?uri=CELEX:32020R06 72 Eamp;from =pt>. Acesso em: 18 set. 2020.

EUROPE UNION. First “ERAvsCORONA” Action Plan, 7 Apr. 2020. Disponível em: < https://ec.europa. eu/info/sites/info/files/covid-firsteravscorona_actions.pdf $>$. Acesso em: 18 set. 2020.

EUROPEAN CENTRE FOR DISEASE PREVENTION AND CONTROL (ECDPC). Coronavirus disease. Disponível em: <https://www.ecdc.europa.eu/en>. Acesso em: 18 set. 2020.

EUROPEAN COMMISSION. European Research Area (ERA) corona platform. Disponível em: < https:// ec.europa.eu/info/funding-tenders/opportunities/portal/screen/covid-19>. Acesso em: 18 set. 2020a.

EUROPEAN COMMISSION. Communication from the Commission to the European Parliament, the Council, the European Economic and Social Committee and the Committee of the Regions. Short-term EU health preparedness for Covid-19 outbreaks, 15 July. 2020b. Disponível em: <https://ec.europa. eu/info/sites/info/files/communication_-_short-term_eu_health_preparedness.pdf $>$. Acesso em: 18 set. 2020. 
EUROPEAN OPEN SCIENCE CLOUD. Site. Disponível em: <https://www.eosc-portal.eu/>. Acesso em: 18 set. 2020.

EUvsVIRUS. Site. Disponível em: <https://www.euvsvirus.org/>. Acesso em: 18 set. 2020.

ORGANIZAÇÃO DAS NAÇÕES UNIDAS (ONU). Plano Global de Resposta Humanitária à Covid- 19. ONU News, 16 jul. 2020. Disponível em: <https://news.un.org/pt/tags/plano-global-de-respostahumanitaria-covid-19>. Acesso em: 18 set. 2020.

RECONCILING ECONOMIC AND SOCIAL EUROPE: the role of ideas, values and politics (RESCEU). Site. Disponível em: <https://www.resceu.eu/>. Acesso em: 18 set. 2020.

RIGHT2CURE. Site. Disponível em: < https://www.right2cure.eu/>. Acesso em: 18 set. 2020.

SÁNCHEZ, Á. Bruselas adelantará dinero a las farmacéuticas para tener acceso preferente a las dosis de la vacuna. El País, Bruselas, I 7 June 2020. Disponível em: < https://elpais.com/sociedad/2020-06-17/ bruselas-adelantara-dinero-a-las-farmaceuticas-para-tener-acceso-preferente-a-las-dosis-de-lavacuna.html>. Acesso em: 18 set. 2020.

UNIÃO EUROPEIA. Comissão Europeia. Resposta global da UE ao coronavírus: apoio aos nossos países parceiros. Disponível em: <https://ec.europa.eu/commission/presscorner/detail/pt/fs_20_607>. Acesso em: 18 set. 2020.

UNITAID. ACT-Accelerator moves to expand access to dexamethasone for low- and middle-income countries for Covid- 19 treatment, 2 July 2020. Disponível em: <https://unitaid.org/news-blog/actaccelerator-moves-to-expand-access-to-dexamethasone-for-low-and-middle-income-countriesfor-covid-19-treatment/\#en>. Acesso em: 18 set. 2020.

WORLD HEALTH ORGANIZATION (WHO). Office Regional for Europe. Publication and technical guidance, training courses, multimedia, statements, latest updates. Disponível em: < https://www.euro. who.int/en/health-topics/health-emergencies/coronavirus-covid-19>. Acesso em: 18 set. 2020a.

WORLD HEALTH ORGANIZATION (WHO). Access to Covid-19 Tools (ACT) Accelerator, 24 Apr. 2020b. Disponível em: < https://www.who.int/publications/m/item/access-to-covid-19-tools-(act)accelerator>. Acesso em: 18 set. 2020. 

No momento, vamos vislumbrando trajetórias possíveis e confirmando tendências, pois as mudanças na economia, na sociedade e na governança global ainda estão em curso. A pandemia segue desafiando o conhecimento científico e as capacidades dos governos, diariamente. Segue pressionando por soluções médico-científicas e acirrando disputas tecnológicas e comerciais, incluindo acusações de espionagem e monopolização antecipada pelos países ricos de milhões de doses de vacinas contra a Covid- 19. $\mathrm{E}$, simultaneamente, contribuindo para reforçar discursos populistas, protecionistas e antimultilateralistas, do cada um por si, o que aumenta o risco de conflitos. Somam-se a esses ingredientes ações de grupos terroristas que veem na pandemia uma oportunidade para firmar sua força (Voronkov, 2020; Guterres, 2020a).

É desse mosaico de questões, fragilidades reveladas, tensões exacerbadas e reposicionamento de aliados estratégicos nos países componentes dessas duas grandes regiões do globo que vamos tratar neste capítulo.

\section{A PANDEMIA E SUAS CIRCUNSTÂNCIAS NAS REGIÕES}

Ásia-Pacífico (AP) e Oriente Médio (OM) reúnem mais de 65 países e territórios e mais de um quarto da população mundial, com grande diversidade cultural, religiosa, socioeconômica e política; têm similaridades quanto a fragilidades dos sistemas de saúde (ou ausência destes), mas vivem realidades diferentes: conflitos históricos ou consequentes de novos arranjos de interesses e fontes de riqueza baseada no petróleo e no turismo religioso, no OM; grande migração de trabalhadores, interdependência da cadeia de suprimentos e fontes de riqueza baseada no turismo cultural e de belezas naturais, na tecnologia de ponta e em insumos estratégicos, na AP.

As ações imediatamente adotadas pelos Estados para conter o Sars-CoV-2 deram bons resultados, mas as consequências econômicas pressionaram os governos pela abertura antes da hora. As diferenças entre os países das duas regiões começaram a aparecer, seja pelo modelo de desenvolvimento econômico, como em Singapura e em alguns países árabes, seja pela estrutura organizacional do Estado, como na Índia; seja pelo seu tamanho, como na Nova Zelândia, no Vietnã e nos Emirados Árabes, seja pela capacidade implantada de testagem, como na Coreia do Sul, na China e em Singapura; seja pelo grande número de pessoas em situação vulnerável, como nos países árabes em conflito e nos países que abrigam grande número de refugiados.

Muitas desigualdades e fragilidades sociais e sanitárias foram trazidas à tona e ganharam enorme visibilidade nas duas regiões: favelas e assentamentos com alto índice populacional, sem serviços adequados de água e saneamento; trabalhadores informais, 
trabalhadores migrantes desamparados; refugiados e deslocados e o drama humanitário dos conflitos; sistemas de saúde precários, pouco inclusivos ou ausentes, com falta de estrutura de serviços e de profissionais da saúde; carga de doenças tratáveis ou evitáveis; fome e desnutrição; desigualdades; risco do retorno do casamento infantil.

\section{ÁSIA-PACÍFICO}

São 49 países e territórios, dois deles os mais populosos do mundo: China e Índia. Dois vizinhos que nestes tempos de pandemia protagonizam, em lados opostos, junto com Rússia e Estados Unidos da América (EUA), um importante jogo geopolítico em torno de uma nova ordem mundial.

A pandemia não se espalhou tão rapidamente na região como se viu em outras partes do mundo. As lições aprendidas com outras epidemias, como a de Sars (síndrome respiratória aguda grave), foram aplicadas. Os governos agiram rápido, fechando fronteiras, implantando o isolamento social, fazendo testagem e rastreamento de contatos, por exemplo, e a transmissão da Covid- 19 se manteve sob controle. E vem se mantendo na maioria dos países, com raras exceções. No entanto, a incidência do SarsCoV-2 variou em toda a região e atingiu países e populações mais vulneráveis de forma mais impactante: mulheres, trabalhadores informais e migrantes. Não foi preciso muito tempo para que as fragilidades dos serviços básicos e a falta de políticas públicas em questões cruciais evidenciassem os novos e urgentes desafios para os governos. Novas lições estão sendo aprendidas.

Apesar do forte crescimento econômico dos países da região e da boa resposta contra a pandemia, o recém-divulgado relatório das Nações Unidas (ONU) sobre o impacto da Covid- 9 na região chama atenção para os altos níveis de desigualdade, baixos níveis de proteção social e um grande setor informal, bem como para uma regressão em paz e justiça e para os níveis preocupantes de danos ao ecossistema, perda de biodiversidade, emissão de gases de efeito estufa e qualidade do ar (UN, 2020a). Mesmo antes da pandemia, os países estavam longe de alcançar os Objetivos de Desenvolvimento Sustentável (ODS) até 2030. Mesmo assim, desenvolveram boa capacidade de resposta a emergências em saúde pública e de detecção precoce e notificação de epidemias. Um exemplo dessa contradição é a Índia: país densamente populoso, com 70\% da população vivendo na pobreza (IDH 0,647), grandes favelas, sistema de saúde desigual, apresenta, no entanto, crescimento econômico e importante desenvolvimento em tecnologia da informação e em insumos e suprimentos estratégicos para saúde e indústria farmacêutica. 
Os danos econômicos da pandemia foram mais sentidos nos países mais dependentes da cadeia de suprimentos da China, para indústria, comércio, além do turismo, muito forte na região. O Banco Asiático para o Desenvolvimento (ADB) disponibilizou financiamentos e realizou várias ações para socorrer os países-membros (ADB Covid- 9 Policy Database, 2020). Os governos locais implantaram várias medidas fiscais e monetárias para aliviar a tensão imediata. Alguns países adotaram subsídios financeiros, isenção de impostos, suspensão temporária de pagamentos, implementação de home office e cofinanciamento de salários (Singapura e Camboja), suspensão ou redução da contribuição para o fundo de pensão (China, Malásia e Vietnam), assistência social temporária (Malásia e Singapura), adicional do cartão de alimentos (Indonésia), descontos em água e luz (Tailândia e Malásia), seguridade social para os desempregados (Filipinas).

Por outro lado, surgiram oportunidades para países produtores de equipamentos e insumos médicos, que realocaram suas produções para fornecer suprimentos para países do Ocidente. E que, além disso, têm expertise no desenvolvimento e uso de tecnologias digitais e de inteligência artificial para rastreamento de contatos e para sistema monetário digital.

A guerra comercial entre China e EUA favoreceu esse movimento num primeiro momento, mas a disputa comercial entre as duas grandes potências evoluiu rapidamente para um embate diplomático e ideológico que, no fundo, é um embate tecnológico - liderança da próxima geração de tecnologias. E já provoca mudanças no cenário geopolítico da região, com reposicionamento de aliados e novos arranjos.

Os países e territórios vizinhos observam esses movimentos com atenção e preocupação e se articulam para cooperar regionalmente seja para garantir o livrecomércio e recuperar a economia a curto prazo, seja para garantir crescimento e reduzir as desigualdades no médio prazo, seja para garantir segurança e paz.

Alianças e acordos estratégicos têm sido firmados e ao mesmo tempo decisões e relatórios econômicos foram resgatados, alguns elaborados ainda em meados de 2019. Na ocasião, os países estavam identificando fragilidades e definindo ações tanto sanitárias quanto econômicas para emergências provocadas por patógenos e por desastres naturais ou causados pelo homem (Declaração de Délhi) (WHO, 20I9).

Os escritórios regionais da Organização Mundial da Saúde (OMS) Ásia Sudeste e Pacífico Ocidental trabalharam em um Plano Estratégico para Covid-19 OMS Ásia-Pacífico (WHO, 2020). A Organização para a Cooperação e Desenvolvimento Econômico (OCDE) produziu dois relatórios orientadores para a região e mais um 
terceiro em parceria com a Asean (Associação dos Estados-Membros do Sudeste Asiático)' para a futura recuperação econômica (Asean \& OECD, 2020).

A Asean teve papel fundamental desde o início da pandemia no trabalho como bloco regional, articuladamente estabelecendo parcerias e colaborações com outros países e organizações multilaterais. E já foram realizadas várias discussões estratégicas para a região, sobre troca de experiências no enfrentamento da Covid-19, criação de oportunidades de recuperação econômica e mecanismos de resposta a emergências: Declaração dos Ministros de Saúde (Asean, 2020a), Biodiversidade e Saúde (Asean, 2020b), Compartilhamento de Políticas (Asean, 2020c); Segurança Regional (Asean, 2020d) e Infraestrutura (Asean, 2020e). A Declaração final da 36 ${ }^{\mathrm{a}}$ Cimeira da Asean (Asean, 2020f) reafirma a cooperação como um bloco que busca a manutenção do diálogo com outros países e organismos internacionais, promovendo a paz, a integração regional e global, a estabilidade e prosperidade, além do compromisso com a prevenção e mitigação dos impactos da Covid- 19.

\section{Em meio à Covid-19, a rivalidade sino-americana na Ásia-Pacífico}

A Covid- 19 aumentou as rivalidades entre os EUA e a China. As relações estão cada vez mais hostis e, em poucos meses, vimos as farpas iniciais se transformarem em ações que avançam para um terreno perigoso, apesar de os dois países ainda estarem conectados economicamente por meio de acordos comerciais. O que começou com uma disputa comercial está virando uma guerra ideológica e de valores, que já envolveu o fechamento, por determinação do governo norte-americano, do consulado chinês em Houston e, em retaliação, o fechamento do consulado americano em Chengdu, na província de Sichuan, sudoeste da China. Mas por que Houston? Por que Chengdu? Entender o significado das duas regiões para os dois países ajuda a entender o significado subjacente a esses atos e os consequentes movimentos em andamento, principalmente para a China. Esse ponto nevrálgico foi apresentado nos Cadernos Cris-Fiocruz - Informe 15 (Marques, 2020a).

Os governos dos países asiáticos acompanham essas hostilidades e buscam se organizar multilateralmente para garantir uma região Indo-Pacífica forte e para construir mudanças de médio e longo prazos tanto em saúde quanto para políticas econômicas e sociais.

\footnotetext{
' A Asean foi criada em 1967, com a assinatura da Declaração de Bangkok pela Indonésia, Malásia, Filipinas, Singapura e Tailândia, com o propósito de cooperação nos campos econômico, social, cultural, técnico, educacional, de promoção da paz e estabilidade regional, por meio do respeito permanente (Asean, 1967). Ao longo de vinte anos, foram se associando Brunei Darussalam, Vietnã (atual presidente), Laos, Myanmar e Camboja, constituindo os 10 Estados-membros.
} 
A ascensão de uma China assertiva na última década, com iniciativas econômicas multilaterais ambiciosas, como a Nova Rota da Seda - Belt and Road Initiative (BRI), também conhecida como One Belt, One Road -, e a redução do papel dos EUA na ordem internacional global provocaram mudanças no equilíbrio regional e indicam mudanças no poder mundial (BRI, 2020). Samuel Pinheiro Guimarães (2020) traça um breve histórico do modelo de atuação das duas potências e descreve as diferentes estratégias na luta pela hegemonia entre os dois países.

A China se tornou importante parceiro econômico para os países da Ásia-Pacífico e ao mesmo tempo estabeleceu redes comerciais por todo o mundo. Os EUA têm grandes interesses na região e estão de olho nos movimentos chineses no mar da China Meridional. ${ }^{2}$ Prato cheio para pressões diplomáticas. Uma ideia de um bloco IndoPacífico Livre e Aberto (Foip, Free Open Indo Pacific) vem sendo defendida pelos EUA e pelo chamado Quad, Diálogo Quadrilateral de Segurança, fórum informal para troca de informações e exercícios militares no Indo-Pacífico constituído por Austrália, Índia, Japão e EUA - e podemos incluir aí Israel e Coreia do Sul, que, além de cooperação econômica, propõem o aprofundamento de contramedidas militares entre potências semelhantes. "Seja por motivos ideológicos, seja por interesses e rivalidades regionais, (esses países) são vistos como potenciais aliados em uma política de enfrentamento à China" (Amorim, 2020).

Heydarian (2020) e Horimoto (2020) falam sobre alguns desses movimentos em busca de multilateralidade e de livre abertura inclusiva e democrática. A iniciativa Foip se propõe livre e aberta, mas seu discurso é visto com ceticismo pelo Sudeste Asiático e é evitado pela Asean, por verem na estratégia uma contenção mal disfarçada contra a China. Para os Estados asiáticos, a China é uma parte indispensável e deve ser engajada por meio da Asean ou de outros mecanismos multilaterais. De seu lado, a China vem trabalhando para acelerar a assinatura de adesão da iniciativa RCEP (Regional Comprehensive Economic Partnership), proposta de livre-comércio na região IndoPacífico entre os dez Estados-membros da Asean (Brunei, Camboja, Indonésia, Laos, Malásia, Mianmar, Filipinas, Singapura, Tailândia e Vietnã) e cinco dos seus parceiros (Austrália, China, Japão, Nova Zelândia e Coreia do Sul). A Índia reluta em aderir à iniciativa, temendo perder espaço comercial: as empresas indianas são quase totalmente contra, mas os diplomatas indianos são a favor. Japão tem feito pressão para a adesão da Índia. O RCEP está sendo considerado o maior acordo comercial do mundo e impulsionará o comércio em todo o grupo, reduzindo tarifas, padronizando regras e procedimentos

\footnotetext{
${ }^{2}$ Wikipedia, 2020.
} 
alfandegários e ampliando o acesso ao mercado, especialmente entre países que não têm acordos comerciais em vigor. E os EUA não estão nele.

E não devemos perder de vista os seis pontos sensíveis para os EUA no embate com a China: tecnologia 5G; corrida espacial para Marte (sonda e minirrobô teleguiado); satélite de comunicação quântica (sistema de comunicação de longa distância, impossível de ser espionado ou hackeado); ações da China no mar da China Meridional. (Cadernos Cris-Fiocruz - Informe II) (Marques, 2020b); ações da China em Hong Kong; ações da China contra a etnia mulçumana uigur no Sudoeste Asiático (Cadernos Cris-Fiocruz - Informe 15) (Marques, 2020a).

\section{ORIENTE MÉDIO}

A região é um caldeirão em ebulição desde os tempos bíblicos. Lealdades e rivalidades históricas. É o local de nascimento e centro espiritual do cristianismo, islamismo, judaísmo, zoroastrismo, yazidi (curdos), mitraísmo, maniqueísmo e baha’i. São I 8 países e territórios em uma região geograficamente pequena, mas com localização estratégica: se estende do Mediterrâneo ao golfo Pérsico e limita-se com o mar Vermelho, importante rota marítima comercial. Seu solo é desértico, mas no subsolo estão $60 \%$ das reservas de petróleo e gás natural do mundo.

O Oriente Médio é palco de disputas entre potências por fatores geoestratégicos (localização entre Ásia e Europa, petróleo, água); conflitos religiosos (cristãos maronitas e ortodoxos, judeus, mulçumanos, xiitas, sunitas, curdos e outros). Algumas alianças se formam pontualmente, mas algumas oposições e influências são clássicas: os pró-Irã e os contra Irã; Rússia e seus aliados versus EUA e seus aliados. Posicionamentos que definem os destinos das sofridas populações.

Os confrontos bélicos atuais já geraram milhões de refugiados e deslocados internamente, colapsaram as infraestruturas de saúde e de educação, com restrições de alimentos e de medicamentos. São tantos agravos que fazem com que a pandemia Covid-19, em alguns países, seja mais um problema entre muitos, inclusive para a ajuda humanitária. A emergência sanitária não conseguiu frear os conflitos nem impulsionar iniciativas de paz. Pelo contrário, alguns grupos e movimentos terroristas estão usando a pandemia para ampliar e fortalecer suas ações. As principais relações e conflitos podem ser acessados nos Cadernos Cris-Fiocruz, Informe 9 (Marques, 2020c).

E como o Sars-CoV-2 atinge todos os países, incluindo aqueles que hospedam os 76 milhões de refugiados e pessoas deslocadas à força, a situação se torna mais crítica porque mais de $80 \%$ desses refugiados estão em países de baixa e média rendas, em 
acampamentos ou em áreas urbanas densamente povoadas, muitas vezes vivendo em condições inadequadas, com saúde pública limitada e frágil ou ausente, além de não terem completo acesso a instalações de saneamento e sistemas de proteção social. Além disso, alguns desses países anfitriões ainda vivem fortemente atingidos por seus próprios conflitos internos e por fome, pobreza e outras doenças epidêmicas, como cólera, malária, dengue, sarampo, poliomielite.

A maioria dos países da região tem no petróleo sua principal fonte de renda e está vendo sua riqueza cair com o confinamento imposto para conter a Covid- 19. O preço do petróleo já estava em baixa antes da pandemia; agora, com queda no consumo à medida que as pessoas foram parando (o ar chegou a ficar mais limpo em algumas cidades), despencou. Omã, Kuwait e Arábia Saudita já estão queimando suas reservas, cortando gastos e até mesmo tomando empréstimos. Alguns já vinham buscando opções para substituir a renda proveniente do petróleo, uma vez que o mundo já fala em alternativas aos combustíveis fósseis. E mesmo depois da pandemia, os preços do óleo negro não devem melhorar rapidamente, portanto os países precisam se mexer mais rápido. No âmbito do seu plano estratégico Visão 2030, a Arábia Saudita melhorou sua infraestrutura para atrair turistas e realizar grandes eventos culturais. Com a pandemia, isso caiu por terra. Outra consequência da queda da produção do petróleo na região foi o retorno dos trabalhadores migrantes que estavam nos oleosos países vizinhos.

Dos países árabes, os Emirados Árabes Unidos têm conseguido manter as contas equilibradas e lançado pacotes financeiros para ajudar a reduzir os efeitos econômicos da pandemia. Outro lançamento que ganhou as mídias mundiais foi o da sonda Hope, do porto espacial do Japão. Os Emirados planejam se tornar um ator importante na indústria espacial; será um impulso para os negócios, segundo o Ministério da Economia Digital, Inteligência Artificial e Sistema de Trabalho Remoto. A sonda Hope vai percorrer 495 milhões de quilômetros e deve chegar a Marte em fevereiro de 2021, coincidindo com o aniversário de 50 anos da formação dos Emirados. China e EUA também lançaram suas sondas para estudar o planeta vermelho. Outra iniciativa dos Emirados, visando à produção de energia limpa, foi a construção da primeira usina nuclear para produção de energia, com tecnologia sul-coreana.

Aumento de impostos, cortes de salário e propostas de privatizações são algumas das soluções propostas pelos governos, mas não foram bem recebidas pelo povo, com muitos desempregados. Além disso, Estados árabes que costumavam se ajudar estão deixando de fazê-lo, seja pela queda na economia, seja por seus posicionamentos nos conflitos regionais. 
Outra consequência num futuro não tão distante envolve a insegurança alimentar na região (Karasapan, 2020). O alerta vem da Rede Global Contra a Crise Alimentar, aliança das Nações Unidas e agências parceiras (FSIN, 2020; UN, 2020c). Os países árabes são grandes compradores de alimentos. A queda na economia provocada pela pandemia poderia levar mais 265 milhões de pessoas à insegurança alimentar e desnutrição. O acirramento dos conflitos e as consequências das mudanças climáticas - praga dos gafanhotos e seca - só pioram a situação.

As Nações Unidas analisaram o impacto da Covid-1 9 na região (UN, 2020b) e, apesar de a pandemia não ter reduzido os conflitos, a ONU enxerga algumas oportunidades para a região, baseadas na cooperação multilateral. Algumas das respostas dos países à pandemia, tanto para controle quanto para recuperação da economia, poderiam ser aproveitadas para fazer avançarem as discussões sobre direitos humanos, reconciliação, deslocamentos, desafios humanitários, para analisar as causas básicas dos conflitos e buscar uma paz sustentável e para fazer progressos tangíveis em direção ao crescimento, prosperidade, equidade e justiça social para todos (Guterres, 2020b). Nesse processo de possibilidades de reconstrução, os investimentos chineses no âmbito da Rota da Seda podem ser uma alternativa para a cooperação.

\section{A iniciativa Nova Rota da Seda (BRI) e investimentos no Oriente Médio}

A política externa do governo Donald Trump afastou os EUA do Oriente Médio. Rússia reduziu seu interesse de garantir o porto sírio, no Mediterrâneo. Situação perfeita para a China investir mais na região e, ao mesmo tempo, garantir o acesso ao mar Vermelho e ao Mediterrâneo, ao petróleo e gás natural.

Também conhecida como One Belt, One Road, a Nova Rota da Seda - Belt and Road Initiative (BRI) é uma ambiciosa estratégia de desenvolvimento que envolve cooperação internacional, lançada pelo governo chinês em 2013, com dois braços: um recria a antiga rota através da Ásia Ocidental e da Europa; o segundo abre novos caminhos por vários oceanos e mares. Propõe uma rede de parcerias com dezenas de países (Visual Capitalist, 2020) ao redor do mundo mediante projetos de comércio, energia e infraestrutura, como rotas marítimas, ferrovias e aeroportos na Ásia Central, no Sudeste Asiático, no Oriente Médio, na África e na América Latina e Caribe.

A BRI (2020) é o projeto central da política externa da China e busca o intercâmbio entre países, com promoção de diálogos, em vez de confrontação. Já foram assinados duzentos documentos de cooperação, com 138 países e trinta organizações internacionais, segundo o site oficial da iniciativa (The People's Republic of China, 2020). 
Para entender um pouco mais sobre a iniciativa e sobre a própria China, recomendo a leitura do artigo do Pablo Ibañez (2020), "Geopolítica e diplomacia em tempos de Covid-19: Brasil e China no limiar de um contencioso", e do capítulo deste e-book sobre o país, preparado pelo André Lobato.

Em meio à pandemia, o país de Xi Jinping segue firme para consolidar a BRI, que ao mesmo tempo é uma ofensiva contra a estratégia americana de aplicar sanções. China e Irã fecharam uma ampla parceria econômica e de segurança que mina os esforços do governo Trump de isolar o governo iraniano por causa de suas ambições nucleares e militares. E cria mais pontos de tensão na já deteriorada relação com os EUA. A presença chinesa será ampliada em bancos, telecomunicações, portos, ferrovias e dezenas de outros projetos. No âmbito da parceria militar, China terá uma base na região, além de treinamento e exercícios conjuntos, pesquisa conjunta e desenvolvimento de armas e compartilhamento de inteligência, e ainda garante à China fornecimento de petróleo iraniano nos próximos 25 anos. O acordo é estratégico para os dois países: o Irã ganha fôlego financeiro e a China se torna um jogador importante para a geopolítica no Oriente Médio, uma vez que os EUA perderam o interesse na região.

O interesse da China na Ásia Ocidental e no Oriente Médio não é de agora. ${ }^{3}$ O país se aproximou do Afeganistão e mantém diálogos com o governo afegão e o Talibã; ampliou sua participação no Paquistão, investindo em infraestrutura e apoio financeiro; mantém acordos com a Arábia Saudita que envolvem licença para quatro campos de exploração; no Qatar, fabricação de petroleiro. Além desses, mantém uma base militar no Djibouti, no chamado Chifre da África, na parte estreita do mar Vermelho - região de redes de vias navegáveis entre Mediterrâneo e oceanos Índico e Pacífico, assim como de redes de comunicação em alto-mar. E assim vai construindo um caminho para acesso a commodities na Nova Rota da Seda; além disso, a expansão logística fortalece laços políticos e diplomáticos (Visual Capitalist, 2020).

\section{Corredor internacional Índia-Rússia}

O Irã, a Índia, a Rússia e o Azerbaijão também estão avançando para concluir o Corredor Internacional de Transporte Norte-Sul, ${ }^{4}$ a iniciativa própria no estilo Belt

\footnotetext{
${ }^{3}$ A China tem acordos estabelecidos com Emirados Árabes Unidos, Kuwait, Turquia, Qatar, Omã, Líbano, Arábia Saudita, Bahrein, Irã, Iraque, Afeganistão, Azerbaijão, Cazaquistão, Quirguistão, Tajiquistão, Uzbequistão e lêmen.

${ }^{4}$ Países-membros: Irã, Rússia, Índia, Azerbaijão, Armênia, Cazaquistão, Quirguistão, Tajiquistão, Ucrânia, Bielorrússia, Omã e Síria.
} 
and Road: uma rota de carga de ferrovias e porto da Índia para o norte da Rússia. Esse corredor também conectaria o Cazaquistão, que é descrito pela China como a "fivela" da BRI.

\title{
TRABALHADORES MIGRANTES, REFUGIADOS E DESLOCADOS E TERRORISMO
}

\author{
A Covid- I 9 é um teste não apenas para nossos sistemas de saúde e \\ mecanismos de assistência médica para responder a doenças infecciosas, \\ mas também de nossa capacidade de trabalhar juntos como uma \\ comunidade de nações diante de um desafio comum. Além desses desafios \\ muito imediatos, o caminho do coronavírus também testará, sem dúvida, \\ nossos princípios, valores e humanidade compartilhada. \\ Michelle Bachelet e Filippo Grandi, Alto \\ Comissariado das Nações Unidas para Refugiados
}

O cenário pandêmico não apenas colocou em xeque os sistemas de saúde dos países, ele trouxe à tona as questões trabalhistas, sociais e de direitos humanos, principalmente da população migrante e dos refugiados e deslocados (UN, 2020d), fruto da falta de políticas públicas, do modelo de crescimento econômico adotado e de muitos conflitos.

Somam-se a essas questões a de como lidar com os grupos extremistas e grupos de ódio que estão explorando os impactos da pandemia da Covid-19 para espalhar medo, violência e divisão. O secretário-geral da Organização das Nações Unidas (ONU), Guterres (2020a), já alertou para a importância de implementar políticas de combate ao terrorismo e seu financiamento. Falou também das novas e emergentes formas de terrorismo - uso de tecnologia digital, ataques cibernéticos e bioterrorismo - e da importância de envolver os jovens, a sociedade civil e a mídia para prevenir o extremismo violento: "Devemos aproveitar o poder do multilateralismo para encontrar soluções práticas”. Entenda mais sobre os grupos terroristas e onde atuam nos Cadernos CrisFiocruz, Informe 12 (Marques, 2020d).

A maioria dos países asiáticos concentrou seu modelo de desenvolvimento econômico apoiado na absorção da mão de obra barata dos migrantes, seja de regiões do próprio país, seja de países vizinhos. Os migrantes representam $40 \%$ de todos os trabalhadores da região e, devido às péssimas condições de abrigo, à falta de acesso a serviços de saúde, à perda do emprego e da capacidade de retornar aos seus países e regiões de origem, estão sendo duramente atingidos pela pandemia. Alguns países 
estão começando a rever a situação, como Índia e Singapura, onde vivem milhões de trabalhadores migrantes. Situações diferentes que exigem soluções urgentes.

Na Índia, a força de trabalho é composta por trabalhadores que se deslocaram das regiões rurais para os grandes centros. Durante o bloqueio para conter a Covid-19, o governo indiano tomou uma série de decisões apressadas e atrapalhadas, causando sofrimento e desordens que, inclusive, contribuíram para espalhar o vírus para as regiões rurais. O governo foi duramente criticado e já começou a trabalhar mudanças. Índia preparou plano para atrair de volta aos centros urbanos os trabalhadores migrantes que fugiram para suas aldeias rurais. O plano, chamado de Housing for All, envolve parcerias público-privadas (PPPs) e prevê o desenvolvimento de moradias com preços de aluguel acessíveis e conversão de habitações vazias do governo em complexos habitacionais acessíveis, até 2022. A previsão é de criar 20 milhões de novas unidades urbanas e 30 milhões de casas rurais. Mas os críticos alertam que será preciso mais do que uma casa para atrair esses trabalhadores que, no início do lockdown, foram obrigados a percorrer centenas de quilômetros a pé e a implorar por alimento (Cadernos Cris-Fiocruz, Informe 6) (Marques, 2020e).

Outro problema é que na Índia há mais de duzentas leis trabalhistas em vigor e o governo trabalha para tentar concentrá-las em quatro grandes leis. Numa tentativa simplista, classifica os trabalhos em: qualificados, não qualificados, formais e informais. Mas as mudanças que começam a ser implementadas vão contra o interesse dos trabalhadores, principalmente em unidades industriais: aumento de horas trabalhadas sem pagamento de horas extras. $\mathrm{O}$ abuso acontece quando esses trabalhadores que perderam suas rendas por conta da crise da pandemia aceitam a situação, o que contraria a convenção da Organização Internacional do Trabalho, como já denunciado a esse órgão internacional.

Em Singapura, o modelo econômico adotado priorizou o crescimento acelerado e optou pela mão de obra barata e transitória dos trabalhadores migrantes estrangeiros, que hoje são cerca de 1,5 milhão de pessoas, das quais cerca de 320 mil estão acomodadas em grandes complexos de dormitórios. A responsabilidade pelo bem-estar social dos trabalhadores ficou nas mãos dos empregadores. Nos dormitórios, a aglomeração dos trabalhadores resultou em grande número de contaminados pela Covid- 19. O governou implantou forças-tarefa para testagem, acompanhamento médico e psicológico, e houve uma grande campanha para evitar discriminação contra esses trabalhadores. A campanha teve resultados positivos, com engajamento da população e de empresas, inclusive com doação de tablets para cursos e jogos cognitivos. Com novo parlamento recentemente eleito, o governo agora está revendo as legislações trabalhistas e está 
focado em capacitação da população singapurense para substituição a médio e longo prazos da mão de obra estrangeira.

O Grande Oriente Médio, que envolve também países árabes do Mediterrâneo e da Ásia Central, é a região com maior número de refugiados e deslocados internamente. E também a região onde estão os países que mais abrigam refugiados - fronteiriços às zonas de conflito -, muitos dos quais mal se recuperaram dos conflitos vividos, com infraestruturas de água e saúde sobrecarregadas, como Turquia (maior número de refugiados), Iraque, Paquistão, Líbano, Jordânia, Irã. São mais de 76 milhões de pessoas afetadas.

Consequentemente, as respostas precisam ser rápidas, não só para atender essas pessoas, mas também para dar apoio financeiro aos países anfitriões, para que possam assimilar essa população de refugiados e incluí-la em seus sistemas nacionais de saúde e de seguridade. Mais de $80 \%$ dos refugiados do mundo estão hospedadas em países de baixa e média rendas. Eles frequentemente enfrentam desafios e vulnerabilidades específicos que devem ser levados em consideração nas operações de prontidão e resposta ao Covid-19. Saiba mais sobre quem são e onde estão os refugiados da região no Informe 9, dos Cadernos Cris Fiocruz (Marques, 2020c).

A ONU chama a atenção para os campos de refugiados em situações precárias, com as pessoas em barracas e acesso limitado a instalações de higiene. E o Alto Comissariado das Nações Unidas para Refugiados (Acnur) cita o caso do assentamento Bazar de Cox, em Bangladesh, que não conseguiu evitar a pandemia de Covid-19. O campo abriga mais de 860 mil refugiados rohingyas, fugidos de Myanmar.

No link < https://www.unhcr.org/refugeebrief/> (UNHCR, 2020) pode-se acompanhar a atualização semanal sobre os refugiados no mundo.

Outro problema seríssimo para o qual organizações (Girls Not Bride, 2020) não governamentais, juntamente com UNFPA (ONU, 2020) e Unicef, estão alertando é o risco da volta dos casamentos entre crianças na Índia, na Síria, no lêmen, em Bangladesh, no Nepal e em países africanos. A crise pode desfazer uma década de trabalho destinado a acabar com essa prática: além do trabalho interrompido dos agentes, o fechamento das escolas e a perda dos meios de subsistência podem levar famílias a casarem suas filhas cedo (menos uma boca para alimentar). 


\section{CENÁRIO DE DESAFIOS E OPORTUNIDADES}

Retomando o pensamento voltado para um mundo melhor no pós-pandemia - mesmo com ela ainda em andamento -, sabemos que o momento é de reflexão sobre economia, saúde pública, desigualdades, ambiente e globalização no futuro que queremos daqui em diante, o novo normal. E que a nossa resiliência envolve mais do que a capacidade de se recobrar, de recuperar o equilíbrio, de voltar à forma original: será preciso ter capacidade de desenvolver novos olhares e novos pensamentos para novos caminhos.

Recentemente, a Asean reuniu especialistas globais da área econômica para discutir ideias e políticas para recuperação pós-pandêmica (Asean, 2020g). Além de destacarem a importância da cooperação e parceria multilateral, o grupo recomendou que se aproveite o período da pandemia para mudar a maneira como as coisas são feitas no sentido de maior inclusão, sustentabilidade e resiliência. Toda crise é uma oportunidade para repensar as prioridades, segundo Maria Demertzis, vice-diretora do think tank Bruegel, dedicado à pesquisa de políticas sobre questões econômicas (Bruegel, 2020).

Como bem observa Lutfey Siddiqi (2020), ${ }^{5}$ é imperativo que os governos adotem uma abordagem proativa, não apenas para proteger os empregos existentes em empresas existentes, mas para promover os setores econômicos do futuro e ajudar na transição de habilidades para os empregos do futuro, isto é, enxergar as janelas de oportunidades.

Nessa equação de cenários futuros de curto, médio e longo prazos, a humanidade, de forma geral, também terá que se organizar para mitigar os riscos associados às futuras pandemias, às mudanças climáticas, à inteligência artificial não gerenciada - o uso da tecnologia inteligente para monitoramento da pandemia cresceu sem regramento legal de privacidade.

Precisamos de países menos dependentes em bens e serviços essenciais, como alimentos e suprimentos médicos. E precisamos também diversificar as cadeias de suprimentos e de fontes de alimentos; reter e atrair talentos e investimentos; melhorar suas redes de segurança social; transformar empresas e modelos de negócios em campos mais promissores; globalizar serviços e capacitar em tecnologias emergentes; capacitar mulheres.

Além disso, os impactos na economia/indústria globalizada - dependência de fornecedores distantes - vão exigir novas estratégias e mais cooperação (Derviş E Strauss, 2020) para o pós-pandemia, um melhor modelo de globalização: empresas manufatu-

\footnotetext{
5 Professor visitante na London School of Economics e professor adjunto da Universidade Nacional de Singapura, membro do Fórum Econômico Mundial Global.
} 
reiras locais com globalização de serviços; tecnologia e softwares para teletrabalho; telemedicina; telerrobótica; computação em nuvem; comércio eletrônico etc., que inclusive não são tão suscetíveis a restrições diretas de políticas, taxas e sanções comerciais, por exemplo. O modelo econômico do futuro será, indiscutivelmente, baseado em dados digitais. A expansão das ações humanos envolverá a nuvem, o mundo digital.

Outro cenário que os governantes terão que enfrentar o quanto antes é a situação dos trabalhadores migrantes e dos refugiados, não só na Ásia-Pacífico e no Oriente Médio. E não dá para esperar o pós-Covid; para muitos, é uma situação de vida ou morte. Enfrentar esse problema que esteve negligenciado por tanto tempo é essencial; a pandemia mostrou que, em todo o mundo, muitos serviços essenciais fundamentais são exercidos por trabalhadores migrantes. São médicos, enfermeiros, profissionais da saúde, motoristas de entrega, de empilhadeiras em portos e aeroportos, de TI, de construção, de mineração, de áreas rurais/agrícolas. Uma reforma nas regras de política de migração pode fazer com que tanto trabalhadores migrantes quanto refugiados se tornem ativos e não onerosos para os sistemas nacionais de saúde e seguridade social dos países anfitriões. E podem contribuir com suas habilidades para a reconstrução no pós-pandemia.

No momento de finalização deste ensaio ( 1 1/08/2020), o número de casos na Índia segue em crescimento acelerado (2.215.074 casos e 44.386 óbitos) e o país ocupa o terceiro lugar na estatística mundial, atrás dos EUA (5.053.133 casos e 162.950 óbitos) e do Brasil (3.035.422 casos e 101 .049 óbitos). No Oriente Médio, o Irã registra 328.844 casos e I 8.616 óbitos. Dados atualizados podem ser acessados na página do Centro de Monitoramento do Coronavírus da Johns Hopkins University (2020).

São números assustadores e desafiadores, que colocam para os países da região desafios a enfrentar, considerando as fragilidades reveladas, as tensões que se exacerbaram e o reposicionamento de aliados estratégicos nos países componentes dessas duas grandes regiões do globo.

\section{REFERÊNCIAS}

ADB COVID- 19 POLICY DATABASE. Site. Disponível em: < https://covid I 9policy.adb.org/>. Acesso em: 18 set. 2020.

AMORIM, C. Reflexões sobre a geopolítica depois da pandemia. Carta Capital, São Paulo, I 5 jun. 2020. Disponível em: <https://www.cartacapital.com.br/opiniao/reflexoes-sobre-a-geopolitica-depois-dapandemia/>. Acesso em: 18 set. 2020. 
ASSOCIATION OF SOUTHEAST ASIAN NATIONS (ASEAN). The Asean Declaration (Bangkok Declaration) Bangkok, 8 Aug. 1967. Disponível em: <https://asean.org/the-asean-declarationbangkok-declaration-bangkok-8-august-1967/>. Acesso em: 18 set. 2020.

ASSOCIATION OF SOUTHEAST ASIAN NATIONS (ASEAN). Joint statement. Special video Conference of Health Ministers of Asean and The United States in Enhancing Cooperation on Coronavirus Disease 2019 (Covid-19) response, 30 Apr. 2020a. Disponível em: <https://asean.org/storage/2020/05/ Adopted_ASEAN-US-Joint-Statement-on-Covid-19.pdf>. Acesso em: 18 set. 2020.

ASSOCIATION OF SOUTHEAST ASIAN NATIONS (ASEAN). Asean calls for nature's conservation to prevent future pandemics. Disponível em: <https://asean.org/asean-calls-natures-conservationprevent-future-pandemics/>. Acesso em: 18 set. 2020b.

ASSOCIATION OF SOUTHEAST ASIAN NATIONS (ASEAN). Asean health experts share government policies in tackling Covid-19 pandemic. Disponível em: <https://asean.org/asean-health-expertsshare-government-policies-tackling-covid-19-pandemic >. Acesso em: 18 set. 2020c.

ASSOCIATION OF SOUTHEAST ASIAN NATIONS (ASEAN). Asean Defence Senior Official's Meeting, 15 May 2020 (Videoconference). Disponível em: <https://asean.org/asean-defence-senior-officialssmeeting-video-conference-15-may-2020/>. Acesso em: 18 set. 2020d.

ASSOCIATION OF SOUTHEAST ASIAN NATIONS (ASEAN). Asean Secretariat, Infrastructure Asia hold inaugural Asean Infrastructure Discussion Series. Disponível em: <https://asean.org/aseansecretariat-infrastructure-asia-hold-inaugural-asean-infrastructure-discussion-series/>. Acesso em: 18 set. 2020 .

ASSOCIATION OF SOUTHEAST ASIAN NATIONS (ASEAN). Chairman's Statement of the 36th Asean Summit, 26 June 2020f. Disponível em: < https://asean.org/storage/2020/06/Chairman-Statementof-the-36th-ASEAN-Summit-FINAL.pdf>. Acesso em: 18 set. 2020.

ASSOCIATION OF SOUTHEAST ASIAN NATIONS (ASEAN). Asean discusses Covid-19 recovery with global experts, 30 July 2020g. Disponível em: < https://asean.org/asean-discusses-covid-19recovery-global-experts/>. Acesso em: 18 set. 2020.

ASSOCIATION OF SOUTHEAST ASIAN NATIONS (ASEAN) \& ORGANISATION FOR ECONOMIC COOPERATION AND DEVELOPMENT (OECD). Enterprise policy responses to Covid- 19 in Asean: measures to boost MSME resilience. Disponível em: <https://asean.org/storage/2020/06/Policy-InsightEnterprise-Policy-Responses-to-Covid-19-in-ASEAN-June-2020v2.pdf>. Acesso em: 18 set. 2020.

BELT AND ROAD INITIATIVE (BRI). Site. Disponível em: < https://www.beltroad-initiative.com/>. Acesso em: 18 set. 2020.

BRUEGEL. Site. Disponível em: <https://www.bruegel.org/> . Acesso em: 18 set. 2020.

DERVIŞ, K. E STRAUSS, S. What Covid- 19 means for international cooperation. Brookings, Washington, 6 Mar. 2020. Disponível em: <https://www.brookings.edu/opinions/what-covid-19-means-forinternational-cooperation/>. Acesso em: 18 set. 2020.

FOOD SECURITY INFORMATION NETWORK (FSIN). Global Report on Food Crises: joint analysis for better decisions. Disponível em: <https://docs.wfp.org/api/documents/WFP-0000114546/ download/?_ga $=2.29956029 .325702878 .1591623739-311363809.1591623739>$. Acesso em: 18 set. 2020.

GIRLS NOT BRIDE. SDGs and child marriage, July 2020. Disponível em: < https://www.girlsnotbrides. org/resource-centre/sdgs-and-child-marriage/>. Acesso em: 18 set. 2020. 
GUIMARÃES, S. P. EUA \& China: duas estratégias na luta pela hegemonia. Outras Palauras, São Paulo, 12 maio 2020. Disponível em: <https://outraspalavras.net/geopoliticaeguerra/eua-china-duasestrategias-na-luta-pela-hegemonia/>. Acesso em: 18 set. 2020.

GUTERRES, A. Secretary-General's remarks at the opening of the Virtual Counter-Terrorism Week United Nations [as delivered]. United Nations Secretary-General, New York, 6 July 2020a. Disponível em: < https:// www.un.org/sg/en/content/sg/statement/2020-07-06/secretary-generals-remarks-the-opening-ofthe-virtual-counter-terrorism-week-united-nations-delivered>. Acesso em: 18 set. 2020.

GUTERRES, A. Covid- 19 on the Arab Region an opportunity to build back better. United Nations, 2020b. Disponível em: <https://www.un.org/en/coronavirus/covid-19-and-arab-region-opportunity-buildback-better $>$. Acesso em: 18 set. 2020.

HEYDARIAN, R. J. At a strategic crossroads: Asean centrality amid Sino-American rivalry in the IndoPacific. Brookings, Washington, Apr. 2020. Disponível em: < https:/www.brookings.edu/wp-content/ uploads/2020/04/fp_20200427_strategic_crossroads.pdf>. Acesso em: 18 set. 2020.

HORIMOTO, T. Indo-Pacific order and Japan-India relations in the midst of Covid-19. Journal of Asian Economic Integration, 2020. Disponível em: < https://doi.org/I0.1177\%2F2631684620940476>. Acesso em: 18 set. 2020.

IBAÑEZ, P. Geopolítica e diplomacia em tempos de Covid-19: Brasil e China no limiar de um contencioso. Espaço e Economia, 18(9), 2020. Disponível em: <https://journals.openedition.org/ espacoeconomia/13257>. Acesso em: 18 set. 2020.

JOHNS HOPKINS UNIVERSITY (JHU). Covid-I 9 Dashboard by the Center for Systems Science and Engineering (CSSE) at Johns Hopkins University (JHU). Disponível em: < https://coronavirus.jhu.edu/ map.html>. Acesso em: 18 set. 2020.

KARASAPAN, O. Middle East food security amid the Covid- 19 pandemic. Brookings, Washington, I 4 July 2020. Disponível em: <https://www.brookings.edu/blog/future-development/2020/07/14/middleeast-food-security-amid-the-covid- 19 -pandemic/?utm_campaign=brookings-commEutm_ medium =emailEutm_content $=9$ | 603800Eutm_source $=$ hs_email > . Acesso em: | 8 set. 2020 .

MARQuES, L. Resposta da Ásia Sudeste, Pacífico Ocidental e Oriente Médio à Covid- 19. Cadernos CrisFiocruz, Panorama da Resposta Global à Covid-19, 15, Rio de Janeiro, 2020a, p. 36-39. Disponível em: $<$ https://www.arca.fiocruz.br/bitstream/icict/43 I24/2/INFORME_15.pdf>. Acesso em: 18 set. 2020.

MARQUES, L. Resposta da Ásia Sudeste, Pacífico Ocidental e Oriente Médio à Covid- 19. Cadernos CrisFiocruz, Panorama da Resposta Global à Covid-19, 11, Rio de Janeiro, 2020b, p. 37-43. Disponível em: $<$ https://www.arca.fiocruz.br/bitstream/icict/43 I 20/2/INFORME_I I.pdf>. Acesso em: 18 set. 2020.

MARQUES, L. Resposta da Ásia Sudeste, Pacífico Ocidental e Oriente Médio à Covid- 19. Cadernos CrisFiocruz, Panorama da Resposta Global à Covid-19, 9, Rio de Janeiro, 2020c, p. 49-56. Disponível em: $<$ https://www.arca.fiocruz.br/bitstream/icict/43 I 18/2/INFORME_9.pdf>. Acesso em: 18 set. 2020.

MARQUES, L. Resposta da Ásia Sudeste, Pacífico Ocidental e Oriente Médio à Covid-1 9. Cadernos CrisFiocruz, Panorama da Resposta Global à Covid-19, 12, Rio de Janeiro, 2020d, p. 37-41. Disponível em: $<$ https://www.arca.fiocruz.br/bitstream/icict/43 12 I/2/INFORME_I2.pdf>. Acesso em: 18 set. 2020.

MARQuES, L. Resposta da Ásia Sudeste, Pacífico Ocidental e Oriente Médio à Covid-19. Cadernos CrisFiocruz, Panorama da Resposta Global à Covid-19, 6, Rio de Janeiro, 2020e, p. 30-34. Disponível em: $<$ https://www.arca.fiocruz.br/bitstream/icict/43034/2/INFORME_6.pdf>. Acesso em: 18 set. 2020. 
ORGANIZAÇÃO DAS NAÇÕES UNIDAS (ONU). Casamento infantil. ONU News, 2020. Disponível em: $<$ https://news.un.org/pt/tags/casamento-infantil>. Acesso em: 18 set. 2020.

SIDDIQI, L. Nine policy taboos overturned by Covid- 1 9. LSE Business Review, I May 2020. Disponível em: $<$ https://blogs.lse.ac.uk/businessreview/2020/05/0 I/nine-policy-taboos-overturned-by-covid-19/>. Acesso em: 18 set. 2020.

THE UN REFUGEE AGENCY (UNHCR). Resumo Semanal dos Refugiados. The Refugee Brief. Disponível em: <https://www.unhcr.org/refugeebrief/>. Acesso em: 18 set. 2020.

THE PEOPLE'S REPUBLIC OF CHINA. The State Council. Site. Disponível em: < http://english.www.gov. cn/beltAndRoad/>. Acesso em: 18 set. 2020.

UNITED NATIONS (UN). Policy Brief: the impact of Covid-I9 on South-East Asia. New York: UN, 2020a. Disponível em: <https://www.un.org/sites/un2.un.org/files/sg_policy_brief_covid_southeast_asia_30_july_2020.pdf>. Acesso em: 18 set. 2020.

UNITED NATIONS (UN). Policy Brief: the impact of Covid-I 9 on the Arab Region an opportunity to build back better. New York: UN, 2020b. Disponível em: <https://www.un.org/sites/un2.un.org/files/sg_ policy_brief_covid-19_and_arab_states_english_version_july_2020.pdf >. Acesso em: 18 set. 2020.

UNITED NATIONS (UN). Policy Brief: the impact of Covid-I 9 on food security and nutrition. New York: UN, 2020c. Disponível em: < https://www.un.org/sites/un2.un.org/files/sg_policy_brief_on_covid_ impact_on_food_security.pdf $>$. Acesso em: 18 set. 2020.

UNITED NATIONS (UN). Policy Brief: Covid-19 and people on the move. New York: UN, 2020d. Disponível em: <https://www.un.org/sites/un2.un.org/files/sg_policy_brief_on_people_on_the_ move.pdf>. Acesso em: 18 set. 2020.

VISUAL CAPITALIST. Rede de parcerias da iniciativa Nova Rota da Seda. Disponível em: < https:// www.visualcapitalist.com/wp-content/uploads/2020/0 I/chinese-diplomacy-spending.html>. Acesso em: 18 set. 2020.

VORONKOV, V. Opening remarks Under-Secretary-General Vladimir Voronkov. In: VIRTUAL COUNTERTERRORISM WEEK, 6 July 2020a, online. Disponível em: <https:/www.un.org/counterterrorism/ sites/www.un.org.counterterrorism/files/200706_usg_remarks_vctwk_opening_session.pdf >. Acesso em: 18 set. 2020.

WIKIPEDIA. Disputas territoriais no Mar da China Meridional. Disponível em: < https://pt.wikipedia. org/wiki/Disputas_territoriais_no_mar_da_China_Meridional>. Acesso em: 18 set. 2020.

WORLD HEALTH ORGANIZATION (WHO). Regional Office for South-East Asia. Delhi declaration on emergency preparedness in the South-East Asia Region. In: REGINAL COMMITTEE MEETING, 72, New Delhi, 6 Sept. 2019. Disponível em: < https://apps.who.int/iris/handle/1 0665/32792 I >. Acesso em: 18 set. 2020.

WORLD HEALTH ORGANIZATION (WHO). 2019 Novel Coronavirus (20 I 9-nCoV) Strategic Preparedness and Response Plan for the South-East Asia Region. New Delhi: Regional Office for South-East Asia, World Health Organization, 2020. Disponível em: < https://www.who.int/docs/default-source/ searo/whe/coronavirus 19/covid-19-sprp-whe-searo-feb-2020.pdf?sfvrsn=9ee49760_2>. Acesso em: 18 set. 2020. 
sociedade justa e solidária, e com um modelo de desenvolvimento que combine erradicação da pobreza, redução das desigualdades sociais e promoção do bem-estar de todos.

Nessa perspectiva, as breves análises apresentadas neste capítulo incluem a evolução da pandemia com base em alguns indicadores e temas selecionados, envolvendo dois grandes grupos. O primeiro está relacionado à organização dos serviços de saúde, à qualidade do cuidado e à segurança do paciente, bem como à saúde dos trabalhadores da saúde. O segundo está relacionado às desigualdades sociais, raciais e étnicas, expressas em maiores impactos da Covid- 19 nas populações que vivem nas favelas e nas populações indígenas, por exemplo.

\section{EVOLUÇÃO DE CASOS E ÓBITOS POR COVID-19 NO BRASIL E NO MUNDO}

A pandemia de Covid-19 teve diferentes repercussões entre os vários países e, também, entre regiões e estados da federação brasileira. Pode-se afirmar que se constitui em um fenômeno complexo, como múltiplas epidemias, dadas as suas manifestações em diferentes contextos sociossanitários e geopolíticos.

As curvas de evolução de casos e de óbitos no Brasil, desde o início da pandemia, apresentaram padrão diferente daquele dos outros países que já se encontravam em um estágio avançado de transmissão comunitária do vírus Sars-CoV-2. De modo a oferecer uma comparação entre esses padrões distintos até a $40^{\mathrm{a}}$ semana epidemiológica (de 27/09 a 03/10/2020), apresentamos, em um primeiro momento, a situação do Brasil comparada com a de outros países, para em seguida apresentar a situação da evolução nos estados brasileiros.

Tanto na Ásia (China, por exemplo) quanto na Europa (Itália, Espanha e Reino Unido, por exemplo) verificou-se rápido aumento no número de casos e de óbitos, que atingiu seu valor máximo (pico) em março ou abril, após produzir forte impacto nesses países (cerca de 150 mil óbitos na Ásia e 225 mil na Europa, segundo dados do Our World in Data). A partir de março, observou-se uma tendência de redução lenta no número de casos e a ocorrência de surtos mais localizados (Gráficos I). 


\section{Gráficos I - Casos e óbitos em países selecionados, totais diários e média móvel}

Casos em países selecionados, totais diários e média móvel Semanas 11 a 40
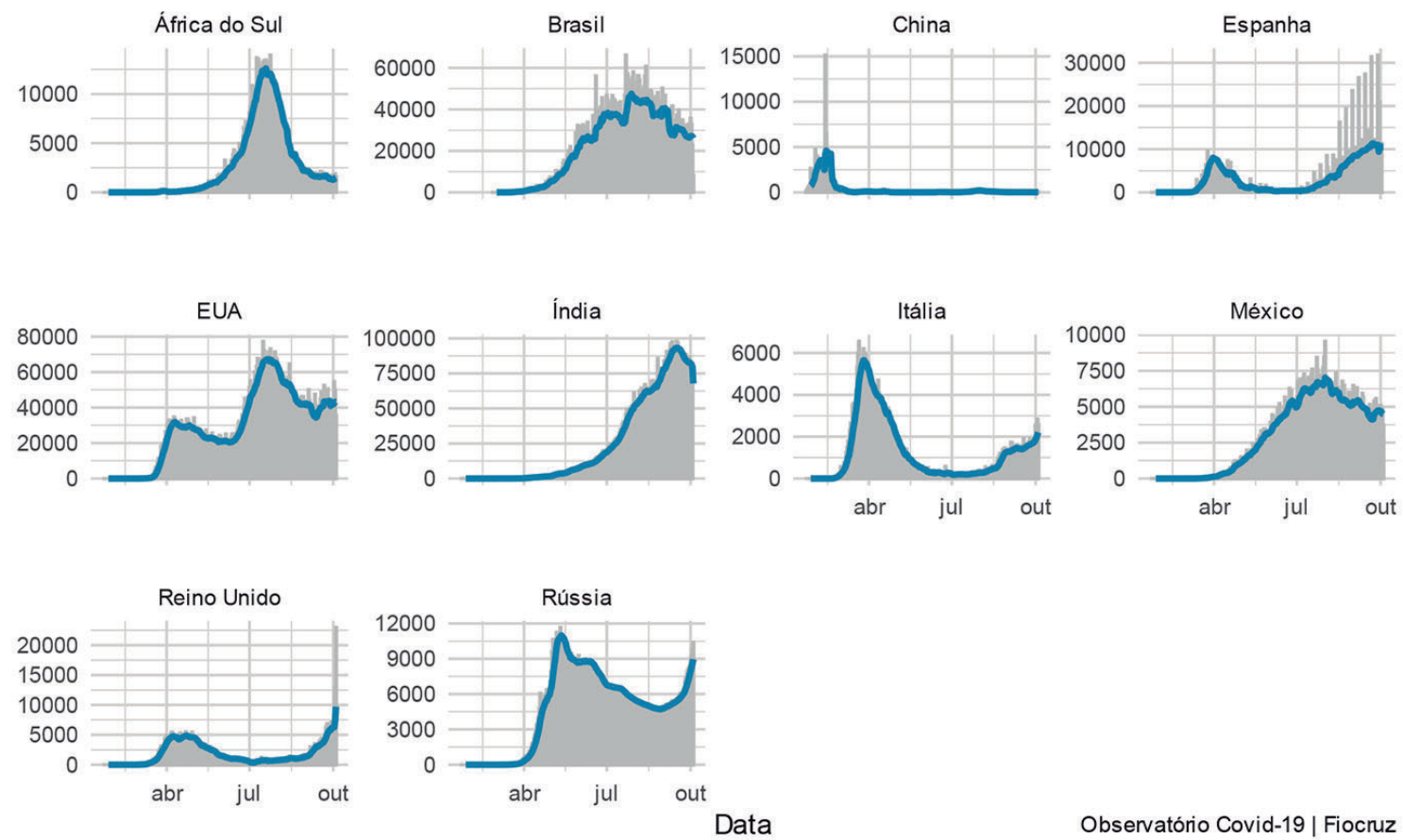

Observatório Covid-19 | Fiocruz

Óbitos em países selecionados, totais diários e média móvel Semanas 11 a 40
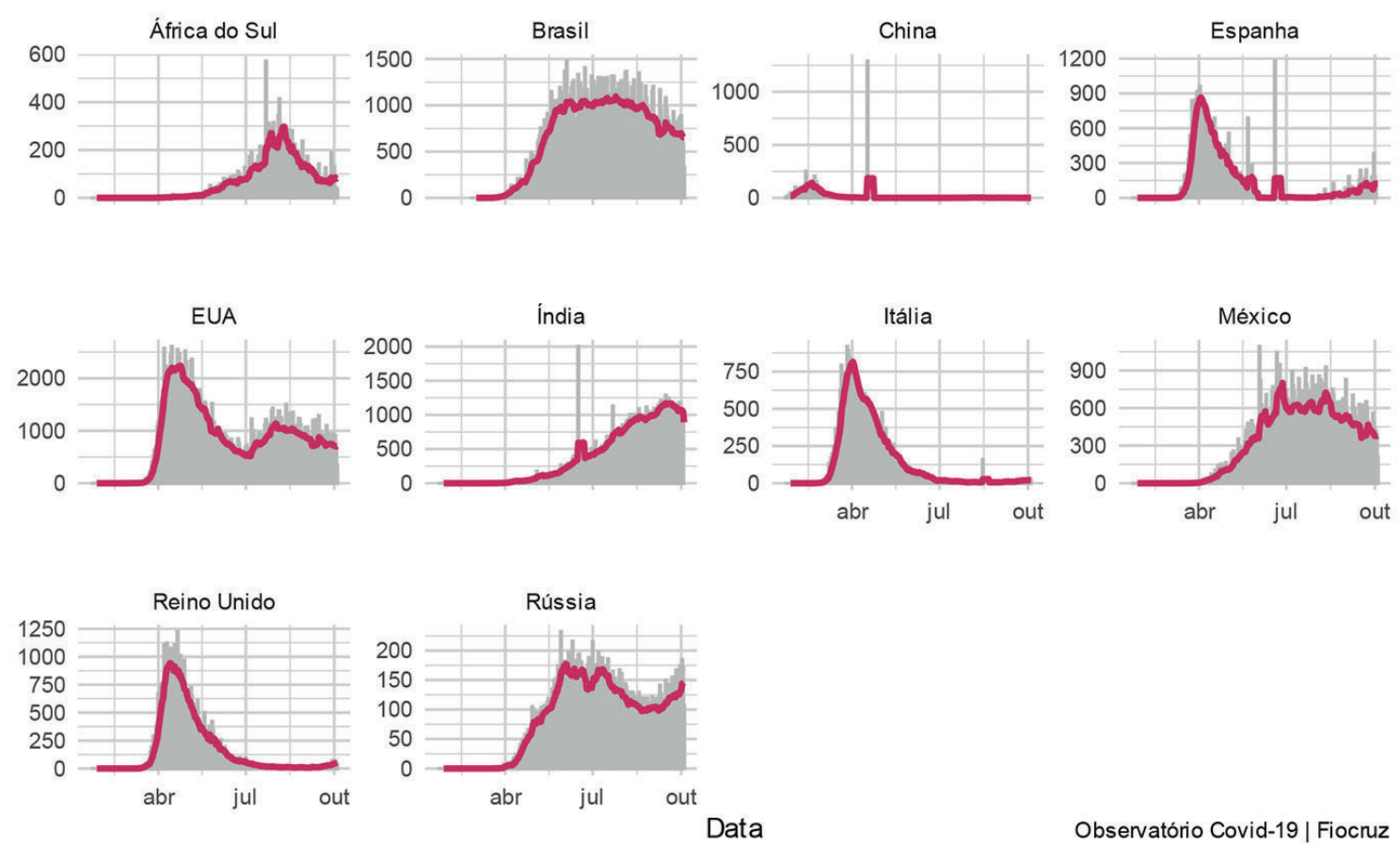

Observatório Covid-19 | Fiocruz 
No Brasil, em comparação com o que ocorreu na Europa e Ásia, observou-se um lento processo de aumento do número de casos e óbitos, com defasagem de duas ou três semanas entre esses eventos, e a formação de um extenso patamar de transmissão desde junho, com ligeira tendência de queda em setembro. O país apresentou um padrão de curva de evolução de casos e de óbitos similar ao do México.

Em termos globais, o Brasil passou a ocupar o segundo lugar em número de casos a partir de maio e em número de óbitos a partir de junho, estando, junto com Estados Unidos da América (EUA) e Índia, entre os três países com mais casos e óbitos totais. Dos países que integram o Brics, Brasil e Índia são os que acumulam maiores números de casos e óbitos. E, quando se combinam taxas de incidência e de mortalidade, vê-se que Brasil e EUA se destacam muito em relação aos outros países, apresentando um padrão muito próximo. Vale notar que nesses países, como Brasil, EUA e Rússia, de dimensões continentais, a epidemia não teve necessariamente epicentros simultâneos, o que explica patamares constantes e segundas ondas prematuras. Observa-se que os países da Europa, passado o verão, vivem um processo de nova onda de casos, mas com letalidade menor que a verificada na primeira onda.

Passados pouco mais de seis meses de declaração da Covid-19 como pandemia global, o Brasil acumula um número de casos de aproximadamente 5 milhões e quase 150 mil óbitos reportados ao Ministério da Saúde. A permanência da pandemia nos próximos meses pode acrescentar algumas dezenas de milhares de novos óbitos no país.

A pandemia atingiu todos os estados e o Distrito Federal, com alguns destes acumulando grande número de casos e óbitos, como demonstra o mapa do país no qual o tamanho dos círculos representa a dimensão do impacto (Mapas 1). Os estados que ao longo destes seis meses apresentaram o maior número de óbitos foram São Paulo (36.000), Rio de Janeiro (18.800), Ceará (9.000), Pernambuco (8.000) e Pará (6.600), também as primeiras áreas atingidas pela entrada e disseminação do vírus, bem como Bahia (7.000) e Minas Gerais (7.700), de evolução mais recente. Outros estados, como Rio Grande do Sul (5.000), Goiás (5.000), Paraná (4.600) e Mato Grosso (3.500), ainda apresentam tendências à elevação do número de óbitos e à manutenção de altas taxas de transmissão, o que constitui um alerta para o sistema de saúde das regiões Sul e Centro-Oeste do país. 


\section{Mapas I - Totais dos casos e óbitos}

\section{Casos por UF}

Números totais até a semana 40

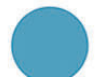
500.000

Observatório Covid-19 | Fiocruz

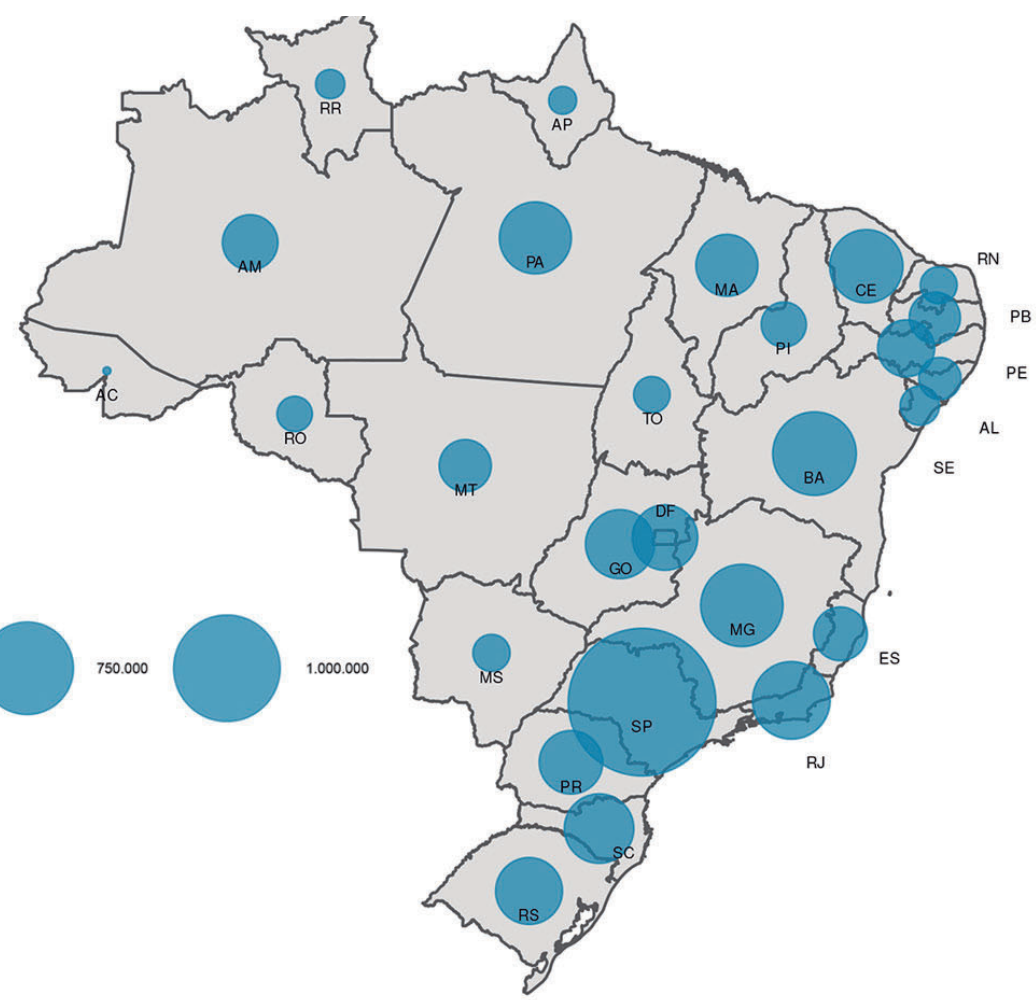

\section{Óbitos por UF}

Números totais até a semana 40

Óbitos
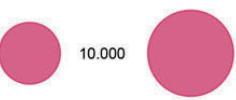
20.000

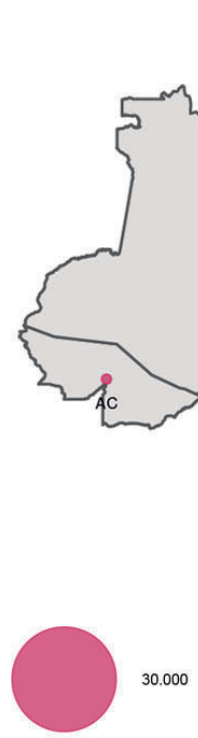

Observatório Covid-19 | Fiocruz 
Dentro do país, a evolução do número de casos e de óbitos por 100 mil habitantes (taxa de incidência e de mortalidade) nos estados e no Distrito Federal apresentou, desde o início, um padrão bastante heterogêneo de evolução ao longo do tempo (Gráficos 2). As taxas de incidência e de mortalidade nos estados envolvem uma combinação de fatores, tais como o nível de desenvolvimento socioeconômico, as condições de diagnóstico (incluindo testes) e assistência aos sintomáticos, bem como as capacidades de prevenção e controle da transmissão do vírus e da doença por meio do conjunto de medidas não farmacológicas.

Gráficos 2 - Evolução dos casos e de mortalidade por 100 mil habitantes

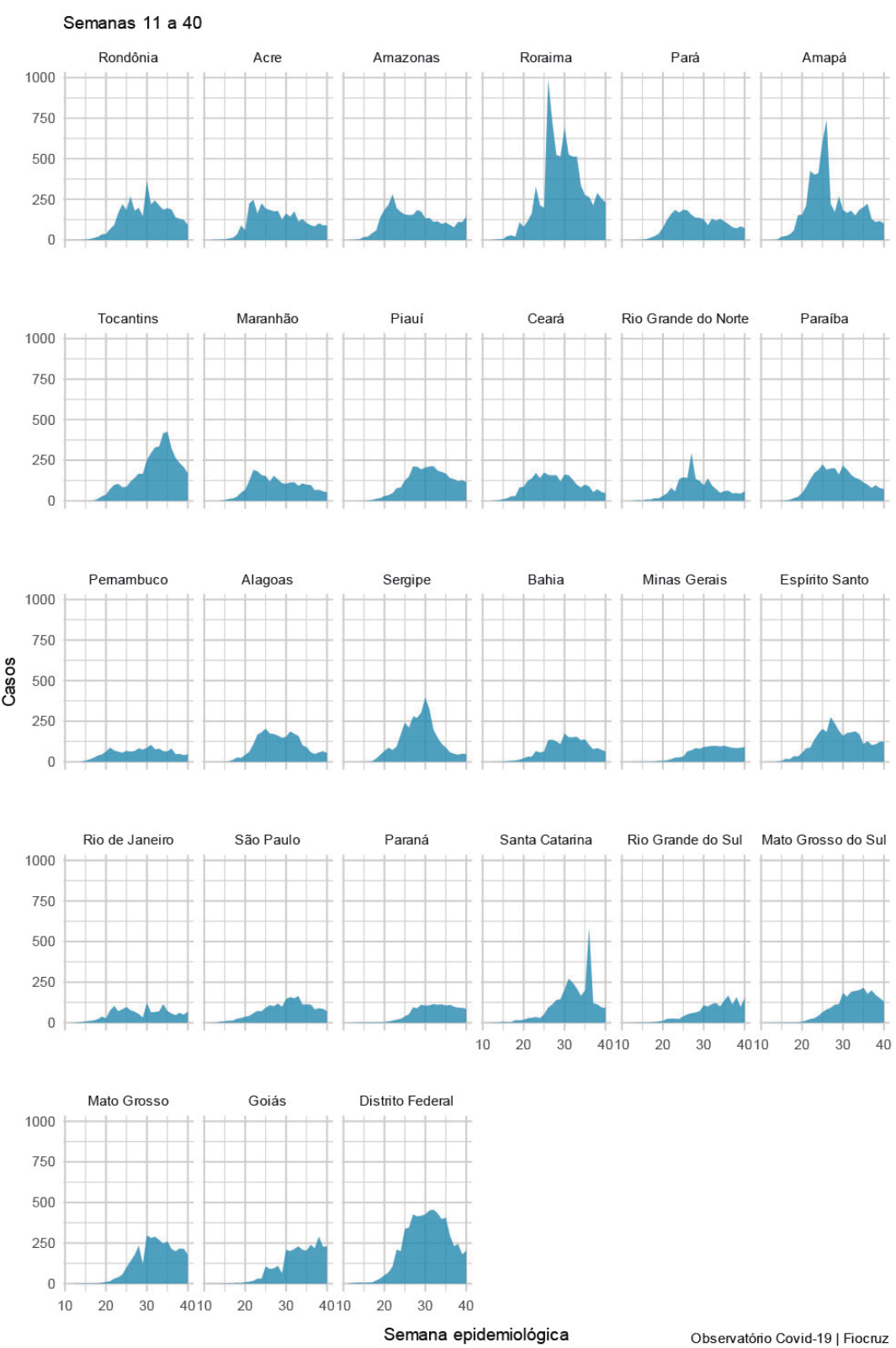


Gráficos 2 - Evolução dos casos e óbitos por 100 mil habitantes (continuação)
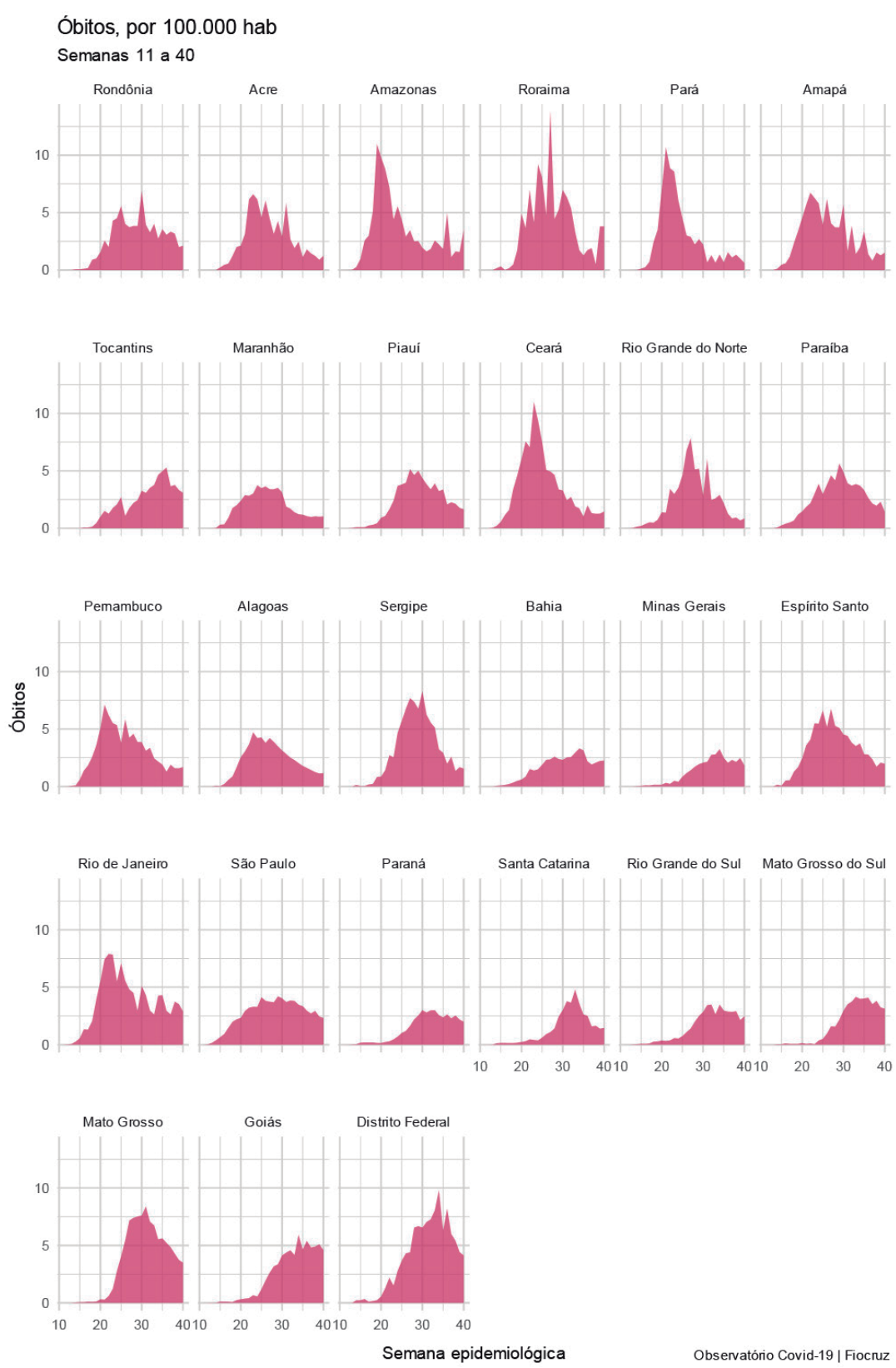

Alguns estados vêm mantendo altas taxas de mortalidade e de incidência, como Roraima, Amapá e Distrito Federal. Nos dois primeiros casos, foi observada também elevada mortalidade hospitalar. Rio de Janeiro, Pernambuco e Ceará apresentam alta letalidade, enquanto Santa Catarina tem mantido baixa letalidade, o que pode estar relacionado à organização do sistema de vigilância e atenção à saúde no enfrentamento da pandemia (Gráfico 3). 
Gráfico 3 - Coeficiente de incidência e de mortalidade por 100 mil habitantes

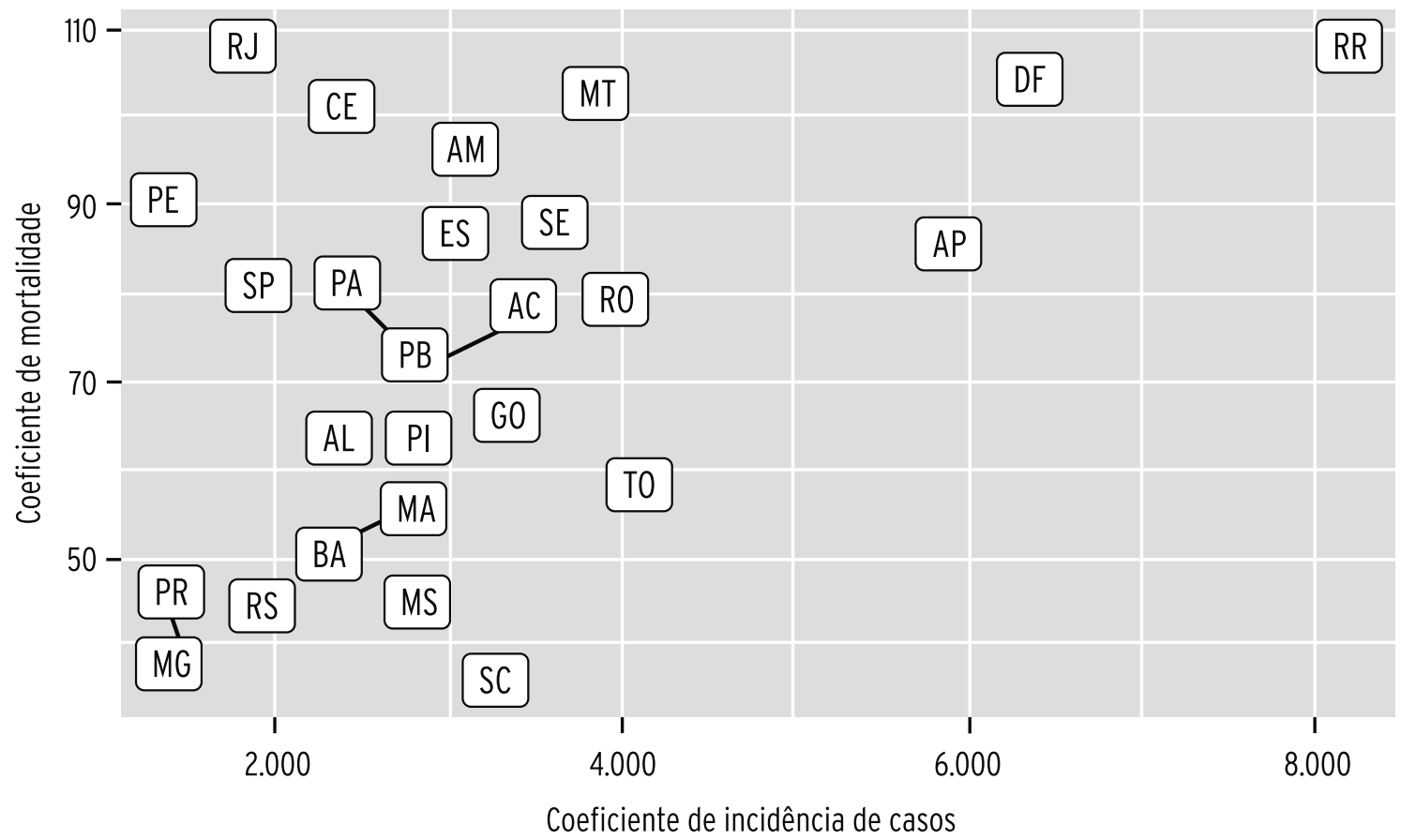

É importante ressaltar que para o conjunto de registros de casos e óbitos por Covid- 19 no Brasil há uma defasagem entre a ocorrência dos eventos (primeiros sintomas da doença, testagem, hospitalização e óbito) e sua divulgação pelas secretarias de Saúde e consolidação dos painéis nacionais. Esse atraso pode não só causar a subestimação de casos e óbitos nas últimas semanas analisadas, como também modificar o formato da curva de monitoramento, levando a interpretações extemporâneas sobre a dinâmica da epidemia em cada estado e no Distrito Federal. Essa defasagem tem implicações diretas sobre a organização e resposta da assistência aos sintomáticos, bem como sobre as capacidades de prevenção e controle da transmissão do vírus e da doença por meio do conjunto de medidas não farmacológicas.

Na análise da evolução, observa-se que o valor máximo do número de casos (pico) ocorreu no Brasil em maio, seguido de um patamar alto que perdura até setembro, quando se observa ligeira tendência de diminuição no número de casos e óbitos, que, se prolongada, pode manter a transmissão da doença nos próximos meses, ou mesmo representar risco de ocorrência de surtos localizados. 


\section{A ORGANIZAÇÃO DOS SERVIÇOS DE SAÚDE: BALANÇO E PERSPECTIVAS}

Se por um lado a disponibilidade de um sistema universal de saúde capilarizado propiciou o acesso a serviços de saúde em diferentes níveis de complexidade a uma parte expressiva da população brasileira acometida pela Covid-19, por outro a pandemia expôs fragilidades desse sistema, acumuladas em função do subfinanciamento e de problemas de gestão. O diagnóstico inicial da capacidade instalada no país para o atendimento de pacientes graves de Covid-19, demandando estruturas de cuidado complexas, estampou grandes desigualdades entre as regiões e forte concentração de recursos voltados para o setor da saúde suplementar em áreas específicas, com proporções elevadas de beneficiários de planos de saúde. Mostrou-se gritante a diferença entre a disponibilidade de leitos de unidade de terapia intensiva (UTI) para atender os $75 \%$ de cidadãos brasileiros dependentes do Sistema Único de Saúde (SUS) e os 25\% portadores de planos de saúde. Ainda assim, a hipótese de o setor privado ampliar a capacidade do suS, defendida por muitos especialistas, foi vencida por forte resistência do setor e de agentes públicos.

A falta de uma coordenação nacional para mitigar desigualdades e otimizar processos de compras de equipamentos e insumos necessários, em um cenário de grande competição global, levou estados e municípios a implementarem suas próprias soluções, muitas vezes competindo entre si. Pecou-se com frequência pelo investimento em estruturas temporárias contra o fortalecimento de estruturas permanentes do SUS. No entanto, não poderíamos deixar de destacar o crescimento, desde fevereiro, do número de leitos de UTI para adultos existentes no país, que passaram de 30.774 para 52.91। (7I,9\%); de respiradores/ventiladores em uso, de 6I.772 para 78.137 (26,5\%); e de tomógrafos em uso, de 4.883 para 5.191 (6,3\%). Neste início de outubro, $20.772(39,3 \%)$ dos 52.9 I I leitos de UTI para adultos existentes estão classificados como leitos para síndrome respiratória aguda grave (Sars) ou Covid- 19 (código 5I), categoria incorporada pelo Cadastro Nacional de Estabelecimentos de Saúde (CNES) por conta da pandemia.

Considerando que a maioria dos pacientes com Covid- 19 não precisa de internação, é também importante sublinhar que faltou investimento na atenção primária à saúde (APS) e na sua integração com a vigilância em saúde, além da ampliação da testagem da população para que se pudesse implementar ações mais efetivas de isolamento.

Os resultados até aqui revelam graves problemas no desempenho do sistema de saúde, com elevada mortalidade por Covid-19, denotando problemas de acesso e baixa capacidade de integração da rede de serviços. Parte das estruturas adicionadas 
ao sistema foram implementadas com atraso, tendo importantes cidades brasileiras experimentado evidente sobrecarga sobre o sistema de saúde. Em consequência, foram registradas muitas mortes em domicílios, em unidades de saúde ambulatoriais e em hospitalizações de somente um dia ou menos de 24 horas, revelando dificuldades de acesso ao cuidado requerido em tempo adequado. Somam-se a esse cenário as imensas iniquidades entre grupos populacionais e regiões, indo além do acesso e transbordando para a qualidade do cuidado de saúde em si e para as chances de bons resultados.

Com esse panorama, entretanto, não se pode deixar de reconhecer o aprendizado que vem se consolidando. À parte as polêmicas em torno de alternativas terapêuticas não sustentadas por evidências científicas, houve melhora substantiva no manuseio clínico dos pacientes, com destaque para os protocolos de tratamento de casos graves. Também tem se imposto a necessidade de valorização de uma perspectiva sistêmica para lidar com problemas complexos, o que pode vir a ser um importante legado.

Um indicador que pode apontar as falhas, dificuldades e adaptações da rede de serviços de saúde para o enfrentamento da pandemia é a taxa de letalidade (Gráfico 4). No início da pandemia, esses valores oscilavam em torno de 12\%, o que é considerado alto para uma doença infecciosa. No decorrer do tempo, diminuíram consideravelmente em quase todos os estados, com exceção do Rio de Janeiro (7\%) e Pernambuco (6\%). Chama a atenção positivamente o estado de Santa Catarina, que tem mantido valores baixos de letalidade, provavelmente em razão de melhor organização do sistema de vigilância e atenção à saúde. No Brasil como um todo, nos últimos meses a taxa de letalidade tem se mantido em torno de 3\%, revelando que para cada 100 pessoas infectadas, cerca de três falecem. Obviamente, o número de casos da doença e dos infectados pelo vírus depende da quantidade de testes de diagnóstico realizados ou do seu diagnóstico clínico. A desproporção entre óbitos e casos registrados revela, portanto, falhas em todo o sistema de saúde, em sua capacidade laboratorial, nas ações de vigilância em saúde e na integração entre atenção primária e serviços de alta complexidade. 


\section{Gráfico 4 - Letalidade por Covid- 19 no Brasil}
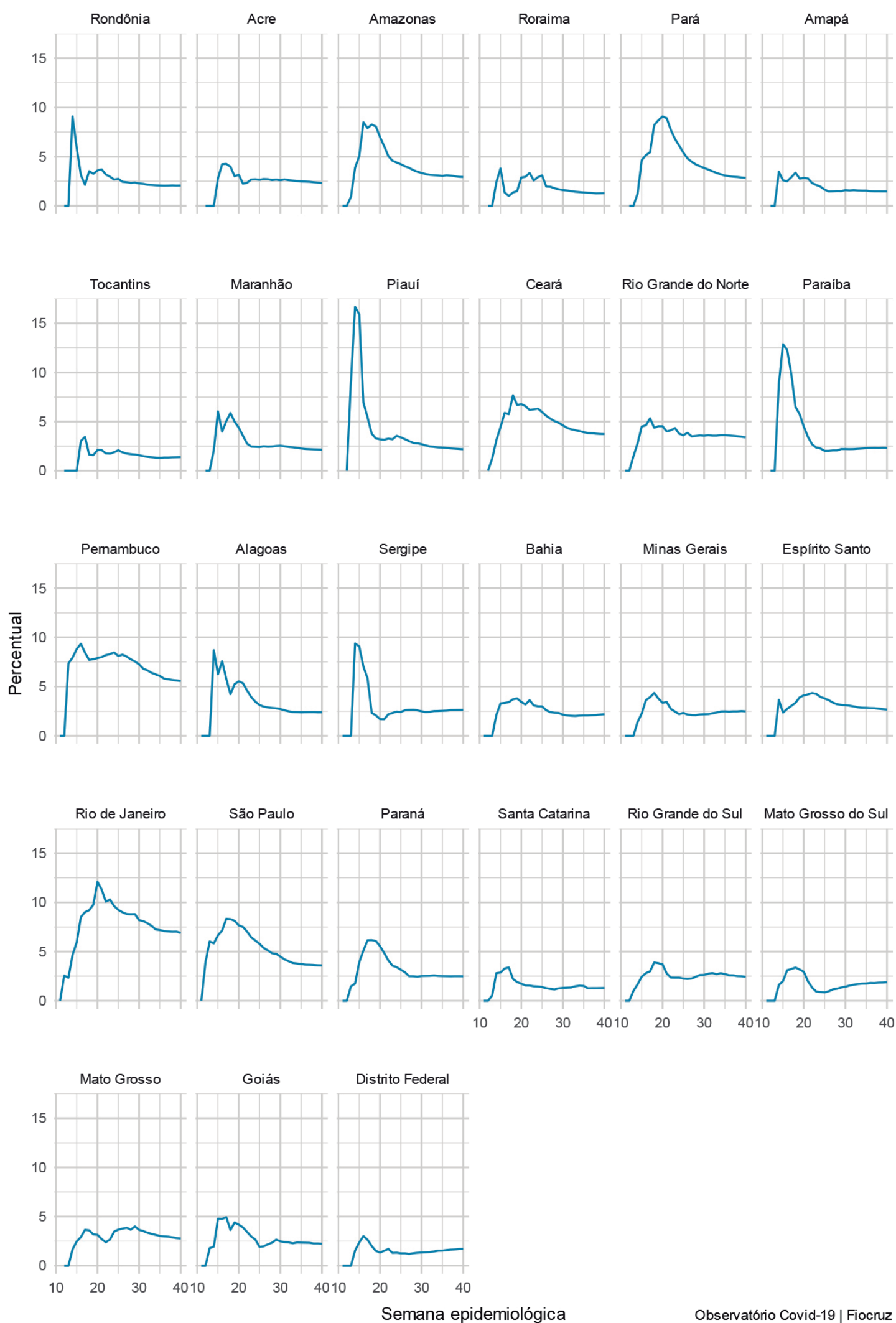

Observatório Covid-19 | Fiocruz 
Prospectivamente, não se pode perder o foco no aprimoramento da capacidade de resposta aos desafios que ainda podem advir da Covid- 19 e, eventualmente, outras condições que podem emergir. É possível que o sistema ainda tenha de experimentar momentos de expansão e retração para lidar com as demandas de serviços postas pela pandemia.

O fortalecimento do SUS - envolvendo a melhoria de suas estruturas e capacitação e valorização dos seus profissionais - deve ser perseguido como único caminho para o atendimento das necessidades de saúde do conjunto da população brasileira. A capacidade da rede de serviços de saúde de produzir os melhores resultados requer que esteja centrada nas pessoas/pacientes e depende da integração entre uma atenção primária à saúde resolutiva, a vigilância em saúde e os serviços de complexidade intermediária e alta, de diagnóstico, tratamento e reabilitação. Para tal integração, fazem-se necessários sistemas de informação eletrônicos, mecanismos reguladores da transição de pacientes entre pontos de atenção e transporte sanitário adequado. O aumento do volume de recursos financeiros é imprescindível, devendo se constituir em pauta fundamental para a melhoria do desempenho do SUS, da qualidade do cuidado de saúde oferecido e da qualidade de vida da população brasileira.

\section{QUALIDADE DO CUIDADO E SEGURANÇA DOS PACIENTES E A SITUAÇÃO DA MORTE MATERNA NA PANDEMIA}

A pandemia causada pelo novo coronavírus (Sars-CoV-2) representou grande ameaça à qualidade do cuidado prestado e à segurança do paciente, em todo o mundo. Não foi diferente no Brasil, que apresentou, ao final de março de 2020, aumento expressivo da demanda por assistência à saúde. Esse aumento, em curto tempo, gerou sobrecarga nos serviços de saúde e para seus trabalhadores. Rotinas, fluxos e protocolos precisaram ser rapidamente revistos e novos leitos providenciados. Mudanças dessa natureza têm impacto sobre a qualidade, em especial pela rapidez com que precisam ser adotadas, sem que haja tempo para a capacitação de profissionais.

Houve dificuldades para adotar medidas de prevenção e controle de infecções. Além da escassez de materiais, em especial dos equipamentos de proteção individual (EPIs), o espaço físico de muitas unidades de saúde não permite a adequada separação de áreas dedicadas a pacientes com Covid- 19 ou mesmo a manutenção do distanciamento recomendado.

Por se tratar de um agente desconhecido, no início da pandemia pouco se sabia sobre a fisiopatologia da doença, que ainda hoje não está completamente elucidada. Isso resultou em dificuldades para o diagnóstico e avaliação dos casos por meio de 
marcadores clínicos e laboratoriais e para a adoção de intervenções terapêuticas eficazes, havendo embates sobre o uso de diversos medicamentos sem comprovação de eficácia e cujo perfil de segurança recomendava cautela em seu uso.

Órgãos do governo, como a Agência Nacional de Vigilância Sanitária (Anvisa), instituições de ensino e pesquisa, e associações de profissionais produziram diversos materiais para orientação sobre práticas seguras tanto para os trabalhadores da saúde quanto para a população em geral. São manuais, notas técnicas, protocolos e vídeos voltados para o controle e a prevenção da doença em diferentes ambientes, abarcando tanto serviços de saúde como hospitais e instituições de longa permanência. Assim, as medidas de precaução foram atualizadas e ganharam ampla divulgação, nas unidades de saúde hoje todos lavam as mãos e usam luvas e máscara ao ter contato com os pacientes.

Os impactos da Covid-19 na qualidade do cuidado e na segurança do paciente podem ser percebidos em várias áreas, mas há uma situação que se revela muito preocupante: o aumento da mortalidade materna no Brasil durante esse período. Inicialmente, a população obstétrica não foi considerada de risco para Covid-19, o que levou a que este grupo não fosse testado. Além disso, houve, por medo do contágio, o adiamento de exames e de consultas, o que implicou demora em identificar problemas mais precocemente. A ocorrência de óbitos em gestantes e puérperas acometidas pela Covid- 9 logo começou a chamar a atenção dos profissionais, gestores e pesquisadores no país, inclusive com a publicação de vários artigos científicos. Em seguida, foram publicados relatórios pela Suécia, Irã, México, Reino Unido e EUA apontando casos graves e mortes em gestantes e puérperas (Nakamura-Pereira et al., 2020). No meio do mês de abril, o Ministério da Saúde (MS) passou a considerar esse grupo como de risco. Até meados de julho foram reportados 2.475 casos de Covid- 19 em gestantes e puérperas, 8,2\% (202) das quais morreram. Entre essas, 5,9\% (12) não haviam sido hospitalizadas, 39,7\% (80) não foram internadas em UTI, 42,6\% (86) não receberam ventilação mecânica e 25,5\% (5I) não tiveram acesso a suporte respiratório.

A análise desses dados mostrou que a etnia negra e morar em área periurbana, sem acesso à Estratégia Saúde da Família, estavam associados a um risco aumentado de resultados adversos. Esses dados indicam as desigualdades e dificuldades de acesso a serviços com atenção especializada e monitoramento adequado das complicações obstétricas (Menezes et al., 2020). 


\section{A SITUAÇÃO DOS TRABALHADORES DA SAÚDE DIANTE DA COVID-19}

Ao longo da evolução da pandemia de Covid-19, tornou-se evidente que um dos grupos de maior risco de adoecimento era o de trabalhadores da área da saúde. Além do contato direto e da exposição a altas cargas virais, a sobrecarga de trabalho e as mudanças de protocolos e rotinas, em um contexto de escassez de EPIs adequados, objeto de preocupação em todo o mundo, deixam esse grupo mais vulnerável. Em nosso país, esse foi um problema grave, objeto de denúncias aos conselhos profissionais. Outro fator relevante, que aumentou a exposição desse grupo, foi a ampliação da oferta de leitos por meio de hospitais de campanha, muitos sem estrutura adequada e sem equipes treinadas, ampliando o risco de exposição ao vírus e ao estresse.

A China, onde a pandemia teve início, reportou que 3.300 profissionais da saúde foram infectados, mas países europeus indicam números muito maiores. Em início de julho de 2020, dados de apenas nove países (Dinamarca, Alemanha, Hungria, Irlanda, Itália, Rússia, Espanha, Turquia e Ucrânia) mostraram que mais de 150 mil profissionais da saúde já haviam sido infectados pelo vírus Sars-CoV-2 (EPSU, 2020).

Diante do aumento de casos e mortes por Covid-19 entre profissionais da saúde na Região das Américas, a Organização Pan-Americana de Saúde (Opas) publicou um alerta aos governos sobre a necessidade de fortalecer a capacidade de serviços de saúde em todos os níveis e de que providenciassem EPIs e treinamento para todos.

No Brasil, os dados variam de acordo com as fontes. Segundo o Observatório do Conselho Federal de Enfermagem (Cofen), em 4 de outubro de 2020 havia registro de 40.608 casos e $44 \mathrm{I}$ óbitos entre seus profissionais (enfermeiros, técnicos e auxiliares de enfermagem). As mulheres respondem por $85 \%$ dos casos e $63 \%$ dos óbitos; destaquese que elas são $85 \%$ da força de trabalho desse segmento. Os óbitos ocorreram com maior frequência nas faixas etárias acima de $4 \mathrm{I}$ anos, mas os casos se concentraram na faixa de 31 a 40 anos.

O Boletim Epidemiológico (BE) dedicado à Covid-19 publicado pela Secretaria de Vigilância em Saúde do Ministério da Saúde trouxe, em 3 de abril, alertas sobre a exposição dos trabalhadores da área da saúde. A partir do BE n 16 (Semana Epidemiológica 21, de 18 de maio), os registros de casos relativos aos trabalhadores da saúde passam a ser apresentados. Àquela época, havia registro de 31.790 casos confirmados nesse segmento de trabalhadores: I4.831 (46,7\%) em São Paulo, 4.45। (14\%) no Rio de Janeiro, 1.669 (5,3\%) no Ceará, I.257 (4\%), no Amazonas e I. 174 (3,7\%) na Bahia.

Até o dia 26 de setembro, haviam sido notificados 1.301 .066 casos de síndrome gripal suspeitos de Covid- 19 em trabalhadores da saúde e confirmados 322.178 casos 
para a doença $(24,8 \%)$. Os mais acometidos são os técnicos/auxiliares de enfermagem (109.955; 34,1\%), enfermeiros (47.339; 14,7\%), médicos (33.032; 10,3\%), agentes comunitários de saúde $(16.546 ; 5,1 \%)$, recepcionistas de unidades de saúde (14.024; 4,4\%) e fisioterapeutas (8.594; 2,7\%), que têm tido forte atuação nas UTIs.

Vale lembrar que, embora não haja dados disponíveis até o momento, diversas publicações e relatos chamam a atenção para as questões relacionadas à saúde mental, como ansiedade, depressão e distúrbios do sono, que têm afetado esse grupo de trabalhadores.

\section{COVID-19 NAS FAVELAS}

Uma primeira e necessária observação sobre o comportamento da doença nas favelas é o reconhecimento de que o espaço urbano é desigual. Nas áreas onde a pobreza urbana é mais acentuada, o novo coronavírus avança de forma mais rápida. Isso porque esses territórios não contam com políticas públicas de qualidade que deem suporte à proteção coletiva. Além disso, em países marcados pelas desigualdades sociais, como o Brasil, a pobreza cresce de modo ampliado, não apenas formando novas periferias, mas também adensando as antigas. As condições de vida nos espaços periféricos urbanos dificultam a adoção de estratégias individuais de prevenção por parte da população, largamente difundidas nas orientações de controle da Covid-19, como o distanciamento social.

Diante da insuficiência/falta de políticas de proteção social, esses territórios têm se caracterizado pela alta densidade de habitações, marcadas pela autoconstrução e autonomia em relação às normas de regulação urbanística, sem regularidade fundiária oficial e com acesso insuficiente ao saneamento básico. Em decorrência das características sociais e ambientais desses espaços, bem como das dificuldades dos serviços de saúde, a ocorrência da Covid-19, a gravidade dos casos e a letalidade da doença apresentam maior magnitude (Linder, 2020). Além disso, as medidas de distanciamento social, restrição de mobilidade e interrupção de atividades de serviços, comércio e indústria têm produzido graves impactos econômicos e sociais entre seus moradores. Isso porque grande contingente populacional de moradores de favelas são trabalhadores informais. Muitos deles perderam suas fontes de renda e outros são impossibilitados de realizar o isolamento, o que acelera ainda mais a velocidade do contágio.

Além dos desafios históricos relacionadas às moradias com pouca ventilação, pouca iluminação e pouco espaço, e à deficiência no acesso aos serviços públicos, a situação das favelas é agravada devido ao contexto de violência estrutural. O Brasil ocupa o primeiro lugar no mundo na posição de país com mais anos de vida perdidos pela violência (Sawaya et al., 2018). 
As análises sobre a situação da Covid- 19 nas favelas do município do Rio de Janeiro, que constam do informativo Boletim Socioepidemiológico (Angelo, 2020), foram feitas com base nos dados oficiais da prefeitura, em dados produzidos por movimentos organizados e naqueles disponibilizados pelas unidades básicas de saúde. Encontrouse imensa dificuldade em realizar análises específicas das favelas, cuja realidade é invisibilizada em razão da ausência/diluição de dados, já que estes são agregados pelo bairro ou pelo CEP.

Esse cenário impôs análises mais acuradas sobre alguns fenômenos, como as taxas de incidência da Covid- 19 maiores nos bairros sem favelas ou com baixa concentração de favelas, respectivamente 115,58 por 10.000 habitantes e 74,98 por 10.000 habitantes (ambas acima da média do Rio de Janeiro, de 70,7I por 10.000 habitantes), quando comparados aos bairros classificados como de "altíssima concentração" de favelas, cujas taxas de incidência até junho de 2020 eram de 24,94 por 10.000 habitantes. Essa situação pôde ser em parte explicada pelo reduzido acesso à testagem pelas populações desses territórios.

A exclusividade do critério laboratorial (até o mês de junho) para a confirmação de casos de Covid- 19 e a restrição dos testes aos casos graves que necessitavam de internação configuraram um contexto de baixa testagem nos serviços públicos de saúde. Isso trouxe dificuldades para a mensuração da magnitude da doença nos espaços periféricos, onde a população é, em sua maioria, usuária do SuS.

Apesar da subnotificação e dos limites na produção de informações específicas sobre as favelas, o acompanhamento das taxas de incidência de Covid- 19 mostra a periferização da doença: em março, início da pandemia, as maiores taxas de incidência foram encontradas em bairros da zona sul, com maior poder aquisitivo. Entretanto, no decorrer dos meses seguintes, a incidência da doença apresentou maior expressão entre os bairros periféricos. A despeito do esforço do serviço de saúde no processo de vigilância de óbitos suspeitos por Covid-19, muitas pessoas morrem sem terem realizado o teste e outras têm a causa do óbito indefinida. A elevação dos óbitos domiciliares é outro indicador importante para a análise das taxas de mortalidade.

Corroborando com essa análise, vê-se que os bairros com alta e altíssima concentração de favelas apresentam maior letalidade (19,47\%), o dobro em relação aos bairros considerados "sem favelas" $(9,23 \%)$, o que indica tanto a falta de acesso ao diagnóstico em tempo adequado como problemas de acesso aos serviços de saúde de maior complexidade assistencial. Territórios como Complexo do Alemão, Costa Barros e Jacarezinho apresentaram as maiores taxas de letalidade observadas, respectivamente 45\%, 22,69\% e 22,22\%. A taxa de letalidade na cidade do Rio de Janeiro ficou em I I,73\%. 
O comportamento desigual da doença na cidade também reitera as desigualdades raciais, expressas pelo maior número de óbitos na população negra. A melhora na informação do quesito raça/cor - observada da primeira para a segunda edição do Boletim Socioepidemiológico - resultou da obrigatoriedade no preenchimento por autodeclaração desse campo no Sistema de Informação de Agravos de Notificação (Sinan). Ação do Ministério Público Federal, a medida foi fruto da intensa mobilização de associações e movimentos sociais, com destaque para os movimentos negros, que denunciaram a invisibilidade de negros e indígenas como um obstáculo à promoção da equidade em saúde. De fato, já no segundo boletim (julho e setembro) é possível observar que as taxas de incidência, de mortalidade e de letalidade por Covid- I 9 no município foram maiores na população negra. O percentual de óbitos por Covid-19 segundo raça/cor nesse período foi de 48,2\% em negros, 31, I 2\% em brancos, porém ainda há $20,15 \%$ de não informados segundo esse quesito. O percentual de casos em negros é de 44,6\%, em brancos de 37,04\%, em amarelos de 3,99\%, em indígenas de 0,17\%, e os ignorados são 14,19\%. Essa doença retrata as bases de nosso racismo estrutural, expresso na imensa vulnerabilização e precarização de vidas negras.

O monitoramento ativo de fontes não oficiais - mídias, redes sociais e contato direto com moradores, coletivos e articuladores locais - trouxe à tona diversas situações que vulnerabilizam ainda mais a população desses territórios, como a precariedade no acesso aos serviços de saúde; a realização de operações policiais em favelas durante a pandemia, a despeito da legislação vigente; a falta de abastecimento de água; as remoções de moradores de suas casas; as mortes no domicílio constatadas por pesquisa comunitária; as diversas situações de racismo; a intensificação dos problemas de saúde mental; a fome e insegurança alimentar, entre outros. Porém, encontrou-se também uma multiplicidade de iniciativas potentes dos moradores das favelas no enfrentamento da pandemia, atuando sobre esse conjunto de problemas abordados com efetivos resultados, a despeito da omissão do Estado em prover ações protetivas emergenciais em face da pandemia.

No trabalho de monitoramento social e epidemiológico da pandemia em favelas constatou-se que a Covid-I 9 atua no sentido de explicitar ainda mais o padrão de desigualdade socio-racial brasileiro. A favela é cotidianamente reiterada como espaço de exclusão, cujo enredo é naturalizado por um projeto político que conta com estratégias potentes de ocultação de sua realidade, tais como a racionalidade utilizada na produção de dados de saúde que a invisibiliza e a falta de ações efetivas de proteção social. 


\section{POVOS INDÍGENAS E COVID-19}

Devido a fatores históricos e socioeconômicos, os povos indígenas são particularmente vulneráveis à Covid- 19 e às suas graves consequências (Abrasco \& ABA, 2020). Diante de desvantagens sociais e de saúde, era notório que o enfrentamento da Covid- 19 no contexto indígena seria desafiador, situação agravada pela baixa execução orçamentária na saúde indígena (Inesc, 2020), pelo frágil diálogo do governo com as representações indígenas na elaboração e implementação das ações e pela reduzida transparência das medidas adotadas para a garantia da prevenção da doença e integralidade da atenção aos casos (Apib, 2020; Abrasco, 2020).

A disputa de narrativas sobre o enfrentamento da pandemia em povos indígenas foi evidenciada pela demora na aprovação da lei 14.021/2020 e na derrubada dos vetos presidenciais (Brasil, 2020c), pelas intervenções do Ministério Público Federal (Brasil, 2020a, 2020b) e, particularmente, pelas interpelações feitas pelo movimento indígena ao Supremo Tribunal Federal, na Ação de Descumprimento de Preceitos Fundamentais 709 (Apib, 2020), e na Comissão Interamericana de Direitos Humanos da Organização dos Estados Americanos (OEA, 2020). Passados seis meses da pandemia, as medidas legislativas e jurídicas ainda não foram plenamente implementadas.

A circulação do Sars-CoV-2 no Brasil resultou em progressiva proporção de indígenas em municípios em alto risco imediato para a pandemia (Grupo de Trabalho, 2020), afetando, rapidamente, os 34 Distritos Sanitários Especiais Indígenas. Em áreas urbanas, foram observadas soroprevalências de anticorpos superiores em indígenas em comparação a outras categorias de cor ou raça, em particular os brancos (UFPel, 2020). A transmissão do vírus em territórios ocupados por povos isolados e de recente contato é alarmante e agravada pelo aumento das invasões ilegais (OPI, 2020).

Divergências entre dados epidemiológicos oficiais da Secretaria Especial de Saúde Indígena (Sesai) e os de outras fontes (CNS, 2020) revelaram problemas na transparência da informação, acesso restrito ao Sistema de Informação da Atenção à Saúde Indígena (Siasi) e falta de integração deste com os demais Sistemas de Informação em Saúde (SIS), bem como a importância da variável cor/raça nos SIS e o racismo institucional. Como resultado, recentemente a Sesai assumiu a necessidade de complementar seus dados sobre óbitos indígenas por Covid-19 com dados de outras fontes (OEA, 2020). Não obstante tais divergências, os dados disponibilizados pela Sesai, em resposta à ADPF 709, evidenciam taxas de mortalidade por Covid- 19 progressivamente mais elevadas na faixa etária a partir dos 50 anos nos indígenas em comparação com a população geral. Tal evidência alerta para os trágicos impactos socioculturais da pandemia, visto que os 
indivíduos de mais idade são os guardiões dos conhecimentos tradicionais, das línguas e da memória das lutas históricas desses povos.

Ainda que o período recente se destaque por violações de direitos indígenas e pelo agravamento das iniquidades em saúde, emergem também como pontos centrais o protagonismo indígena na luta por seus direitos e o papel fundamental do Subsistema de Atenção à Saúde Indígena (Sasi-SUS).

Considerando que ainda estamos em uma pandemia com muita heterogeneidade e desigualdade entre os estados, municípios e territórios específicos, como áreas indígenas ou de favelas, por exemplo, faz-se necessário ampliar e fortalecer as capacidades de enfrentamento da sociedade e do SUS como um todo, envolvendo grande participação da sociedade e intersetorial.

Tendo como referência a Lei Orgânica da Saúde (lei 8.080, de 1990), é necessário fortalecer ainda mais a universalidade e a integralidade das ações e serviços de saúde por meio da ampliação do financiamento e fortalecimento do SUS, criando as necessárias condições para a melhoria de suas estruturas, bem como para a capacitação e valorização dos seus profissionais, garantindo a qualidade do cuidado, a segurança dos pacientes e a saúde dos trabalhadores da saúde. Isso envolve investimentos e ampliação para uma atenção primária que seja resolutiva e integrada tanto à vigilância em saúde e suas capacidades de monitoramento e ações de prevenção como aos serviços de alta e média complexidades e suas capacidades de diagnóstico, tratamento e reabilitação. O SUS deve estar preparado para enfrentar os impactos na saúde provocados pela pandemia, que vão muito além dos provocados pelo vírus Sars-CoV-2, combinando desde os impactos na saúde mental e provocados pelo aumento da violência doméstica até os resultantes da descontinuidade de tratamentos ou mesmo da desassistência em saúde.

Tendo como referência a Constituição de 1988, o enfrentamento desta crise deve combinar simultaneamente políticas e ações sobre os determinantes e condicionantes da saúde, envolvendo segurança alimentar, acesso à moradia e ao saneamento básico, geração de empregos e renda, garantia ao acesso à educação e ao transporte público seguro, além do acesso aos bens e serviços essenciais, incluindo os de saúde, com qualidade e segurança para todos. Reduzir as desigualdades sociais e criar condições para uma vida decente e sustentável, com promoção da saúde, são metas a serem perseguidas em todas as políticas e ações, reduzindo a vulnerabilidade dos diferentes grupos sociais, como também de nossa sociedade como todo, diante desta e das próximas pandemias. 


\section{REFERENNCIAS}

ANGELO, J. R. et al. Boletim Socioepidemiológico da Covid-I 9 nas favelas. Observatório Covid- 19 da Fiocruz - Informação para a ação, 2020. Disponível em: <https://portal.fiocruz.br/sites/portal.fiocruz.br/ files/documentos/boletim_socioepidemiologicos_covid_nas_favelas_l.pdf >. Acesso em: 18 set. 2020.

ARTICULAÇÃO DOS POVOS INDÍGENAS DO BRASIL (APIB). ADPF 709 no Supremo: povos indígenas e o direito de existir!, 2020. Disponível em: < http://apiboficial.org/2020/08/0 1/adpf-709-no-supremopovos-indigenas-e-o-direito-de-existir/>. Acesso em: 18 set. 2020.

ASSOCIAÇÃO BRASILEIRA DE SAÚDE COLETIVA (ABRASCO) \& ASSOCIAÇÃO BRASILEIRA DE ANTROPOLOGIA (ABA). A Covid- 19 e os povos indígenas: desafios e medidas para controle do seu avanço. Nota Conjunta Abrasco/ABA, 2020. Disponível em: <https://www.abrasco.org.br/site/ outras-noticias/notas-oficiais-abrasco/a-covid-19-e-os-povos-indigenas-desafios-e-medidaspara-controle-do-seu-avanco/45866/>. Acesso em: 18 set. 2020.

ASSOCIAÇÃO BRASILEIRA DE SAÚDE COLETIVA (ABRASCO). Nota técnica em resposta à intimação n. 2636/2020. Manifestação ao Supremo Tribunal Federal do Grupo de Consultores do GT de saúde indígena da Associação Brasileira de Saúde Coletiva e Fundação Oswaldo Cruz referente à medida cautelar na arguição de descumprimento de preceito fundamental 709, 2020. Disponível em: <https://www. abrasco.org.br/site/gtsaudeindigena/wp-content/uploads/sites/I 2/2020/08/Resposta-intimacaoFiocruz-Abrasco-Final-17-08-c2-2.pdf>. Acesso em: 18 set. 2020.

BRASIL. Ministério Público Federal. Em nota pública, MPF alerta sobre descaso com saúde indígena durante pandemia da Covid-19, 2020a. Disponível em: < http://www.mpf.mp.br/pgr/noticias-pgr/emnota-publica-mpf-alerta-sobre-descaso-com-a-saude-indigena-durante-pandemia-da-covid- $1>$. Acesso em: 18 set. 2020.

BRASIL. Ministério Público Federal. Covid-19: MPF recomenda ações emergenciais de proteção à saúde dos povos indígenas, 2020b. Disponível em: <http://www.mpf.mp.br/df/sala-de-imprensa/ noticias-df/covid-19-20 I 3-mpf-recomenda-acoes-emergenciais-de-protecao-a-saude-dos-povosindigenas >. Acesso em: 18 set. 2020.

BRASIL. Senado em Notícias. Congresso derruba vetos de Bolsonaro à lei que protege indígenas na pandemia, 2020c. Disponível em: <https://wwwl2.senado.leg.br/noticias/materias/2020/08/19/ congresso-derruba-vetos-de-bolsonaro-a-lei-que-protege-indigenas-na-pandemia $>$. Acesso em: 18 set. 2020.

CONSELHO NACIONAL DE SAÚDE (CNS). 2020. Divergência de dados sobre Covid- 19 na população indígena dificulta medidas efetivas de proteção. Disponível em: <http://conselho.saude.gov.br/ ultimas-noticias-cns/1357-divergencia-de-dados-sobre-covid- I9-na-populacao-indigenadificulta-medidas-efetivas-de-protecao >. Acesso em: 18 set. 2020.

EUROPE PUBLIC SERVICE UNION (EPSU). Health workers bear brunt of Covid- 19 infections, 2020. Disponível em: <https://www.epsu.org/article/health-workers-bear-brunt-covid-19-infections>. Acesso em: 18 set. 2020.

FUNDAÇÃO OSWALDO CRUZ (FIOCRUZ). Boletim Observatório Covid- 19 após 6 meses de pandemia no Brasil. Observatório Covid-19 - Informação para a ação, 2020. Disponível em: <https://agencia. fiocruz.br/sites/agencia.fiocruz.br/files/u34/boletim_covid_6meses.pdf $>$. Acesso em: 18 set. 2020. 
GRUPO DE TRABALHO. Risco de espalhamento da Covid-19 em populações indígenas: considerações preliminares sobre vulnerabilidade geográfica e sociodemográfica. Relatório n. 4 do Grupo de Métodos Analíticos de Vigilância Epidemiológica (MAVE), PROCC/Fiocruz e EMap/FGV, Grupo de Trabalho sobre Vulnerabilidade Sociodemográfica e Epidemiológica dos Povos Indígenas no Brasil à Pandemia de Covid- 19 e colaboradores. 18 de abril, 05 e 20 de maio de 2020. Disponível em: http://covid- 1 9.procc.fiocruz.br/

INSTITUTO DE ESTUDOS SOCIOECONÔMICOS (INESC). Mesmo com pandemia, governo gastou menos com saúde indígena em comparação a igual período de 2019. Disponível em: <https://www.inesc.org. br/mesmo-com-pandemia-governo-gastou-menos-com-saude-indigena-em-comparacao-a-igualperiodo-de-2019/>. Acesso em: 18 set. 2020.

LINDER, L. Desigualdade eleva letalidade na favela, diz estudo. Portal DW, 28 maio 2020. Disponível em: < https:/www.dw.com/pt-br/desigualdade-eleva-letalidade-da-covid-na-faveladiz-estudo/a-53586352>. Acesso em: I jun. 2020.

MENEZES, M. O. et al. Risk factors for adverse outcomes among pregnant and postpartum women with acute respiratory distress syndrome due to Covid- 19 in Brazil. International Journal of Gynecology $\mathcal{E}$ Obstetrics, 2020. Disponível em: < https://doi.org/1 0.1002/ijgo.13407>. Acesso em: 18 set. 2020.

NAKAMURA-PEREIRA, M. et al. Covid-19 and maternal death in Brazil: an invisible tragedy. Revista Brasileira de Ginecologia e Obstetrícia, 42(8): 445-447, 2020. Disponível em: < http://www.scielo.br/ scielo.php?script $=$ sci_arttextEpid $=$ SO I 00-72032020000800445Elng $=$ enEnrm $=i s o>$. Acesso em: 18 set. 2020.

OBSERVATÓRIO COVID- I 9 DA FUNDAÇÃO OSWALDO CRUZ. Site. Disponível em: < https://portal. fiocruz.br/observatorio-covid-19>. Acesso em: 18 set. 2020.

OBSERVATÓRIO DOS DIREITOS HUMANOS DOS POVOS INDÍGENAS ISOLADOS E DE RECENTE CONTATO (OPI). Emergência sanitária no Vale do Javari e a situação dos povos de recente contato diante da Covid- 19. Disponível em: <https://povosisolados.com/2020/06/21/emergencia-sanitaria-no-vale-do-javari-e-asituacao-dos-povos-de-recente-contato-diante-da-covid-19/>. Acesso em: 18 set. 2020.

ORGANIZACIÓN DE LOS ESTADOS AMERICANOS (OEA). Comisión Interamericana de Derechos Humanos. PS 177. Audiencia: pandemia y pueblos indígenas de la Amazonia, 6 oct. 2020. Disponível em: < https://www.facebook.com/CIDH.OEA/videos/vb. $194263083953643 / 126954486005$ I 009/?t ype $=2 \varepsilon$ theater $>$. Acesso em: 18 set. 2020.

OUR WORLD DATA. Statistics and Research. Coronavirus pandemic (Covid-19). Disponível em: $<$ https://ourworldindata.org/coronavirus > . Acesso em: 18 set. 2020.

SAWAYA, A. L. et al. Os dois Brasis: quem são, onde estão e como vivem os pobres brasileiros. Estudos Avançados. 17(48). Estudos Avançados. 17(48): 21 -44, 2003. Disponível em: < http://www.scielo. $\mathrm{br} / \mathrm{scielo}$.php?script $=$ sci_arttextEpid $=$ SO I 03-40 I $42003000200003 \xi \operatorname{lng}=\mathrm{ptEnrm}=\mathrm{iso}>$. Acesso em: 18 set. 2020.

UNIVERSIDADE FEDERAL DE PELOTAS. Epicovid- 19-BR divulga resultados sobre o coronavírus no Brasil, 2020. Disponível em: <http://epidemio-ufpel.org.br/site/content/sala_imprensa/noticia_detalhe. php?noticia $=3128>$. Acesso em: 18 set. 2020. 



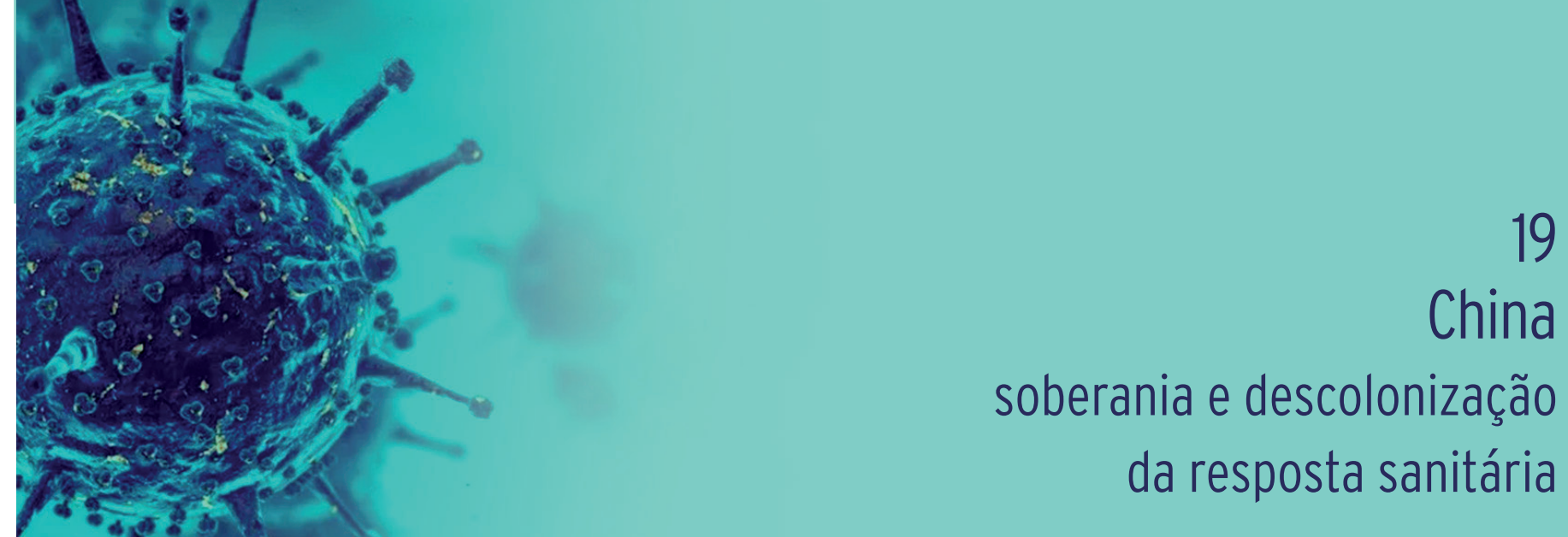

André Lobato

Dimeira a ser paralisada pela pandemia, a economia chinesa cresceu 3,2\% no segundo quadrimestre (Moss, 2020), mantendo um total de mortos confirmados inferior ao de Massachusetts, estado americano onde ficam Harvard e MIT (Massachusetts Institute of Technology). A epidemia começou num momento marcado por uma mudança estrutural da governança global: o retorno da China ao lugar histórico de exportadora de tecnologia perdido após a Guerra do Ópio (Su, 2019). Esse conflito foi marcado, economicamente, pela inversão do superávit comercial da China com o Ocidente. E, por isso, se aproxima da guerra comercial lançada contra a China num momento em que suas técnicas de produção se equiparam ou se aproximam às de vários países do mundo, ou as ultrapassam. A sensação preexistente de um ataque, ou um conflito, favoreceu suspeições de que o país estava sob um ataque biológico.

Independentemente de especulações, a resposta sanitária chinesa foi apoiada pela mesma estrutura que sustenta seu retorno à condição de polo tecnológico global: planejamento de longo prazo com financiamento para construção das instituições nacionais e desenvolvimento de um mercado interno escolarizado com poder de compra e de produção. O resultado foi uma resposta sanitária completa: socialmente na contenção dos contágios e tecnologicamente nas várias fases do enfrentamento do antígeno.

\section{A RESPOSTA}

Durante a pandemia, o complexo industrial da saúde chinês, com crescente capacidade de produção de máquinas de alta tecnologia, recebeu apoio de outros setores, como o automobilístico, para produção de máscaras, respiradores e virtualmente todos os itens da resposta sanitária imediata. Em maio, US $\$ 10$ bilhões em equipamentos 
médicos e 30 bilhões de máscaras já haviam sido exportados. No começo de junho, a produção de equipamentos de proteção individual aumentou 90 vezes em relação ao início da pandemia (Fighting..., 2020). Além da manutenção dos empregos durante a quarentena, com reduções de custos para empregadores (energia, internet, impostos) e trabalhadores (empréstimos, vouchers e redução do seguro de saúde), o governo chinês também reuniu e organizou a distribuição de capacidades produtivas de mais de 10 mil empresas e 500 mil trabalhadores para responder às demandas iniciais da pandemia. O governo agora estimula a economia de "baixo contato" e direciona parte dos empregos ameaçados pelas mudanças de consumo com, por exemplo, treinamentos de assistentes de compras on-line. Isso tem levado a inovações, como a compra de produtos agrícolas orgânicos diretamente dos produtores em feiras virtuais.

A resposta epidêmica contou com importantes avanços no campo da ciência feitos pela Nova China, o país fundado como resposta às sucessivas invasões marítimas, durante os séculos XIX e XX, de países como França, Japão, Reino Unido e Estados Unidos da América (EUA). Mas, como se sabe agora, a mais eficaz forma de combater o vírus requer imenso esforço social de minimização dos deslocamentos e manutenção de práticas básicas de higiene. Grandes mobilizações para enfrentar desafios comuns fazem parte da dinâmica de revoltas populares, espírito nacionalista e senso de sacrifício que marcam o movimento histórico chinês, com especial repercussão para os membros do Partido Comunista, que governam o país desde que saíram vitoriosos da Guerra Civil em 1949. Essa mobilização nacional contra o vírus incluiu o apoio nacional para o isolamento de Wuhan, centro do surto global por semanas, e a mudança radical de expectativas, pois eram esperadas cerca de 3 bilhões de viagens nos meses em que o surto alcançou seu ponto mais preocupante. Isso porque entre dezembro e março se realiza na China o maior movimento migratório do planeta, com centenas de milhões viajando para comemorar a virada do calendário lunar, que está no ano 4718 (Chinasage, 2020). Wuhan é um dos nodos do transporte nacional; caso não tivesse sido fechada, o número de mortos na China provavelmente seria maior do que as populações de muitos países.

Apesar do vasto histórico de invenções e descobertas chinesas ao longo dos milênios, a incorporação da ciência moderna passa a ocorrer principalmente com o movimento Ciência e Democracia, associado ao movimento 4 de Maio (Wikipedia, 2020). Ideias como a teoria darwinista corroboravam ideologicamente com as necessidades de transformação e adequação diante de invasores que não eram bárbaros, mas tecnologicamente mais sofisticados. No caso da medicina, porém, a sabedoria ancestral na formulação de diagnósticos e no preparo de fármacos foi dividida entre uma versão tradicional e uma moderna/ocidental. As ciências biológicas 
tiveram influência da produção norte-atlântica mesmo durante o período em que a modernização do país era inspirada pelo modelo soviético.

No âmbito da biotecnologia, e especialmente na genética, o mercado e as ciências chinesas estão particularmente avançados. O país foi classificado como o mais inovador (Vasconcellos et al., 20 I 8) se levada em consideração a proporção entre patentes e renda média. Parte do maquinário dos centros de testagem da Fiocruz (Câmera $\&$ Cruz, 2020) instalados no Rio de Janeiro são da empresa chinesa BGI/MGl. Esta empresa contribuiu fortemente para a escala de testes (BGl's..., 2020) na ordem dos 500 mil/dia vista em Wuhan, Pequim e Urumqi. A BGI começa em Pequim, na Academia Chinesa de Ciências, parcialmente inspirada na academia soviética, e hoje situa-se em Shenzhen, também conhecida como o Vale do Silício chinês. Nos últimos três anos, a Fundação Oswaldo Cruz (Fiocruz) assinou memorandos de entendimento com organizações chinesas, entre elas o Centro de Controle de Doenças da China, a BGl e a Academia Chinesa de Ciências. Parte dos resultados da colaboração consiste no empréstimo, realizado no ano passado, de duas máquinas de sequenciamento que hoje são operadas em Bio-Manguinhos por cientistas da Fiocruz fazendo pesquisa translacional com o Sars-Cov-2. Trata-se de um projeto pioneiro: foi a primeira instalação de máquinas da BGI/MGI no Brasil.

Apesar dos avanços tecnológicos que permitiram uma resposta sanitária completa (do sequenciamento do patógeno à fase 3 de testes clínicos da vacina), a participação da medicina tradicional não pode ser minimizada. Tanto por seu histórico - há registros de inoculação contra varíola no século III a.C. (The History of Vaccines, 2020) - quanto por sua participação na resposta sanitária neste século XXI. Ela foi associada ao fato de os quadros clínicos não terem se agravado (Mai $\varepsilon$ Lo, 2020), com um composto específico para o tratamento da doença tendo sido desenvolvido, e a comissão nacional responsável por sua gestão teve assento na formulação e execução da estratégia de enfrentamento da Covid-19. Do ponto de vista da diplomacia internacional, por exemplo, Pequim, em suas tratativas multilaterais, manteve constante valorização da medicina tradicional chinesa, tanto em relação ao mercado de fármacos quanto no diálogo multilateral com outras medicinas tradicionais.

Crucial, entretanto, foi o cordão sanitário em Wuhan, que ocorreu após o anúncio da transmissibilidade do vírus entre pessoas. Com menos de mil infectados confirmados, Wuhan, e a conurbação adjacente, foi colocada em quarentena total. O anúncio da transmissibilidade foi feito por Zhong Nanshan, médico cuja popularidade na China pode ser comparada à de Drauzio Varela no Brasil (Wang \& Moritsugu, 2020). Nanshan identificou várias falhas no sistema de resposta chinês durante a epidemia de síndrome respiratória aguda grave (Sars) em 2003 e ganhou notoriedade com isso. 
Os meios de transporte foram fechados e um rigoroso esquema de quarentena foi imposto. A ampla aceitação da realidade sanitária pode ser creditada à experiência da epidemia de Sars e ao alto valor que a ciência tem para a sociedade chinesa de forma geral. Houve, é claro, vários registros de insatisfação em relação a um estado de quarentena quase total em Wuhan, que acabou servindo de modelo inalcançável em muitos países. A mais famosa dessas críticas, a poetisa Fang Fang, ganhou destaque (Wong, 2020) na mídia ocidental por sua insatisfação com a quarentena prolongada, compulsória e com os decorrentes prejuízos às liberdades individuais. O rastreamento ativo de pessoas com suspeita de contaminação também foi duramente criticado na mídia ocidental (Gan, Lee E Culver, 2020). É difícil saber o quanto a associação entre quarentena e autoritarismo, feita enquanto a China era o centro da pandemia, prejudicou a narrativa, depois necessária no mundo todo, de que a quarentena não é uma manifestação de um Leviatã comunista, nem a doença é uma enfermidade exclusiva de um povo amarelo.

Em sua capacidade produtora, diferentes níveis de governança organizaram recursos para sustentar o cordão sanitário em Wuhan. Linhas de abastecimento interprovinciais foram estabelecidas para a garantia de equipamentos e alimentos. Atividades em cidades não atingidas, como retorno às aulas, também foram suspensas, em solidariedade aos quarentenados. Houve também grande esforço social de coordenação das quarentenas. Territórios foram subdivididos em grupos menores de pessoas e isolados, com voluntários impedindo a entrada de não moradores em condomínios residenciais. Houve casos em que a polícia foi chamada para apoiar o controle sanitário, que, como nos demais países, não foi acatado por toda a população. Mas, de forma geral, o vazio absoluto das cidades e o uso generalizado de máscaras demonstra que as instruções epidemiológicas foram absorvidas e seguidas pela população em geral.

Do ponto de vista institucional, mais de vinte províncias estabeleceram planos legislativos de combate sanitário, muitos deles baseados em leis de emergência preexistentes. A resposta local inclui, por exemplo, apropriações temporárias de terrenos e veículos, suspensão de atividades com aglomeração de pessoas e a obrigatoriedade de entidades privadas garantirem itens diários básicos. Algumas dessas medidas também foram criticadas na mídia anglófila. O NPC Observer, que segue o Legislativo chinês, apontou, por exemplo, que havia poucas garantias de indenização aos proprietários que tiveram seus bens utilizados pelos governos locais (Zhang $\&$ Wei, 2020). Mas reconhece que o Congresso Nacional do Povo, que se reuniu presencialmente em Pequim com algumas semanas de atraso, reconheceu corretas as ações locais (The People's Republic of China, 2020a). Novas leis foram aprovadas, entre elas uma que praticamente bane 0 consumo de animais selvagens e cria novas restrições para mercados de animais vivos. 
As reformas no sistema de saúde merecem uma análise mais detalhada numa próxima oportunidade. Elas indicam um aprofundamento da saúde pública, humana e animal.

Além do fechamento de estradas por pequenos camponeses e apropriações emergenciais de terrenos para receber doentes, ministérios e grandes empresas organizaram ativamente os capitais e os recursos humanos disponíveis para manter ou reorientar a produção industrial. Isso permitiu, por exemplo, não só a construção dos hospitais como estruturas de campanha, mas o desenvolvimento de novas soluções associadas a emergências sanitárias, como centros de testagens infláveis. Linhas rápidas de comunicação com outros países, como a estabelecida com a Coreia do Sul, facilitaram o funcionamento das cadeias produtivas. Mas, no geral, especialmente em sua área mais populosa, a China parou. Xangai, com 26 milhões de habitantes, ficou deserta, e conta 7 mortos e 7 centenas de casos confirmados. Em Jiangxi, por exemplo, houve protestos contra a reabertura de uma ponte que a liga a Hubei. A polícia, que ajudou a fechar, participou, então, na reabertura. O principal elemento do consenso sobre a segurança da cidade, porém, foi uma testagem em massa, iniciada após esse protesto, de 10 milhões de pessoas em 19 dias como um esforço de pôr fim à "quarentena psicológica" da cidade atingida pelo vírus (The People's Republic of China, 2020b).

Enquanto isso, elementos básicos como renda, moradia e alimentação não sofreram grandes alterações. Primeiro com a prorrogação do feriado de fim de ano e depois com instruções para o pagamento integral dos salários dos funcionários desmobilizados pela quarentena. A estrutura macroeconômica chinesa corroborou: baixo desemprego histórico (níveis inferiores a 6\%), poupança razoável, bancos estatais operando geográfica e setorialmente, e um avançado ecossistema digital com microfinanciamento e métodos de pagamento. Muitas das medidas anticíclicas chinesas foram orientadas para proteger o emprego em pequenas empresas.

Diante do desafio que ameaçava importantes planos para o ano, como a erradicação da miséria, e da alta adesão da população ao esforço social do isolamento, o governo chinês passou a propagar a defesa da vida como meta principal. A afirmação de que a vida é de importância "suprema”, independentemente do custo, ganhou força nos discursos do presidente Xi Jinping (Jianfeng, 2020). Assim, o esforço social de redução dos contágios obteve coordenação centralizada e de alto nível. A resposta inicial, entretanto, foi particularmente criticada pelos chineses, que ficaram insatisfeitos com a ação do Centro de Controle de Doenças pela demora na identificação da transmissibilidade do vírus. De certa forma, o desempenho de outros países considerados mais desenvolvidos pelos chineses, como EUA e Reino Unido, favoreceu a imagem interna da resposta chinesa. A ênfase no valor da vida também foi mencionada pelo primeiro-ministro Le 
Keqiang quando pediu às instituições financeiras que sacrificassem seus lucros pela recuperação econômica do país (Financial..., 2020).

\section{CONTEXTO INTERNACIONAL}

Esse grande esforço de enfrentamento epidêmico, que contou com mais de 8 milhões de voluntários, ocorre num contexto de acirramento das agressividades contra a China. $A$ agenda de conflito dos EUA com a China foi revigorada durante a pandemia mesmo após a assinatura da Fase I do acordo comercial, que visava a diminuir o déficit comercial dos EUA (Freking $\&$ Wiseman, 2020). Sanções contra a Huawei foram implementadas, sendo a mais sofisticada a que impede que a empresa encomende chips com desenho próprio se as máquinas usadas para "desenhar" os semicondutores tiverem tecnologia estadunidense. É como se a Tramontina impedisse que determinadas receitas fossem feitas em suas panelas. Outro movimento foi o de retardar o desenvolvimento de $5 \mathrm{C} \mathrm{em}$ mercados internacionais até que haja tecnologia disponível com padrões dominados pelos EUA (Open..., 2020). A iniciativa tem sido bem-sucedida, com países optando por adiar a implementação de tecnologias de maior produtividade para não contrariar o discurso de que a liderança estadunidense é crucial para a segurança da comunidade internacional.

Países de tradição multilateral se mostraram dispostos a, de forma mais ou menos ativa, integrar-se numa frente anti-China encabeçada Washington. As ações dessa frente eclipsaram em alguns momentos o noticiário internacional sobre a solidariedade entre os países durante a pandemia. Ataques à China vieram principalmente de governos formados por pessoas que creditaram aos cientistas chineses a invenção do vírus, aos seus diplomatas o estigma de vendedores de bugigangas mascarados e compararam o seu sistema político a uma camisa de força despótica. Boa parte das acusações são facilitadas pelo racismo estrutural contra asiáticos e chineses em particular, e outra parte, ao elaborado nível de propaganda envolvido na contenção do desenvolvimento no país. Da forma como está, cria-se a impressão de que a única relação bilateral possível entre Brasil e China é a que garante a entrada de dólares na balança comercial brasileira. A participação do Brasil nos mercados de $5 \mathrm{G}$ chegou a ser retratada como uma concessão aos chineses devido à fragilização do Brasil (Mello, 2020). Segundo o argumento, o Brasil ficou fragilizado por atacar a China e, agora, cedeu permitindo que a empresa líder do setor participe de licitações.

Alguns porta-vozes da diplomacia chinesa, especialmente os mais jovens, foram mais incisivos diante de questionamentos, por exemplo, sobre os direitos humanos de muçulmanos dentro e fora da China e sobre as liberdades individuais dentro e fora de 
Hong Kong. Centenas de milhares de contas em redes sociais consideradas pró-China foram banidas de plataformas como Youtube, Facebook e Twitter durante a pandemia. Num movimento pouco comum, o Ministério das Relações Exteriores da China publicou nota sobre a conversa entre os chanceleres Wang yi e Sergei Lavrov em que o chinês diz ao russo que o governo dos EUA "pirou” e só promove o "egoísmo" e o "unilateralismo" (República Popular da China, 2020).

\section{COOPERAÇÃO INTERNACIONAL}

A cooperação internacional chinesa e mais especificamente a sanitária, porém, não atende a categorias precisas de alinhamento com os EUA. Emirados Árabes, Brasil e Filipinas estão entre os primeiros países a testar as vacinas chinesas fora da China e têm acordos de importação e produção (World's..., 2020). O Brasil, por exemplo, é um dos primeiros países a ter duas instituições - Fiocruz e Academia Brasileira de Ciências - partícipes na Aliança Internacional de Organizações Científicas (Anso). Essa aliança é um desdobramento (Anso, 2020) da Iniciativa Cinturão e Rota. Xi Jinping e Bolsonaro, por exemplo, se encontraram em 2019 e, na declaração conjunta, apoiaram "sinergias entre as políticas de desenvolvimento", a Iniciativa Cinturão e Rota e o Programa de Parceria de Investimento (PPI) (Declaração..., 2020). Em março, os presidentes voltaram a se falar por telefone sobre a pandemia (Jinping, 2020). Embora a mídia estatal chinesa tenda mais ao elogio do que à denúncia, especialmente quando se trata de países em desenvolvimento, o Brasil acabou classificado por blogs e jornalistas independentes como um exemplo de resposta antissanitária' (o link leva à busca, em mandarim, de imagens relacionadas ao termo).

A Anso tem também um Corredor de Saúde, cuja premissa são a prevenção e o controle de epidemias. Alguns de seus principais pontos são: produtos de saúde, água limpa, serviço médico de baixo custo e remédios e vacinas. A iniciativa busca operar com uma miríade de atores que vão da Fundação Gates ao Novo Banco de Desenvolvimento (New Development Bank).

No âmbito multilateral, a China reforçou a relevância da Organização Mundial da Saúde (OMS) durante a $73^{\mathrm{a}}$ Assembleia Mundial de Saúde e também em encontros com organismos multilaterais como a União Africana, a Comunidade de Estados Latino-Americanos e Caribenhos (Celac) e o Grupo dos Vinte (G20). Boa parte da ação chinesa nesses organismos foi analisada considerando-se um contexto de disputa pela sobrevivência da hegemonia "americana", como discutido pelo Departamento de Estado

消极抗疫: 消 $=$ negativo, 极 $=$ polo, 抗 $=$ resistir, 疫 $=$ doença. 
da Casa Branca (United States of America, 2020). Houve, é importantíssimo notar, a manutenção de canais diplomáticos e científicos, como aquele entre os centros de controle de doenças dos EUA e da China (Delaney, 2020). Além dos EUA, as principais cooperações clínicas foram com Alemanha e Reino Unido. A cooperação internacional em saúde chinesa organizou conferências clínicas com mais de 140 países do mundo e lançou material informativo em várias línguas. Consulados e embaixadas chinesas também apoiaram as doações, primeiro para a China e depois da China, em inúmeros países. Frases da literatura local foram usadas para expressar mensagens de solidariedade internacional em países distintos como Argentina e Irã.

Levando em consideração o debate sobre hegemonia e superioridade tecnológica, muito predominante também no Brasil, a resposta sanitária chinesa foi autossuficiente e não dependeu de assistência externa. Não foi necessário o envio de uma única amostra que não fosse estritamente para cooperação sanitária internacional (Lobato, 2019). Ao contrário, as amostras foram rapidamente digitalizadas, depositadas em biobancos adequados e disponibilizadas para a comunidade científica com acesso à internet. O resultado mais esperado desse desenvolvimento, as vacinas chinesas, incitaram a discussão para além das propriedades tecnológicas das imunizações coletivas e fortaleceram o debate sobre o que são e como seriam geridos bens públicos globais sanitários (Cris/Fiocruz, 2020). A afirmação de que a aprovação de uma vacina chinesa seria um bem público global foi feita pelo presidente chinês em uma teleconferência na $73^{a}$ Assembleia Mundial de Saúde (Urgente..., 2020).

Historicamente, países como China, Brasil e Índia discorrem sobre os custos da propriedade intelectual para o tratamento e a imunização de suas populações, atingidas por doenças comunicáveis ou não comunicáveis. Agora é possível organizar a discussão sobre custo e retorno esperado de investimentos com novos atores da indústria farmacêutica.

\section{SOBERANIA SANITÁRIA}

A pandemia, então, colocou mais um elemento para ser medido pela régua da disputa entre potências: a capacidade biotecnológica e organização social necessárias para manter a segurança sanitária nacional e, em último caso, a soberania. Assim, o momento atual propicia a rediscussão de questões coloniais da historicidade das respostas sanitárias, como a dependência da ciência feita nas antigas capitais imperiais. Nessa perspectiva, a pandemia marca uma nova fase do desenvolvimento da Nova China e da ciência global. 
Embora vacinas e chips de computador tenham valores de uso distintos, e, portanto, seus preços tenham diferentes elasticidades, ambas hoje configuram um mercado tão essencial às populações que suas questões de custos passam por constantes fases de politização. Por exemplo, os termos "diplomacia de máscaras" e "diplomacia do lobo" são polissêmicos e ganham sentidos distintos a depender do interlocutor. Normalmente, e especialmente na imprensa norte-atlântica, ganham um aspecto negativo de, respectivamente, desconfiança e demonstração de força. Na China, porém, podem significar solidariedade sanitária internacional e autodefesa. De fato, várias medidas começaram a ser tomadas por Pequim no que concerne à segurança sanitária de suas importações, especialmente alimentos, e a capacidade sanitária dos países de sustentarem seus papéis nas cadeias internacionais de produção.

Estudos recentes têm sugerido que a China passe a classificar os países de acordo com seu risco epidemiológico e que a cooperação bilateral e multilateral estimule o fortalecimento das capacidade de prevenção em controle de epidemias (Yan, 2020). Internamente, a China prepara um novo salto na capacidade instalada para prevenção epidêmica. A Comissão Nacional de Desenvolvimento e Reforma, cuja capacidade de planejamento e execução não deve ser menosprezada, anunciou os planos para fortalecimento da resposta nas próximas epidemias:

1. Melhoria da testagem com ampliação dos laboratórios de biossegurança P3, em grandes cidades e capitais provinciais, e P2, em cidades médias. Pela organização administrativa, seriam cerca de 30 laboratórios P3 e outros 300 P2.

2. Criação de um sistema nacional de centros hospitalares de doenças infectocontagiosas, que serão construídos ou adaptados, com, por exemplo, novos laboratórios. A capacidade de atendimento deve ser ampliada levando-se em consideração medicamentos e locais adequados para tratamento das principais epidemias e também pode incluir espaços da assistência médica tradicional.

3. A comissão prevê ainda a construção e adequação de locais de quarentena. Por exemplo: estádios de esportes, em projeto ou já executados, devem pensar nas trocas de ar e disposição de resíduos contaminados, caso venham a ser locais de quarentena.

4. A comissão quer aprimorar a oferta de insumos, a coordenação das linhas de produção, a manutenção de estoques e a capacidade produtiva geral.

5. Finalmente, é feita a sugestão de que haja uma coordenação multilateral internacional para a alocação dos suprimentos de emergência (The People's Republic of China, 2020c). 
Elementos de mercado também estão em jogo, como a inserção da testagem nucleica no seguro básico de saúde e a criação de um fundo filantrópico para a OMS (WHO, 2020). Prevê-se, assim, um crescimento ainda maior da capacidade instalada de testagens da China, com a consequente expansão de áreas afins, como a da indústria de equipamentos médicos. Tratar-se-á de um salto grande, especialmente se considerarmos que o país se classifica como uma nação em desenvolvimento. Mesmo que tenha havido uma inversão de expectativas em relação ao desempenho dos países desenvolvidos e em desenvolvimento durante esta pandemia, importantes feitos ainda precisam ser realizados para que o país se transforme "numa sociedade moderadamente próspera", como almeja (WHO, 2020).

Alguns elementos dessa prosperidade serão semelhantes aos de outros países, como ambições espaciais e tecnologias que prolonguem a vida; outros serão distintos. O sistema de monitoramento ativo chinês, com quarentenas mandatórias para possíveis infectados, certamente se distancia da concepção do corpo como um espaço de direito individual. Da mesma forma, a máscara pode ser um totem de afirmação da sociabilidade ou um apagamento da identidade social. A influência dos epidemiologistas no debate geral da sociedade também irá variar. No caso chinês, além de máscaras, a ressocialização pós-surto tem ocorrido com uso dos predominantes códigos QR, que já tinham várias utilidades, como métodos de pagamento. $A$ alta disponibilidade de testes nucleicos, a miríade de aplicativos, a disponibilização aberta de dados epidemiológicos e a garantia de tratamento permitem que o resultado negativo para Sars-Cov-2 seja um totem de amizade facilmente disponível on-line, de forma a fortalecer um contrato social de controle dos contágios.

Essas inovações dificilmente seriam possíveis caso as plataformas digitais chinesas fossem as mesmas das do Brasil de hoje. Mais improvável ainda que houvesse tamanha capacidade instalada não tivesse a China oferecido financiamento adequado para a expansão do maquinário de sequenciamento. Isso já vinha ocorrendo com a terceirização dos serviços de sequenciamento genético dos mais variados campos da ciência para a China, especialmente para Shenzhen (Cyranoski, 20l6).

A pandemia expõe mais uma faceta das capacidades produtivas chinesas, que representam um fator de mudança nas margens de lucro e no estabelecimento de padrões industriais, e indicam a criação de novos mercados com tecnologias nativas. A trajetória tecnológica do país, então, move-se não necessariamente para a convergência homogeneizadora de padrões, mas apresenta a possibilidade de heterogeneização desses padrões, ao menos no que se refere à resposta sanitária. Sem dúvida, a teoria econômica 
focada no equilíbrio entre oferta e demanda tem dificuldades de lidar com a necessidade atual de "superprodução" de vacinas e tratamentos.

Países e organizações interessados em expandir suas possibilidades de ação provavelmente encontrarão portas abertas na comunidade sanitária chinesa. O país possui uma rica produção acadêmica, é atuante nos fóruns multilaterais e tem capitaneado projetos de megaciência próprios, que vão da face escura da Lua ao sequenciamento genético. Tem também, no Brasil e em outros países, demonstrado a disposição de manter laços internacionais entre cidades irmãs e mantido relações com entidades federadas e seus arranjos específicos.

O Brasil, república ou império, entretanto, tem um histórico de aproximação e distanciamento da China. O restabelecimento das relações diplomáticas, em 1974 , ocorreu dois anos após a visita de Nixon à China. Desde então, e principalmente dos anos 2000 para cá, importantes acordos estratégicos foram assinados com o país (Brasil, 2020). A Subcomissão de Saúde da Comissão Sino-Brasileira de Alto Nível de Concertação e Cooperação (Cosban) foi iniciada em 2015 (Brasil, 2015). Seis satélites do programa binacional já foram lançados. Muitos desses mecanismos podem se beneficiar de um maior engajamento do setor Saúde.

A pandemia certamente oferecerá oportunidades para o aprofundamento da cooperação em ciência e tecnologias de saúde: na vacina, na formulação de modelos econômicos que deem conta dos desafios de financiamento, no reposicionamento de tratamentos clínicos, na atualização de modelos epidemiológicos ou no fortalecimento da soberania sanitária brasileira com o desenvolvimento de centros de prevenção e controle. São apenas alguns exemplos. Isso, porém, exigirá uma adequação da estratégia brasileira ao reposicionamento dos Estados nacionais diante do desenvolvimento chinês. Geograficamente, China e Brasil estão em lados opostos do planeta, mas muitos dos desafios do desenvolvimento dos dois países são comuns. Tratando do tema das distâncias, o poeta Zhang Jiuling escreveu: "Em conhecer-te não há distância / as distâncias são vizinhas” ( 相知无远近, 万里尚为邻 ). Brasil e China são certamente distantes, mas os desafios sanitários do mundo globalizado os fazem vizinhos.

\section{REFERÊNCIAS}

ALLIANCE OF INTERNATIONAL SCIENCE ORGANIZATION (ANSO). Anso news. Disponível em: $<$ http://www.anso.org.cn/about/history/>. Acesso em: 18 set. 2020.

BGl'S Coronavirus Response? Building a lab in Wuhan, China. Genetic Engineering E Biotechnology News, 40(3): 10-1I, 2020. Disponível em: <https://www.liebertpub.com/doi/10.1089/gen.40.03.02>. Acesso em: 18 set. 2020. 
BRASIL. Ministério da Relações Exteriores. Ata da Quarta Reunião da Comissão Sino-Brasileira de Alto Nível de Concertação e Cooperação (COSBAN). Brasília, 26 jun. 20I5. Disponível em: <http:// www.itamaraty.gov.br/pt-BR/notas-a-imprensa/I 0340-ata-da-quarta-reuniao-da-comissao-sinobrasileira-de-alto-nivel-de-concertacao-e-cooperacao-cosban>. Acesso em: 18 set. 2020.

BRASIL. Ministério da Relações Exteriores. República Popular da China. Disponível em: <http://www. itamaraty.gov.br/pt-BR/ficha-pais/4926-republica-popular-da-china>. Acesso em: 18 set. 2020.

CÂMERA, A. \& CRUZ, M. Covid- 19: Fiocruz amplia capacidade nacional de testagem. Agência Fiocruz de Notícias, Rio de Janeiro, 10 ago. 2020. Disponível em: <https://agencia.fiocruz.br/covid-19fiocruz-amplia-capacidade-nacional-de-testagem>. Acesso em: 18 set. 2020.

CHINASAGE. Chinese calendars. Disponível em: <https://www.chinasage.info/calendar/history. htm >. Acesso em: 18 set. 2020.

CYRANOSKI, D. China's bid to be a DNA superpower. University Frères Mentouri Constantine I, 22 June 2016. Disponível em: <https://www.umc.edu.dz/index.php/fr/2013-0I-21-15-55-15/affiliationassure/item/1 135-china-s-bid-to-be-a-dna-superpower >. Acesso em: 18 set. 2020.

DECLARAÇÃO Conjunta entre a República Federativa do Brasil e a República Popular da China. XinhuaNet, Beijing, 25 out. 2019. Disponível em: <http://portuguese.xinhuanet.com/201910/25/c_138502640.htm >. Acesso em: 18 set. 2020.

DELANEY, R. US CDC had "very good interaction" with China after coronavirus outbreak, says director Robert Redfield. South China Morning Post, Beijing, 13 May 2020. Disponível em: <https://www. scmp.com/news/china/diplomacy/article/3084092/us-cdc-had-very-good-interaction-china-aftercoronavirus >. Acesso em: 18 set. 2020.

FIGHTING Covid- 19: China in action. XinhuaNet, Beijing, 7 June 2020. Disponível em: <http://www. xinhuanet.com/english/2020-06/07/c_139120424.htm>. Acesso em: 18 set. 2020.

FINANCIAL institutions urged to "sacrifice" profit to support businesses. Caixin, 18 Jun. 2020. Disponível em: <https://www.caixinglobal.com/2020-06-18/financial-institutions-urged-tosacrifice-profit-to-support-businesses-101568891.html>. Acesso em: 18 set. 2020.

FREKING, K. \& WISEMAN, P. Read the full U.S.-China "Phase I" trade agreement. PBS - News Hour, Arlington, 16 Jan. 2020. Disponível em: <https://www.pbs.org/newshour/economy/read-the-full-us-china-phase-1-trade-agreement>. Acesso em: 18 set. 2020.

GAN, N.; LEE, L. \& CULVER, D. Healthy Wuhan residents say they were forced into mass coronavirus quarantine, risking infection. CNN, Beijing, 24 Feb. 2020. Disponível em: <https://edition.cnn. com/2020/02/22/asia/china-coronavirus-roundup-intl-hnk/index.html>. Acesso em: 18 set. 2020.

JIANFENG, Z. "People's life, health top priorities": Xi Jinping stresses people-centered approach in development and epidemic control. CCT.com English, 23 maio 2020. Disponível em: <http://english. cctv.com/2020/05/23/ARTILFCwej3TI tD2m2ny4A5Y200523.shtml>. Acesso em: 18 set. 2020.

JINPING, X. Unity and cooperation are the international community's most potent weapon to overcome the pandemic. Qiushi Journal, I2(2): 43, 2020. Disponível em: <http://english.qstheory.cn/202004/22/c_II25885463.htm >. Acesso em: 18 set. 2020. 
LOBATO, A. Explorando elementos conceituais e de governança para políticas públicas em biotecnologia. In: NUPPAA. CAPACIDADES ESTATAIS E INOVAÇÃO, 3, 23-24 out. 2019, Rio de Janeiro. Disponível em: $<$ https://www.researchgate.net/publication/343889834_Explorando_Elementos_Conceituais_e_ de_Governanca_para_Politicas_Publicas_em_Biotecnologia >. Acesso em: 18 set. 2020.

MAI, J. E LO, K. Beijing pushes traditional Chinese medicine as coronavirus treatment despite questions over benefits. South China Morning Post, Beijing, 23 Mar. 2020. Disponível em: <https://www. scmp.com/news/china/society/article/3076500/beijing-pushes-traditional-chinese-medicinecoronavirus >. Acesso em: 18 set. 2020.

MELLO, P. C. Ataques fragilizam Brasil e ajudam China a obter concessões, avalia acadêmico. Disponível em: <https://wwwl.folha.uol.com.br/mundo/2020/04/ataques-fragilizam-brasil-e-ajudam-chinaa-obter-concessoes-avalia-academico.shtml>. Acesso em: 18 set. 2020.

MOSS, T. China becomes a refuge for U.S. companies after overcoming Covid- 19. The Wall Street Journal, New York, 7 Aug. 2020. Disponível em: <https://www.wsj.com/articles/china-becomes-a-refuge-foru-s-companies-after-overcoming-covid-19-11596792603>. Acesso em: 18 set. 2020.

OPEN standards, not sanctions, are America's best weapon against Huawei. The Economist, London, 8 Apr. 2020. Disponível em: <https://www.economist.com/leaders/2020/04/08/open-standards-notsanctions-are-americas-best-weapon-against-huawei>. Acesso em: 18 set. 2020.

REPÚBLICA POPULAR DA CHINA. Ministério das Relações Exteriores. Wang Yi conversa por telefone com o chanceler russo, Lavrov (Tradução livre). Disponível em: < https://www.fmprc.gov.cn/web/ wjbzhd/t I 798648.shtml>. Acesso em: 18 set. 2020.

SU, A. As trade war escalates, Chinese remember "national humiliation". Los Angeles Times, Los Angeles, 13 May 2019. Disponível em: < https://www.latimes.com/world/la-fg-china-trade-wartariffs-colonialism-humiliation-20190513-story.html>. Acesso em: 18 set. 2020.

THE HISTORY OF VACCINES. Chinese Smallpox Inoculation. Disponível em: <https://www. historyofvaccines.org/content/early-chinese-inoculation>. Acesso em: 18 set. 2020.

THE PEOPLE'S REPUBLIC OF CHINA. National People's Congress. Disponível em: < http://www.npc. gov.cn/englishnpc/c2846/column2.shtml >. Acesso em: 18 set. 2020a.

THE PEOPLE'S REPUBLIC OF CHINA. Wuhan screens nearly IOM people in citywide Covid- 19 tests, 3 June 2020. Disponível em: <http://english.scio.gov.cn/chinavoices/2020-06/03/content_76I20885. htm >. Acesso em: 18 set. $2020 \mathrm{~b}$.

THE PEOPLE'S REPUBLIC OF CHINA. The State Council Information Office. SCIO briefing on China's efforts to accomplish economic and social development goals for 2020, 28 May 2020c. Disponível em: <http://english.scio.gov.cn/pressroom/2020-05/28/content_76100176_9.htm>. Acesso em: 18 set. 2020.

UNITED STATES OF AMERICA. U.S. Department of State. Communist China and the free world's future. Speech by Michael R. Pompeo, The Richard Nixon Presidential Library and Museum, Yorba Linda, 23 July 2020. Disponível em: <https://www.state.gov/communist-china-and-the-free-worlds-future/>. Acesso em: 18 set. 2020.

URGENTE: vacina chinesa contra Covid-19 será bem público global quando disponível, diz Xi. XinhuaNet, Beijing, 18 maio 2020. Disponível em: <http://portuguese.xinhuanet.com/202005/18/c_139066921.htm >. Acesso em: 18 set. 2020. 
VASCONCELLOS, A. G. et al. Revisiting the concept of Innovative Developing Countries (IDCs) for its relevance to health innovation and neglected tropical diseases and for the prevention and control of epidemics. PLoS Neglected Tropical Diseases, 12(7): 1-20, 2018. Disponível em: <https://www.arca. fiocruz.br/handle/icict/27683>. Acesso em: 18 set. 2020.

CENTRO DE RELAÇÕES INTERNACIONAIS EM SAÚDE (CRIS/FIOCRUZ). Vacinas e Medicamentos para Covid- 19 como Bens Públicos Globais. Seminário virtual latino-americano, 20 jul. 2020. Disponível em: $<$ https://youtu.be/exjkp4BeSPo>. Acesso em: 18 set. 2020.

WANG, Y. \& MORITSUGU, K. Human-to-human transmission confirmed in China coronavirus. AP News, Beijing, 19 Jan. 2020. Disponível em: <https://apnews.com/article/l 4d7dcffa205d9022fa9ea 593bb2a8c5>. Acesso em: 18 set. 2020.

WIKIPEDIA. May Fourth Movement. Disponível em: <https://en.wikipedia.org/wiki/May_Fourth_ Movement>. Acesso em: 18 set. 2020.

WONG, C. H. A Wuhan writer rages against China's communist machine and becomes an online star. The Wall Streel Journal, New York, I April 2020. Disponível em: <https://www.wsj.com/ articles/a-wuhan-writer-rages-against-chinas-communist-machine-and-becomes-an-onlinestar-11585733403>. Acesso em: 18 set. 2020.

WORLD HEALTH ORGANIZATION (WHO). WHO's Covid- I 9 Solidarity Response Fund receives financial support from the China Population Welfare Fund, 20 May 2020. Disponível em: <https://www.who. int/news-room/feature-stories/detail/who-s-covid- 19 -solidarity-response-fund-receives-financialsupport-from-the-china-population-welfare-fund>. Acesso em: 18 set. 2020.

WORLD’s first Covid- 9 vaccine production line wins approval. Global Times, 8 May 2020. Disponível em: <https://www.globaltimes.cn/content/l 1 96829.shtml>. Acesso em: 18 set. 2020.

YAN, G. et al. Covid- I 9 Pandemic: global epidemiological trends and China's subsequent preparedness and responses. Chinese Journal of Epidemiology, 41: 3-13, 2020. Disponível em: < http://rs.yiigle.com/ yufabiao/1 184750.htm>. Acesso em: 18 set. 2020.

ZHANG, H. \& WEI, C. A Survey of Legislative Responses to Covid- 19 by Chinese Provinces. NBC Observer, 17 May 2020. Disponível em: <https://npcobserver.com/2020/05/17/a-survey-oflegislative-responses-to-covid-19-by-chinese-provinces/>. Acesso em: 18 set. 2020. 


\section{0 \\ Covid-19 \\ o impossível America first \\ Santiago Alcázar}

s Estados Unidos da América (EUA) tiveram papel crucial na criação das Nações Unidas e dos organismos que emanaram do Acordo de Bretton Woods, o Acordo Geral sobre Tarifas e Comércio (Gatt), o Banco Mundial e o Fundo Monetário Internacional (FMI). Havia um otimismo entre os seus líderes, que acreditavam que a força de sua moeda e a defesa de valores como liberdade, democracia e direitos humanos seriam suficientes para conter ameaças à sua pretendida hegemonia de poder. Tudo parecia possível para aquele país firmemente assentado na ciência e na tecnologia. A Guerra Fria, no entanto, reclamava atenção e fazia ver que havia um outro lado. As tensões eram constantes, assim como a ameaça de uma possível extinção.

Diante da incerteza do amanhã, afrouxaram-se os laços da comunidade, o que permitiu que brotassem as sementes do individualismo, não como mera possibilidade, mas como projeto econômico, social e político. A vitória de Ronald Reagan com a bandeira da desregulação foi a fórmula para turbinar a economia, derrotar os democratas e sufocar o adversário, que colapsaria em pouco tempo. A visão unidimensional levaria a ações unilaterais, de que é exemplo a segunda guerra do Iraque. Os EUA pareciam deixar de lado a construção do sistema das Nações Unidas, que eles mesmo haviam ajudado a erguer. O presidente Donald Trump acentuaria ainda mais a perspectiva unidimensional, com a denúncia de acordos internacionais e a saída de organismos multilaterais.

\section{OS ESTADOS UNIDOS, AS NAÇÕES UNIDAS E A PANDEMIA}

Ao refletir sobre os 75 anos da criação da Organização das Nações Unidas (ONU), seria proveitoso estender o olhar para toda a sua arquitetura, e não apenas fixálo naquela saliência que, por estar mais à frente, parece dominante. Fazem parte do 
sistema, ademais de seus seis órgãos constitutivos, 15 agências especializadas, II programas e fundos, múltiplos conselhos, comissões, comitês e secretariados. A estrutura é complexa e pode dar a sensação de passos perdidos em um labirinto. Há, no entanto, uma lógica que permeia todo o imponente edifício e constitui o fio de Ariadne para guiar os incautos que nele se aventuram sem referências. Todas as partes têm o mesmo propósito: normatizar. As agências especializadas não têm outro objetivo e as demais partes elaboram ou contribuem para elaborar normas. A Organização Mundial da Saúde (OMS), por exemplo, produz normas sanitárias para consideração dos Estadosmembros, que após exame as modificam e adotam. O consenso, nesse contexto, é importante para a solidificação da norma, que passa assim a ser a norma a seguir. A Convenção para o Controle do Tabaco é um exemplo, assim como também o é o Regulamento Sanitário Internacional.

Essa é, talvez, a principal diferença entre o mundo que foi deixado para trás e o do pós-guerra. Ao passo que aquele parecia uma avenida sem demarcações e sinalizações, por onde cada um trafegava em confusões babilônicas, este procura ordenar o fluxo de comércio global, primeiro com o Gatt e depois com a sua sucessora, a Organização Mundial do Comércio (OMC); a estabilidade financeira internacional, com o FMI; os empréstimos para o desenvolvimento, com o Banco Mundial, e assim por diante. Uma típica Assembleia Geral adota mais de trezentas resoluções, o que demonstra o elevado grau de concordância entre os países sobre diversos assuntos.

É forçoso reconhecer que grande parte dessa imponente arquitetura do pós-guerra é o resultado da ação dos EUA, que com seu entusiasmo pela criação e fortalecimento de instituições, com a confiança de que a força de sua moeda, usada no esforço de reconstrução levado a cabo pelo Plano Marshall, e a defesa de valores como liberdade, democracia e direitos humanos seriam suficientes para conter a ameaça do avanço do outro regime, adversário, que também disputava a hegemonia do poder.

O mundo multilateral nascente tinha a ambição de estabelecer um sistema internacional integrado, com capacidade de previsão, como a da Organização Mundial de Meteorologia (OMM); de velar pelo fluxo aéreo, como a Organização Internacional de Aviação Civil (OIAC) e até acordar nomes geográficos, sob a responsabilidade do Grupo das Nações Unidas sobre Nomes Geográficos (UNGEGN, na sigla em inglês). O multilateralismo era, assim, a resposta à crescente complexidade do mundo do pósGuerra, que corria para enfrentar os desafios lançados pela aparentemente inesgotável energia do que vinha rotulado como modernidade. Era então preciso disciplinar aquela explosão vulcânica que, se deixada em seu próprio curso, traria de volta os piores temores da geração que havia assistido da primeira fila aos horrores da guerra e a um nível de destruição inédito na história da humanidade. 
Cabe esclarecer que havia multilateralismo no período entreguerras. A Liga das Nações e o Birô Internacional do Trabalho, o nome original da OIT, são talvez os exemplos mais emblemáticos. Os anos 20, contudo, foram marcados por revanchismos e exigências insensatas, que foram alimentando um ambiente de suspeitas mútuas, nada propícias para o assentamento da confiança naquelas instituições. Era aos pés dos grandes nomes das políticas nacionais de então que se depositavam as esperanças, como se a grandeza atribuída a eles fosse suficiente para guiá-los para um futuro brilhante. Como se sabe, o único brilho que se viu depois foi o da luz refletida nos metais das armas produzidas em massa, porque era necessário precaver-se contra o outro, que não era confiável, e assim por diante. A Liga e a OIT ainda tentaram buscar soluções de consenso no início da Grande Depressão. O ambiente, no entanto, não era favorável. Não seria legitimo descartar que se tivesse havido, naquele momento, cooperação entre os bancos centrais das maiores economias, é possível que se tivesse evitado o colapso em escala global. Mas a cooperação não se materializou, e cada um dos que podiam contribuir para a solução fechou-se como ostra em mar protecionista. A depressão estendeu-se até 1939 , e teria durado mais se não tivesse eclodido outra guerra mundial, de novo, a segunda no século, mais cruel e devastadora que todas as outras.

É contra esse pano de fundo, que lembrava Guernica, que se criou o sistema multilateral, com o propósito de formular, estabelecer e difundir normas e recomendações para ordenar a complexidade de relações do mundo moderno. Havia entendimento de que a Torre de Babel não era o modelo a ser adotado para os muitos desafios que viriam. Havia também boa-fé entre alguns, e café para os mais calejados, que faziam reservas porque não podiam desvencilhar-se do déjà-vu que os acompanhava como encosto.

O mundo que se seguiu foi, assim, mais previsível, sem enfrentamento direto entre as grandes potências. A economia americana disparou e alcançou níveis invejáveis. Tudo parecia possível, porque a lanterna da ciência estava ao alcance de todos e a tecnologia apresentava-se para oferecer soluções para tudo. Não havia desconhecido que não pudesse ser conhecido, nem escuridão que não pudesse ser iluminada. Havia otimismo e ouvia-se jazz. Para grande felicidade dos americanos, muitos os tinham como exemplo e faziam tudo para imitá-los, nas vestimentas, no gosto pelo rock'n roll e nas maneiras saciadas com Coca-Cola. Os EUA deixavam de ser uma extensão territorial para se transformarem em um modo de ser espalhado pelo mundo. Universidades magníficas, indústria pujante, empregos com níveis salariais suficientes para que alguém sem educação pudesse ter uma casa boa, num bairro bom, com carro na garagem e filhos estudando em boas escolas públicas. O American dream era mais do que um sonho: era uma realidade ao alcance de todos. 
A Aliança Atlântica era, como o nome indica, um pacto costurado entre aliados que confiavam um no outro. E por que seria de outra maneira? Afinal, a nação que havia derrotado a varíola e a poliomielite e compartilhava o conhecimento para que outros pudessem fazer o mesmo era digna de crédito. Ademais, a liderança absoluta em inovações em todas as áreas era inquestionável.

Naquele mundo, Hollywood encarregava-se de maquiar as falhas e deficiências para que a imagem, se não a realidade, fosse perfeita. Havia, contudo, um incômodo que nenhum roteirista podia ignorar. O outro, o adversário que também arregimentava seguidores e imitadores. Retratado com sobrancelhas pesadas e bigodes espessos, o adversário, diziam, era terrível. Tinha as mesmas capacidades, fazia foguetes, aviões e bombas temíveis. Mas os carros, como eram feios, e ruins. Ninguém trocaria um Chevrolet por um deles.

O mundo dividia-se em dois campos, um mais apegado à liberdade, outro mais afeito à igualdade. A fraternidade aconchegava-se mais a esta última, mas não vacilava em cruzar fileiras quando entoavam canções de gospel nas tardes quentes de verão. À chamada da Internacional, os outros respondiam com Elvis e os Beatles. Nos dois lados as aglomerações eram enormes. A tensão era grande e uma geração inteira aprendeu a viver como se não houvesse um amanhã. Talvez tenha sido isso, não é certo, mas os laços que prendiam os indivíduos a uma comunidade foram se desfazendo. Se a morte e a destruição completas são uma possibilidade real, argumentavam, então para que o compromisso e a responsabilidade com a comunidade? As sementes do individualismo exacerbado estavam lançadas, e era só esperar para que o fermento da discórdia fizesse o resto. Não haviam feito o mesmo com os núcleos atômicos, que uma vez desobrigados das forças que os mantinham unidos liberavam uma quantidade assombrosa de energia? Desapegado da comunidade que o mantinha atado, o indivíduo também poderia liberar uma energia inimaginável, sugeria a lógica de similitudes.

O individualismo era, e é, um fenômeno global, mas foi nos States que alcançou sua maior expressão. A conclusão dos anos de colégio é a passagem para a liberdade. O jovem estudante que vai ao college escolhe uma instituição longe de casa. Depois, concluída essa etapa, escolhe um trabalho longe do college e da família, numa corrida para a frente, sem retrovisor e no regrets. A energia vulcânica parecia descontrolar-se. Tudo era questionado e a relatividade de Einstein, que nada tinha a ver com isso, era invocada para dizer que não havia certezas.

No plano político norte-americano a disputa era entre republicanos e democratas. As tensões da Guerra Fria, no plano externo, continuavam, e a pergunta "capitalismo ou socialismo?" pairava no ar. Nas eleições presidenciais de 1980, os republicanos 
entenderam que tinham a resposta. O capitalismo desimpedido, sem travas, daria sentido ao mercado, sufocaria a alternativa e exibiria uma capacidade de atração nunca antes vista. A vitória esmagadora de Ronald Reagan em 1980, montado no princípio da desregulamentação, parecia uma comprovação. A desregulamentação era uma espécie de varinha mágica que poria abaixo todas as normas e regulamentos, ainda que criados para disciplinar e proteger o sistema econômico de ações predatórias. Mágica porque, ao extinguir o edifício de normas, os custos de produção cairiam, levando junto os impostos e, como era lógico esperar, a necessidade de tanto Estado, que encolheria e reduziria suas funções ao mínimo. O Estado sempre foi a pedra no sapato dos republicanos. A fórmula encontrada parecia perfeita e seria propagada aos quatro ventos. Desregulamentar para reduzir os impostos e encolher o Estado era o caminho a ser seguido, a Via Ápia moderna por onde passariam a transitar as políticas econômicas de corte neoliberal. Tudo parecia bem, no melhor dos mundos. Os negócios iam de vento em popa. As críticas e os protestos eram silenciados pelo sopro do vento.

O êxito da escolha republicana seria medido pelo desmoronamento do bloco soviético, bem como pela conversão dos democratas à nova seita. Estes passaram a ser mais realistas que o rei e a dizer àqueles, como se estivessem a ensinar o pai-nosso ao vigário, "It's the economy, stupid!", durante a campanha que eventualmente levaria Bill Clinton e os new democrats à Casa Branca. Haviam entendido, assim como antes os republicanos, que para ser competitivos na arena política teriam de se reinventar e se mostrar mais atrativos naquele ambiente político. Foi o que fizeram. Nos anos 80 , moveram-se à direita em termos econômicos, tornando-se idênticos aos republicanos, a ponto de terem conseguido mais êxito que eles no desempenho dos negócios (Glover, 2016). Para evitarem a descaracterização, mantiveram uma roupagem cultural de esquerda (a cultural liberal, expressão usada nos EUA), simpática a um leque de causas antipáticas aos republicanos, com especial ênfase nas demandas de uma população de classe média, branca e urbanizada. Divididos dessa maneira esquizofrênica, os democratas ignoraram as causas que favoreciam o aumento das iniquidades que nenhuma cultura progressista poderia impedir. O mantra de Milton Friedman, "There is no such thing as a free lunch", sugeria a imagem de um dedo acusador contra a traição dos democratas, que passariam a se interessar exclusivamente pelo êxito nas eleições, ainda que ao custo de perder o segmento da população que sempre lhes dera votos. Não é de estranhar que, àquela época, muitos cruzaram as fileiras para o lado republicano, complicando ainda mais a tarefa de entender a paisagem política daquele país.

Havia, ainda, uma ordem internacional e um respeito às instituições multilaterais. "Guernica" era um quadro e muitos não lembravam mais o que o havia motivado. O original, que estivera em Nova York até depois da morte de Franco, voltara à Es- 
panha. Em 1955, Picasso encomendara aos tecelões da famosa casa Aubusson três reproduções, na mesma escala ciclópica. Nelson Rockefeller, que era um admirador, comprou uma delas, doada às Nações Unidas pela família em 1985. A magnífica tapeçaria "Guernica" foi pendurada no hall que conduz à sala do Conselho de Segurança, certamente como uma advertência a todos os que se aventurassem a nela entrar.

O tempo continuou previsível, mas havia nuvens no horizonte que poderiam trazer surpresas. Na manhã de terça-feira, I I de setembro de 200 I, tudo iria mudar e o mundo nunca mais seria o mesmo. Milhares de mortos e feridos, graves sequelas respiratórias e uma humilhação sem precedentes. Fazia-se urgente uma resposta que o clamor popular reclamava. A dificuldade, contudo, era equacioná-la, pois o grupo terrorista Al-Qaeda havia assumido a responsabilidade. Estados respondem aos Estados. $\mathrm{O}$ ataque a Pearl Arbor levara os EUA a entrarem na II Guerra, mas o que se faz contra um grupo terrorista permeável a todas as fronteiras? As discussões cheias de raiva e indignação subiram de tom até se tornarem perigosas por resvalarem na irracionalidade.

Em 4 de fevereiro de 2003, o secretário de Estado Colin Powell iria ao Conselho de Segurança para apresentar o caso a favor de uma intervenção militar contra o Iraque. $\mathrm{Na}$ véspera, à noite, os assessores davam os últimos retoques na antessala do Conselho de Segurança onde, no dia seguinte, o secretário se posicionaria em frente às câmeras de TV. A tapeçaria "Guernica" foi encoberta com pano azul, a mesma cor da bandeira das Nações Unidas. Disseram que era somente para diminuir a informação visual e realçar a figura do secretário de Estado. De qualquer jeito, "Guernica" nunca fora anteriormente encoberta e aquele gesto sugeria uma licença para ignorar a advertência.

O fim já havia acontecido. Agora era o começo. Pôr abaixo as normas e as regulamentações, os compromissos e as responsabilidades de todo o sistema multilateral para dar livre curso à fúria vulcânica do indivíduo que quer fazer justiça com as próprias mãos, como num duelo em pleno sol, numa cidade empoeirada.

A guerra no Iraque foi a concretização da irracionalidade. Tudo parecia virado de cabeça para baixo. A raiva contra os EUA aumentou consideravelmente, como era de se esperar, mas agora também havia uma repulsa contra as Nações Unidas. A explosão que matou Sérgio Vieira de Mello foi um claro sinal de que a organização que havia sido criada para preservar as futuras gerações da loucura das guerras e da destruição era vista por alguns como sócia do aniquilamento absurdo que estavam testemunhando em seu próprio país.

A história nunca é linear. Os passos são erráticos, cheios de voltas. O olhar distrai-se com a profusão de imagens produzidas por um mundo profundamente interconectado. 
Perde-se a floresta, mas não se ganha necessariamente a árvore. Na confusão deixa-se escapar muita coisa, inclusive o bom senso, que, segundo o racionalista Descartes, é a coisa mais bem repartida no mundo.

O espírito individualista não combina bem com normas e regulamentos. Tampouco com acordos internacionais. Estes são vistos como instrumentos que tolhem a liberdade e a criatividade. Devem, por isso, ser descartados. Na era da inovação, é preciso confiar na capacidade de alguns, nos que perscrutam a realidade e encontram pepitas de oportunidades. Assim reza a nova doutrina libertária, que vê nos acordos internacionais um estorvo. A medula individualista não pode confiar em nenhum grupo com mais de uma pessoa, mas todos sabem que isso é um exagero e não deve ser levado a sério.

O presidente Donald Trump elegeu-se com o mote America first. No pronunciamento que fez em frente ao Capitólio, na cerimônia de posse, deixou claro que na sua gestão os EUA trilhariam o seu próprio caminho de maneira livre e desimpedida. Não mais seriam o guia que ajuda os outros, com grande dispêndio de esforço e energia e, pior, sem reconhecimento. Nos dias seguintes ampliou aquele anúncio com o esclarecimento de que o país faria única e exclusivamente a defesa intransigente de seus próprios interesses e não se envolveria mais em guerras que ninguém entendia nem sabia ao certo onde se desdobravam. Os amigos históricos terão tossido nervosos ao tomarem conhecimento daquelas palavras que diziam, sem sombra de dúvida, que seriam largados no meio do caminho, sem esperança de socorro em caso de necessidade. Preocupava a eles a Rússia de Putin, que anexara sem vacilar a Crimeia, em resposta, é verdade, à possível expansão da Organização do Tratado do Atlântico Norte (Otan) a leste, mas isso não era importante agora. Também causava alarme o modo como os russos haviam ocupado a Síria sem cerimônia, para evitar que eles fizessem o mesmo. Agora, caso eles, os russos, olhassem para oeste, o que poderia advir? E ainda havia a China, cada vez mais saliente e assertiva, aos seus olhos. Onde estava o bom senso? E o sistema que havia garantido a paz e a segurança do pós-guerra?

Enquanto aquelas perguntas iam sendo levantadas, Trump ia retirando o seu país de uma lista de acordos e instituições: o Acordo de Paris, sobre mudança do clima; o Plano de Ação Conjunto Global (JCPOA, na sigla em inglês), sobre o teto para estoque de urânio enriquecido que o Irã deveria respeitar; a Organização das Nações Unidas para a Educação, a Ciência e a Cultura (Unesco), o Conselho de Direitos Humanos... A cada retirada da principal potência mundial de um daqueles arranjos enfraquecia-se o multilateralismo, a ponto de alguns porem em dúvida a sua eficácia em uma eventual futura grande crise. 
"Que crise?", poder-se-ia perguntar. O risco de uma crise política era inexistente. A crise financeira de 2007-2008 tinha sido uma tribulação de bancos. Uma crise sanitária era possível, mas a última, a do ebola, havia sido contida com eficácia. O caminho isolacionista parecia seguro e proveitoso.

A Covid- 19 mudou tudo isso. Em 9 de março deste ano, as negociações em bolsas foram interrompidas por um algoritmo que havia disparado quando, aos 4 minutos da abertura dos mercados, os valores despencaram verticalmente. Era a primeira vez que, desde o início da crise de 2007-2008, o circuit breaker fora acionado. Nos dias seguintes assistiu-se de novo, com crescente apreensão, ao disparo automático daquele algoritmo. As perdas não estavam na casa dos bilhões, mas na dos trilhões. O mundo havia parado, literalmente.

A pandemia era a maior ameaça que o mundo testemunhara desde a II Guerra. Seu impacto sobre os mercados era comparável ao da Grande Depressão. A interrupção nas cadeias de produção e distribuição reduziria as trocas comerciais aos níveis de muitos anos atrás. Colégios e universidades fechados ameaçavam o futuro de uma geração de jovens. Aumento brutal do desemprego na economia formal e perdas incalculáveis de postos de trabalho na economia informal. Pedidos de concordatas em série.

Grande número de internações hospitalares provocou o colapso de sistemas de saúde. Médicos e enfermeiros exaustos, algumas vezes incapazes de prestar atendimento por falta de material: respiradores, máscaras e luvas apropriadas. Caminhões frigoríficos para acolher os mortos. Coveiros esgotados. A evocação do caos talvez não seja suficiente para descrever aquele estado de coisas. A imagem que vem à mente é a do "Triunfo da morte", a pintura renascentista de Pietr Bruegel.

Esperava-se uma resposta à altura dos acontecimentos. As Nações Unidas e a OMS saíram à frente, com recomendações, programas e estratégias que contaram com o decidido apoio da comunidade internacional. Esperava-se que Trump voltasse atrás na sua decisão de cortar laços com ela, pois saltava à vista que para enfrentar a Covid- 19 era preciso o esforço de todos, trabalhando na mesma direção.

As falas do presidente de 20 de janeiro a 18 de março podem ser acessadas na linha do tempo disponível, por exemplo, no site da CBS News (Watson, 2020). As avaliações variam: "temos um plano", "tudo está sob controle", "em alguns dias os casos irão desaparecer", "fiquem calmos". No dia 18 de março, o presidente pareceu diferente. A esperança voltou, por um instante. Naquele dia, com efeito, no briefing na Casa Branca, Trump se definiu como um presidente em tempo de guerra. Com as inspiradoras palavras "Now it's our time. We must sacrifice together, because we are all in this 
together, and we will come through together", o presidente Trump parecia pronto para abraçar o espírito que levou a grande nação norte-americana a combater o inimigo comum durante a II Guerra. Não foi o que aconteceu. Nos dias seguintes voltaria a minimizar a importância do novo coronavírus.

O número de contaminações e óbitos cresceu vertiginosamente. O que para muitos era chocante. O país da ciência e da tecnologia, a potência mundial, referência para muitos, tornara-se um exemplo do que não deveria ser feito. A popularidade do presidente começou a se abalar. Como sempre, era preciso encontrar um bode expiatório. A China. E a OMS.

No primeiro dia da $73^{\text {a }}$ sessão ordinária da Assembleia Mundial da Saúde, em 18 de maio, soube-se que Trump havia encaminhado carta ao diretor-geral da OMS, na qual informava que, caso esta não passasse por reformas substanciais nos próximos 30 dias, a suspensão do pagamento da contribuição norte-americana seria permanente. As reformas a que se referia Trump eram relativas, principalmente, a pôr um fim à alegada influência chinesa naquela organização. A carta é um bom exemplo de não diplomacia, talvez inédito. Antes do final daquele mês veio o anúncio da retirada dos EUA da OMS, em plena pandemia da Covid-19. Mais um abandono num mundo que reclamava, e reclama, união.

A decisão do presidente Trump parecia seguir um padrão. Anteriormente, com efeito, no início de maio, ele havia informado que os EUA não participariam do esforço liderado pela União Europeia e o Grupo dos Vinte (G20) para desenvolver uma vacina contra a Covid-19. Em junho anunciaria a decisão de retirar as tropas estacionadas na Alemanha, aparentemente em resposta ao fato de a chanceler alemã, Angela Merkel, não ter comparecido à reunião do G7 realizada em Washington. Merkel alegou a pandemia para não comparecer. Trump teria entendido de outra maneira. Que tipo de consideração teriam motivado mais essa retirada? Non sequitur talvez seja a expressão que melhor expressa o que para alguns observadores parecia difícil entender. Em todo caso, Berlim não teria sido previamente comunicada.

Se há uma coisa que a Covid- I 9 ensina é que para combatê-la é preciso o esforço de todos os governos e de todas as sociedades. A vacina virá, ou não. Ninguém sabe, como tampouco se será efetiva a imunidade por ela oferecida. Neste contexto, a única coisa razoável a fazer é procurar fortalecer os laços de união e velar para que ninguém seja deixado para trás, como a promessa da Agenda 2030. É preciso insistir: a Covid- 19 resistirá a qualquer tentativa de solução unilateral. Ninguém estará seguro se todos não estiverem seguros. Pode-se, talvez, pensar que outras questões também exigem a união 
de todos para o encaminhamento de soluções, como a mudança climática, por exemplo. É verdade, mas há uma diferença crucial. A pandemia da Covid- 19 faz a hora, não espera acontecer, como na canção. O desastre é visível aqui e agora, e não para de aumentar a cada instante. A mudança climática é uma realidade inexorável, mas mais lenta.

O lema solipsista America first será confirmado ou abandonado em novembro deste ano. Na primeira hipótese, a saída dos EUA de organismos multilaterais e a denúncia de acordos internacionais significará o abandono de seu papel de ator principal no plano externo. Sua capacidade de aglutinar, influir e liderar no campo diplomático ficará seriamente comprometida, se não extinta. O espaço vazio terá de ser preenchido de alguma maneira. Uma possibilidade é a China. Outra, mais provável, é o próprio multilateralismo, que poderá ser reformado, ajustado e modificado, mas terá que ser um instrumento coletivo que priorize de maneira conjunta e urgente as necessidades da comunidade humana e as do planeta. Na segunda hipótese, a de abandono da bandeira de Trump, o caminho à frente será difícil e não sem riscos, pois os EUA já perderam a credibilidade para propor soluções que beneficiem a todos. Como se sabe, a credibilidade é algo que custa muito caro e muito tempo. Para perdê-la, basta um instante e um gesto impensado.

Muito se tem dito sobre a distância que ainda separa a China dos EUA. Medida pela distribuição per capita da riqueza produzida, a distância, de fato, é ainda grande. Mas é provável que a medida que interessa não seja a do produto interno bruto (PIB) per capita, mas a que define a desigualdade. No imediato pós-guerra, os EUA eram o país mais rico do mundo e a desigualdade era menor. Os salários dos CEOs eram aproximadamente vinte vezes superiores aos de seus empregados de médio escalão. Hoje são quatrocentas vezes maiores. Naqueles anos, a energia extraordinária daquele país era suficiente para reconstruir o mundo e exercer liderança em todas as áreas. É possível que aquela energia dependesse de um certo grau de desigualdade que, quando ultrapassado, torna-se menor. Não há dúvida de que os EUA perderam o apetite para liderar. Talvez seja uma questão de energia, ou de falta dela. A China, por outro lado, é um país com menor grau de desigualdade, mas com um apetite incomensurável. É possível que esteja a caminho de se tornar desigual, como hoje os EUA. Mas a distância é grande ainda.

Novembro virá. A Covid- 9 não irá desaparecer como num passo de mágica, e muito menos com a fórmula America first. É impossível.

A pandemia da Covid- 19 demonstraria o absurdo da opção America first. A pandemia atinge a todos, ao mesmo tempo. Não há primeiro porque não há segundo. Ninguém 
estará seguro se todos não estiverem seguros. É impossível. Ainda assim, aquela opção já produziu efeitos deletérios, certamente permanentes. A credibilidade norte-americana, antes aceita, é hoje globalmente contestada. A denúncia de acordos e a retirada de organismos gera vazios que têm que ser preenchidos.

Especula-se sobre a possibilidade de a China vir a ocupar aqueles vazios deixados pelos EUA. Essa mudança na configuração do poder global parece sugerir uma nova arrumação de cadeiras. Na complexidade do mundo de hoje, com a possibilidade de novas pandemias, talvez mais severas, e com o grave estado de saúde do planeta, tal mudança, vista na perspectiva ampla da realidade, é insignificante e, por isso, irrelevante. O desafio do pós-pandemia é algo maior: a construção de possibilidades, como no espírito da Carta de São Francisco, para salvar o planeta e a humanidade de uma iminente catástrofe, talvez definitiva.

\section{REFERÊNCIAS}

GLOVER, J. Trump is right about one thing: "the economy does better under the Democrats". Forbes, 7 Nov. 2016. Disponível em: < https://www.forbes.com/sites/realspin/2016/11/07/trump-is-rightabout-one-thing-the-economy-does-better-under-the-democrats/\#4b830b606786>. Acesso em: 18 set. 2020.

WATSON, K. A timeline of what Trump has said on coronavirus. CBS News, 3 Apr. 2020. Disponível em: $\quad<$ https://www.cbsnews.com/news/timeline-president-donald-trump-changing-statementson-coronavirus/>. Acesso em: 18 set. 2020. 




\section{Fiocruz como Ator da Saúde Global}

Ana Helena Gigliotti de Luna Freire, Ilka Maria Vilardo Montefinese, Letícia Cristina Pereira de Castro, Luciana Peixoto Affonso,

Luiz Eduardo Fonseca e Paulo Marchiori Buss

A Fundação Oswaldo Cruz (Fiocruz) é uma instituição pública e estratégica de saúde, vinculada ao Ministério da Saúde. Nos seus 120 anos de existência, tornou-se uma das mais eminentes instituições de ciência e tecnologia em saúde da América Latina. Sua missão é

produzir, disseminar e compartilhar conhecimentos e tecnologias em saúde voltados para o fortalecimento e a consolidação do Sistema único de Saúde (SUS) e que contribuam para a promoção da saúde e da qualidade de vida da população brasileira, para a redução das desigualdades sociais e para a dinâmica nacional de inovação, tendo a defesa do direito à saúde e da cidadania ampla como valores centrais. (Fiocruz, 2020a)

A atuação internacional da Fiocruz se iniciou desde a sua própria criação e até hoje se desenvolve em função tanto de demandas advindas do reconhecimento de sua excelência e de seus princípios de solidariedade quanto de seu empenho em desenvolver e aprimorar suas potencialidades. O VIII Congresso Interno da Fundação, realizado em 2018, estabeleceu, em sua Tese 10, que "a Fiocruz se faz presente e está comprometida com um mundo mais solidário e igualitário, por meio da cooperação técnica internacional, baseada nos conceitos de diplomacia da saúde e ciência e tecnologia em saúde no contexto da saúde global" (Fiocruz, 2018).

Como reflexo da multidisciplinaridade peculiar e característica da Fiocruz, o presente capítulo pretende apresentar um diverso e resumido rol, não exaustivo, de aspectos da atuação internacional da fundação no cenário pandêmico de 2020, envolvendo diversos atores institucionais, eixos de atuação, formas de cooperação e parceiros internacionais. 


\section{ATUAÇÃO INTERNACIONAL DA FIOCRUZ NO ENFRENTAMENTO DA COVID-19}

A Fiocruz surgiu para responder a grandes desafios sanitários do século $X X$. Em 2020, se defronta com uma situação de gravidade humanitária ímpar e, da mesma forma, honra sua história e trajetória, mantendo-se a serviço da sociedade brasileira, na busca por soluções que enfrentem os grandes desafios trazidos pela pandemia causada pelo novo vírus Sars-Cov-2. A instituição tem atuado em diferentes linhas de ação, que podem ser agrupadas em torno de seis eixos principais (Fiocruz, 2020b):' apoio a diagnósticos; atenção à saúde; pesquisa e produção de medicamentos e vacinas; informação e comunicação; apoio às populações vulnerabilizadas; educação.

As diversas iniciativas de enfrentamento da Covid-19 são levadas a cabo no âmbito de um contexto institucional que pode compreender a articulação de suas vicepresidências com as unidades, centros e escritórios, como também ações de caráter mais descentralizado, partindo de um ou mais de seus vários institutos (ou unidades), laboratórios ou indivíduos (dentro de suas atribuições profissionais). Essas diferentes fontes desafiam o mapeamento completo das ações, o que não impossibilita identificar que um expressivo conjunto delas tem alcance internacional, notadamente nas esferas da pesquisa, do desenvolvimento tecnológico e da informação e comunicação.

O Centro de Relações Internacionais em Saúde (Cris/Fiocruz) secretaria a Câmara Técnica de Cooperação Internacional da Fiocruz (CTCl), instância consultiva que congrega as assessorias internacionais das vice-presidências e dos institutos (unidades técnicocientíficas) e centros da fundação. Neste capítulo são abordadas as principais parcerias internacionais estabelecidas pela instituição no contexto da pandemia, com base nas informações fornecidas por esta comunidade institucional de relações internacionais que é a CTCI Fiocruz.

Em levantamento realizado com os membros da CTCl em maio de 2020, identificou-se que a maior parte das atividades internacionais da Fiocruz para o enfrentamento da Covid- 19 estava concentrada nas áreas de pesquisa e de informação e comunicação em saúde, ainda que muitas vezes tangenciando a área de diagnóstico e ensaios/estudos clínicos. Levando-se em conta que o eixo Pesquisa compreende também o desenvolvimento e produção de medicamentos e vacinas, esta é uma área de atuação relevante da instituição, com destaque para as atividades relacionadas à parceria internacional para desenvolvimento de uma vacina entre Bio-Manguinhos, a Universidade de Oxford e a biofarmacêutica AstraZeneca, do Reino Unido.

\footnotetext{
I Programa Sexta de Conversa, com a presidente Nísia Trindade, exibido em I9 jun. 2020.
} 
As demandas externas que integram a agenda internacional também têm se concentrado na área da pesquisa. No âmbito da Organização Mundial da Saúde (OMS), a presidente da Fiocruz, Nísia Trindade Lima, tem participado das reuniões periódicas de saúde global, que congregam lideranças de instituições governamentais, organismos internacionais e academia, para discutir avanços nas medidas de enfrentamento da pandemia nos diferentes países, compartilhar lições aprendidas e debater desafios e o papel da OMS no apoio aos países-membros.

Antes mesmo de a pandemia ter sido declarada pela OMS, a Fiocruz participou do Fórum Global de Pesquisa e Inovação (Global Research and Innovation Forum on Covid-19), realizado na sede da OMS em Genebra, em fevereiro de 2020, com mais de 400 cientistas de todo o mundo, no qual se iniciou a mobilização internacional na resposta à Covid-19. A presidente foi uma das debatedoras e coordenou sessões de definição de prioridades para uma agenda de pesquisa global (Dias, 2020a). A segunda edição desse fórum aconteceu de forma virtual em julho, envolvendo mais de 1.200 pesquisadores e estudiosos que trabalharam em colaboração, compartilhando métodos e dados em nove grupos de trabalho, dos quais três tiveram participação da Fiocruz: Caracterização e manejo clínico; Terapêuticas; Ciências sociais. Pautado pelas principais atualizações do eixo Pesquisa e Desenvolvimento na temática da Covid-19, o fórum buscou reportar os principais avanços e questões que ainda precisam de respostas e elaboração (Patnaik, 2020). Como resultado, destaca-se um plano de pesquisa global, com a identificação das questões emergentes de pesquisa, das principais lacunas científicas e de novas prioridades.

O estudo Solidarity também teve seus dados revisados no fórum. Este projeto da OMS visa a investigar a eficácia de quatro esquemas de tratamento para a Covid-19, por meio da conjugação de esforços de diversas instituições do mundo para oferecer rápida resposta sobre a eficácia dos medicamentos (Fiocruz lidera..., 2020). No Brasil, a iniciativa está, sob a coordenação da Fiocruz, sendo implementada em 18 hospitais de 12 estados brasileiros, para investigar a eficácia dos quatro tratamentos propostos: cloroquina (este posteriormente eliminado); remdesivir; combinação loponavir-ritonavir; e isolado ou combinado ao interferon beta- I a (Fiocruz lidera..., 2020). Nesta instituição, o estudo tem a coordenação do Instituto Nacional de Infectologia Evandro Chagas (INI) e conta com o apoio da Vice-Presidência de Produção e Inovação em Saúde (VPPIS) e de Farmanguinhos, que fornecerá parte dos medicamentos utilizados.

Reforçando o importante papel da Fiocruz como ator global no campo da saúde, a presidente Nísia Trindade participa ativamente de comissões internacionais (Lima, 2020), tais como: 
- Rede de Saúde para Todos da Rede de Soluções de Desenvolvimento Sustentável das Nações Unidas (https://www.unsdsn.org), como copresidente (20l9);

- Grupo consultivo da OMS do Acelerador de Pesquisa \& Desenvolvimento no plano de trabalho multiagencial para a implementação do Objetivo de Desenvolvimento Sustentável 3 (ODS3) da Agenda 2030 (2019);

- International Steering Committee for the Nairobi Summit on ICPD25 (2019) (Nairobi Statement, 2020);

- Grupo de aconselhamento ao Roteiro de Pesquisa das Nações Unidas para a Recuperação Covid- 19 (2020) (Dias, 2020b).

A Fiocruz integra um grupo de mais de 70 cientistas e instituições de mais de 30 países em uma coalizão internacional de enfrentamento da pandemia em países com renda média e baixa (Dias, 2020c). A iniciativa, chamada Covid- 19 Clinical Resarch Coalition (2020), visa a acelerar as pesquisas nas áreas em que o vírus pode causar sérios problemas em sistemas de saúde já fragilizados, resultando em maior impacto na saúde de populações vulneráveis. A coalizão reúne uma equipe multidisciplinar de especialistas em saúde, incluindo cientistas, médicos, institutos de pesquisa do setor governamental, ministérios da Saúde, academia, organizações sem fins lucrativos de pesquisa e desenvolvimento, organizações não governamentais (ONGs), organizações internacionais e patrocinadores, todos comprometidos em encontrar soluções para o Covid- 19 em ambientes com recursos limitados.

Por intermédio do Cris, a instituição participa da iniciativa da World Federation of Public Health Associations (WFPHA) e da Latin American Alliance for Global Health (Alasag), que submeteram carta às Nações Unidas intitulada "Iniquidade em saúde durante a pandemia: um grito por liderança ética global" (Sustainable Health Equity, 2020), endossada por diversas associações globais, nacionais e locais, propondo a formação de uma força-tarefa global para a defesa da equidade no enfrentamento a pandemia. A carta foi assinada por inúmeras pessoas e organizações consagradas e de relevância internacional.

No âmbito das vice-presidências da fundação, destaca-se a intervenção da VPPIS na formalização do acordo com AstraZeneca para compra de lotes e transferência de tecnologia da vacina desenvolvida pela Universidade Oxford e no apoio ao projeto Solidarity, especialmente no tocante ao estudo multicêntrico. A Vice-Presidência de Pesquisa e Coleções Biológicas (VPPCB) trabalha em novo alinhamento do biobanco (em construção) para diagnóstico, desenvolvimento de vacina e outros medicamentos, voltado para a atuação em uma rede global de enfrentamento das emergências 
sanitárias globais. Os esforços da Vice-Presidência de Educação, Informação e Comunicação (Vpeic) ofereceram suporte na repatriação dos brasileiros que estavam estudando no exterior e acompanhamento nos casos de maior dificuldade. Os alunos estrangeiros que não puderam voltar para seus países de origem foram testados e estão sendo acompanhados em suas necessidades. Sediando o Centro Colaborador de Saúde Pública e Ambiente da Organização Pan-Americana da Saúde (Opas), a VicePresidência de Ambiente, Atenção e Promoção à Saúde (VPAAPS) foi solicitada pelo organismo internacional a coordenar um webinário regional para apoiar os países da América Latina e Caribe na implementação de resolução da OMS que reforça ações relacionadas a água, saneamento e higiene nas unidades de saúde. A Vice-Presidência de Gestão e Desenvolvimento Institucional (VPGDI) e suas respectivas unidades técnico-administrativas e coordenações têm atuado com pleno suporte em muitas das atividades relatadas neste capítulo.

$\mathrm{Na}$ atuação mais individualizada por parte de unidades e laboratórios, um dos destaques internacionais é o Laboratório de Vírus Respiratórios e Sarampo, do Instituto Oswaldo Cruz (LVRS/IOC). Nomeado como Laboratório de Referência da OMS para a Covid- 19 nas Américas, passou a integrar a rede de laboratórios especializados da OMS para Covid-19. Nessa condição, o LVRS/IOC apoia os laboratórios da região, especialmente de países de média e baixa rendas, realizando sequenciamento genético de amostras para referência global; acompanhando a evolução do vírus e identificando mutações que possam ser relevantes para testes de diagnóstico, desenvolvimento de vacina e tratamentos; e desenvolvendo e programando métodos de ponta para ensaios. Ainda em fevereiro de 2020, especialistas do laboratório promoveram a capacitação técnica de profissionais de nove países da América Latina (Argentina, Bolívia, Chile, Colômbia, Equador, Panamá, Paraguai, Peru e Uruguai), sob os auspícios da Opas. O treinamento foi dedicado aos protocolos de análise preconizados pela OMS e já implementados no Brasil, de forma a preparar equipes de laboratórios desses países para responder à emergência sanitária.

Pesquisadores do IOC/Fiocruz, em parceria com a University College London, no Reino Unido, desenvolveram um novo protocolo para sequenciamento genético do novo coronavírus. A metodologia oferece ampla cobertura de todo o genoma do vírus e reduz falhas que possam ocorrer no processo. Além disso, permite sequenciar o genoma completo do patógeno diretamente em amostras de pacientes, sem a necessidade de procedimentos de isolamento viral. Com o novo protocolo, os especialistas já decodificaram 54 genomas completos do novo coronavírus, referentes a amostras de pacientes de seis estados do Brasil. O trabalho amplia o conhecimento sobre os 
vírus causadores da enfermidade no país, expandindo significativamente o número de sequências genéticas disponíveis e incluindo dados na plataforma GISAID (2020), que promove o compartilhamento de informações genômicas sobre os vírus influenza, sincicial respiratório e Sars-CoV-2 (Fiocruz..., 2020).

O IOC também participa de um grupo interdisciplinar para o desenvolvimento de estudos sobre a Covid-19, a iniciativa chamada COV-IRT, Covid-I 9 International Research Team. O grupo de pesquisa utiliza um modelo de grande consórcio de ciência aberta para melhorar de maneira eficiente e rápida o entendimento do novo coronavírus, identificar alvos terapêuticos em potencial para a doença e desenvolver uma vacina segura e eficaz. A iniciativa prevê a utilização de abordagens interdisciplinares com a participação de especialistas em big data, ciência de dados e bioinformática.

Além da coordenação do estudo internacional, conduzido com a OMS, o INI/Fiocruz tem desenvolvido parcerias internacionais nas áreas de pesquisa, assistência, estudos clínicos e tratamento, notadamente com os Estados Unidos da América (EUA), das quais se destacam:

- Estudo prospectivo de respostas imunológicas agudas à infecção por SarsCoV-2 - Integra a CoVPN (Coronavirus Prevention Network), rede formada pela fusão de outras redes financiadas pelo Instituto Nacional de Alergia e Doenças Infecciosas dos EUA (NIAID/NIH), que visa a atender à necessidade premente de vacinas e anticorpos monoclonais (mAbs) contra o Sars-CoV-2 (CoVPN, 2020). Seu objetivo é desenvolver e conduzir estudos para garantir a avaliação rápida e completa de vacinas e anticorpos monoclonais para a prevenção da doença. O estudo do INI inscreverá participantes que tenham resultado positivo para o vírus Sars-CoV-2 por RT-PCR, procurando recrutar 400 participantes em três grupos clínicos: assintomáticos, pacientes sintomáticos não hospitalizados e pacientes sintomáticos hospitalizados.

- Adaptive Platform Treatment Trial for Outpatients with Covid-19 (Adapt Out Covid) - Estudo integrante da rede Aids Ensaio Clínico Grupo (ACTG), financiado pelos Institutos Nacionais de Saúde dos EUA (NIH), que visa a avaliar a eficácia e a segurança de agentes para o tratamento de adultos com Covid- 19 sintomáticos não hospitalizados.

- Plasma Convalescente - Ensaio clínico randomizado de fase 2 para avaliar a eficácia e a segurança de plasma humano convalescente anti-Sars-CoV-2 em adultos gravemente enfermos com Covid-19, em parceria com a Universidade Columbia, EUA. 
- Estudo de fase III, randomizado, duplo-cego, multicêntrico, para avaliar a eficácia e a segurança do remdesivir com tocilizumabe em comparação ao remdesivir com placebo em pacientes hospitalizados com pneumonia grave pela Covid- 19.

- Projeto One Health - Colaboração entre o INI e o Instituto Canadense de Pesquisa em Saúde (ClHR), que conta com a participação de Equador, México e Ruanda.

Também se dedicando à pesquisa, porém com foco em diagnóstico, estudos clínicos e desenvolvimento de vacinas para Covid-19, Bio-Manguinhos tem estabelecido parcerias entre as quais a de maior destaque é a relacionada à vacina desenvolvida pela Universidade de Oxford.

Ao amparo de carta-compromisso firmada entre o governo britânico, o Ministério da Saúde brasileiro e a Casa Civil da Presidência da República, foi assinado o Memorando de Entendimento (MoU) entre o Ministério da Saúde, a Fiocruz e a biofarmacêutica AstraZeneca (que detém o licenciamento), definindo os parâmetros econômicos e tecnológicos para a produção da vacina da Covid-19, desenvolvida pela Universidade de Oxford e em fase III de estudos clínicos no Brasil e em outros países. Após o MoU, será assinado um acordo na modalidade de encomenda tecnológica, modelo de compra pública que pressupõe o desenvolvimento e o risco tecnológico, permitindo o compartilhamento do último. No âmbito do acordo serão adquiridos os primeiros lotes do ingrediente ativo farmacêutico (IFA), cerca de 30,4 milhões de doses para processamento final entre dez. 2020 e jan. 2021, e será iniciado o processo de incorporação tecnológica, que permitirá investimento no parque tecnológico da Fiocruz, aumentando sua capacidade de reagir a novas epidemias e conferindo autossuficiência na produção nacional. Se a vacina se mostrar segura e eficaz, o acordo prevê a possibilidade de a instituição se tornar responsável por seu fornecimento para a América Latina, em função de sua capacidade produtiva. Há também outra parceria com a Universidade de Oxford e a Emergex Vaccines, para uma vacina sintética, em fase de estudos pré-clínicos.

Outra parceria internacional de Bio-Manguinhos se dá no fornecimento de kits diagnósticos para o novo coronavírus, com a empresa norte-americana Chembio Diagnostics. O Kit Teste Rápido DPP, registrado na Agência Nacional de Vigilância Sanitária (Anvisa) em abril de 2020, detecta anticorpos das classes IgM (infecção recente, a partir do $5^{\circ}$ dia após o início dos sintomas) e lgG (memória), de forma independente e diferencial. Diferentemente do teste molecular, esse kit dispensa estrutura laboratorial e pode ser utilizado em ambulatórios e unidades básicas de atenção primária à saúde. O resultado sai em no máximo 20 minutos. Para ampliar a capacidade de processamento das centrais analíticas, foi estabelecida parceria com a empresa alemã Perkin Elmer para processar as amostras. 
Destaca-se também como colaboração internacional a doação de 30 mil testes moleculares RT-PCR ao Laboratório Central de Saúde do Paraguai.

O Centro de Desenvolvimento Tecnológico em Saúde (CDTS) desenvolveu parcerias com empresas americanas e centros de pesquisa franceses. Em particular, com a Agilent Chemical Analysis Life Sciences and Diagnostics no experimento proteômico Shotgun Discovery Driven, que objetiva mapear a resposta celular à infecção pelo Sars-CoV-2 e o consequente tratamento com os diferentes fármacos. As amostras geradas serão analisadas no espectrômetro de massas de última geração 6545XT AdvanceBio LC/Q-TOF, na sede da empresa na Califórnia, EUA. Outra ação em destaque é o financiamento, por meio de um edital flash da Agência Nacional Francesa de Pesquisa em HIV/Aids e Hepatites Virais (ANRS), da pesquisa Políticas de Saúde e Capacidade Diagnóstica de um País do Sul, em fase de coleta de dados. Outra parceria é com o Instituto de Microbiologia da Academia Chinesa de Ciências na pesquisa de nova tecnologia para sorologia de Covid-19, tendo sido depositado pedido de patente no Instituto Nacional de Propriedade Industrial (INPI).

No Instituto René Rachou (IRR/Fiocruz), em Minas Gerais, as parcerias internacionais se dão nos âmbitos da pesquisa, diagnóstico e estudos clínicos, nas quais as principais instituições parceiras são a University of Georgia e o Vaccine Research and Development Center (VRDC) da University of California Irvine, ambos dos EUA. Para diagnóstico e estudos clínicos a principal parceira é a Harvard School of Public Health, EUA.

O IRR desenvolve pesquisa em colaboração com 17 instituições ou universidades estrangeiras em quase todos os continentes e em diferentes áreas do saber: pesquisa na área de ciências sociais relacionadas aos impactos sociais da Covid- 19 na população e sobre a sindemia com outras arboviroses; análise da epidemia usando modelização de sistemas; estudos epidemiológicos e de prognóstico sobre a enfermidade.

A colaboração com a University of California (UCI Irvine), em especial, produziu um microarranjo contendo antígenos de vários coronavírus humanos, incluindo o SarsCoV-2, além de outras viroses respiratórias, como a HINI. Se os projetos submetidos a diversos editais de agências nacionais e internacionais forem aprovados, se dará início a pesquisa para identificar os melhores antígenos do novo coronavírus para o desenvolvimento de vacinas e sistemas de diagnóstico e, em paralelo, quantificar e qualificar a resposta de $\operatorname{lgM}$ e $\lg \mathrm{C}$ da população testada.

Na Bahia, as parcerias em pesquisas e estudos clínicos têm se dado entre o Instituto Gonçalo Moniz (IGM/Fiocruz) e a Universidade da Filadélfia, EUA. Os estudos são relacionados à coagulação e alterações hematológicas na Covid- 19. Também há parceria 
com o Instituto Carlos III, da Espanha, para o projeto Eulac-PerMed, no âmbito do consórcio ICPermed, do qual a Fiocruz é membro.

Em Pernambuco, para o enfrentamento da pandemia o Instituto Aggeu Magalhães (IAM/Fiocruz) firmou colaboração com a Universidade de Oxford para estabelecer intercâmbio de informações sobre a doença através da plataforma clínica global Isaric Data Plataform. Além disso, participa da colaboração com a Opas e a Secretaria Estadual de Saúde no projeto Qualificação do Modelo de Atenção à Saúde do Estado de Pernambuco, no Âmbito do Combate à Covid-19. O IAM firmou ainda colaboração com o Canadian Institutes of Health Research (ClHR), com o objetivo de comparar as respostas à epidemia de Covid- I 9 no Brasil, no Canadá, na França e no Mali.

A Fiocruz Brasília (Gereb) destaca a pesquisa em parceria com o Centro de Integração de Dados e Conhecimentos para Saúde (Cidacs/Fiocruz Bahia), Impacto Social do Confinamento pelo Surto de Coronavírus Covid-I9 na América Latina - Brasil, que inclui participação de instituições do Chile, Equador, Espanha e México. E a pesquisa multicêntrica envolvendo doenças crônicas não transmissíveis (álcool, tabaco, agrotóxicos e alimentos ultraprocessados), com Costa Rica, México e Chile.

Até aqui, a área da pesquisa dialogou com o eixo Diagnóstico e apresentou desenvolvimento nos campos de produção de vacinas e medicamentos e estudos clínicos.

$\mathrm{Na}$ interface entre as áreas de pesquisa e informação e comunicação em saúde, o Instituto Carlos Chagas, do Paraná (ICC/Fiocruz), também estabeleceu parceria com a Universidade de Oxford, Reino Unido, para análise de dados. Outra iniciativa internacional do ICC que vem se fortalecendo e está em fase de formalização é a parceria com a Universidade de Toronto, Canadá, no tema de avaliação genética de pessoas que contraem a Covid- 19 (proteínas virais e parte imunológica da doença).

$\mathrm{Na}$ interface informação e comunicação/pesquisa, o Instituto de Comunicação e Informação Científica e Tecnológica em Saúde (Icict/Fiocruz) está trabalhando com alguns parceiros internacionais, dos quais se destacam:

- Institut de Recherche pour le Développement (IRD), França. Projeto sobre a interação entre variáveis climáticas e Covid- 19.

- Moovit, EUA. Acesso a dados sobre utilização de transporte público no Brasil e no mundo.

- Facebook, EUA. Symptom Map to Track and Show Covid-I 9 Symptoms through Academic Partnerships: a network of infectious disease epidemiologists at universities around the world working with technology companies to use aggregated mobility data to support the Covid-19 response. 
- McMaster-Canada, Canadá, e Universitat de Valencia, Espanha. Hábitos Saudáveis e Estilo de Vida durante a Pandemia do Covid- I 9: uma websurvey para a população brasileira.

- Rede Internacional Virus Outbreak Data Network (Vodan). Disponibilização de acervo bibliográfico sobre a Covid- 19.

\section{As parcerias com as empresas Moovit e Facebook permitem monitoramento em tempo real de mobilidade social e de possíveis sintomas de Covid-19 compartilhados nas redes sociais.}

Na Casa de Oswaldo Cruz (COC/Fiocruz), a cooperação internacional para a Covid- 19 tem se dado no âmbito da informação e comunicação em saúde com a Universidade Paris 8, da França, e o Centro Internacional para o Estudo da Preservação e Restauração de Bens Culturais (Iccrom), da Itália. Com Paris 8, houve ampliação do projeto relacionado à divulgação científica, para abordar temas relacionados à Covid- 19. Com o Iccrom, está em fase de negociação uma cooperação envolvendo também o Instituto de Conservação Canadense (CCl Canadá), na área de patrimônio históricocultural. No âmbito dessa parceria - ainda não formalizada, mas já em andamento - foi desenvolvida uma ação específica de tradução de alguns materiais sobre patrimônio em tempos de Covid (Iccrom, 2020), para a edição do número especial do Journal of Science Communication (JCOM), Covid-19 and Science Communication.

Com a Rede Brasileira de Bancos de Leite Humano, do Instituto Fernandes Figueira (RBLH/IFF/Fiocruz), e o Icict, as parcerias têm sido nas áreas de educação, prevenção e redução do contágio, informação e comunicação em saúde e assessoria/consultoria a bancos de leite humano/ministérios da Saúde de Colômbia, Bolívia, México, Argentina, Equador, Peru, Uruguai, Paraguai, Costa Rica, Guatemala, El Salvador, Honduras, Nicarágua, Panamá, Uruguai, Cabo Verde, Moçambique e Angola. Vídeos, documentos e outros registros foram disponibilizados no âmbito da rede. Houve também a criação de comitês técnicos para elaboração de recomendações para a RBLH, que foram publicadas em três idiomas. Em março foi realizada uma reunião com a Rede IberoAmericana de Bancos de Leite Humano para debater sobre as boas práticas em tempos de Covid- 19, o que resultou em demandas por mais reuniões técnicas com este objetivo. Colômbia, México, Cabo Verde e Costa Rica já foram assessorados.

No universo da educação, sempre mantendo interfaces com outros eixos de atuação, a Escola Politécnica de Saúde Joaquim Venâncio (EPSJV/Fiocruz) tem parcerias nas áreas de educação, informação e comunicação e trabalho e educação dos técnicos em saúde, estabelecidas com os países e instituições-membros da Rede Internacional de Educação 
de Técnicos em Saúde (Rets). Os membros dessa rede trocam informações sobre o trabalho e a formação dos técnicos em saúde em tempos de Covid- 19. O grupo trabalha na publicação em formato de revista eletrônica sobre o tema. Está em fase final o processo de redesignação da EPSJV como Centro Colaborador da Opas/OMS.

A Escola Nacional de Saúde Pública Sergio Arouca (Ensp/Fiocruz) tem parcerias nas áreas de educação, pesquisa, atenção à saúde, saúde do trabalhador e informação e comunicação em saúde. Uma das prioridades da atuação internacional da Ensp é a cooperação por meio das redes estruturantes em saúde. A Fiocruz, por intermédio da Ensp em parceria com o Cris, teve a iniciativa de fundar e refundar as Redes de Escolas e Centros Formadores de Saúde Pública da América Latina e da Comunidade dos Países de Língua Portuguesa (CPLP) (apresentadas em capítulo específico deste livro), assumindo a Secretaria Executiva das duas redes estruturantes. A Ensp participa também da iniciativa em rede Covid- 19 Salud Colectiva y Pandemia: desafíos para la academia y los movimientos sociales en la construcción de un programa de acción, em que instituições científicas e acadêmicas se juntam a movimentos sociais (sindicatos, movimentos camponeses, movimentos indígenas) para debater e propor ações diante do cenário da pandemia. O primeiro encontro virtual dessa rede congregou I 9 organizações de sete países americanos mais a Índia.

Em termos de cooperação em pesquisas relacionadas à Covid-19, a pesquisa Viver com Corona é um projeto de ciência cidadã criado por uma equipe de cientistas do Centro Internacional de Segurança e Desenvolvimento (ISDC, Alemanha), do Instituto Leibniz de Cultivos Vegetais e Ornamentais (IGZ, Alemanha), do Instituto Mundial de Pesquisas Econômicas para o Desenvolvimento, da Universidade das Nações Unidas (UNU-Wider, Finlândia) e do Instituto de Estudos para o Desenvolvimento (IDS, UK), e conta com a colaboração estreita de diversos parceiros internacionais. No Brasil, o projeto está sendo conduzido pelo Departamento de Estudos sobre Violência e Saúde Jorge Careli (Claves/Ensp/Fiocruz).

A Ensp também coordena, em parceria com a Escola de Enfermagem de Ribeirão Preto e da Escola Nacional de Saúde Pública da Universidade Nova de Lisboa, o projeto Termômetro Social Covid-19 - Brasil, pesquisa social comparada de mensuração da reação populacional à pandemia de Covid-19 e às medidas governamentais de contenção e resposta à pandemia. Em ambos os casos, trata-se de pesquisa qualitativa baseada em questionários on-line (Life with Corona, 2020 e Icict/Fiocruz, 2020) que visam a proporcionar melhor compreensão de como as pessoas vivenciam a quarentena e lidam com ela durante a pandemia de Covid-19. Com o objetivo de investigar o impacto da quarentena na qualidade de vida da população em diferentes regiões do 
país, são coletados dados sobre exposição ao coronavírus, práticas e percepções, os quais são complementados por outros tipos de informação, como compra de alimentos, comportamento social, atitudes, satisfação de vida e bem-estar mental. As pesquisas fornecerão informações para pesquisadores que estudam implicações sociais e econômicas da pandemia.

Entre as demais colaborações estabelecidas no âmbito da Ensp, destacam-se também as parcerias com a Delegação Regional do Comitê Internacional da Cruz Vermelha (CICV) para a formulação de materiais para profissionais da saúde que atuam em áreas de risco e violência.

Tantos desafios também demandam a solidariedade entre os povos. Por intermédio da sua Coordenação de Estratégias de Integração Regional e Nacional, a Fiocruz coordena no Brasil o projeto intitulado Investigação, Educação e Biotecnologia Aplicadas à Saúde, financiado pelo Fundo de Convergência Estrutural (Focem) do Mercosul. No âmbito da solidariedade, destacam-se, além já citada doação ao Paraguai de 30 mil kits para diagnóstico molecular de Covid-19, duas ações recentes. A primeira é o programa de Doutorado em Ciências da Saúde, em parceria com o Ministério da Saúde do Paraguai, com 12 alunos matriculados, a grande maioria funcionários do Laboratório Central de Saúde Pública daquele país. Na segunda, o Focem injetou recursos nos países partícipes, tendo o Brasil recebido 1,3 milhão de dólares, além de duas centrais analíticas (que permitem maior rapidez no processamento de amostras para diagnóstico molecular) que já foram adquiridas e recebidas na Fiocruz Bahia e na Fiocruz Pernambuco.

A cooperação internacional praticada pela Fiocruz se mostra multifacetada, refletindo sua ampla atuação no campo da saúde pública. Originalmente, os seis principais eixos em torno dos quais se desenrolam as ações desenvolvidas para enfrentar a pandemia se aplicam prioritariamente ao cenário brasileiro, muitas vezes não necessariamente comportando ações de cunho também internacional. Contudo, as considerações aqui levantadas permitem perceber que muitos dos pontos da agenda internacional da Fiocruz dialogaram com os todos os seus eixos de atuação, sobretudo no apoio ao diagnóstico, que é tema de muitas pesquisas em colaboração internacional.

A Fiocruz desempenha seu papel no cenário internacional de maneira centralizada, por intermédio da Presidência e das vice-presidências, mas também de maneira descentralizada, pela atuação de seus institutos, laboratórios e profissionais. O Centro de Relações Internacionais em Saúde (Cris) sistematiza, com a Câmara Técnica 
de Cooperação Internacional, as atividades desenvolvidas pelas diferentes unidades, gerando relatórios anuais e de periodicidade menor neste ano pandêmico. A atuação institucional é, porém, muitas vezes pautada por políticas públicas definidas por governos, e não por políticas de Estado, o que pode gerar dificuldade no tocante à coesão e à sustentabilidade de suas ações. O cenário pandêmico não só amplia as possibilidades de cooperação, como as impele, na medida em que coloca desafios globais que não podem ser resolvidos isoladamente por um país ou instituição, mas demandam solidariedade, articulação, sinergia e coordenação.

Contudo, deve-se reconhecer que este capítulo não contém todos os projetos de cooperação internacional nos quais a Fiocruz se encontra envolvida, dada a dinâmica acelerada que esta tomou desde o início do ano, num esforço enorme para colaborar no enfrentamento da enfermidade. Por isso, recomenda-se aos interessados o acesso sistemático ao portal da Fiocruz, no qual, a cada dia, encontrarão informações atualizadas sobre a ampla e complexa cooperação internacional da instituição.

Como a pandemia se encontra aparentemente a meio caminho, seguramente a cooperação internacional da Fiocruz continuará a se desenvolver, sempre fiel à orientação de atuar como instituição estratégica do Estado brasileiro, com suas melhores tradições de amizade e colaboração com instituições científicas de todas as partes do mundo.

\section{REFERÊNCIAS}

COVID- I 9 CLINICAL RESEARCH COALITION. Site. Disponível em: < https://covid I 9crc.org/>. Acesso em: 18 set. 2020.

COVID-19 PREVENTION NETWORK (CoVPN). Site. Disponível em: <https://www. coronaviruspreventionnetwork.org/>. Acesso em: 18 set. 2020.

DIAS, J. Fiocruz participa de evento na OMS sobre novo coronavírus. Agência Fiocruz de Notícias, Rio de Janeiro, II fev. 2020a. Disponível em: < https://portal.fiocruz.br/noticia/fiocruz-participa-de-eventona-oms-sobre-novo-coronavirus>. Acesso em: 18 set. 2020.

DIAS, J. Presidente da Fiocruz auxilia em Roteiro de Pesquisa das Nações Unidas para a Recuperação da Covid-19. Agência Fiocruz de Notícias, Rio de Janeiro, 5 ago. 2020b. Disponível em: <https:// agencia.fiocruz.br/presidente-da-fiocruz-auxilia-em-roteiro-de-pesquisa-das-nacoes-unidas-pararecuperacao-da-covid-19>. Acesso em: 18 set. 2020.

DIAS, J. Fiocruz becomes part of a Coalition to accelerate research on covid-19. Portal Fiocruz, Rio de Janeiro, 6 abr. 2020c. Disponível em: <https://portal.fiocruz.br/en/news/fiocruz-becomes-partcoalition-accelerate-research-covid-19>. Acesso em: 18 set. 2020.

FIOCRUZ desenvolve protocolo para sequenciar o coronavírus. Portal de Notícias, Rio de Janeiro, I jun. 2020. Disponível em: <https://portal.fiocruz.br/noticia/fiocruz-desenvolve-protocolo-parasequenciar-o-coronavirus >. Acesso em: 18 set. 2020. 
FIOCRUZ LIDERA no Brasil ensaio clínico "Solidarity" (Solidariedade) da OMS. Portal Fiocruz, Rio de Janeiro, 27 mar. 2020. Disponível em: <https://portal.fiocruz.br/noticia/fiocruz-lidera-no-brasilensaio-clinico-solidarity-solidariedade-da-oms>. Acesso em: 18 set. 2020.

FUNDAÇÃO OSWALDO CRUZ (FIOCRUZ). VIII Congresso Interno: a Fiocruz e o futuro do SUS e da democracia. Relatório final. Rio de Janeiro: Fiocruz, jun. 20 I8. Disponível em: $<$ https://congressointerno. fiocruz.br/sites/congressointerno.fiocruz.br/files/documentos/VIII\%20Congresso $\% 20$ Interno $\% 20$ -\%20Relat\%C3\%B3rio\%20Final.pdf>. Acesso em: 18 set. 2020.

FUNDAÇÃO OSWALDO CRUZ (FIOCRUZ). Perfil institucional. Disponível em: < https://portal.fiocruz. br/perfil-institucional>. Acesso em: 18 set. 2020a.

FUNDAÇÃO OSWALDO CRUZ (FIOCRUZ). Sexta de Conversa, 19 jun. 2020b. Disponível em: <https:// www.youtube.com/watch?v=ihQM56TyrFY>. Acesso em: 18 set. 2020.

GISAID. Site. Disponível em: <www.gisaid.org>. Acesso em: 18 set. 2020.

INTERNATIONAL CENTRE FOR THE STUDY OF THE PRESERVATION AND RESTORATION OF CULTURAL PROPERTY (ICCROM). Preparing for closure of heritage sites and institutions. Disponível em: <https:// www.iccrom.org/preparing-closure-heritage-sites-and-institutions >. Acesso em: 18 set. 2020.

INSTITUTO DE COMUNICAÇÃO E INFORMAÇÃO CIENTíFICA E TECNOLÉGICA EM SAÚDE/ FUNDAÇÃO OSWALDO CRUZ (ICICT/FIOCRUZ) REDCap. Pesquisa social comparada de mensuração da reação populacional à pandemia de Covid- 19 e às medidas governamentais de contenção e resposta à pandemia - Termômetro Social Covid-19 - Brasil. Disponível em: <https://is.gd/termometrobrasil> . Acesso em: 18 set. 2020.

LIFE WITH CORONA. Disponível em: <https://lifewithcorona.org/ptb/>. Acesso em: 18 set. 2020.

LIMA, C. Nísia Trindade Lima: conheça a trajetória da presidente da Fiocruz. Agência Fiocruz de Notícias, Rio de Janeiro, 9 set. 2020. Disponível em: < https://agencia.fiocruz.br/nisia-trindade-lima-conhecatrajetoria-da-presidente-da-fiocruz>. Acesso em: 18 set. 2020.

NAIROBI STATEMENT. Governance. International Steering Committee. Disponível em: < https://www. nairobisummiticpd.org/content/governance >. Acesso em: 18 set. 2020.

PATNAIK, P. WHO-led Research \& Innovation Forum on Covid- 19: July 2. Geneva Health Files, Geneva, 3 July 2020. Disponível em: <https://genevahealthfiles.wordpress.com/2020/07/03/researchinnovation-forum-on-covid-19-at-who-july-2-2020/>. Acesso em: 18 set. 2020.

SUSTAINABLE HEALTH EQUITY. Site. Disponível em: <https://www.sustainablehealthequity.org/>. Acesso em: 18 set. 2020. 


\section{A Estratégia de Redes Estruturantes na Cooperação Internacional da Fiocruz} América Latina e CPLP

Sebastián Tobar, Felix Júlio Rosenberg, Augusto Paulo José da Silva, Rosa Maria Pinheiro Souza, Pedro Burger, Beatriz Nascimento,

Felippe Amarante, Helifrancis Condé Groppo Ruela, Rosa Maria Pinheiro Souza, Ana Beatriz de Noronha, Luciana Frederico Milagres e João Aprígio

E m II de março de 2020, o diretor-geral da Organização Mundial da Saúde (OMS) L declarou a Covid-19 como uma pandemia. Cinco meses depois, a enfermidade já atinge mais de 20 milhões de pessoas em todo o planeta, causando mais de 700 mil mortes, metade das quais acontecem na América Latina.

Na África, ainda que o número de casos registrados represente apenas $5 \%$ do total global, até agosto foram confirmados mais de um milhão de adoecimentos, com quase 25 mil mortes. Nos países africanos que integram a Comunidade dos Países de Língua Portuguesa (CPLP) - Angola, Cabo Verde, Guiné-Bissau, Guiné Equatorial, Moçambique e São Tomé e Príncipe -, o total gira em torno de 15 mil casos registrados, com pouco mais de 250 óbitos, o que representa aproximadamente 1,4\% dos casos e 1,1\% das mortes ocorridas no continente.

Nesse sentido, a Covid- 19 confirma-se como uma questão de saúde global, definida como

problemas de saúde que transcendem as fronteiras nacionais e os governos e que requerem intervenções nas forças e fluxos globais que determinam a saúde das pessoas. Requer novas formas de governança em nível nacional e internacional, as quais procuram incluir uma ampla gama de atores. (Kickbusch \& Berger, 20I0)

No contexto pandêmico, o trabalho em rede constitui uma grande oportunidade de atuar compartilhando esforços e promovendo a construção de capacidades por meio da cooperação para o desenvolvimento da saúde. 


\section{ASPECTOS CONCEITUAIS}

O conceito de redes tem sido utilizado há algum tempo na área da saúde, com diversos significados. Em geral, o termo pode ser usado em situações onde é possível identificar interações ou trocas entre diferentes membros, os nós da rede, para enfrentar desafios comuns. As redes podem ser de profissionais, de pessoas ou de instituições. Mesmo assim, em última análise, é por meio das pessoas que as instituições que compõem uma rede são conectadas.

No caso da Fundação Oswaldo Cruz (Fiocruz), trata-se de conectar pessoas ou instituições que não se constituam "em si", mas como "redes para" ou "redes meio" (Rovere, 1998), que procuram dar uma resposta melhor a determinado problema de saúde pública ou ao sistema de saúde, provendo uma ação coletiva.

O trabalho em rede permite a articulação de diferentes atores pertencentes a instituições que se agrupam voluntariamente e possibilita a troca e a conjugação de esforços, experiências e conhecimentos para o alcance de objetivos ou de solução para problemas comuns. Nesse sentido, a noção de rede está intimamente relacionada às relações ou vínculos entre os atores que pertencem às instituições.

A ligação entre membros da rede tem o propósito de que estes possam desenvolver atividades comuns, procurar atingir determinados objetivos ou resolver problemas, o que os faz constituírem uma identidade comum. Dessa forma, o interesse comum entre pessoas ou instituições é essencial para "envolver" os participantes da rede.

O trabalho em rede é caracterizado pela adaptabilidade dos membros das redes e pela flexibilidade, abertura, horizontalidade, fluidez e espontaneidade das relações estabelecidas entre eles.

As pessoas ou instituições "enredam" ou constroem redes a partir de esforços conjuntos ou cooperam com base no valor da heterogeneidade entre eles para 0 benefício conjunto. Uma rede envolve conectar pessoas e instituições dentro de uma heterogeneidade. Então, construir redes envolve assumir a heterogeneidade, permitindonos imaginar uma heterogeneidade organizada (Rovere, 1998).

\section{A PANDEMIA COMO UM DESAFIO COMUM}

Em um cenário de maior vulnerabilidade como o atual, no qual a Covid- 19 traspassa as fronteiras nacionais, globalizando seus riscos sanitários, sociais e econômicos, o trabalho em rede se apresenta como grande oportunidade para a cooperação em saúde. 
A Região das Américas tornou-se o epicentro atual da pandemia de Covid-19. O diretor-geral da OMS tem reiterado que, "apesar de todas as nossas diferenças, somos uma raça humana compartilhando o mesmo planeta e nossa segurança é interdependente - nenhum país estará seguro até que estejamos todos seguros". Mais que nunca, a pandemia veio mostrar que saúde e bem-estar é um desafio comum a todos em todos os lugares.

A globalização, comumente atrelada ao progresso e ao desenvolvimento, também excluiu grande parte da população mundial que não usufrui seus benefícios. A pandemia escancarou essas desigualdades ao afetar diferentemente grupos populacionais e de países. Mesmo com cenários diferentes, a Covid-19 atingiu praticamente todos os países, tornando-se, portanto, uma questão cujo enfrentamento traz em si um desafio comum, tornando-se também um desafio às abordagens em rede no campo da saúde global, que já vinham se implantando antes da crise.

No início deste século, tivemos importantes exemplos de cooperação em saúde por meio de redes, os quais poderiam servir de modelo na luta contra a nova pandemia do Sars-2Cov: o Conselho de Saúde Sul-Americano da União de Nações Sul-Americanas (Unasul) e o Conselho dos Ministros da Saúde da CPLP. Nesses processos de integração regional - Unasul e CPLP -, a Fiocruz impulsionou uma modalidade de trabalho em rede chamada "cooperação estruturante".

\section{COOPERAÇÃO ESTRUTURANTE: MODELO EM REDE}

Buscando um processo de cooperação mais adequado para os países em desenvolvimento, a Fiocruz promove, desde 2009, uma nova modalidade de cooperação denominada "cooperação estruturante em saúde". Essa modalidade incorpora um planejamento estratégico focado nas realidades nacionais de cada país ou instituição, entendendo-os como parceiros, e por isso descarta a concepção tradicional de doadores e destinatários da cooperação. Essa perspectiva deixa de lado os programas de ajuda verticais (intervenções com foco em doenças ou problemas específicos), adotando um enfoque horizontal, voltado para o desenvolvimento integral dos sistemas de saúde.

Essa nova perspectiva enfatiza o longo prazo e a construção de capacidades nos países por meio do fortalecimento das instituições estruturantes dos sistemas de saúde para que adquiram liderança genuína nos processos nacionais; permite avançar para a saúde universal; busca estabelecer o equilíbrio entre ações específicas voltadas para a resolução de problemas imediatos com geração de conhecimento e desenvolvimento de capacidades institucionais nacionais sustentáveis; incorpora na cooperação em 
saúde a perspectiva dos determinantes sociais da saúde e das ações intersetoriais; e prioriza programas de saúde pública (com foco na população), ao invés de programas e atividades voltados estritamente para indivíduos.

No marco da extinta Unasul e da CPLP, a Fiocruz tem promovido a criação de diversas redes visando a superar as fragilidades dos componentes dominantes da cooperação, as quais se orientam para o desenvolvimento institucional dos sistemas de saúde dos países parceiros. Essas ações buscam conjugar

intervenções específicas de construção de capacidades locais e de geração de conhecimento, promovendo o diálogo entre os atores, de forma a capacitá-los a assumir protagonismo na liderança dos processos do setor saúde e promover a formulação autônoma de uma agenda para o desenvolvimento do setor. (Almeida et al., 20 I 0: 28)

Trata-se, portanto, de apoiar o desenvolvimento do sistema de saúde em suas várias dimensões, buscando a concretização de sistemas baseados em direitos, com universalidade, integralidade, qualidade e equidade.

Vários autores veem as redes como potencialmente capazes de construir sujeitos dispostos e aptos a transformar a realidade (Franco, 2006; Souza E Costa, 2019). O cotidiano das práticas de saúde é caracterizado por permanentes fluxos operacionais, políticos, comunicativos e simbólicos, os quais, incorporados em rede, conferem aos trabalhadores a ideia de pertencimento entre si, entre os trabalhadores e os equipamentos de saúde, e a uma rede maior que opera conectando fluxos com outros computadores e usuários.

O trabalho em rede permite que diferentes grupos de atores sociais e políticos resolvam problemas comuns, constituindo uma estratégia organizacional para compartilhar recursos, práticas e conhecimentos entre as instituições de forma a maximizar a eficácia e eficiência de suas ações.

Com a infeliz suspensão da Unasul, patrocinada pelos governos de Argentina, Brasil, Chile, Colômbia, Chile, Peru e Paraguai, perdeu-se um importante espaço político regional e de saúde na América do Sul, no momento de pandemia de Covid-19, doença que põe em xeque toda a estrutura de governança global, regional e nacional em saúde e que torna extremamente necessária a cooperação mútua.

Por essas razões, a Fiocruz desenvolveu e implementou estratégias para continuar o trabalho em rede, por meio de outros guarda-chuvas institucionais, promovendo o trabalho conjunto. 


\section{REDE DE ESCOLAS E CENTROS FORMADORES EM SAÚDE PÚBLICA DA AMÉRICA LATINA (RESP-AL): UMA NOVA ETAPA DO FUNCIONAMENTO EM REDE}

Com a dissolução da Unasul, a Escola Nacional de Saúde Pública Sergio Arouca (Ensp) e o Centro de Relações Internacionais em Saúde (Cris) da Fiocruz realizaram negociações com a Coordenação do Programa Sub-Regional para a América do Sul da Organização Pan-Americana da Saúde (Opas/OMS), propondo a ressignificação da Resp/ Unasul em uma nova rede.

Em 31 de maio de 2019 foi realizada a primeira reunião sobre a proposta de organização de uma nova rede latino-americana na área da formação em saúde pública, que considerasse os logros alcançados nos anos anteriores pela rede ancorada na Unasul, privilegiando e mantendo as articulações que nasceram entre instituições e pessoas durante os anos de funcionamento da Resp-Unasul. Nesse primeiro momento, contou-se com a participação de instituições da Argentina e do Brasil, Equador, México, Paraguai, Peru e Uruguai. Posteriormente, em dezembro do mesmo ano, foi oficialmente fundada a nova Rede de Escolas e Centros Formadores em Saúde Pública da América Latina (Resp-AL), no contexto do III Colóquio Latino-Americano de Formação em Saúde Pública. Assinaram a ata fundadora instituições de I I países. Além dos participantes na primeira reunião, somaram-se instituições da Bolívia, do Chile, da Costa Rica e de Cuba.

$\mathrm{Na}$ criação de uma rede latino-americana consideram-se os desafios da formação de graduação e pós-graduação em saúde pública nos países da região, propondo estratégias de intercâmbio de experiências e saberes e compartilhamento de ações visando ao fortalecimento das estratégias formativas em cada país. Com a proposta de que todos os países-membros formem suas redes nacionais, como já ocorre na Argentina e no Brasil, Chile e Peru, esta iniciativa configura-se como uma "rede de redes", propondo organizar, nos casos apropriados, redes de convocação das instituições nacionais.

Cada uma das instituições que fazem parte da rede está imersa em determinado contexto econômico, político, cultural, epidemiológico, de saúde e na própria história e estrutura dos sistemas de saúde de seus países e, a partir de tal contexto, desenvolve suas funções em pesquisa, desenvolvimento, inovação, educação, bem como em cooperação e ação comunitária.

Um dos aspectos fundamentais na conformação de redes é a comunicação, entendida como crucial para o desenvolvimento de uma cultura de grupo, o que também ajuda a criar um senso comum de realização (Gocan $\mathcal{E}$ Laplante, 2014). Nesse sentido, a Resp-AL tem investido em diversas iniciativas para proporcionar uma comunicação dinâmica entre os diversos países, instituições e profissionais envolvidos, como grupos 
de e-mail e WhatsApp, além da elaboração de um website (http://www.respal.ensp. fiocruz.br/). No contexto da pandemia de Covid- I 9, a fluidez no diálogo e as interações constantes têm sido fundamentais, com trocas em tempo real de informações políticas, sociais, epidemiológicas de cada país representado na rede, além de debates e reflexões em torno da conjuntura, dos desafios e das lições aprendidas.

Exemplo concreto da articulação promovida no âmbito da Resp-AL foi a Declaração Conjunta sobre a Pandemia de Covid-19, em que seus membros manifestam preocupação com o cenário de ascensão da epidemia em alguns países e com o fato de alguns governos priorizarem a retomada da produção em detrimento da saúde. A declaração enfatiza a importância do distanciamento social combinado com políticas sociais governamentais, como a renda mínima, e da atenção primária como estratégia para uma saúde pública, universal, integral e equânime (Resp-AL, 2020).

Por meio da articulação em rede, as instituições participantes da Resp-AL têm desenvolvido importantes atividades on-line, como debates e seminários sobre temas essenciais no contexto da pandemia de Covid- 19, seja por meio das Redes Nacionais de Formação em Saúde Pública, a exemplo da brasileira RedEscola, da chilena, da peruana e da argentina, seja por meio da própria rede latino-americana. Em reunião virtual, os membros da Resp definiram temas prioritários para o debate conjunto, em uma sequência de webinários a serem coordenados alternadamente. Nesse contexto foi realizado um seminário virtual sobre Vacinas para a Covid- 19 como Bens Globais, em parceria com outras redes como a Rede Internacional de Educação de Técnicos em Saúde (Rets) e a Rede de Institutos da Comunidade de Países de Língua Portuguesa (Rinsp-CPLP).

\section{A REDE DE ESCOLAS NACIONAIS DE SAÚDE PÚBLICA DA COMUNIDADE DE PAÍSES DE LÍNGUA OFICIAL PORTUGUESA (RENSP-CPLP)}

O ano de 2019 também marcou a formação da Rensp-CPLP. Essa proposta de uma rede de formação em saúde pública no âmbito da CPLP já era um objetivo do Plano Estratégico de Cooperação em Saúde da Comunidade (Pecs-CPLP). Em reunião realizada em Lisboa em fevereiro de 20 I 9, representantes das instituições formadoras de Portugal, Brasil, Angola, Cabo-Verde, Guiné-Bissau e Moçambique, bem como de outros representantes de países da CPLP que participaram por videoconferência, fundaram a rede e elaboraram o seu primeiro Plano de Trabalho.

Desde então foi desenvolvido também um plano de comunicação, com o lançamento de um sítio web para a rede (Rensp/CPLP, 2020), e realizadas reuniões virtuais de organização. Em 2020, o Plano de Trabalho foi atualizado e integrado ao calendário 
do Pecs, com atividades previstas para os dois últimos anos do ciclo atual. Uma das primeiras atividades previstas foi a realização de diagnóstico das capacidades formativas (cursos, outras ações formativas e tecnologias educacionais) existentes nas instituiçõesmembros da rede por meio de um questionário de mapeamento. A Secretaria Executiva da Rensp é exercida conjuntamente pela Ensp/Fiocruz e pela Ensp Nova, da Universidade Nova de Lisboa, em Portugal.

\section{AS REDES DE INSTITUTOS NACIONAIS DE SAÚDE}

Os Institutos Nacionais de Saúde Pública (INSP) são organismos científico-técnicos especializados de Estado que executam funções cruciais em saúde pública, tais como a vigilância, detecção e monitoramento de doenças; investigação e controle de surtos; análise de informações para apoiar a formulação de políticas; pesquisa; formação de recursos humanos; promoção da saúde e ciências laboratoriais. Dado seu caráter científico, os INSP são fontes confiáveis de assessoramento para níveis políticos e de decisão, com uma missão de longo prazo vinculada ao alcance de decisões autônomas e soberanas, baseadas nas realidades próprias dos respectivos países e regiões.

Tendo como fundamento essas funções, cruciais para a estruturação de sistemas sólidos de saúde, a Associação Internacional de Institutos Nacionais de Saúde Pública (IANPHI, na sigla em inglês) foi criada em 2006, no Rio de Janeiro, por 39 membros fundadores, incluindo, entre outros, os institutos de Saúde Pública do Brasil (Fiocruz), da Finlândia (KTL), de Portugal (IHMT) e dos EUA (CDC), contando com um subsídio inicial de 20 milhões de USD da Fundação Bill \& Melinda Gates por intermédio do Instituto de Saúde Global da Universidade de Emory. Em fins de 2019, a IANPHI contava com 114 instituições-membros em 99 países, cobrindo uma população de mais de 5 bilhões de pessoas.

A prioridade de IANPHI é fortalecer os sistemas nacionais de saúde mediante o estabelecimento e desenvolvimento de INSP. Contando com a colaboração dos seus institutos-membros, de outras instituições associadas e de plataformas de cooperação técnica entre pares, a IANPHI apoia países de escassos recursos na criação dos seus respectivos institutos.

Durante a epidemia, a IANPHI tem realizado eventos em rede virtual (webinars) especificamente direcionados aos seus institutos-membros. Nesses eventos foram apresentadas as experiências dos institutos nacionais de Saúde Pública da Itália, Coreia, China e África Ocidental no combate à Covid, além de temas estratégicos como a redução das medidas de lockdown na Europa, instrumentos para a predição da evolução da pandemia e a mobilização das ciências comportamentais durante a emergência. 
Nos últimos anos, a IANPHI promoveu a constituição de redes regionais com o objetivo de fortalecer a cooperação regional, facilitar o apoio mútuo e a assistência técnica e fortalecer as respectivas capacidades. A associação dispõe de quatro redes regionais, na África, Ásia, Europa e América Latina e Caribe, esta última particularmente ativa durante a pandemia.

A Fiocruz participa de duas redes internacionais de institutos nacionais de saúde pública e as coordena: a Rede de Institutos da Comunidade de Países de Língua Portuguesa (Rinsp-CPLP) e a Rede Regional Latino-Americana e do Caribe (Rede IANPHI LatAm / Rins-Unasur). Ambas foram criadas há aproximadamente uma década com o objetivo de fortalecer estruturas científicas e técnicas de Estado que reduzam a dependência externa e consolidem soluções soberanas para os problemas nacionais, regionais e internacionais de saúde, mediante o esforço solidário de pares.

\section{Rinsp-CPLP}

A Rede de Institutos da Comunidade de Países de Língua Portuguesa (Rinsp-CPLP) foi criada em 22 de março de 201 I na cidade de Bissau, com a presença de representantes dos institutos de Saúde Pública dos cinco Países Africanos de Língua Portuguesa, os Palop (Angola, Cabo Verde, Guiné-Bissau, Moçambique e São Tomé e Príncipe), mais os de Timor Leste, Brasil e três institutos de Portugal, de acordo com a resolução do Plano Estratégico de Cooperação em Saúde da Comunidade (Pecs/CPLP).

A rede está ativa desde então, concentrando esforços no apoio mútuo para a criação de institutos nos países-membros que não possuem essa estrutura e para a elaboração, implementação e avaliação dos respectivos planos estratégicos para o seu fortalecimento. Dessa forma, no período foram criados os institutos de Saúde Pública em Guiné-Bissau e Cabo Verde; foi fortalecido o Instituto Nacional de Saúde de Moçambique, que se tornou referência técnica e científica para o país e para toda a região; foi apoiado o planejamento do Instituto Nacional de Investigação em Saúde de Angola e foram desenvolvidas bases conceituais para a criação de institutos em São Tomé e Príncipe e em Timor Leste.

Com o início da epidemia de Covid-19, a programação de cooperação técnica previamente estabelecida com base nas diretrizes do Plano Estratégico de Cooperação em Saúde teve que ser suspensa. No seu lugar foi criado um ciclo de reuniões virtuais bissemanais entre os diretores das suas instituições-membros ou seus representantes.

Inicialmente, foi realizada uma consulta temática que atendesse a três objetivos principais: I) a realização de debates sobre assuntos de interesse prioritário relativos ao papel dos institutos no combate à epidemia; b) seleção de projetos em curso nos 
institutos que pudessem ser objeto de colaboração para a sua execução regional, com potencial para a captação de recursos financeiros externos; e c) ações específicas de cooperação técnica por meio virtual.

De acordo com essa agenda, foram realizados, até o momento da publicação deste trabalho, três encontros temáticos virtuais que trataram, respectivamente, do papel dos institutos nas questões relacionadas à pesquisa genômica do vírus e aos seus usos práticos; do estado da arte do conhecimento a respeito da imunidade em Covid- 19 e dos usos das provas sorológicas para o diagnóstico e o monitoramento epidemiológico; e do papel da atenção primária em saúde no combate à epidemia. Os mesmos temas foram debatidos no âmbito da Rede Regional da América Latina e Caribe da IANPHI. As principais conclusões, que têm impacto significativo nas estratégias de combate à Covid, serão analisadas mais adiante.

\section{Rins-Unasul e Rede IANPHI-LatAm}

Dependente do Conselho de Saúde Sul-Americano, também existia a Rede SulAmericana de Institutos Nacionais de Saúde Pública (Rins-Unasul), efetivada em 2010 sob a coordenação do Instituto Nacional de Saúde do Peru e com a Fiocruz atuando como a sua Secretaria Executiva.

O principal objetivo da Rins-Unasul foi cooperar mutuamente para a criação e consolidação dos institutos nacionais de Saúde de todos os seus países-membros, mantendo reuniões presenciais periódicas e realizando missões de cooperação técnica, principalmente no campo do planejamento estratégico.

Como resultado da ruptura, em 2018 , da maioria dos governos da região com a Unasul, a sua rede de institutos deixou de operar como tal. Entretanto, continuou constituída a partir do final desse mesmo ano, quando a Associação Internacional de Institutos Nacionais de Saúde Pública (IANPHI) criou a Rede Regional da América Latina e Caribe sob a coordenação da Fiocruz, a rede IANPHI LatAm, que com o aparecimento da pandemia adquiriu maior presença analisando e debatendo importantes aspectos do papel que cabe aos institutos exercer no seu combate.

A referida rede é composta pelos institutos de Argentina, Bolívia, Brasil, Colômbia, Costa Rica, Chile, Equador, El Salvador, México, Panamá, Peru e Venezuela, além da Agência Caribenha de Saúde Pública (CARPHA). 


\section{As redes de institutos diante da pandemia da Covid-19}

A pandemia potencializou os encontros virtuais entre seus membros, que têm servido para discutir diversos temas priorizados por eles. Em ambas as redes as principais questões foram semelhantes.

Com relação ao uso da genômica, ficou evidenciado que o acesso a essa tecnologia está reduzido apenas aos países de maior desenvolvimento econômico, que conseguiram realizar mapas genômicos completos de diversas cepas circulantes nos seus países e em alguns dos outros países das suas respectivas redes. Por meio desse mecanismo foi possível identificar origens diversas da introdução e da distribuição interna do vírus e avaliar as potenciais mutações genéticas, que teriam reflexos evidentes na elaboração de vacinas e na predição de variações no curso de desenvolvimento da gravidade da doença.

A discussão sobre o uso das provas sorológicas evidenciou novamente a grande iniquidade entre os diversos países que compõem ambas as redes. É consenso entre todos os cientistas que essas provas só devem ser utilizadas para inquéritos populacionais, sendo desaconselhado o seu uso para o diagnóstico individual, mas alguns países às voltas com sérias dificuldades orçamentárias para acessar os testes moleculares aconselhados para tanto têm desenvolvido estratégias algorítmicas para utilizar os testes sorológicos como indicadores preliminares e os moleculares apenas para confirmação.

Com relação ao papel dos institutos na atenção primária para o combate à pandemia, lamentavelmente a resposta da grande maioria destes é bastante reduzida.

Para os próximos encontros estão propostos, entre outros, os temas: acesso às vacinas e outros medicamentos como bens públicos comuns; papel dos institutos na prevenção e controle dos desastres naturais; desigualdades.

\section{A REDE INTERNACIONAL DE EDUCAÇÃO DE TÉCNICOS EM SAÚDE (RETS)}

A Rede Internacional de Educação de Técnicos em Saúde (Rets) é uma articulação entre instituições e organizações envolvidas com a formação e a qualificação de pessoal técnico da área da saúde. Sua missão é fortalecer os sistemas nacionais de saúde, com base no pressuposto de que a qualificação dos trabalhadores é uma dimensão fundamental para a implementação de políticas públicas de saúde que atendam às necessidades das populações.

A Rets, criada em 1996 tendo como Secretaria Executiva a Escola de Saúde Pública da Costa Rica, funcionou até 200I, quando foi desativada. Em setembro de 2005, com a transferência da Secretaria Executiva para a Escola Politécnica de Saúde Joaquim 
Venâncio (EPSJV/Fiocruz), que havia se tornado Centro Colaborador da Opas/OMS para a Educação de Técnicos em Saúde em 2004, a rede foi reativada e hoje reúne 122 membros, de vinte países, entre instituições formadoras, órgãos de governo, organismos multilaterais e associações profissionais.

Ao fim de 1995, com coordenação da Opas/OMS, foi realizado amplo estudo sobre a situação da formação do pessoal técnico em saúde, que reuniu 70 centros em 16 países do continente americano. A pesquisa identificou inúmeros problemas, entre os quais sérias deficiências nos processos de planejamento de recursos humanos, inexistência de informação sistematizada sobre educação e trabalho desses profissionais e desatualização dos planos de estudo. A construção de uma rede internacional de educação de técnicos em saúde foi definida como prioritária e considerada importante forma de potencializar o conhecimento e a experiência acumulada, assim como de estimular o crescimento dos diferentes grupos, seja de docência, pesquisa ou prestação de serviços de saúde. São objetivos da rede:

1. possibilitar a cooperação técnica e a colaboração entre os membros na área da formação e desenvolvimento de pessoal técnico em saúde;

2. difundir informações resultantes de pesquisas sobre os trabalhadores desse nível a fim de fortalecer seu desenvolvimento, assim como dos serviços de saúde de que participam;

3. potencializar o acúmulo de conhecimento, estimulando a integração e o crescimento de grupos de docentes, pesquisadores, planejadores, administradores e prestadores de serviço;

4. promover o crescimento e o fortalecimento das suas instâncias organizativas e estimular a captação de recursos financeiros para garantir a sua sustentabilidade;

5. identificar as necessidades educacionais e de formação, bem como outros requisitos básicos das diferentes especialidades técnicas existentes.

\section{A Rets-CPLP e a Rets-Unasul: unindo esforços para fortalecer a formação de técnicos em saúde}

Em maio de 2009, a aprovação do Plano Estratégico de Cooperação em Saúde da CPLP foi o ponto de partida para a criação, em dezembro do mesmo ano, da Rede de Escolas Técnicas de Saúde da CPLP (Rets-CPLP). Na ocasião também foi criada a Rede de Escolas Técnicas da Unasul (Rets-Unasul), cuja origem está relacionada à criação do então Conselho de Saúde Sul-Americano e à Agenda Sul-Americana da Saúde, 
estabelecida em dezembro de 2008. Naquele momento, ambas as redes foram formadas como sub-redes da Rets, já amplamente consolidada.

Na 4 a Reunião Geral da Rets, realizada em novembro de 2018 no Rio de Janeiro, e com a extinção da Unasul, seus membros decidiram estabelecer, além do Plano de Trabalho e do Plano de Comunicação da rede, um Plano de Ações Regionalizadas para a América Latina. Na mesma ocasião também foi realizada a $4^{\text {a }}$ Reunião Ordinária da Rets-CPLP.

\section{A Rets e a pandemia de Covid-19: comunicação permanente entre os membros}

Na reunião de novembro de 2018, os planos de trabalho aprovados já previam o incremento do uso das tecnologias de informação e comunicação (TIC) para fortalecer o trabalho da rede. Nesse sentido, foram intensificadas tanto as ações de comunicação com o público externo, por meio do website da Rets (Rets, 2020a), de suas redes sociais (Facebook, Twitter, Instagram e YouTube) e de seu boletim eletrônico quinzenal, quanto a comunicação interna, entre os membros da rede, por meio do informe trimestral da Secretaria Executiva e de grupos de WhatsApp.

Essas iniciativas se mostraram essenciais no contexto da pandemia, pois acabaram proporcionando um incremento das ações que vinham sendo realizadas, mas também a possibilidade e a necessidade de pensar na manutenção da rede num cenário futuro de poucos recursos financeiros e possíveis dificuldades na realização de atividades presenciais.

A primeira ação definida foi a criação de um grupo de WhatsApp específico para discutir os aspectos da pandemia no âmbito da América Latina. A partir daí, foram realizadas a I ${ }^{a}$ Reunião Virtual da Rets para os países latino-americanos, em 22 de maio deste ano, com a presença de 45 pessoas (Rets, 2020b), e a I ${ }^{a}$ Reunião Virtual da RetsCPLP, em I de julho, com mais de 30 participantes (Rets, 2020b). Nos dois encontros, a prioridade foi discutir a formação de técnicos em saúde no contexto da pandemia. Nas reuniões, os países apresentaram os desafios que estão enfrentando e começaram a discutir novas possibilidades de cooperação e a continuidade de ações já em andamento.

De acordo com os membros, dois grandes problemas são as desigualdades sociais que impedem o acesso de grande número de alunos às tecnologias de ensino a distância e a impossibilidade de acesso aos serviços de saúde por alunos em fase de estágio. Tais problemas podem gerar enorme lacuna na formação dos técnicos em saúde, com reflexos bastante negativos nos serviços de atenção à saúde das populações. 
Das propostas aprovadas nas reuniões, é possível destacar:

I. A criação de uma página Covid-19 no website da Rets, para a divulgação de materiais produzidos sobre a Covid- 19 e compartilhados por seus membros.

2. A realização, em caráter virtual, do I Colóquio Virtual Latino-Americano de Educação Interprofissional e Formação de Técnicos em Saúde, cuja versão presencial seria realizada em maio de 2020, na Colômbia.

3. A publicação de uma edição especial Covid-19 da Revista Rets, em formato eletrônico, abordando inúmeros aspectos da pandemia e seus reflexos na formação e no trabalho dos técnicos em saúde.

4. A tradução emergencial de materiais didáticos e informativos sobre Covid-19 para atender um número maior de países. Nesse sentido foi lançada, em julho, a versão em espanhol da cartilha "Orientações para cuidadores domiciliares de pessoa idosa na epidemia do Coronavírus - Covid- 19" (Groisman et al., 2020) e está sendo discutida a possibilidade de tradução da "Ferramenta de bolso para agentes de saúde e cuidadores na ativa em defesa da vida na epidemia Covid- 19" (Leal et al., 2020) e do "Manual sobre biossegurança para reabertura de escolas no contexto da Covid-19" (Pereira et al., 2020), todos publicados pela EPSJV/Fiocruz.

5. A elaboração de um curso virtual, adequado às condições tecnológicas dos Palop, fruto de parceria entre a Escola Superior de Tecnologia da Saúde de Lisboa (ESTeSL) e a EPSJV/Fiocruz; e

6. O estabelecimento, via Coordenação da Rede Universitária de Telemedicina (Rute), de uma parceria com a Rede Nacional de Ensino e Pesquisa (RNP) para a distribuição de salas de webconferência para membros dos Palop que tenham interesse em utilizar a plataforma desta rede para reuniões e processos formativos durante a pandemia. Inicialmente foram disponibilizadas dez salas e, caso necessário, outras poderão sê-lo.

Além dessas atividades, a Rets tem buscado incrementar sua interação com outras redes e parceiros para a organização de eventos virtuais sobre inúmeros aspectos relacionados à pandemia, como foi o caso do webinar "As vacinas e medicamentos para a Covid- 19 como bens públicos globais“, realizado em 30 de julho (Cris/Fiocruz, 2020).

Também está prevista, ainda este ano, a realização de um webinar sobre os desafios das instituições para o retorno às atividades presenciais de formação. 


\section{REDE GLOBAL DE BANCOS DE LEITE HUMANO (rBLH-BR)}

A Rede Brasileira de Bancos de Leite Humano (rBLH-BR), cuja coordenação está sediada na Fiocruz com suporte técnico do Instituto Nacional de Saúde da Mulher, da Criança e do Adolescente Fernandes Figueira (IFF) e do Instituto de Comunicação e Informação Científica e Tecnológica em Saúde (lcict), conta com 224 bancos de leite humano distribuídos em todos os estados do território nacional. O modelo brasileiro é reconhecido mundialmente pelo desenvolvimento tecnológico inédito que alia baixo custo a alta qualidade. Em razão dessa experiência, a rBLH-BR coordena também a Rede Global de Bancos de Leite Humano, que tem o objetivo de, mediante cooperação técnica internacional, formar multiplicadores que possibilitem a transferência de tecnologia para outros países. A Rede Global apoia também organismos multilaterais como a SecretariaGeral Ibero-Americana, com a criação do Programa Ibero-Americano de Bancos de Leite Humano (2008), que integra todos os países da região da Ibero-América e a Comunidade de Países de Língua Portuguesa (2017).

Em tempos da pandemia de Covid-19, as discussões técnicas que a Rede Global de Leite Humano tem promovido em suas duas seções, a Ibero-Americana e a da CPLP, visam ao conjunto de políticas e iniciativas de enfrentamento voltadas para assegurar a segurança das doadoras, dos profissionais da saúde envolvidos em todas as etapas dos processos de trabalho dos BLHs e dos recém-nascidos contemplados pelas doações.

\section{A RBLH-CPLP no enfrentamento da Covid-19}

A Rede de Bancos de Leite Humano da Comunidade de Países de Língua Portuguesa (rBLH-CPLP) reuniu-se virtualmente em maio de 2020, em meio à pandemia de Covid- 19 , para apresentar os desafios enfrentados e as ações desenvolvidas para manter suas atividades. As recomendações de segurança em virtude da pandemia não interferem na continuidade da amamentação e extração do leite pela mãe, desde que de acordo com seu desejo, com suas condições clínicas e com as medidas recomendadas para evitar a transmissão do vírus. Algumas atitudes garantem a segurança, como lavar as mãos antes de tocar o bebê ou retirar o leite; usar e trocar adequadamente a máscara facial; e seguir todas as orientações e recomendações para a extração segura do leite.

A falta de informação e o grande desafio gerado pela Covid- 19 acabaram ampliando a atuação das redes em modalidades virtuais e a progressiva institucionalização que ajuda a criar novas oportunidades para abordar problemas comuns e articular respostas para a 
adoção de medidas coletivas, além de contribuir para o fortalecimento das capacidades institucionais para o enfrentamento dos problemas de saúde dos países.

O trabalho em rede pode ser uma opção significativa para cooperação técnica, troca de conhecimentos e experiências, treinamento, aprimoramento de capacidades e transferência de tecnologia em condições de mais igualdade de poder e recursos, bem como para aprendizagem mútua e coordenação de políticas e estratégias de desenvolvimento entre os países parceiros.

A pandemia tem permitido a adoção de modalidades de trabalho virtual com potencial para a cooperação em saúde que ainda podem ser exploradas em maior medida.

O aprendizado entre pares, como acontece no âmbito das redes, e a cooperação estruturante representam um enfoque poderoso e flexível para o fortalecimento de capacidades nacionais e para o empoderamento de todos os participantes em prol da saúde pública como um todo e, especificamente no momento atual, para o enfrentamento da pandemia da Covid-19.

\section{REFERÊNCIAS}

ALMEIDA, C. M. et al. A concepção brasileira de "cooperação Sul-Sul estruturante" em saúde. Reciis Revista Eletrônica de Comunicação, Informação E Inovação em Saúde, 4(I): 25-35, 20 I 0. Disponível em: <https://www.reciis.icict.fiocruz.br/index.php/reciis/article/view/696>. Aceso: 2/10/20.

CENTRO DE RELAÇÕES INTERNACIONAIS EM SAÚDE (CRIS/FIOCRUZ). Vacinas e Medicamentos para Covid- 9 como Bens Públicos Globais. Seminário virtual latino-americano, 30 jul. 2020. Disponível em: $<$ https://www.youtube.com/watch?v=exjkp4BeSPo >. Acesso em: 18 set. 2020.

FRANCO, T. B. As redes na micropolítica do processo de trabalho em saúde. In: PINHEIRO, R.; FERLA, A. A. \& MATOS, R. A. Gestão em Redes: tecendo os fios da integralidade em saúde. Rio de Janeiro: Lappis, IMS/Uerj, Abrasco, 2006.

GOCAN, S. \& LAPLANTE, M. A. Interprofessional collaboration in Ontario's family health teams: a review of the literature. Journal of Research in Interprofessional Practice and Education, 3(3): 1-19, 2014.

GROISMAN, D. et al. (Coords.). Orientações para Cuidadores Domiciliares de Pessoa Idosa na Epidemia do Coronavírus - Covid-19. Rio de Janeiro: EPSJV/Fiocruz, Icict/Fiocruz, 2020. Disponível em: <http:// www.epsjv.fiocruz.br/sites/default/files/files/CartilhaCuidadorldoso_Covid-19.pdf>. Acesso em: 18 set. 2020.

KICKBUSCH, I \& BERGER, C. Diplomacia da saúde global. Reciis - Revista Eletrônica de Comunicação, Informação E Inovação em Saúde, 4(1): 19-24, mar. 2010.

LEAL, A. L. G. et al. Ferramenta de Bolso para Agentes de Saúde e Cuidadores da Ativa em Defesa da Vida na Epidemia Covid-19. Rio de Janeiro: Disponível em: EPSJV/Fiocruz, 2020. Disponível em: < http://www.epsjv. fiocruz.br/sites/default/files/files/ferramenta\%20de\%20bolso\%203.pdf>. Acesso em: 18 set. 2020. 
PEREIRA, I. D. F. et al. Manual sobre Biossegurança para Reabertura de Escolas no Contexto da Covid-I9. Rio de Janeiro: EPSJV/Fiocruz, 2020. Disponível em: < http://www.epsjv.fiocruz.br/sites/default/files/ manual_reabertura.pdf $>$. Acesso em: 18 set. 2020.

REDE DE ESCOLAS NACIONAIS DE SAÚDE PÚBLICA DA COMUNIDADE DOS PAÍSES DE LÍNGUA PORTUGUESA (RENSP/CPLP). Site. Disponível em: <http://rensp.ensp.fiocruz.br/>. Acesso em: 18 set. 2020.

REDE INTERNACIONAL DE EDUCAÇÃO DE TÉCNICOS DE SAÚDE (RETS). Site. Disponível em: < http:// www.rets.epsjv.fiocruz.br>. Acesso em: 18 set. 2020a.

REDE INTERNACIONAL DE EDUCAÇÃO DE TÉCNICOS DE SAÚDE (RETS). O trabalho e a formação dos técnicos de saúde em tempos de pandemia de Covid- I9. In: REUNIÃO VIRTUAL DA REDE DE ESCOLAS TÉCNICAS EM SAÚdE DA COMUNIDADE DOS PAÍSES DE LÍNGUA PORTUGUESA (RETS-CPLP), I, I 7 jul. 2020b, on-line. Disponível em: < http://www.rets.epsjv.fiocruz.br/la-reuniao-virtual-da-retscplp>. Acesso em: 18 set. 2020.

REDE DE ESCOLAS E CENTROS FORMADORES EM SAÚDE PÚBLICA DA AMÉRICA LATINA (RESP$A L)$. Declaração da Rede de Escolas e Centros Formadores em Saúde Pública da América Latina sobre a Pandemia de Covid-19, 2020. Disponível em: < http://www.respal.ensp.fiocruz.br/sites/default/files/ declaracao_covid-_resp-al.pdf>. Acesso em: 18 set. 2020.

ROVERE, M. Redes: hacia la construcción de redes en salud: los grupos humanos, las instituciones y la comunidad. Secretaría de Salud Pública. Rosario, 1998.

SOUZA, P. R. M. \& COSTA, P. P. Educação permanente em saúde na formação da Rede Brasileira de Escolas de Saúde Pública. Saúde em Debate, 43(n. esp.): I 16-129, 2019. Disponível em: < https://www. scielo.br/pdf/sdeb/v43nspel/0I03-1 I04-sdeb-43-spe0I-01 I6.pdf>. Acesso: 18 nov. 2019. 
Formato: $16 \times 23 \mathrm{~cm}$

Tipologia: GoudySnas Lt BT, GoudySans Md BT e Interstate-LightCondensed Rio de Janeiro, dezembro de 2020

Não encontrando nossos títulos em livrarias, contactar a Editora Fiocruz:

Av. Brasil, 4036, térreo, sala 112 - Manguinhos

21040-36 I - Rio de Janeiro, RJ

Tel.: (2I) 3882-9039 e 3882-9007

Telefax: (21) 3882-9006

editora@fiocruz.br

www.fiocruz.br/editora 
Passados os primeiros meses da pandemia do novo coronavírus no Brasil, o Observatório Covid- I 9 Fiocruz, em parceria com a Editora Fiocruz e com o apoio da Rede SciELO Livros, traz para o público leitor um conjunto de livros instantâneos sobre as análises nele realizadas desde que foi criado para subsidiar o seu combate.

Nesta série Informação para Ação na Covid- 19 será apresentado um balanço do conjunto de documentos (notas e relatórios técnicos, boletins, informes, recomendações, ensaios, artigos, entre outros) produzidos em resposta à pandemia. Cada volume da série se estrutura em torno de um tema: aspectos globais da pandemia e da diplomacia em saúde; cenários epidemiológicos e vigilância em saúde; as políticas e a gestão dos serviços e sistemas de saúde; orientações para os cuidados e a saúde dos trabalhadores da saúde; impactos sociais e desigualdades sociais na pandemia.

Com a publicação destes estudos em livros de acesso aberto colocamos à disposição do público o conjunto de informações e conhecimentos gerados no âmbito do Observatório Covid- 19 Fiocruz, realizamos um balanço e uma reflexão sobre como chegamos ao cenário atual e apontamos caminhos para um futuro próximo. E, ao mesmo tempo, mantemos o registro histórico desse conhecimento produzido a quente, no calor da hora.

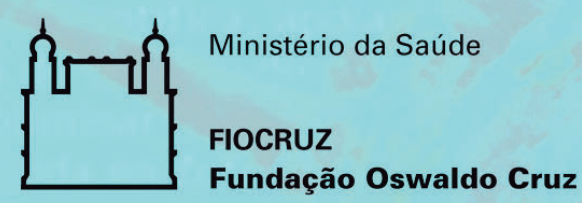

OBSERVATÓRIO COVID-19

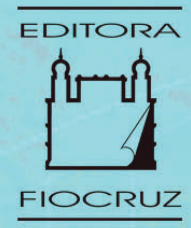

